\title{
FOLIICOLOUS FUNGI OF WAYANAD DISTRICT IN KERALA STATE, INDIA
}
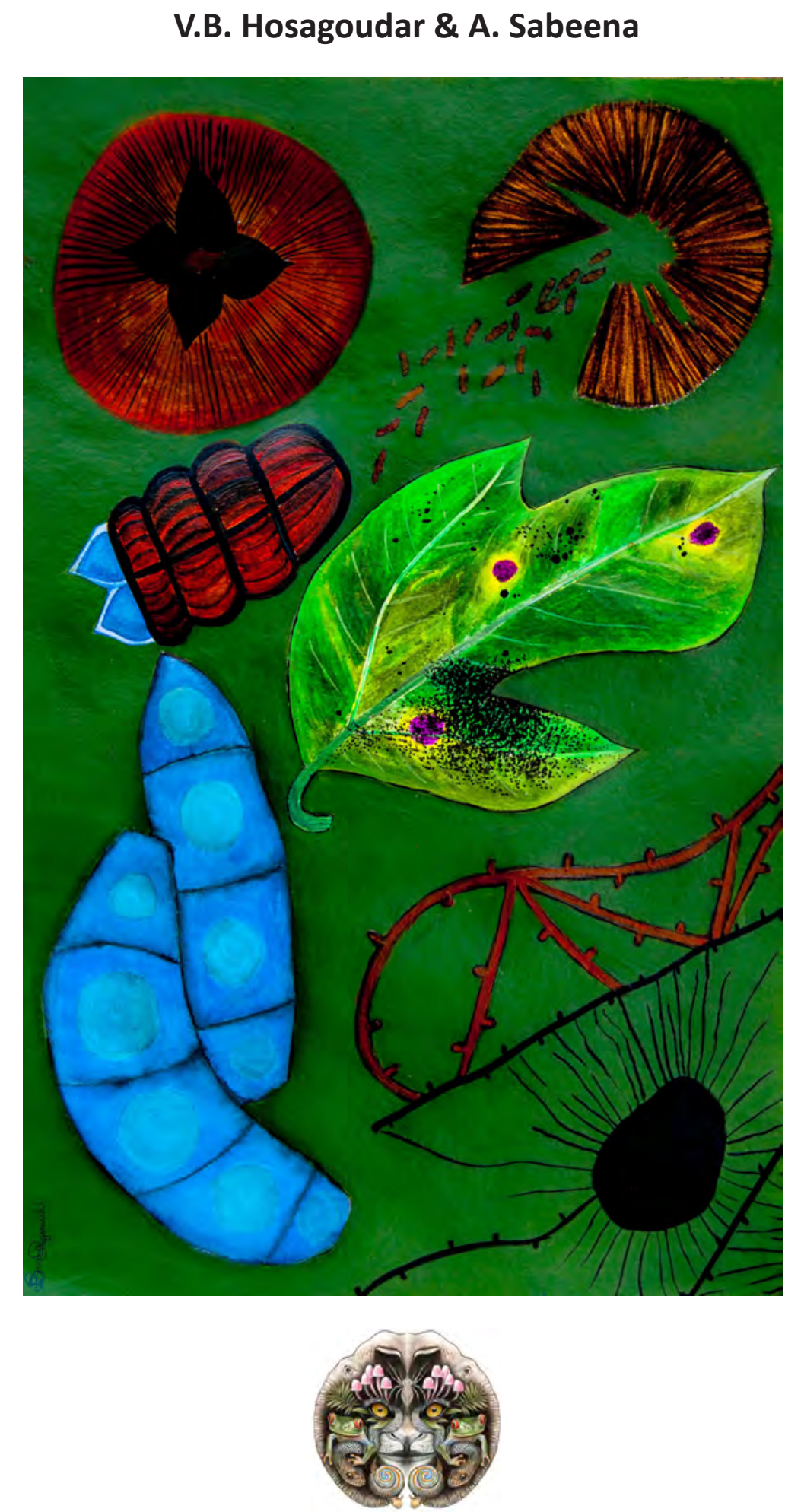

Journal of Threatened Taxa

July 2014 | Vol. 6 | No. 7 | Pages: 5909-6052 | Date of Publication: 19 July 2014 
1. Introduction

\section{CONTENTS}

2. Key to groups

3. The genus Amazonia.

4. The genus Appendiculella.

5. The genus Armatella

6. The genus Asteridiella

7. The genus Irenopsis

8. The genus Meliola

9. Meliolinaceae

10. Asterinales

11. The genus Asterina

12. The genus Asterolibertia

13. The genus Ishwaramyces

14. The genus Meliolaster .

15. The genus Prillieuxina

16. Key to the Anamorphic Genera

17. The genus Asterostomella

18. The genus Asterostomula

19. The genus Mahanteshamyces

20. Lembosiaceae

21. The genus Echidnodella

22. The genus Lembosia

23. Schiffnerulaceae

24. Phyllachorales

25. Other Ascomycetes

26. Key to the Hyphomycetes

27. References

28. Host family-Hosts-Fungus Index 


\section{Folicolous fungi of WAYANAd District in KeRALA STATE, INDIA}

\section{V.B. Hosagoudar ${ }^{1} \&$ A. Sabeena ${ }^{2}$}

182 Jawaharlal Nehru Tropical Botanic Garden and Research Institute, Thiruvananthapuram, Kerala 695562, India

${ }^{182}$ Jawaharlal Nehru Tropical Botanic Garden and Research Institute, Thiruvananthapuram,
${ }^{1}$ vbhosagoudar@rediffmail.com (corresponding author), ${ }^{2}$ asabeenarasheed@gmail.com

Abstract: This comprises an account of the 580 foliicolous fungal collections collected along with the host leaves of 220 host plants belonging to 70 families of flowering plants from Wayanad District resulted in recording 175 fungal species distributed among 29 fungal genera, belonging to black mildews, Meliolales: namely, Amazonia (6), Appendiculella (1), Armatella (6), Asteridiella (12), Irenopsis (7), Meliola (96); Meliolinaceae: Meliolina (1); Asterinales: Asterinaceae: Asterina (47), Asterolibertia (1), Ishwaramyces (1), Meliolaster (1), Prillieuxina (2), Asterostomella (1), Asterostomula (1), Mahanteshamyces (1), Lembosiaceae: Echidnodella (1), Lembosia (2), Schiffnerulaceae: Questieriella (2), Sarcinella (4), Schiffnerula (9); Phyllachoraceae: phyllachora (5); Hyphomycetes: Acrodictys (1), Spiropes (3), Ampullifera (1), Passalora (1), Colemaniella (1), Acremoniula (1); Other Ascomycetes: Leptosphaerulina (1), Rehmidothis (1).

Keywords: Foliicolous fungi, India, taxonomy, Western Ghats.

DOI: http://dx.doi.org/10.11609/JoTT.03658.5909-6052

Editor: B. Shivaraju, Bengaluru, India.

Manuscript details: Ms \# 03658 | Received 03 August 2013 | Final received 08 December 2013 | Finally accepted 05 February 2014

Citation: Hosagoudar, V.B. \& A. Sabeena (2014). Foliicolous fungi of Wayanad District in Kerala State, India. Journal of Threatened Taxa 6(7): 5909-6052; http://dx.doi.org/10.11609/JoTT.03658.5909-6052

Copyright: (C) Hosagoudar \& Sabeena 2014. Creative Commons Attribution 4.0 International License. JoTT allows unrestricted use of this article in any medium for non-profit purposes, reproduction and distribution by providing adequate credit to the authors and the source of publication.

Funding: Jawaharlal Nehru Tropical Botanic Garden \& Research Institute, Palode, Thiruvananthapuram, Kerala, India

Competing Interest: The authors declare no competing interests.

Author Contribution: VBH has identified the fungi and AS has studied and helped in the preperation of the manuscript.

Author Details: V.B. HOSAGOUDAR has been working on the taxonomy of foliicolous fungi for nearly four decades; A. SABEENA has been working on the same topic since eight years.

Acknowledgements: We are grateful to Dr. P.G. Latha, Director, JNTBGRI, Palode for the facilities.

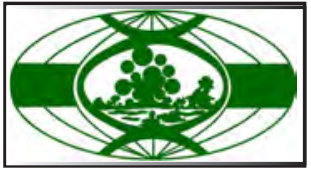




\section{INTRODUCTION}

Wayanad, the $12^{\text {th }}$ district in Kerala State, was formed from Kozhikode and Kannur Districts on 01 November 1980 , with Kalpetta as its district head quarters. It has an area of $2132 \mathrm{~km}^{2}$, located towards north-east of Kerala, $11^{0} 27^{\prime}-15^{\circ} 58^{\prime} \mathrm{N} \& 75^{\circ} 47^{\prime}-70^{\circ} 27^{\prime} \mathrm{E}$ (Image 1), stands on the southern tip of the Deccan Plateau and has a glory of majestic rugged terrain of the Western Ghats, having lofty ridges interspersed with dense forest, tangled with jungles and deep valleys, located at an altitude ranging from 700-2100 m. The name Wayanad originated from Mayakshetra (Maya's land). It is also known as Vayal (paddy fields) and Naad (land), a land of paddy fields. Since large area of the district is covered by forest and is a hilly terrain, the district is with least population.

According to archaeological evidence, the Wayanad forests have been inhabited for more than 3,000 years. Historians are of the view that human settlement existed in these parts for at least 3,000 years. Much evidences of new stone age civilization can be seen in the hills throughout the present day Wayanad District. The two caves of Ampukuthimala, with pictures on their walls and pictorial writings, speak volumes of a bygone civilization. The recorded history of this district exists only from the $18^{\text {th }}$ century onwards. In ancient times, this land was ruled by the Rajas of the Veda Dynasty. In later days, Wayanad came under the rule of the Pazhassi Raja Dynasty of ancient Kottayam. When Hyder Ali became the ruler of Mysore, he invaded Wayanad and brought it under his sway. In the days of Tippu Sultan, Wayanad was restored to the Kottayam royal dynasty. But Tippu handed over the entire region of northern Kerala to the British, signing the treaty of Srirangapattana with British army officer and colonial administrator Cornwallis. This was followed by fierce and internecine encounters between the British and Pazhassi Raja of Kottayam. When the Raja was driven to the wilderness of Wayanad, he organised the war-like Kurichiya tribals into a sort of people's militia and engaged the British in several guerrilla type encounters. In the end, the British could get only the dead body of the Raja, who committed suicide in the forest. Thus, Wayanad fell into the hands of the British and with it came a new era. The British authorities opened up the plateau to cultivation of tea and other cash crops by constructing roads across the dangerous slopes of Wayanad, to Kozhikode and Thalassery. Later, they extended these new roads to the cities of Mysore and Ooty through Gudalur. Settlers emigrated from all parts of Kerala and the fecund lands proved a veritable goldmine with incredible yields of cash crops. When the State of Kerala came into being in November 1956, Wayanad was part of Kannur District. Later, southern Wayanad was added to Kozhikode District. In order to fulfill the aspirations of the people of Wayanad for development, North Wayanad and South Wayanad were carved out and joined together to form the present district of Wayanad. This district consists of three taluks: Vythiri, Mananthavady and Sultan's Battery.

There are tribal populations in the area who still practice age-old customs and rituals and live a nomadic life. Some of the tribal populations include Paniyas, Adiyas, Kattunayakan, Kurumans and Kurichiyans. It is the district with the highest share in the adivasi population (about $36 \%$ ) of Kerala. Wayanad also has a large settler population. The Jains from Karnataka came in the $13^{\text {th }}$ century. The Hindu Nairs from KottayamKurumbranadu, in Kannur District, made an entry in the $14^{\text {th }}$ century and established their feudal system. They were followed by Muslims. There were large scale migrations from southern Kerala in the early 1940s. Christians came in the 1950s from Travancore region. In the last few decades there was a complete marginalisation of the indigenous people. Alienated from their land, exploited by the settlers and neglected by the state, their struggle for rights to the land has so far been unsuccessful.

\section{Forest Types}

The flora of Wayanad are characteristic of the Western Ghats and the plantation crops grown in the cool climate. A major portion of the district is covered by coffee. Trees of the wild type like rose-wood, anjili (Artocarpus), mullumurikku (Erythrina), several species of cassia and many other nondescript varieties are still preserved here and there, to give shade to the coffee plants. These trees give a sembalance of wilderness to the landscape of Wayanad. In a majority of coffee plantations, the age-old species are replaced by the silver-oak which is suited to the cold climate. This tree grows quickly and its cultivation is widespread among coffee plantations for shade and for giving support to pepper. It is used for the Plywood Industry and thus is economical to the farmers. Eucalyptus grandis, a shorter variety of eucalyptus, whose fragrant smell suffuses the very air around it, is cultivated on a large scale in certain parts of the district. Eucalyptus oil is extracted on commercial basis from its leaves. Of the 20,864ha of reserve forest, the major portion is teak plantation. Areca nut palms and jack trees are also grown here. Tea is grown as an industry in large estates. The soil and climate of Wayanad are suitable for horticulture 
on commercial basis. For promoting the cultivation of vegetables and raising of orchards, the Kerala Agricultural University is running a Regional Agricultural Research Station at Ambalavayal. With the clearing of forests, the diverse and bustling animal life, characteristic of the forests of Western Ghats, has vanished from Wayanad. One can still see the Bonnet Macaque, Slender Loris, mongooses, Jungle Cats, squirrels, jackals, hares, etc., in the limited forest areas. The world's largest venomous snake, the King Cobra is also found here. Elephant, bear and other wild animals from the neighbouring wild life sanctuaries of Karnataka and Tamil Nadu, stray into the Begur forest range and the forests around Muthanga, which is $20 \mathrm{~km}$ away from the town of Sulthan Bathery. Karapuzha Dam near Menangadi 10km, Banasura Sagar Dam $20 \mathrm{~km}$ from Vythiri. Today large game is found only in region that border with Karnataka and Tamil Nadu. Here there is one of the largest concentrations of wild Asiatic Elephants in whole world. Tiger, Bison, Sambhar, Spotted Deer, Boar, Leopard, Wild Dog and other Large Mammals are also present in fairly decent numbers. Wayanad Wildlife Sanctuary is the core forest region of this district. The native Adivasis mainly consist of various sects like Paniyas, Kurumas, Adiyars, Kurichyas, Ooralis, Kattunaikkans, etc.

This district comprises: west coast tropical semievergreen forests, southern moist mixed deciduous forest, southern dry mixed deciduous forests and moist bamboo brakes and this rich forest has been protected in the form of Wayanad Wildlife Sanctuary, harbouring more than 2000 flowering plant species and the present work on the foliicolous fungi forms the first of its kind for the this area.

\section{Mountains}

Chembra Peak $(2,100 \mathrm{~m})$, Banasura Peak $(2,073$ $m)$, Bramhagiri $(1,608 \mathrm{~m})$ are some of the important mountains in the district.

\section{Rivers}

The Kabini River, one of the three east flowing rivers of Kerala, is an important tributary of the Kaveri River. Almost the entire Wayanad District is drained by Kabini and its three tributaries, the Panamaram, Mananthavady, and Kalindy rivers. The Banasura Sagar Dam is built on one of the tributaries of the Kabini River.

\section{Climate}

The distance from the mean sea level and the amount of forest cover creates a pleasant climate in the region. Generally the year is divided into four seasons; cold weather (December-February) hot weather (MarchMay) south-west monsoon (June-September) and north-east monsoon (October-November). During the hot weather the temperature goes up to a maximum of $35^{\circ} \mathrm{C}\left(95^{\circ} \mathrm{F}\right)$ and during the cold weather the temperature goes down to $07^{\circ} \mathrm{C}\left(45^{\circ} \mathrm{F}\right)$. The greater temperature variation in the last $5-6$ years is in the range of $18^{\circ} \mathrm{C}$ $\left(64^{\circ} \mathrm{F}\right)-28^{\circ} \mathrm{C}\left(82^{\circ} \mathrm{F}\right)$. The average rainfall is $2,500 \mathrm{~mm}$ per year.

\section{Economy}

Wayanad is $3.79 \%$ urbanised. Agriculture, is the main stay of the economy. Coffee, tea, cocoa, pepper, plantain and vanilla are the main crops. Besides these cash crops, the most important crop in the district is rice.

\section{Key to groups}

1. Produce black mycelial colonies on the host surface Black mildews

1. Not so Phyllachoraceae

2. Produce tar spots 3

2. Not so.

3. Produce yellow rust pustules on the host surface. Rust fungi

3. Not so. ..4

4. Produce superficial perithecia which are attached to host surface. Leptospharulina

4. Persist only in conidial form .Hyphomycetes

\section{BLACK MILDEWS}

These are the ectophytic, black colony forming fungi belong to different groups

\section{Key to the groups of Black Mildews}

1. Produce thick, black, woolly colonies on the lower surface of the leaves. ..Meliolinaceae

1. Always not so .2

2. Produce two-celled appressoria and often phialides, ascomata perithecial. Meliolales

2. Produce 1-2-celled appressoria, phialides absent, ascomata thyriothecium. .3 3. Thyriothecia dehisce stellately or vertically, anamorph mostly pycnothyrial.... Asterinales 3. Thyriothecia dissolve at the centre, anamorph polymorphic, e.g, Sarcinella, Questieriella, etc. Schiffnerulaceae 


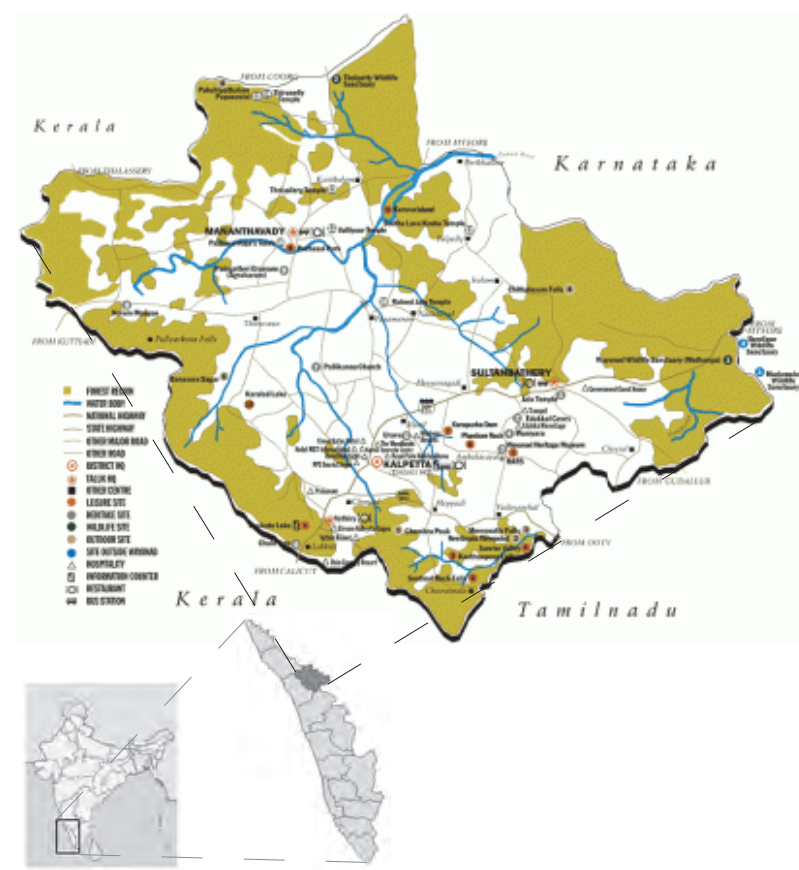

Image 1. Wayanad District map. (Source: District Tourism Promotion Council, Wayanad (DTPC))

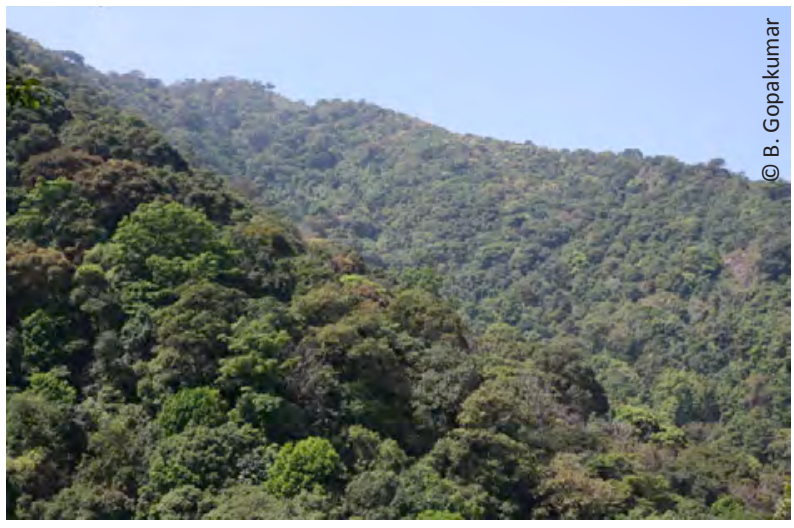

Image 2. Evergreen forest

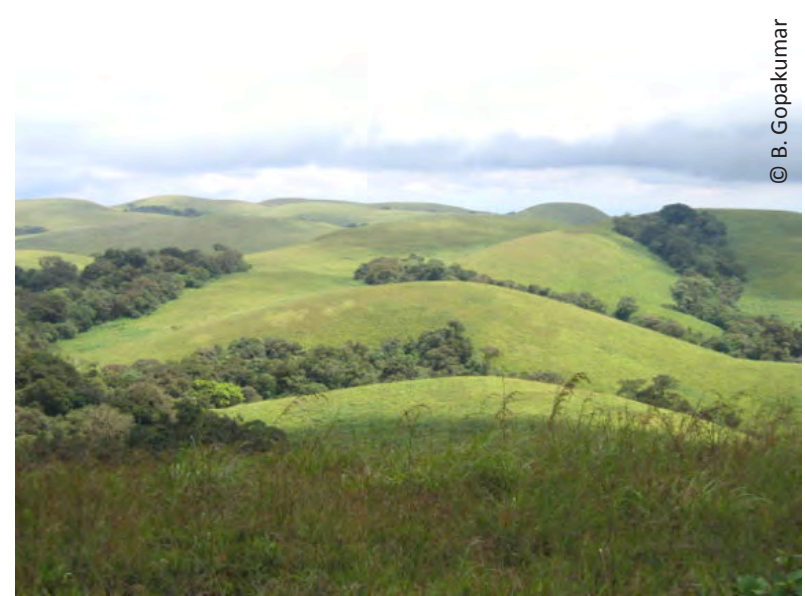

Image 3. Hill shola forest

\section{MELIOLALES}

Meliolales Gaumann ex Hawksworth \& O. Eriksson, Systema Ascomycetum 5: 142, 1986; Hosag., Meliolales of India 2: 28, 2008; Hosag. \& Agarwal, Taxonomic studies of Meliolales. Identification Manual, p. 3, 2008.

Parasites on vascular plants. Mycelium mostly superficial, appressoriate. Appressoria mostly two celled, rarely many celled. Phialidic (in Meliolaceae), phialides unicellular. Ascomata flattened-globose to globose, \pm ostiolate, peridium smooth, surface cells protruded, often supplemented with setae and or appendages; asci born on basal hymenium, unitunicate, 2-8 spored, clavate to cylindrical, evanescent; ascospores 1-4 septate, brown at maturity.

\section{TYPE FAMILY: MELIOLACEAE}

\section{Key to the families}

1. Ascospores 1-2-septate ......................Armatellaceae

1. Ascospores 3-4-septate ...........................Meliolaceae

\section{ARMATELLACEAE}

Armatellaceae Hosag., Sydowia 55: 162, 2003; Hosag., Meliolales of India 2: 28, 2008; Hosag. \& Agarwal, Taxonomic studies of Meliolales. Identification Manual, p. 3, 2008.

Leaf parasites, ectophytes, mycelium with appressoria, phialides absent, mycelial setae absent. Perithecia on superficial hyphae, globose, verrucose; asci 4-8-spored; ascospores 1-2-septate, brown at maturity.

Type genus: Armatella Theiss. \& Sydow

The family Armatellaceae includes the genera: Armatella and Basavamyces but the present study includes the former genus.

\section{MELIOLACEAE}

Meliolaceae Martin ex Hansf., Mycol. Pap. 15: 23, 1946; Hosag., Meliolales of India 2: 29, 2008; Hosag. \& Agarwal, Taxonomic studies of Meliolales. Identification Manual, p. 4, 2008.

Parasitic on vascular plants; mycelium mostly superficial; appressoriate, phialidic. Ascomata flattenedglobose to globose, \pm ostiolate, peridium with conoid cells, larviform and striated appendages, or with repent or strong setae. Asci unitunicate, 2-4-spored, clavate to cylindrical, evanescent; ascospores 3-4-septate, brown at maturity.

Type genus: Meliola Fries 


\section{Key to the genera of Meliolaceae}

1. Perithecia flattened-globose, hidden in the radiating mycelium Amazonia

1. Perithecia globose, discrete, not hidden in the radiating mycelium. ...2

2. Mycelial setae present Meliola

2. Mycelial setae absent. ....3

3. Perithecial setae and larviform appendages present

3. Both perithecial setae and larviform appendages absent.

Asteridiella

4. Only perithecial setae present. Irenopsis

4. Only larviform appendages present.....Appendiculella

\section{Digital formula}

After the generic level confirmation, a specific formula called the Beeli's Formula (digital formula) is used for the identification up to species level. Beeli Formula consists of eight digits. The first four digits before the stop (left side to the stop) represent the morphological characters like ascospore septation, presence or absence and the nature of the perithecial setae or appendages, presence or absence and the nature of the mycelial setae and the arrangements of appressoria, respectively. The second four digits, after the stop, represent the measurements such as length and breadth of ascospores, diameter of perithecia and length of mycelial setae, respectively. The species having both simple and dentate setae is denoted by $1 / 3$, while species having straight and uncinate setae are designated as $1 / 2$. The Beeli Formula is modified here to accommodate the genus Armatella having one septate ascospores.

MORPHOLOGY (first four digits from left)

1. Normal septation of ascospores
1. 1-septate
2. 3-septate
3. 4-septate

\section{Perithecia}

1. Without setae or appendages

2. With larviform, horizontally striated appendages

3. With uncinate or coiled setae

4. With straight setae

3. Mycelial setae (often on perithecia and from subiculam)

1. Absent

2. Simple
3. Simple, entire, uncinate or coiled

4. Dentate or shortly furcate (up to $30 \mu \mathrm{m}$ )

5. Branched (branches more than $30 \mu \mathrm{m}$ )

4. Appressoria

1. Alternate or unilateral (less than $1 \%$ opposite)

2. Regularly opposite

3. Both opposite and alternate

II. MEASUREMENTS (second four digits from the full stop)

5. Maximum ascospore length
1. Up to $20 \mu \mathrm{m}$
2. 21-30 $\mu \mathrm{m}$
3. $31-40 \mu \mathrm{m}$
4. $41-50 \mu \mathrm{m}$
5. 51-60 $\mu \mathrm{m}$
6. More than $60 \mu \mathrm{m}$ long

6. Maximum ascospore width
1. Up to $10 \mu \mathrm{m}$
2. $11-20 \mu \mathrm{m}$
3. 21-30 $\mu \mathrm{m}$
4. More than $31 \mu \mathrm{m}$

7. Maximum diameter of perithecia
1. Up to $100 \mu \mathrm{m}$
2. $101-200 \mu \mathrm{m}$
3. 201-300 $\mu \mathrm{m}$
4. More than $301 \mu \mathrm{m}$

8. Maximum length of mycelial setae
1. Up to $300 \mu \mathrm{m}$
2. 301-500 $\mu \mathrm{m}$
3. 501-1000 $\mu \mathrm{m}$
4. More than $1000 \mu \mathrm{m}$
5. Absent.

The treatment of species and varieties consists of the original citation of the correct name, citation of the world monograph and Indian monographs, relevant synonyms (if any) based on the monographs of Hansford (1961) and Hosagoudar (1996). The citation is followed by the description based on the present collections, which are deposited in TBGT (Tropical Botanic Garden and Research Institute, Thiruvananthapuram), $\mathrm{HClO}$ (Herbarium Cryptogamae Indiae Orientalis), New Delhi and at STET Herbarium, Mannargudi, Tamil Nadu. At the end of the description of each taxon, notes have been provided regarding their identification and distribution. Line drawings have been provided to the studied taxa. 


\section{The genus Amazonia}

Amazonia Theiss., Ann. Mycol. 11: 499, 1913.

Actinodothis Sydow \& Sydow, Philippine J. Sci. 9: 174, 1914.

Meliolaster Doidge, Trans. Royal Soc. South Africa 8: 123, 1920 (non Meliolaster Hohnel).

Amazoniella Bat. \& Maia, Broteria 29: 73, 1960.

Mycelium superficial, brown, septate, branched, appressoriate. Perithecia borne under radiating mycelium, wall radial, shield like, non-ostiolate to ostiolate, hemispherical, inner wall pale, thin. Asci 2-4 spored, evanescent; ascospores brown, 3-4 septate.

Type: A. psychotriae (P. Henn.) Theiss.

Amazonia flacourtiae Hosag., Siddappa \& Udaiyan, Nova Hedwigia 56:193, 1993; Hosag., Meliolales of India, p. 68, 1996. (Fig. 1).

Materials examined: TBGT 5947, 30.ix.2007, on leaves of Flacourtia sp. (Flacourtiaceae), Padinharathara, coll. M.C. Riju.

Colonies amphigenous, thin to subdense, up to $2 \mathrm{~mm}$ in diameter, confluent. Hyphae substraight to flexuous, branching opposite at acute angles, loosely reticulate, cells 12.5-22x6-9.5 $\mu \mathrm{m}$. Appressoria alternate, straight, rarely curved, antrorse, 15.5-25 $\mu \mathrm{m}$ long; stalk cells cuneate, 3-6.5 $\mu \mathrm{m}$ long; head cells ovate, entire, 12.5-20.5x8-14 $\mu \mathrm{m}$. Phialides mixed with appressoria, alternate to opposite, ampulliform, 15.5-22x6-9.5 $\mu \mathrm{m}$. Perithecia flattened-globose, scattered, up to $124 \mu \mathrm{m}$ in diameter; ascospores obovoidal, 4-septate, strongly constricted at the septa, 34-46.5×12.5-18.5 $\mu \mathrm{m}$.

Amazonia goniothalami Hosag., Rajkumar, C.K. Biju \& Abraham, Mycotaxon 72: 431, 2001; Hosag., Zoos' Print J. 21:2322, 2006; Hosag., Meliolales of India 2: 187, 2008. (Fig. 2).

Materials examined: $\mathrm{HClO}$ 44801, TBGT 1038, 26.xii.2002, on leaves of Goniothalamus wyanadensis (Bedd.) Bedd. (Annonaceae), Chandanathode, coll. M. Kamarudeen \& P.A. Jose.

Colonies predominantly hypophyllous, subdense to dense, up to $5 \mathrm{~mm}$ in diameter, confluent. Hyphae straight, branching alternate to opposite at acute angles, loosely to closely reticulate, cells $9-16 \times 6-8 \mu \mathrm{m}$. Appressoria alternate, antrorse to closely antrorse, straight, 18-26 $\mu \mathrm{m}$ long; stalk cells cylindrical to cuneate, 6-8 $\mu \mathrm{m}$ long; head cells ovate, oblong to cylindrical, entire, $12-15 \times 8-12 \mu \mathrm{m}$. Phialides not seen. Perithecia flattened-globose, radiating, up to $160 \mu \mathrm{m}$ in diameter; ascospores oblong to ellipsoidal, 4-septate, constricted at the septa, 44-48x20-23 $\mu \mathrm{m}$.
This is the only record of the genus Amazonia on the members of the family Annonaceae (Hansford 1961; Hosagoudar 1996; Hosagoudar et al. 1997).

Amazonia gordoniicola Hosag., C.K. Biju \& Abraham, Nova Hedwigia 80: 467, 2005; Hosag., Meliolales of India 2: 87, 2008. (Fig. 3).

Materials examined: HClO 43677, TBGT 330, 16.iv.1999, on leaves of Gordonia sp. (Theaceae), Banasuran mala, coll. C.K. Biju.

Colonies mostly epiphyllous, subdense, up to $3 \mathrm{~mm}$ diam., confluent. Hyphae straight to substraight, branching in alternate to opposite position at acute angles, loosely reticulate, cells $19-24 \times 5-7 \mu \mathrm{m}$. Appressoria alternate, about $1 \%$ opposite, antrorse to subantrorse, 12-20 $\mu \mathrm{m}$ long; stalk cells cylindrical to cuneate, 3-5 $\mu \mathrm{m}$ long; head cells ovate, rarely oblong to globose, entire, rarely angular to truncate at the apex, 9-15x9-13 $\mu \mathrm{m}$. Phialides mixed with appressoria, alternate to opposite, ampulliform, 16-20x6-8 $\mu \mathrm{m}$. Perithecia scattered, in radiating hyphae, up to $150 \mu \mathrm{m}$ diameter; ascospores oblong to rarely slightly ellipsoidal, 4-septate, constricted at the septa, 35-37x15-17 $\mu \mathrm{m}$.

The similar $A$. toquian Petrak is known on Ternstroemia toquian (Theaceae) from the Philippines. Contrasting with $A$. toquian, this species has loosely reticulate mycelia, numerous appressoria, and 4-septate smaller ascospores (Hansford 1961).

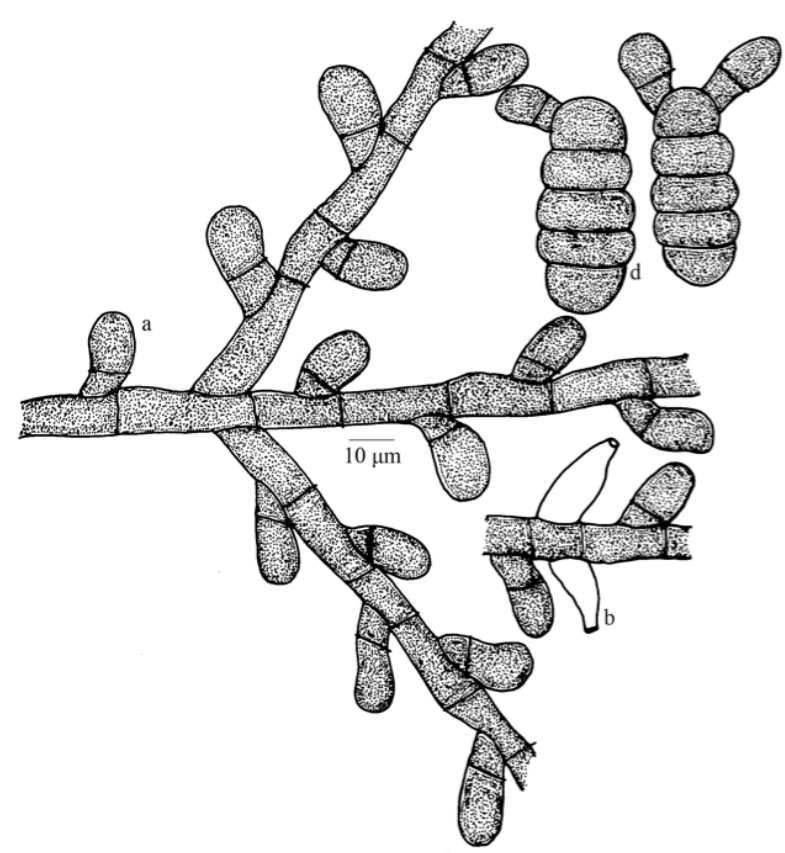

Figure 1. Amazonia flacourtiae a - Appressorium; b - Phialide; d - Ascospores 
Amazonia peregrina Sydow \& Sydow, Ann. Mycol. 15: 238, 1917; Hansf., Sydowia Beih. 2:507, 1961; Hosag. \& Goos, Mycotaxon 36: 236, 1989; 42:126, 1991; Hosag., Meliolales of India, p.74, 1996.

Meliola peregrina Sydow \& Sydow, Philippine J. Sci. 8: 479, 1913. (Fig. 4).

Materials examined: $\mathrm{HClO}$ 50329, TBGT 4246, 31.x.2007, on leaves Maesa indica (Roxb.) DC. (Myrsinaceae), $10^{\text {th }}$ Mile, Banasura sagar, coll. V.B. Hosagoudar et al.

Colonies amphigenous, mostly hypophyllous, crustaceous, up to $2 \mathrm{~mm}$ in diameter, confluent. Hyphae straight to undulating, branching alternate to opposite at acute angles, closely reticulate, forming solid mycelial mat and impart thalloid appearance, cells 13-16.6x6-8 $\mu \mathrm{m}$. Appressoria alternate to unilateral, very closely arranged, antrorse, straight to curved, 13-16.5 $\mu \mathrm{m}$ long; stalk cells cuneate, 3.5-5 $\mu \mathrm{m}$ long; head cells globose, entire, 10-13x10-11.5 $\mu \mathrm{m}$. Phialides mixed with appressoria, alternate, ampulliform, 13-16.5x6.5-8 $\mu \mathrm{m}$. Perithecia mostly aggregated, flattened-globose, glabrous, black, up to $281 \mu \mathrm{m}$ in diameter; ascospores cylindrical to obovoidal, 4-septate, constricted at the septa, 36-43×13-16 $\mu \mathrm{m}$.

This species mostly occurs on the leaves infected with Meliola groteana Sydow but can be easily distinguished by its crustose colonies.

Amazonia syzygii Hosag. in Hosag. \& Goos, Mycotaxon 36: 236, 1989; 42:126, 1991; Hosag., Dayal \& Goos, Mycotaxon 46: 202,1993; Hosag., Meliolales of India, p.74, 1996. (Fig. 5).

Materials examined: HClO 49847, TBGT 3999,

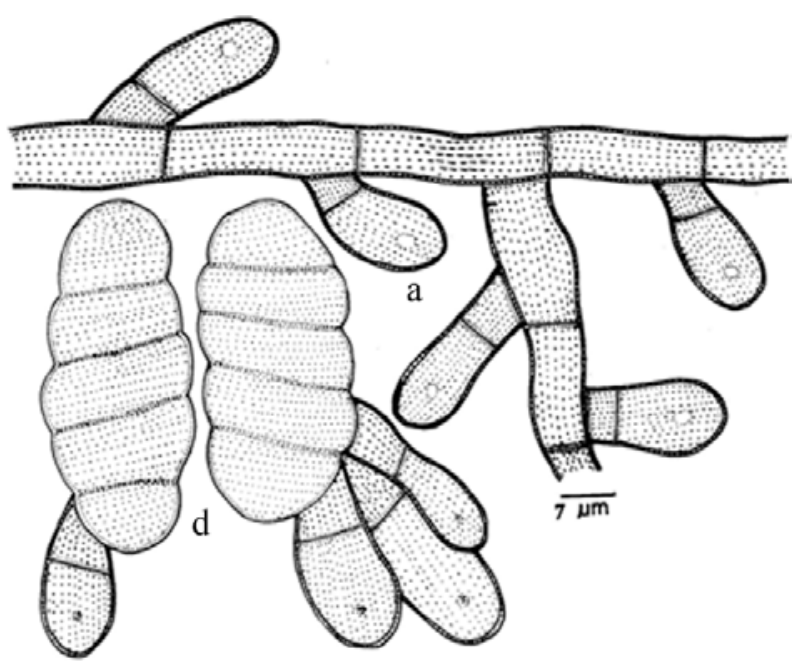

Figure 2. Amazonia goniothalami a - Appressorium; d - Ascospores

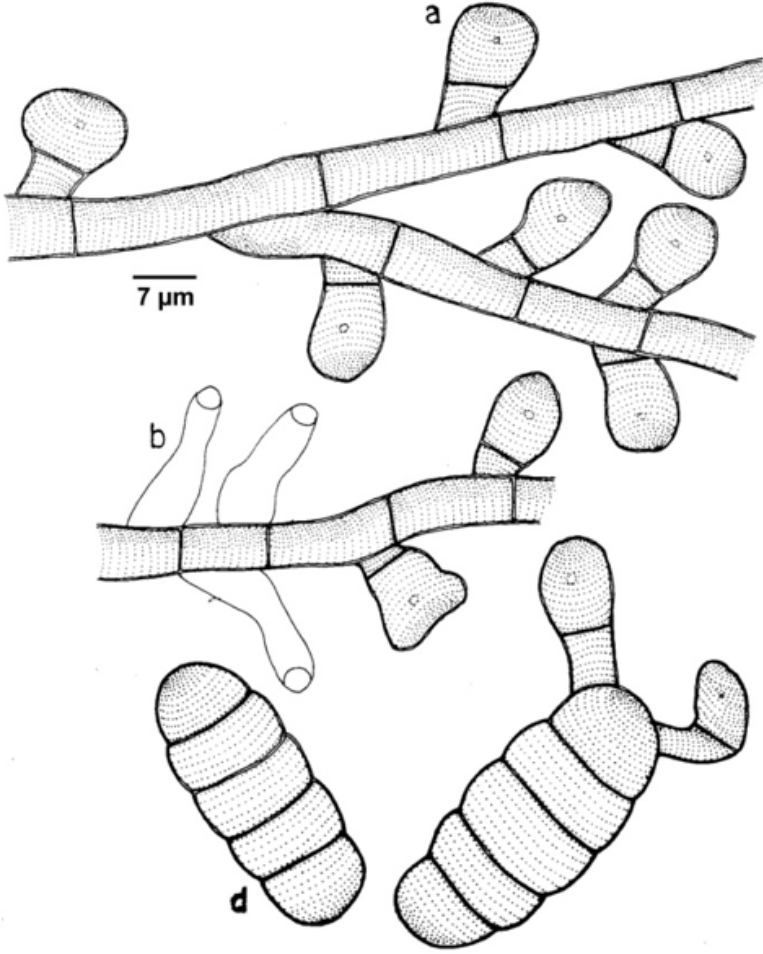

Figure 3. Amazonia gordoniicola

a - Appressorium; b - Phialide; $\mathbf{d}$ - Ascospores

12.ii.2009, on leaves of Syzygium sp. (Myrtaceae), Wayanad, coll. Jacob Thomas et al.

Colonies amphigenous, subdense, crustose to slightly velvety, up to $2 \mathrm{~mm}$ in diameter, rarely confluent. Hyphae substraight to slightly undulate, branching mostly opposite at wide angles, closely reticulate, cells 16-20x6-8 $\mu \mathrm{m}$. Appressoria alternate, straight, antrorse to spreading, $18-20 \mu \mathrm{m}$ long; stalk cells cylindrical to cuneate, 4-8 $\mu \mathrm{m}$ long; head cells ovate to subglobose, entire, $10-14 \times 8-10 \mu \mathrm{m}$. Phialides mixed with appressoria, opposite to alternate, conoid to ampulliform, 20-24x8-10 $\mu \mathrm{m}$. Perithecia flattenedglobose, scattered to grouped, up to $180 \mu \mathrm{m}$ in diameter; ascospores obovate, 4-septate, slightly constricted at the septa, 44-48x16-20 $\mu \mathrm{m}$.

Amazonia vaccinii Hosag., C.K. Biju \& Abraham, Nova Hedwigia 80: 468, 2005; Hosag., Meliolales of India 2: 87, 2008. (Fig. 6).

Materials examined: $\mathrm{HClO}$ 43603, TBGT 289, 20.xi.1998, on leaves of Vaccinium sp. (Vacciniaceae), Banasuran mala, coll. C.K. Biju.

Colonies amphigenous, mostly epiphyllous, thin to subdense, up to $5 \mathrm{~mm}$ diameter, confluent. Hyphae straight to substraight, branching in opposite to unilateral position at acute angles, loosely to closely reticulate, 


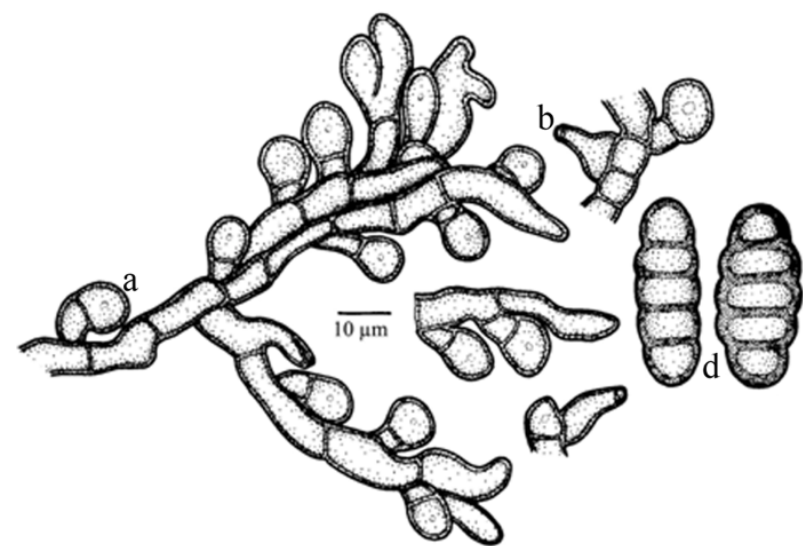

Figure 4. Amazonia peregrina

a - Appressorium; b - Phialide; d - Ascospores

cells $12-28 \times 6-8 \mu \mathrm{m}$. Appressoria alternate, straight to slightly curved, antrorse to spreading, 14-18 $\mu \mathrm{m}$ long; stalk cells cuneate, $4-7 \mu \mathrm{m}$ long; head cells oblong to globose, straight to slightly curved, entire to sublobate, 9-13x8-10 $\mu \mathrm{m}$. Phialides mixed with appressoria but apparently on separate mycelial branches, alternate to opposite, ampulliform, $14-23 \times 6-8 \mu \mathrm{m}$. Perithecia hidden in the radiating mycelium, flattened-globose, fringed hyphae appressoriate, up to $120 \mu \mathrm{m}$ diameter; ascospores oblong, 4-septate, constricted at the septa, 33-37x14-16 $\mu \mathrm{m}$.

The similar $A$. kakachiana Hosag. is known on Vaccinium leschenaultii var. zeylanicum (Ericaceae) from the southern Western Ghats of peninsular India. Contrasting with A. kakachiana, has 4-septate ascospores (Hosagoudar, 1996).

\section{The genus Appendiculella}

Appendiculella Hohn. in Sitz. K. Akad. Wiss. Wien, Math.-naturw. KI. 128: 556, 1919.

Irene Stev., Ann. Mycol. 25: 420, 1927 (non Irene Theiss. \& Sydow, 1917).

Mycelium superficial, brown, septate, branched, appressoriate. Perithecia globose, discrete, \pm ostiolate, larviform and striated appendages present; asci 2-4 spored; ascospores brown 3-4 septate.

Type: A. calostroma (Desm.) Hohn.

Appendiculella calostroma (Desm.) Hohnel in Sitzb. K.Akad. Wissen. Wien. Math. Naturw. KI. 138:556, 1919; Kapoor, Indian Phytopathol. 20: 151, 1967; Kar \& Maity, Norw. J. Bot. 19: 248, 1972; Hosag., Meliolales of India, p. 77, 1996

Meliola calostroma (Desm.) Hohnel, Ann. Mycol.

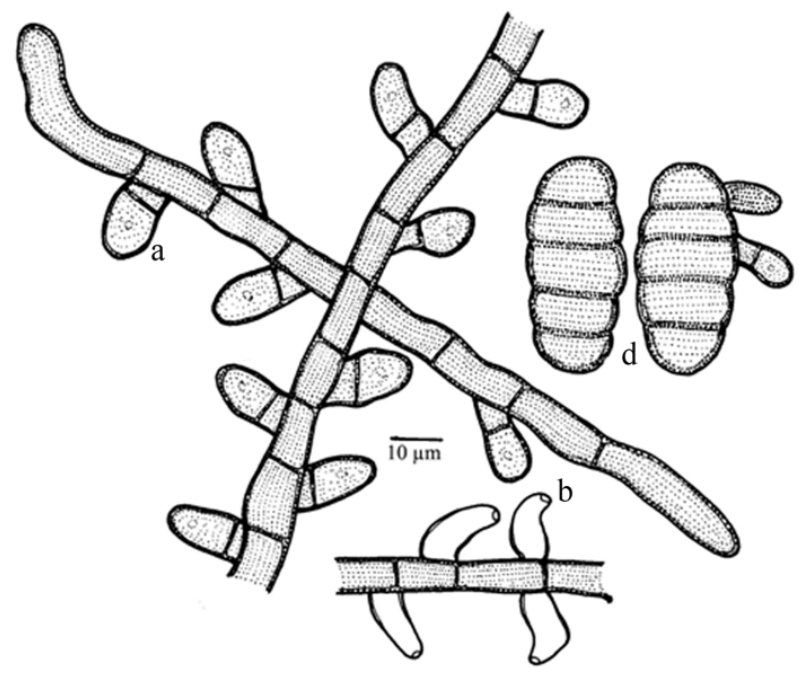

Figure 5. Amazonia syzygii

$a$-Appressorium; $\mathbf{b}$ - Phialide; $\mathbf{d}$ - Ascospores

\section{5:363, 1917.}

Irene calostroma (Desm.) Hohnel, Ann. Mycol. 16:213, 1918.

Meliola rubicola Henn., Hedwigia 43: 140, 1904.

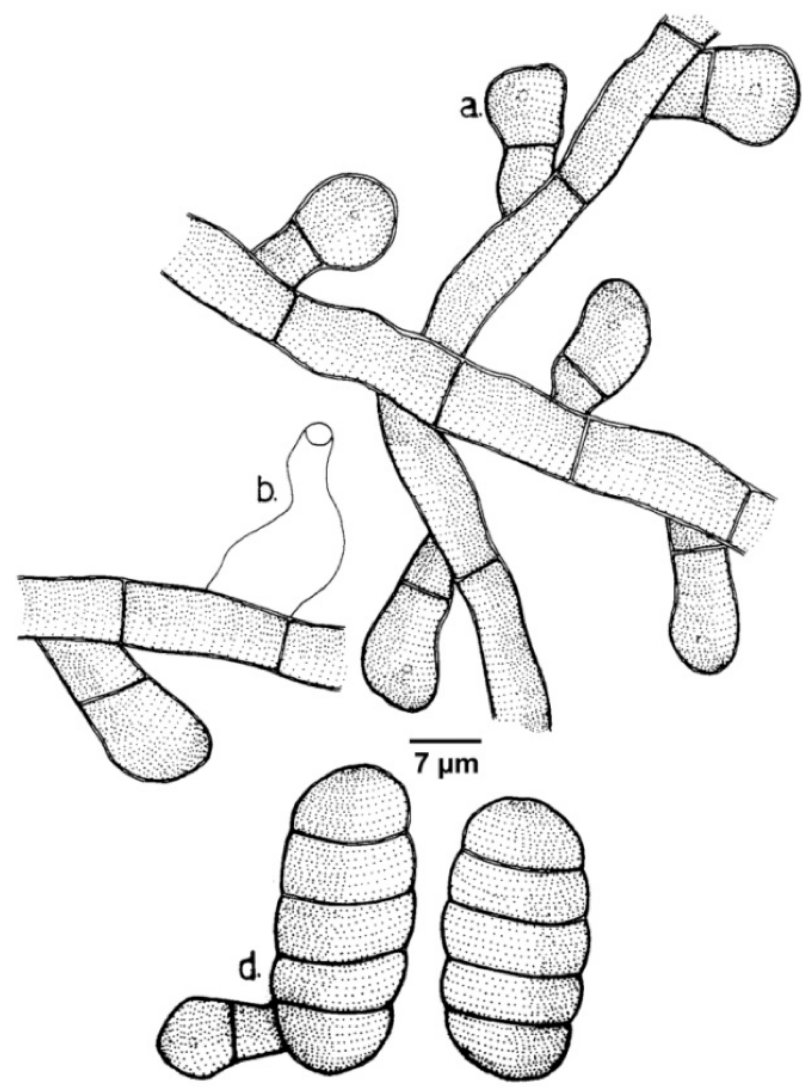

Figure 6. Amazonia vaccinii

a - Appressorium; b - Phialide; d - Ascospores 


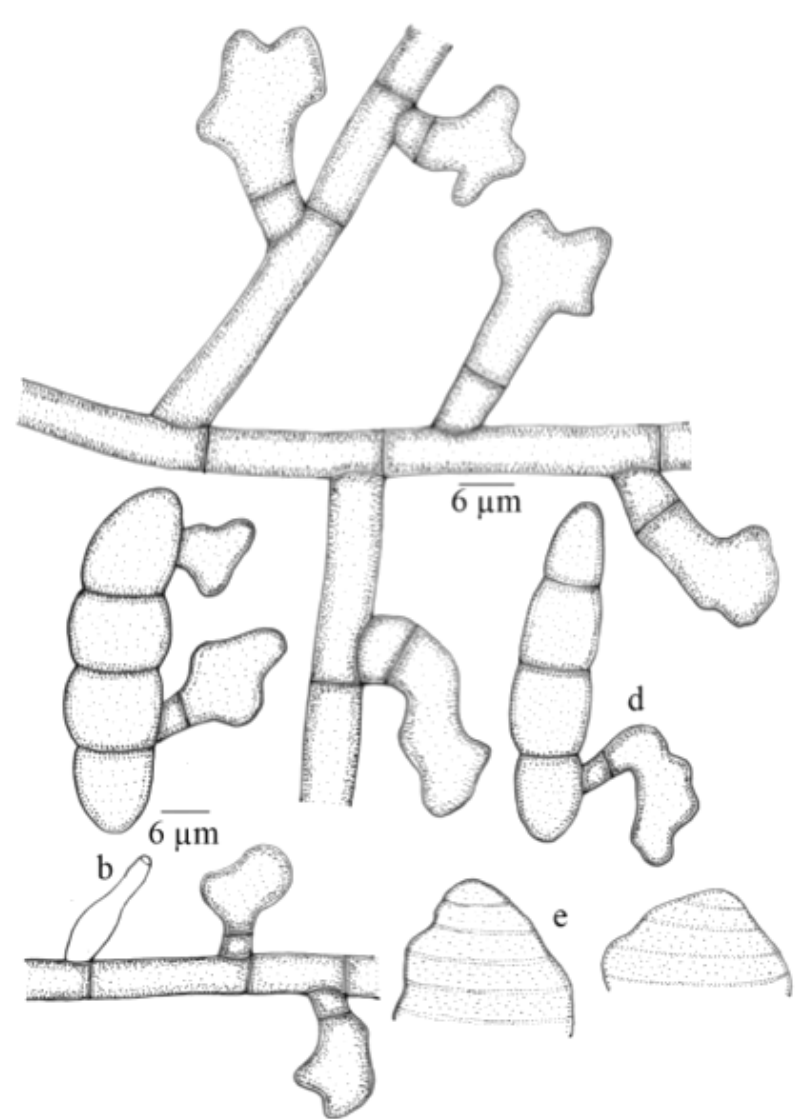

Figure 7. Appendiculella calostroma

a - Appressorium; b - Phialide; d - Ascospores; e - Perithecial appendages

Irenina rubi Stev. \& Rold. var. angulosa Stev. \& Rold., Philippine J. Sci. 56: 52, 1935.

Irenopsis crataegi Bose, Indian Phytopathol. 13:144, 1962. (Fig. 7).

Materials Examined: TBGT 5691, 23.xii.2007, on leaves of Rubus ellipticus Smith (Rosaceae), Banasuran mala, coll. M.C. Riju.

Colonies amphigenous, mostly epiphyllous, dense, crustose, up to $2 \mathrm{~mm}$ in diameter. Hyphae mostly straight, branching mostly opposite at wide angles, loosely reticulate, cells $37-50 \times 6-8 \mu \mathrm{m}$. Appressoria alternate, antrorse to spreading, 24-28 $\mu \mathrm{m}$ long; stalk cells cylindrical to cuneate, 9-12.5 $\mu \mathrm{m}$ long; head cells globose, irregularly sublobate, 12-15.5x18-25 $\mu \mathrm{m}$. Phialides mixed with appressoria, opposite to alternate, conoid to ampulliform, 18-28x9-12.5 $\mu \mathrm{m}$. Perithecia mostly grouped at the centre of the colony, up to $300 \mu \mathrm{m}$ in diameter; perithecial appendages many, cylindrical to conoid, twisted, rounded at the apex, 49-95x18-25 $\mu \mathrm{m}$; ascospores ellipsoidal, mostly curved, 3-septate, slightly constricted at the septa, 40-43.5×15-18 $\mu \mathrm{m}$.

\section{The genus Armatella}

Armatella Theiss. \& Sydow, Ann. Mycol. 13: 235, 1915; 15: 410, 1917. Arx, Fungus (Wageningen) 28: 1, 1958. Verona \& Benedek, Mycopath. Mycol. appl. 18: pl. 6, 115, 1961; Muller \& Arx, Beitr. Krypt. Der schweiz 2: 882, 1962; Katumoto, Bull. Fac. Agric. Yamaguti Univ. 13: 291, 1962; Hosag., J. Econ. Taxon. Bot. 15: 195, 1991.

Armata Yamam., Sci. Rep. Hyago Univ. Agric., Agric. Biol. Ser. 3: 89, 1958.

Artallendea Bat. \& Maia, Atas Inst. Micol. Univ. Recife 1: 221, 1960; Katumoto, Bull. Fac. Agric. Yamaguti Univ. 13: 291, 1962.

Mycelium superficial, brown, septate, branched, appressoriate. Perithecia globose, non-ostiolate or ostiolate, thick walled, verrucose. Mycelial setae, perithecial setae and perithecial appendages lacking. Asci usually 4-8 spored; ascospores typically brown (initially hyaline, later turn brown) and one septate at maturity.

Type: A. litseae (P. Henn.) Theiss. \& Sydow

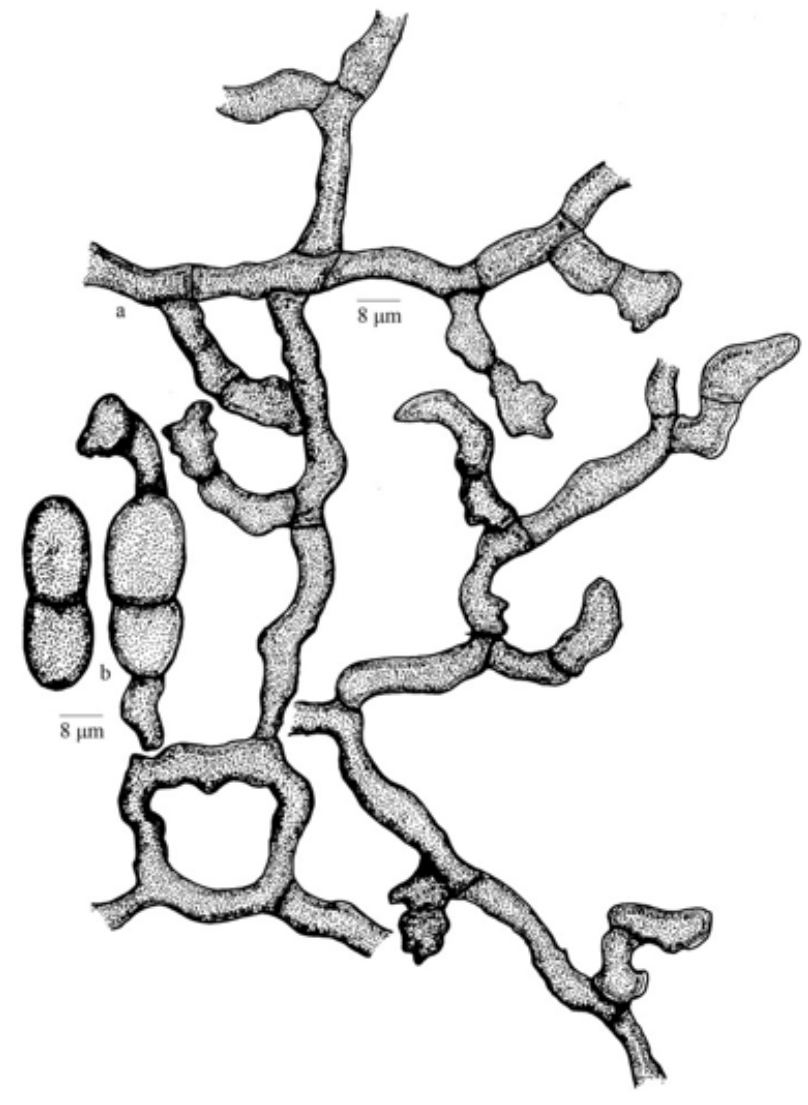

Figure 8. Armatella apollonigena

a - Appressoriate mycelium; b - Ascospores 
Armatella apollonigena Hosag. \& Sabeena, J. Threatened Taxa 5(13): 4805, 2013.

Material examined: TBGT 6536 (holotype), PBL 129 (isotype), 30.xi.2007, on leaves of Apollonias sp (Lauraceae), Padinharathara, Puducherry Kadavu, coll. M.C. Riju.

Colonies amphigenous, thin to subdense, up to $3 \mathrm{~mm}$ in diameter, confluent. Hyphae flexuous to crooked, branching irregular at acute to wide angles, form loosely and irregularly reticulate mycelial net, cells $35-45 \times 5-7$ $\mu \mathrm{m}$. Appressoria alternate, rarely opposite, straight to variously curved, antrorse to subantrorse, 12-32 $\mu \mathrm{m}$ long; stalk cells cylindrical, often gibbous, 5-12 $\mu \mathrm{m}$ long; head cells ovate, oblong, straight to curved, mostly entire, but rarely sinuate, 7-20x7-12 $\mu \mathrm{m}$. Perithecia scattered, up to $350 \mu \mathrm{m}$ in diameter; perithecial wall cells mammiform, up to $17 \mu \mathrm{m}$ long; ascospores oblong, uniseptate, slightly constricted at the septum, 3237x10-12 $\mu \mathrm{m}$, wall smooth.

There are 16 species of the genus Armatella are known on the members of family Lauraceae. Of these, Armatella apolloniadis (Hosagoudar et al. 2005) is known on this host from the Western Ghats region of Kerala State. However, Armatella apollonigena differs from Armatella apaolloniadis Hosag. et al. in having unicellular basal cells of the appressoria, entire to sublobate and globose to oblong head cells in contrast to globose angular to sublobate ones (Hosagoudar 2008). Ascospores germinated by producing appressoria from the apical portion of each cells but no symptom of collapsing cells.

Armatella balakrishnanii Hosag., J. Econ. Taxon. Bot. 15: 196, 1991; Hosag., Sarbhoy, Agarwal \& Khan, Mycotaxon 56: 348, 1995; Hosag. \& Abraham, J. Mycopathol. Res. 38: 2, 2000; J. Econ. Taxon. Bot. 25:
562, 2001; Hosag., Zoos' Print J. 21: 2323, 2006; Hosag., Meliolales of India 2:103, 2008 (Fig. 9).

Materials examined: 28.xii.2008 HClO 50580, TBGT 4495 , on leaves of Cinnamomum malabatrum (Burm.f.) Blume (Lauraceae), $16^{\text {th }}$ mile, Padinharathara, M.C. Riju; HCIO 50578, TBGT 4497 14.ii.2009, Tirunelly, coll. M.C. Riju.

Colonies hypophyllous, thin, spreading, up to $8 \mathrm{~mm}$ in diameter. Hyphae smooth walled, crooked, branching alternate to irregular at acute angles, closely reticulate, cells 9-25x4-7 $\mu \mathrm{m}$. Appressoria alternate, antrorse to reflexed, 15-115 $\mu \mathrm{m}$ long; stalk cells aseptate to several septate, straight to tortuous, 3-103 $\mu \mathrm{m}$ long; head cells globose, narrowly ovate, angular, entire, 9-13×10-12 $\mu \mathrm{m}$. Perithecia scattered, globose, verrucose, up to $115 \mu \mathrm{m}$ in diam.; ascospores ellipsoidal, mostly aseptate but few ascospores septate, cells unequal, 43-50x18-22 $\mu \mathrm{m}$.

Multiseptate basal cells, entire head of the appressoria and the ascospores not constricted at the septum are the characters of this taxon.

Armatella cinnamomicola Hansf., Reinwardtia 3: 87, 1954; Hosag. \& Goos, Mycotaxon 36: 237, 1989; Hosag., J. Econ. Taxon. Bot. 15: 197, 1991; Hosag., Sarbhoy, Agarwal \& Khan, Mycotaxon 56: 349, 1995; Hosag. \& Balakr., J. Econ. Taxon. Bot. 19: 363, 1995; Hosag. \& Abraham, J. Mycopathol. Res. 38: 2, 2000; J. Econ. Taxon. Bot. 25: 563, 2001; Hosag., J. Econ. Taxon. Bot. 29: 435, 2005; Zoos' Print J. 21: 2323, 2006; Meliolales of India 2:107, 2008 (Fig. 10).

Materials examined: $\mathrm{HClO}$ 45293, TBGT 1331 16.x.2001, on leaves of Cinnamomum malabatrum (Burm.f.) Blume (Lauraceae), Wayanad, coll. M. Kamarudeen; HClO 49648, TBGT 3890, 17.ix.2008, Periya, coll. M. Harish \& P.J. Robin; HClO 49205, TBGT 3444, 14.ii.2009, Tirunelly, coll. Jacob Thomas et al.;

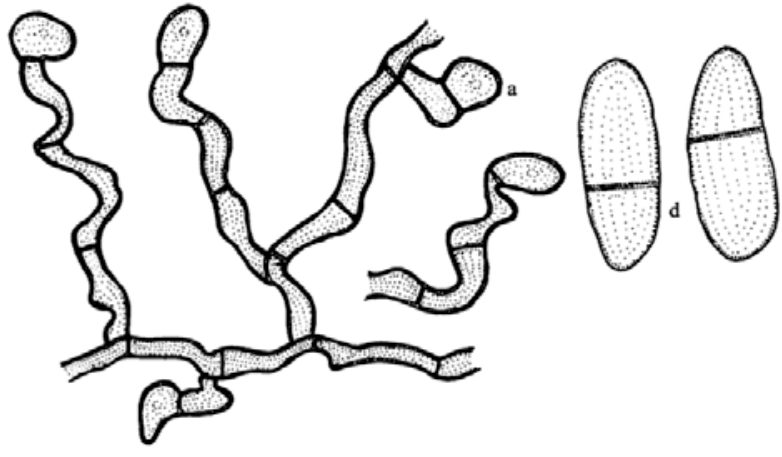

Figure 9. Armatella balakrishnanii a - Appressoriate mycelium; $d$ - Ascospores

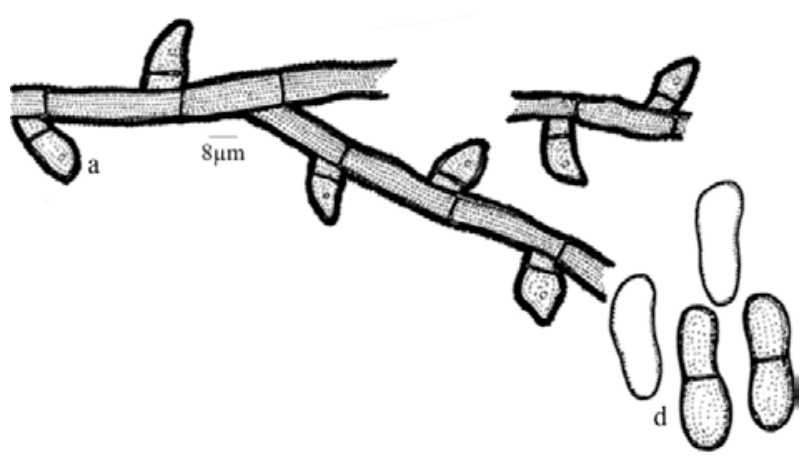

Figure 10. Armatella cinnamomicola

a - Appressoria,; - Ascospores 
HCIO 49813, TBGT 3965, 16.ii.2009, Periya, coll. Gireesh et al.

Colonies epiphyllous, thin to subdense, crustose, up to $4 \mathrm{~mm}$ in diameter, confluent. Hyphae crenulated, straight to substraight, branching alternate to irregular at acute angles, loosely reticulate, cells $15-40 \times 6-9$ $\mu \mathrm{m}$, outer wall crenulated except the growing tips. Appressoria alternate, antrorse to spreading, straight to curved, 16-23 $\mathrm{mm}$ long; stalk cells cylindrical to cuneate, 4-6 $\mu \mathrm{m}$ long; head cells ovate, broadly conoid, rarely globose, $13-20 \times 8-13 \mu \mathrm{m}$, outer wall crenulated. Perithecia seated on tortuous ex appressoriate mycelia, scattered, globose, up to $215 \mu \mathrm{m}$ in diameter; ascospores initially hyaline, continuous, oblong with rounded ends, dumbbell shaped, mature ascospores 1-septate with mostly equal cells, cinnamon brown to dark brown, 23-30x10-13 $\mu \mathrm{m}$, germinating cells enlarge to form appressoria and the other one empties and collapses.

External surface of both hyphae and appressoria are crenulated.

Armatella cryptocaryae Hosag., J. Econ. Taxon. Bot. 15: 198, 1991; Sarbhoy, Agarwal \& Khan, Mycotaxon 56: 350, 1995; Hosag. C.K. Biju \& Abraham, J. Econ. Taxon. Bot. 25: 298, 2001; Hosag., J. Econ. Taxon. Bot. 29: 436, 2005; Hosag., Zoos' Print J. 21: 2323, 2006; Hosag., Meliolales of India 2: 108, 2008 (Fig. 11).

Materials examined: HClO 44698, TBGT 979, 6.ii.2002, on leaves of Litsea coriacea (Heyne ex Meissner) Hook.f. (Lauraceae), Chandanathode, coll. M. Kamarudeen; HClO 45097, TBGT 1152, 21.iv.2003, L. deccanensis Gamble, Periya, coll. G. Rajkumar \& P. A. Jose; HClO 49814, TBGT 3966, 16.ii.2009, Phoebe sp. (Lauraceae), TBGT 6267, 5.xi.2009, Gurukulam Botanic Garden, coll. A. Sabeena \& M.C. Riju.

Colonies epiphyllous, thin, crustose, up to $2 \mathrm{~mm}$ in diameter. Hyphae smooth walled, straight to substraight,

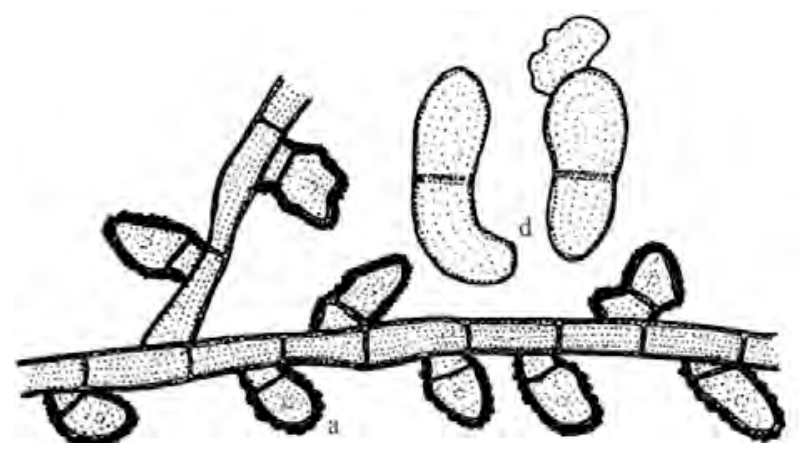

Figure 11. Armatella cryptocaryae

a - Appressoriate mycelium; d - Ascospores branching alternate to irregular at acute angles, loosely reticulate, cells $12-19 \times 4-7 \mu \mathrm{m}$. Appressoria alternate, antrorse to spreading, 15-25 $\mu \mathrm{m}$ long; stalk cells single celled, cylindrical to cuneate, 3-7 $\mu \mathrm{m}$ long; head cells ovoid, conoid, slightly angular, entire, outer wall crenulated, 12-19x9-13 $\mu \mathrm{m}$. Perithecia scattered, seated on exappressoriate mycelium, up to $140 \mu \mathrm{m}$ in diameter; ascospores ellipsoidal, 1-septate, brown, 3137x12-13 $\mu \mathrm{m}$.

Only apical cells of the appressoria are crenulated.

Armatella katumotoi Hosag., Sydowia 40: 113, 1987; J. Econ. Taxon. Bot. 15: 199, 1991; Hosag. \& Abraham, J. Econ. Taxon. Bot. 25: 564, 2001; Hosag., J. Econ. Taxon. Bot.29: 436, 2005; Meliolales of India 2:111, 2008 (Fig. 12).

Materials examined: $\mathrm{HClO}$ 44273, TBGT 678, 9.i.2002, on leaves of Persea macrantha (Nees) Kosteerm. (Machilus macrantha Nees) (Lauraceae), Wayanad, coll. M. Kamarudeen; HCIO 44811, TBGT 1048, 27.xii.2002, Persea sp., Periya, coll. M. Kamarudeen \& P.A. Jose; $\mathrm{HClO}$ 49868, TBGT 4020, 16.ii.2009, Litsea sp. (Lauraceae), Periya, coll. Harish et al.

Colonies hypophyllous, thin, scattered, diffused, up to $5 \mathrm{~mm}$ in diameter. Hyphae smooth walled, flexuous to crooked, branching alternate to irregular at acute angles, loosely reticulate, cells $15-46 \times 4-6 \mu \mathrm{m}$. Appressoria alternate, variously curved, 18-46 $\mu \mathrm{m}$ long; stalk cells aseptate to several septate, flexuous to crooked, 6-40.5 $\mu \mathrm{m}$ long; head cells ovate to globose, entire to stellately lobate, 6-13x12-16 $\mu \mathrm{m}$. Perithecia scattered, seated on exappressoriate mycelium, verrucose, up to $217 \mu \mathrm{m}$ in diameter; ascospores brown, ellipsoidal, 1-septate, 28-31x12-15 $\mu \mathrm{m}$.

Multiseptate basal cells and lobate head cells of the appressoria distinguishes this species.

Armatella litseae (P. Henn.) Theiss. \& Sydow, Ann. Mycol. 13: 235, 1915; Hansf. \& Thirum., Farlowia 3: 286, 1984; Kar \& Maity, Norway J. Bot. 19: 250, 1972; Hosag. J. Econ. Taxon. Bot. 15: 200, 1991; Yanxing, Yousheng, Bin \& Guangzheng, Flora Fungorum Sinicorum 4: 48, 1996; Hosag. \& Abraham, J. Econ. Taxon. Bot. 25: 565, 2001; Hosag., C.K. Biju \& Abraham, J. Mycopathol. Res. 40: 192, 2002; Hosag., J. Econ. Taxon. Bot. 29: 436, 2005; Zoos' Print J. 21: 2324, 2006; Hosag., Meliolales of India 2:113, 2008.

Dimerosporium litseae P. Henn., Bot. Jahrb. Syst. 32: 42, 1903.

Artallendea cinnamomi Bat. \& Maia, Atas Inst. Micol. Recife 1: 222, 1960 (Fig. 13). 
Materials examined: TBGT 6176, 4.xi.2009, on leaves of Cinnamomum malabathrum (Burm.f.) Blume (Lauraceae), Padinharathara, coll. A. Sabeena \& M.C. Riju.

Colonies hypophyllous, thin, crustaceous, up to $6 \mathrm{~mm}$ in diameter, rarely confluent. Hyphae smooth walled, substraight to undulate, branching mostly alternate at wide angles, loosely reticulate, cells 1630x6-8 $\mu \mathrm{m}$. Appressoria alternate, about 5\% opposite, antrorse, straight to curved, 15-20 $\mu \mathrm{m}$ long; stalk cells single celled, cylindrical to cuneate, 3-6 $\mu \mathrm{m}$ long; head cells globose, stellately sublobate, 11-13×15-16 $\mu \mathrm{m}$. Perithecia seated on tortuous exappressoriate mycelium, scattered, verrucose, up to $300 \mathrm{~mm}$ in diameter; ascospores initially hyaline and continuous, oblong with rounded ends, dumb bell shaped, matured spores 1-septate with unequal cells, 30-36x11-13 $\mu \mathrm{m}$. During germination, one cell of the spore enlarges to produce appressorium and the other empties into it and collapses.

Globose and lobate head cells of the appressoria are the characters of this taxon.

\section{The genus Asteridiella}

Asteridiella McAlpine, Proc. Linn. Soc. New South Wales, p. 38, 1897.

Irene Theiss. \& Sydow, Ann. Mycol. 15: 194, 1917 (non Irene Stev., 1927).

Irenina Stev., Ann. Mycol. 25: 411, 1927.

Mycelium superficial, brown, septate, branched,

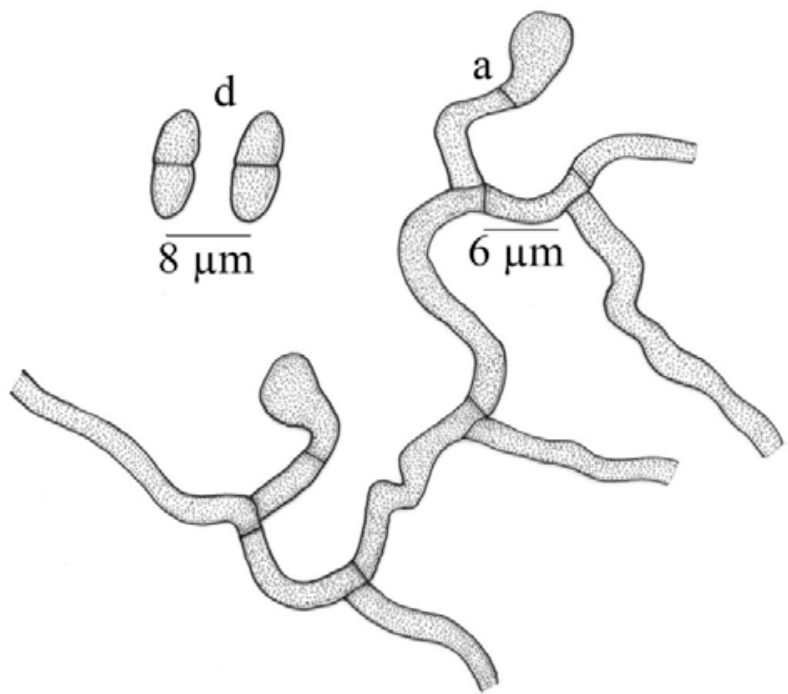

Figure 12. Armatella katumotoi

a - Appressoriate mycelium; d - Ascospores appressoriate, mycelial setae absent. Perithecia globose, discrete, \pm ostiolate, without setae and appendages, conoid cells projecting and are non-striated; asci 2-4spored, evanescent; ascospores brown, 3-4 septate.

Type: A. solani McAlpine

Asteridiella americana Hansf., Sydowia 10:51, 1957; Sydowia 2:529. 1961; Patil \& Thite, J. Shivaji Univ.18:220, 1978; Hosag., Nova Hedwigia 47:537, 1988; Meliolales of India, p.79, 1996 (Fig. 14).

Materials Examined: $\mathrm{HClO}$ 49641, TBGT 3883, 19.ii.2008, on leaves of Linoceira malabarica Wall. ex G. Don (Oleaceae), Periya, coll. M. Harish \& P.J. Robin.

Colonies epiphyllous, dense, crustose, up to $2 \mathrm{~mm}$ in diameter. Hyphae substraight to undulate, branching opposite to irregular at acute angles, loosely to closely reticulate, cells 15-34x6-9 $\mu \mathrm{m}$. Appressoria alternate, mostly antrorse, rarely recurved, 30-37 $\mu \mathrm{m}$ long; stalk cells cylindrical to cuneate, 6-9 $\mu \mathrm{m}$ long; head cells ovate, globose, deeply and irregularly lobate, 2428x18-24 $\mu \mathrm{m}$. Phialides mixed with appressoria, conoid to ampulliform, 18-31x9-12.5 $\mu \mathrm{m}$. Perithecia scattered to loosely aggregated, up to $155 \mu \mathrm{m}$ in diameter; perithecial cells conoid to mammiform, up to $22 \mu \mathrm{m}$ long; ascospores obovoidal, 4-septate, constricted at the septa, 40-43.5x15-18.6 $\mu \mathrm{m}$.

Ascospores in the present collection are considerably smaller as against reported (43-49×20-23 $\mu \mathrm{m}$ ) (Hansford 1957).

Asteridiella combreti (Stev.) Hansf. var. leonensis Hansf., Sydowia Beih. 20: 160, 1961; Hosag. \& Goos,

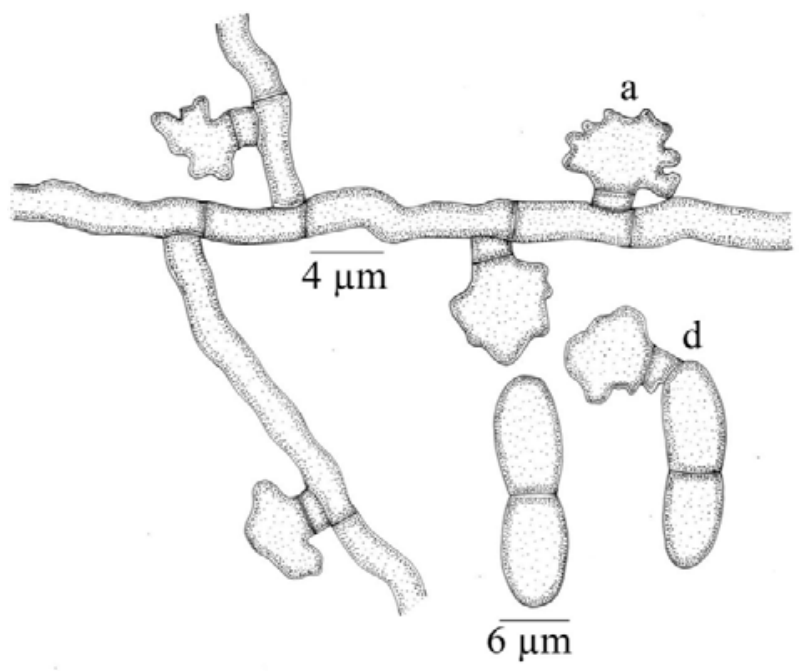

Figure 13. Armatella litseae

a - Appressoriate mycelium; d - Ascospores 
Mycotaxon 36: 238, 1989; Hosag., Meliolales of India, p 83, 1996 (Fig. 15).

Materials examined: $\mathrm{HClO} 50861, \mathrm{TBGT}$ 4778; $\mathrm{HClO}$ 50863, TBGT 4780; HClO 50867, TBGT 4784; HCIO 50869, TBGT 4786, 5.xi.2009, on leaves of Terminalia sp. (Combretaceae), Gurukulam Botanic Garden, Periya, coll. A. Sabeena \& M.C. Riju; HClO 45253, TBGT 1291, 7.iii.2001, Combretaceae member, Periya, coll.

\section{G.Rajkumar \& P.A. Jose}

Colonies epiphyllous, subdense, up to $4 \mathrm{~mm}$ in diameter, confluent. Hyphae substraight to undulate, branching alternate to opposite at wide angles, loosely reticulate, cells $21-34 \times 6-8 \mu \mathrm{m}$. Appressoria alternate, straight, antrorse, 19-27 $\mu \mathrm{m}$ long; stalk cells cylindrical to cuneate, 6-8 $\mu \mathrm{m}$ long; head cells globose, entire, angular, 11-18x11-16 $\mu \mathrm{m}$. Phialides borne on a separate mycelial branch, opposite, ampulliform, 1325x4-8 $\mu \mathrm{m}$, tip twisted and variously bent. Perithecia scattered, verrucose, up to $185 \mu \mathrm{m}$ in diam.; perithecial cells mammiform, 8-11 $\mu \mathrm{m}$ long; ascospores obovoidal, 4-septate, constricted at the septa, 35-42x11-18 $\mu \mathrm{m}$.

Perithecia were widely opened at the centre

Asteridiella elaeocarpi-tuberculati Hosag., Crypt. Bot. 2/3: 183, 1987; Hosag., Meliolales of India, p.87, 1996(Fig. 16).

Materials examined: $\mathrm{HClO}$ 48035, TBGT 2818, 7.xii.2006, on leaves of Elaeocarpus tuberculatus Roxb. (Elaeocarpaceae), Mylattumala, coll. M. Harish V. Gireesh Kumar \& K. Anilkumar.

Colonies epiphyllous, subdense, up to $2 \mathrm{~mm}$ in diameter, confluent. Hyphae substraight to undulate,

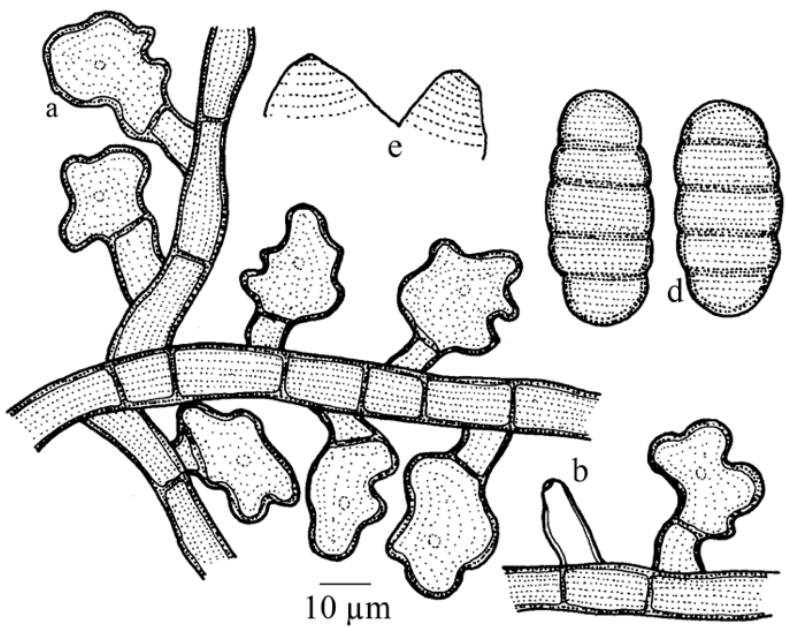

Figure 14. Asteridiella americana

a - Appressorium; b - Phialide; d - Ascospores; e - Perithecial wall cells branching opposite at wide angles, loosely reticulate, cells 31-36x4-6.5 $\mu \mathrm{m}$. Appressoria alternate, straight to curved, antrorse, 18-28 $\mu \mathrm{m}$ long; stalk cells cylindrical to cuneate, 6-9.5 $\mathrm{mm}$ long; head cells globose, ovate, truncate at the apex, entire, 16-18.5x12-15.5 $\mu \mathrm{m}$. Phialides borne on a separate mycelial branch, mostly opposite, ampulliform, 18-25x6-9.5 $\mu \mathrm{m}$. Perithecia scattered, seated on exappressoriate mycelia, globose, up to $124 \mu \mathrm{m}$ in diameter; perithecial cells conoid, curved, acute at the apex, up to $15 \mu \mathrm{m}$ long; ascospores obovoidal, 4-septate, slightly constricted at the septa, 40-46.5x15-18.5 $\mu \mathrm{m}$.

Asteridiella formosensis (Yamam.) Hansf., Sydowia 10: 48, 1957; Sydowia Beih. 2: 686, 1961; Hosag. \& Goos, Mycotaxon 36: 240, 1989; 42: 128, 1991; Hosag., Kaveriappa, Raghu \& Goos, Mycotaxon 51:109, 1994; Hosag, Meliolales of India, p. 90, 1996.

Irene formosensis Yamam., Trans. Nat. Hist. Soc. Taiwan 31: 15, 1941.

Meliola formosensis (Yamam.) Cif., Mycopathologia

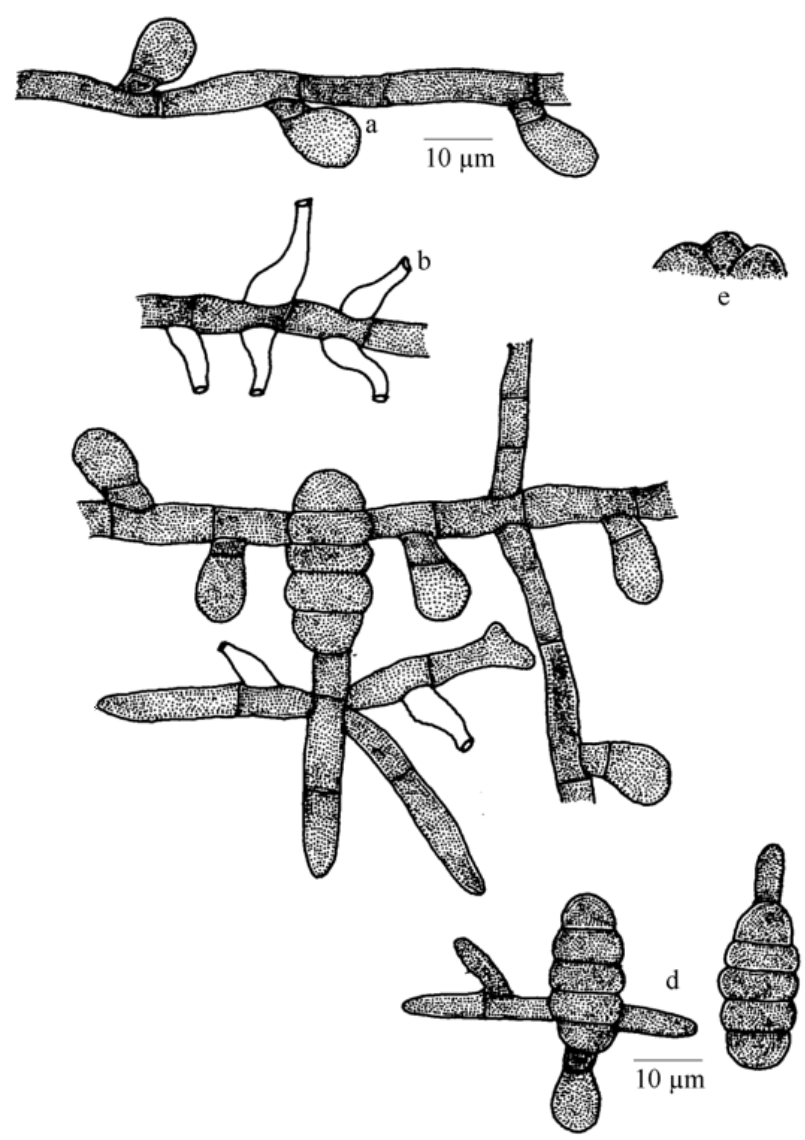

Figure 15. Asteridiella combreti var. leonensis

a - Appressorium; b - Phialide; $d$ - Ascospores; e - Perithecial wall cells 


\section{7: 87, 1954 (non Yamam., 1941). (Fig. 17).}

Materials examined: HCIO 48178, TBGT 2914, 10.xi.2010, on leaves of Callicarpa sp. (Verbenaceae), $16^{\text {th }}$ mile, Padinharathara, coll. M.C. Riju; HCIO 50831, TBGT 4748, 4.xi.2009, Callicarpa arborea, Padiharathara, coll. M.C. Riju \& A. Sabeena.

Colonies epiphyllous, thin, smooth, up to $4 \mathrm{~mm}$ in diameter, confluent. Hyphae substraight to undulate, branching alternate at wide angles, loosely reticulate, cells $28-43 \times 6-8 \mu \mathrm{m}$. Appressoria alternate, straight to curved, antrorse, spreading, 24-36 $\mu \mathrm{m}$ long; stalk cells cuneate to cylindrical, 8-12 $\mu \mathrm{m}$ long; head cells ovate, clavate, entire to sublobate, 17-23x11-16 $\mu \mathrm{m}$. Phialides born on a separate mycelial branch, mostly opposite, rarely unilateral, often two phialides borne very closely on a single mycelial cell, ampulliform, 10-18x6-8 $\mu \mathrm{m}$. Perithecia scattered, up to $216 \mu \mathrm{m}$ in diameter; perithecial wall cells obtusely conoid, 6-10 $\mu \mathrm{m}$ long; ascospores ellipsoidal, 4-septate, constricted at the septa, middle cell slightly larger, 41-46×20-26 $\mu \mathrm{m}$.

These collections slightly differed from the species description in having smaller perithecial cells.

Asteridiella glycosmidis Hosag., C.K. Biju \& Abraham, Nova Hedwigia 80: 478, 2005; Hosag., Meliolales of India 2: 134, 2008 (Fig. 18).

Materials examined: $\mathrm{HClO}$ 43607, TBGT 292, 16.iv.1999, on leaves of Glycosmis pentaphylla (Retz.) DC. (G. cochinchinensis sensu Gamble) (Rutaceae), on the way to Manandawadi, coll. C.K. Biju; HClO 44628, TBGT 910, 23.ix.2002, Tirunelly, coll. K. Vijayakumar.

Colonies amphigenous, crustose, up to $1 \mathrm{~mm}$ diameter, rarely confluent. Hyphae substraight,

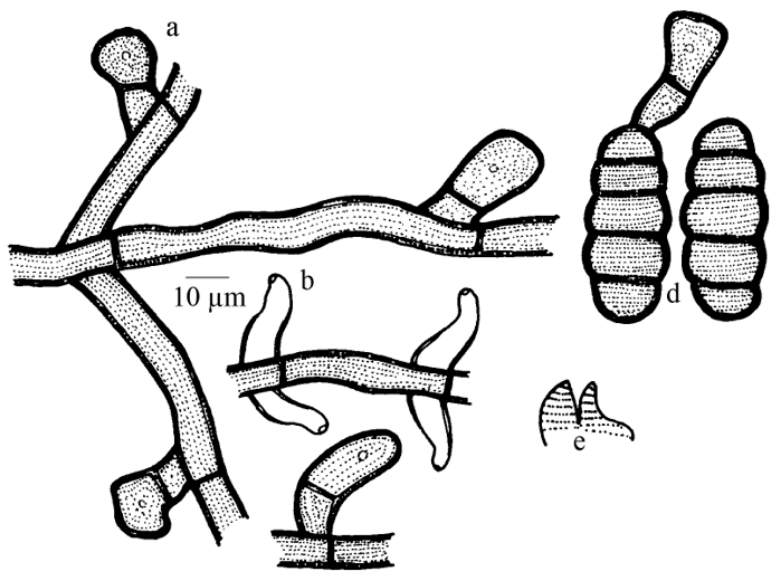

Figure 16. Asteridiella elaeocarpi-tuberculati a - Appressorium; b - Phialide; d - Ascospores; e - Perithecial wall cells

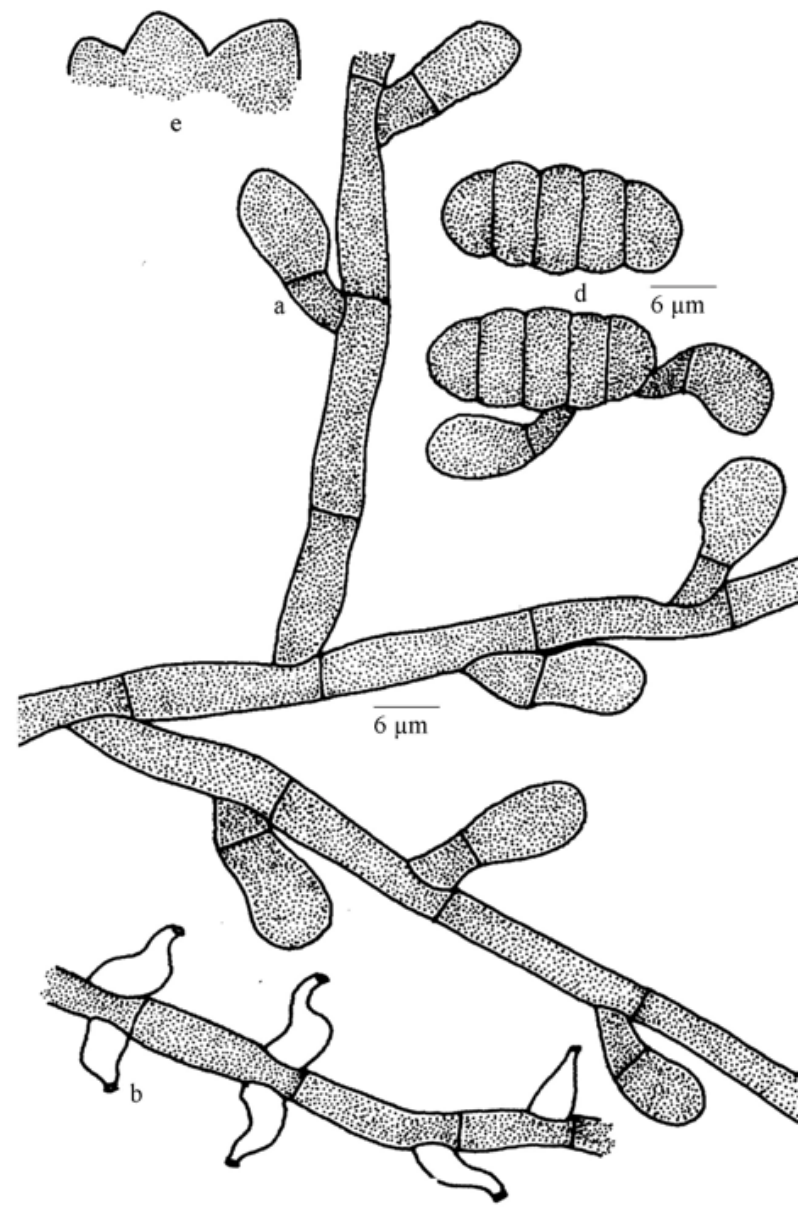

Figure 17. Asteridiella formosensis

a - Appressorium; b - Phialide; d - Ascospores; e - Perithecial wall cells

branching in irregular position at acute angles, loosely to closely reticulate, sometimes form solid mycelial mat, cells 9-15x3-5 $\mu \mathrm{m}$. Appressoria alternate, antrorse to closely antrorse, 14-23 $\mu \mathrm{m}$ long; stalk cells cylindrical to cuneate, 4-10 $\mu \mathrm{m}$ long; head cells straight to curved, ovate, cylindrical to globose, rarely entire, sublobate to deeply and irregularly lobate, 14-23x7-9 $\mu \mathrm{m}$. Phialides mixed with appressoria, numerous in some colonies, alternate to opposite, ampulliform, 14-23x7-9 $\mu \mathrm{m}$. Perithecia not matured, up to $100 \mu \mathrm{m}$ diameter; ascospores oblong to cylindrical, 4-septate, constricted at the septa, 38-42x14-16 $\mu \mathrm{m}$.

The colonies of this taxon were mixed with the colonies of Meliola cadigensis Yates. var. glycosmidis (Kapoor) Hosag. Asteridiella glycosmidis is close to $A$. trachylaena (Sydow) Hansf. in having lobate head cells of the appressoria but differs from it in having shorter appressoria and smaller ascospores (Hansford 1961). It also differs from $A$. acronychiae $\mathrm{Hu}$ in having lobate 
head cells of appressoria and smaller ascospores (Hu et al. 1996, 1999).

Asteridiella micheliae Hosag., Archana \& Agarwal, Indian Phytopath. 60: 237, 2007; Hosag., Meliolales of India 2: 139, 2008 (Fig. 19).

Material examined: HCIO 51047, TBGT 4964, 27.xii.2008, on leaves of Michelia champaka L. (Magnoliaceae), Puthuserrykadavu, Wayanad, coll. M.C. Riju; HClO 49973, HClO 47370, TBGT 4125, 14.iii.2007, $16^{\text {th }}$ mile, Padinharathara, coll. M.C. Riju.

Colonies epiphyllous, thin, up to $4 \mathrm{~mm}$ in diameter. Hyphae substraight, branching alternate to opposite at wide angles, loosely reticulate, cells $19-22 \times 3-5 \mu \mathrm{m}$. Appressoria alternate, antrorse, mostly straight, 13-14 $\mu \mathrm{m}$ long; stalk cells cylindrical to cuneate, 5-6 $\mu \mathrm{m}$ long; head cells ovate, oblong, angular to sublobate, 8-10x6$8 \mu \mathrm{m}$. Phialides mixed with appressoria, alternate to opposite, ampulliform, 12-13x4-5 $\mu \mathrm{m}$. Perithecia scattered, globose, up to $145 \mu \mathrm{m}$ in diameter; perithecial wall cells mammiform, obtuse at the tip, up to $20 \mu \mathrm{m}$ long; ascospores obovoidal to slightly cylindrical,

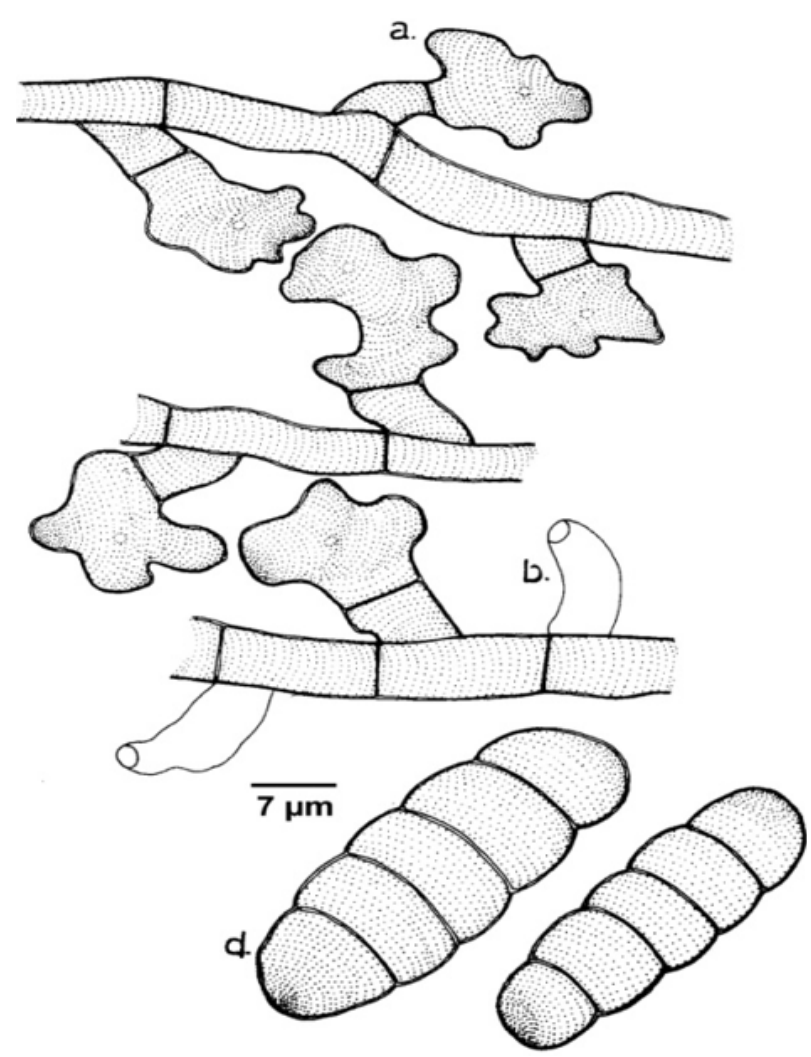

Figure 18. Asteridiella glycosmidis a - Appressorium; b - Phialide; d - Ascospores

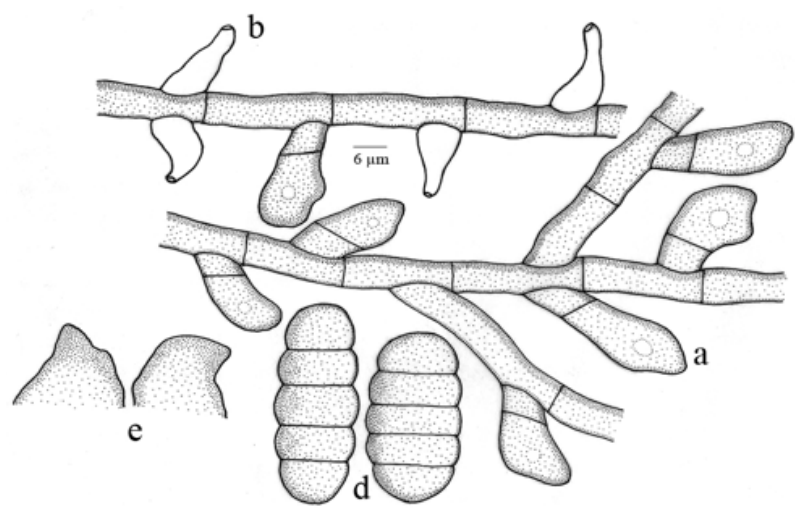

Figure 19. Asteridiella micheliae

a - Appressorium; b - Phialide; $d$ - Ascospores; e - Perithecial wall cells

4-septate, constricted at the septa, 20-29×10-12 $\mu \mathrm{m}$.

It differs from Asteridiella crustacea (Speg.) Hansf. and Asteridiella werdernannii Hansf. in having distinctly smaller ascospores and shorter appressoria (Hansford, 1961).

\section{Asteridiella millettiicola sp. nov.}

V.B. Hosagoudar \& G.R. Archana (Fig. 20).

(urn:Isid:indexfungorum.org:names: 809136)

Material examined: $\mathrm{HClO} 50888$ (holotype), TBGT 4805 (isotype), 14.ii.2009, on leaves of Millettia sp. (Fabaceae), Tirunelly, coll. Girish Kumar et al.

Colonies hypophyllous, subdense, up to $3 \mathrm{~mm}$ in diameter, confluent. Hyphae substraight to flexuous, branching mostly opposite at acute to wide angles, loosely to closely reticulate, cells $12-31 \times 4-6.5 \mu \mathrm{m}$. Appressoria alternate, straight to curved, antrorse to subantrorse, 20-37 $\mu \mathrm{m}$ long; stalk cells, 1-2 septate, cylindrical to

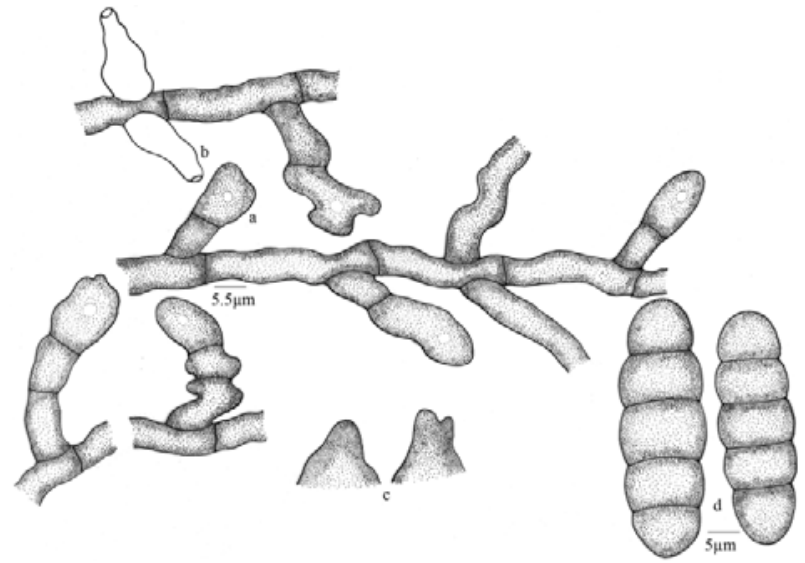

Figure 20. Asteridiella millettiicola sp. nov.

a - Appressorium; b - Phialide; c - Perithecial wall cells; d - Ascospores 
cuneate in case of unicellular, while, straight, crooked to variously curved in case of multicellular, 4-27.5 $\mu \mathrm{m}$ long; head cells straight to variously curved, ovate, oblong, entire to angular, sublobate to lobate, 16-21x9-16 $\mu \mathrm{m}$. Phialides mixed with appressoria, opposite to unilateral, ampulliform, 12-24x6-8 $\mu \mathrm{m}$. Perithecia scattered, up to $112 \mu \mathrm{m}$ in diameter, perithecial wall cells conoid, mammiform, up to $16 \mu \mathrm{m}$ long; ascospores obovoidal, 4-septate, slightly constricted at the septa, 40-43×17-21 $\mu \mathrm{m}$.

Etymology: Named after the host genus.

This species differs from Asteridiella millettiae Hosag. et al. in having straight to flexuous hyphae; having 1-2 septate stalk cells of the appressoria (Hosagoudar 2008).

Asteridiella phaulopsidis Hosag., Zoos' Print J. 21: 2462, 2006; Hosag., Meliolales of India 2: 144, 2008 (Fig. 21).

Materials examined: $\mathrm{HClO}$ 50607, TBGT 4524; $\mathrm{HClO}$ 50609,TBGT 4526, 5.xi.2009, on leaves of Phaulopsis micranthus (Acanthaceae), Gurukulam Botanical Garden, Periya, coll. M.C. Riju \& A. Sabeena.

Colonies epiphyllous, dense, up to $1 \mathrm{~mm}$ in diameter, often confluent. Hyphae substraight to flexuous, branching alternate to irregular at acute angles, loosely to closely reticulate, cells $16-25 \times 5-7 \mu \mathrm{m}$. Appressoria alternate, antrorse to closely antrorse, 16-20 $\mu \mathrm{m}$ long; stalk cells cylindrical to cuneate, 3-10 $\mu \mathrm{m}$ long; head cells ovate to globose, entire, angular to stellately lobate, 9-12x9-11 $\mu \mathrm{m}$. Phialides mixed with appressoria, alternate to opposite, ampulliform, 16-19x5-7 $\mu \mathrm{m}$. Perithecia scattered to loosely grouped, globose, up to $125 \mu \mathrm{m}$ in diameter; perithecial wall cells conoid, projected, up to $13 \mu \mathrm{m}$ long; ascospores oblong to ellipsoidal, 4-septate, slightly constricted at the septa, 30-36x11-13 $\mu \mathrm{m}$.

Based on the Beeli formula 3101. 3220, Asteridiella phaulopsidis can be compared with $A$. thumbergiaechrysopsidis (Hansf. \& Deight.) Hansf. known on Thunbergia chrysops from Sierra Leone but differs from it in having shorter appressoria with stellately lobate head cells and perithecial wall cells are conoid in contrast to mammiform (Hansford 1961).

Asteridialla scolopiae Hosag. Meliolales of India, p104, 1996 (Fig. 22).

Materials examined: $\mathrm{HClO}$ 43609, TBGT 294, 14.iv.1999, on leaves of Scolopia crenata (Wight \& Arn.) Clos (Flacourtiaceae), Chembra peak, coll. C.K. Biju.

Colonies amphigenous, dense, crustose, up to $3 \mathrm{~mm}$ in diameter, scattered, rarely confluent. Hyphae straight to substraight, branching mostly opposite at acute angles, loosely to closely reticulate, cells $12-15.5 \times 5-9$ $\mu \mathrm{m}$. Appressoria alternate, about $1 \%$ opposite in loosely reticulated colonies while about $5 \%$ opposite in densely reticulated colonies, antrorse, 15-28 $\mu \mathrm{m}$ long; stalk cells cuneate, 3-12.5 $\mu \mathrm{m}$ long; head cells globose, ovate, oblong, mostly entire, rarely angular, 12-15.5x9-12.5 $\mu \mathrm{m}$. Phialides mixed with appressoria, opposite to alternate, ampulliform, 15-18.8x5-7 $\mu \mathrm{m}$. Perithecia scattered, up to $186 \mu \mathrm{m}$ in diameter; perithecial cells mammiform, straight to curved, up to $22 \mu \mathrm{m}$ long; ascospores obovoidal, 4-septate, strongly constricted at the septa, 43-47x17-19 $\mu \mathrm{m}$.

This species is close to Asteridiella deightonii Hansf. in having few opposite appressoria but differs from it in having substraight hyphae, entire to angular head cells of appressoria and smaller ascospores.

Asteridiella symploci-microphyllae Hosag. \& Sabeena, Bioscience Discovery 2(1): 117, 2011; Hosag., J. Threatened Taxa 5(6): 4008, 2013 (Fig. 23).

Material examined: $\mathrm{HClO}$ 50636, TBGT 4553, 1.xi.2007, on leaves of Symplocos macrophylla Wallich ex DC. (Symplocaceae), Banasuramala, coll. A. Chandraprabha.

Colonies amphigenous, subdense, up to $3 \mathrm{~mm}$ in diameter, confluent. Hyphae straight to substraight, branching opposite to unilateral at acute to wide angles, loosely to closely reticulate, cells $17-32 \times 6-8$ $\mu \mathrm{m}$. Appressoria alternate to unilateral, antrorse to subantrorse, 15-20 $\mu \mathrm{m}$ long; stalk cells cylindrical to cuneate, 2-7 $\mu \mathrm{m}$ long; head cells globose to ovate, entire, 10-15x10-12 $\mu \mathrm{m}$. Phialides mixed with appressoria, alternate to opposite, ampulliform, 15-25x5-10 $\mu \mathrm{m}$. Perithecia scattered, up to $240 \mu \mathrm{m}$ in diameter.; perithecial wall cells conoid to mammiform, up to $50 \mu \mathrm{m}$ long; ascospores cylindrical, 4-septate, constricted at

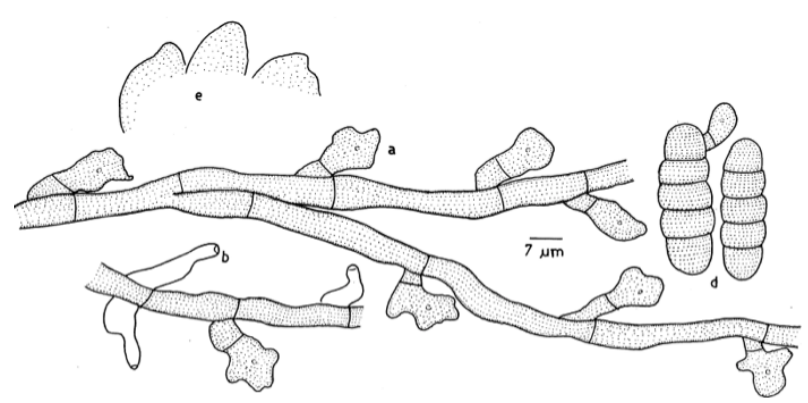

Figure 21. Asteridiella phaulopsidis

a - Appressorium; b - Phialide; d - Ascospores; e - Perithecial wall cells 
the septa, $32-40 \times 15-17 \mu \mathrm{m}$.

Asteridiella vivekananthanii Hosag., Sydowia 40: 114, 1987; Hosag. \& Goos, Mycotaxon 42: 120, 1991; Hosag., Kaveriappa, Raghu \& Goos, Mycotaxon 51: 110, 1994, Hosag., Meliolales of India, p.105, 1996 (Fig. 24).

Materials examined: $\mathrm{HClO}$ 43610, TBGT 295, 18.xi.1998, on leaves of Clerodendrum viscosum Vent (Verbenaceae), Chembra peak, coll. C.K. Biju; HCIO 49225, TBGT 3464, 16.ii.2009, Periya, coll. Jacob Thomas et al.

Colonies epiphyllous, subdense to dense, up to $4 \mathrm{~mm}$ in diameter, confluent. Hyphae flexuous to crooked, branching alternate to irregular at acute angles, very closely reticulate, cells 15.5-18.5x4-6.5 $\mu \mathrm{m}$. Appressoria alternate to unilateral, straight to mostly curved, antrorse to spreading, 16-31 $\mu \mathrm{m}$ long; stalk cells cylindrical to cuneate, 3-12.5 $\mu \mathrm{m}$ long; head cells ovate, globose, entire to angulose, 15-18.5×12-15.5 $\mu \mathrm{m}$; few appressoria 46-50 $\mathrm{mm}$ long and stalk cells 1-septate, 15-18.5 $\mu \mathrm{m}$ long. Phialides few, mixed with appressoria, opposite to alternate, conoid to ampulliform, 15-31x6$12.5 \mu \mathrm{m}$. Perithecia scattered, up to $250 \mu \mathrm{m}$ in diameter; perithecial wall cells conoid to mammiform, up to $22 \mu \mathrm{m}$ long; ascospores obovoidal, 4-septate, slightly curved, 31-37x12.5-18.5 $\mu \mathrm{m}$.

This species was mixed with Meliola clerodendricola Henn.

Asteridiella wyanadensis Hosag., C.K. Biju \& Abraham, Nova Hedwigia 80: 479, 2005; Hosag., Meliolales of India 2: 152, 2008 (Fig. 25).

Materials examined: $\mathrm{HClO}$ 43611, TBGT 329, 4.iv.1999, on leaves of Mallotus sp. (Euphorbiaceae), Chembra, coll. C.K. Biju.

Colonies hypophyllous, thin, up to $3 \mathrm{~mm}$ diameter. Hyphae flexuous, branching alternate to opposite at acute to wide angles, loosely to closely reticulate, cells 15-30x5-8 $\mu \mathrm{m}$. Appressoria alternate, antrorse to subantrorse, 11-20 $\mu \mathrm{m}$ long; stalk cells cylindrical to cuneate, 3-6 $\mu \mathrm{m}$ long; head cells ovate to globose, entire, rarely angular, 8-13x9-13 $\mu \mathrm{m}$. Phialides mixed with appressoria, alternate to opposite, ampulliform, 16-20x4-6 $\mu \mathrm{m}$. Perithecia scattered, immature, up to $120 \mu \mathrm{m}$ diam.; ascospores oblong, 4-septate, constricted at the septa, 33-36×12-15 $\mu \mathrm{m}$.

This species is close to Asteridiella phyllanthi (Deight.) Hansf. known on Phyllanthus wildennannii from Sierra Leone. However, differs from it in having flexuous hyphae, absence of opposite appressoria and

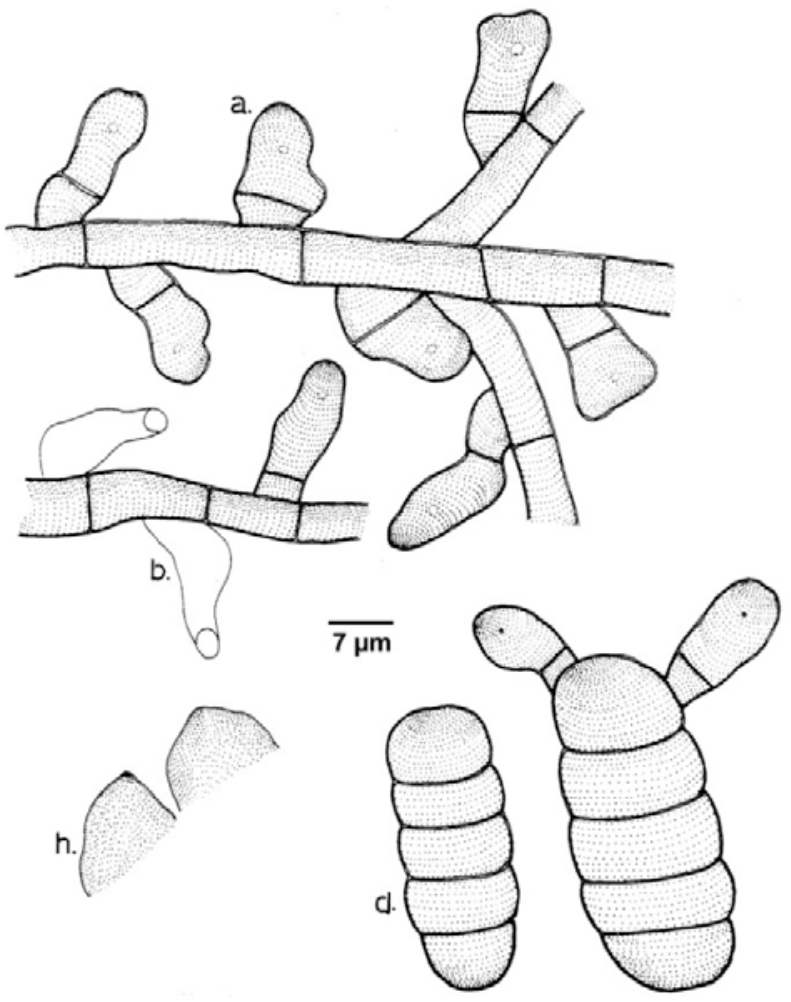

Figure 22. Asteridialla scolopiae a - Appressorium; b - Phialide; $d$ - Ascospores; $\mathrm{h}$ - Perithecial wall cells

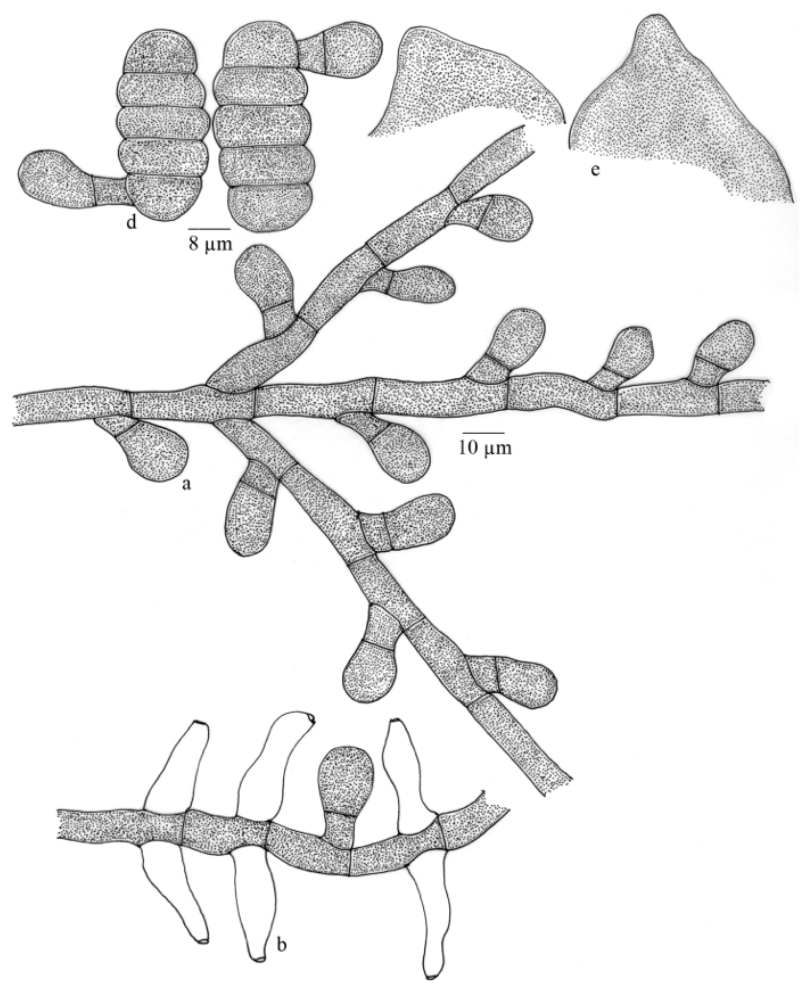

Figure 23. Asteridiella symploci-microphyllae

a - Appressorium; b - Phialide; d - Ascospores; e - Perithecial wall cells 
having ovate and entire head cells of appressoria.

\section{The genus Irenopsis}

Irenopsis Stev., Ann. Mycol. 25: 411, 1927; Hansf., Sydowia Beih 2: 25, 1961; Hosag., Meliolales of India, p.107, 1996; Meliolales of India 2: 162, 2008; Hosag. \& Agarwal, Taxonomic Studies of Meliolales. Identification manual, p. 121, 2008.

Mycelium superficial, brown, septate, branched, appressoriate, mycelial setae absent. Perithecia globose, descrete, \pm ostiolate, with prominent, dark-brown setae, larviform appendages absent; asci 2-4 spored, evanescent; ascospores brown, 3-4 septate.

Type: I. tortuosa (Wint.) Stev.

Irenopsis benguetensis Stev. \& Rold. ex Hansf., Sydowia 26: 311, 1963; Hosag. \& Goos, Mycotaxon 36 : 242, 1989; Hosag., Meliolales of India, p. 107, 1996.

Irenopsis benguetensis Stev. \& Rold., Philippine J. Sci. 56: 49, 1935; Hansf., Sydowia Beih. 2: 321, 1961(nom. invalid.).

Meliola benguetensis (Stev. \& Rold.) Cif., Mycopathologia 7:87, 1954 (non Stev. \& Rold., 1935) (Fig. 26, Image 4).

Materials examined: $\mathrm{HClO}$ 44790, TBGT 1027, 27.xii.2002, on leaves of Ficus exaspirata Vahl. (Moraceae), Periya, coll. M. Kamarudeen \& P.A. Jose; HCIO 49998, TBGT 4150, 18.ix.2008, on Ficus sp., Tirunelly, coll. P.J. Robin et al.; HCIO 50739, TBGT 4656, 6.xi.2009, Padinharathara, coll. A. Sabeena \& M.C. Riju.

Colonies amphigenous, mostly epiphyllous, subdense to dense, up to $4 \mathrm{~mm}$ in diameter, rarely confluent. Hyphae straight to undulate, branching alternate at acute angles, loosely to closely reticulate, cells 16-36x4$10 \mu \mathrm{m}$. Appressoria alternate, antrorse to subantrorse, spreading, 26-36 $\mu \mathrm{m}$ long; stalk cells cylindrical to cuneate, 9-17 $\mu \mathrm{m}$ long; head cells globose, subangulose to irregularly sublobate, $14-22 \times 12-20 \mu \mathrm{m}$. Phialides mixed with appressoria and also born on a separate mycelial branch, alternate, ampulliform, 16-24x7-10 $\mu \mathrm{m}$. Perithecia scattered to aggregated, verrucose, up to $140 \mu \mathrm{m}$ in diameter; perithecial setae $4-8$, straight, spreading, dark-brown at base and pale brown towards the apex, obtuse and mostly straight at the tip, up to $160 \mu \mathrm{m}$ long and 7-10 $\mu \mathrm{m}$ thick; ascospores ellipsoidal, 4-septate, constricted at the septa, 36-43×16-26 $\mu \mathrm{m}$.

This is the only species on the host genus Ficus in the Western Ghats of Peninsular India (Hosagoudar, 1996).

Irenopsis hiptages Yamam. var. indica Hosag. \& Sabeena, J. Threatened Taxa 5 (6): 4011, 2013; Hosag., J. Threatened Taxa 5(6): 4015, 2013 (Fig. 27).

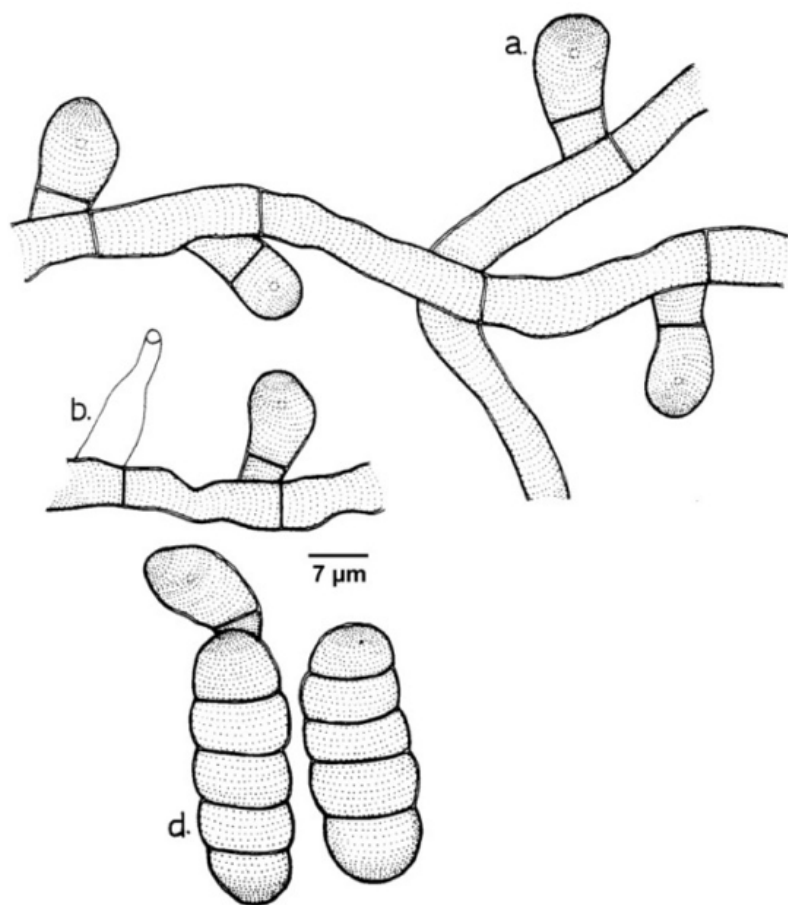

Figure 25. Asteridiella wyanadensis

a - Appressorium; b - Phialide; d - Ascospores 


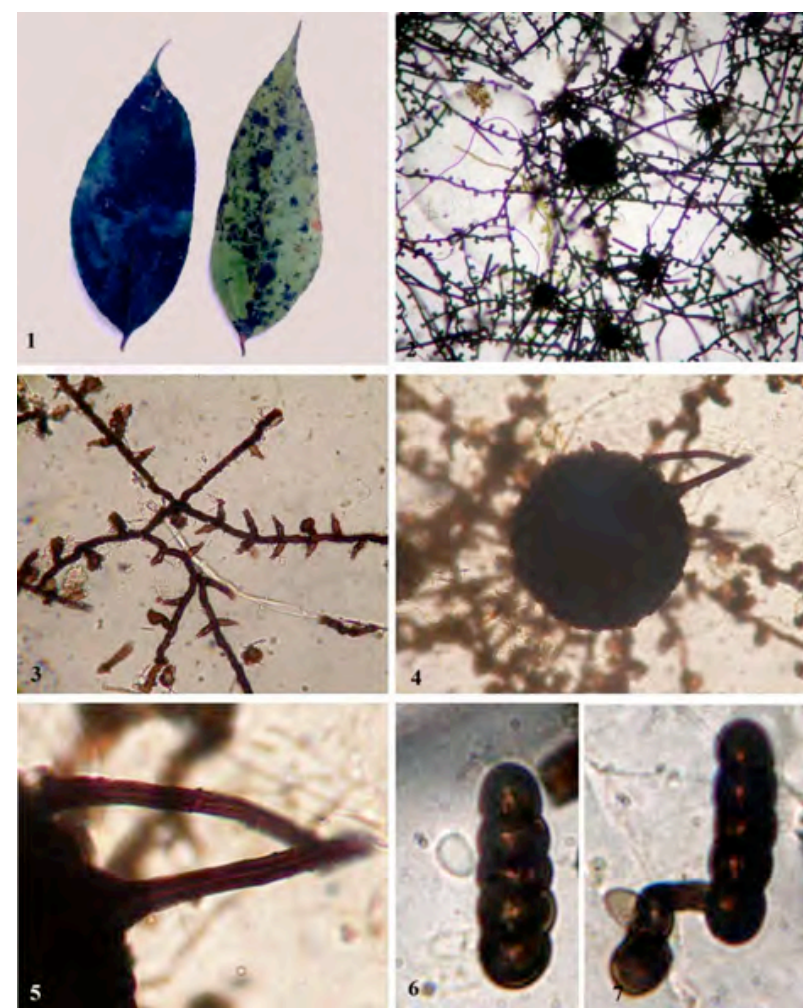

Image 4. Irenopsis benguetensis

1 - Infected leaves of Ficus tinctoria ssp. parasitica; $\mathbf{2}$ - Colony with perithecia; 3 - Appressoriate mycelium with phialides; 4 - Perithecium; 5 - Perithicial setae; 6 - Ascospore; 7 - Germinating ascospore

Materials examined: TBGT 5747, 18.ix2008, on leaves of Hiptage sp. (Malphigiaceae), Thirunelli, coll. P.J. Robin et al.

Colonies amphigenous, subdense, up to $3 \mathrm{~mm}$ in diameter, confluent. Hyphae straight to substraight, branching opposite at acute to wide angles, loosely reticulate, cells $17-25 \times 6-8 \mu \mathrm{m}$. Appressoria alternate, unilateral to $3-4 \%$ opposite, antrorse to subantrorse, 22-30 $\mu \mathrm{m}$ long; stalk cells cylindrical to cuneate, 5-10 $\mu \mathrm{m}$ long; head cells ovate, entire, mostly angular to rarely sublobate, 15-20x12-17 $\mu \mathrm{m}$. Phialides mixed with appressoria, alternate to opposite, ampulliform, 15-25x7-10 $\mu \mathrm{m}$. Perithecia scattered, up to $190 \mu \mathrm{m}$ in diameter; perithecial setae simple, straight, obtuse at the tip, up to $117 \mu \mathrm{m}$ long; ascospores cylindrical, 4-septate, constricted at the septa, 47-55x17-22 $\mu \mathrm{m}$. This is the only taxon known on this host genus from the Western Ghats region.

Irenopsis molleriana (Wint.) Stev., Ann. Mycol. 25: 437, 1927; Hansf., Sydowia Beih. 2: 184, 1961; Hosag., Sarbhoy, Agarwal \& Khan, Mycotaxon 56: 354, 1995; Hosag., Abraham \& Crane, Mycotaxon 71: 151, 1999;

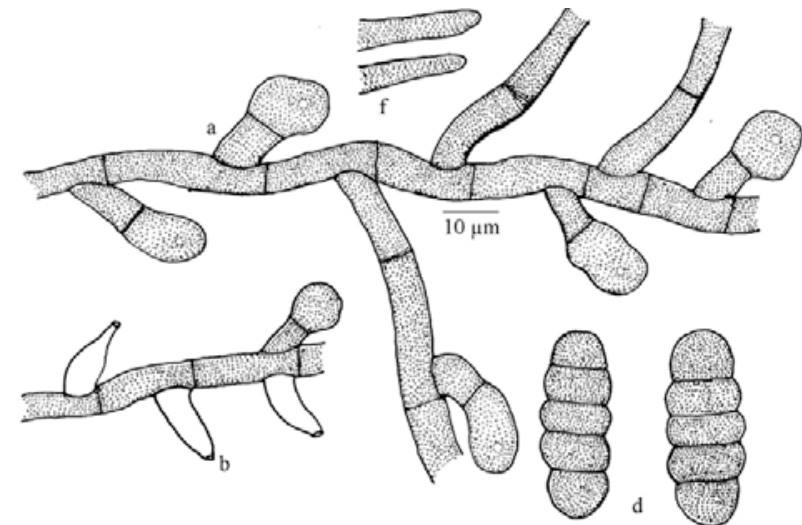

Figure 26. Irenopsis benguetensis

a - Appressorium; b - Phialide; $d$ - Ascospores; $f$ - Apical portion of the perithecial setae

Hosag., C.K. Biju \& Abraham, J. Econ. Taxon. Bot. 25: 299, 2001; Hosag., Meliolales of India 2: 168, 2008.

Meliola molleriana Wint., Hedwigia 25: 98, 1886.

Meliola (Irenina) procera Cif., Ann. Mycol. 36: 219, 1938 (Fig. 28).

Materials examined: HClO 50742, TBGT 4659, 4.xi.2009, on leaves of Hibiscus furcatus Roxb. ex DC. (Malvaceae), Padinharathara, coll. A. Sabeena \& M.C. Riju.

Colonies epiphyllous, thin, subvelvety, up to $4 \mathrm{~mm}$ in diameter, rarely confluent. Hyphae substraight to undulate, branching mostly opposite at acute to wide angles, loosely reticulate, cells $21-41 \times 6-7 \mu \mathrm{m}$. Appressoria alternate, antrorse to spreading, straight to curved, 14-22 $\mu \mathrm{m}$ long; stalk cells cylindrical to cuneate, 2-5 $\mu \mathrm{m}$ long; head cells ovate, subglobose, entire, subangular to slightly sublobate, 9.6-16.8x9-17 $\mu \mathrm{m}$. Phialides mixed with appressoria, alternate to opposite, ampulliform, 14-24x4-7 $\mu \mathrm{m}$. Perithecia scattered to loosely grouped, verrucose, up to $170 \mu \mathrm{m}$ in diameter; perithecial setae, 10-16 in number, simple, straight to slightly flexuous, septate, smooth, obtuse to subacute at the tip, up to $106 \mu \mathrm{m}$ long; ascospores obovoidal, 4-septate, slightly constricted at the septa, 33-38x12-17 $\mu \mathrm{m}$.

The present collections show a slight variation from the type species in having longer appressoria and shorter ascospores. Kapoor (1967) assigned Irenopsis species parasitic on Triumfetta bartramia to this taxon (Hosagoudar 1996).

Irenopsis sidae (Rehm) Hughes var. indica Hosag. \& Manoj., Zoos' Print J. 18: 1000, 2002; Hosag., Meliolales of India 2: 168, 2008 (Fig. 29).

Materials examined: HCIO 50743, TBGT 4660; HCIO 


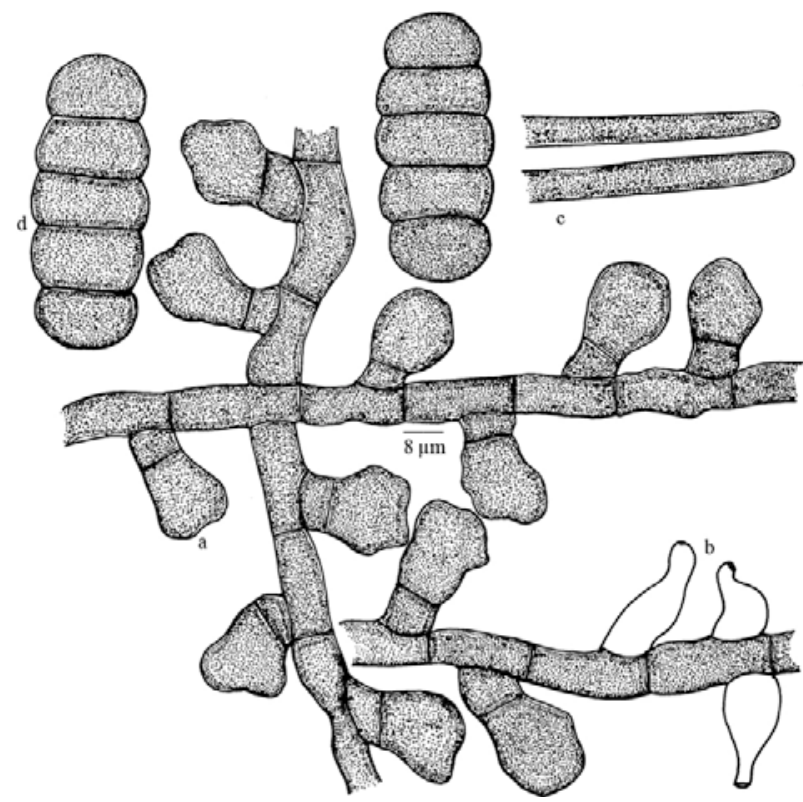

Figure 27. Irenopsis hiptages var. indica a - Appressorium; b - Phialide; c - Apical portion of the perithecial setae; $d$ - Ascospores

50741, TBGT 4658, 6.xi.2009, on leaves of Sida sp. (Malvaceae), Padinharathara, coll. A. Sabeena \& M.C. Riju.

Colonies amphigenous, mostly epiphyllous, subdense to dense, up to $2 \mathrm{~mm}$ in diameter, confluent. Hyphae straight to flexuous, branching alternate, opposite to irregular at acute angles, loosely to closely reticulate, cells 22-29x7-9 $\mu \mathrm{m}$. Appressoria alternate, about $5 \%$ opposite, antrorse, subantrorse to rarely retrorse, 14-18 $\mu \mathrm{m}$ long; stalk cells cylindrical to cuneate, 3-6 $\mu \mathrm{m}$ long; head cells ovate to globose, entire, angular to truncate at the apex, straight to curved, 9-13x8-10 $\mu \mathrm{m}$. Phialides mixed with appressoria, alternate to opposite,

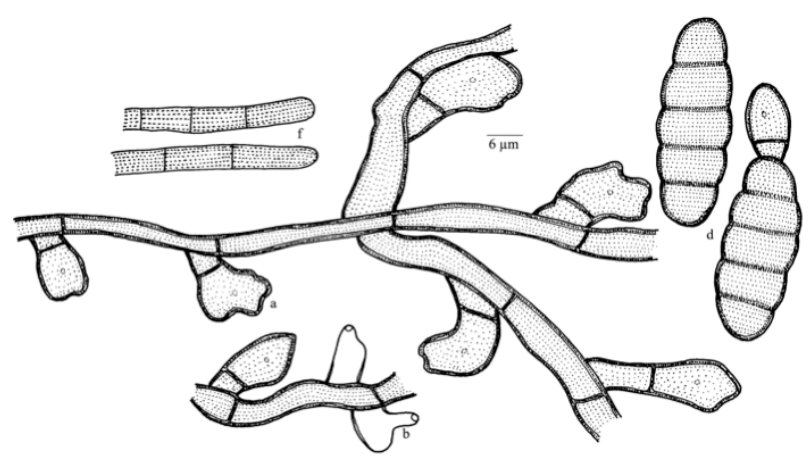

Figure 28. Irenopsis molleriana

a - Appressorium; $b$ - Phialide; $f$ - Apical portion of the perithecial setae; $d$ - Ascospores

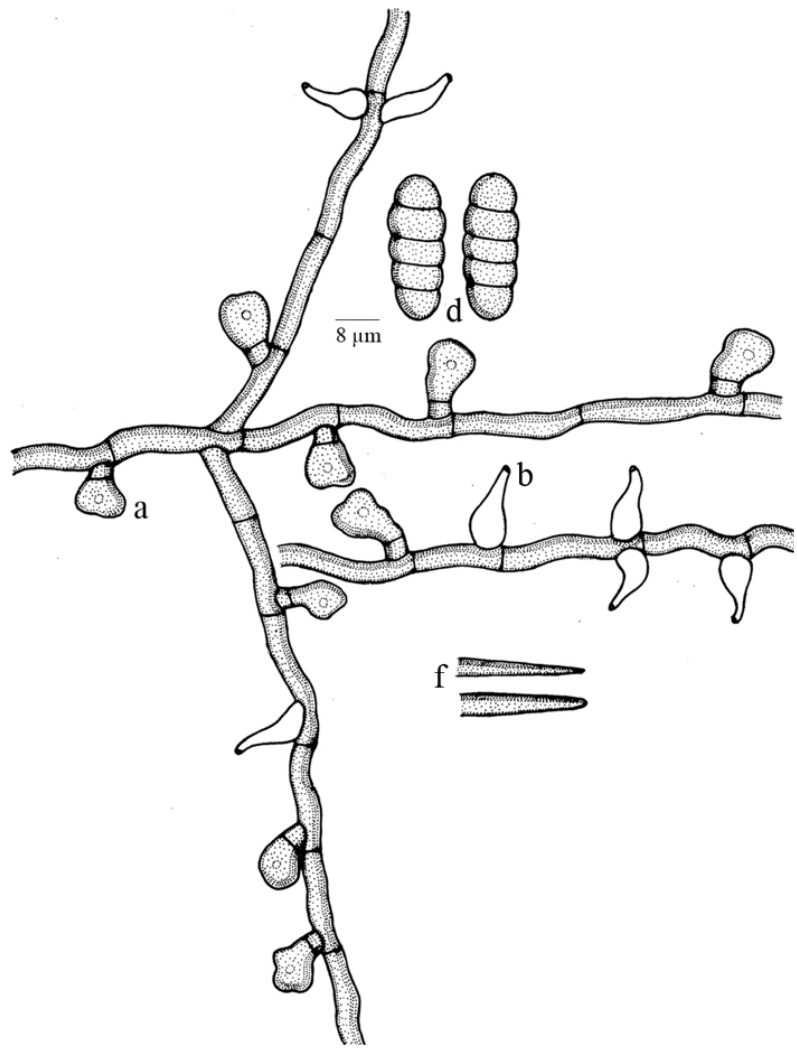

Figure 29. Irenopsis sidae var. indica

a - Appressorium; $b$ - Phialide; $f$ - Apical portion of the perithecial; d - Ascospores

ampulliform, 14-18x6-8 $\mu \mathrm{m}$. Perithecia scattered, globose, up to $150 \mu \mathrm{m}$ in diameter; perithecial cells slightly projected; perithecial setae 0-12 in numbers, simple, straight, acute at the apex, deep brown, septa not visible, up to $125 \mu \mathrm{m}$ long; ascospores oblong, 4-septate, slightly constricted at the septa, 30-32x11-13 $\mu \mathrm{m}$.

Based on the digital formula, the present collection is close to Irenopsis aciculosa (Wint.) Stev. known on many members of the family Malvaceae from the tropical countries and $I$. sidae Hughes known on Sida javensis and S. mysorensis from Philippines. However, the latter species differs from the former in having only straight but not incurved perithecial setae. Hence, the present collection is closer to the latter species (Hansford 1961). The variety differs from the type species in having dense colonies, 5\% opposite appressoria and shorter perithecial setae.

Irenopsis trichiliae Hosag. \& Riju, J. Threatened Taxa 2(4): 824, 2010; Hosag., J. Threatened Taxa 5(6): 4014, 2013 (Fig. 30).

Material examined: HClO 48177, TBGT 2913, 
10.xi.2007, on leaves of Trichilia sp. (Meliaceae), $16^{\text {th }}$ mile, Padinharathara, coll. M.C. Riju.

Colonies epiphyllous, subdense, scattered, up to $2 \mathrm{~mm}$ in diam., confluent. Hyphae straight to flexuous, branching opposite to alternate at acute to wide angles, loosely to closely reticulate, cells $11-33 \times 6-11$ $\mu \mathrm{m}$. Appressoria alternate, unilateral, antrorse to subantrorse, 13-26 $\mu \mathrm{m}$ long; stalk cells cylindrical to cuneate, 4-11 $\mu \mathrm{m}$ long; head cells globose, angular, sublobate to deeply lobate, $8-18 \times 11-18 \mu \mathrm{m}$. Phialides mixed with appressoria, opposite to unilateral, ampulliform, 17-24x6-9 $\mu \mathrm{m}$. Perithecia scattered, up to $209 \mu \mathrm{m}$ in diameter; perithecial setae $0-5$ in number, straight, simple, obtuse at the apex, up to $198 \mu \mathrm{m}$ long; ascospores cylindrical, 4-septate, slightly constricted at the septa, 37-47x15-18 $\mu \mathrm{m}$

Irenopsis chukrasiae Hosag., I. inidica (Anahosur) Hosag., I. murrayae Hosag. \& Rajkumar are known on the members of the family Meliaceae (Hosagoudar 1996; Hosagoudar et al. 2001). Irenopsis trichiliae differs from I. chukrasiae in having only unicellular stalk cells of the appressoria and from I. indica in having straight hyphae and $0-5$ perithecial setae. It also differs from I. murrayae in having angular to lobate head cells of the appressoria.

Irenopsis triumfettae (Stev.) Hansf. \& Deight., Mycol. Pap. 23: 14, 1948; Hansf., Reinwardtia 3: 107, 1954; Sydowia Beih. 2: 368, 1961; Hosag. \& Goos, Mycotaxon

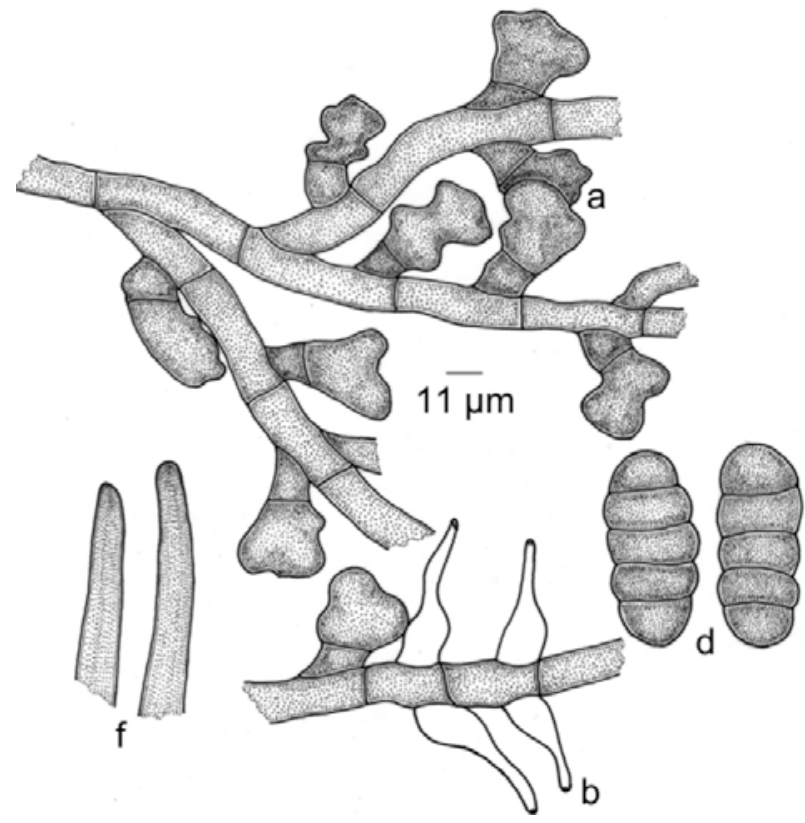

Figure 30. Irenopsis trichiliae

a - Appressorium; $b$ - Phialide; $\mathbf{f}$ - Apical portion of the perithecial setae; $d$-Ascospores
36: 244, 1989; 42: 128, 1991; Hosag., Meliolales of India, p. $118,1996$.

Meliola triumfettae Stev., Illinois Biol. Monogr. 2: 30, 1916; Deight., Mycol. Pap. 9:17, 1944.

Irenopsis coronata (Speg.) Stev. var. triumfettae (Stev.) Stev., Ann. Mycol. 25: 435, 1927: Stev. \& Rold., Philippine J. Sci. 56: 51, 1933.

Meliola coronata Speg. var. triumfettae (Stev.) Cif., Mycopathologia 8:117, 1954.

Irenopsis molleriana sensu Kapoor, Indian Phytopathol. 20: 151, 1967 (Fig. 31).

Materials examined: $\mathrm{HClO}$ 43691, TBGT 348, 19.xi.1998, on leaves of Triumfetta rhomboidea Jacq. (Tiliaceae), Banasuran mala, coll. C.K. Biju.

Colonies amphigenous, mostly epiphyllous, subdense, scattered, up to $3 \mathrm{~mm}$ in diameter, rarely confluent. Hyphae undulate to tortuous, branching opposite to alternate at wide angles, loosely to closely reticulate, cells $15-20 \times 6-8 \mu \mathrm{m}$. Appressoria alternate, mostly straight, antrorse, 18-22 $\mu \mathrm{m}$ long; stalk cells cylindrical to cuneate, 6-8 $\mu \mathrm{m}$ long; head cells globose, entire to sublobate, $12-16 \times 12-14 \mu \mathrm{m}$. Phialides mixed with appressoria, alternate to opposite, ampulliform, 18-20x6-8 $\mu \mathrm{m}$. Perithecia scattered to aggregated, up to $207 \mu \mathrm{m}$ in diam.; perithecial setae $6-8$, straight, spreading, continuous, curved or uncinate at the apex, apex obtuse, 99-144x6-8 $\mu \mathrm{m}$; ascospores ellipsoidal, 4-septate, constricted at the septa, 36-44×12-16 $\mu \mathrm{m}$.

Common species on this host genus

Irenopsis triumfettae (Stev.) Hansf. \& Deight. var. indica Hosag. \& Abraham, J. Mycopathol. Res. 36: 98, 1998; Hosag., Meliolales of India 2: 174, 2008 (Fig. 32).

Materials examined: $\mathrm{HClO} 50728, \mathrm{TBGT} 4645 ; \mathrm{HClO}$ 50730, TBGT 4647; HCIO 50732, TBGT 4649, 6.xi.2009, on leaves of Triumfetta sp. (Tiliaceae), Puthucherry Kadavu, coll. A. Sabeena \& M.C. Riju.

Colonies amphigenous, dense, up to $1 \mathrm{~mm}$ in diameter, confluent. Hyphae straight to flexuous, branching irregular at acute angles, loosely reticulate, cells 24-29x7-9 $\mu \mathrm{m}$. Appressoria alternate, antrorse to subantrorse, 17-22 $\mu \mathrm{m}$ long; stalk cells cylindrical to cuneate, 4-8 $\mu \mathrm{m}$ long; head cells globose to slightly ovate, entire, $12-15 \times 12-15 \mu \mathrm{m}$. Phialides numerous, mixed with appressoria, alternate to opposite, ampulliform, 14-22x7-9 $\mu \mathrm{m}$. Perithecia scattered, globose, verrucose, up to $160 \mu \mathrm{m}$ in diameter; perithecial setae $6-8$, simple, straight to slightly curved, tortuous to beaded and granulose towards the apex, obtuse at the apex, up to $140 \mu \mathrm{m}$ long; ascospores oblong, 4-septate, slightly constricted at the septa, 36-46×12-17 $\mu \mathrm{m}$. 


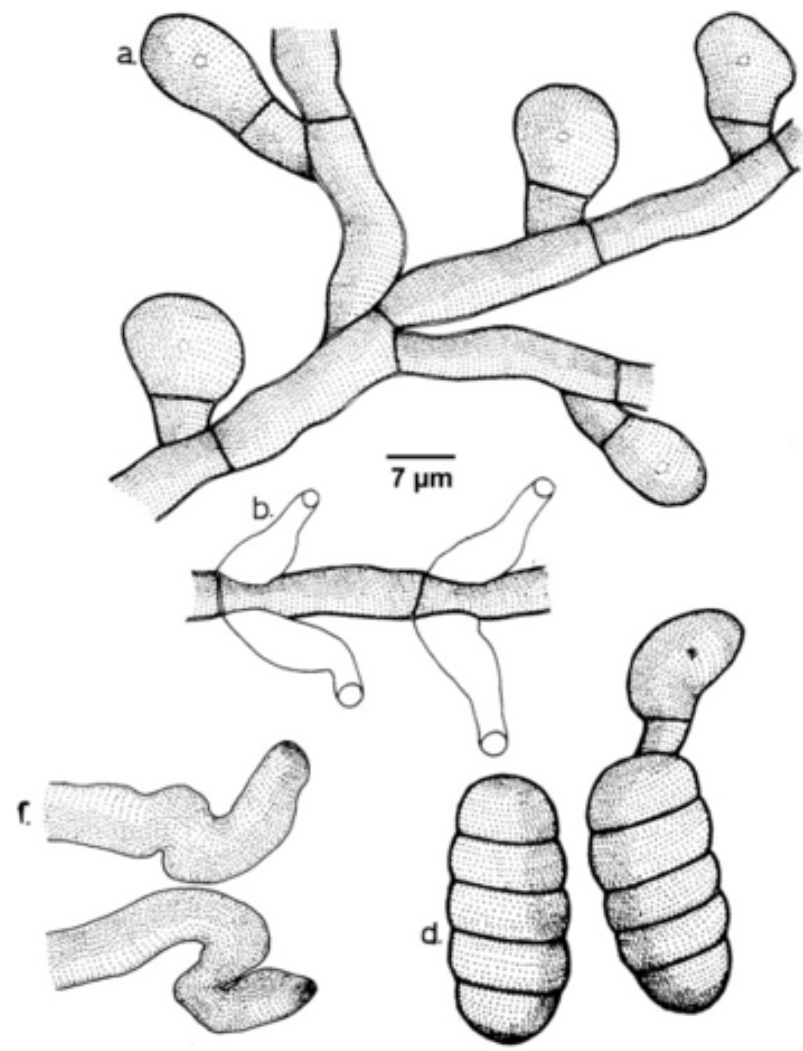

Figure 31. Irenopsis triumfettae

a - Appressorium; $b$ - Phialide; $f$ - Apical portion of the mycelial setae; d - Ascospores

This taxon is similar to Irenopsis triumfettae (Stev.) Hansf. \& Deight. var. glyphaeicola (Deight.) Hansf. \& Deight. in the morphology of the perithecial setae but differs from it in having entire head cells of the appressoria.

\section{The genus Meliola}

Meliola Fries emend. Bornet, Ann. Sci. Nat. III: 16: 267, 1851.

Meliola Fries, Syst. Orb. Veg. P., 111, 1825.

Amphitrichum Fries, Syst. Mycol. 2: 513, 1829 (p.p.)

Myxothecium Kuntze ex Fries, Syst. Mycol. 3: 232, 1829.

Couturea Cast. In Fries, Summ. Veg. Sand. P., 407, 1846.

Asteridieum Sacc., Syll. Fung. 1: 49, 1882.

Mycelium superficial, brown, septate, branched, appressoriate, mycelial setae present. Perithecia globose, descrete, \pm ostiolate; asci 2-4 spored, evanescent; ascospores brown, 3-4 septate.

Type: M. psidii Fries

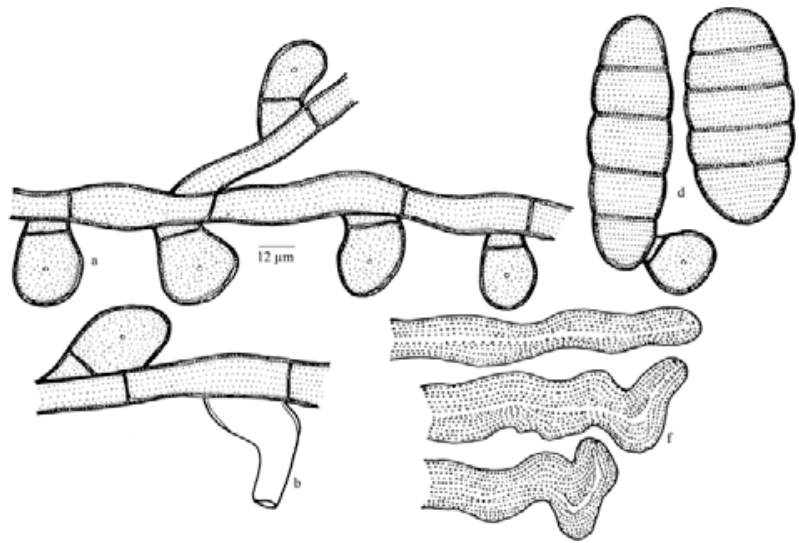

Figure 32. Irenopsis triumfettae var. indica

a - Appressorium; b - Phialide; $f$ - Apical portion of the perithecial setae; $d$ - Ascospores

Meliola psidii Fries is conseved over the earlier synonym M. trichostroma (Kuntze) Toro (Crane \& Jones, 2001).

Meliola abdulkalamii Hosag. \& Riju, Plant Pathology \& Quarantine 1(2): 123, 2011; Hosag., J. Threatened Taxa 5(6): 4015, 2013 (Fig. 33).

Material examined: HCIO 51041, TBGT 4958; HCIO 51042, TBGT 4959, 14.vi.2009, on leaves of Aralia sp. (Araliaceae), 16th mile, Padinharathara, coll. M.C. Riju.

Colonies epiphyllous, crustose, up to $5 \mathrm{~mm}$ in diameter, scattered, confluent. Hyphae straight to flexuous, branching opposite at acute to wide angles, loosely to closely reticulate, cells $20-33 \times 5-8 \mu \mathrm{m}$. Appressoria alternate, unilateral, antrorse to subantrorse, 17-20 $\mu \mathrm{m}$ long; stalk cells cylindrical to cuneate, $5-8 \mu \mathrm{m}$ long; head cells globose, subglobose, entire, 7-10×7-13 $\mu \mathrm{m}$. Phialides mixed with appressoria, mostly opposite, rarely alternate, ampulliform, 12-18×7-8 $\mu \mathrm{m}$. Mycelial setae simple, straight, obtuse, clavate, inflated, notched to bifid at the apex, ends broadly rounded, up to $320 \mu \mathrm{m}$ long. Perithecia up to $230 \mu \mathrm{m}$ in diameter; ascospores cylindrical to oblong, 4-septate, slightly constricted at the septa, $27-33 \times 10-13 \mu \mathrm{m}$.

The present species is distinct from other Meliola species known on members of Araliaceae in having broadly obtuse, inflated to bifid tips of the mycelial setae (Hansford 1961, Hosagoudar 1996, 2008, Hu et al., 1996, 1999).

Meliola abri Hosag. \& Riju, Plant Pathology \& Quarantine 1(2): 124, 2011; Hosag., J. Threatened Taxa 5(6): 4015, 2013 (Fig. 34).

Material examined: HCIO 51190, TBGT 5070, 
16.i.2011, on leaves of Abrus pulchellus Wallich ex Thwaites (Fabaceae), Padinharathara, coll. M.C. Riju.

Colonies epiphyllous, thin, scattered, up to $3 \mathrm{~mm}$ in diam. Hyphae flexuous to crooked, branching opposite at wide angles, loosely reticulate, cells $17-30 \times 5-8 \mu \mathrm{m}$. Appressoria alternate to unilateral, up to $1 \%$ opposite, antrorse, subantrorse to retrorse, $17-20 \times 10-13 \mu \mathrm{m}$; stalk cells cylindrical to cuneate, $2-3 \mu \mathrm{m}$ long; head cells globose, ovate, straight to curved, $12-15 \times 10-13 \mu \mathrm{m}$. Phialides mixed with appressoria, opposite to unilateral, ampuliform, 20-25x5-8 $\mu \mathrm{m}$. Mycelial setae scattered to grouped around perithecia, simple, straight, acute at the tip, up to $360 \mu \mathrm{m}$ long. Perithecia scattered, up to $130 \mu \mathrm{m}$ in diameter; ascospores cylindrical, 4-septate, constricted at the septa, 30-33×10-13 $\mu \mathrm{m}$.

Meliola bicornis Wint. is known on Abrus canescens from Sierra Leone (Hansford, 1961), but this is a complex species and Hansford (1961) has segregated more than hundred species. Based on the simple setae and smaller ascospores, we prefer to accommodate our collection in a new species.

Meliola actephilae Hosag., C.K. Biju \& Abraham, Nova Hedwigia 80: 482, 2005; Hosag., Meliolales of India 2: 187, 2008 (Fig. 35).

Materials examined: $\mathrm{HClO}$ 43614, TBGT 321, 15.iv. 1999, on leaves of Actephila excelsa (Dalz.) Muell.-Arg. (Euphorbiaceae), Tirunelly, coll. C.K. Biju.

Colonies amphigenous, caulicolous, mostly

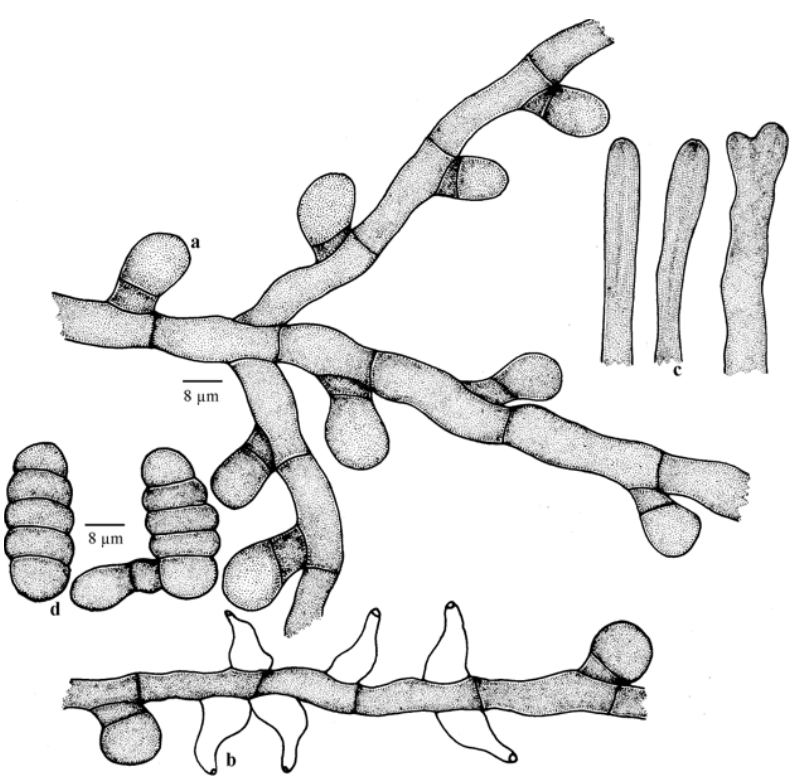

Figure 33. Meliola abdulkalamii

a - Appressorium; b - Phialide; c - Apical portion of mycelial setae; d - Ascospores hypophyllous, dense, up to $5 \mathrm{~mm}$ in diameter, rarely confluent. Hyphae straight to substraight, branching mostly opposite at acute to wide angles, closely reticulate and often form solid mycelial mat, cells $22-26 \times 6-10 \mu \mathrm{m}$. Appressoria opposite, solitary, about 15\% alternate, antrorse to subantrorse, straight to curved, 19-23 $\mu \mathrm{m}$ long; stalk cells cylindrical to cuneate, 4-7 $\mu \mathrm{m}$ long; head cells oblong to cylindrical, angular to slightly sublobate, often entire, 12-16x9-11 $\mu \mathrm{m}$. Phialides mixed with appressoria, alternate to opposite, ampulliform, 1923x8-10 $\mu \mathrm{m}$. Mycelial setae many, scattered, simple, straight, stlightly curved and often flexuous, acute at the tip, up to $300 \mu \mathrm{m}$ long. Perithecia scattered to grouped, up to $140 \mu \mathrm{m}$ in diameter; ascospores cylindrical, 4-septate, constricted at the septa, 40-44x11-14 $\mu \mathrm{m}$.

This species differs from Meliola homalanthi Boed. and its variety in having predominantly opposite and oblong to cylindrical, angular to sublobate appressoria (Hansford 1961).

Meliola affinis Sydow var. indica Hosag., Nova Hedwigia 47: 538, 1988; Hosag., Meliolales of India, p. 124, 1996 (Fig. 36).

Materials examined: $\mathrm{HClO}$ 47373, TBGT 2411, 19.ix.1999, on leaves of Memecylon sp. (Melastomataceae), Banasuranmala, coll. C.K. Biju.

Colonies hypophyllous, very thin, up to $4 \mathrm{~mm}$ in diameter, confluent. Hyphae substraight to undulate, branching opposite to irregular at subacute to wide angles, loosely to closely reticulate, cells $16-34 \times 4-8$ $\mu \mathrm{m}$. Appressoria alternate, distantly arranged, straight to curved, mostly antrorse, 14-22 $\mu \mathrm{m}$ long; stalk cells cylindrical to cuneate, 9-14 $\mu \mathrm{m}$ long; head cells ovate,

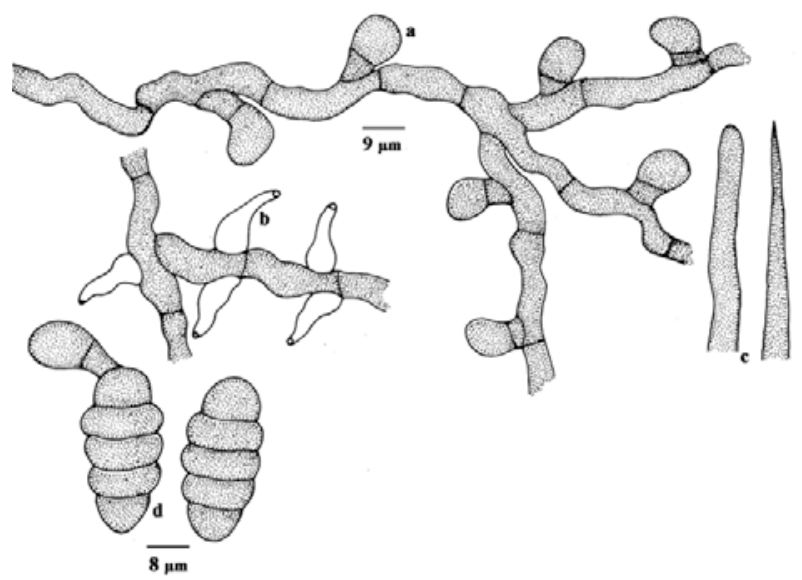

Figure 34. Meliola abri

a - Appressorium; b - Phialide; c - Apical portion of mycelial setae; d - Ascospores 


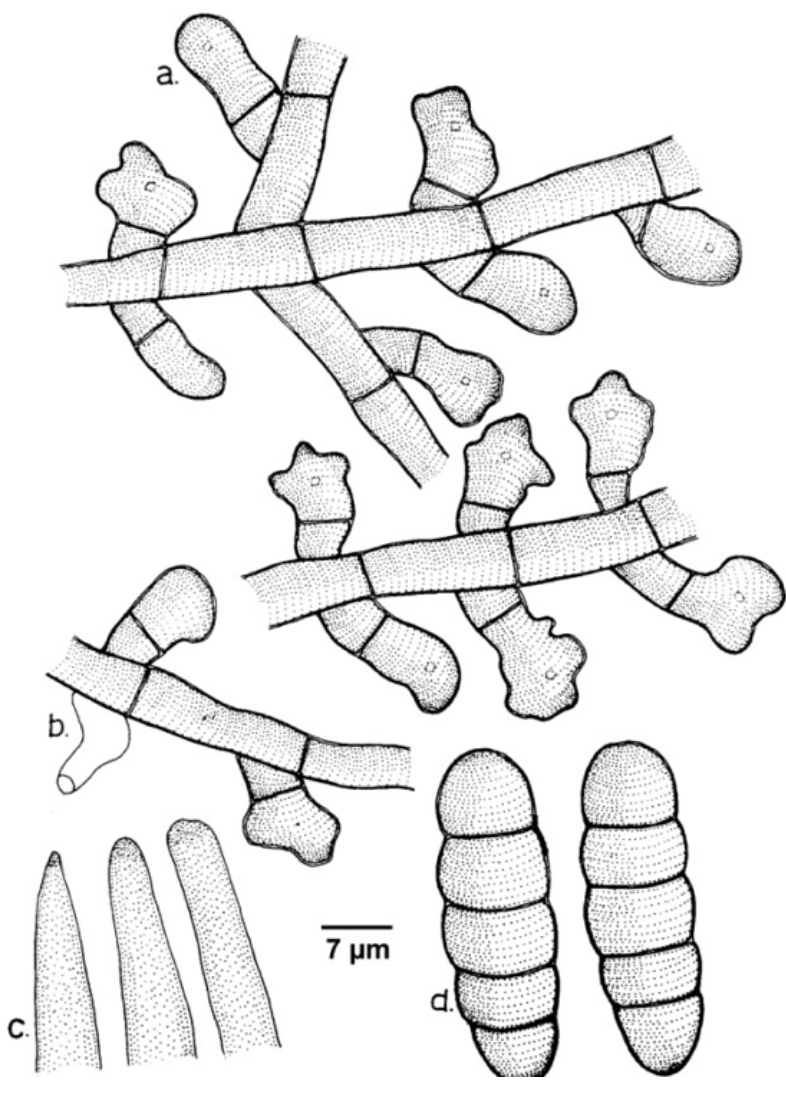

Figure 35. Meliola actephilae

a - Appressorium; b - Phialide; c - Apical portion of mycelial setae; d - Ascospores

pointed towards the apex with broadly rounded ends, entire, 9-14x6-10 $\mu \mathrm{m}$. Phialides mixed with appressoria, opposite to alternate, ampulliform, 19-24x6-10 $\mu \mathrm{m}$. Mycelial setae grouped around perithecia, straight, simple, acute, up to $670 \mu \mathrm{m}$ long. Perithecia scattered, verrucose, up to $130 \mu \mathrm{m}$ in diameter; ascospores cylindrical to obovoidal, 4-septate, constricted at the septa, 36-41x14-17 $\mu \mathrm{m}$.

Very thin hypophyllous colonies and distantly placed appressoria are the characteristics of the species Meliola affinis Sydow. However, the variety differs from the var. affinis in having smaller ascospores (Hansford, 1961; Hosagoudar, 1988).

Meliola ailanthi Sharma, Mohanan \& Florence, Kerala Forest Research Institute Report 36: 248, 1985 (ailanthii) emend. Hosag. in Hosag., Raghu \& Pillai, Nova Hedwigia 58: 524, 1994; Hosag., Meliolales of India, p. 126, 1996 (Fig. 37).

Materials examined: HCIO 48171, TBGT 2907; June 30, 2007 HClO 48173, TBGT 2909, 29.vi.2009, on leaves of Ailanthus malabarica DC. (Simaroubiaceae), $16^{\text {th }}$ mile,
Padinharathara, coll. M.C. Riju.

Colonies epiphyllous, scattered, dense, velvety, up to $2 \mathrm{~mm}$ in diameter. Hyphae straight, rarely substraight, branching mostly opposite at acute angles, loosely to closely reticulate, cells 20-28x5-7 $\mu \mathrm{m}$. Appressoria alternate, straight, antrorse, 12-23 $\mu \mathrm{m}$ long; stalk cells cylindrical to cuneate, 5-7 $\mu \mathrm{m}$ long; head cells ovate to cylindrical, entire, 9-16x8-11 $\mu \mathrm{m}$. Phialides mixed with appressoria, alternate to opposite, ampulliform, 16-21x9-13 $\mu \mathrm{m}$. Mycelial setae numerous, straight to slightly curved but not uncinate, simple, acute to 2-3 times dentate at the tip, up to $265 \mu \mathrm{m}$ long. Perithecia scattered to loosely grouped, verrucose, up to $179 \mu \mathrm{m}$ in diam.; ascospores obovoidal, 4-septate, constricted at the septa, 36-41x12-16 $\mu \mathrm{m}$.

This taxon was described by Sharma et al. (1985) from Kerala but it was inadequate for the identification. Later, Hosagoudar (1994) emended it by providing detailed description along with line drawings.

Meliola ailanthicola Hosag. \& Riju, J. Threatened Taxa 2(4): 824, 2010; Hosag., J. Threatened Taxa 5(6):4017, 2013 (Fig. 38).

Material examined: HCIO 48170 (holotype), TBGT 2906 (isotype); $\mathrm{HClO}$ 48173, TBGT 2909, 30.ix.2007, on leaves of Ailanthus triphysa malabarica (Dennst.) Alston

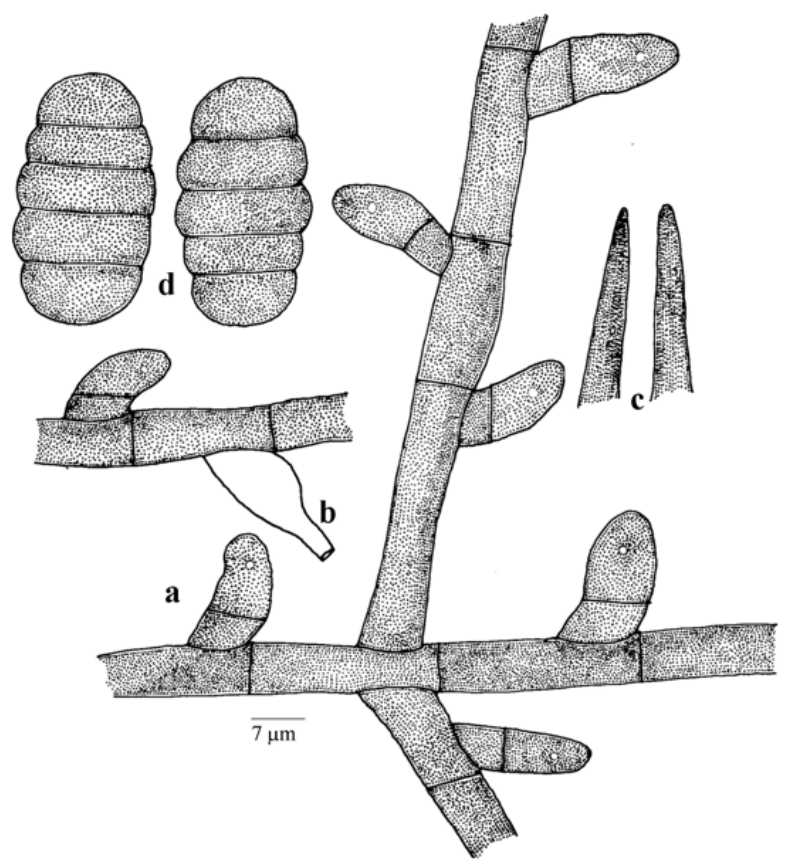

Figure 36. Meliola affinis var. indica

a - Appressorium; b - Phialide; c - Apical portion of mycelial setae; d - Ascospores 
(Simaroubaceae), 16th mile, Padinharathara, coll. M.C. Riju.

Colonies hypophyllous, thin, up to $4 \mathrm{~mm}$ in diameter, confluent. Hyphae crooked, branching alternate to opposite at acute to wide angles, loosely to closely reticulate, cells $13-33 \times 4-9 \mu \mathrm{m}$. Appressoria alternate to unilateral, straight to curved, antrorse, subantrorse to retrorse, 13-27 $\mu \mathrm{m}$ long; stalk cells cylindrical to cuneate, 4-16 $\mu \mathrm{m}$ long; head cells ovate, globose, truncate to slightly lobate, $8-13 \times 6-9 \mu \mathrm{m}$. Phialides mixed with appressoria, opposite, alternate to unilateral, ampulliform, 13-22x4-9 $\mu \mathrm{m}$. Mycelial setae scattered, simple, straight, acute, obtuse to $2-5$ dentate at the tip, up to $400 \mu \mathrm{m}$ long. Perithecia scattered, up to $160 \mu \mathrm{m}$ in diameter; ascospores obovoidal, 4-septate, slightly constricted at the septa, 37-44×13-16 $\mu \mathrm{m}$.

This species differs from Meliola ailanthi Sharma et al. emend. Hosag. in having strongly appressed colonies on the lower surface of the leaves and having distinctly crooked mycelium (Hosagoudar 1996).

Meliola allophyli-concanici Hosag. in Hosag., Raghu \& Pillai, Nova Hedwigia 58: 535, 1994; Hosag., Meliolales of India, p. 126, 1996 (Fig. 39).

Materials examined: HClO 49436, TBGT 3681, 15.ii.2009, on leaves of Allophylus sp. (Sapindaceae), Begoor, coll. Harish et al.

Colonies epiphyllous, scattered, dense, up to $2 \mathrm{~mm}$ in diameter. Hyphae straight, branching opposite at acute angles, loosely to closely reticulate, cells $14-22 \times 9-12$ $\mu \mathrm{m}$. Appressoria opposite, crowded after an interval, antrorse to subantrorse, recurved, 17-22 $\mu \mathrm{m}$ long;

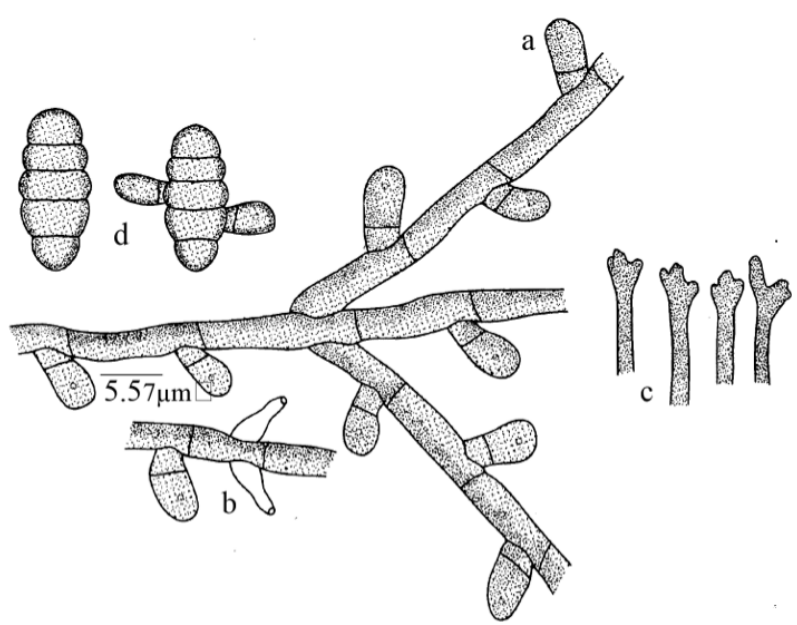

Figure 37. Meliola ailanthi

a - Appressorium; b - Phialide; c - Apical portion of mycelial setae; d - Ascospores

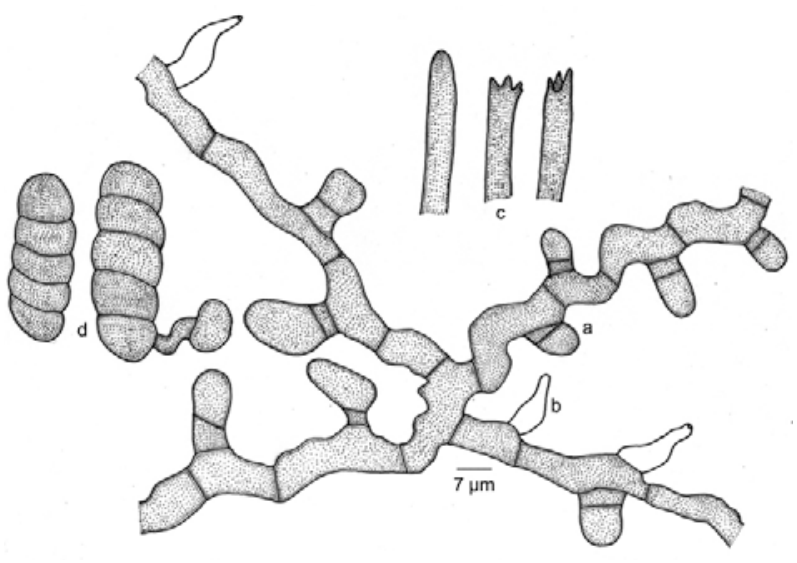

Figure 38. Meliola ailanthicola

a - Appressorium; b - Phialide; c - Apical portion of mycelial setae; d - Ascospores

stalk cells cuneate, 6-8 $\mu \mathrm{m}$ long; head cells globose, cylindrical, entire, 12-16x12-14 $\mu \mathrm{m}$. Phialides mixed with appressoria, alternate to opposite, ampulliform, 17-22x9-12 $\mu \mathrm{m}$. Mycelial setae grouped around perithecia, simple, straight, acute, obtuse to dentate at the tip, up to $576 \mu \mathrm{m}$ long. Perithecia, scattered to loosely grouped, verrucose, up to $174 \mu \mathrm{m}$ in diameter; ascospores obovoidal, 4-septate, constricted at the septa, 36-41x14-19 $\mu \mathrm{m}$.

The present taxon can be compared with Meliola capensis (K. \& C.) Theiss. var. lacaniodisci Hansf. \& Deight. and Meliola capensis (K. \& C.) Theiss. var. baileyana Hansf. However, the present taxon differs from them in having appressoria with globose head cells, in contrast to conoid (Hansford 1961).

Meliola allophyli-serrulati Hosag. \& Abraham, J. Mycopathol. Res. 36: 99, 1998; Hosag., Meliolales of India, p. 187, 2008 (Fig. 40).

Materials examined: $\mathrm{HClO}$ 45071, TBGT 1126, 21.iv.2003, on leaves of Allophylus cobbe (L) Raeusch. (Sapindaceae), Periya, coll. M. Kamarudeen \& P.A. Jose.

Colonies hypophyllous, subdense, crustose, up to $2 \mathrm{~mm}$ in diameter, rarely confluent. Hyphae straight, rarely crooked, branching mostly opposite at acute to wide angles, loosely reticulate, cells 19-21x8-10 $\mu \mathrm{m}$. Appressoria opposite, about 5\% alternate, antrorse to subantrorse, mostly straight, rarely curved, 19-27 $\mu \mathrm{m}$ long; stalk cells cylindrical to cuneate, 4-10 $\mu \mathrm{m}$ long; head cells globose, ovate, rounded to rarely truncate at the apex, entire, 14-17x12-15 $\mu \mathrm{m}$. Phialides mixed with appressoria, alternate to opposite, ampulliform, 21-32x9-12 $\mu \mathrm{m}$. Mycelial setae moderately numerous, 


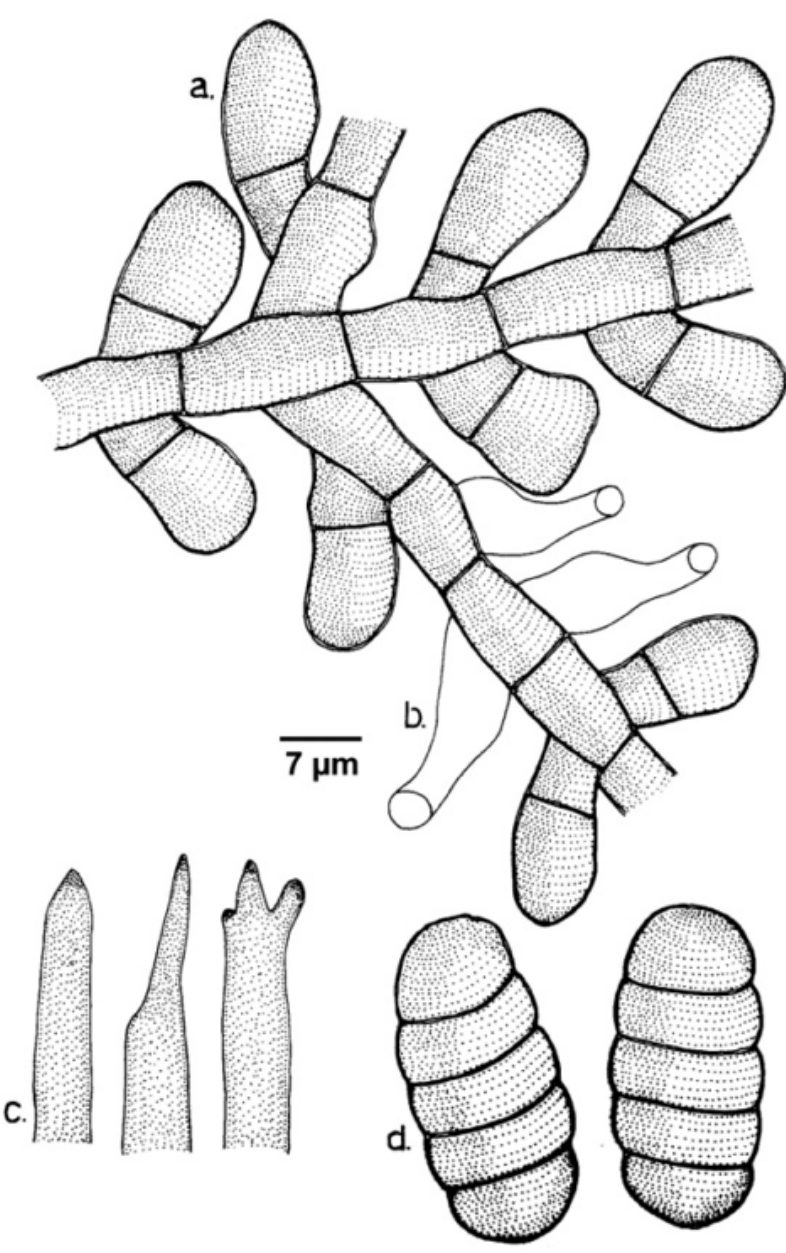

Figure 39. Meliola allophyli-concanici

a - Appressorium; b - Phialide; c - Apical portion of mycelial setae; d - Ascospores

scattered to grouped around perithecia, simple, straight to curved, acute to obtuse at the tip, up to $620 \mu \mathrm{m}$ long. Perithecia scattered, up to $170 \mu \mathrm{m}$ in diameter; ascospores oblong to cylindrical, straight to slightly curved, 4-septate, slightly constricted at the septa, 4346x17-20 $\mu \mathrm{m}$.

Meliola anceps Sydow \& Sydow, Ann. Mycol. 14: 76, 1916; Stev., Ann.Mycol. 28: 205, 1928; Hansf., Sydowia Beih. 2: 586, 1961; Hosag. \& Goos, Mycotaxon 37: 218, 1990; Hosag., Meliolales of India, p. 129, 1996.

Meliola makilingiana Sydow \& Sydow, Ann. Mycol. 15: 188, 1917.

Meliola mussaendae Sydow \& Sydow, Ann. Mycol. 15: 190, 1917(Fig. 41 \& Image 5).

Materials examined: HCIO 50916, TBGT 4833, 1.xi.2007, on leaves of Mussaenda philippica A.Rich. (Rubiaceae), Banasuranmala, Padinharathara, coll. M.C. Riju.
Colonies epiphyllous, thin, up to $2 \mathrm{~mm}$ in diameter, rarely confluent. Hyphae substraight to undulate, branching opposite to irregular at acute angles, loosely to closely reticulate, cells $22-54 \times 4-8 \mu \mathrm{m}$. Appressoria closely arranged, alternate, unilateral, closely antrorse, 17-24 $\mu \mathrm{m}$ long; stalk cells cylindrical to cuneate, 6-13 $\mu \mathrm{m}$ long; head cells ovate, globose, entire, slightly angular, 10-15x8-10 $\mu \mathrm{m}$. Phialides mixed with appressoria, opposite, irregular, ampulliform, 12-25x6$10 \mu \mathrm{m}$. Mycelial setae scattered to grouped around perithecia, straight to curved, simple, rounded to bifid at the tip, often show knobs in the middle, up to $292 \mu \mathrm{m}$ long. Perithecia scattered, up to $175 \mu \mathrm{m}$ in diameter; ascospores obovoidal, 4-septate, slightly constricted at the septa, 27-33x10-12 $\mu \mathrm{m}$.

This host plant is extensively cultivated in India and it appears to be a threat to it.

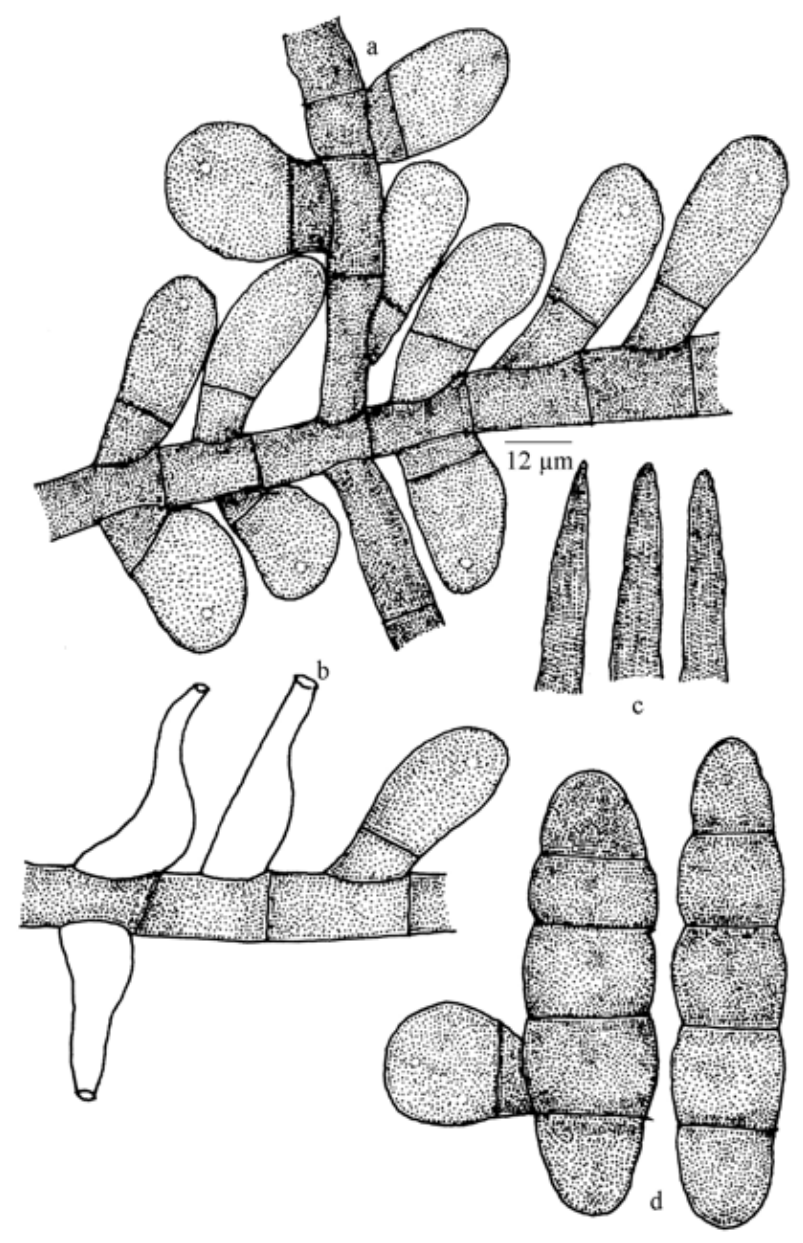

Figure 40. Meliola allophyli-serrulati

a - Appressorium; b - Phialide; c - Apical portion of mycelial setae; d - Ascospores 
Meliola aphanamixidis Hosag. in Hosag. \& Goos, Mycotaxon 37: 404, 1990; Hosag., Meliolales of India, p. 133, 1996 (Fig. 42).

Materials examined: TBGT 5943, 10.xi.2007, on leaves of Aphanamixis polystachya (Wall.) Parker (Amoora rohituka Wight \& Arn.) (Meliaceae), 16 ${ }^{\text {th }}$ Mile, Padinharathara, coll. M.C. Riju.

Colonies epiphyllous, dense, velvety, up to $2 \mathrm{~mm}$ in diameter, rarely confluent. Hyphae substraight to slightly crooked, branching opposite to irregular at wide angles, loosely to closely reticulate, cells $12-28 \times 9-12.5$ $\mu \mathrm{m}$. Appressoria opposite, crowded after intervals, rarely solitary, antrorse, subantrorse, recurved, 21-31 $\mu \mathrm{m}$ long; stalk cells cylindrical to cuneate, 6-12.5 $\mu \mathrm{m}$ long; head cells ovate, globose, angular, truncate, straight to curved, entire, 15-18.5x9-15.5 $\mu \mathrm{m}$. Phialides mixed with appressoria, opposite to alternate, ampulliform, 18-25x9-12.5 $\mu \mathrm{m}$. Mycelial setae mostly grouped around perithecia, simple, straight, acute to obtuse at the tip, up to $572 \mu \mathrm{m}$ long. Perithecia seated on exappressoriate mycelium, scattered, verrucose, up to $232 \mu \mathrm{m}$; ascospores obovoidal, 4-septate, constricted at the septa, $52-56 \times 18-22 \mu \mathrm{m}$.

Meliola aporusae Hosag. \& Robin, Bioscience Discovery 2 (2): 264, 2011; Hosag., J. Threatened Taxa 5(6):4017, 2013 (Fig. 43).

Materials examined: $\mathrm{HClO}$ 50925, TBGT 4842, 23.xii.2008, on leaves of Aporusa sp. (Euphorbiaceae), Banasuranmala, coll. M.C. Riju.

Colonies amphigenous, mostly hypophyllous, crustose, up to $4 \mathrm{~mm}$ in diameter, confluent. Hyphae straight to substraight, branching mostly opposite to alternate at acute angles, loosely reticulate, cells 19-

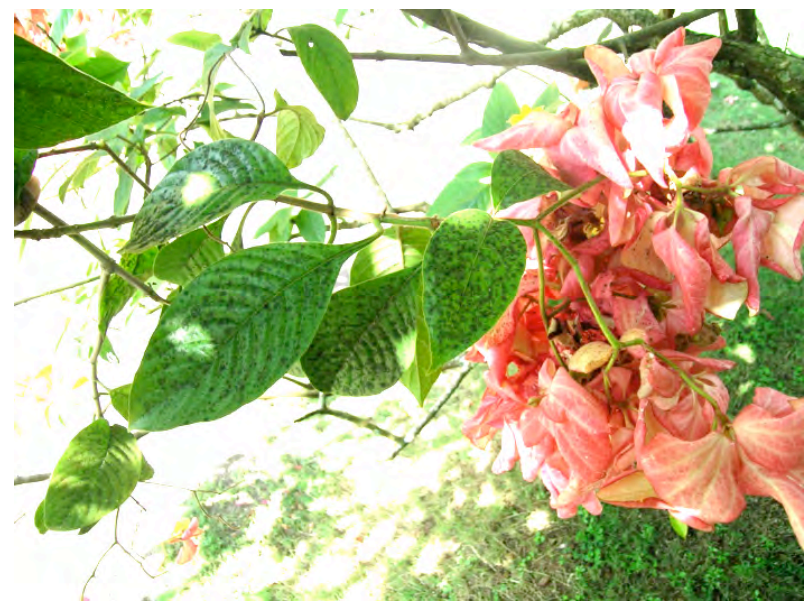

Image.5 . Meliola anceps-Infected leaves

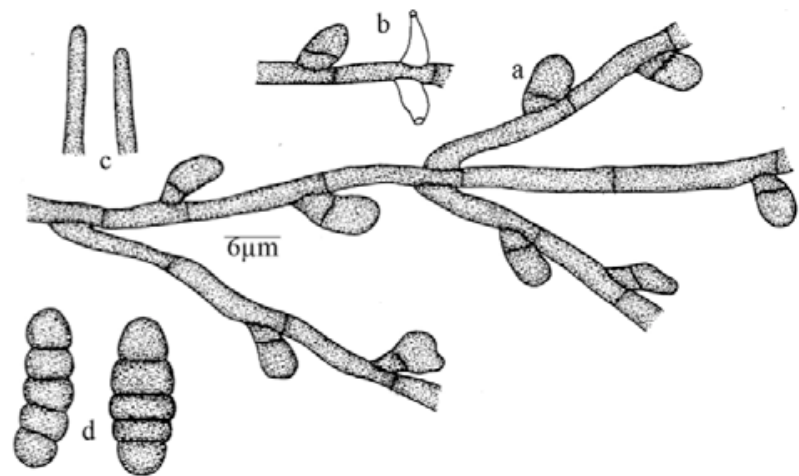

Figure 41. Meliola anceps

a - Appressorium; b - Phialide; c - Apical portion of mycelial setae; d - Ascospores

24x5-7 $\mu \mathrm{m}$. Appressoria alternate, about 15\% opposite, antrorse to subantrorse, spreading, 24-29 $\mu \mathrm{m}$ long; stalk cells cylindrical to cuneate, 10-12 $\mu \mathrm{m}$ long; head cellsovate, clavate, globose, entire to 2-5 times lobate, often slightly angular 12-19x14-19 $\mu \mathrm{m}$. Phialides mixed with appressoria, alternate, ampulliform, 17-24x7-10 $\mu \mathrm{m}$. Mycelial setae few, simple, straight, obtuse at the tip, up to $410 \mu \mathrm{m}$ long. Perithecia scattered, up to $115 \mu \mathrm{m}$ in diam.; ascospores ellipsoidal, 4-septate, constricted at the septa, 41-43×14-17 $\mu \mathrm{m}$.

Based on the digital formula, the present species is close to Meliola goleoria Hansf. and M. tetrorchidiicola Hansf. known on Galeario filiformis and Tetrorchidium rubivenium from Java and Brazil, respectively. However, differs from both in having stellately lobate head cells of the appressoria (Hansford 1961). Based on the lobate head cells, it can be compared with $M$. octephilae Hosag. et al. but differs from it in having only $15 \%$ opposite appressoria with stellately lobate head cells (Biju et al. 2005; Hosagoudar 2008; Hosagoudar \& Agarwal 2008).

Meliola ardisiicola Hosag., Rajkumar \& Jose, Indian Phytopathol. 57: 455, 2004; Hosag., Meliolales of India, p. 190, 2008 (Fig. 44).

Materials examined: HCIO 45230, TBGT 1267, 21.iv.2003, on leaves of Ardisia missionis Wallich ex DC. (Myrsinaceae), Periya, coll. G. Rajkumar \& P.A. Jose; TBGT 5568, 30.ix.2007, Ardisia sp., Padinharathara, coll. M.C. Riju.

Colonies epiphyllous, dense, crustose, up to $2 \mathrm{~mm}$ in diameter, confluent. Hyphae straight to substraight, branching mostly opposite at acute to wide angles, loosely to closely reticulate, cells 11-16x7-9 $\mu \mathrm{m}$. Appressoria alternate, closely placed, straight to curved, mostly antrorse, rarely retrorse, 24-31 $\mu \mathrm{m}$ long; stalk 


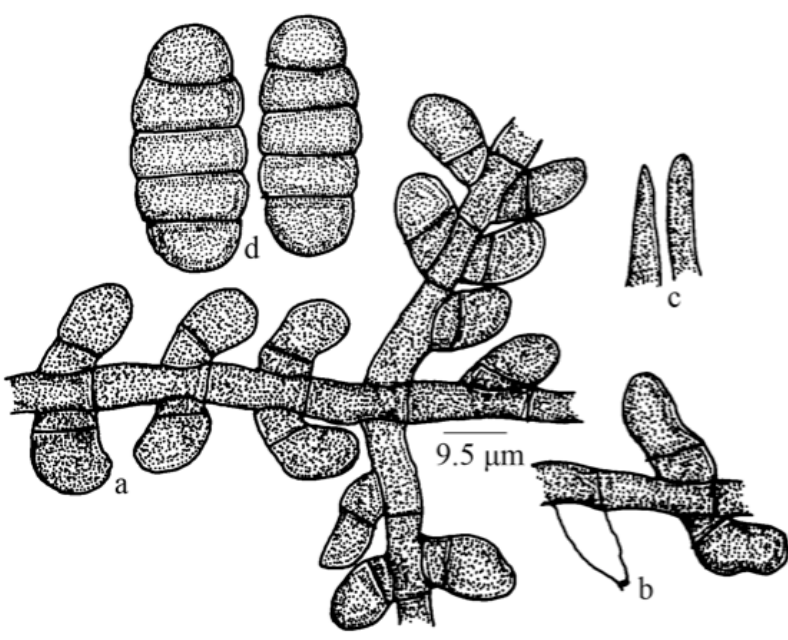

Figure 42. Meliola aphanamixidis

a - Appressorium; b - Phialide; c - Apical portion of mycelial setae; d - Ascospores

cells cylindrical to cuneate, 6-10 $\mu \mathrm{m}$ long; head cells oblong, cylindrical, rarely broadly ovate, entire, straight to slightly curved, $17-21 \times 8-10 \mu \mathrm{m}$. Phialides mixed with appressoria, alternate, scattered, ampulliform, 19-24x6-8 $\mu \mathrm{m}$. Mycelial setae scattered, simple, straight, acute at the tip, up to $380 \mu \mathrm{m}$ long. Perithecia scattered, globose, up to $180 \mu \mathrm{m}$ in diameter; ascospores obovoidal, cylindrical, 4-septate, slightly constricted at

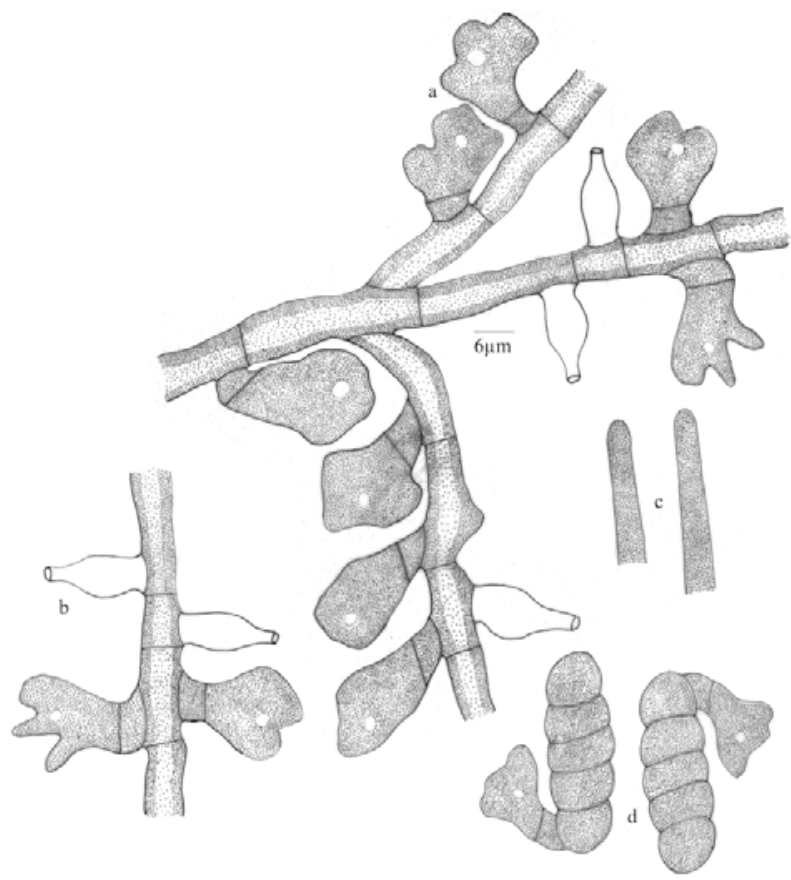

Figure 43. Meliola aporusae

a - Appressorium; b - Phialide; c - Apical portion of mycelial setae; d - Ascospores the septa, 35-40x12-18 $\mu \mathrm{m}$.

Meliola ardisiigena Hosag., Sabeena \& Robin, Bioscience Discovery 2:120, 2011; Hosag., J. Threatened Taxa 5(6):4018, 2013 (Fig. 45).

Material examined: HCIO 50639 (isotype), TBGT 4556 (holotype), 27.ix.2008, on leaves of Ardisia sp. (Myrsinaceae), Pulpally, coll. P.J. Robin et al.

Colonies hypophyllous, subdense to dense, up to $3 \mathrm{~mm}$ in diameter, confluent. Hyphae substraight, branching opposite to unilateral at acute to wide angles, loosely to closely reticulate, cells $15-30 \times 5-7 \mu \mathrm{m}$. Appressoria alternate, up to $30 \%$ opposite to unilateral, antrorse to subantrorse, 12-22 $\mu \mathrm{m}$ long; stalk cells cylindrical to cuneate, 2-7 $\mu \mathrm{m}$ long; head cells ovate, globose, entire, 10-17x7-12 $\mu \mathrm{m}$. Phialides mixed with appressoria, alternate to opposite, ampulliform, 12-25x5-10 $\mu \mathrm{m}$. Mycelial setae simple, straight, acute to obtuse at the tip, up to $350 \mu \mathrm{m}$ long. Perithecia scattered, up to $200 \mu \mathrm{m}$ in diam.; ascospores elliptic, 4-septate, constricted at the septa, 42-57x12-15 $\mu \mathrm{m}$.

Meliola ardisiicola Hosag. et al. is known on Ardisia missionis from the high ranges of Western Ghats (Hosagoudar 2008). However, the present new species differs from it in having longer and 30\% opposite appressoria and longer ascospores.

Meliola aristolochigena Hosag. \& Archana, J. Threatened Taxa 1: 348, 2009; Hosag., J. Threatened Taxa 5(6):4019, 2013 (Fig. 46).

Material examined: $\mathrm{HClO}$ 50362, TBGT 4279, 5.xi.2009, on leaves of Aristolochia grandiflora Sw. (Aristolochiaceae), Gurukulam Botanic Garden, Periya, coll. A. Sabeena \& M.C. Riju.

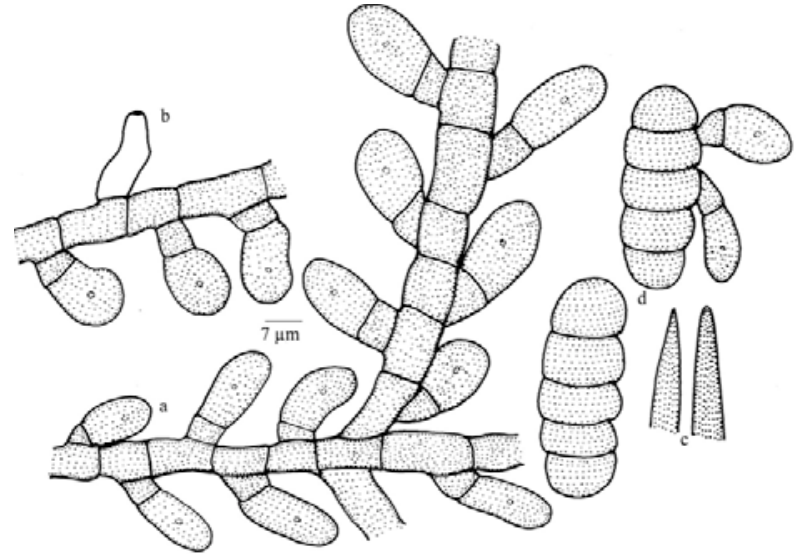

Figure 44. Meliola ardisiicola

a - Appressorium; b - Phialide; c - Apical portion of mycelial setae; d - Ascospores 
Colonies epiphyllous, thin to dense, up to $2 \mathrm{~mm}$ in diam. Hyphae substraight to flexuous, branching alternate, opposite to irregular at acute to wide angles, loosely to closely reticulate, cells $12-16 \times 8-10$ $\mu \mathrm{m}$. Appressoria alternate to about 3\% opposite, antrorse to subantrorse, 14-20 $\mu \mathrm{m}$ long; stalk cells cylindrical to cuneate, 3-7 $\mu \mathrm{m}$ long; head cells ovate to globose, entire, 11-13x9-13 $\mu \mathrm{m}$. Phialides mixed with appressoria, alternate to opposite, ampulliform, 1620x8-10 $\mu \mathrm{m}$. Mycelial setae scattered, simple, straight, acute to obtuse at the tip, up to $540 \mu \mathrm{m}$ long. Perithecia scattered, up to $120 \mu \mathrm{m}$ in diam.; ascospores oblong to cylindrical, 4-septate, constricted at the septa, 3540x12-14 $\mu \mathrm{m}$.

Having opposite appressoria, Meliola aristolochigena can be compared with $M$. catharinensis Hansf. reported on Aristolochia triangularis from Brazil (Hansford, 1961). However, differs from it in having distinctly longer appressoria (14-20 $\mu \mathrm{m}$ against 11-15 $\mu \mathrm{m})$ and mycelial setae $(540 \mu \mathrm{m}$ against $230 \mu \mathrm{m})$.

Meliola artocarpi Yates, Philippine J. Sci. 12: 362, 1917; Hansf., Sydowia Beih. 2: 328, 1961; Hosag. \& Goos, Mycotaxon 42: 130, 1991; Hosag., Kaveriappa, Raghu \& Goos, Mycotaxon 51: 111, 1994; Hosag., Meliolales of

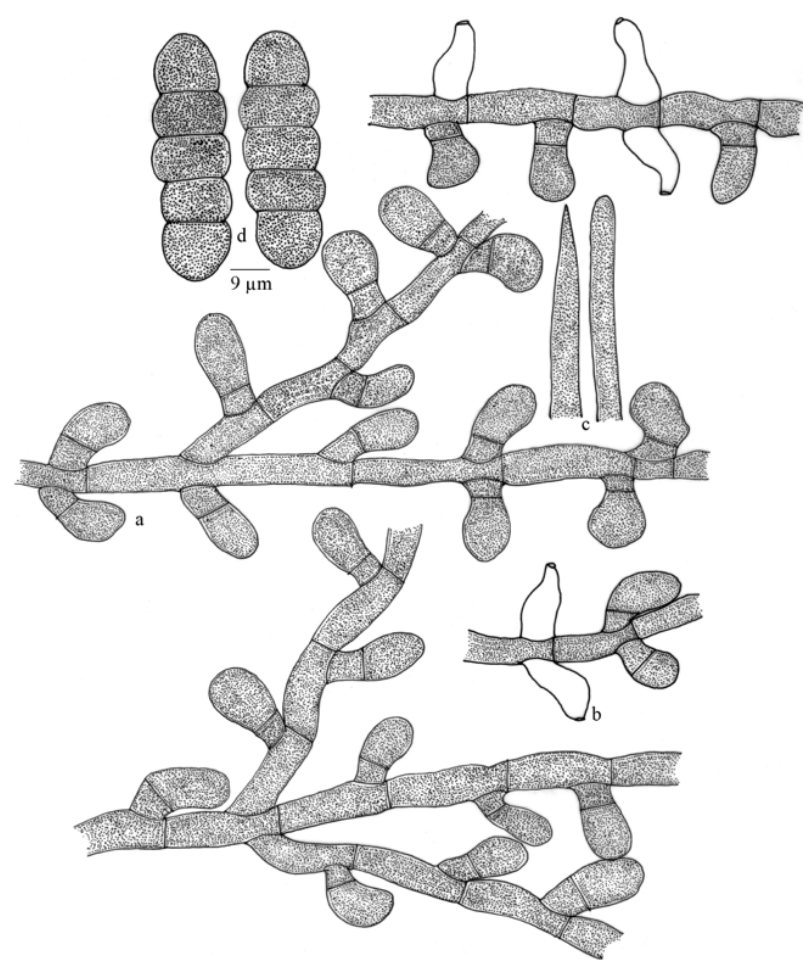

Figure 45. Meliola ardisiigena

a - Appressorium; b - Phialide; c - Apical portion of mycelial setae; d - Ascospores
India, p. 133, 1996 (Fig. 47 \& Image 6).

Materials examined: HClO 42181, TBGT 53, 28.iii.1996, on leaves of Artocarpus heterophyllus Lam. (Moraceae), Karadimala, coll. V.B. Hosagoudar.

Colonies epiphyllous, dense, velvety, up to $2 \mathrm{~mm}$ in diameter. Hyphae straight to substraight, branching alternate at acute angles, closely reticulate, cells 2436x7-9.6 $\mu \mathrm{m}$. Appressoria alternate, antrorse, 26-41 $\mu \mathrm{m}$ long; stalk cells cylindrical to cuneate, margin may wavy or entire, 9-17 $\mu \mathrm{m}$ long; head cells ovate, angular to sublobate, $16-24 \times 17 \mu \mathrm{m}$. Phialides borne on separate mycelial branch, $1 \%$ mixed with appressoria, alternate to unilateral, ampulliform, 19-26x7-10 $\mu \mathrm{m}$. Mycelial setae densely scattered, simple, curved, obtuse at the tip, up to $430 \mu \mathrm{m}$ long. Perithecia scattered, verrucose, up to $170 \mu \mathrm{m}$ in diameter; ascospores obovate, 3-4 septate, constricted at the septa, 50-53×16-19 $\mu \mathrm{m}$.

Epiphyllous colonies, uncinate and obtuse mycelial setae are the characteristics of this species.

Common throughout Southern Western Ghats.

Meliola atalantiae Hosag. in Hosag. \& Goos, Mycotaxon 37: 220, 1990; Hosag., Meliolales of India, p. 135, 1996 (Fig. 48).

Materials examined: $\mathrm{HClO}$ 50365, TBGT 4282; $\mathrm{HClO}$ 49888, TBGT 4040, 18.ix.2008, on leaves of Atlantia sp. (Rutaceae), Thirunelly, coll. M. Harish et al.; $\mathrm{HClO} 49437$, TBGT 3682, 16.ii.2009, Thirunelly, coll. Harish et al.,

Colonies amphigenous, mostly hypophyllous, crustaceous, up to $8 \mathrm{~mm}$ in diameter, rarely confluent. Hyphae straight, substraight to crooked, branching opposite to irregular at acute angles, loosely reticulate, cells $20-28 \times 6-8 \mu \mathrm{m}$. Appressoria alternate, about $20 \%$ opposite, straight to curved, subantrorse to spreading, 20-30 $\mu \mathrm{m}$ long; stalk cells cylindrical to cuneate, 4-10

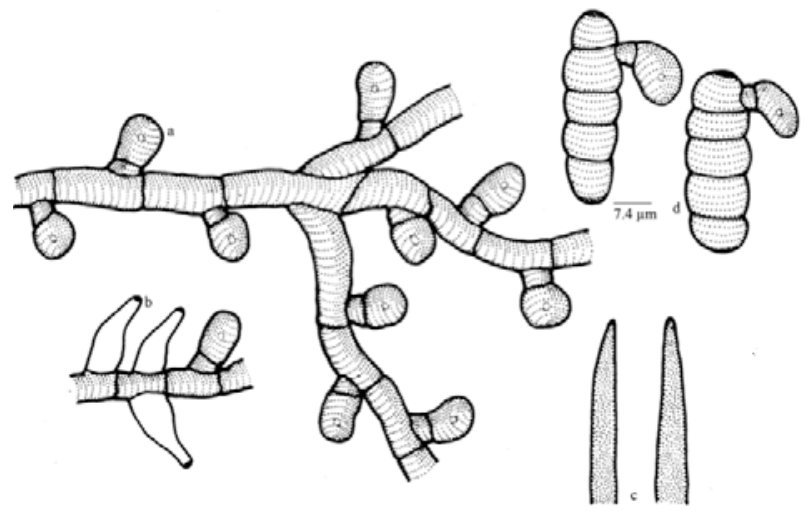

Figure 46. Meliola aristolochigena

a - Appressorium; b - Phialide; c - Apical portion of mycelial setae; d - Ascospores 
$\mu \mathrm{m}$ long; head cells ovate, conoid, rounded at the apex, entire, 14-20x8-10 $\mu \mathrm{m}$. Phialides mixed with appressoria, opposite to alternate, ampulliform, 2026x8-12 $\mu \mathrm{m}$. Mycelial setae scattered, straight, often curved, simple, acute to 2-3 dentate to cristate at the tip, up to $765 \mu \mathrm{m}$ long. Perithecia scattered, immature; ascospores oblong, 4-septate, constricted at the septa, 40-44x14-16 $\mu \mathrm{m}$.

Meliola beilschmiediae Yamam. var. cinnamomicola Hosag. in Hosag. \& Goos, Mycotaxon 87: 222, 1990; Hosag., Meliolales of India, p. 142, 1996 (Fig. 49).

Materials examined: $\mathrm{HClO}$ 44335, TBGT 718, 10.i.2002, on leaves of Cinnamomum macrocarpum (Lauraceae), Periya, coll. M. Kamarudeen.

Colonies hypophyllous, dense, velvety, up to $3 \mathrm{~mm}$ in diameter, rarely confluent. Hyphae flexuous, branching alternate to irregular at acute angles, closely reticulate, form almost solid mycelial mat, cells 20-30x6-8 $\mu \mathrm{m}$. Appressoria alternate, straight to variously curved, antrorse to reflexed, 20-24 $\mu \mathrm{m}$ long; stalk cells cylindrical to cuneate, 6-10 $\mu \mathrm{m}$ long; head cells globose, ovate, angular, entire, 14-16x12-14 $\mu \mathrm{m}$. Phialides few, mixed with appressoria, opposite to alternate, ampulliform, 18-22x8-10 $\mu \mathrm{m}$. Mycelial setae numerous, evenly scattered, straight, simple, acute to variously dentate at the tip, up to $684 \mu \mathrm{m}$ long. Perithecia closely scattered,
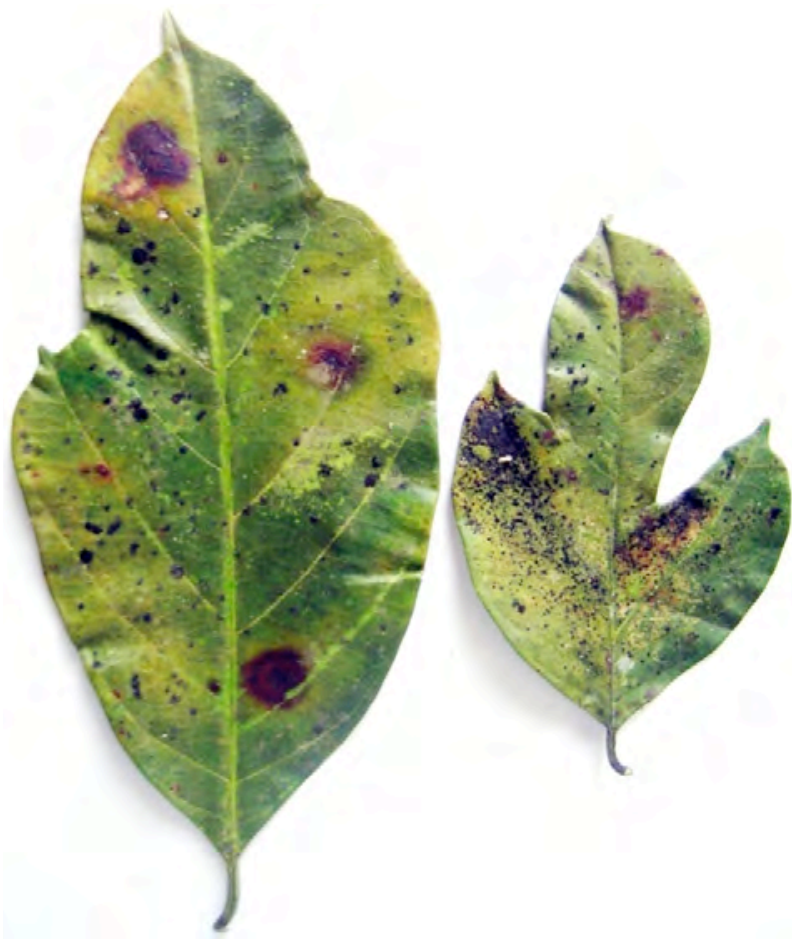

Image 6. Meliola artocarpi-Infected leaves

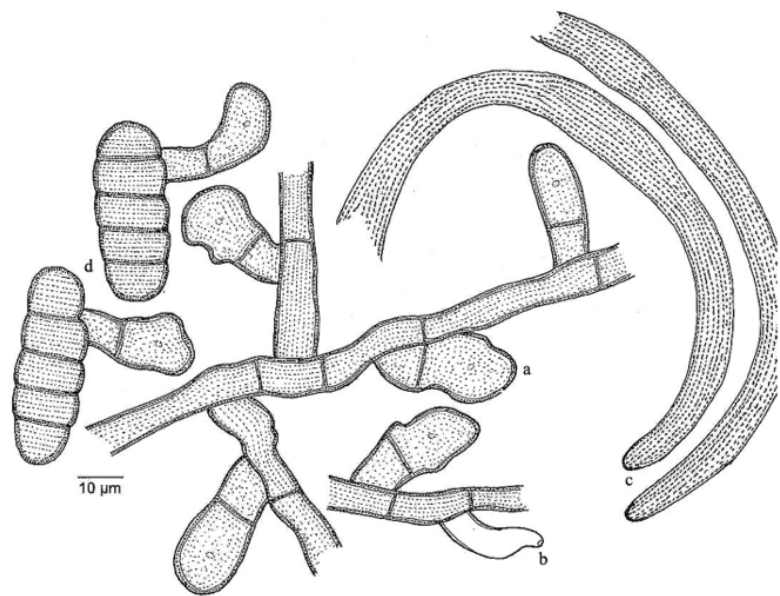

Figure 47. Meliola artocarpi

a - Appressorium; b - Phialide; c - Apical portion of mycelial setae; d - Ascospores

verrucose, up to $216 \mu \mathrm{m}$ in diameter; ascospores obovoidal, 4-septate, slightly constricted at the septa, 54-60x16-20 $\mu \mathrm{m}$.

Meliola buteae Hafiz, Azmatulla \& Kafi, Biologia 1: 112, 1955; Hansf., Sydowia Beih. 2: 291, 1961; Thite \& Patil, Kavaka 10: 29, 1982; Hosag. \& Goos, Mycotaxon 37: 223, 1990; Hosag., Meliolales of India, p. 148, 1996 (Fig. 50).

Materials examined: $\mathrm{HClO}$ 49063, TBGT 3318, 19.xi.2008, on leaves of Butea parviflora Roxb. (Fabaceae), Pulpally, coll. M. Harish \& P.J. Robin; HCIO 49628, TBGT 3870, 19.ix.2008, coll. M. Harish \& P.J.

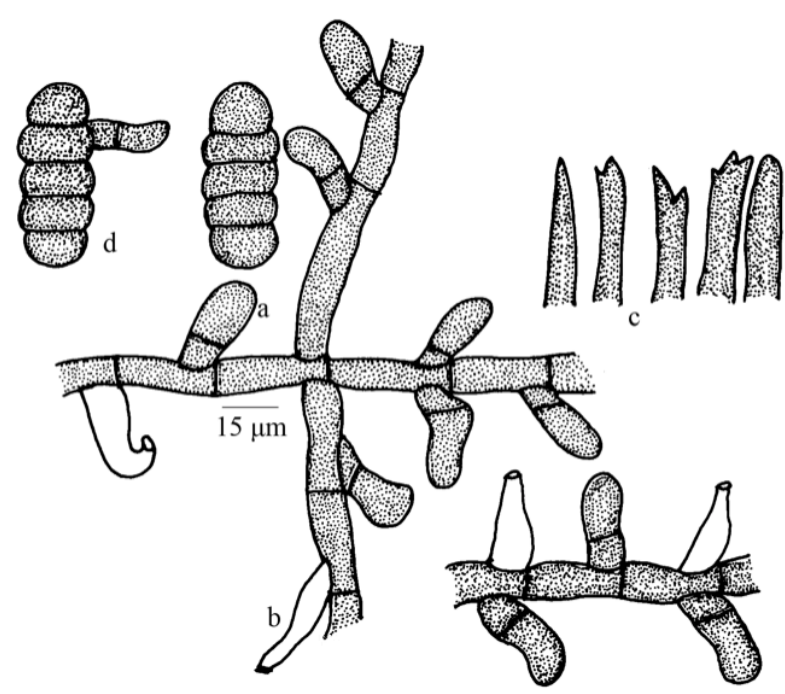

Figure 48. Meliola atalantiae

a - Appressorium; b - Phialide; c - Apical portion of mycelial setae; d - Ascospores 


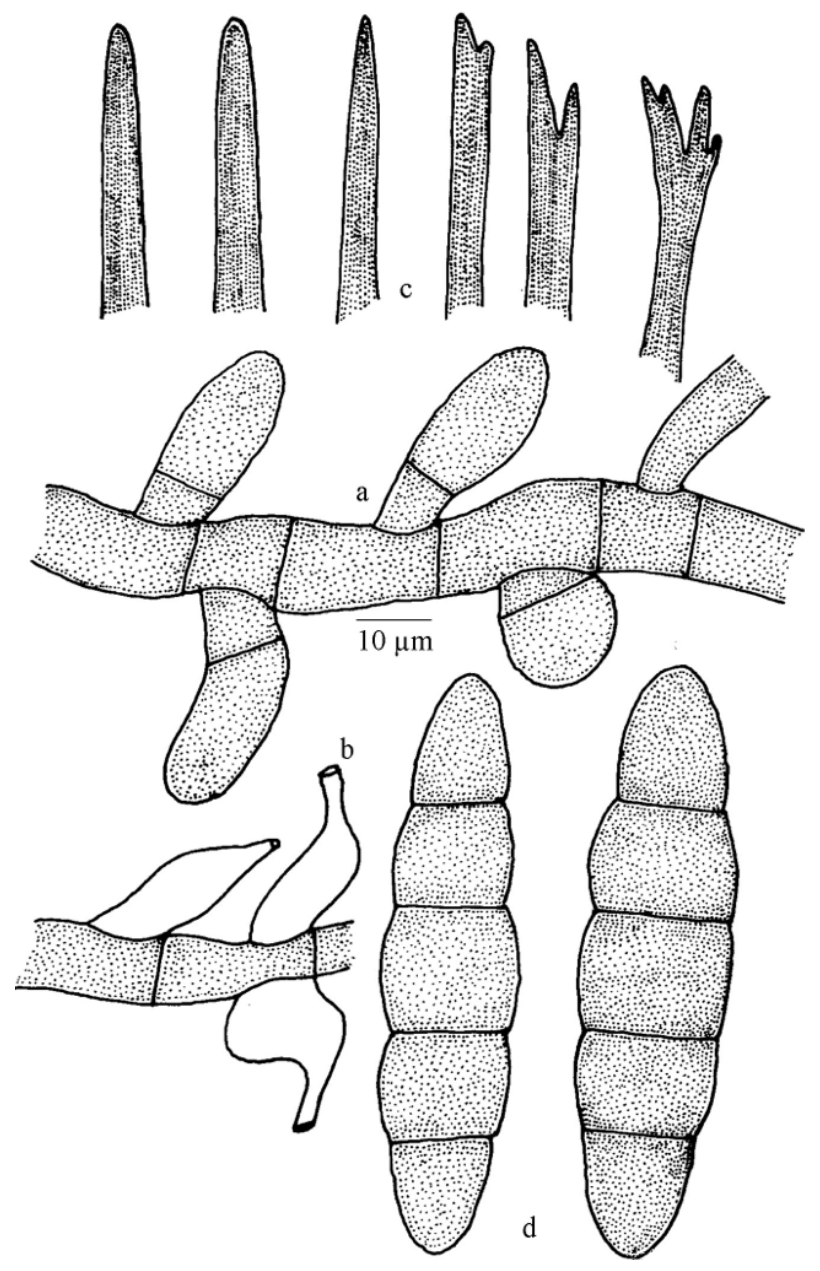

Figure 49. Meliola beilschmiediae var. cinnamomicola a - Appressorium; b - Phialide; c - Apical portion of mycelial setae; d - Ascospores

Robin; HClO 50845; TBGT 4762; HClO 50854, TBGT 4771, 6.xi.2009, Butea monosperma (Lam.) Taubert, Padinharathara, coll. M.C. Riju \& A. Sabeena.

Colonies epiphyllous, dense, velvety, up to $3 \mathrm{~mm}$ in diameter, confluent. Hyphae straight to substraight, branching opposite at wide angles, loosely reticulate, cells $21-31 \times 5-7 \mu \mathrm{m}$. Appressoria opposite to alternate, about $5 \%$ unilateral, subantrorse to spreading, $12-$ $17 \mu \mathrm{m}$ long; stalk cells cylindrical to cuneate, 2-5 $\mu \mathrm{m}$ long; head cells cylindrical, clavate, subglobose, entire to angulose, 9-12x9-12 $\mu \mathrm{m}$. Phialides mixed with appressoria, alternate to opposite, ampulliform, 14-19x7-9 $\mu \mathrm{m}$. Mycelial setae numerous, scattered, straight, simple, acute at the tip, up to $680 \mu \mathrm{m}$ long. Perithecia scattered, verrucose, globose, up to $170 \mu \mathrm{m}$ in diameter; ascospores cylindrical, 4-septate, constricted at the septa, 36-38x14-17 $\mu \mathrm{m}$.

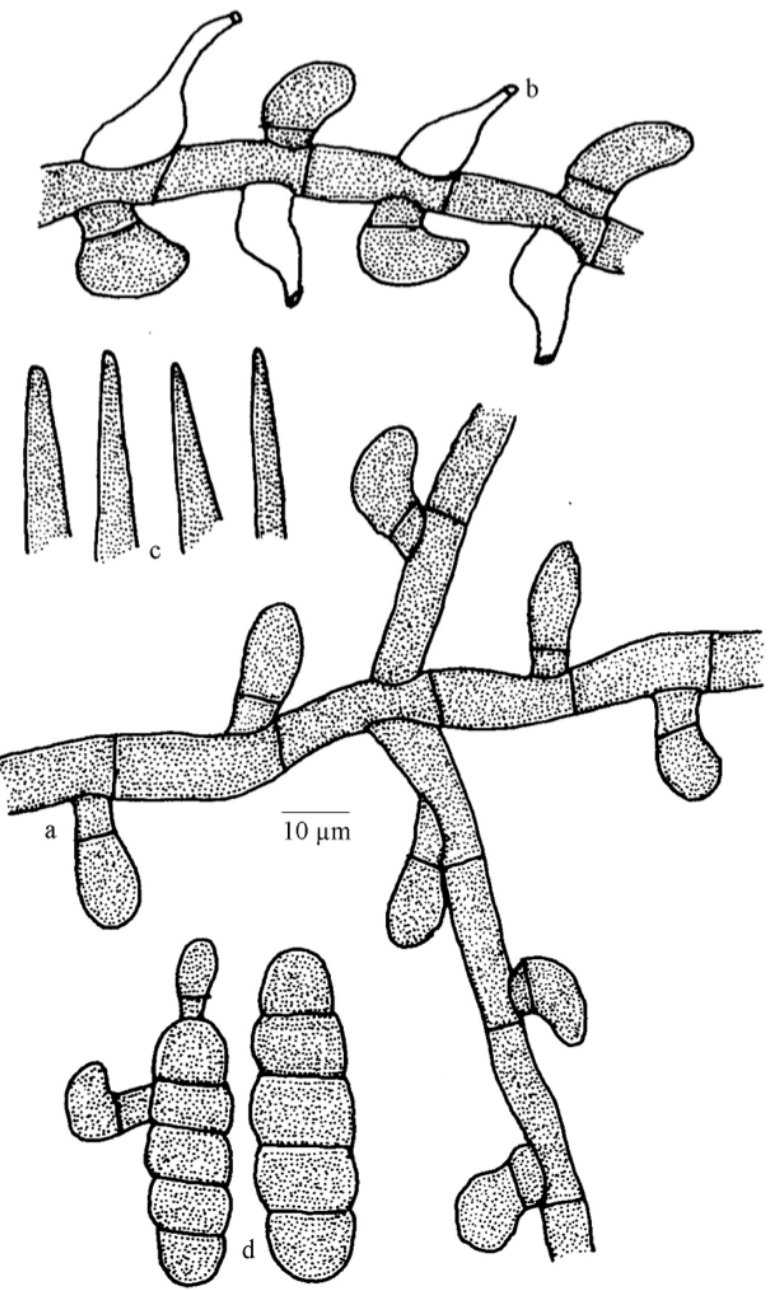

Figure 50. Meliola buteae

a - Appressorium; b - Phialide; c - Apical portion of mycelial setae; d - Ascospores

This species is very common on this host genus in the Western Ghats

Meliola butleri Sydow, Ann. Mycol. 9: 379, 1911; Hansf., Sydowia Beih. 2: 382, 1961; Srinivasulu, Nova Hedwigia Beih. 47: 423, 1974; Hosag., J. Econ. Tax. Bot. 9: 375, 1987; Hosag., Meliolales of India, p. 148, 1996; J. Econ. Taxon. Bot. 30: 947, 2006.

Amazonia butleri Stev., Ann. Mycol. 25: 415, 1927 (Fig. 51).

Materials examined: $\mathrm{HClO}$ 50843, TBGT 4760, 6.xi.2009, on leaves of Citrus sp. (Rutaceae), Padinharathara, coll. M.C. Riju \& A. Sabeena.

Colonies amphigenous, mostly epiphyllous, dense, up to $4 \mathrm{~mm}$ in diameter. Hyphae straight to undulate, branching opposite to irregular at wide angles, closely 


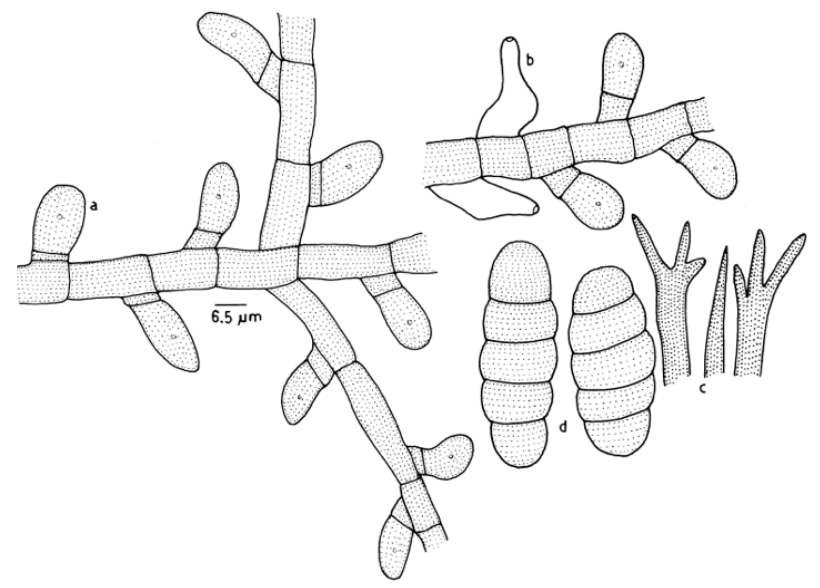

Figure 51. Meliola butleri

a - Appressorium; b - Phialide; c - Apical portion of mycelial setae; d - Ascospores

reticulate, cells $11-25 \times 6-8 \mu \mathrm{m}$. Appressoria alternate to opposite, antrorse, curved, 15-24 $\mu \mathrm{m}$ long; stalk cells cylindrical to cuneate, 4-6 $\mu \mathrm{m}$ long; head cells ovate, clavate, cylindrical, often curved, entire, 12-17x7-10 $\mu \mathrm{m}$. Phialides mixed with appressoria, opposite to alternate, ampulliform, 15-21x6-8 $\mu \mathrm{m}$. Mycelial setae scattered, straight, acute to dentate, up to $685 \mu \mathrm{m}$ long. Perithecia scattered, verrucose, up to $232 \mu \mathrm{m}$ in diam.; ascospores oblong to subellipsoidal, 4-septate, constricted at the septa, 32-45x14-19 $\mu \mathrm{m}$.

The present taxon can be compared with Meliola citricola Sydow. The former has mostly epiphyllous, smaller, crustose colonies with straight hyphae, mostly antrorse appressoria and dentate mycelial setae. However, the latter has mostly hypophyllous, larger, velvety colonies with crooked mycelium, irregularly curved appressoria and both acute and dentate mycelial setae.

Meliola cadigensis Yates var. toddaliae Hosag., C.K. Biju \& Abraham, Nova Hedwigia 80: 484, 2005; Hosag., Meliolales of India, p. 199, 2008 (Fig. 52).

Materials examined: $\mathrm{HClO}$ 43617, TBGT 299, 19.xi.1998, on leaves of Toddalia sp. (Rutaceae), Banasuranmala, coll. C.K. Biju.

Colonies amphigenous, dense, up to $2 \mathrm{~mm}$ diameter, rarely confluent. Hyphae substraight to flexuous, branching alternate to opposite at acute angles, loosely to closely reticulate, cells $12-28 \times 6-8 \mu \mathrm{m}$. Appressoria alternate, 5\% opposite, antrorse to closely antrorse, 12-18 $\mu \mathrm{m}$ long; stalk cells cylindrical to cuneate, 3-7 $\mu \mathrm{m}$ long; head cells mostly ovate, entire, 9-12x8-10 $\mu \mathrm{m}$. Phialides mixed with appressoria, alternate to opposite,

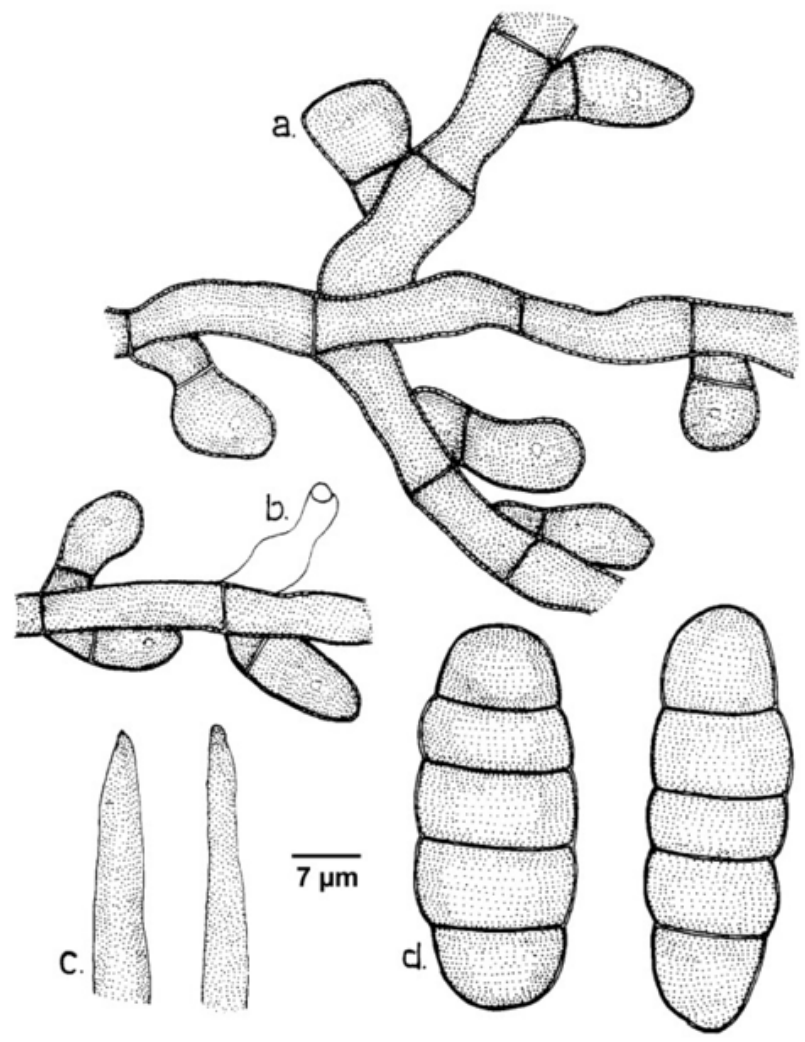

Figure 52. Meliola cadigensis var. toddaliae a - Appressorium; b - Phialide; c - Apical portion of mycelial setae; d-Ascospores

ampulliform, 16-24x6-8 $\mu \mathrm{m}$. Mycelial setae scattered to grouped around perithecia, simple, predominantly straight, few curved, acute to obtuse at the tip, up to $540 \mu \mathrm{m}$ long; perithecia scattered to loosely grouped, up to $165 \mu \mathrm{m}$ diam.; ascospores oblong to cylindrical, 4-septate, constricted at the septa, 35-39×14-16 $\mu \mathrm{m}$.

Meliola cadigensis Yates var. glycosmidis (Kapoor) Hosag., Crypt. Bot. 213: 186, 1991; Hosag., Meliolales of India, p. 149, 1996.

Meliola glycosmidis Kapoor, Indian Phytopath. 20: 153, 1967; Hosag. \& Goos, Mycotaxon 37: 234, 1990 (Fig. 53).

Materials examined: $\mathrm{HClO}$ 49067, TBGT 3322; $\mathrm{HClO}$ 49072, TBGT 3327; HCIO 51151, TBGT 5031; HClO 51294, TBGT 5174, 18.ix.2008, on leaves of Glycosmis mauritiana (Lam.) Tanaka $\{(G$. pentaphylla Correa) $\}$ (Rutaceae), Thirunelly, coll. M. Harish \& P.J. Robin; HClO 42970, TBGT 246, 11.viii.1998, coll. C.K.Biju; HClO 44628, TBGT 910, 23.ix.2002, coll. K. Vijayakumar; HCIO 49399, TBGT 3644, 12.ii.2009, coll. P.J. Robin et al.; HCIO 49649, TBGT 3891, 17.xi.2008, Periya, coll. M. Harish \& P.J. Robin; HCIO 49438, TBGT 3683, 15.ii.2009, Begoor, 


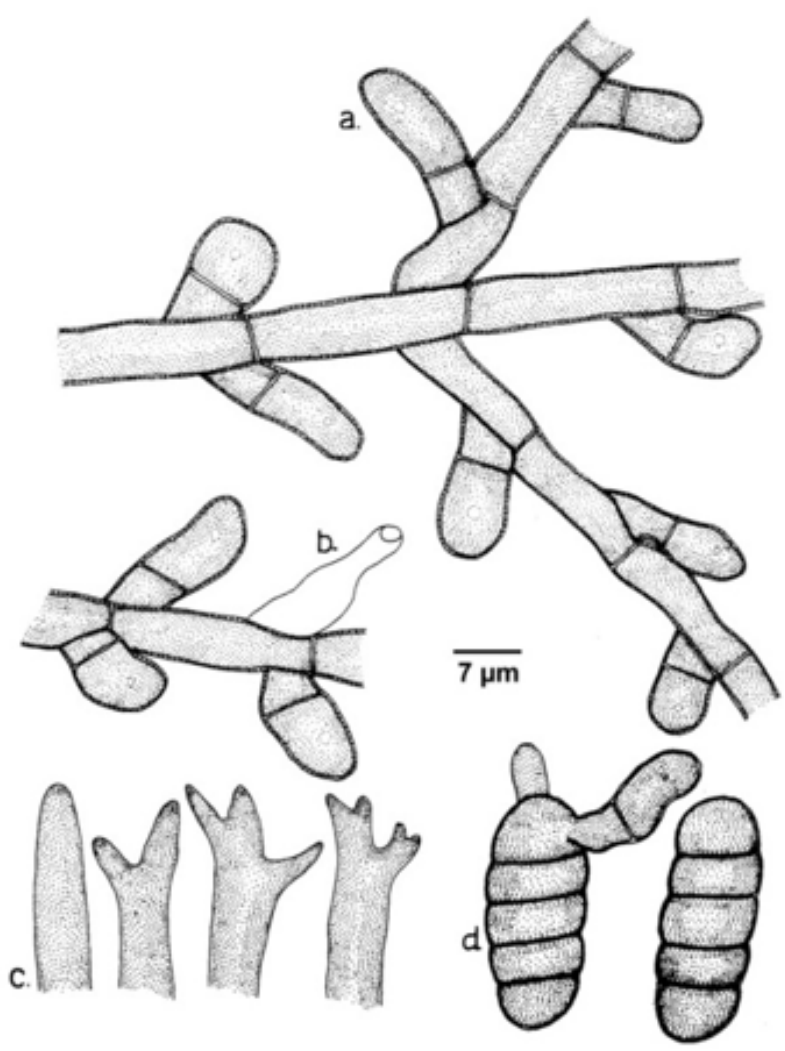

Figure 53. Meliola cadigensis var. glycosmidis

a - Appressorium; b - Phialide; c - Apical portion of mycelial setae; d - Ascospores

coll. Harish et al.; HCIO 49966, TBGT 4118, 16.ix.2007, Puthuserrkadavu, coll. M.C. Riju; HCIO 50826, TBGT 4743; HCIO 50828, TBGT 4745, 4.xi.2009, Padinharathara, coll. M.C. Riju \& A. Sabeena.

Colonies amphigenous, mostly epiphyllous, dense, velvety, scattered, cover all the upper surface of the leaves, up to $4 \mathrm{~mm}$ in diameter, confluent. Hyphae straight to substraight, branching opposite at acute to wide angles, closely reticulate to form a mycelial mat, cells 12-22x7-10 $\mu \mathrm{m}$. Appressoria alternate and opposite, crowded, straight to curved, antrorse to spreading, 14$22 \mu \mathrm{m}$ long; stalk cells cylindrical to cuneate, 4-10 $\mu \mathrm{m}$ long; head cells ovate, globose to subglobose, entire, rounded at the apex, 9-12x7-12 $\mu \mathrm{m}$. Phialides mixed with appressoria, opposite to alternate, ampulliform, 14-22x7-10 $\mu \mathrm{m}$. Mycelial setae numerous, scattered, straight, simple, acute to dentate at the tip, up to $700 \mu \mathrm{m}$ long. Perithecia scattered, verrucose, up to $180 \mu \mathrm{m}$ in diameter; ascospores obovoidal to slightly ellipsoidal, 4-septate, constricted at the septa, 33-38x12-16 $\mu \mathrm{m}$.

The variety differs from the species in having dentate mycelial setae.
Meliola cannonicola Hosag. \& C.K. Biju, Indian Phytopath. 57: 456, 2004; Hosag., Meliolales of India, p. 202, 2008 (Fig. 54).

Materials examined: HClO 45266, TBGT 1304, 16.iv.1999, on leaves of Toddalia asiatica (L.) Lam. (Rutaceae), Banasuran Mala, coll. C.K. Biju.

Colonies epiphyllous, dense, scattered, velvety, up to $3 \mathrm{~mm}$ in diameter, rarely confluent. Hyphae straight to substraight, branching alternate to opposite at acute angles, loosely to closely reticulate, cells 19-24x6-8 $\mu \mathrm{m}$. Appressoria alternate, 5\% opposite, antrorse to subantrorse, 19-24 $\mu \mathrm{m}$ long; stalk cells cylindrical to cuneate, 4-8 $\mu \mathrm{m}$ long; head cells oblong, clavate, cylindrical, entire to rarely slightly angular, 14-16x9$11 \mu \mathrm{m}$. Phialides mixed with appressoria, alternate to opposite, ampulliform, 19-24x8-10 $\mu \mathrm{m}$. Mycelial setae scattered, simple, straight, acute at the tip, up to $980 \mu \mathrm{m}$ long. Perithecia scattered to loosely grouped, up to $136 \mu \mathrm{m}$ in diam.; ascospores oblong to cylindrical, 4-septate, constricted at the septa, 38-44x13-15 $\mu \mathrm{m}$.

There are six taxa of the genus Meliola on the host genus Toddalia (Hansford 1961; Mibey \& Hawksworth 1997). The present taxon is close to Meliola toddalicola Hansf. and M. toddalicola Hansf. var. indica Hansf. \& Thirum. in having alternate and opposite appressoria. This taxon differs from the former in having smaller and only $5 \%$ appressoria and having shorter mycelial setae. It also differs from the latter taxon in having only $5 \%$ opposite appressoria and longer mycelial setae.

Meliola cannonii Hosag., J. Mycopathol. Res. 43: 22, 2005; Hosag., Meliolales of India, p. 201, 2008 (Fig. 55).

Materials examined: $\mathrm{HClO}$ 43818, TBGT 389, 20.ix.2008, on leaves of Strychnos nux-vomica L. (Strychnaceae), Pulpally, coll. M. Harish. \& P.J Robin.

Colonies amphigenous, mostly hypophyllous, subdense, up to $2 \mathrm{~mm}$ in diameter, confluent. Hyphae substraight, flexuous to crooked, branching opposite to irregular at acute to wide angles, loosely reticulate, cells $16-20 \times 6-8 \mu \mathrm{m}$. Appressoria alternate, less than $1 \%$ opposite, antrorse, subantrorse to recurved, 17-26 $\mu \mathrm{m}$ long; stalk cells cylindrical to cuneate, 6-10 $\mu \mathrm{m}$ long; head cells ovate, oblong, entire to angular, attenuated to truncate at the apex, 11-16x8-12 $\mu \mathrm{m}$. Phialides numerous, mixed with appressoria, alternate to opposite, ampulliform, 12-20x6-8 $\mu \mathrm{m}$. Mycelial setae scattered to grouped around perithecia, simple, straight, curved to uncinate, acute at the tip, up to $350 \mu \mathrm{m}$ long. Perithecia scattered to loosely grouped, up to $130 \mu \mathrm{m}$ in diameter; ascospores cylindrical, 4-septate, constricted at the septa, 30-32×12-15 $\mu \mathrm{m}$. 


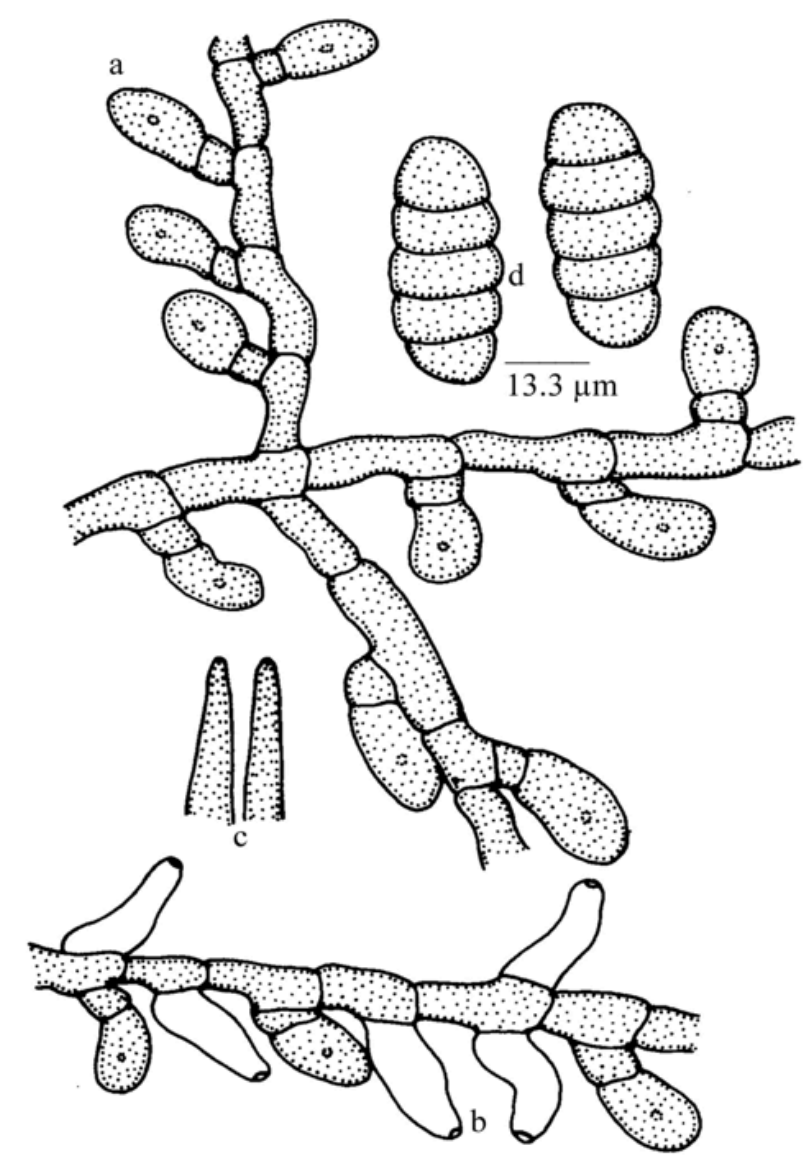

Figure 54. Meliola cannonicola

a - Appressorium; b - Phialide; c - Apical portion of mycelial setae; d- Ascospores

Based on the morphology of appressoria, Meliola cannonii is similar to M. strychni-multiflorae Hansf. known on Strychnos multiflora from Philippines but differs from it in having comparatively closely arranged appressoria, shorter and straight to uncinate mycelial setae.

Meliola canavaliae Hosag. \& Riju, Plant Pathology \& Quarantine 1(2): 125, 2011; Hosag., J. Threatened Taxa 5(6):4022, 2013 (Fig. 56).

Material examined: HClO 51043, TBGT 4960; HClO 51044, TBGT 4961, 10.i.2011, on leaves of Canavalia sp. (Fabaceae), 16th mile, Padinharathara, coll. M.C. Riju.

Colonies foliicolous, epiphyllous, thin, scattered, up to $4 \mathrm{~mm}$ in diameter. Hyphae flexuous to undulate, branching mostly opposite at acute to wide angles, loosely to closely reticulate, cells $15-38 \times 5-8 \mu \mathrm{m}$. Appressoria alternate, unilateral, rarely opposite, straight to slightly curved, antrorse, subantrorse to retrorse, 10-18 $\mu \mathrm{m}$ long; stalk cells cylindrical to cuneate,

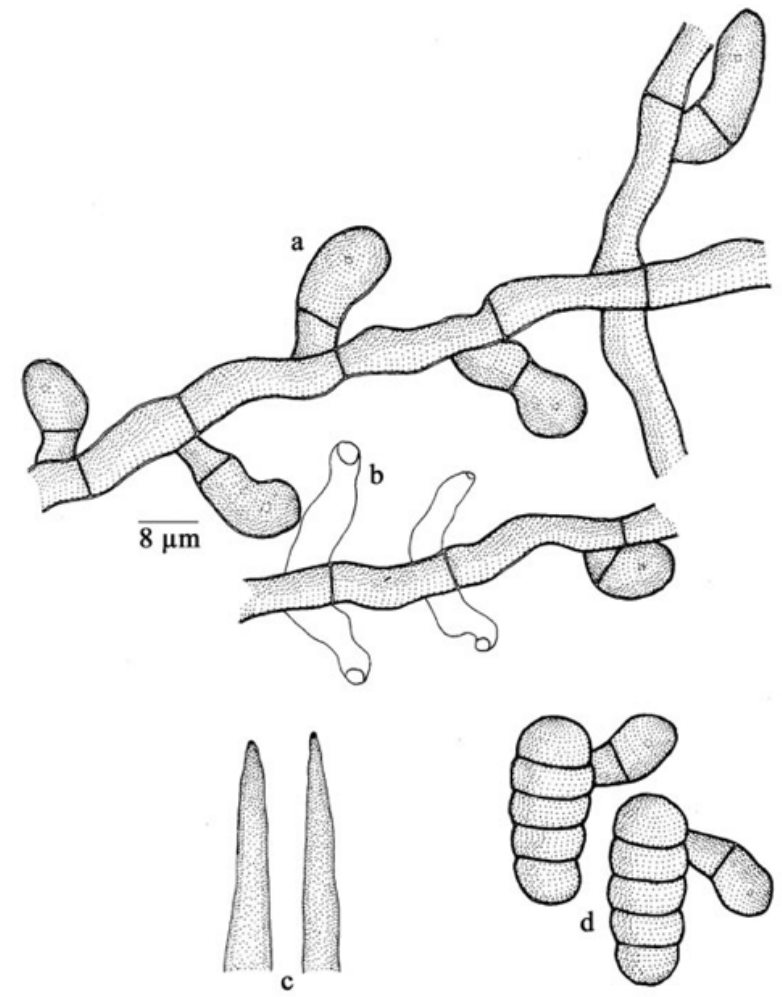

Figure 55. Meliola cannonii

a - Appressorium; b - Phialide; c - Apical portion of mycelial setae; d - Ascospores

2-8 $\mu \mathrm{m}$ long; head cells ovate, globose, 10-15x8-15 $\mu \mathrm{m}$. Phialides mixed with appressoria, opposite, unilateral, ampulliform, 15-25x7-10 $\mu \mathrm{m}$. Mycelial setae scattered to grouped around perithecia, simple, straight to slightly curved, acute to obtuse at the tip, up to $340 \mu \mathrm{m}$ long. Perithecia scattered, up to $160 \mu \mathrm{m}$ in diameter; ascospores cylindrical, 4-septate, slightly constricted at the septa, 33-35x10-13 $\mu \mathrm{m}$.

Hansford (1961) identified M. teramni Sydow infecting leaves of Canavalia ensiformis collected by F.C. Deighton from Sierra Leone. The present fungus is similar but differs in having shorter (340 $\mu \mathrm{m}$ vs. 1000 $\mu$ ), acute to obtuse setae (in contrast to 2-4 dentate or furcate) and smaller ascospores (33-35x10-13 $\mu \mathrm{m}$ vs. 35-42x13-16 $\mu \mathrm{m})$.

Meliola canthiicola Hosag., C.K. Biju \& Abraham, J. Econ. Taxon. Bot. 25: 69, 2001; Hosag., Meliolales of India, p. 204, 2008 (Fig. 57).

Materials examined: $\mathrm{HClO}$ 43828, TBGT 360, 18.xi.1999, on leaves of Canthium rheedii DC. (Rubiaceae), Chembra hills, coll. C. K. Biju.

Colonies amphigenous, mostly epiphyllous, dense, 
velvety, up to $3 \mathrm{~mm}$ in diameter. Hyphae straight to flexuous, branching alternate to opposite at acute angles, closely reticulate, cells 20-24x8-10 $\mu \mathrm{m}$. Appressoria alternate, antrorse to closely antrorse, 28-35 $\mu \mathrm{m}$ long; stalk cells cylindrical to cuneate, 8-13 $\mu \mathrm{m}$ long; head cells ovate, oblong, entire, angular to slightly lobate, attenuated and broadly rounded to truncate at the apex, 19-23x12-16 $\mu \mathrm{m}$. Phialides borne on a separate mycelial branch, alternate to opposite, ampulliform, 15-18x7-9 $\mu \mathrm{m}$. Mycelial setae scattered, simple, straight to rarely curved, acute at the tip, up to $500 \mu \mathrm{m}$ long. Perithecia scattered, up to $25 \mu \mathrm{m}$ in diameter; ascospores slightly ellipsoidal, 4-septate, constricted at the septa, 44-47x19-22 $\mu \mathrm{m}$.

Morphologically, Meliola canthiicola is similar to $M$. canthii Hansf. but differs from it in having the phialides borne on a separate mycelial branch and smaller ascospores.

Meliola capensis (Kalch. \& Cooke) Theiss. var. allophylicola Hansf. \& Deight., Mycol.Pap. 23: 45, 1948; Hansf., Sydowia Beih. 2: 437, 1961; Kar \& Bhattacharya, Indian Phytopath. 35: 39, 1982; Hosag., Meliolales of India, p. 154, 1996 (Fig. 58).

Materials examined: HCIO 46690, TBGT 2031, 27.xii.2002, on leaves of Allophylus sp. (Sapindaceae), Periya, coll. M. Kamarudeen \& P.A. Jose.

Colonies epiphyllous, dense, velvety, up to $4 \mathrm{~mm}$ in diameter, confluent. Hyphae straight to substraight, branching opposite at acute to wide angles, loosely to closely reticulate, cells $16-26 \times 6-7 \mu \mathrm{m}$. Appressoria

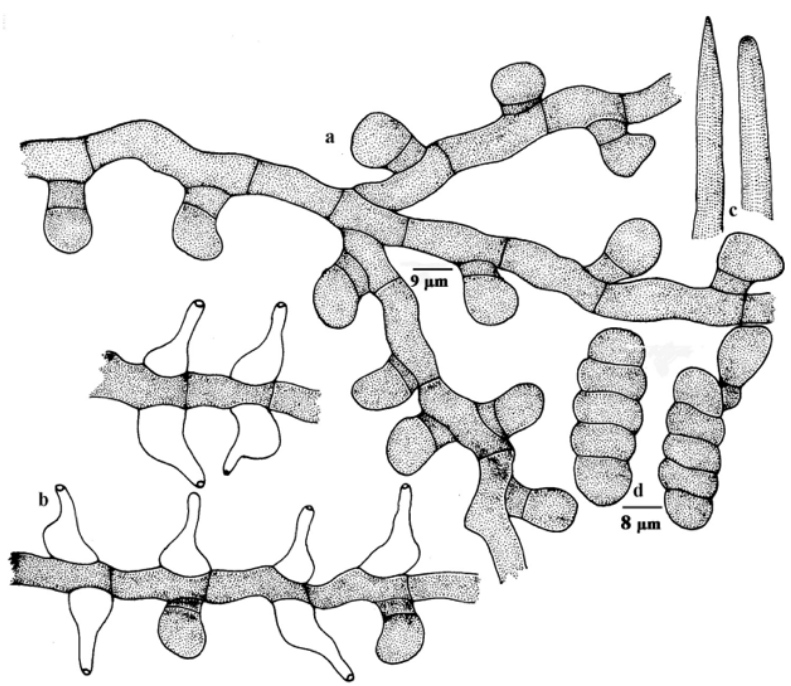

Figure 56. Meliola canavaliae

a - Appressorium; b - Phialide; c - Apical portion of mycelial setae; d - Ascospores alternate and opposite, $10 \%$ unilateral, antrorse to subantrorse, straight to curved, 16-24 $\mu \mathrm{m}$ long; stalk cells cylindrical to cuneate, $2-7 \mu \mathrm{m}$ long; head cells ovate, globose to subglobose, entire to subangular, 12-17x9$12 \mu \mathrm{m}$. Phialides mixed with appressoria, opposite to alternate, ampulliform, 21-26x7-10 $\mu \mathrm{m}$. Mycelial setae numerous, scattered to grouped around perithecia, simple, straight, acute, obtuse to dentate at the tip, up to $580 \mu \mathrm{m}$ long. Perithecia scattered, numerous, verrucose, up to $170 \mu \mathrm{m}$ in diameter; ascospores obovoidal to cylindrical, 4-septate, constricted at the septum, 3643×14-17 $\mu \mathrm{m}$.

Subglobose to oblong head cells of the appressoria distinguishes this taxon. Common species in the Western Ghats.

Meliola capensis (Kalch. \& Cooke) Theiss. var. malayensis Hansf., Sydowia 10: 67, 1951; Sydowia Beih. 2: 439, 1961; Hosag. \& Goos, Mycotaxon 37: 224, 1990; Hosag., Meliolales of India, p. 156, 1996 (Fig. 59).

Materials examined: HClO 49965, TBGT 4117 14.iii.2007, on leaves of Nephelium longan Lour. (Sapindaceae), Batherry, coll. M.C. Riju; HClO 44495, TBGT 785, 21.v.2002, Nephelium sp., Wayanad, coll. M.Kamarudeen.

Colonies epiphyllous, dense, velvety, up to $4 \mathrm{~mm}$ in diameter, rarely confluent. Hyphae straight, branching

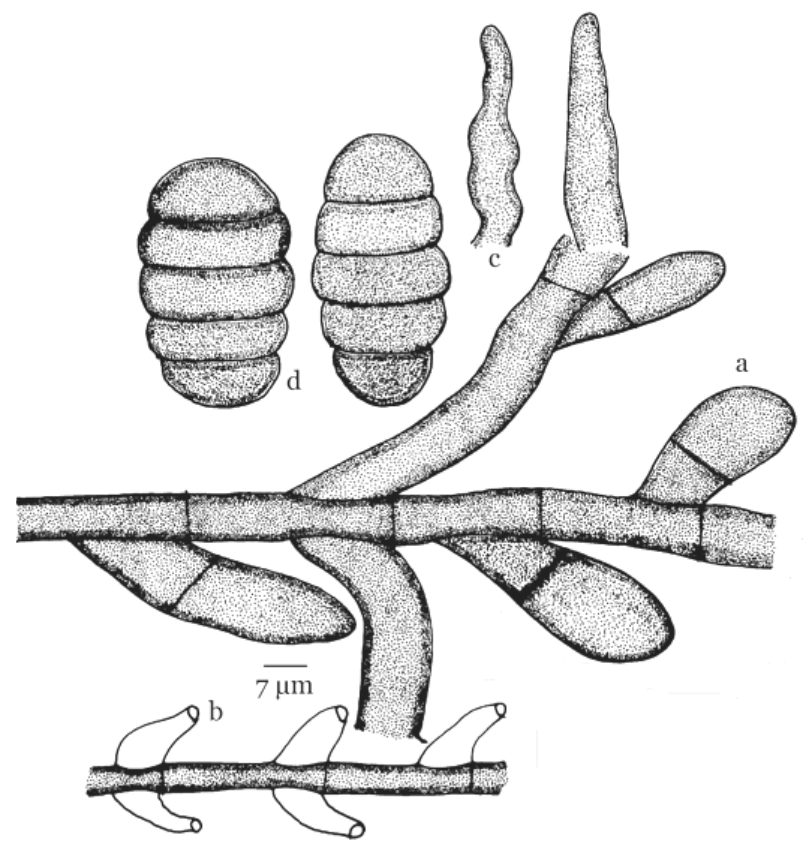

Figure 57. Meliola canthiicola

a - Appressorium; b - Phialide; c - Apical portion of mycelial setae; d - Ascospores 
opposite at wide angles, loosely to closely reticulate, cells $12-7 \times 6-8 \mu \mathrm{m}$. Appressoria opposite to alternate, straight to curved, antrorse to spreading, 11-18 $\mu \mathrm{m}$ long; stalk cells cylindrical to cuneate, 1-3 $\mu \mathrm{m}$ long; head cells ovate to cylindrical, attenuated at the apex, entire, 9-14x6-8 $\mathrm{mm}$. Phialides mixed with appressoria, alternate to opposite, ampulliform, 12-18x6-8 $\mu \mathrm{m}$. Mycelial setae grouped around perithecia, straight, simple, acute, obtuse to variously dentate at the tip, up to $660 \mu \mathrm{m}$ long. Perithecia scattered, globose, up to $150 \mu \mathrm{m}$ in diameter; ascospores subellipsoidal to cylindrical, 4-septate, constricted at the septa, 28-36x12-16 $\mu \mathrm{m}$.

Ovate, conoid and slightly recurved head cells of appressoria are the distinguishing characters of this species.

Common species in the Western Ghats.

Meliola capensis (Kalch. \& Cooke) Theiss. var. schleicherae Hosag. \& Pillai in Hosag., Raghu \& Pillai, Nova Hedwigia 58: 583, 1994; Hosag., Meliolales of India, p. 157, 1996(Fig. 60).

Materials examined: TBGT 3938, 15.ii.2009, on leaves of Schleichera oleosa (Lour.) Oken (Sapindaceae),

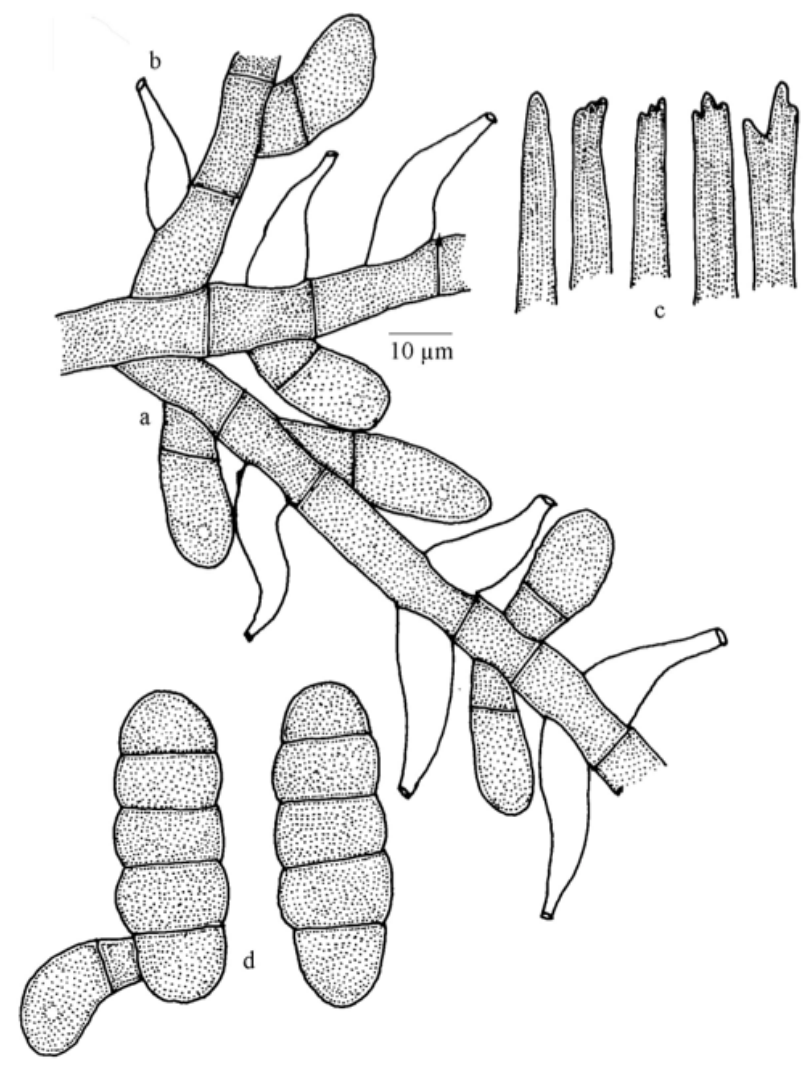

Figure 58. Meliola capensis var. allophylicola a - Appressorium; b - Phialide; c - Apical portion of mycelial setae; d - Ascospores
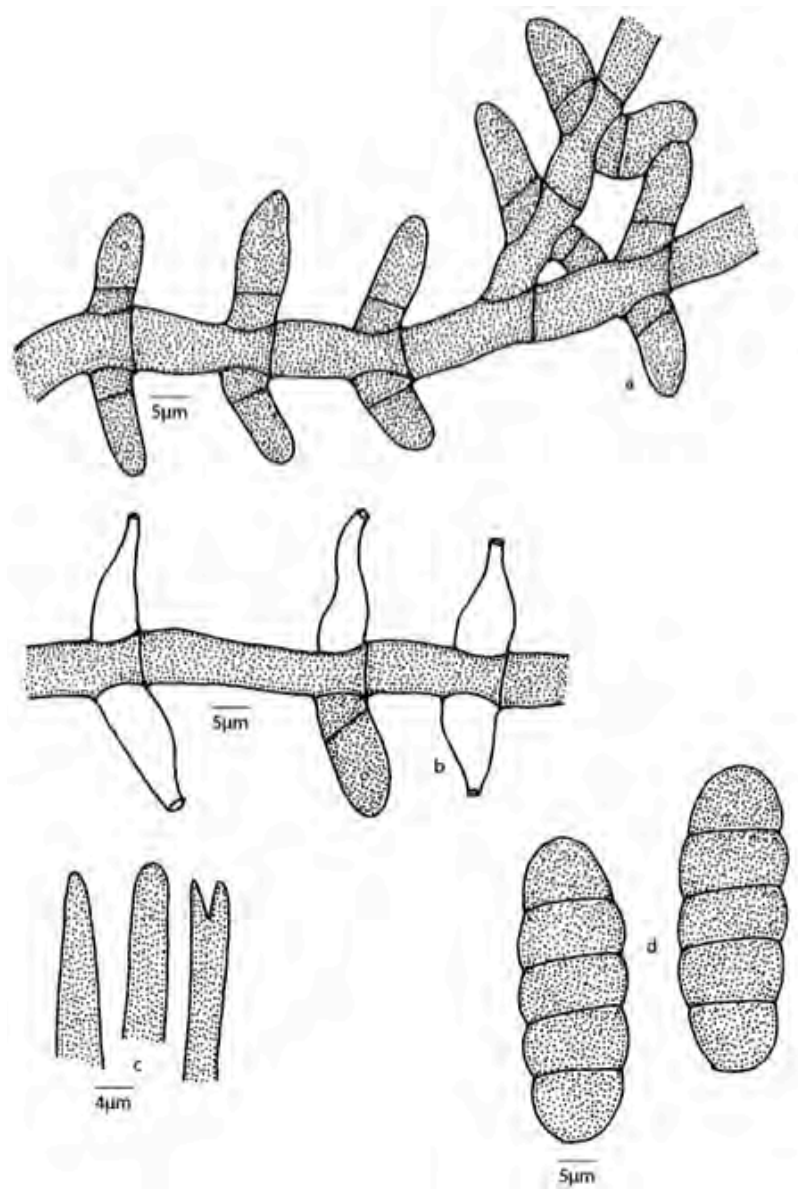

Figure 59. Meliola capensis var. malayensis

a - Appressorium; b - Phialide; c - Apical portion of mycelial setae; d - Ascospores

Wayanad, coll. Jacob Thomas et al.

Colonies epiphyllous, dense, velvety, up to $3 \mathrm{~mm}$ in diameter, confluent. Hyphae straight, branching opposite at acute angles, loosely to closely reticulate, cells 14-26x4-7 $\mu \mathrm{m}$. Appressoria opposite, crowded, 12-14 $\mu \mathrm{m}$ long; stalk cells cuneate, 2-4 $\mu \mathrm{m}$ long; head cells conoid, entire, 9-12x6-7 $\mu \mathrm{m}$. Phialides mixed with appressoria, alternate to opposite, ampulliform, 14-21x4-7 $\mu \mathrm{m}$. Mycelial setae scattered, straight, simple, acute to dentate at the tip, up to $480 \mu \mathrm{m}$ long. Perithecia scattered, verrucose, up to $140 \mu \mathrm{m}$ in diameter; ascospores obovoidal, 4-septate, constricted at the septa, 31-36x14-17 $\mu \mathrm{m}$.

Opposite, crowded to sparse appressoria with conoid head cells distinguishes this taxon.

Endemic to southern Western Ghats

Meliola careyae (Stev.) Hosag. var. indica Hosag., Persoonia 18:2, 2003 (Fig. 61). 
Materials examined: $\mathrm{HClO}$ 44368, TBGT 631, 6.ii.2002, on leaves of Careya arborea Roxb. (Lecythidaceae), Periya; HCIO 44798, TBGT 1035, 26.xii.2002, Chandanathode, coll. M. Kamarudeen \& P.A. Jose; HCIO 44868, TBGT 1096, 09.iii.2001, Periya, coll. G. Rajkumar \& P.A. Jose; HCIO 43672, TBGT 336, 19.ix.1998, Banasuranmala, C.K. Biju.

Colonies epiphyllous, dense, up to $5 \mathrm{~mm}$ in diameter, rarely confluent. Hyphae straight to substraight, branching alternate to opposite at acute to wide angles, closely reticulate and form solid mycelial mat, cells 12 26x4-8 $\mu \mathrm{m}$. Appressoria opposite, about 3\% alternate, antrorse to subantrorse, 14-18 $\mu \mathrm{m}$ long; stalk cells cylindrical to cuneate, 3-5 $\mathrm{mm}$ long; head cells ovate, rarely globose, entire, 9-13x9-12 $\mu \mathrm{m}$. Phialides mixed with appressoria, alternate to opposite, ampulliform, 16-23x8-10 $\mu \mathrm{m}$. Mycelial setae scattered to grouped around perithecia, straight, simple, acute at the tip, up to $350 \mu \mathrm{m}$ long. Perithecia scattered, up to $175 \mu \mathrm{m}$ in diameter; ascospores oblong to cylindrical, 4-septate, constricted at the septa, 36-44×14-16 $\mu \mathrm{m}$.

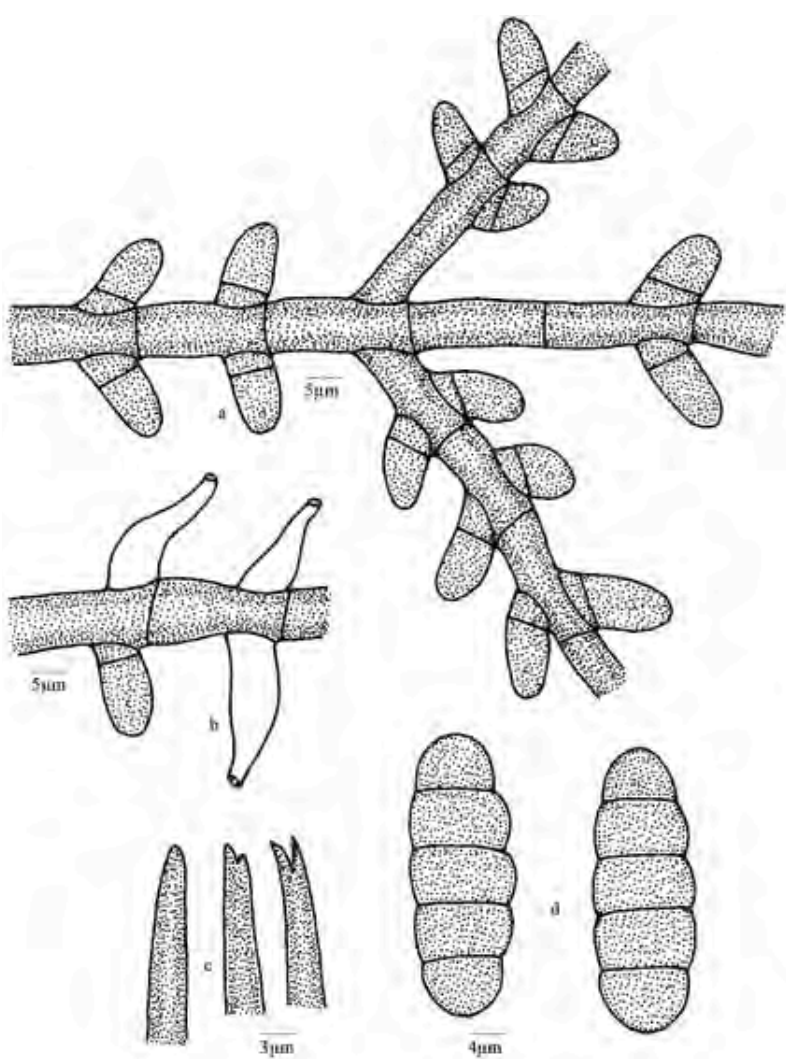

Figure 60. Meliola capensis var. schleicherae

a - Appressorium; b - Phialide; c - Apical portion of mycelial setae; d - Ascospores
Meliola celastrigena Hosag., Plant Pathology \& Quarantine 3(1): 5, 2013 (Fig. 62).

Materials examined: TBGT 6232, 15.ii.2008, on Celasteraceae member, Periya, coll. M.C Riju.

Colonies hypophyllous, dense, velvety, scattered, up to $6 \mathrm{~mm}$ in diameter. Hyphae straight to slightly undulate, branching alternate to unilateral at acute to wide angles, loosely to closely reticulate, cells 19-30x6-9 $\mu \mathrm{m}$. Appressoria alternate, antrorse, subantrorse, spreading, retrorse, 37-42 $\mu \mathrm{m}$ long; stalk cells cylindrical to cuneate, 11-16 $\mu \mathrm{m}$ long; head cells ovate, clavate, lobate to stellately lobate, 24-27x24$26 \mu \mathrm{m}$. Phialides mixed with appressoria, alternate, conoid to ampulliform, 16-35x5-9 $\mu \mathrm{m}$. Mycelial setae numerous, scattered, simple, acute to obtuse at the tip, up to $430 \mu \mathrm{m}$ long. Perithecia scattered, up to $120 \mu \mathrm{m}$ in diameter; ascospores curved, ellipsoidal, 3-septate, deeply constricted at the septa, 57-59x19-21 $\mu \mathrm{m}$.

Meliola euonymi Stevens ex Hansf. known on Euonymus sp. from Philippines (Hansford 1961) but the present species differs from it in having shorter appressoria (36-42 vs. 40-55 $\mu \mathrm{m}$ ) and ascospores (1921 vs. $22-24 \mu \mathrm{m})$.

Meliola chandrasekharanii Hosag. in Hosag. \& Goos, Mycotaxon 37: 225, 1990; 42: 133, 1991; Hosag.,

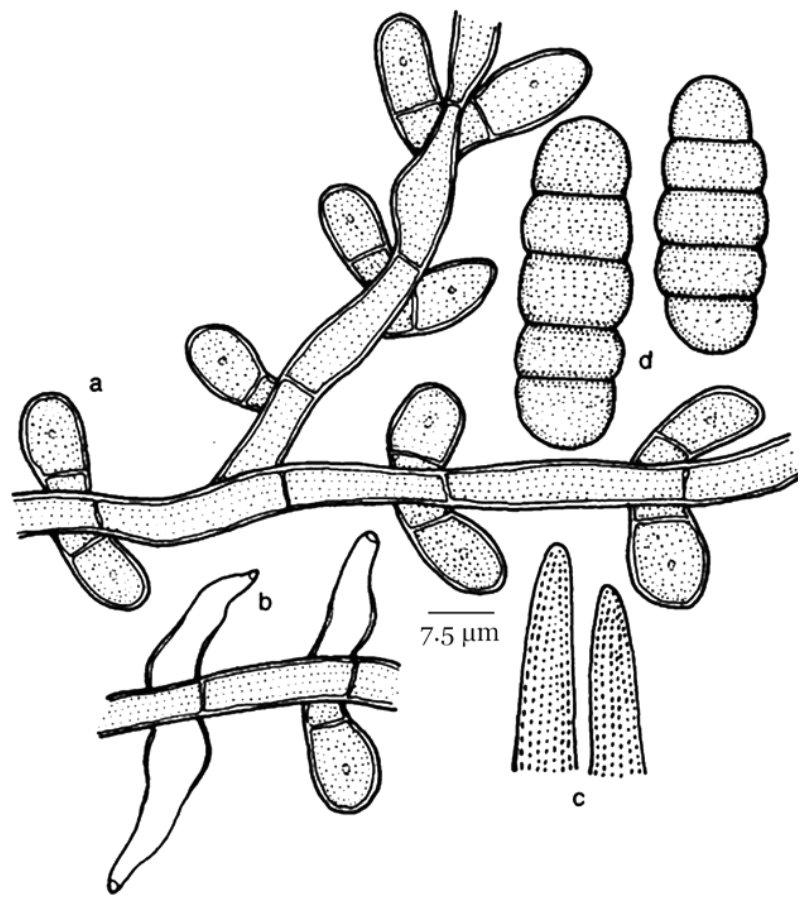

Figure 61. Meliola careayae var. indica

a - Appressorium; b - Phialide; c - Apical portion of mycelial setae; d - Ascospores 
Meliolales of India, p. 164, 1996 (Fig. 63).

Materials examined: $\mathrm{HClO}$ 44350, TBGT 587, 6.ii.2002, on leaves, stems and petioles of Nothapodytes nimmoniana (Graham) Mabberly (Icacinaceae), Periya, coll. M.Kamarudeen; HCIO 48005, TBGT 2788, 6.xii.2006, coll. M. Harish et al.; HCIO 49069, TBGT 3324, 18.ix.2008, Thirunelly, coll. M. Harish et al.; HCIO 44793, TBGT 1030; HClO 48008, TBGT 2791, 27.xii.2002, Nothopodites sp., Periya, M. Kamarudeen \& P.A. Jose; TBGT 5719, 22.iii.2008, Padinharathara, coll. M.C. Riju; HClO 50645, TBGT 4562, 26.xii.2007, coll. M.C. Riju; HCIO 51297, TBGT 5177, 27.xii.2007, coll. M.C. Riju; TBGT 3939, 13.ii.2007, Thirunelly, coll. M. Harish et al.; HCIO 51277, TBGT 5157, 22.iii.2008, Wayanad, coll. M.C. Riju et al.; HClO 51232, TBGT 5112, 23.xii.2008; TBGT 5723, 23.iii.2008.

Colonies amphigenous, caulicolous, mostly epiphyllous, velvety, cover almost all the part of upper surface of the leaf, up to $3 \mathrm{~mm}$ diameter, confluent. Hyphae substraight to undulate, branching alternate to opposite at acute angles, closely reticulate and form a mycelial mat, cells 15-29x6-9 $\mu \mathrm{m}$. Appressoria alternate, about 1\% opposite, straight to curved, spreading, mostly antrorse, 17-26 $\mu \mathrm{m}$ long; stalk cells cuneate to cylindrical, 4-9 $\mu \mathrm{m}$ long; head cells subglobose, ovate, angular to sublobate, 11-18x13-15 $\mu \mathrm{m}$. Phialides borne on a separate mycelial branch,

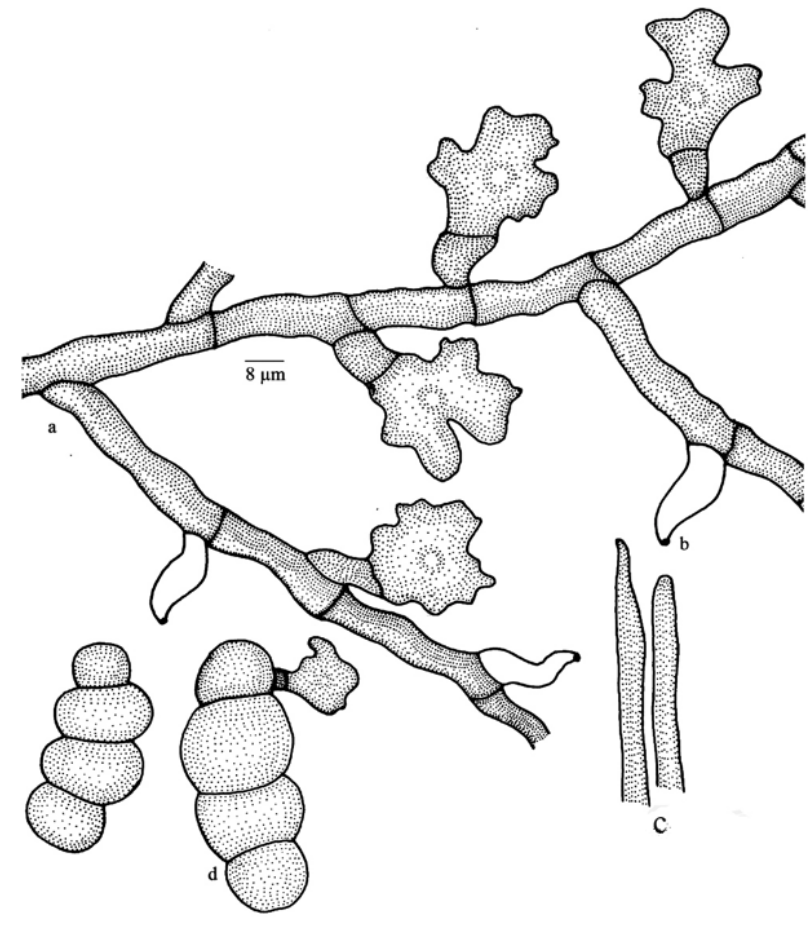

Figure 62. Meliola celastrigena

a - Appressorium; b - Phialide; c - Apical portion of mycelial setae; d - Ascospores

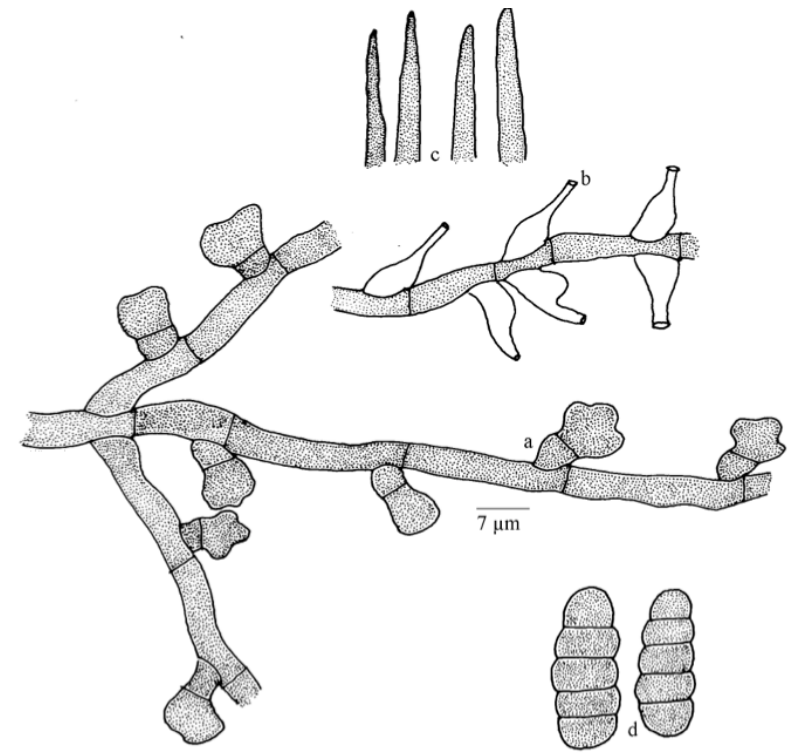

Figure 63 Meliola chandrasekharanii

a - Appressorium; b - Phialide; c - Apical portion of mycelial setae; d - Ascospores

alternate to opposite, ampulliform, 15-26x6-9 $\mu \mathrm{m}$. Mycelial setae numerous, scattered to grouped around perithecia, straight, simple, acute to obtuse at the tip, up to $490 \mu \mathrm{m}$ long. Perithecia scattered, verrucose, up to $160 \mu \mathrm{m}$ in diameter; ascospores obovoidal to cylindrical, 4-septate, 33-40x11-15 $\mu \mathrm{m}$.

Because of the lobate head cells of appressoria and separately borne phialides the present collection merits its placement in the above mentioned.

Meliola citricola Sydow \& Sydow, Ann.Mycol. 15: 183, 1917; Hansf., Sydowia Beih. 2: 246, 1961; Kar \& Maity, Norw. J. Bot. 19: 246, 1972; Hosag. \& Goos, Mycotaxon 37: 326, 1990; 42: 133, 1991; Hosag., Meliolales of India, p. 167, 1996; J. Econ. Taxon. Bot. 30: 949, 2006 (Fig. 64).

Materials examined: $\mathrm{HClO}$ 49963, TBGT 4115, 15.iii.2007, on leaves of Citrus sp. (Rutaceae), Puthuserrykadavu, coll. M.C. Riju; HClO 50843, TBGT 4760, 6.xi.2009, Padinharathara, coll. M.C. Riju \& A. Sabeena.

Colonies amphigenous, dense, velvety, up to $6 \mathrm{~mm}$ in diameter. Hyphae straight to substraight, branching opposite to irregular at acute to wide angles, closely reticulate to form a mycelial mat, cells 9-26x6-7 $\mu \mathrm{m}$. Appressoria alternate to opposite, about $10 \%$ unilateral, antrorse to retrorse, straight to curved, closely packed, 16-24 $\mu \mathrm{m}$ long; stalk cells cylindrical to cuneate, 4-7 $\mu \mathrm{m}$ long; head cells cylindrical, ovate, clavate, entire, curved to recurved, $12-16 \times 7-10 \mu \mathrm{m}$. Phialides mixed 


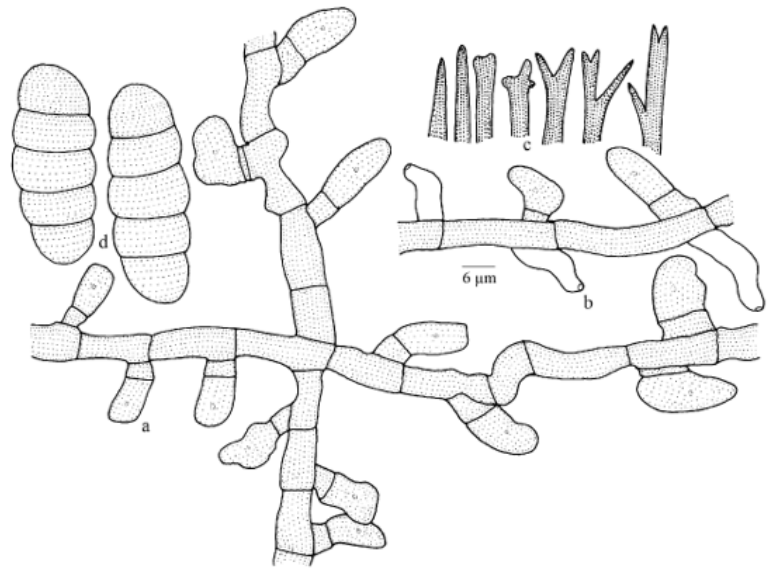

Figure 64. Meliola citricola

a - Appressorium; b - Phialide; c - Apical portion of mycelial setae; d-Ascospores

with appressoria, opposite to alternate, ampulliform, 16-26x6-7 $\mu \mathrm{m}$. Mycelial setae numerous, scattered, straight, simple, acute to variously dentate at the tip, up to $810 \mu \mathrm{m}$ long. Perithecia scattered, verrucose, up to $190 \mu \mathrm{m}$ in diameter; ascospores cylindrical to subellipsoidal, 4-septate, constricted at the septa, 3641x14-19 $\mu \mathrm{m}$.

Two species of the genus Meliola, namely M. butleri Sydow and $M$. citricola Sydow have been recorded on the host genus Citrus. However, the latter differs from the former in having opposite and alternate appressoria and obtuse to dentate mycelial setae.

Meliola clerodendricola Henn., Hedwigia 37: 288, 1895; Hansf., Sydowia Beih. 2: 694, 1961; Hosag. \& Goos, Mycotaxon 37: 226, 1990; Hosag., Kaveriappa, Raghu \& Goos, Mycotaxon 51: 111, 1994; Hosag., Meliolales of India, p. 169, 1996.

Meliola sakawensis Henn. var. longispora Beeli, Bull. Jard. Bot. Etat. 7: 98, 1920.

Meliola sakawensis P. Henn., Hedwigia 43: 141, 1904; Stev., Ann. Mycol. 26: 248, 1928 (Fig. 65).

Materials examined: $\mathrm{HClO}$ 49630, TBGT 3872, 16.ix.2008, on leaves of Clerodendrum viscosum Vent. (Verbenaceae), Periya, coll. M. Harish \& Robin P.J.; HCIO 49970, TBGT 4122, 14.iii.2007, Puthuserrykadavu, coll. M.C. Riju; HClO 50819, TBGT 4736, 4.xi.2009, Clerodendrum sp., Padiharathara, coll. M.C. Riju \& A. Sabeena.

Colonies amphigenous, mostly epiphyllous, dense, scattered, up to $2 \mathrm{~mm}$ in diameter, confluent. Hyphae undulate to tortuous, branching alternate to opposite at

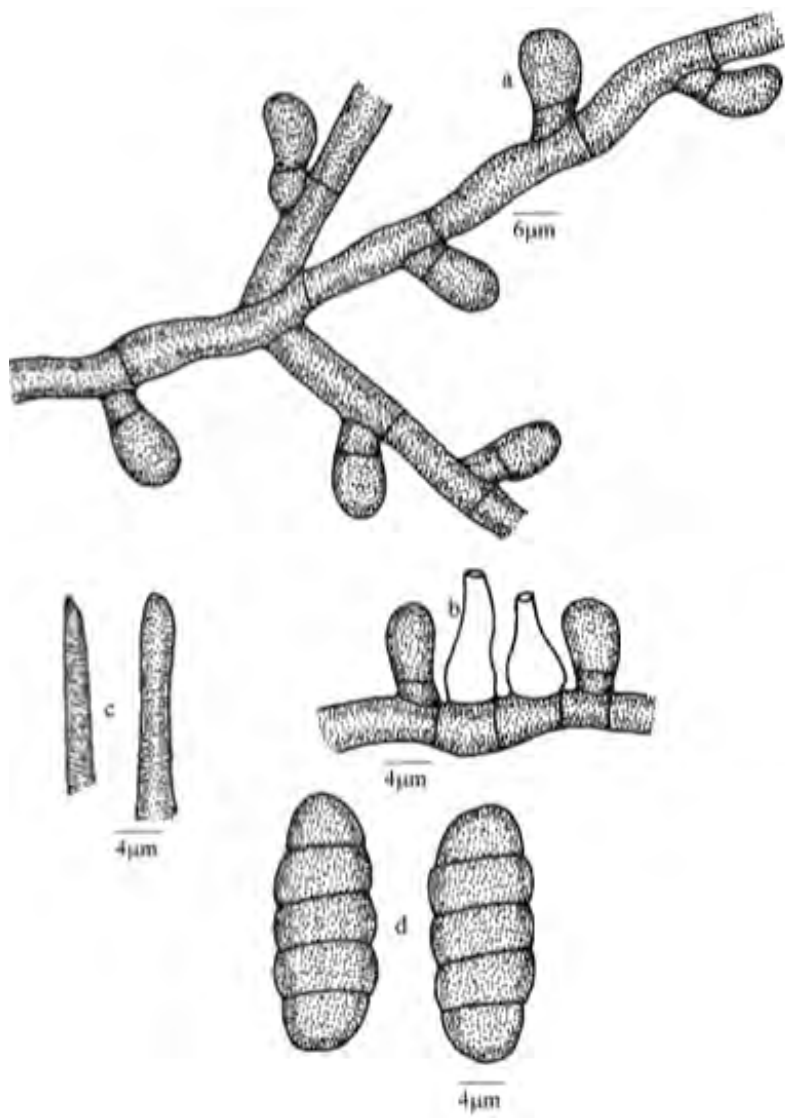

Figure 65. Meliola clerodendricola

a - Appressorium, b - Phialide, c - Apical portion of mycelial setae, d-Ascospores

acute to wide angles, loosely to closely reticulate, cells 16-24x4-6 $\mu \mathrm{m}$. Appressoria alternate to unilateral, straight to curved, antrorse to reflexed, 12-17 $\mu \mathrm{m}$ long; stalk cells cylindrical to cuneate, 4-7 $\mu \mathrm{m}$ long; head cells ovate, globose, entire, 7-10x6-7 $\mu \mathrm{m}$. Phialides mixed with appressoria, opposite to alternate, ampulliform, 14-17 $\mu \mathrm{m}$. Mycelial setae few, grouped around perithecia, simple, acute to obtuse at the tip, up to $220 \mu \mathrm{m}$ long. Perithecia grouped, verrucose, up to $130 \mu \mathrm{m}$ in diameter; ascospores obovoidal to ellipsoidal, 4-septate, constricted at the septa, 28-34×12-14 $\mu \mathrm{m}$.

This is the only species of the genus Meliola on this host in the Western Ghats region.

Common in the Western Ghats of Peninsular India

Meliola crescentiae Stev., Ann. Mycol. 26: 240, 1928; Hansf., Sydowia Beih. 2: 673, 1961; Hosag., Meliolales of India, p. 174, 1996 (Fig. 66 \& Image 7).

Materials examined: $\mathrm{HClO}$ 48182, TBGT 2918, 29.vi.2007, on leaves of Oroxylum sp. (Bignoniaceae), $16^{\text {th }}$ mile, Padinharathara, coll. M.C. Riju; HCIO 48184, 


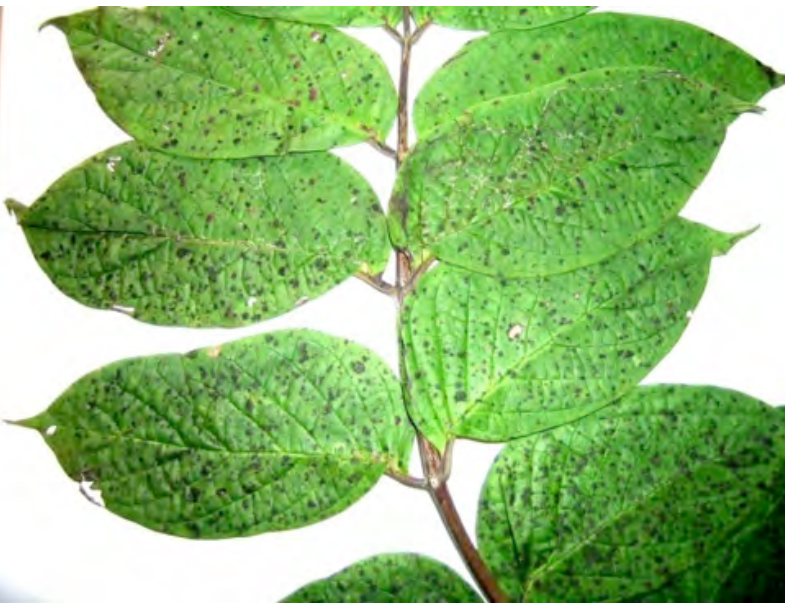

Image 7. Oroxylum sp.-Infected leaves

TBGT 2920, 10.xi.2007 coll. M.C. Riju; HCIO 50754, TBGT 4671; HClO 50756, TBGT 4673, 6.xi.2009, Pajenelia sp., Chennalodu, coll. A. Sabeena \& M.C. Riju.

Colonies epiphyllous, thin to subdense, subvelvety, up to $3 \mathrm{~mm}$ in diameter, confluent. Hyphae straight to substraight, branching opposite at acute to wide angles, loosely to closely reticulate, cells $19-36 \times 4-12$ $\mu \mathrm{m}$. Appressoria alternate, antrorse to subantrorse, straight to curved, 14-24 $\mu \mathrm{m}$ long; stalk cells cylindrical to cuneate, 4-10 $\mu \mathrm{m}$ long; head cells globose to subglobose, subangular, entire, 9-14x9-12 $\mu \mathrm{m}$. Phialides mixed with appressoria, alternate to opposite, ampulliform, 12-28x4-7 $\mu \mathrm{m}$. Mycelial setae numerous, scattered, straight, simple, subacute to obtuse at the tip, up to $220 \mu \mathrm{m}$ long. Perithecia scattered, verrucose, up to $120 \mu \mathrm{m}$ in diameter; ascospores oblong to subellipsoidal, 4-septate, constricted at the septa, 31-34×12-14 $\mu \mathrm{m}$.

This collection matches well with assigned species.

Meliola cycleae Hosag. in Hosag. \& Goos, Mycotaxon 37: 228, 1990; Hosag., Meliolales of India, p. 176, 1996 (Fig. 67).

Materials examined: $\mathrm{HClO}$ 49206, TBGT 3445, 14.ii.2009, on leaves, stems and petioles of Cyclea peltata Cooke (Menispermaceae), Thirunelly, coll. Jacob Thomas et al.; HClO 49976, TBGT 4128; HClO 50004, TBGT 4156, 14.iii.2007, Puthuserrykadavu, coll. M.C. Riju; HClO 50334, TBGT 4251, 5.xi.2009, Gurukulam Botanic Garden, Periya, coll. A. Sabeena \& M.C. Riju; HClO 50823, TBGT 4740, 4.xi.2009, Padinharathara, coll. M.C. Riju \& A. Sabeena; HCIO 50825, TBGT 4742, 6.xi.2009, Chennalode, coll. M.C. Riju \& A. Sabeena; HCIO 49068, TBGT 3323, 17.ix.2008, Periya, coll. M. Harish \& P.J. Robin; HClO 49639, TBGT 3881, HClO 49206, TBGT 3445, 14.ii.2009, Thirunelli, coll. Jacob Thomas et al.;

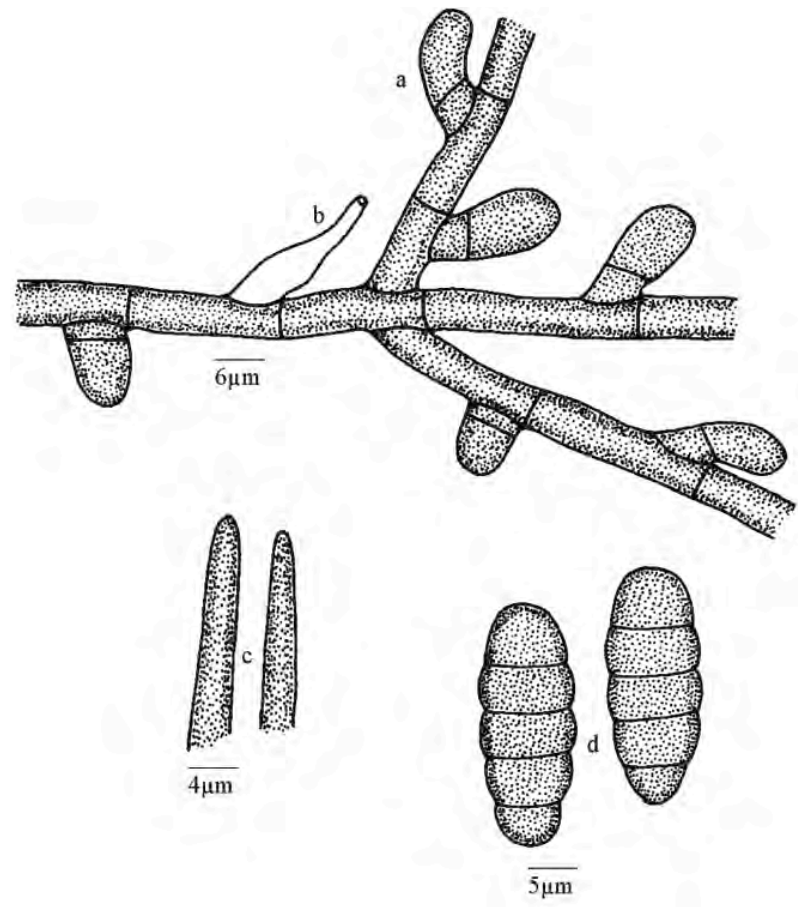

Figure 66. Meliola crescentiae

a - Appressorium; b - Phialide; c - Apical portion of mycelial setae; d - Ascospores

HCIO 49976, TBGT 4128, 14.iii.2007, Puthuserrykadavu, coll. M.C. Riju.

Colonies amphigenous, mostly epiphyllous, subdense to dense, up to $3 \mathrm{~mm}$ in diameter, confluent. Hyphae substraight to slightly undulate, branching opposite to irregular at acute to wide angles, loosely to closely reticulate, cells $14-36 \times 6-8 \mu \mathrm{m}$. Appressoria alternate to unilateral, straight, antrorse, 16-28 $\mu \mathrm{m}$ long; stalk cells cuneate, 7-12 $\mu \mathrm{m}$ long; head cells ovate, versiform, slightly and bluntly pointed at the apex, entire, 1417x12-14 $\mu \mathrm{m}$. Phialides born on a separate mycelial branch, alternate to opposite, conoid to ampulliform, 12-22x6-8 $\mu \mathrm{m}$. Mycelial setae scattered to grouped around perithecia, simple, acute at the tip, up to 420 $\mu \mathrm{m}$ long. Perithecia scattered, verrucose, up to $160 \mu \mathrm{m}$ in diameter; ascospores oblong, 4-septate, slightly constricted at the septa, 36-40×15-20 $\mu \mathrm{m}$.

Meliola cymbopogonis Kapoor, Indian Phytopathol. 20: 152, 1967; Hosag. \& Goos, Mycotaxon 37: 229, 1990; Hosag., Meliolales of India, p. 177, 1996 (Fig. 68).

Materials examined: HClO 43632, TBGT 300, 18.xi.1998, on leaves of Cymbopogon sp. (Poaceae), Chembra, coll. C.K. Biju.

Colonies epiphyllous, rarely amphigenous, subdense 

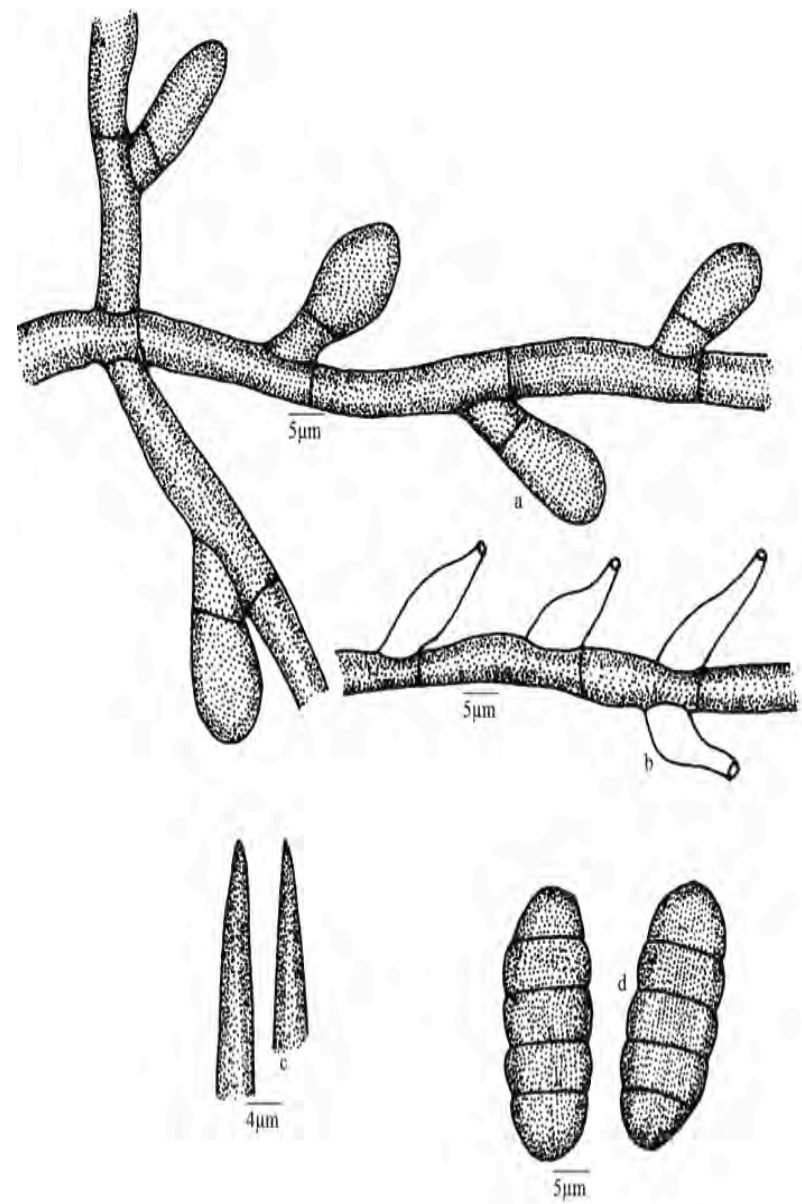

Figure 67. Meliola cycleae

a - Appressorium; b - Phialide; c - Apical portion of mycelial setae d - Ascospores

to dense, velvety, up to $3 \mathrm{~mm}$ in diameter. Hyphae straight to tortuous, straight hyphae run along the veins and tortuous hyphae cross the straight hyphae, branching mostly opposite at wide to acute angles, loosely to closely reticulate, cells $14-22 \times 6-8 \mu \mathrm{m}$. Appressoria alternate, unilateral, antrorse, spreading, 10-24 $\mu \mathrm{m}$ long; stalk cells cuneate to cylindrical, 4-12 $\mu \mathrm{m}$ long; head cells ovate, globose, angular to sublobate, 10-14x12-14 $\mu \mathrm{m}$. Phialides few, mixed with appressoria, alternate to opposite, ampulliform, 1218x10-12 $\mu \mathrm{m}$. Mycelial setae straight, dichotomously branched at the tip, up to $176 \mu \mathrm{m}$ long till branching, primary branches up to $20 \mu \mathrm{m}$ long, while, tertiary up to $10 \mu \mathrm{m}$ long, branchlets retrorse, acute to obtuse at the tip. Perithecia scattered, up to $120 \mu \mathrm{m}$ in diameter; ascospores ellipsoidal, 4-septate, constricted at the septa, 38-44x12-14 $\mu \mathrm{m}$.

Dichotomously branched mycelial setae on this host genus is the distinguishing character of this species.
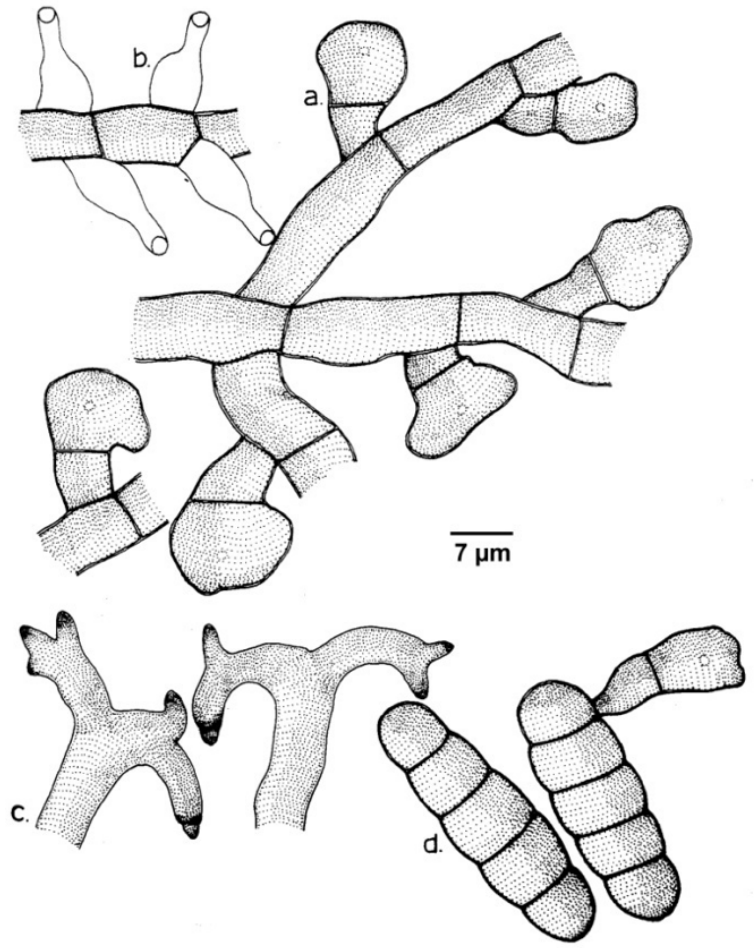

Figure 68. Meliola cymbopogonis

a - Appressorium; b - Phialide; c - Apical portion of mycelial setae; d - Ascospores

Meliola densa Cooke, Grevillea 12: 85, 1884; Hansf., Sydowia Beih. 2: 141, 1961; Hosag. \& Goos, Mycotaxon 37: 229, 1990; Hosag., Kaveriappa, Raghu \& Goos, Mycotaxon 51: 111, 1994; Hosag., Meliolales of India, p. 178, 1996 (Fig. 69).

Materials examined: $\mathrm{HClO}$ 45254, TBGT 1292, 7.iii.2001, on leaves of Syzygium sp. (Myrtaceae), Periya, coll. G. Rajkumar \& P.A. Jose; HClO 49971, TBGT 4123, 14.iii.2007, Puthuserrykadavu, coll. M.C. Riju; HClO 50030, TBGT 4182, 6.xii.2006, Periya, coll. Gireesh et al.

Colonies hypophyllous, dense, velvety, up to $5 \mathrm{~mm}$ in diameter, confluent. Hyphae substraight to tortuous, branching opposite to irregular at wide angles, closely reticulate, cells $18-40 \times 8-10 \mu \mathrm{m}$. Appressoria alternate, straight to variously bent, antrorse, spreading, 18-24 $\mu \mathrm{m}$ long; stalk cells cylindrical to cuneate, 6-14 $\mu \mathrm{m}$ long; head cells curved, ovate, cylindrical, angulose, entire, 12-16x8-12 $\mu \mathrm{m}$. Phialides mixed with appressoria, opposite to alternate, ampulliform, neck elongated and twisted, 22-30x8-10 $\mu \mathrm{m}$. Mycelial setae fairly numerous, simple, broadly uncinate to arcuate above, very few are straight, acute to obtuse at the tip, up to $540 \mu \mathrm{m}$ long. Perithecia scattered, verrucose, up to $180 \mu \mathrm{m}$ in diam.; ascospores obovoidal, 4-septate, 
constricted at the septa, 46-48x18-20 $\mu \mathrm{m}$.

Hypophyllous dense colonies with uncinate mycelial setae are the distinguishing characters of this species. This species occurs on many genera of Myrtaceae.

Meliola dimidiatae Hosag. in Hosag. \& Goos, Mycotaxon 37: 229, 1990; Hosag., Meliolales of India, p. 181, 1996. (Fig. 70).

Materials examined: HClO 50643, TBGT 4560, 30.ix.2007, on leaves of Nothopodytes nimmoniana (Graham) Mabb. (Icacinaceae), Padinharathara, coll. M.C. Riju.

Colonies epiphyllous, subdense, subvelvety, scattered, up to $3 \mathrm{~mm}$ in diameter, rarely confluent. Hyphae flexuous, branching opposite to irregular at acute to wide angles, loosely to closely reticulate, cells 16-28x4-7 $\mu \mathrm{m}$. Appressoria alternate and unilateral, rarely opposite, straight to curved, antrorse to reflexed, spreading, 14-19 $\mu \mathrm{m}$ long; stalk cells cylindrical to cuneate, 4-6 $\mu \mathrm{m}$ long; head cells globose, ovate, curved, entire, 12-14x9-12 $\mu \mathrm{m}$. Phialides mixed with appressoria, alternate to opposite, ampulliform, 1624x7-10 $\mu \mathrm{m}$. Mycelial setae numerous, scattered, often grouped around perithecia, straight, simple, acute, up to $520 \mu \mathrm{m}$ long. Perithecia scattered, verrucose, up to $130 \mu \mathrm{m}$ in diameter; ascospores cylindrical to subellipsoidal, 4-septate, constricted at the septa, 4043×16-19 $\mu \mathrm{m}$.

This species differs from other Meliola species reported on the members of the family Icacinaceae in having globose head cells of appressoria, straight mycelial setae and 4-septate ascospores.

Endemic to southern Western Ghats

Meliola dysoxyligena Hosag. \& Riju, Plant Pathology \& Quarantine 1(2): 126, 2011; Hosag., Journal of Threatened Taxa 5(6):4029, 2013 (Fig. 71).

Material examined: HCIO 51045, TBGT 4962; HCIO 51037, TBGT 4954; HClO 51038, TBGT 4955; HClO 51052, TBGT 4969, 26.xii.2009, on leaves of Dysoxylum sp. (Meliaceae), Chennalode, Padinharathara, coll. M.C. Riju.

Colonies epiphyllous, dense, velvety, up to $5 \mathrm{~mm}$ in diameter. Hyphae substraight to crooked, branching opposite to irregular at acute to wide angles, loosely to closely reticulate, cells $20-45 \times 7-8 \mu \mathrm{m}$. Appressoria alternate, unilateral, opposite, antrorse, subantrorse to retrorse, $15-17 \times 7-10 \mu \mathrm{m}$; stalk cells cylindrical to cuneate, 3-5 $\mu \mathrm{m}$ long; head cells globose, subglobose, entire to rarely truncate, $10-13 \times 7-10 \mu \mathrm{m}$. Phialides mixed with appressoria, alternate to opposite,

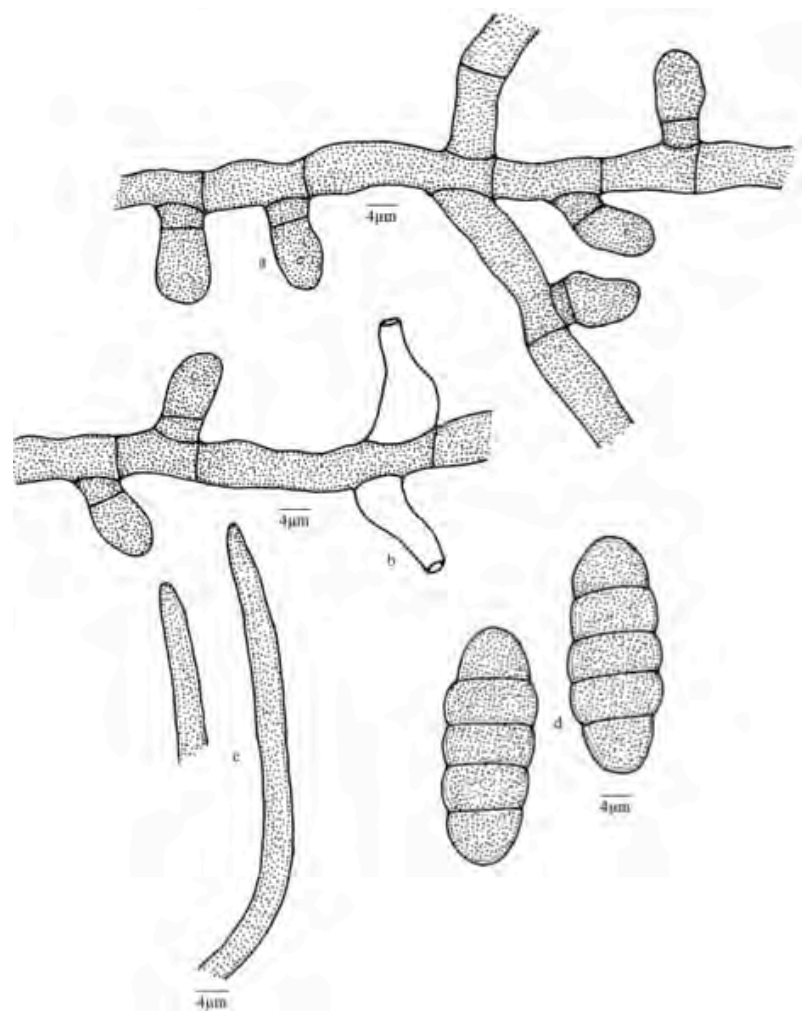

Figure 69. Meliola densa

a - Appressorium; b - Phialide; c - Apical portion of mycelial setae; d - Ascospores

ampulliform, 15-38x7-10 $\mu \mathrm{m}$. Mycelial setae scattered, simple, straight, acute to 2-3-times dentate at the tip, up to $200 \mu \mathrm{m}$ long. Perithecia scattered, up to $210 \mu \mathrm{m}$ in diameter; ascospores cylindrical to oblong, 4-septate, slightly constricted at the septa, 35-40x12-15 $\mu \mathrm{m}$.

Meliola ptaeroxyli Doidge, M. Carapace Hansf. \& Deight. and $M$. toonae Hosag. \& Sabu are the species that have simple and dentate mycelial setae. The present fungus differs from M. ptaeroxyli in not producing a pathogenic effect on the host, from $M$. carapace in having shorter appressoria (15-17 $\mu \mathrm{m}$ vs. $24-40 \mu \mathrm{m})$ and

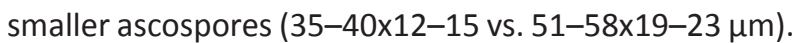
It differs from $M$. toonae in having shorter appressoria (15-17 $\mu \mathrm{m}$ vs. 16-24 $\mu \mathrm{m}$ ) and shorter ascospores (35$40 \mu \mathrm{m}$ vs. 40-44 $\mu \mathrm{m}$ ) (Hansford 1961; Hosagoudar 1996, 2008; Hu et al. 1996, 1999). The neck or apical portion of the phialides are unusually elongated, often variously bent and proliferate as hyphae by holding the phialoconidia in their neck.

Meliola erythropali Hosag. in Hosag. \& Goos, Mycotaxon 37: 232, 1990 (erythropalii); Hosag., Meliolales of India, p. 190, 1996 (Fig. 72). 


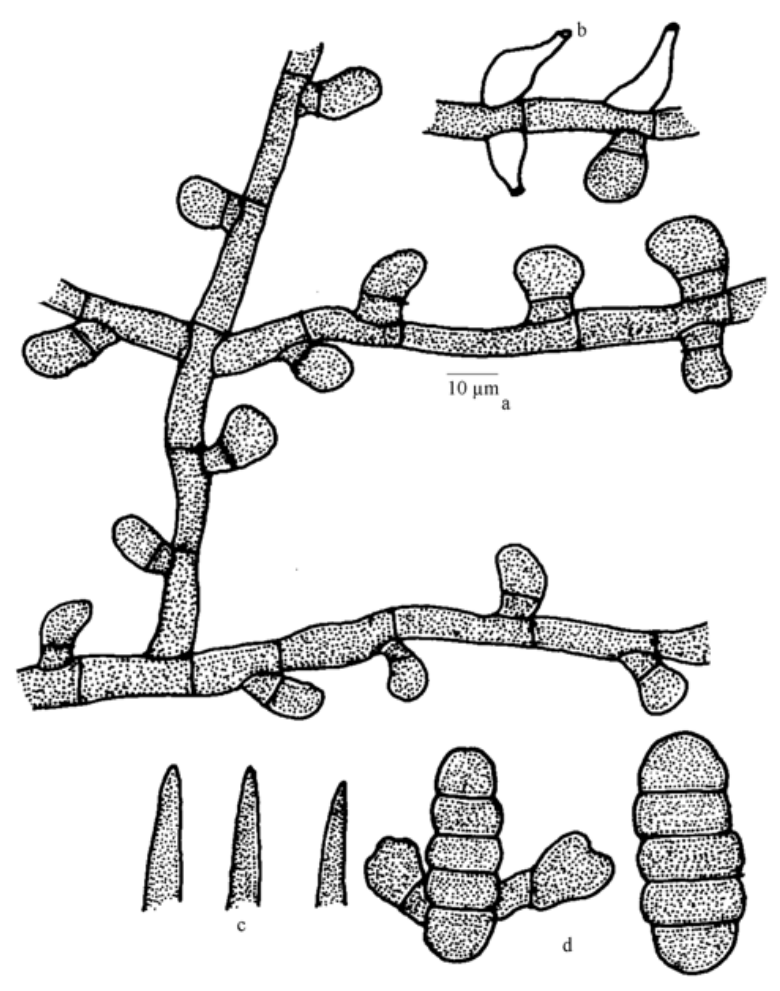

Figure 70. Meliola dimidiatae

a - Appressorium; b - Phialide; c - Apical portion of mycelial setae; d - Ascospores

Materials examined: $\mathrm{HClO}$ 43629, TBGT 322, on leaves of Erythropalum populifolium (Arn.) Masrt. (Erythropalaceae), Chembra, coll. C.K.Biju; 4.iv.1999; TBGT 3754, 18.ii.2009, Periya, coll. P.J. Robin et al.

Colonies amphigenous, caulicolous, dense, velvety, up to $5 \mathrm{~mm}$ in diameter, confluent. Hyphae straight to slightly undulate, branching opposite to irregular at acute to wide angles, loosely reticulate, cells $14-41 \times 4-7 \mu \mathrm{m}$. Appressoria alternate to unilateral, straight, antrorse, spreading, 12-22 $\mu \mathrm{m}$ long; stalk cells cylindrical to cuneate, 2-5 $\mu \mathrm{m}$ long; head cells ovate, globose, slightly curved, entire, 9-17x7-9 $\mu \mathrm{m}$. Phialides few, mixed with appressoria, alternate to opposite, ampulliform, 14$26 \times 6-8 \mu \mathrm{m}$. Mycelial setae scattered, grouped around perithecia, numerous, simple, straight, acute at the tip, up to $310 \mu \mathrm{m}$ long. Perithecia scattered, verrucose, up to $170 \mu \mathrm{m}$ in diameter; ascospores cylindrical, 4-septate, slightly constricted at the septa, 33-40×9-14 $\mu \mathrm{m}$.

This is the only species of the genus Meliola on the members of the family Erythropalaceae.

Endemic to Southern Western Ghats

Meliola flemingiicola Hosag., Jose \& H. Biju in Hosag., J. Mycopathol. Res. 43: 26, 2005; Hosag., Meliolales of

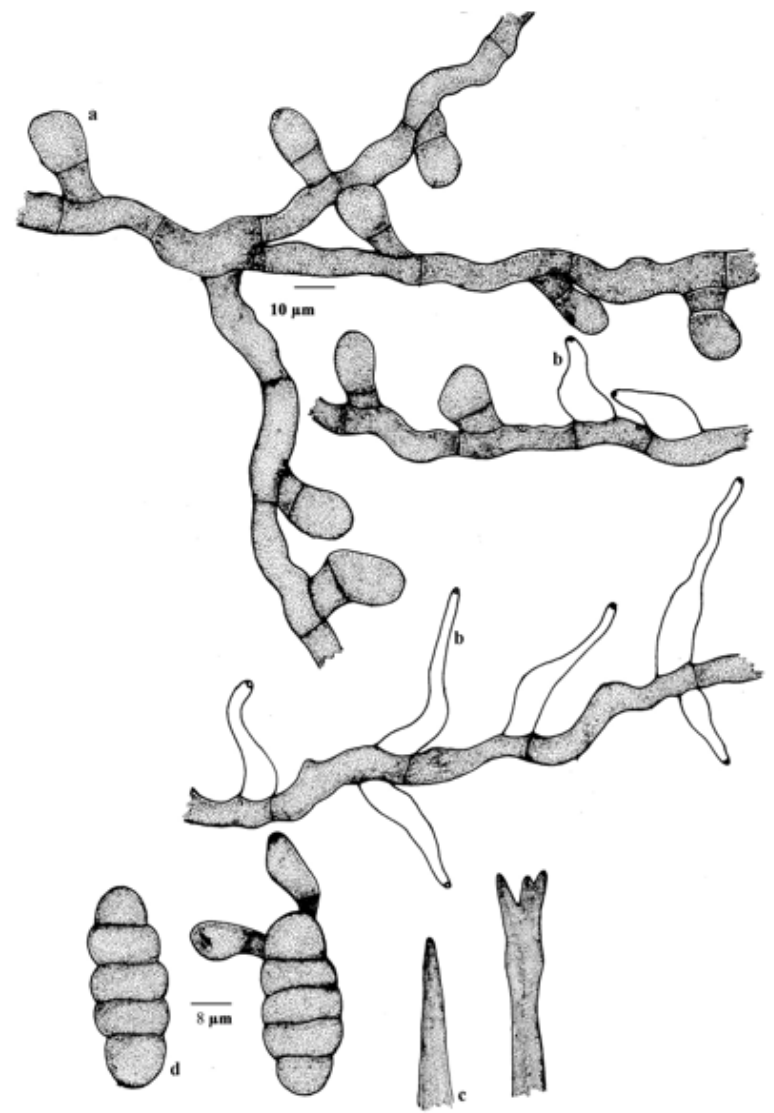

Figure-71. Meliola dysoxyligena

a - Appressorium; b - Phialide; c - Apical portion of mycelial setae; d - Ascospores

India 2: 243, 2008. (Fig. 73).

Materials examined: $\mathrm{HClO}$ 43616, TBGT 298, 19.xi.1998, on leaves of Flemingia sp. (Fabaceae), Banasuranmala, coll. C.K.Biju.

Colonies epiphyllous, dense, crustose to velvety, scattered, up to $2 \mathrm{~mm}$ in diameter, rarely confluent. Hyphae substraight to flexuous, branching irregular at acute to wide angles, loosely to closely reticulate, cells $17-28 \times 6-8 \mu \mathrm{m}$. Appressoria alternate, about $20 \%$ opposite, antrorse, subantrorse to rarely recurved, 12$16 \mu \mathrm{m}$ long; stalk cells cylindrical to cuneate, 3-7 $\mu \mathrm{m}$ long; head cells globose, entire, rarely truncate at the apex, 9-11x10-12 $\mu \mathrm{m}$. Phialides mixed with appressoria, alternate to opposite, ampulliform, 14-21x8-10 $\mu \mathrm{m}$. Mycelial setae scattered to grouped around perithecia, simple, straight, obtuse, dentate to cristate at the apex, up to $441 \mu \mathrm{m}$ long. Perithecia scattered to loosely grouped, globose, up to $140 \mu \mathrm{m}$ in diameter; ascospores oblong to cylindrical, 4 septate, slightly constricted at the septa, 33-36x11-13 $\mu \mathrm{m}$. 
Meliola gamblei Hosag. in Hosag. \& Goos, Mycotaxon 42: 134, 1991; Hosag., Meliolales of India, p. 201, 1996. (Fig. 74)

Materials examined: HCIO 49435, TBGT 3680, 16.ii.2009, on leaves of Smilax sp. (Smilacaceae), Periya, coll. Harish et al.

Colonies epiphyllous, dense, crustose, up to $2 \mathrm{~mm}$ in diameter, confluent. Hyphae substraight to crooked, branching opposite at acute angles, loosely to closely reticulate, cells $18-31 \times 6-9 \mu \mathrm{m}$. Appressoria alternate, straight to curved, antrorse to spreading, 18-22 $\mu \mathrm{m}$ long; stalk cells cylindrical to cuneate, 4-5 $\mu \mathrm{m}$ long; head cells ovoid to globose, straight to curved, often bluntly pointed at the apex, entire, $12-15.5 \times 12-14 \mu \mathrm{m}$. Phialides mixed with appressoria, opposite to alternate, ampulliform, 15-25x6-9.5 $\mu \mathrm{m}$. Mycelial setae few, straight, simple, acute to obtuse at the tip, up to $650 \mu \mathrm{m}$ long. Perithecia scattered, verrucose, up to $280 \mu \mathrm{m}$ in diameter; ascospores obovoidal, 4-septate, slightly constricted at the septa, 37-43.5x15-18.5 $\mu \mathrm{m}$.

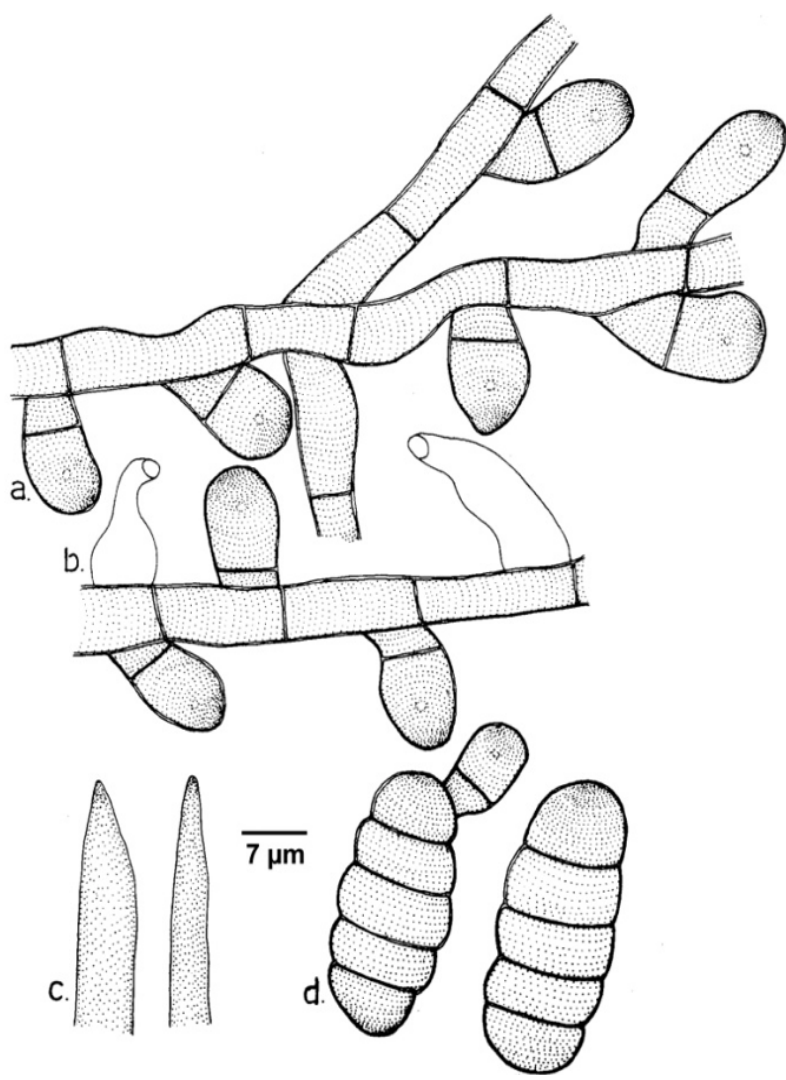

Figure 72. Meliola erythropali

a - Appressorium; b - Phialide; c - Apical portion of mycelial setae; d - Ascospores

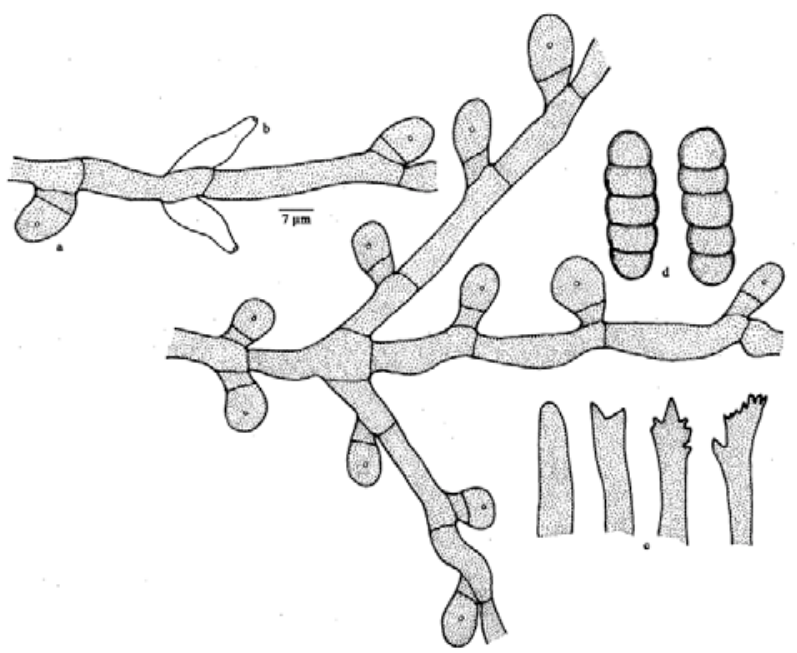

Figure 73. Meliola flemingiicola

a - Appressorium; b - Phialide; c - Apical portion of mycelial setae; d - Ascospores

Meliola gemellipoda Doidge, Bothalia 1: 80, 1920; Stev., Ann. Mycol. 26: 229, 1928; Hansf., Sydowia Beih. 2: 530, 1961; Hosag. \& Goos, Mycotaxon 37: 232, 1990; Hosag., Meliolales of India, p. 204, 1996.

Meliola busogensis Hansf., J. Linn. Soc. Bot. 51: 538, 1938. (Fig. 75)

Materials examined: $\mathrm{HClO}$ 49462, TBGT 3704; $\mathrm{HClO}$ 49771, 9.ix.2008, on leaves of Jasminum sp. (Oleaceae), Pulpally, coll. P.J. Robin et al., TBGT 3923, 14.ii.2009, Thirunelly, coll. Jacob Thomas et al.; HCIO 49967, TBGT 4119, 13.iii.2007, Puthuserrykadavu, coll. M.C. Riju; HCIO 50841, TBGT 4758, 5.xi.2009, Jasminum malabaricum Wight, Gurukulam Botanical Garden, coll. M.C. Riju \& A. Sabeena; HCIO 49627, TBGT 3869, 20.ix.2008, Jasminum sp., Pulpally, coll. M. Harish \& P.J. Robin.

Colonies amphigenous, mostly epiphyllous, dense, up to $3 \mathrm{~mm}$ in diameter, confluent. Hyphae straight to slightly undulate, branching opposite at acute to subacute angles, loosely to closely reticulate, cells $12-$ 19x4-7 $\mu \mathrm{m}$. Appressoria opposite (very few unilateral), straight to slightly curved, closely antrorse, 14-19 $\mu \mathrm{m}$ long; stalk cells cuneate, 4-7 $\mu \mathrm{m}$ long; head cells subglobose to ovate, entire, 9-14x7-10 $\mu \mathrm{m}$. Phialides few, mixed with appressoria, alternate to opposite, ampulliform, 16-26x7-10 $\mu \mathrm{m}$. Mycelial setae fairly numerous, scattered to mostly grouped around perithecia, straight, simple, acute to obtuse at the tip, up to $570 \mu \mathrm{m}$ long. Perithecia scattered, verrucose, up to $120 \mu \mathrm{m}$ in diameter; ascospores obovoidal, 4-septate, slightly constricted at the septa, 43-50x14-20 $\mu \mathrm{m}$.

This is distinct from other species having opposite 


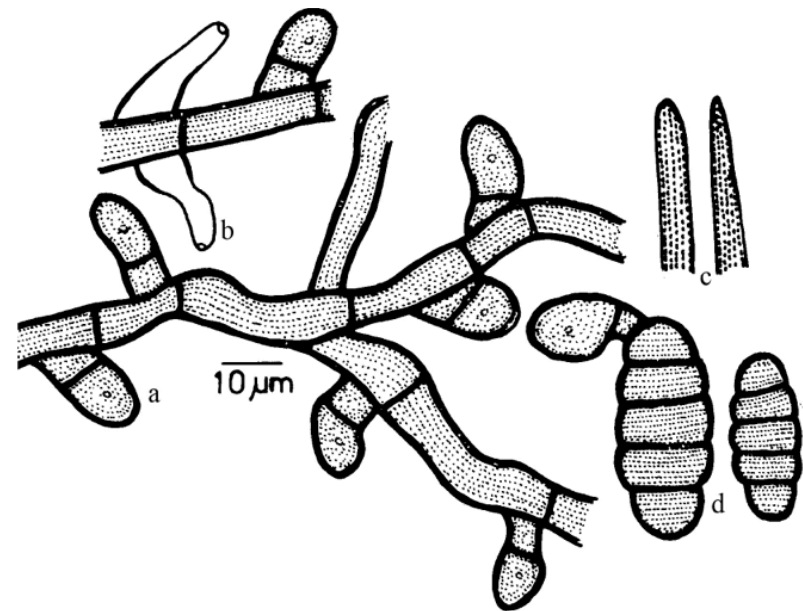

Figure 74. Meliola gamblei

a - Appressorium; b - Phialide; c - Apical portion of mycelial setae; d - Ascospores

appressoria.

Not very common in the Western Ghats

Meliola glanduliferae Hosag., C.K. Biju \& Abraham, Nova Hedwigia 80: 485, 2005; Hosag., Meliolales of India 2: 250, 2008 (Fig. 76).

Materials examined: $\mathrm{HClO}$ 43630, TBGT 328, 16.iv.1999, on leaves of Olea glandulifera Wallich ex G. Don (Oleaceae), Banasuran mala, coll. C.K.Biju.

Colonies amphigenous, subdense to dense, up to $2 \mathrm{~mm}$ diameter, confluent. Hyphae substraight to flexuous, branching mostly opposite, loosely to rather closely reticulate, cells $12-18 \times 5-7 \mu \mathrm{m}$. Appressoria alternate, straight to curved, antrorse to subantrorse, 19-22 $\mu \mathrm{m}$ long; stalk cells cylindrical to cuneate, 7-9 $\mu \mathrm{m}$ long; head cells oblong to cylindrical, broadly rounded to rarely truncate at the apex, entire, 11-16x6-8 $\mu \mathrm{m}$. Phialides mixed with appressoria, alternate to opposite, ampulliform, 19-24x4-7 $\mu \mathrm{m}$. Mycelial setae scattered, simple, straight, acute to slightly obtuse at the tip, up to $200 \mu \mathrm{m}$ long. Perithecia scattered, up to $160 \mu \mathrm{m}$ diam.; ascospores obovoidal to cylindrical, 4-septate, constricted at the septa, 35-40×14-16 $\mu \mathrm{m}$.

Meliola gliricidiicola Hosag. \& Agarwal, Indian Phytopath. 56: 103, 2003; Hosag., Meliolales of India 2: 251, 2008; Hosag. \& Agarwal, Taxonomic studies of Meliolales. Identification Manual, p. 178, 2008. (Fig. 77)

Materials examined: $\mathrm{HClO}$ 49964, TBGT 4116, 16.iii.2007, on leaves of Gliricidia sp. (Fabaceae), Batherry, coll. M.C. Riju.

Colonies amphigenous, mostly epiphyllous, subdense to dense, up to $2 \mathrm{~mm}$ in diameter, often confluent.

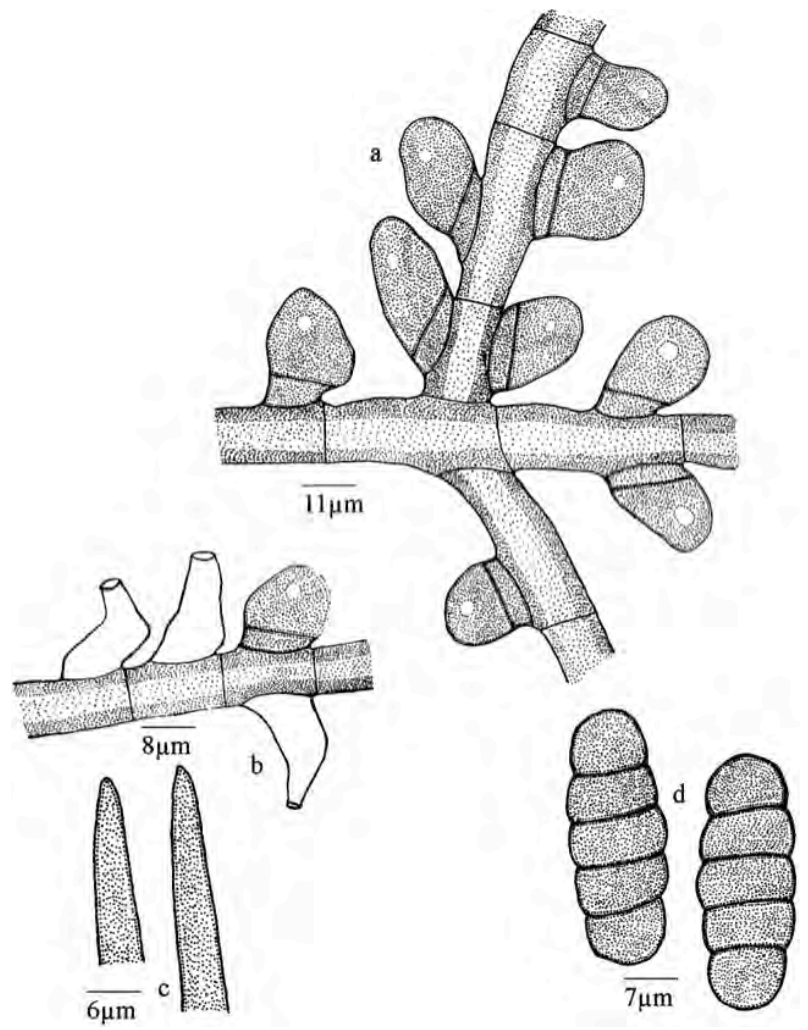

Figure 75. Meliola gemellipoda

a - Appressorium; b - Phialide; c - Apical portion of mycelial setae; d - Ascospores

Hyphae straight to flexuous, branching mostly opposite at acute to wide angles, loosely to closely reticulate, cells $14-21 \times 4-8 \mu \mathrm{m}$. Appressoria alternate, opposite, subantrorse to spreading, 11-16 $\mu \mathrm{m}$ long; stalk cells cylindrical to cuneate, 3-5 $\mu \mathrm{m}$ long; head cells globose, rarely ovate, straight to slightly curved, entire, 9-10x7$11 \mu \mathrm{m}$. Phialides mixed with appressoria, alternate to opposite, ampulliform, 8-16x6-8 $\mu \mathrm{m}$. Mycelial setae scattered to grouped around perithecia, simple, straight, acute at the tip, up to $368 \mu \mathrm{m}$ long. Perithecia scattered, up to $164 \mu \mathrm{m}$ in diameter; ascospores mostly cylindrical, 4-septate, constricted at the septa, 32-37x9-13 $\mu \mathrm{m}$.

Meliola gliricidicola can be compared with Meliola nyanzae Hansf. having the same Beeli formula 3113. 3222. However, it differs from it in not causing any pathogenic effect on the host. It differs from Meliola bicornis Wint. in having only acute setae and smaller ascospores. It also differs from Meliola cranatissima Sydow in having phialides mixed with appressoria, mycelial setae acute and having smaller ascospores (Hansford, 1961).

Meliola groteana Sydow var. maesae Hosag., C.K. 
Biju \& Abraham, Nova Hedwigia 80: 486, 2005; Hosag., Meliolales of India 2: 257, 2008. (Fig. 78).

Materials examined: HClO 43673, TBGT335, 18.xi.1998, on leaves of Maesa indica (Roxb.) DC. (Myrsinaceae), Chembra hills, coll. C.K. Biju; HCIO 50329, TBGT 4246, 31.x.2007, $10^{\text {th }}$ Mile, Banasura sagar, coll. V.B. Hosagoudar et al.; HCIO 49059, TBGT 3314, 16.ix.2008, Periya, coll. M. Harish \& P.J. Robin; HCIO 49210, TBGT 3449, 14.ii.2009, Thirunelly, coll. Jacob Thomas et al.; HClO 47399, TBGT 2437, 21.iv.2003, Maesa perrottetiana A.DC., Periya, coll. G. Rajkumar \& P.A. Jose.

Colonies mostly hypophyllous, dense, velvety, up to $5 \mathrm{~mm}$ diameter, confluent. Hyphae straight to flexuous, branching mostly opposite at acute angles, loosely to closely reticulate, cells $12-16 \times 5-7 \mu \mathrm{m}$. Appressoria alternate, about $30 \%$ opposite, antrorse to subantrorse, 12-16 $\mu \mathrm{m}$ long; stalk cells cylindrical to cuneate, 3-5 $\mu \mathrm{m}$ long; head cells predominantly globose, rarely ovate, entire, 9-11x8-11 $\mu \mathrm{m}$. Phialides few, mixed with appressoria, alternate to opposite, ampulliform, 16-

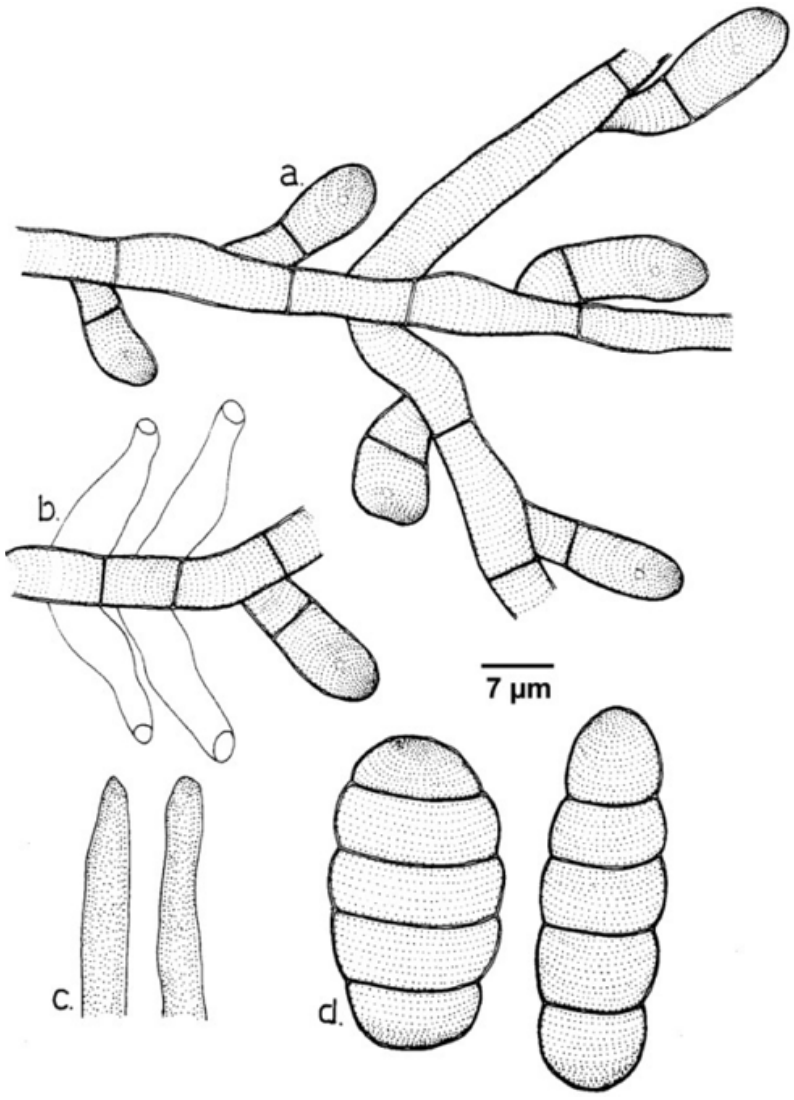

Figure 76. Meliola glanduliferae

a - Appressorium; b - Phialide; c - Apical portion of mycelial setae; d - Ascospores 20x8-11 $\mu \mathrm{m}$. Mycelial setae densely scattered, simple, straight, flexuous to arcuate, obtuse to acute at the tip, up to $300 \mu \mathrm{m}$ long. Perithecia scattered, up to $175 \mu \mathrm{m}$ diameter; ascospores obovoidal to cylindrical, 4-septate, slightly constricted at the septa, 33-40x-12-15 $\mu \mathrm{m}$.

The present collection can readily be assigned to the type species. However, the new variety differs from var. groteana in having straight to arcuate mycelial setae and smaller ascospores.

Meliola gymnemae Jana, Ghosh \& Das, Indian Phytopath. 58: 444, 2005; Hosag., Meliolales of India 2: 259, 2008. (Fig. 79).

Materials examined: $\mathrm{HClO}$ 49377, TBGT 3622, 16.ii.2009, on the leaves of Gymnema sylvestre (Retz.) R. Br. ex Schultes (Asclepiadaceae), Periya, coll. P.J. Robin et al.; HClO 50002, TBGT 4154 13.iii.2007, Puthuserrykadavu, coll. M.C. Riju; $\mathrm{HClO}$ 49422, TBGT 3667, 14.ii.2009, Gymnema sp., Thirunelly, Harish et al.; HCIO 49803, TBGT 3955, 8.iii.2008, Periya, coll. P.J. Robin et al.

Colonies amphigenous, mostly epiphyllous, dense, velvety, scattered, up to $3 \mathrm{~mm}$ in diameter. Hyphae substraight to undulate, branching opposite at acute angles, closely reticulate, cells $12-26 \times 4-7 \mu \mathrm{m}$. Appressoria alternate to unilateral, antrorse, straight to

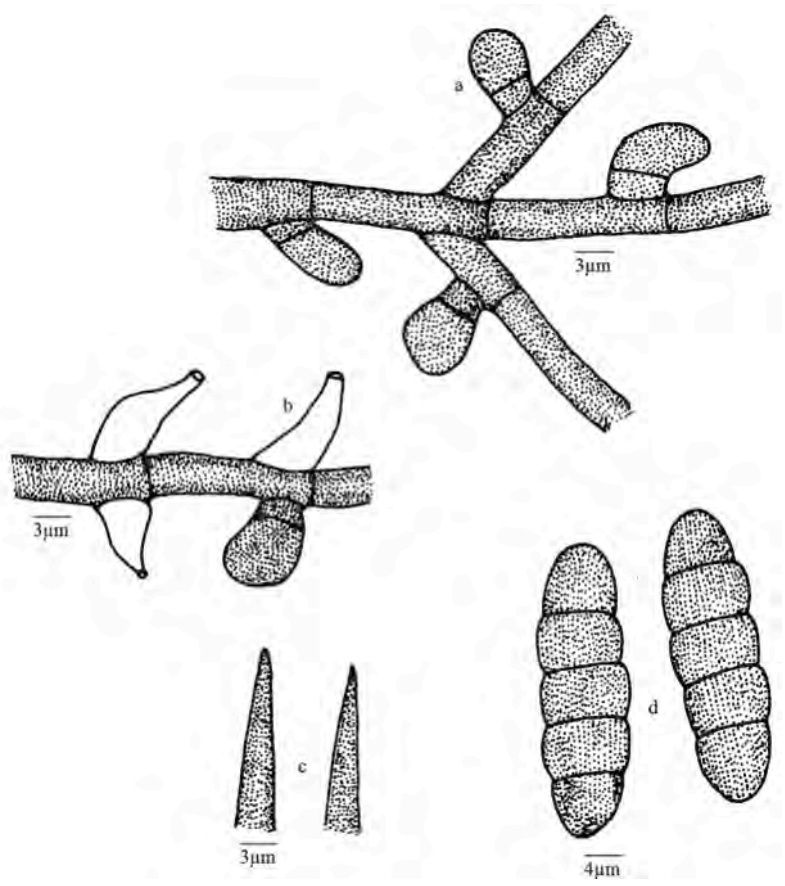

Figure 77. Meliola gliricidiicola

a - Appressorium; b - Phialide; c - Apical portion of mycelial setae; d - Ascospores 
curved, 14-22 $\mu \mathrm{m}$ long; stalk cells cylindrical to cuneate, 2-7 $\mu \mathrm{m}$ long; head cells ovate, globose to subangular, cylindrical, entire, 12-17x9-12 $\mu \mathrm{m}$. Phialides borne on a separate mycelial branch, alternate to opposite, ampulliform, 14-22x6-7 $\mu \mathrm{m}$. Mycelial setae numerous, scattered, straight, simple, acute at the tip, up to $390 \mu \mathrm{m}$ long. Perithecia scattered to grouped, verrucose, up to $170 \mu \mathrm{m}$ in diameter; ascospores cylindrical to subellipsoidal, 4-septate, slightly constricted at the septa, 31-36×12-14 $\mu \mathrm{m}$.

This fungus causes severe damage on this medicinally important plant.

Meliola hemidesmicola Hosag., Meliolales of India, p. 212, 1996. (Fig. 80)

Materials examined: $\mathrm{HClO}$ 49064, TBGT 3319, 20ix.2008, on leaves of Hemidesmus indicus (L.) R. Br. (Periplocaceae), Pulpally, coll. M. Harish \& P.J. Robin; HClO 44796, TBGT 1033, 26.xii.2002, Chandanathode, coll. M. Kamarudeen \& P.A. Jose.

Colonies epiphyllous, dense, confluent and cover an entire upper surface of the leaves. Hyphae straight to slightly undulate, branching mostly opposite at wide angles, loosely to closely reticulate, cells $21-29 \times 4-7$ $\mu \mathrm{m}$. Appressoria alternate, antrorse to subantrorse,

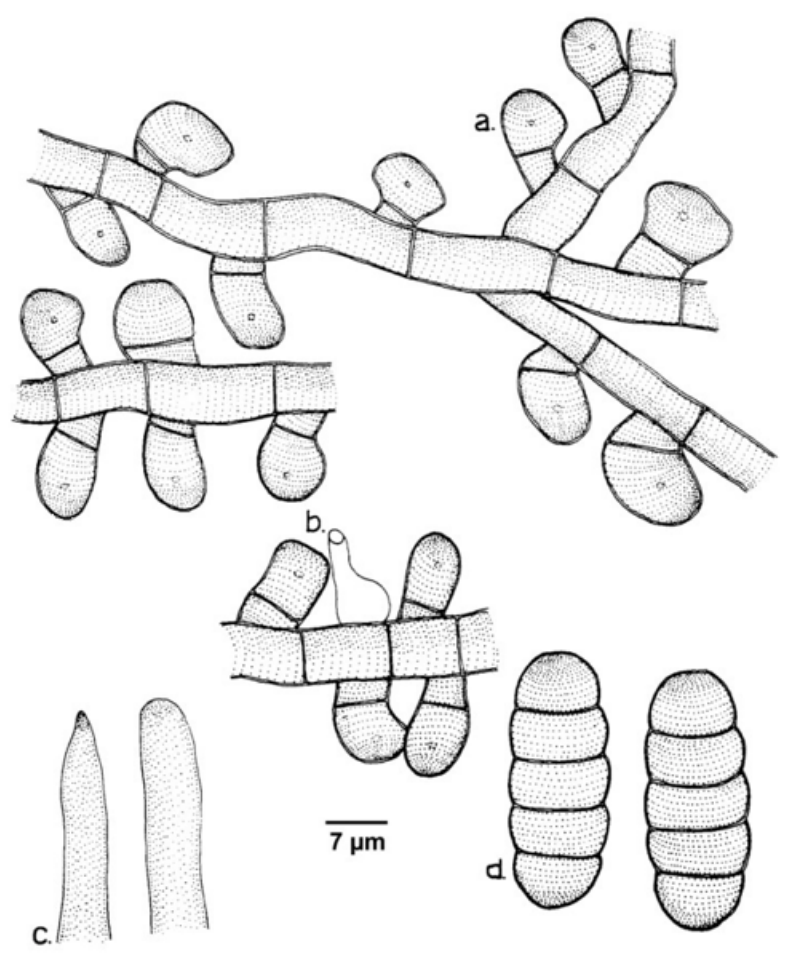

Figure-78. Meliola groteana var. maesae

a - Appressorium; b - Phialide; c - Apical portion of mycelial setae; d - Ascospores
16-24 $\mu \mathrm{m}$ long; stalk cells cylindrical to cuneate, 4-7 $\mu \mathrm{m}$ long; head cells ovate, globose, entire, 12-14x9-12 $\mu \mathrm{m}$. Phialides mixed with appressoria, alternate to opposite, ampulliform, 19-24x4-7 $\mu \mathrm{m}$. Mycelial setae fairly numerous, scattered, simple, straight, acute at the tip, up to $680 \mu \mathrm{m}$ long. Perithecia scattered, verrucose, up to $120 \mu \mathrm{m}$ in diameter; ascospores oblong to subellipsoidal, 4-septate, constricted at the septa, 31-36x12-14 $\mu \mathrm{m}$.

This species differs from Meliola hemidesmi Kamal \& Gupta in having longer mycelial setae, smaller perithecia and ascospores (Hosagoudar, 1996).

Endemic to Southern Western Ghats

Meliola holigarnae Stev., Mem. Dept. Agric. India, Bot. Ser. 15: 108, 1928; Hansf., Sydowia Beih. 2: 468, 1961; Thite \& Kulkarni, J. Shivaji Univ. (Sci.) 6: 162, 1973; Hosag., J. Econ. Tax. Bot. 7: 45, 1985; Hosag. \& Goos, Mycotaxon 37: 234, 1990; 42: 135, 1991; Hosag., Dayal \& Goos, Mycotaxon 46: 204, 1993; Hosag., Raghu \& Pillai, Nova Hedwigia 58: 529, 1994; Hosag., Meliolales of India, p. 217, 1996. (Fig. 81 \& Image 8).

Materials examined: $\mathrm{HClO}$ 45105, TBGT 1160, 26.xii.2002, on leaves of Holigarna arnottiana Hook.f. (Anacardiaceae), Periya, coll. M. Kamarudeen \& P.A. Jose; HCIO 45159, TBGT 1214, 27.xii.2002, Chandanathode, coll. M. Kamarudeen \& P.A. Jose; HClO 49382, TBGT 3627; HCIO 49384, TBGT 3629, 16.ii.2009, Holigarna sp., Periya, Wayanadu, coll. Gireesh Kumar et al.

Colonies hypophyllous, dense, velvety, up to $8 \mathrm{~mm}$ in diameter, confluent. Hyphae strongly appressed to the host surface, crooked, branching alternate to irregular at acute to wide angles, closely reticulate, cells $37-54 \times 6-$ $8 \mu \mathrm{m}$. Appressoria scattered, alternate to unilateral, antrorse to reflexed, variously curved, 25-50 $\mu \mathrm{m}$ long; stalk cells cylindrical, flexuous, usually elongated, 8-20

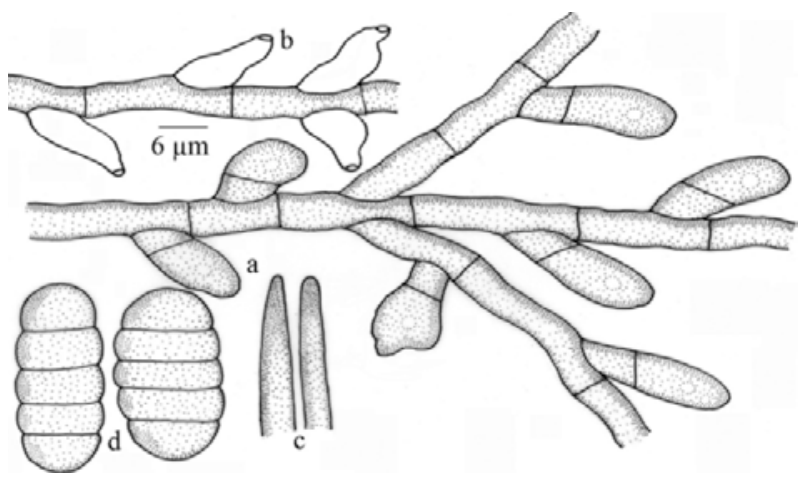

Figure-79. Meliola gymnemae

a - Appressorium, b - Phialide, c - Apical portion of mycelial setae, d-Ascospores 
$\mu \mathrm{m}$ long; head cells ovate, versiform, angulose, entire to lobate, straight to curved, 17-22x14-18 $\mu \mathrm{m}$. Phialides few, mixed with appressoria, conoid to ampulliform, 11-26x4-8 $\mu \mathrm{m}$. Mycelial setae numerous, straight, flexuous, simple, acute to obtuse at the tip, up to $826 \mu \mathrm{m}$ long. Perithecia scattered, verrucose, up to $286 \mu \mathrm{m}$ in diam.; ascospores ellipsoidal, 4-septate, constricted at the septa, middle cell largest, 62-74×23-30 $\mu \mathrm{m}$.

The present taxon can be easily distinguished by its flexuous mycelial setae and fusiform, large ascospores with the larger central cell.

Meliola ichnocarpi-volubili Hansf., Sydowia 16: 320, 1963; Hosag., Abraham \& Pushpangadan, The Meliolineae - A Supplement, 1987; Hosag., Zoos' Print J.

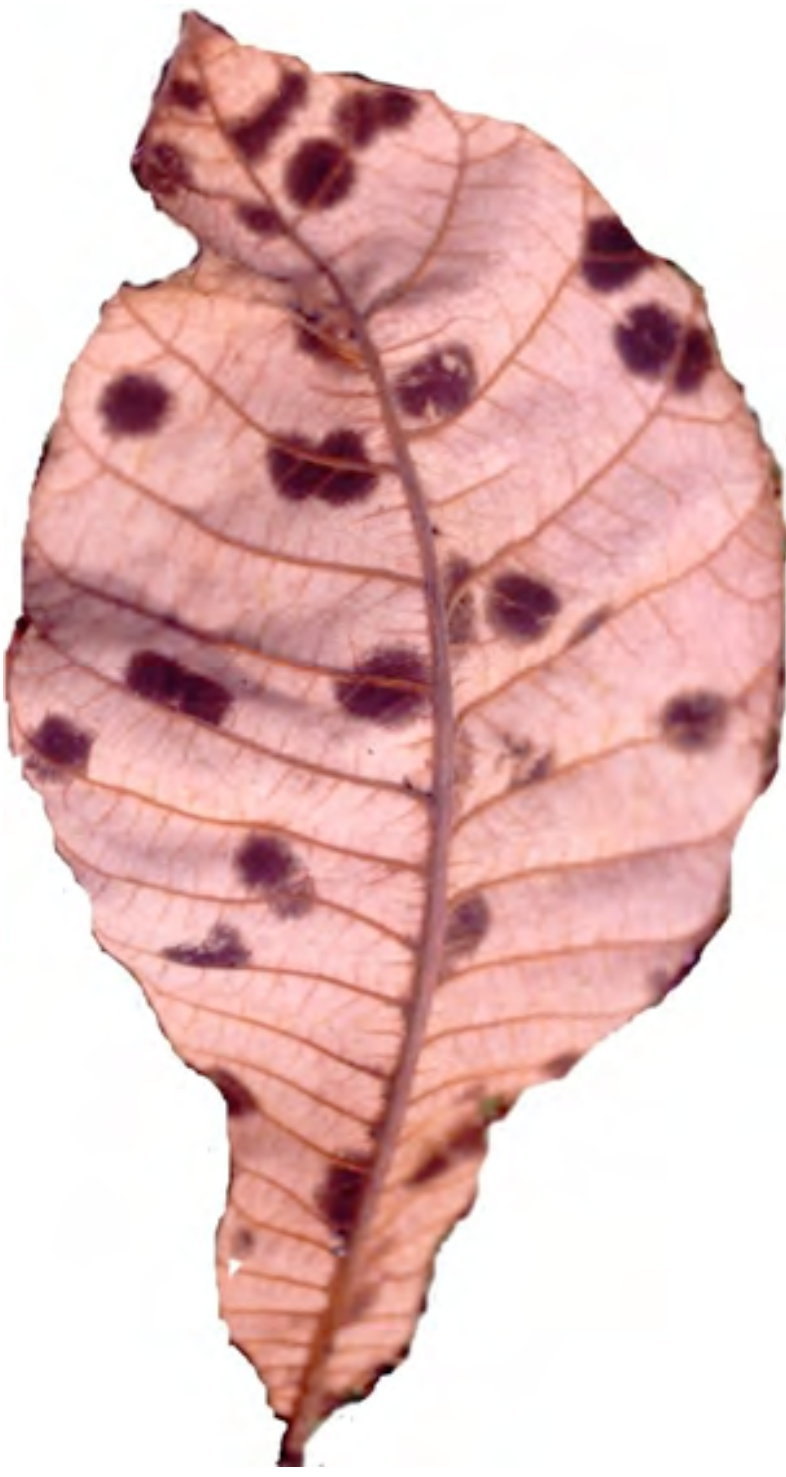

Image. 8. Meliola holigarnae-Infected leaf
18: 1002, 2002; Hosag., Meliolales of India 2: 268, 2008.

Meliola ichnocarpi Stev. \& Rold., Philippine J. Sci. 56: 66,

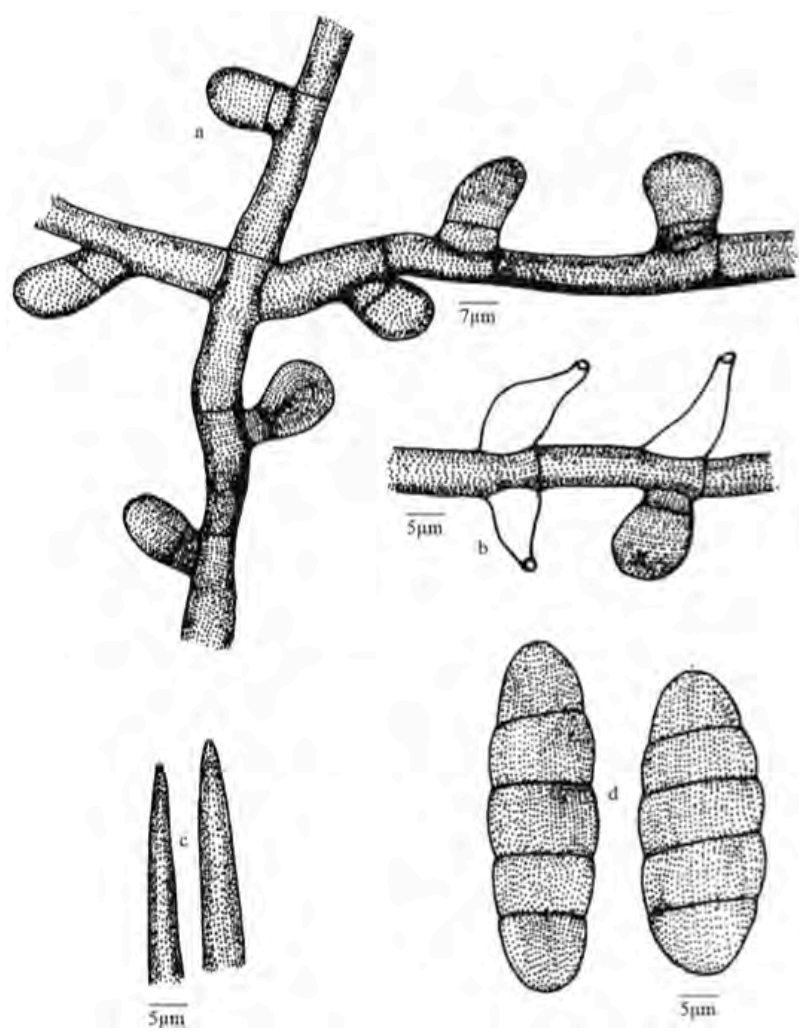

Figure-80. Meliola hemidesmicola

a - Appressorium, b - Phialide, c - Apical portion of mycelial setae, d-Ascospores

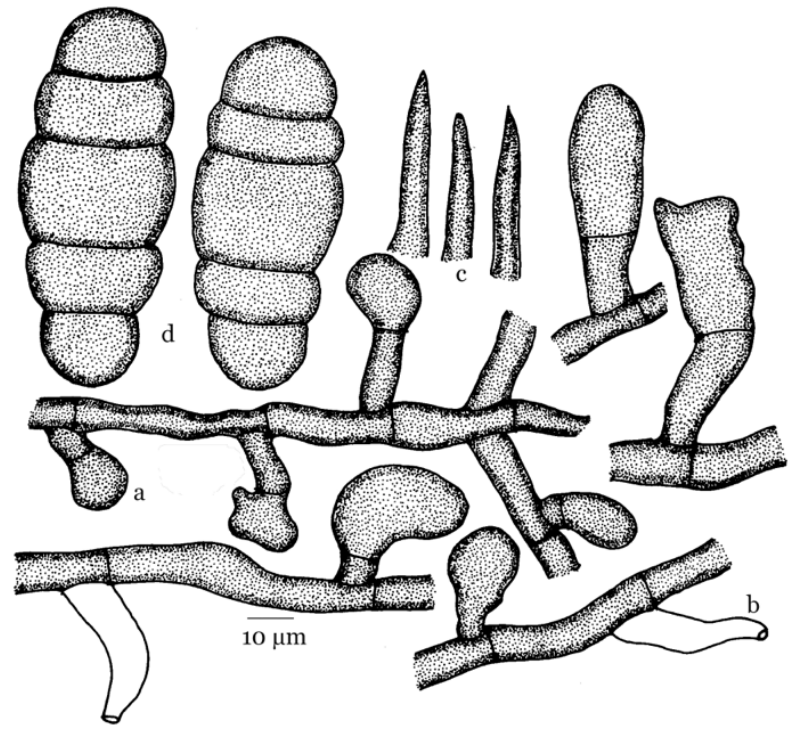

Fig.-81. Meliola holigarnae

a - Appressorium; b - Phialide; c - Apical portion of mycelial setae; d - Ascospores 
1935 (non Hansf. \& Thirum., 1948); Hansf., Sydowia Beih. 2: 561, 1961. (Fig. 82).

Materials examined: TBGT 5575, 10.xi.2007, on leaves of Quirivelia frutescens (L.) M.R. Almeida \& S.M. Almieda $\{($ Ichnocarpus frutescens (L.) R. Br.) $\}$ (Apocynaceae), Padinharathara, coll. M.C. Riju.

Colonies amphigenous, mostly epiphyllous, dense, velvety, up to $3 \mathrm{~mm}$ in diameter, confluent and covering almost upper surface of the leaves. Hyphae straight to substraight, branching opposite at acute to wide angles, closely reticulate, cells $16-29 \times 4-7 \mu \mathrm{m}$. Appressoria alternate, about $5 \%$ unilateral, straight to curved, antrorse to spreading, 9-14 $\mu \mathrm{m}$ long; stalk cells cylindrical to cuneate, upto $2 \mu \mathrm{m}$ long; head cells globose to subglobose, ovate, entire, 7-12x7-10 $\mu \mathrm{m}$. Phialides mixed with appressoria, alternate to opposite, ampulliform, 14-19x4-10 $\mu \mathrm{m}$. Mycelial setae numerous, scattered, straight, simple, acute to obtuse at the tip, up to $420 \mu \mathrm{m}$ long. Perithecia scattered, verrucose, up to $130 \mu \mathrm{m}$ in diameter; ascospores cylindrical to obovoidal, 4-septate, constricted at the septa, 26-38x12-14 $\mu \mathrm{m}$.

Meliola ichnocarpi Hansf. \& Thirum. and Meliola ichnocarpi-volubili Hansf. are known on this host genus. The former species differs from the latter in having longer appressoria $(15-30 \mu \mathrm{m})$ and larger ascospores

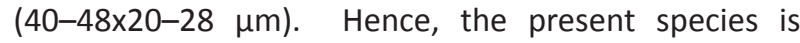
accommodated in the latter species.

Meliola jasmini Hansf. \& Stev., J. Linn. Soc. London 5: 273, 1937; Hansf., Sydowia Beih. 2: 235, 1961; Hosag., Indian J. Bot. 11: 185, 1988; Hosag. \& Raghu, New Botanist 20: 70, 1993; Hosag., Meliolales of India, p. 226,

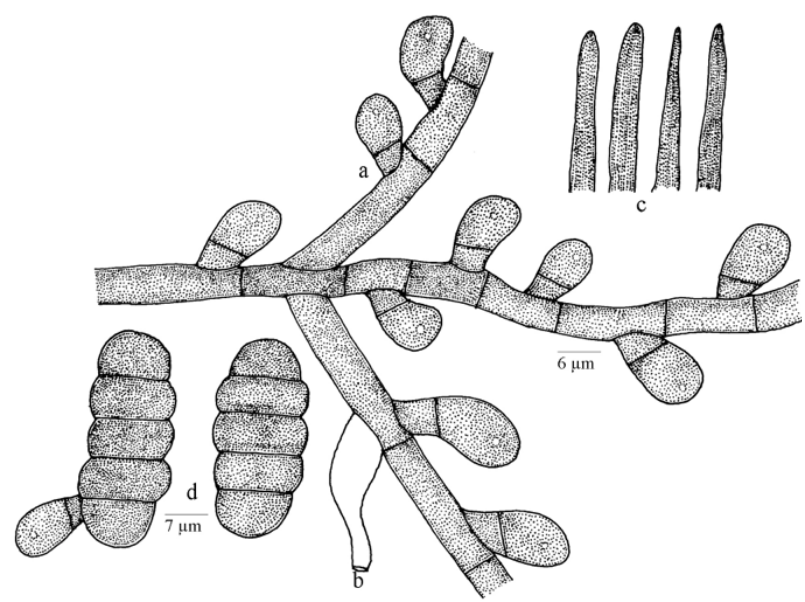

Figure-82. Meliola ichnocarpi-volubili

a - Appressorium; b - Phialide; c - Apical portion of mycelial setae; d - Ascospores
1996. (Fig. 83).

Materials examined: $\mathrm{HClO}$ 49887, TBGT 4039, 17.ix.2008, on leaves of Jasminum rottlerianum Wallich ex A. DC. (Oleaceae), Periya, coll. Harish et al.; HClO 50401, TBGT 4318, 6.xi.2009, Thariyode, coll. A. Sabeena \& M. C. Riju; HClO 44600, TBGT 887, 19.iii.1997, Jasminum sp., Tirunelly, coll. S. Shiburaj; HCIO 48055, TBGT 2838, 6.xii.2006, Kunkichira, Periya, coll. M. Harish, V. Gireesh Kumar \& K. Anilkumar; TBGT 3701, 10.ix.2008, Thirunelly, coll. Robin et al.; TBGT 4061, 11.xi.2007, Jasminum sp., coll. A. Chandraprabha; Puthuserrykadavu, coll. M.C Riju; HCIO 49969, TBGT 4121, 13.iii.2007; HCIO 50846, TBGT 4763, 6.xi.2009, on Jasminum cordifolium Wallich ex G.Don, Padinharathara, coll. M.C. Riju \& A. Sabeena; HCIO 50848, TBGT 4765, 6.xi.2009, Chennalode, coll. A. Sabeena \& M.C. Riju; HCIO 48055, TBGT 2838, 6.xii.2006, on Jasminum sp., Kunkichira, Periya, coll. M. Harish, V. Gireesh Kumar \& K. Anilkumar; HCIO 49066, TBGT 3321, 18.ix.2008, Thirunelly, coll. M. Harish et al.; HClO 49442, TBGT 3687, 20.ix,2008, Mananthavady, coll. P.J.Robin et al.; HCIO 43626, TBGT 304, 18.xi.1998, Chembra, coll. C.K. Biju.

Colonies hypophyllous, thin, velvety, up to $3 \mathrm{~mm}$ in

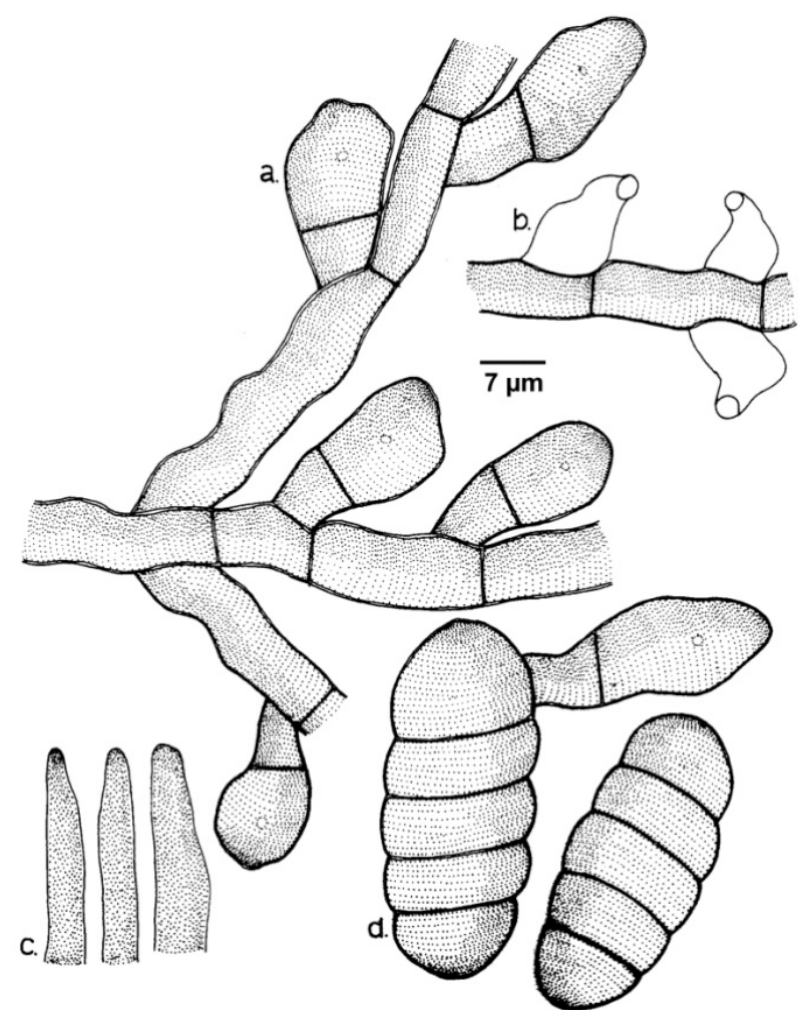

Figure 83. Meliola jasmini

a - Appressorium; b - Phialide; c - Apical portion of mycelial setae; d - Ascospores 
diameter, confluent. Hyphae straight to substraight, branching opposite at acute to wide angles, loosely reticulate, cells $21-36 \times 4-7 \mu \mathrm{m}$. Appressoria alternate, straight to curved, subantrorse to spreading, 24-26 $\mu \mathrm{m}$ long; stalk cells cylindrical to cuneate, 7-12 $\mu \mathrm{m}$ long; head cells globose, ovate, slightly angular, entire, 14-19x12-14 $\mu \mathrm{m}$. Phialides borne on a separate mycelial branch, opposite to alternate, ampulliform, 14-24x7-10 $\mu \mathrm{m}$. Mycelial setae numerous, scattered, straight, simple, acute to obtuse at the tip, up to $380 \mu \mathrm{m}$ long. Perithecia scattered, verrucose, up to $130 \mu \mathrm{m}$ in diameter; ascospores obovoidal, 4-septate, constricted at the septa, 33-38x14-17 $\mu \mathrm{m}$.

This species is distinct from other Meliola species known on Jasminum species in having phialides borne on separate mycelial branches.

This host appears to be the source of inoculation for the cultivated Jasminum species.

Meliola jasmini Hansf. \& Stev. var. microspora Hosag., C.K. Biju \& Abraham, Nova Hedwigia 80: 488, 2005; Hosag., Meliolales of India, 2: 273, 2008. (Fig. 84)

Materials examined: HCIO 43626; TBGT 304, 19.xi.1998, on leaves of Jasminum sp. (Oleaceae),

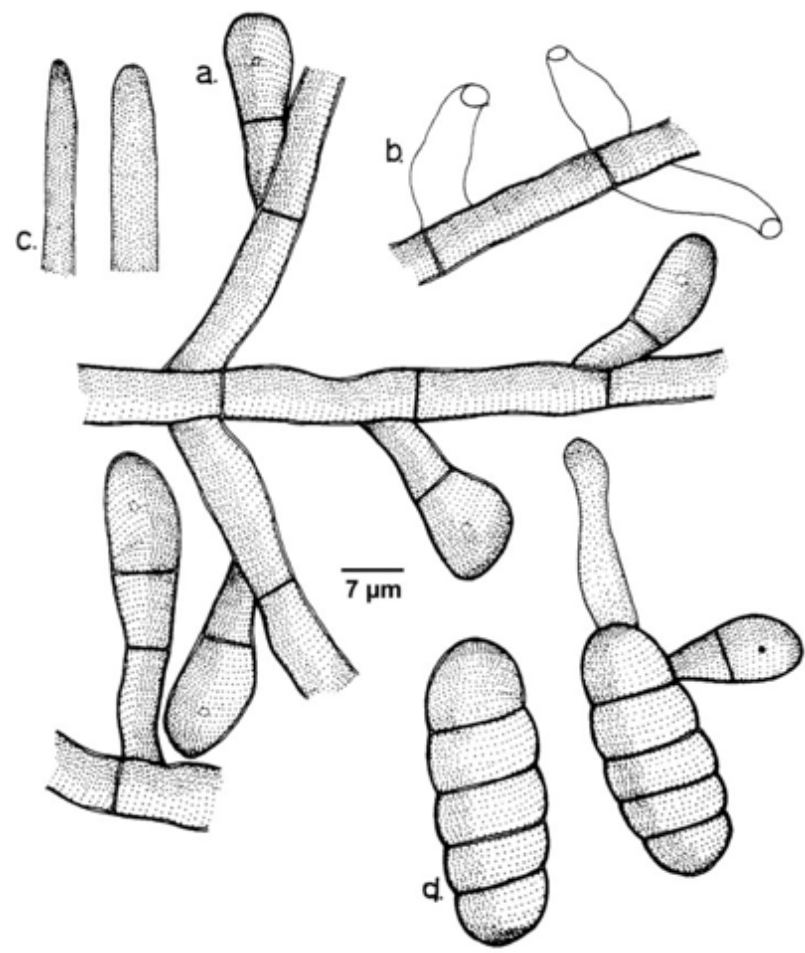

Figure 84. Meliola jasmini var. microspora a - Appressorium; b - Phialide; c - Apical portion of mycelial setae; d - Ascospores
Banasuran mala, coll. C.K. Biju.

Colonies amphigenous, thin, confluent, up to $2 \mathrm{~mm}$ diameter. Hyphae straight to substraight, branching opposite to rarely unilateral at wide angles, loosely reticulate, cells 20-29x4-6 $\mu \mathrm{m}$. Appressoria alternate, antrorse, rarely 3-celled, straight, 14-25 (-33) $\mu \mathrm{m}$ long; stalk cells cylindrical, 4-13 $\mu \mathrm{m}$ long; head cells ovate to clavate, entire to sublobate, 6-14x6-10 $\mu \mathrm{m}$. Phialides borne on a separate mycelial branch, alternate to opposite, ampulliform, 14-19x4-7 $\mu \mathrm{m}$. Mycelial setae few, grown from the subiculum of perithecia, acute to obtuse at the apex, simple, straight, up to $177 \mu \mathrm{m}$ long. Perithecia scattered, up to $110 \mu \mathrm{m}$ in diam; ascospores oblong, 4-septate, constricted at the septa, 25-30x11$13 \mu \mathrm{m}$.

The present collection is close to Meliola jasmini Hansf. \& Stev. but the new variety differs from the var. jasmini in having smaller ascospores and shorter and less mycelial setae.

Meliola jasminigena Hosag., Plant Pathology \& Quarantine 3(1): 7, 2013. (Fig. 85).

Materials examined: TBGT 6231 (holotype), 2.i.2010, on leaves of Jasminum bignoniaceum Wallich ex DC. (Oleaceae), Periya, coll. M.C. Riju.

Colonies epiphyllous, thin, scattered, up to $1 \mathrm{~mm}$ in diameter. Hyphae crooked, branching alternate to

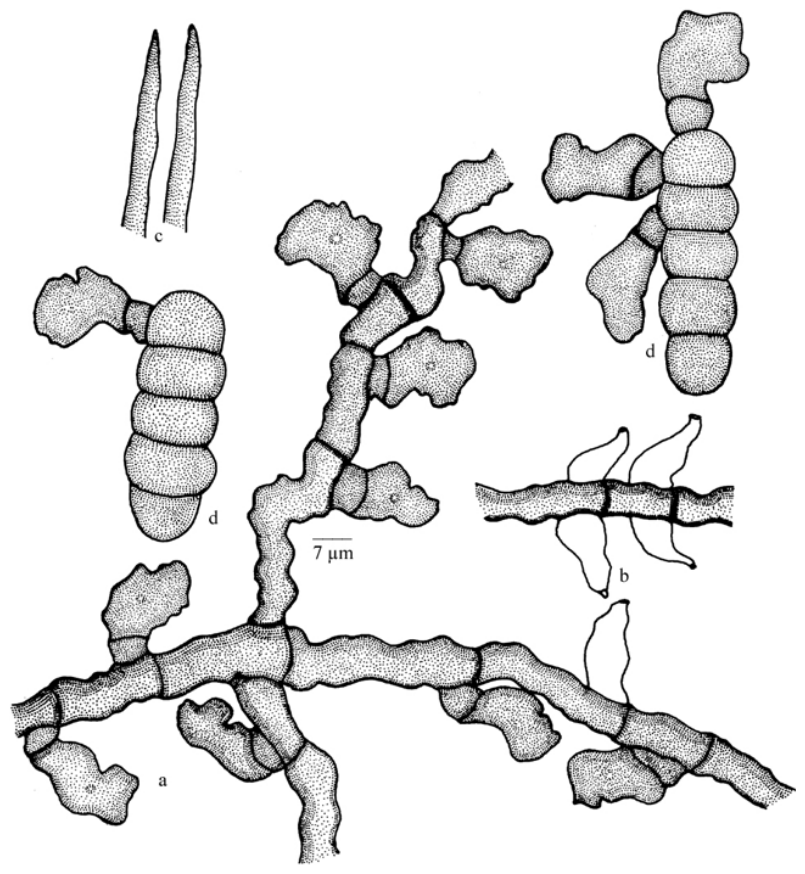

Figure 85. Meliola jasminigena

a - Appressorium; b - Phialide; c - Apical portion of mycelial setae; d - Ascospores 
opposite at acute to wide angles, loosely to very closely reticulate, cells $16-22 \times 6-10 \mu \mathrm{m}$. Appressoria alternate to unilateral, antrorse, subantrorse to retrorse, straight to curved, 19-29 $\mu \mathrm{m}$ long; stalk cells cylindrical to cuneate, 4-10 $\mu \mathrm{m}$ long; head cells ovate, clavate, oblong to cylindrical, entire, angular and crenately lobate to sublobate, 16-22x12-16 $\mu \mathrm{m}$. Phialides mixed with appressoria, alternate, ampulliform, 17-24x6-10 $\mu \mathrm{m}$. Mycelial setae numerous, simple, straight, acute at the tip, up to $410 \mu \mathrm{m}$ long. Perithecia scattered, up to $110 \mu \mathrm{m}$ in diameter; ascospores cylindrical, 4-septate, slightly constricted at septa, 48-50×15-18 $\mu \mathrm{m}$.

This species is similar to Meliola jasminicola var. africana Hansf. in having crooked mycelium and in the morphology of appressoria. However, it differs in having phialides mixed with appressoria, longer ascospores (48-50 vs. 31-39 $\mu \mathrm{m})$.

Meliola kamettiae Hosag. \& Riju, J. Threatened Taxa 2(4): 824, 2010; Hosag., J. Threatened Taxa 5(6): 4038, 2013. (Fig. 86)

Material examined: $\mathrm{HClO}$ 48175, TBGT 2911; HClO 48183, TBGT 2919, 30.ix.2007, on leaves of Kamettia caryophyllata Roxb. (Apocynaceae), Puthusserikadavu, Padinharathara, coll. M.C. Riju; HCIO 50751, TBGT 4668; HCIO 50753, TBGT 4670, 6.xi.2009, Kamettia sp., Padinharathara, coll. A. Sabeena \& M.C. Riju.

Colonies hypophyllous, scattered, dense, velvety, up to $4 \mathrm{~mm}$ in diameter, rarely confluent. Hyphae straight to substraight, branching mostly opposite at acute to wide angles, loosely to closely reticulate, cells $13-35 \times 4-7$ $\mu \mathrm{m}$. Appressoria alternate, unilateral, straight, antrorse,

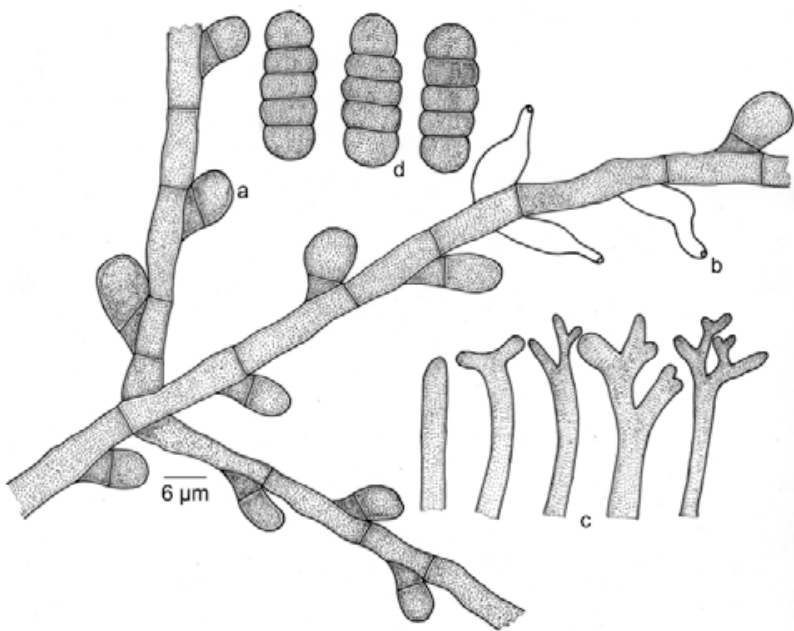

Figure 86. Meliola kamettiae

a - Appressorium; b - Phialide; c - Apical portion of mycelial setae; d - Ascospores
11-20 $\mu \mathrm{m}$ long; stalk cells cylindrical to cuneate, 2-9 $\mu \mathrm{m}$ long; head cells ovate, globose, 7-13×6-11 $\mu \mathrm{m}$. Phialides mixed with appressoria, opposite, alternate, unilateral, ampulliform, 11-22x4-7 $\mu \mathrm{m}$. Mycelial setae numerous, up to $260 \mu \mathrm{m}$ long, simple, straight, few slightly curved to uncinate, obtuse, bifid, trifid, often subdentate to furcated to branched at the tip, branches up to $30 \mu \mathrm{m}$ long. Perithecia scattered, up to $150 \mu \mathrm{m}$ in diameter; ascospores cylindrical, 4-septate, slightly constricted at the septa, 26-33x8-11 $\mu \mathrm{m}$.

Straight, slightly curved to uncinate, obtuse, bifid, trifid, often subdentate to furcated mycelial setae distinguishes this taxon from rest of the Meliola species reported on the members of the family Apocynaceae (Hansford 1961; Hosagoudar 1996, 2008; Hosagoudar et al. 1997).

Meliola lepianthedis Hosag. \& Kamar. in Hosag., C.K. Biju \& Abraham, J. Econ. Taxon. Bot. 25: 72, 2001; Hosag., Meliolales of India, 2: 278, 2008. (Fig. 87)

Materials examined: $\mathrm{HClO}$ 43714, TBGT 364, 8.xii.2000, on leaves of Lepianthes umbellata (L.) Rafin (Piperaceae), Wayanad, coll. M. Kamarudeen.

Colonies amphigenous, predominantly epiphyllous, dense, up to $2 \mathrm{~mm}$ in diameter, confluent. Hyphae straight to flexuous, branching opposite to alternate at acute to wide angles, loosely reticulate, cells $14-18 \times 6-8$

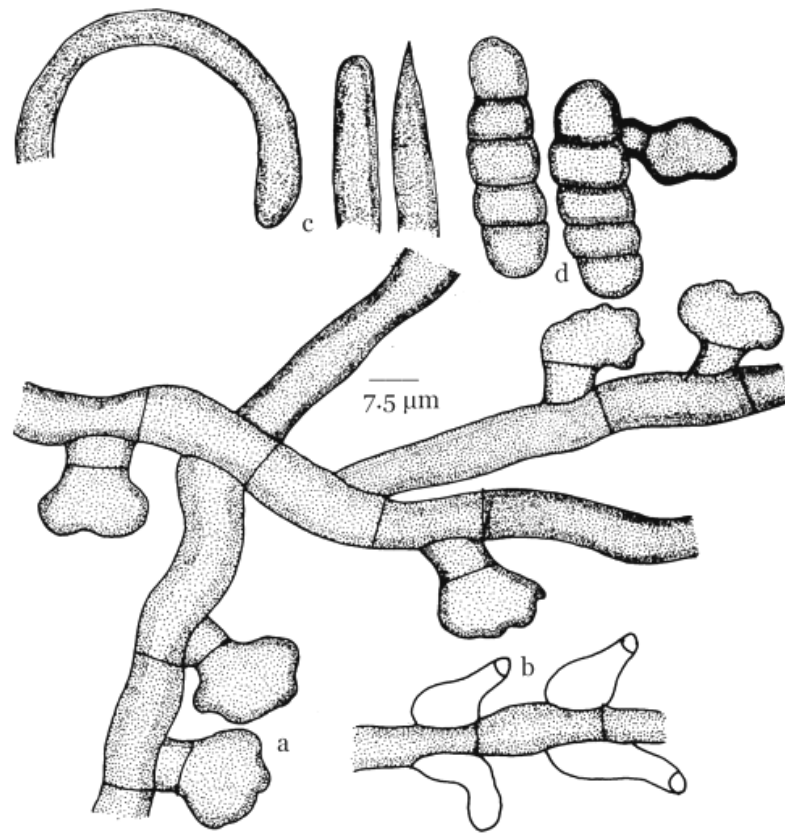

Figure 87. Meliola lepianthedis

a - Appressorium; b - Phialide; c - Apical portion of mycelial setae; d-Ascospores 
$\mu \mathrm{m}$. Appressoria alternate, antrorse to subantrorse, 16-23 $\mathrm{mm}$ long; stalk cells cylindrical to cuneate, 4-8 $\mu \mathrm{m}$ long; head cells globose, minutely and irregularly lobate, 11-16x12-18 $\mu \mathrm{m}$. Phialides borne on a separate mycelial branch, alternate to opposite, ampulliform, 14-21x8-10 $\mu \mathrm{m}$. Mycelial setae scattered to grouped around perithecia, simple, straight to uncinate, acute to broadly rounded at the apex, up to $300 \mu \mathrm{m}$ long. Perithecia scattered, up to $120 \mu \mathrm{m}$ in diameter; ascospores cylindrical, straight to curved, 4- septate, not constricted at the septa, 40-42×9-12 $\mu \mathrm{m}$.

Sublobate head cells of the appressoria, broadly obtuse tip and uncinate mycelial setae distinguishes this species.

Meliola ligustri Hosag. in Hosag. \& Goos, Mycotaxon 37: 236, 1990; Hosag., Meliolales of India, p. 236, 1996, Meliolales of India 2: 293, 2008. (Fig. 88).

Materials examined: $\mathrm{HClO}$ 44867, TBGT 1095, 7.iii.2001, on leaves of Ligustrum walkeri Roxb. ssp. walkeri (Decne) Green (L. walkeri Decne) (Oleaceae), Periya, coll. G. Rajkumar \& P.A. Jose; HClO 45197, TBGT 1233, 11.viii.1998, Thirunelli, coll. C.K.Biju; HCIO 50005, TBGT 4157, 14.iii.2007, on Ligustrum sp.
Puthuserrykadavu, coll. M.C. Riju; HClO 49058, TBGT 3313, 19.ix.2008, Kattikulam, coll. M. Harish et al.; HCIO 49061, TBGT 3316, 19.ix.2008, Pulpally, coll. M. Harish \& P.J. Robin; HCIO 49071, TBGT 3326, 18.xi.2008, Thirunelly, coll. M. Harish \& P.J. Robin; HCIO 49647, TBGT 3889, 16.xi.2008, Periya coll. M. Harish \& P.J. Robin; HClO 49209, TBGT 3448; HCIO 49252, TBGT 3491, 14.ii.2009, Thirunelly, coll. Jacob Thomas et al.

Colonies amphigenous, subdense, up to $4 \mathrm{~mm}$ in diameter, confluent. Hyphae flexuous, branching opposite to irregular at wide angles, loosely reticulate, cells $20-30 \times 6-8 \mu \mathrm{m}$. Appressoria alternate, spreading, antrorse, straight to curved, 20-24 $\mu \mathrm{m}$ long; stalk cells cylindrical to cuneate, 6-8 $\mu \mathrm{m}$ long; head cells globose, cylindrical, versiform, angulose, entire, 12-18x8-10 $\mu \mathrm{m}$. Phialides mixed with appressoria, alternate to opposite, ampulliform, tip twisted and elongated, 16-20x6-8 $\mu \mathrm{m}$. Mycelial setae fairly numerous, scattered, simple, acute to obtuse at the tip, up to $270 \mu \mathrm{m}$ long. Perithecia scattered, up to $160 \mu \mathrm{m}$ in diameter; ascospores obovoidal, 4-septate, constricted at the septa, 3640x14-16 $\mu \mathrm{m}$.

Alternate and antrorse appressoria and simple mycelial setae are the characters of this species.

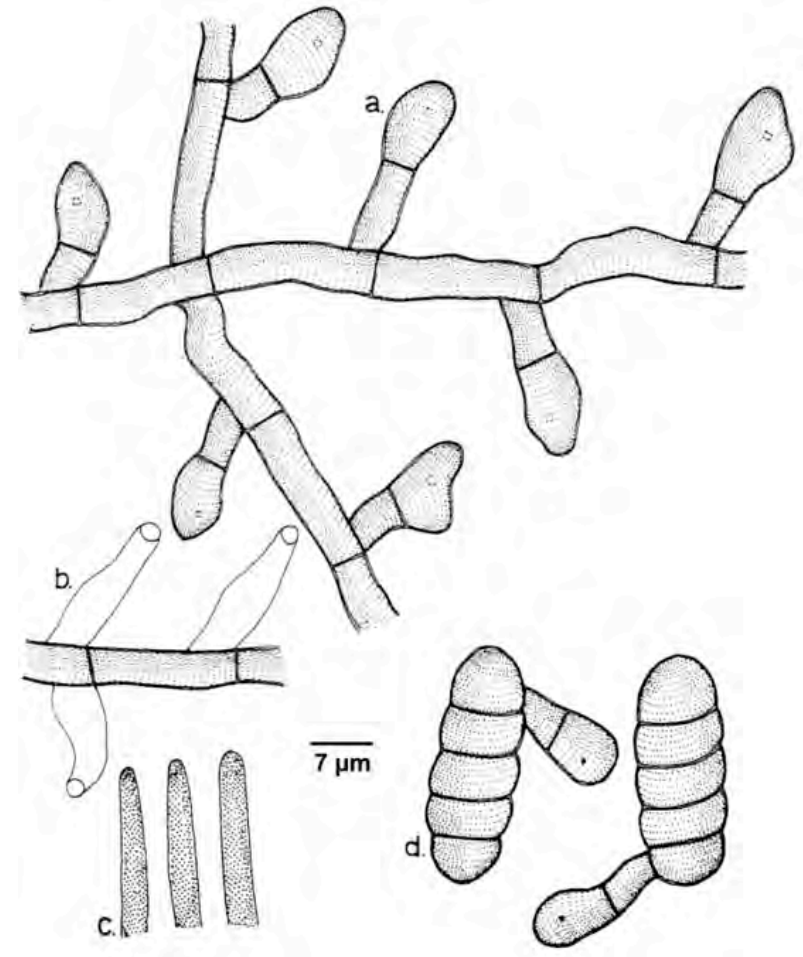

Figure 88. Meliola ligustri

a - Appressorium; b - Phialide; c - Apical portion of mycelial setae; d - Ascospores

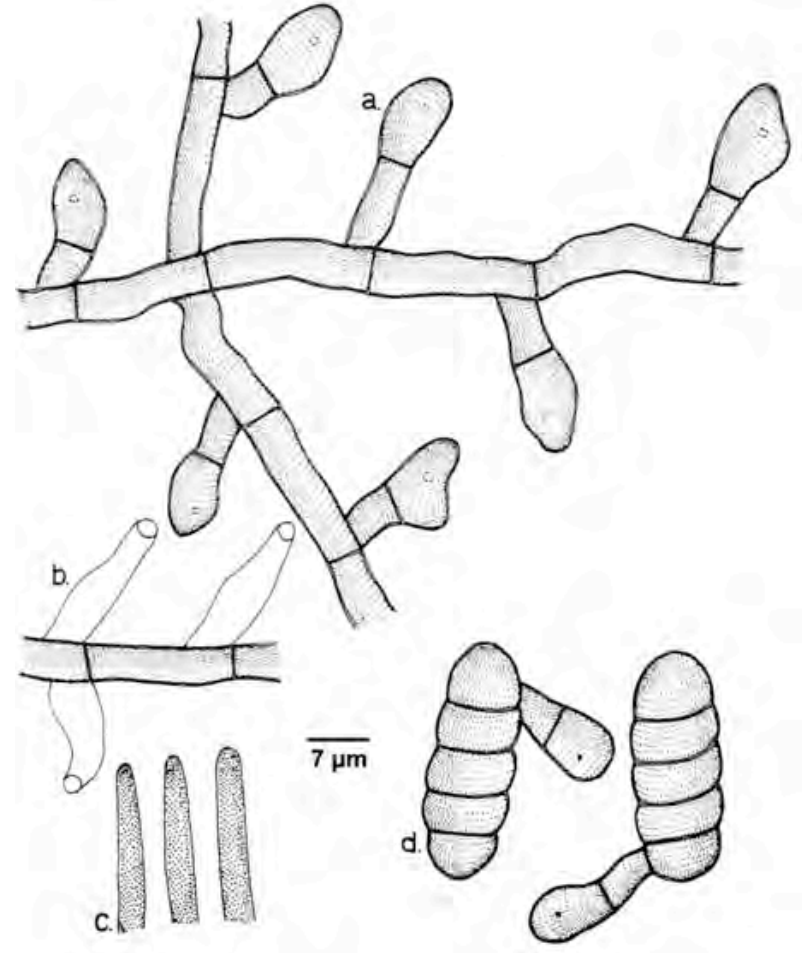

Figure 89. Meliola ligustricola

a - Appressorium; b - Phialide; c - Apical portion of mycelial setae; d - Ascospores 
Meliola ligustricola Hosag., C.K. Biju \& Abraham, Nova Hedwigia 80: 489, 2005; Hosag., Meliolales of India 2: 280, 2008. (Fig. 89)

Materials examined: $\mathrm{HClO}$ 43625, TBGT 305; HCIO 43624, TBGT 306, 19.xi.1998, on leaves of Ligustrum perrottettii DC. (Oleaceae), Banasuran mala, coll. C.K. Biju.

Colonies amphigenous, moistly epiphyllous, thin, up to $4 \mathrm{~mm}$ diameter. Hyphae substraight to undulate, branching opposite to irregular at acute angles, loosely reticulate, cells $17-23 \times 4-6 \mu \mathrm{m}$. Appressoria alternate, straight to slightly curved, antrorse to spreading, 16-27 $\mu \mathrm{m}$ long; stalk cells cylindrical to cuneate, 5-15 $\mu \mathrm{m}$ long; head cells ovate to obovate, attenuated and broadly rounded towards apex, entire, 9-16x7-8 $\mu \mathrm{m}$. Phialides borne on a separate mycelial branches, alternate, opposite, ampulliform, 14-23x4-6 $\mu \mathrm{m}$. Mycelial setae few, grouped around perithecia, simple, straight, flexuous to curved, acute at the tip, up to $185 \mu \mathrm{m}$ long. Perithecia scattered, globose, verrucose, up to $115 \mu \mathrm{m}$ diameter; ascospores obovoidal, 4-septate, constricted

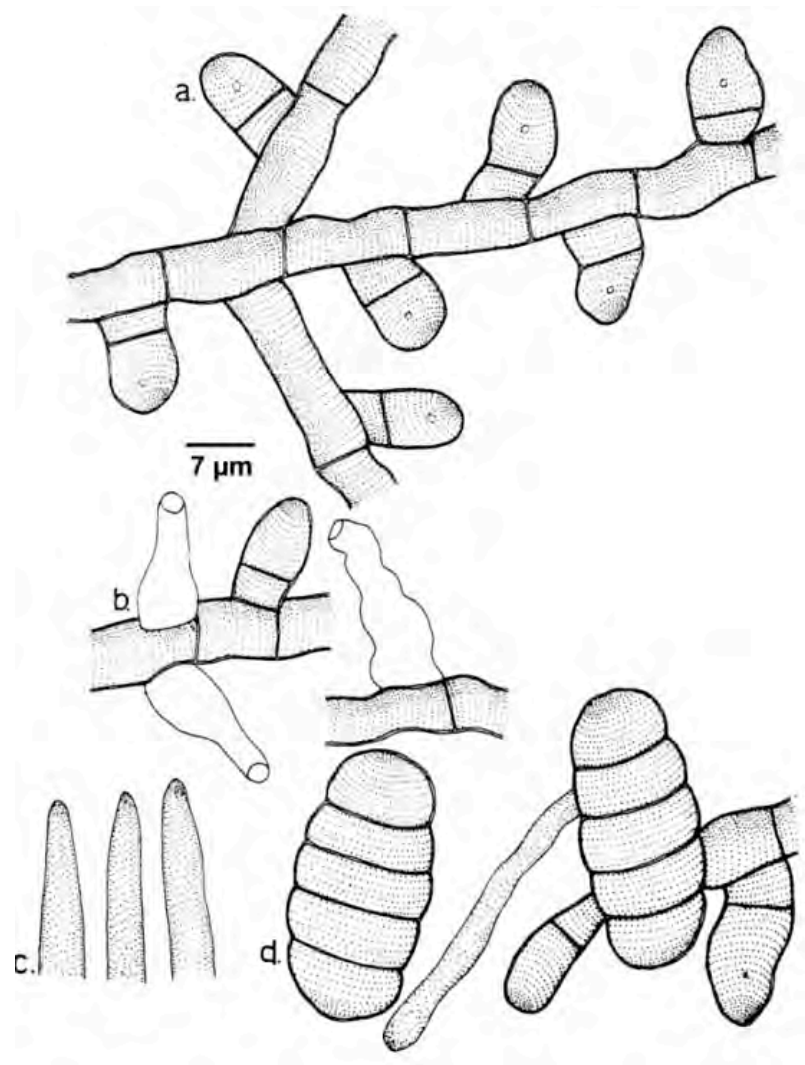

Figure 90. Meliola litsea var. keralensis

a - Appressorium; b - Phialide; c - Apical portion of mycelial setae; d - Ascospores at the septa, 26-29x11-12 $\mu \mathrm{m}$.

Meliola litseae Sydow var. keralensis Hosag. in Hosag. \& Goos, Mycotaxon 37: 238, 1990 (keralense); Hosag., Meliolales of India, p. 240, 1996. (Fig. 90).

Materials examined: $\mathrm{HClO}$ 43622, TBGT 323, 16.iv.1999, on leaves of Litsea sp. (Lauraceae), Banasuranmala, coll. C.K.Biju.

Colonies epiphyllous, subdense, up to $3 \mathrm{~mm}$ in diameter, rarely confluent. Hyphae substraight, branching opposite at wide angles, loosely reticulate, cells $14-20 \times 8-10 \mu \mathrm{m}$. Appressoria alternate, antrorse, 26-28 $\mu \mathrm{m}$ long; stalk cells cuneate, 6-8 $\mu \mathrm{m}$ long; head cells ovate, versiform, entire, $18-20 \times 12-14 \mu \mathrm{m}$. Phialides mixed with appressoria, alternate to opposite, 18-26x8$10 \mu \mathrm{m}$. Mycelial setae few, mostly grouped around perithecia, simple, acute, up to $578 \mu \mathrm{m}$ long. Perithecia mostly scattered, seated on exappressoriate hyphae, up to $186 \mu \mathrm{m}$ in diameter; ascospores obovoidal, 4-septate, slightly constricted at the septa, 36-38x18-20 $\mu \mathrm{m}$.

This variety differs from the type variety in having the perithecia seated on exappressoriate mycelium.

Meliola litseae Sydow \& Sydow var. rotundipoda Hansf., Reinwardtia 3: 88, 1954; Sydowia Bieh. 2: 57, 1961; Hosag. \& Goos, Mycotaxon 37: 239, 1990; Hosag., Meliolales of India, p. 241, 1996.

Meliola litseae Graff, Mem. Torry Bot. Club 17: 61, 1918 (non Sydow \& Sydow, 1917). (Fig. 91).

Materials examined: $\mathrm{HClO}$ 43621, TBGT 287, 16.iv.1999, on leaves of Actinodaphne sp. (Lauraceae), Banasuran hills, coll. C.K.Biju.

Colonies epiphyllous, dense, velvety, up to $4 \mathrm{~mm}$ diameter, confluent. Hyphae straight to undulate, branching opposite at wide angles, loosely reticulate, cells $14-20 \times 6-8 \mu \mathrm{m}$. Appressoria alternate, straight to curved, antrorse, rarely spreading, 24-26 $\mu \mathrm{m}$ long; stalk cells cylindrical to cuneate, 4-8 $\mu \mathrm{m}$ long; head cells versiform, obovate, rarely truncate, entire, 16-20x8-10 $\mu \mathrm{m}$. Phialides mixed with appressoria, alternate to opposite, ampulliform, 20-24×10-12 $\mu \mathrm{m}$. Mycelial setae few, straight, simple, acute at the tip, up to $612 \mu \mathrm{m}$ long. Perithecia scattered, up to $200 \mu \mathrm{m}$ in diameter; ascospores obovate, 4-septate, slightly constricted at the septa, 44-48x18-20 $\mu \mathrm{m}$.

The present collection has slightly longer appressoria.

Meliola machili Yamam., Trans. Nat. Hist. Soc. Taiwan 31: 23, 1941; Hansf., Sydowia Beih. 2: 54, 1961; Hosag. \& Goos, Mycotaxon 37: 239, 1990; Hosag., Dayal \& Goos, Mycotaxon 46: 206, 1993; Hosag., Meliolales of India, p. 
244, 1996. (Fig. 92).

Materials examined: $\mathrm{HClO}$ 50702, TBGT 4619; HCIO 50704, TBGT 4621; HCIO 51065, TBGT 4982, 5.xi.2009, on leaves of Persea macrantha (Nees) Kosterm. (Lauraceae), Gurukulam Botanic Garden, coll. A. Sabeena \& M.C. Riju.

Colonies hypophyllous, dense, velvety, up to $4 \mathrm{~mm}$ in diameter, confluent. Hyphae crooked, branching opposite to irregular at acute to wide angles, loosely to closely reticulate, rarely form solid mycelial mat, cells 14-29x7-10 $\mu \mathrm{m}$. Appressoria alternate to unilateral, straight to curved, antrorse, spreading, 16-22 $\mu \mathrm{m}$ long; stalk cells cylindrical to cuneate, 4-10 $\mu \mathrm{m}$ long; head cells ovate, globose, slightly angular, truncate, entire, 12-14x9-14 $\mu \mathrm{m}$. Phialides mixed with appressoria, alternate to unilateral, 9-14x7-10 $\mu \mathrm{m}$. Mycelial setae numerous, scattered to grouped around perithecia, straight, simple, acute at the tip, up to $470 \mu \mathrm{m}$ long. Perithecia scattered, verrucose, up to $250 \mu \mathrm{m}$ in diameter; ascospores obovoidal to cylindrical, 4-septate, constricted at the septa, 53-55x19-22 $\mu \mathrm{m}$.

Crooked mycelia, spreading appressoria and mostly angular head cells of the appressoria are the distinct characters of this species.

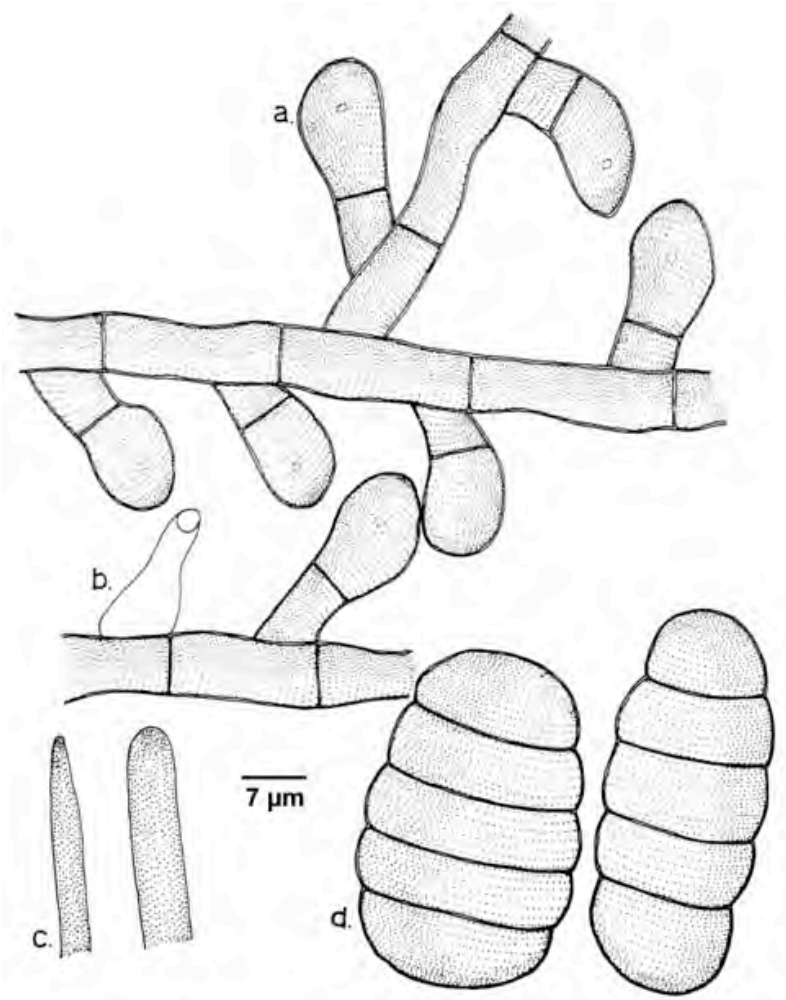

Figure 91. Meliola litseae var. rotundipoda

a - Appressorium; b - Phialide; c - Apical portion of mycelial setae; d - Ascospores
Common on this host in the Southern Western Ghats

Meliola malabarensis Hansf., Proc. Linn. Soc. London 157: 182, 1946; Sydowia Beih. 2: 531, 1961; Thite \& Kulkarni, J. Shivaji Univ. 5: 161, 1973; Hosag. \& Goos, Mycotaxon 37: 240, 1990; 42: 135, 1991; Hosag., Dayal \& Goos, Mycotaxon 46: 206, 1993; Hosag., Meliolales of India, p. 246, 1996. (Fig. 93)

Materials examined: $\mathrm{HClO} 50745, \mathrm{TBGT} 4662 ; \mathrm{HClO}$ 50844, TBGT 4761, 5.xi.2009, on leaves of Olea dioica Roxb. (Oleaceae), Gurukulam Botanical Garden, Periya, coll. M.C. Riju \& A. Sabeena; HCIO 50915, TBGT 4832, 1.xi.2007, Padinharathara, coll. M.C. Riju; HClO 43699, TBGT 339, 19.xi.2009, Banasuranmala, coll. C.K.Biju; HCIO 49222, TBGT 3461, 16.ii.2009, Periya, coll. Jacob Thomas et al.

Colonies epiphyllous, dense, up to $5 \mathrm{~mm}$ in diameter, confluent. Hyphae straight to slightly undulate, branching opposite at wide to acute angles, loosely to closely reticulate, cells 9-16x4-6 $\mu \mathrm{m}$. Appressoria alternate, straight to curved, antrorse to spreading, 12-17 $\mu \mathrm{m}$ long; stalk cells cylindrical to cuneate, 2-5 $\mu \mathrm{m}$ long; head cells ovate, globose, cylindrical, slightly

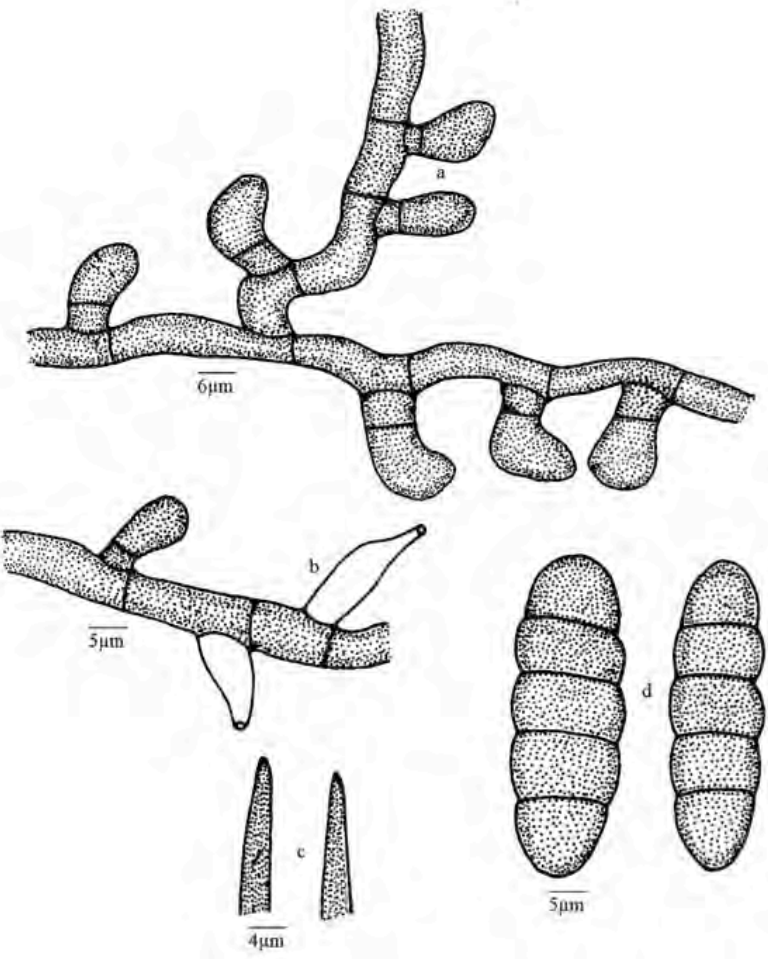

Figure 92. Meliola machili

a - Appressorium; b - Phialide; c - Apical portion of mycelial setae; d - Ascospores 
curved, entire, 9-14x7-10 $\mu \mathrm{m}$. Phialides mixed with appressoria, opposite to alternate, ampulliform, 1426x6-7 $\mu \mathrm{m}$. Mycelial setae grouped around perithecia, straight, simple, acute at the tip, up to $340 \mu \mathrm{m}$ long. Perithecia scattered, verrucose, up to $150 \mu \mathrm{m}$ in diameter; ascospores obovoidal, 4-septate, constricted at the septa, 33-36x14-17 $\mu \mathrm{m}$.

Epiphyllous colonies with ovate head cells of the appressoria distinguishes this species.

Endemic to Southern Western Ghats

Meliola malacotricha Speg., Ann. Soc. Cienc. Argentina 22: 59, 1888; Hansf., Sydowia Beih. 2: 647, 1961; Gupta \& Gupta, Indian Phytopath. 38: 390, 1985; Hosag., Meliolales of India, p. 247, 1996.

Meliola ipomoeae Earle, Muhlenbergia 1: 10, 1901.

Meliola merremiae Rehm, Philippine J. Sci. 8: 253, 1913.

Meliola hewittiae Rehm, Philippine J. Sci. 8: 253, 1913.

Meliola ipomoeae Rehm, Ann. Mycol. 12: 171, 1914.

Meliola lepistomonis Hansf., J. Linn. Soc. London 51: 277, 1937. (Fig. 94)

Materials examined: $\mathrm{HClO}$ 50744, TBGT 4661; HCIO
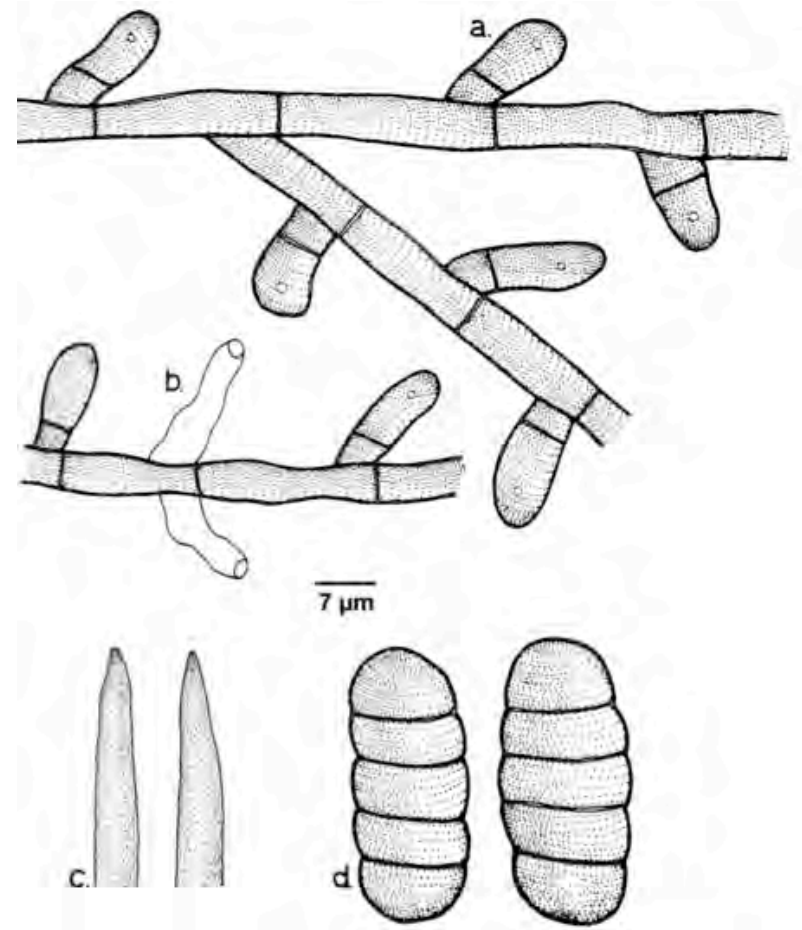

Figure 93. Meliola malabarensis

a - Appressorium; b - Phialide; c - Apical portion of mycelial setae d - Ascospores
51073, TBGT 4990, 6.xi.2009, on leaves of Argyereia speciosa (L. f.) Sweet (Convolvulaceae), Dam site, coll. A. Sabeena \& M.C. Riju; HCIO 44627, TBGT 909, 25.ix.2002, Argeyreia sp., Thirunelly, coll. K. Vijayakumar.

Colonies epiphyllous, dense, velvety, up to $2 \mathrm{~mm}$ in diameter, rarely confluent. Hyphae undulate to slightly crooked, branching opposite to alternate at acute angles, loosely to closely reticulate, cells $12-29 \times 4-6 \mu \mathrm{m}$. Appressoria opposite, $20 \%$ alternate, straight to curved, closely antrorse to spreading, 9-14 $\mu \mathrm{m}$ long; stalk cells very small, cylindrical to cuneate, 2-4 $\mu \mathrm{m}$ long; head cells globose to subglobose, ovate, entire, 7-10x7-9 $\mu \mathrm{m}$. Phialides mixed with appressoria, opposite to alternate, ampulliform, 12-19x4-10 $\mu \mathrm{m}$. Mycelial setae grouped around perithecia, straight, simple, acute, to obtuse at the tip, up to $550 \mu \mathrm{m}$ long; Perithecia grouped at the centre, verrucose, up to $170 \mu \mathrm{m}$ in diameter; ascospores obovoidal to cylindrical, 4-septate, constricted at the septa, 36-41x14-17 $\mu \mathrm{m}$.

Common on this host in the this area
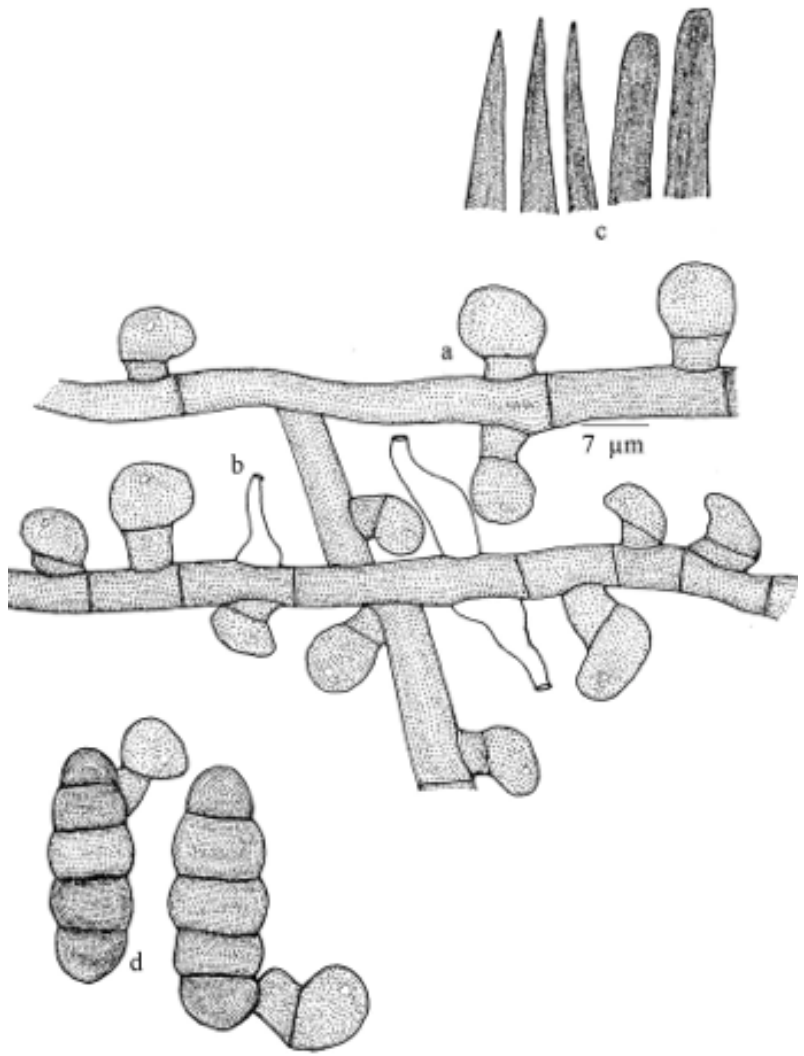

Figure 94. Meliola malacotricha

a - Appressorium; b - Phialide; c - Apical portion of mycelial setae; d - Ascospores 
Meliola malacotricha Speg. var. major Beeli, Bull. Jard. Bot. Etat. 7: 89, 1920; Hansf., Sydowia Beih. 2: 649, 1961; Hosag. \& Goos, Mycotaxon 37: 240 1990; 42: 137, 1991; Hosag., Crypt. Bot. 2/3: 186, 1991; Hosag., Raghu \& Pillai, Nova Hedwigia 58: 540, 1994; Hosag., Meliolales of India, p. 249, 1996. (Fig. 95)

Materials examined: HCIO 50003, TBGT 4155, 14.iii.2007, on leaves of Argyereia sp. (Convolvulaceae), Puthuserrykadavu, coll. M.C. Riju; HCIO 50349, TBGT 4266, 5.xi.2009, Merremmia umbellata, Gurukulam Botanic Garden, Periya, coll. A. Sabeena \& M.C. Riju.

Colonies amphigenous, mostly epiphyllous, dense, velvety, up to $2 \mathrm{~mm}$ in diameter, confluent. Hyphae straight to slightly crooked, branching mostly opposite at acute angles, closely reticulate, cells $16-34 \times 7-10$ $\mu \mathrm{m}$. Appressoria mostly opposite, about 5\% unilateral, antrorse to spreading, straight to curved, 12-14 $\mu \mathrm{m}$ long; stalk cells cuneate, 2-5 $\mu \mathrm{m}$ long; head cells ovate to subglobose, entire, 7-12 x 7-10 $\mu \mathrm{m}$. Phialides mixed with appressoria, opposite and alternate, ampulliform, 14-21 x 7-10 $\mu \mathrm{m}$. Mycelial setae fairly numerous, scattered to grouped around perithecia, simple, straight, acute to obtuse at the tip, up to $580 \mu \mathrm{m}$ long. Perithecia scattered to grouped, verrucose, up to $180 \mu \mathrm{m}$ in diameter; ascospores oblong to cylindrical, 4-septate, strongly constricted at the septa, 36-43 x 12-17 $\mu \mathrm{m}$.

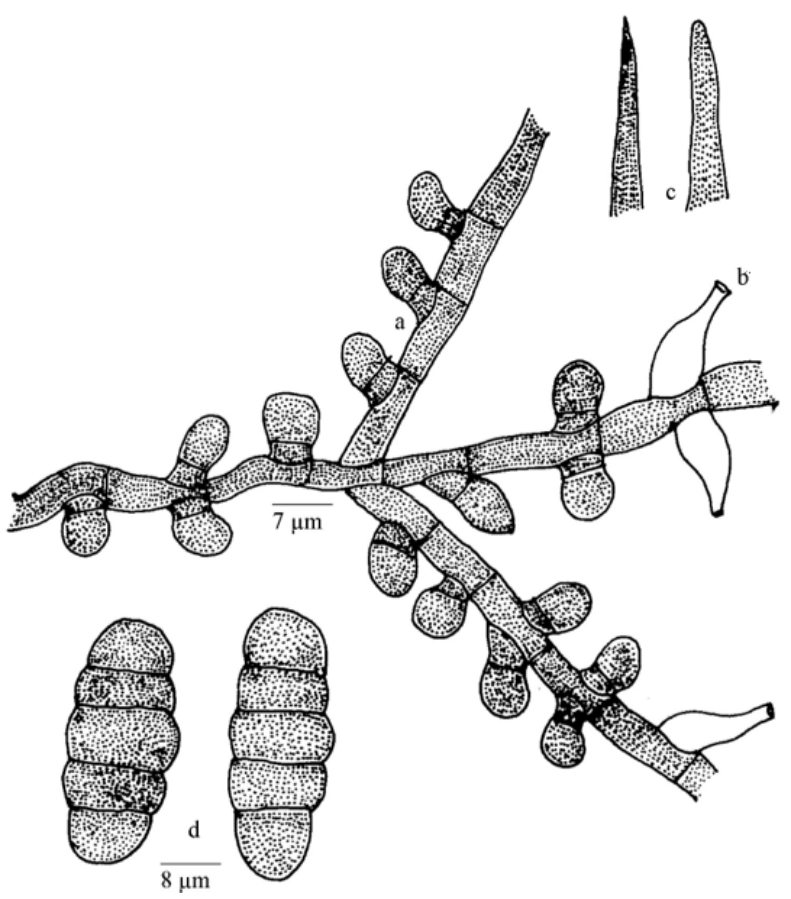

Figure 95. Meliola malacotricha var. major

a - Appressorium; b - Phialide; c - Apical portion of mycelial setae; d - Ascospores
This species is very close to $M$. bonamiae Hansf. \& Deight. but differs from it in having shorter appressoria and mycelial setae.

Meliola mangiferae Earle, Bull. New York Bot. Gard. 3: 307, 1905; Hansf., Sydowia Beih. 2: 464, 1961; Hansf. \& Thirum., Farlowia 3: 296, 1948; Hansf., Sydowia Beih. 2: 464, 1961; Hosag. \& Goos, Mycotaxon 37: 240, 1990; Hosag., Crypt. Bot. 2/3: 186, 1991; Hosag. \& Ansari, J. Andaman Sci. Assoc. 7: 89, 1991; Hosag., Meliolales of India, p. 250, 1996. (Fig. 96)

Materials examined: $\mathrm{HClO}$ 50914, TBGT 4831, 1.xi.2007, on leaves of Mangifera indica L. (Anacardiaceae), Wayanad, coll. M.C. Riju; TBGT 5588, 29.x.2007, Thirunelly, coll. M.C. Riju; HCIO 51298, TBGT 5178, 14.ii.2009, Padinharathara, coll. M.C. Riju; HCIO 49217, TBGT 3456, 14.ii.2009, Thirunelly, coll. Jacob Thomas et al.; HClO 49217, TBGT 3457; HClO 49806, TBGT 3958, 15.ii.2009, Begoor, coll. Gireesh et al.; HCIO

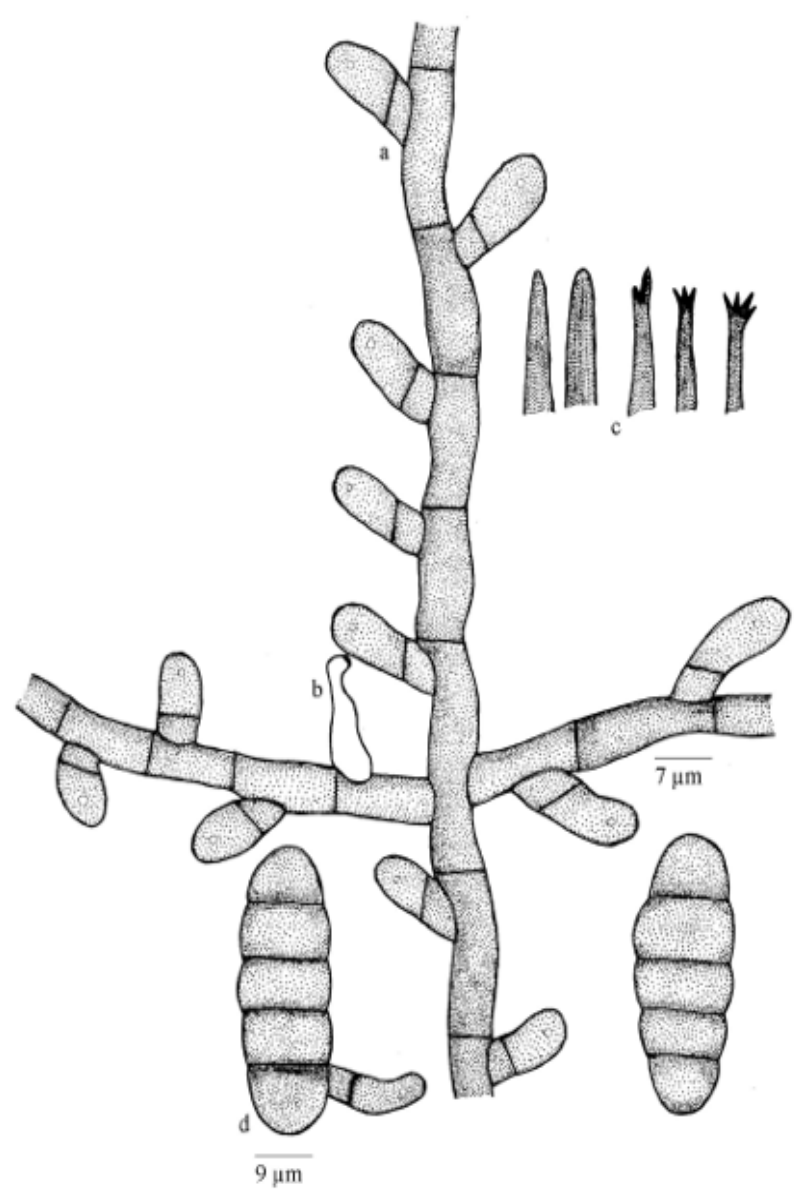

Figure 96. Meliola mangiferae

a - Appressorium; b - Phialide; c - Apical portion of mycelial setae; d - Ascospores 
50731, TBGT 4648, 6.xi2009, Padinharathara, coll. A. Sabeena \& M.C. Riju.

Colonies amphigenous, mostly hypophyllous, dense, velvety, up to $5 \mathrm{~mm}$ in diameter. Hyphae straight, branching opposite at acute to wide angles, loosely to closely reticulate, cells $19-36 \times 7-10 \mu \mathrm{m}$. Appressoria alternate, $2 \%$ unilateral, straight to variously curved, 21-29 $\mathrm{mm}$ long; stalk cells cylindrical to cuneate, 4-7 $\mu \mathrm{m}$ long; head cells cylindrical, versiform, attenuated and rounded at the apex, entire to subangular, straight to curved, $16-24 \times 9-12 \mu \mathrm{m}$. Phialides few, mixed with appressoria, alternate to opposite, ampulliform, 1624x4-10 $\mu \mathrm{m}$. Mycelial setae fairly numerous, scattered, simple, straight, acute, obtuse to dentate at the tip, up to $720 \mu \mathrm{m}$ long; perithecia scattered, verrucose, up to $230 \mu \mathrm{m}$ in diameter; ascospores obovoidal to ellipsoidal, middle cell slightly larger, 50-55×24-26 $\mu \mathrm{m}$.

This species was observed in all the seasons on the cultivated and wild mango trees.

This is the only Meliola species known on this host genus. It infects both cultivated and wild Mango trees. Biochemical analysis of the host plant may reveal several interesting facts regarding the harmful or useful nature of the fungus.

Meliola mayapeae Stev., Illinois Biol. Monograph 2: 48, 1916; Hansf., Sydowia Beih. 2: 536, 1961; Hosag., Dayal \& Goos, Mycotaxon 46: 206, 1993; Hosag., Meliolales of India, p. 252, 1996. (Fig. 97)

Materials examined: HClO 49962, TBGT 4114, 30.ix.2007, on leaves of Ligustrum sp. (Oleaceae), Puthuserrykadavu, coll. M.C. Riju.

Colonies epiphyllous, dense, up to $2 \mathrm{~mm}$ in diam., often confluent. Hyphae straight to flexuous, branching opposite at wide angles, closely reticulate, cells 1534x5-7 $\mu \mathrm{m}$. Appressoria alternate, antrorse, reflexed to spreading, mostly straight, 15-18.5 $\mu \mathrm{m}$ long; stalk cells cylindrical to cuneate, 3-6.5 $\mu \mathrm{m}$ long. Phialides mixed with appressoria, opposite to alternate, ampulliform, 15-18.5x7-9.5 $\mu \mathrm{m}$. Mycelial setae grouped around perithecia, straight, simple, acute to obtuse at the tip, up to $235 \mu \mathrm{m}$ long. Perithecia loosely grouped, up to $186 \mu \mathrm{m}$ in diameter; ascospores obovoidal, 4-septate, slightly constricted at the septa, 37-40.5×15-18.5 $\mu \mathrm{m}$.

Meliola mayapiicola Stev. var. indica Hosag., Nova Hedwigia 47: 541, 1988; Hosag., Meliolales of India, p. 253, 1996. (Fig. 98)

Materials examined: $\mathrm{HClO}$ 43619, TBGT 308, 11.xi.1998, on leaves of Chionanthus mala-elengi (Dennst.) Green (Linociera malabarica Wallich ex G.
Don) (Oleaceae), Banasuranmala, coll. C.K.Biju; $\mathrm{HClO}$ 49631, TBGT 3873; HCIO 49638, TBGT 3880, 16.ix.2008, Linociera malabarica Wallich ex G. Don, Periya, coll. M. Harish \& P.J Robin; HCIO 49632, TBGT 3874; HCIO 49640, TBGT 3882, 17.ix.2008, coll. Harish \& P.J Robin; HCIO 49770, TBGT 3922, 13.ii.2009, Thirunelly, coll. Jacob Thomas et al.; HCIO 49772, TBGT 3924, 14.ii.2009, coll. Jacob Thomas et al.; HClO 49643, TBGT 3885, 18.ix.2008, coll. Harish \& P.J Robin; HCIO 49812, TBGT 3964, 16.ii.2009, Begoor, coll. Gireesh et al.

Colonies epiphyllous, rarely hypophyllous, dense, crustose to velvety, up to $2 \mathrm{~mm}$ in diameter. Hyphae substraight, branching mostly opposite at acute to wide angles, closely reticulate, cells $15-34 \times 7-10 \mu \mathrm{m}$. Appressoria alternate, antrorse to recurved, 18-25 $\mu \mathrm{m}$ long; stalk cells cylindrical to cuneate, $6-10 \mu \mathrm{m}$ long; head cells ovate, cylindrical, entire, rarely angular to sublobate, 12-16x9-13 $\mu \mathrm{m}$. Phialides mixed with appressoria, alternate to opposite, ampulliform, 1219x9-13 $\mu \mathrm{m}$. Mycelial setae grouped around perithecia, straight to curved, simple, acute at the tip, up to $500 \mu \mathrm{m}$ long. Perithecia scattered, up to $125 \mu \mathrm{m}$ in diameter; ascospores obovoidal, 4-septate, constricted at the septa, 40-47x12-18 $\mu \mathrm{m}$.

This taxon mostly associated with $M$. linocieraemalabaricae and can be easily distinguished by their smaller epiphyllous colonies.

The present collection slightly varies in having smaller ascospores than to the assigned taxon.

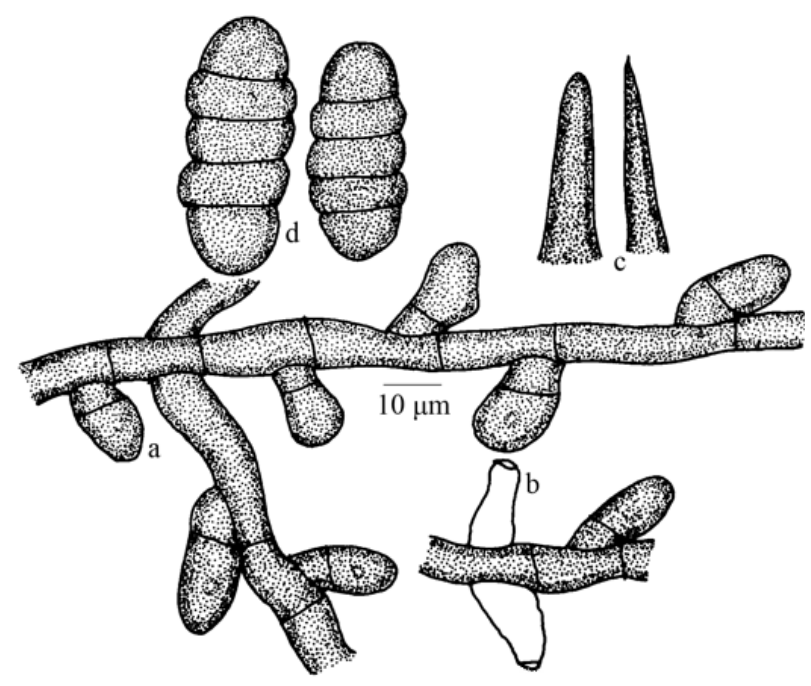

Figure 97. Meliola mayapeae

a - Appressorium; b - Phialide; c - Apical portion of mycelial setae; d - Ascospores 
Meliola millettiae-chrysophyllae Deight. var. indica Hosag., Siddappa \& Udaiyan, Nova Hedwigia 56: 198, 1993; Hosag., Meliolales of India, p. 257, 1996. (Fig. 99)

Materials examined: HCIO 43645, TBGT 310, 19.xi.1998, on leaves of Derris benthamii (Thwaites) Thwaites (Fabaceae), Banasuranmala, coll. C.K.Biju.

Colonies amphigenous, thin to crustose, up to $5 \mathrm{~mm}$ in diameter, rarely confluent. Hyphae straight to substraight, branching mostly opposite at acute to wide angles, loosely to closely reticulate, cells $19-40 \times 6-8$ $\mu \mathrm{m}$. Appressoria alternate and opposite, straight to curved, antrorse to spreading, 12-18 $\mu \mathrm{m}$ long; stalk cells cylindrical to cuneate, 3-6 $\mu \mathrm{m}$ long; head cells ovate, globose to subglobose, entire, 9-13x6-10 $\mu \mathrm{m}$. Phialides mixed with appressoria, alternate to opposite, ampulliform, 12-19x6-10 $\mu \mathrm{m}$. Mycelial setae fairly numerous, scattered, straight to curved but not uncinate, acute, obtuse to minutely dentate at the tip, up to $560 \mu \mathrm{m}$ long. Perithecia scattered, globose, up to $210 \mu \mathrm{m}$ in diameter; ascospores oblong to subellipsoidal, 4-septate, constricted at the septa, 38-42x12-16 $\mu \mathrm{m}$.

This taxon was known on Millettia splendens from

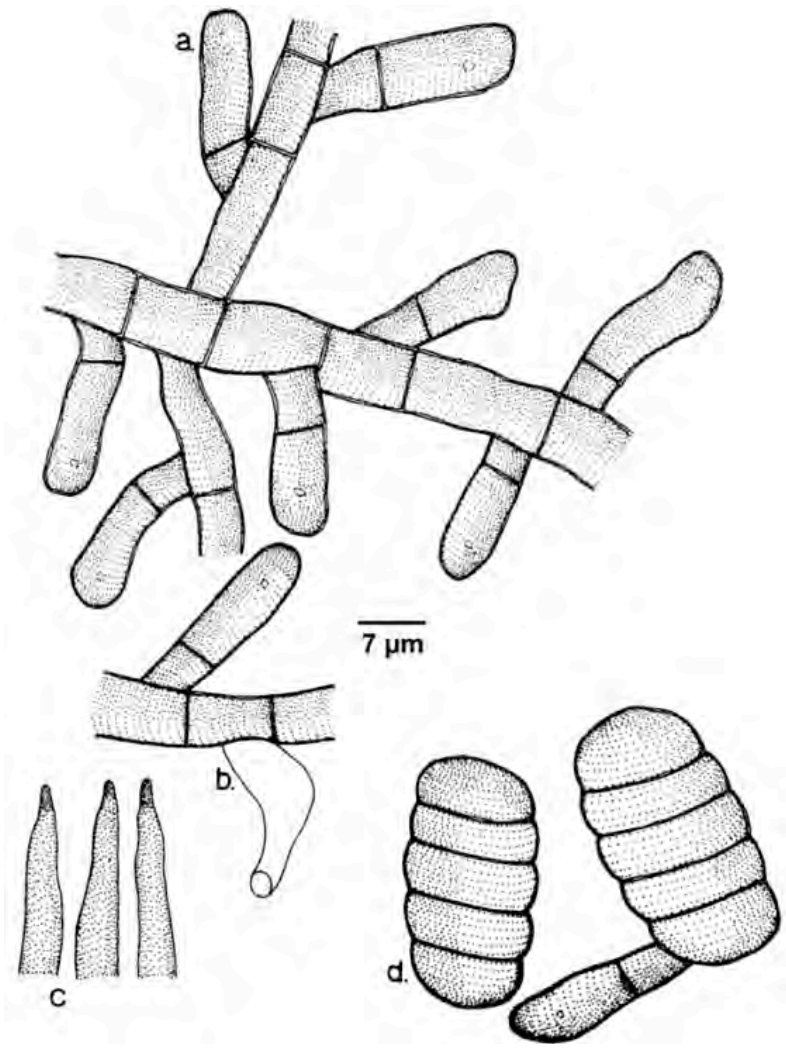

Figure 98. Meliola mayapiicola var. indica

a - Appressorium; b - Phialide; c - Apical portion of mycelial setae; d - Ascospores
Nilgiris, Tamil Nadu. Here very few setae are minutely dentate at the tip and there are every chances of missing this character. Except slightly long appressoria, the present collection matches well with the assigned taxa.

This taxon was only known from the present locality in Kerala. The collection reveals its distribution towards the Southern tips of Western Ghats.

Meliola nairii Hosag. in Hosag. \& Goos, Mycotaxon 37: 409, 1990; Hosag., Meliolales of India, p. 262, 1996. (Fig. 100)

Materials examined: TBGT 5943, 10.xi.2007, on leaves of Aphanamixis polystachya (Wall.) Parker (Amoora rohituka Wight \& Arn.) (Meliaceae), 16 ${ }^{\text {th }}$ Mile, Padinharathara, coll. M.C. Riju.

Colonies epiphyllous, minute, subdense, up to $2 \mathrm{~mm}$ in diameter. Hyphae straight, substraight to flexuous, branching opposite to irregular at wide angles, loosely reticulate, cells 18-31x6-9.5 $\mu \mathrm{m}$. Appressoria alternate, antrorse to subantrorse, 12-15.5 $\mu \mathrm{m}$ long; stalk cells cylindrical to cuneate, 3-6 $\mu \mathrm{m}$ long; head cells ovate, broadly rounded at the apex, straight to curved, entire, 9-12.5x6-9.5 $\mu \mathrm{m}$. Phialides mixed with appressoria, alternate to opposite, ampulliform, 18-22x9-12.5 $\mu \mathrm{m}$. Mycelial setae few, grouped around perithecia, straight,

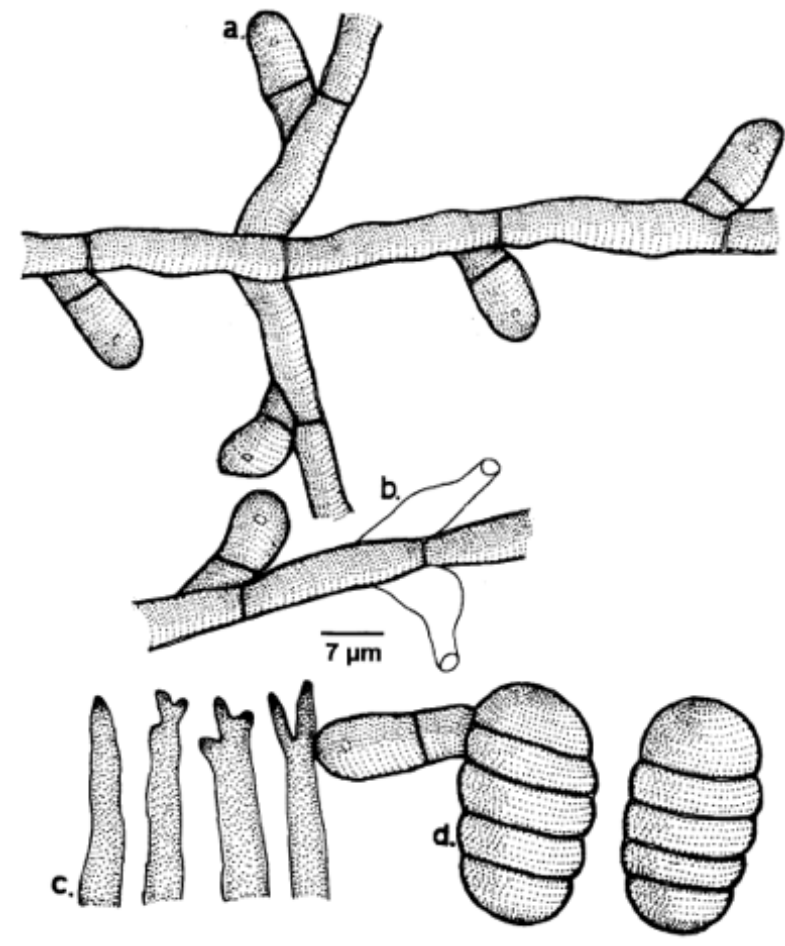

Figure 99. Meliola millettiae-chrysophyllae var. indica a - Appressorium; b - Phialide; c - Apical portion of mycelial setae; d - Ascospores 
flexuous, acute to obtuse at the tip, up to $310 \mu \mathrm{m}$ long. Perithecia scattered, verrucose, up to $155 \mu \mathrm{m}$ in diameter; ascospores obovoidal, 4-septate, constricted at the septa, 31-34×15-18.5 $\mu \mathrm{m}$.

Meliola neolitseae Yamam., Trans. Nat. Hist. Soc. Taiwan 31: 24, 1941; Hansf., Sydowia Beih. 2: 50, 1961; Hosag. \& Goos, Mycotaxon 37: 241, 1990; Hosag., Meliolales of India, p. 264, 1996. (Fig. 101)

Materials examined: $\mathrm{HClO}$ 45151, TBGT 1206, 16.iv.1999, on leaves of Neolitsea sp. (Lauraceae), Banasuran mala, coll. C.K. Biju; HCIO 43697, TBGT 341, 17.ii.2000, on Cryptocarya sp., Chembra hills, coll. C.K.Biju.

Colonies hypophyllous, subdense, subvelvety, up to $8 \mathrm{~mm}$ in diameter. Hyphae substraight to tortuous, branching opposite to irregular at acute to wide angles, loosely reticulate, cells $18-22 \times 8-10 \mu \mathrm{m}$. Appressoria alternate to unilateral, straight to curved, antrorse, spreading, 22-28 $\mu \mathrm{m}$ long; stalk cells cylindrical to cuneate, 6-8 $\mu \mathrm{m}$ long; head cells clavate, versiform, angulose, entire to slightly lobate, 14-22x12-16 $\mu \mathrm{m}$. Phialides mixed with appressoria, alternate to opposite, ampulliform, 18-26x8-10 $\mu \mathrm{m}$. Mycelial setae scattered, straight, simple, acute to 2-3 dentate, up to $900 \mu \mathrm{m}$ long. Perithecia scattered, up to $210 \mu \mathrm{m}$ in diameter; ascospores ellipsoidal, 4-septate, constricted at the

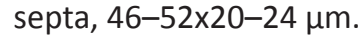

This is the only known species on this host genus in the Western Ghats.

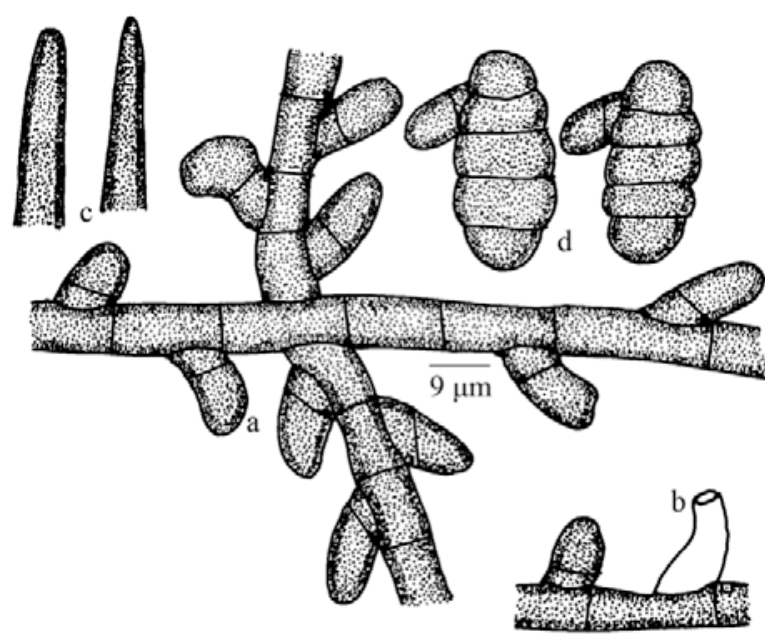

Figure 100. Meliola nairii

a - Appressorium; b - Phialide; c - Apical portion of mycelial setae; d - Ascospores
Meliola nothopegiae Hansf., Sydowia 10: 80, 1957; Sydowia Beih. 2: 469, 1961; Thite \& Kulkarni, J. Shivaji Univ. 6: 163, 1973; Hosag., Lakshmanan \& Viswanathan, Indian J. Bot. 11: 187, 1988; Hosag. \& Goos, Mycotaxon 37: 242, 1990; Hosag., Kaveriappa, Raghu \& Goos, Mycotaxon 51: 113, 1994; Hosag., Meliolales of India, p. 266, 1996. (Fig. 102)

Materials examined: TBGT 6178, 15.iii.2007, on leaves of Nothopegia sp. (Anacardiaceae), Padinharathara, coll. M.C. Riju.

Colonies amphigenous, mostly epiphyllous, subdense, up to $5 \mathrm{~mm}$ in diameter. Hyphae of the epiphyllous colonies straight, branching regularly opposite at acute angles, loosely reticulate. While the hyphae of the hypophyllous colonies crooked, branching opposite to irregular at wide angles, cells $18-26 \times 6-8$ $\mu \mathrm{m}$. Appressoria alternate, subantrorse to antrorse, 24-36 $\mu \mathrm{m}$ long; stalk cells cuneate, 6-14 $\mu \mathrm{m}$ long; head cells cylindrical, versiform, slightly angulose, entire, 16-22x12-14 $\mu \mathrm{m}$. Phialides mixed with appressoria, alternate to opposite, ampulliform, 10-20x8-10 $\mu \mathrm{m}$. Mycelial setae scattered to grouped around perithecia, straight, simple, acute at the tip, up to $675 \mu \mathrm{m}$ long. Perithecia scattered to aggregated, up to $164 \mu \mathrm{m}$ in

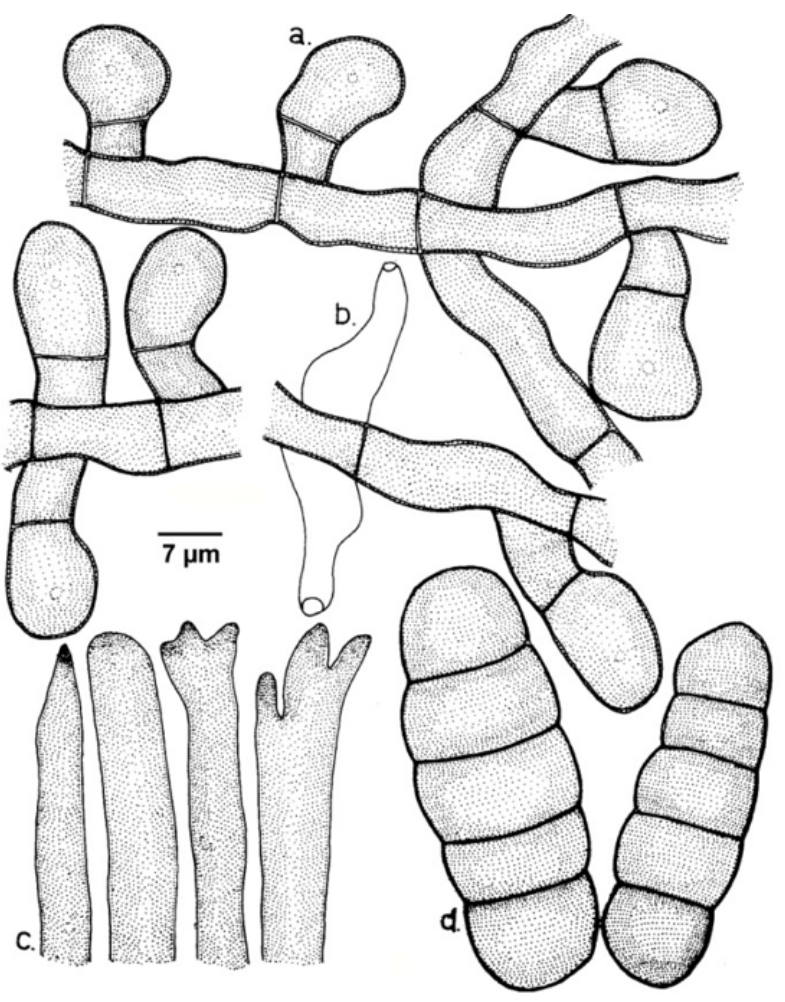

Figure 101. Meliola neolitseae

a - Appressorium; b - Phialide; c - Apical portion of mycelial setae; d - Ascospores 
diam.; ascospores obovoidal, 4-septate, constricted at the septa, 44-50x18-20 $\mu \mathrm{m}$.

This is the only species known on this host genus

Meliola oleacearum Hosag., Sydowia 54: 55, 2002; Hosag., Meliolales of India 2: 293, 2008; Hosag. \& Agarwal, Taxonomic Studies of Meliolales. Identification Manual, p. 205, 2008. (Fig. 103)

Materials examined: $\mathrm{HClO}$ 48041, TBGT 2824, 6.xii.2006, on leaves of Olea dioica Roxb. (Oleaceae), Kunkichira, Periya, coll. M. Harish, V. Gireesh Kumar \& K. Anilkumar; TBGT 3933; HClO 49626, TBGT 3868, 15.ii.2009, coll. Jacob Thomas et al., 19.ix.2008, Pulpally, coll. M.Harish \& P.J. Robin; HClO 49060, TBGT 3315, 17.ix.2008, Perya coll. M.Harish \& P.J. Robin.

Colonies hypophyllous, dense, up to $5 \mathrm{~mm}$ in diameter, confluent. Hyphae straight to substraight, branching opposite at acute angles, loosely to closely reticulate, cells 19-29x4-7 $\mu \mathrm{m}$. Appressoria alternate, straight to curved, antrorse, retrorse to spreading, 16-26 $\mu \mathrm{m}$ long; stalk cells cylindrical to cuneate, 4-10 $\mu \mathrm{m}$ long; head cells ovate, cylindrical, slightly truncate at the apex, entire, 9-17x7-10 $\mu \mathrm{m}$. Phialides mixed with appressoria, alternate to opposite, ampulliform, 16-26x6-8 $\mu \mathrm{m}$. Mycelial setae numerous, scattered, grouped around perithecia, simple, straight, acute at the tip, up to $320 \mu \mathrm{m}$ long. Perithecia scattered, verrucose, up to $160 \mu \mathrm{m}$ in diameter; ascospores obovoidal,

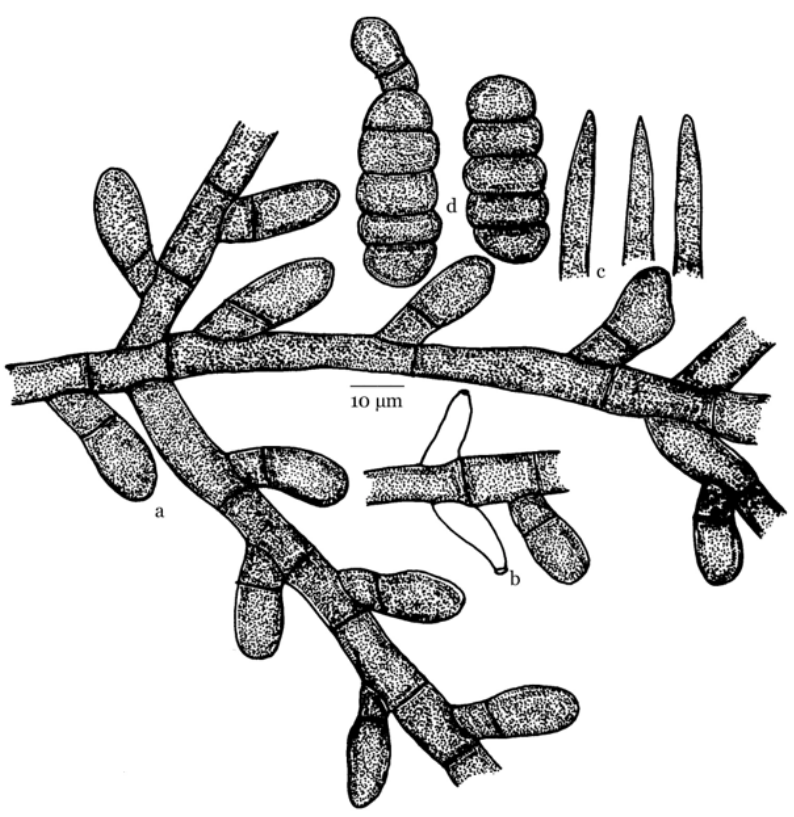

Figure 102. Meliola nothopegiae

a - Appressorium; b - Phialide; c - Apical portion of mycelial setae; d - Ascospores 4-septate, constricted at the septa, 33-38x14-19 $\mu \mathrm{m}$.

The present species is similar to Meliola petiolaris Doidge known on Olea laurifolia from South Africa (Hansford, 1961) in having curved to uncinate mycelial setae. However, the present taxon differs from it in having shorter appressoria and straight, sigmoid, flexuous and uncinate setae.

Meliola oleicola Doidge, Bothalia 1: 73, 1922. (Fig. 104)

Material examined: $\mathrm{HClO}$ 45294, TBGT 1332, 16.iv.1999, on leaves of Ligustrum sp. (Oleaceae), Banasuranmala, coll. C.K. Biju.

Colonies epiphyllous, thin to subdense, up to $2 \mathrm{~mm}$ in diameter, confluent. Hyphae straight to substraight, branching opposite to unilateral at acute to wide angles, loosely reticulate, cells 20-27x5-7 $\mu \mathrm{m}$. Appressoria alternate to unilateral, antrorse to subantrorse, 17-35 $\mu \mathrm{m}$ long; stalk cells cylindrical to cuneate, 5-17 $\mu \mathrm{m}$ long; head cells ovate, clavate, entire, 12-17x7-12 $\mu \mathrm{m}$. Phialides mixed with appressoria, opposite to unilateral, ampulliform, 17-27x5-7 $\mu \mathrm{m}$ long. Mycelial setae scattered, simple, straight, acute to obtuse at the tip, up to $300 \mu \mathrm{m}$ long. Perithecia scattered, up to $100 \mu \mathrm{m}$ in diameter; ascospores oblong to cylindrical, 4-septate, constricted at the septa, $32-35 \times 12-15 \mu \mathrm{m}$.

Meliola oligomera Sydow, Ann. Mycol. 15: 190, 1917; Hansf., Sydowia Beih. 2: 345, 1961; Hosag., J. Mycopathol. Res. 43: 29, 2005; Hosag., Meliolales of India, 2: 293, 2008.

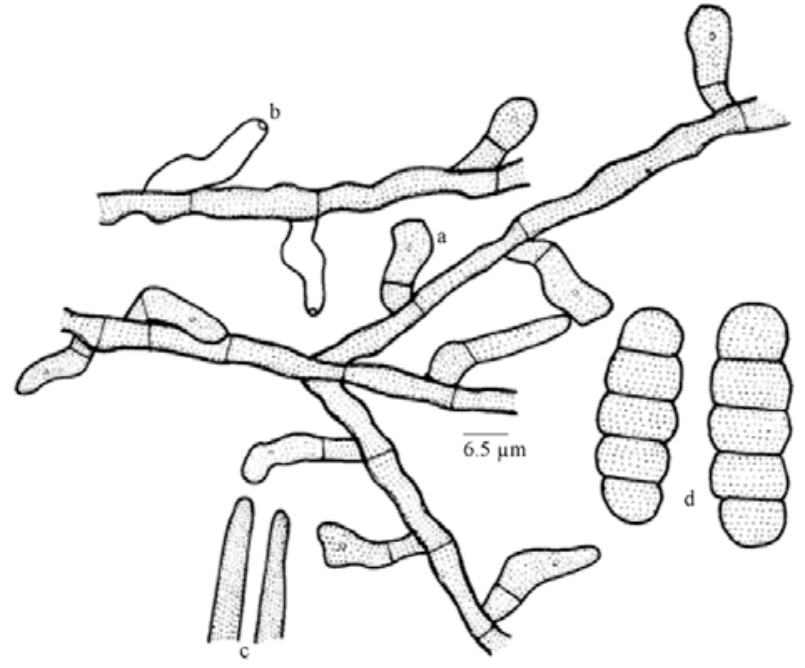

Figure 103. Meliola oleacearum

a - Appressorium; b - Phialide; c - Apical portion of mycelial setae; d - Ascospores 
Meliola reinkingii Sydow, Ann. Mycol. 18: 98, 1920. (Fig. 105)

Materials examined: $\mathrm{HClO}$ 44799, TBGT 1036, 22.xii.2002, on leaves of Hippocratea sp (Hippocrateaceae), periya, coll. M. Kamarudeen.

Colonies amphigenous, mostly epiphyllous, dense, velvety, up to $5 \mathrm{~mm}$ in diameter, confluent. Hyphae substraight to flexuous, branching alternate to irregular at acute to wide angles, loosely to closely reticulate, cells $12-23 \times 6-7 \mu \mathrm{m}$. Appressoria alternate, antrorse to subantrorse, straight to rarely curved, 20-31 $\mu \mathrm{m}$ long; stalk cells cylindrical to cuneate, $6-13 \mu \mathrm{m}$ long; head cells ovate, globose, angular, sublobate to irregularly lobate, 14-18x12-18 $\mu \mathrm{m}$. Phialides mixed with appressoria, alternate to opposite, ampulliform, 17-21x6-8 $\mu \mathrm{m}$. Mycelial setae numerous, simple, mostly straight, often curved, acute at the tip, up to $300 \mu \mathrm{m}$ long. Perithecia scattered to loosely grouped, up to $200 \mu \mathrm{m}$ in diameter; ascospores 3-septate, straight but slightly curved during germination, constricted at the septa, 44-47x14-16 $\mu \mathrm{m}$.

This species differs from Meliola hippocrateicola Hansf. \& Dieght. in having all alternate appressoria.

Meliola panici Earle, Muchlenbergia 1: 12, 1901; Hansf., Sydowia Beih. 2: 745, 1961; Gupta \& Gupta, Indian Phytopath. 58: 390, 1985; Hosag. \& Goos, Mycotaxon 42: 136, 1991; Hosag., Meliolales of India, p. 276, 1996. (Fig. 106)

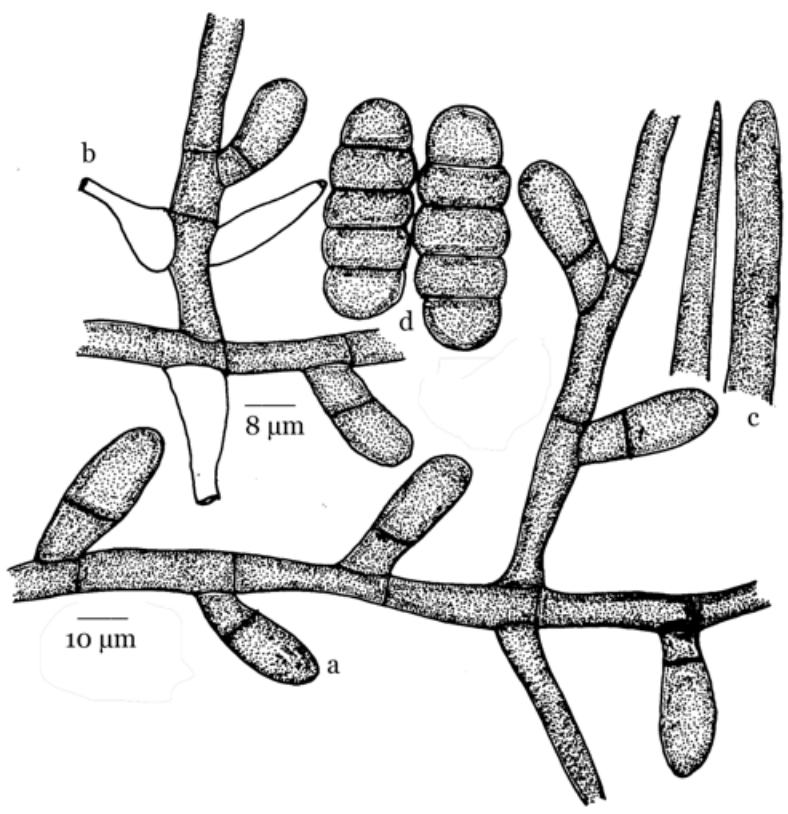

Figure 104. Meliola oleicola

a - Appressorium; b - Phialide; c - Apical portion of mycelial setae; d - Ascospores
Materials examined: TBGT 3932, 18.ii.2009, on leaves of Poaceae (Grass), Muthanga, coll. Jacob Thomas et al.

Colonies epiphyllous, dense, up to $2 \mathrm{~mm}$ in diameter. Mycelium straight to substraight, branching opposite to irregular at acute to wide angles, closely reticulate, cells $14-21 \times 6-8 \mu \mathrm{m}$. Appressoria alternate, straight to curved antrorse to recurved, 14-22 $\mu \mathrm{m}$ long; stalk cells cylindrical to cuneate, 3-7 $\mu \mathrm{m}$ long; head cells ovate, globose, entire, angular to sublobate, 11-16x12-15 $\mu \mathrm{m}$. Phialides borne on a separate mycelial branch, alternate to opposite, ampulliform, 12-16x6-9 $\mu \mathrm{m}$. Mycelial setae few, straight, simple, acute to obtuse at the tip, upto $335 \mu \mathrm{m}$ long. Perithecia mostly grouped, verrucose, up to $156 \mu \mathrm{m}$ in diameter; ascospores obovoidal, 4-septate, slightly constricted at the septa, 33-37x11-14 $\mu \mathrm{m}$.

This is the most common species on the members of the family Poaceae. Common in Southern Western Ghats.

Meliola phyllanthigena Hosag., Plant Pathology \& Quarantine 3(1): 7, 2013. (Fig. 107)

Materials examined: TBGT 6233 (holotype), 2.ii.2008, on leaves of Phyllanthus sp. (Euphorbiaceae), Periya, coll. M.C. Riju et al.

Colonies epiphyllous, subdense, up to $2 \mathrm{~mm}$ in diameter. Hyphae straight to substraight, branching alternate to opposite at acute to wide angles, closely and densely reticulate, cells $16-27 \times 6-10 \mu \mathrm{m}$. Appressoria densely arranged, alternate, antrorse, subantrorse to closely antrorse, 25-34 $\mu \mathrm{m}$ long; stalk cells cylindrical to cuneate, 6-13 $\mu \mathrm{m}$ long; head cells ovate, globose, entire, 17-22x11-15 $\mu \mathrm{m}$. Phialides mixed with appressoria, alternate to opposite, ampulliform, 22-29x6-10 $\mu \mathrm{m}$. Mycelial setae numerous, closely scattered, simple,

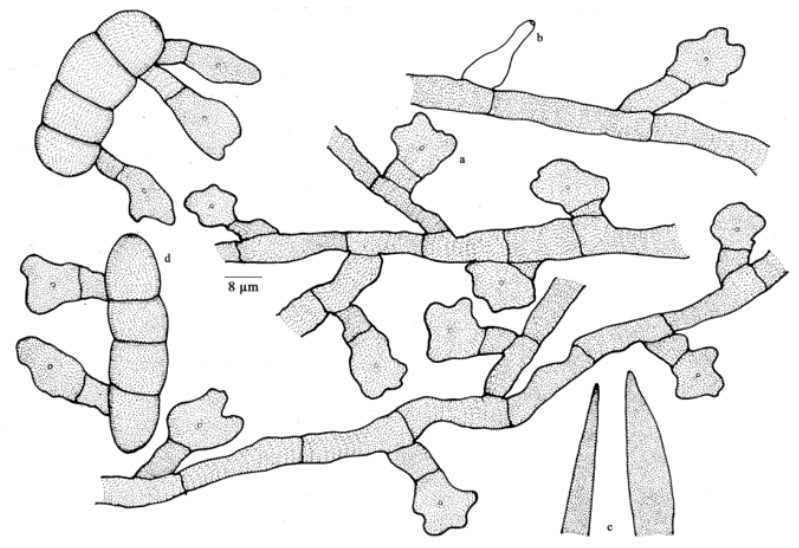

Figure 105. Meliola oligomera

a - Appressorium; b - Phialide; c - Apical portion of mycelial setae; d-Ascospores 
straight, about $10 \%$ uncinate, acute at the tip, up to $300 \mu \mathrm{m}$ long. Perithecia scattered, up to $130 \mu \mathrm{m}$ in diameter; ascospores oblong to cylindrical, 4-septate, slightly constricted at septa, 48-51x18-20 $\mu \mathrm{m}$.

This is a unique species of the genus known on the members of Euphorbiaceae in having uncinate mycelial setae (Hansford 1961).

Meliola plectroniae Hansf., Sydowia 9: 72, 1955; Beih. 2: 702, 1961; Hosag., Meliolales of India, p. 284, 1996; Hosag. \& Goos, Mycotaxon 37: 228, 1990 (Fig. 108).

Meliola coilicosa Nair \& Kaul, Sydowia 36: 204, 1983.

Materials examined: TBGT 4073, 30.x.2007, on leaves of Canthium dicoccum (Gaertn.) Teys \& Benn. (Plectronia umbellata Benth. \& Hook.) (Rubiaceae), Wayanad, coll. A. Chandraprabha.

Colonies hypophyllous, thin, up to $5 \mathrm{~mm}$ in diameter, confluent. Hyphae substraight to flexuous, branching mostly alternate, branches of the main hyphae tortuous, loosely reticulate, cells $18-30 \times 6-8 \mu \mathrm{m}$. Appressoria
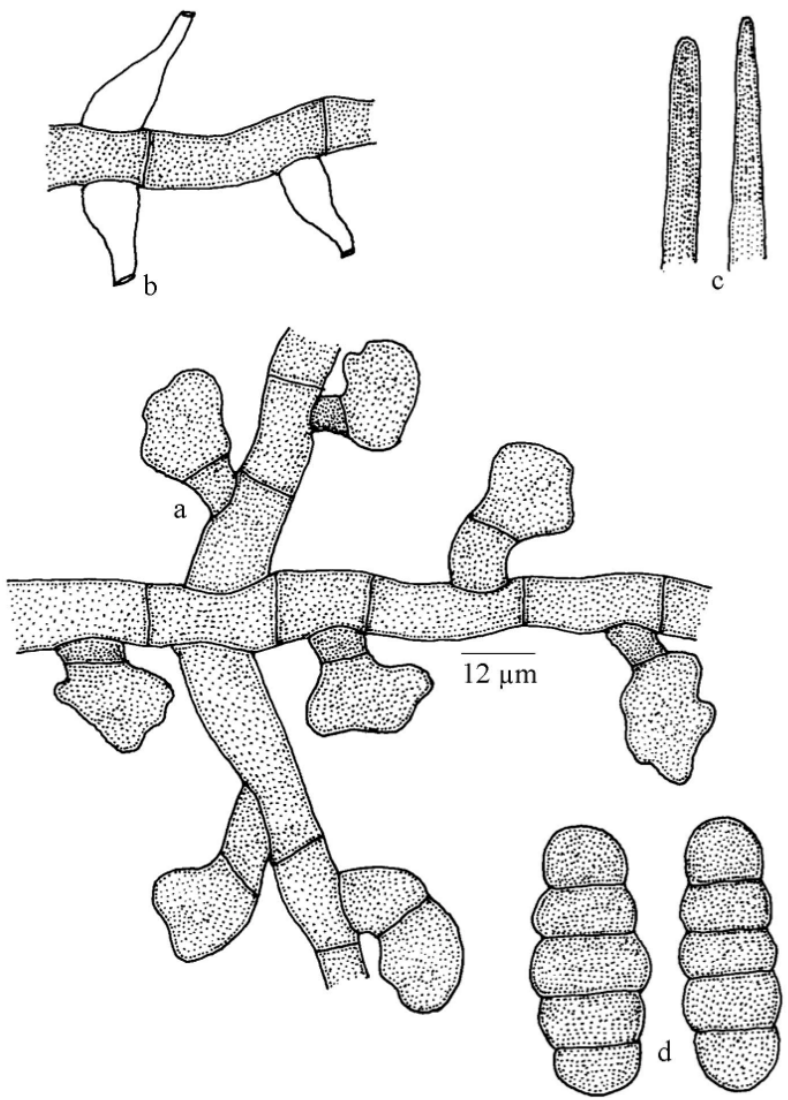

Figure 106. Meliola panici

a - Appressorium; b - Phialide; c - Apical portion of mycelial setae; d - Ascospores alternate, straight to variously curved, 24-34 $\mu \mathrm{m}$ long; stalk cells aseptate to many septate, tortuous, aseptate stalk cells $8-16 \mu \mathrm{m}$ long, while, septate stalk cells up to $80 \mu \mathrm{m}$ long; head cells semilunar, versiform, ovate, angular, straight to mostly curved, 16-22x10-14 $\mu \mathrm{m}$. Phialides mixed with appressoria, alternate to opposite, ampulliform, 20-24x8-10 $\mu \mathrm{m}$. Mycelial setae thinly scattered, simple, straight, acute, up to $360 \mu \mathrm{m}$ long. Perithecia scattered, up to $110 \mu \mathrm{m}$ in diameter; ascospores cylindrical, ellipsoidal, 4-septate, constricted at the septa, $52-56 \times 16-18 \mu \mathrm{m}$.

Dense colonies and variously curved multiseptate appressoria distinguish this species.

Meliola premnigena Hosag. \& Riju, Plant Pathology \& Quarantine 1(2), 121, 2011; Hosag., J. Threatened Taxa 5(6): 4046, 2013. (Fig. 109).

Material examined: HClO 51189, TBGT 5069, 10.i.2011, on leaves of Premna glaberrima Wight (Verbenaceae), Banasuran mala, coll. M.C. Riju.

Colonies epiphyllous, velvety, up to $5 \mathrm{~mm}$ in diam. Hyphae flexuous to crooked, branching opposite at acute to wide angles, cells 15-25x5-8 $\mu \mathrm{m}$. Appressoria alternate, unilateral, antrorse to subantrorse, 15-23 $\mu \mathrm{m}$ long; stalk cells cylindrical to cuneate, $5-8 \mu \mathrm{m}$ long; head cells globose, subglobose, entire to sublobate, 10-18x7$13 \mu \mathrm{m}$. Phialides mixed with appressoria, opposite,

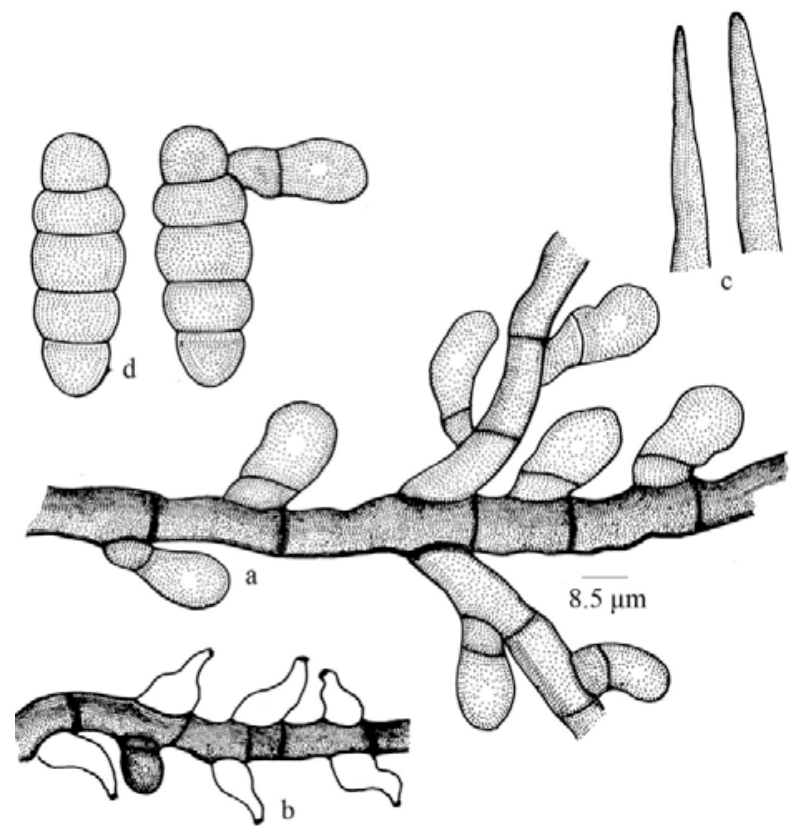

Figure 107. Meliola phyllanthigena

a - Appressorium; b - Phialide; c - Apical portion of mycelial setae; d - Ascospores 
alternate to unilateral, ampulliform, 14-23x4-6 $\mu \mathrm{m}$. Mycelial setae scattered, simple, straight, slightly curved to uncinate, up to $300 \mu \mathrm{m}$ long. Perithecia scattered, up to $150 \mu \mathrm{m}$ in diameter; ascospores cylindrical to oblong, 4-septate, slightly constricted at the septa, 32-38x12-15 $\mu \mathrm{m}$.

Based on the alternate appressoria and simple setae, this species comes close to $M$. cookeana Speg. and $M$. premnae Hansf. However, it differs from the former in not having inflated, dentate or furcate apex of mycelial setae. It differs from the latter in having straight hyphae and mycelial setae in contrast to flexuous, crooked, uncinate and twisted mycelial setae (Hansford 1961). It also differs from M. premnicola in having only obtuse mycelial setae in contrast to variously dentate ones (Hosagoudar 1996).

Meliola psophocarpi Hosag. \& Riju, J. Threatened Taxa 2(4): 824, 2010; Hosag., J. Threatened Taxa 5(6): 4046, 2013. (Fig. 110; Image 9).

Material examined: 30.xi.2007, $\mathrm{HClO} 48174$ (holotype), TBGT 2910 (isotype), on leaves of Psophocarpus tetragonolobus L. (Fabaceae), 16th mile, Padinharathara, coll. M.C. Riju; HCIO 50351, TBGT 4268, 6.xi.2009, coll. A. Sabeena \& M.C. Riju.

Colonies foliicolous, fructicolous, epiphyllous, thin, scattered, up to $3 \mathrm{~mm}$ in diameter, often confluent. Hyphae undulate, branching mostly opposite at wide angles, loosely to closely reticulate, cells $11-33 \times 4-7 \mu \mathrm{m}$. Appressoria alternate, unilateral, up to $3 \%$ opposite,

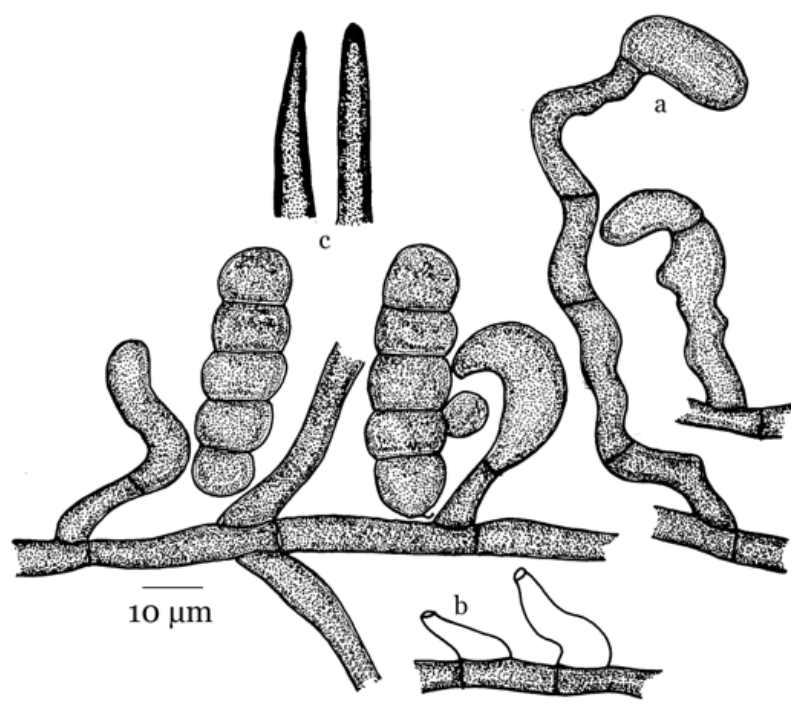

Figure 108. Meliola plectroniae

a - Appressorium; b - Phialide; c - Apical portion of mycelial setae; d - Ascospores

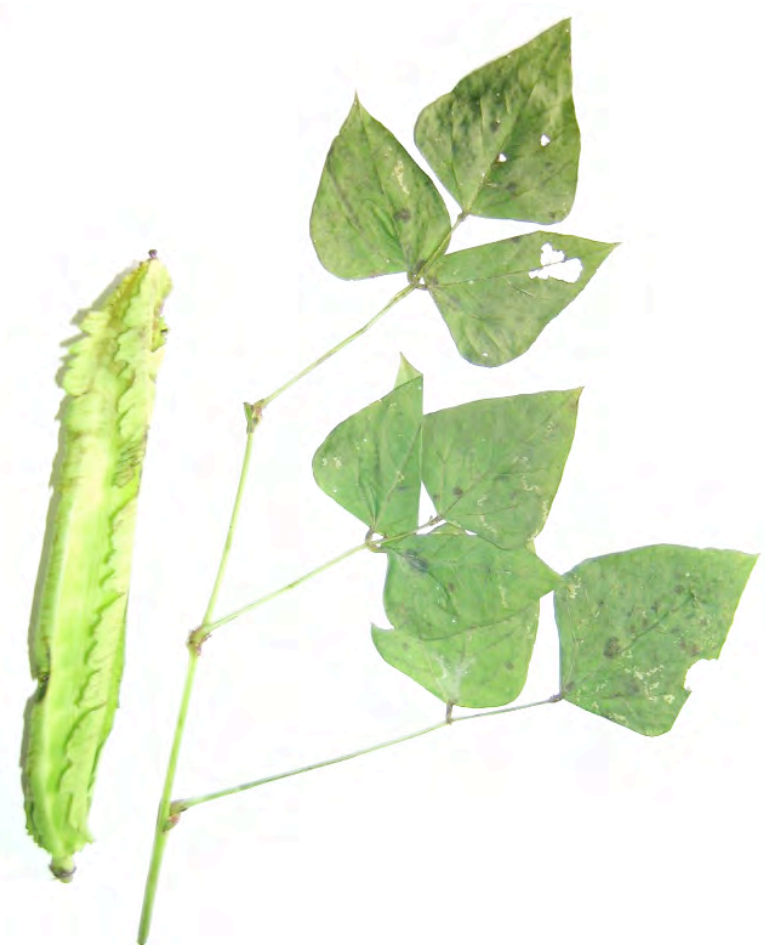

Image.9. Meliola psophocarpi-Infected leaves and pod

straight to slightly curved, subantrorse to retrorse, 11-20 $\mu \mathrm{m}$ long; stalk cells cylindrical to cuneate, 2-11 $\mu \mathrm{m}$ long; head cells ovate, globose, 8-11 $\mu \mathrm{m}$ in diam. Phialides mixed with appressoria, alternate, opposite, unilateral, ampulliform, 13-20x6-9 $\mu \mathrm{m}$. Mycelial setae scattered, simple, straight to slightly curved, acute to

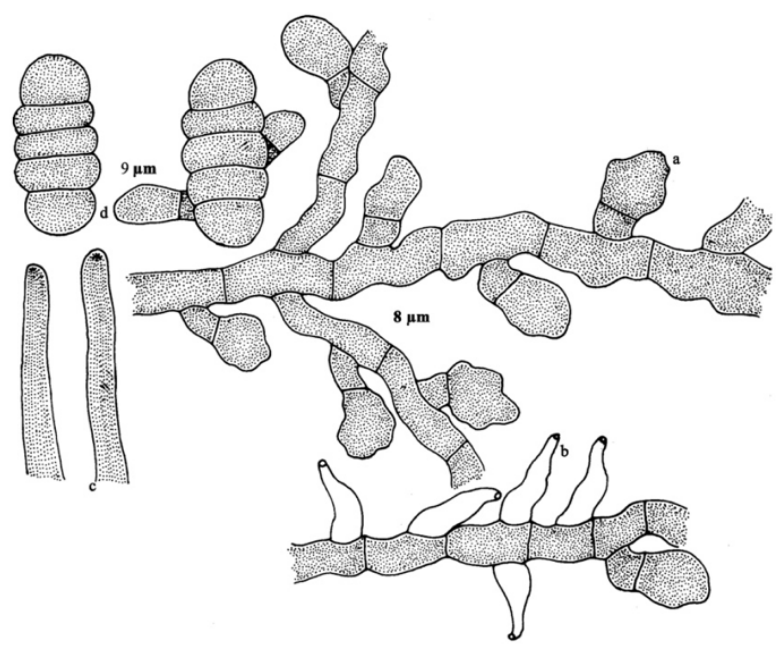

Figure 109. Meliola premnigena

a - Appressorium; b - Phialide; c - Apical portion of mycelial setae; $d$ Ascospores 
obtuse at the tip, up to $360 \mu \mathrm{m}$ long. Perithecia scattered, up to $130 \mu \mathrm{m}$ in diam.; ascospores cylindrical, 4- septate, slightly constricted at the septa, 33-38x8-11 $\mu \mathrm{m}$.

Psophocarpus tetragonolobus is a climbing shrub, native of South East Asia, has been extensively cultivated in the backyards for its quadrangular pods used in the culinary purposes. The leaves of this plant is being infected with the black mildew fungus and is similar to $M$. nyanzae in having the same digital formula but differs from it in not being a strong parasite in producing pathogenic symptoms (Hansford 1961; Hosagoudar 1996; Hu et al. 1996, 1999).

Meliola pushpangadanii Hosag. \& Abraham in Hosag., Abraham \& Goos, Mycotaxon 66: 106, 1998; Hosag., Meliolales of India 2: 311, 2008; Hosag. \& Agarwal, Taxonomic Studies of Meliolales. Identification Manual, p. 217, 2008. (Fig. 111)

Materials examined: TBGT 4043, 16.ix.2008, on leaves of Persea sp. (Lauraceae), Periya, coll. Harish et al.

Colonies hypophyllous, thin, subvelvety, scattered, spreading, up to $4 \mathrm{~mm}$ in diameter. Hyphae crooked, branching irregular at acute to wide angles, loosely to closely reticulate, cells 31-50x4-7 $\mu \mathrm{m}$. Appressoria scattered, alternate, antrorse, ubantrorse to retrorse, straight to curved, 16-22 $\mu \mathrm{m}$ long; stalk cells cylindrical to cuneate, 4-9 $\mu \mathrm{m}$ long; head cells globose, entire, 14-17x16-19 $\mu \mathrm{m}$. Phialides mixed with appressoria, alternate to opposite, ampulliform, 16-22x9-12 $\mu \mathrm{m}$. Mycelial setae fairly numerous, mostly grouped around perithecia, simple, straight to flexuous, acute at the tip, up to $1580 \mu \mathrm{m}$ long. Perithecia scattered, up to $220 \mu \mathrm{m}$ in diameter; ascospores slightly fusiform, 4-septate, constricted at the septa, 40-43×16-19 $\mu \mathrm{m}$.

This species differs from Meliola cryptocariicola Hosag. \& Raghu and M. patileana Hosag. in having only alternate appressoria, straight to flexuous and acute mycelial setae (Hosagoudar, 1996).

\section{Endemic to Southern Western Ghats}

Meliola quadrispina Racib., Parasit. Algen and Pilze Java's 3: 33, 1900; Hansf., Sydowia Beih. 2: 646, 1961; Thite \& Patil, Kavaka 10: 30, 1982; Hosag. \& Goos, Mycotaxon 37: 244, 1990; Hosag., Meliolales of India, p. 293, 1996.

Meliola quadrifurcata Rehm, Philippine J. Sci. 8: 181, 1913; Leafl. Philippine Bot. 6: 2194, 1914. (Fig. 112)

Materials examined: $\mathrm{HClO}$ 50349, TBGT 4266, 5.xi.2009, on leaves of Merremia unbellata (L.) Hallier

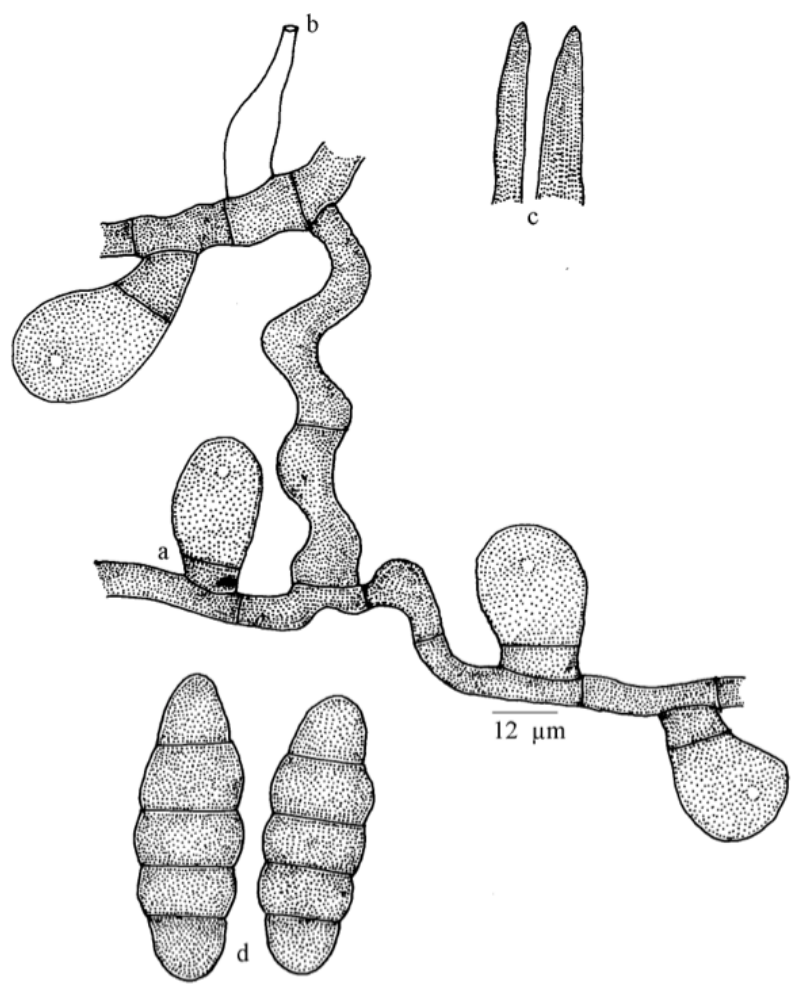

Figure 111. Meliola pushpangadanii

a - Appressorium; b - Phialide; c - Apical portion of mycelial setae; d - Ascospores a - Appressorium; b - Phialide; c - Apical portion of mycelial setae; d - Ascospores 
f. (Convolvulaceae), Gurukulam Botanic Garden, Periya, coll. A. Sabeena \& M.C. Riju.

Colonies amphigenous, caulicolous, mostly epiphyllous, dense, up to $4 \mathrm{~mm}$ in diameter, confluent. Hyphae undulate to tortuous, branching irregular, loosely to closely reticulate, cells $20-40 \times 6-8 \mu \mathrm{m}$. Appressoria alternate to unilateral, antrorse, spreading, straight to curved, 16-24 $\mu \mathrm{m}$ long; stalk cells cylindrical to cuneate, 6-14 $\mu \mathrm{m}$ long; head cells ovate, versiform, angulose, rarely irregularly sublobate, 10-16x12-16 $\mu \mathrm{m}$. Phialides mixed with appressoria, alternate to opposite, ampulliform, 20-24x6-10 $\mu \mathrm{m}$. Mycelial setae numerous, uniformly scattered, dichotomously branched, length till the first branching is up to $162 \mu \mathrm{m}$, from first to second branching up to $24 \mu \mathrm{m}$ long and the final branchlets up to $136 \mu \mathrm{m}$ long, obtuse to acute at the tip. Perithecia mostly grouped, up to $261 \mu \mathrm{m}$ in diameter; ascospores broadly obovoidal, 4-septate, constricted at the septa, 40-50x14-22 $\mu \mathrm{m}$.

Branched mycelial setae are the characters of this species.

Meliola scleropyri Hosag. in Hosag. \& Goos, Mycotaxon 37: 247, 1990; Hosag., Meliolales of India, p. 307, 1996. (Fig. 113).

Materials examined: $\mathrm{HClO}$ 49220, TBGT 3459, 15.ii.2009, on leaves of Scleropyrum pentandrum

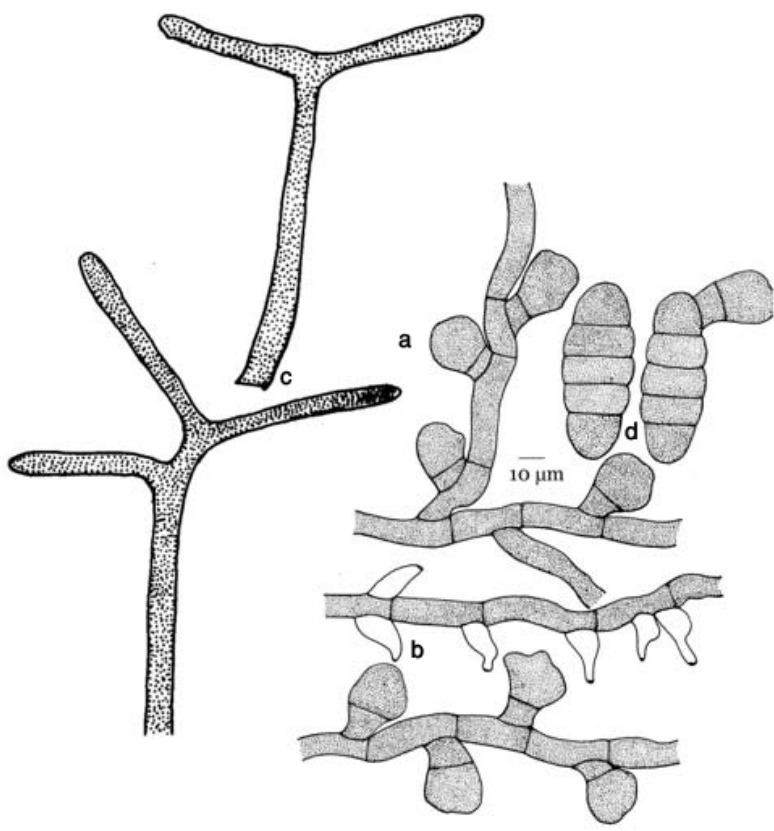

Figure 112. Meliola quadrispina

a - Appressorium; b - Phialide; c - Apical portion of mycelial setae; d - Ascospores
(Dennst.) Mabberley (Santalaceae), Begur, coll. Jacob Thomas et al.,

Colonies amphigenous, dense, velvety, up to $5 \mathrm{~mm}$ in diameter, confluent. Hyphae substraight to undulate, branching opposite to irregular at acute angles, loosely to closely reticulate, cells $19-26 \times 6-7 \mu \mathrm{m}$. Appressoria alternate, subantrorse to antrorse, 16-24 $\mu \mathrm{m}$ long; stalk cells cylindrical to cuneate, 2-10 $\mu \mathrm{m}$ long; head cells ovate to subglobose, rarely subangular, entire, 12-17x9$12 \mu \mathrm{m}$. Phialides mixed with appressoria, alternate to opposite, ampulliform, 16-24x7-10 $\mu \mathrm{m}$. Mycelial setae numerous, scattered, straight to slightly curved, flexuous, simple, acute to obtuse at the tip, up to $360 \mu \mathrm{m}$ long. Perithecia scattered, verrucose, up to $110 \mu \mathrm{m}$ in diameter; ascospores obovoidal, 4-septate, constricted at the septa, 33-41x12-17 $\mu \mathrm{m}$.

This species differs from Meliola hainanensis $\mathrm{Hu}$ reported on Scleropyrum wallichianum from China. However, differs from it in having only alternate and longer appressoria, simple and not dentate mycelial setae and also ascospores are smaller (Hosagoudar et al. 1997; Hu et al. 1997, 1999).

Endemic to Southern Western Ghats.

Meliola stenospora Wint., Hedwigia 25: 97, 1886; Hansf., Sydowia Beih. 2: 75, 1961; Hosag. \& Raghu, New Botanist 20: 72, 1993; Hosag., Meliolales of India, p. 314, 1996. (Fig. 114).

Materials examined: $\mathrm{HClO}$ 49255, TBGT 3582, 17.ix.2008, on leaves of Piper sp. (Piperaceae), Periya,

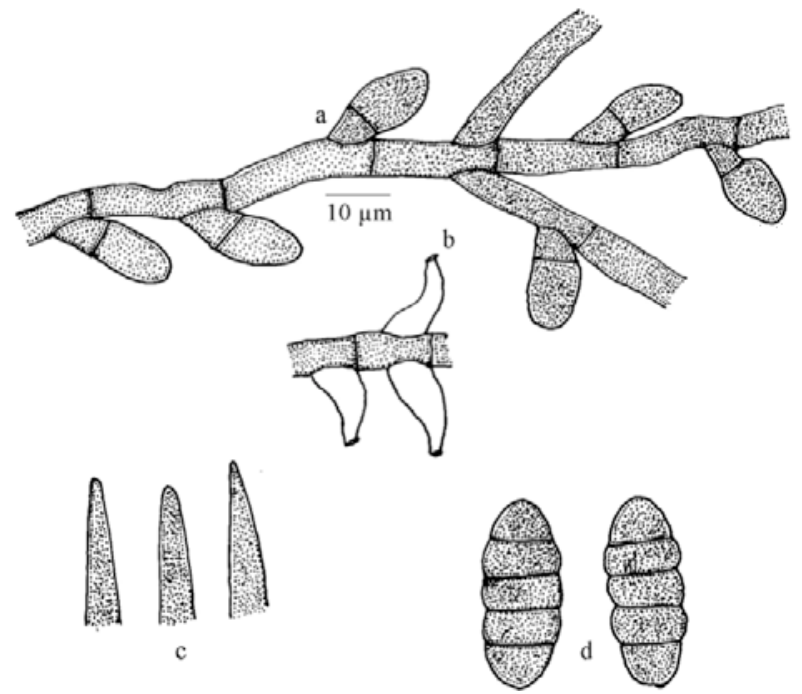

Figure 113. Meliola scleropyri

a - Appressorium; b - Phialide; c - Apical portion of mycelial setae; d - Ascospores 
coll. Gireesh Kumar et al.; HClO 44385, TBGT 610, 5.ii.2002, Wayanad, coll. M. Kamarudeen.

Colonies hypophyllous, thin, spreading, up to $5 \mathrm{~mm}$ in diameter, rarely confluent. Hyphae substraight to slightly crooked, branching opposite at acute to wide angles, loosely to closely reticulate, cells 19-27x8$10 \mu \mathrm{m}$. Appressoria alternate to unilateral, straight to curved, antrorse to spreading, 19-24 $\mu \mathrm{m}$ long; stalk cells cylindrical to cuneate, $4-8 \mu \mathrm{m}$ long; head cells truncate, angular to slightly lobate, 12-16x14-19 $\mu \mathrm{m}$. Phialides borne on a separate mycelial branch, alternate to opposite, ampulliform, 16-24x8-11 $\mu \mathrm{m}$. Mycelial setae simple, straight, acute at the tip, up to $450 \mu \mathrm{m}$ long. Perithecia scattered, up to $180 \mu \mathrm{m}$ in diameter; ascospores cylindrical to slightly crescent shaped, 4-septate, constricted at the septa, 35-43×12-16 $\mu \mathrm{m}$.

Infects the plants growing in shade and moisture

Meliola stenospora Wint. var. major Hansf., Sydowia 16: 303, 1963; Patil \& Pawar, Indian Phytopathol. 39: 306, 1986; Hosag., Meliolales of India, p. 316, 1996.

Meliola stenospora Wint. var. major Hansf., Sydowia Beih. 2: 75, 1961. (Fig. 115).

Materials examined: $\mathrm{HClO}$ 49255, TBGT 3494,

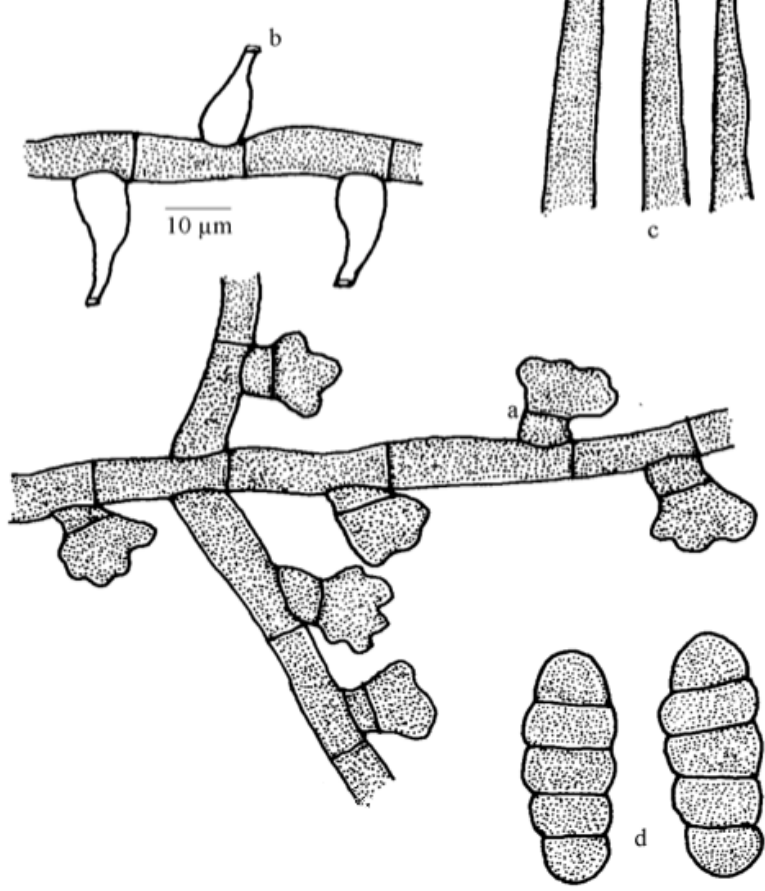

Figure 114. Meliola stenospora

a - Appressorium; b - Phialide; c - Apical portion of mycelial setae; d - Ascospores 17.ix.2008, on leaves of Piper sp. (Piperaceae), Periya, coll. Gireesh Kumar et al.

Colonies mostly epiphyllous, subdense, thinly velvety, up to $3 \mathrm{~mm}$ in diameter, confluent. Hyphae substraight to slightly undulate, branching opposite to irregular at wide angles, closely reticulate, cells 2025x8-10 $\mu \mathrm{m}$. Appressoria alternate, about $1 \%$ opposite, spreading to antrorse, straight to curved, 17-23 $\mu \mathrm{m}$ long; stalk cells cuneate to cylindrical, 3-9 $\mu \mathrm{m}$ long; head cells subglobose with crenate to lobulate margin, 11$15 \times 12-20 \mu \mathrm{m}$. Phialides borne on a separate mycelial branch, opposite to alternate, ampulliform, 17-20x7-9 $\mu \mathrm{m}$. Mycelial setae mostly grouped around perithecia, straight, simple, acute, up to $1000 \mu \mathrm{m}$ long. Perithecia loosely grouped, verrucose, up to $170 \mu \mathrm{m}$ in diam.; ascospores oblong, 4-septate, slightly constricted at the septa, 37-43×11-15 $\mu \mathrm{m}$.

Meliola sterculiacearum Hosag. \& Kamar. in Hosag., J. Mycopathol. Res. 43: 31, 2005; Hosag., Meliolales of India 2: 325, 2008. (Fig. 116).

Materials examined: $\mathrm{HClO}$ 44786, TBGT 1023, 22.xii.2002, on leaves of Sterculia sp. (Sterculiaceae), Periya, coll. M. Kamarudeen.

Colonies amphigenous, dense, spreading, up to $2 \mathrm{~mm}$ in diameter, confluent. Hyphae straight to substraight, branching mostly opposite at acute angles, loosely to very closely reticulate and form a solid mycelial mat, cells 14-16x6-8 $\mu \mathrm{m}$. Appressoria alternate, antrorse to closely antrorse, 12-16 $\mu \mathrm{m}$ long; stalk cells cylindrical to cuneate, 3-5 $\mu \mathrm{m}$ long; head cells ovate, globose, entire, 8-12x9-11 $\mu \mathrm{m}$. Phialides mixed with appressoria, alternate to opposite, ampulliform, $14-16 \times 6-8 \mu \mathrm{m}$.

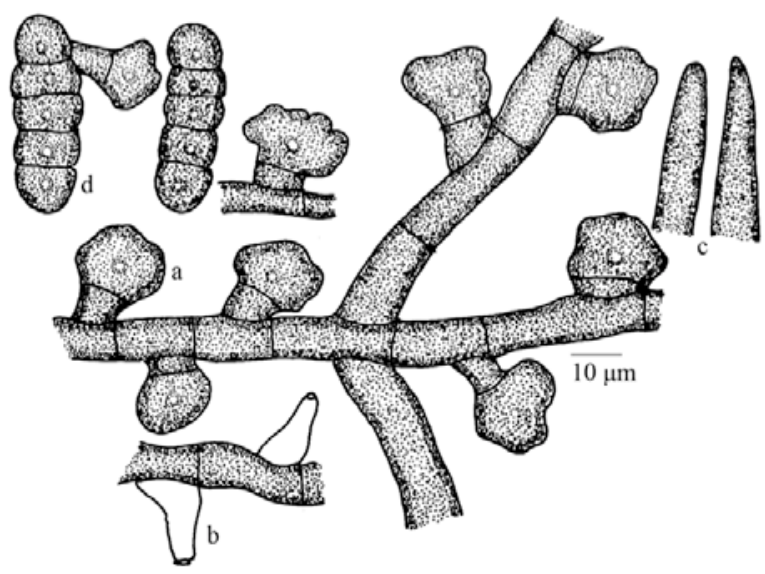

Figure 115. Meliola stenospora var. major

a - Appressorium; b - Phialide; c - Apical portion of mycelial setae; d - Ascospores 
Mycelial setae thinly scattered, simple, straight, acute at the tip, up to $450 \mu \mathrm{m}$ long. Perithecia scattered, globose, up to $160 \mu \mathrm{m}$ in diameter; ascospores oblong, ellipsoidal, 4-septate, constricted at the septa, 36-39×16-18 $\mu \mathrm{m}$.

Based on the Beeli formula, 3111.3222, this species can be compared with Meliola melochiae Hansf. However, differs from it in having dense colonies, straight hyphae, antrorse appressoria and longer mycelial setae. Meliola sterculiae Hansf. \& Deight. known on Sterculia tragacantha from Uganda but $M$. sterculiacearum differs from it in absence of $15 \%$ opposite appressoria, having simple setae and smaller ascospores (Hansford, 1961).

Meliola subramanyaensis Hosag., J. Mycopathol. Res. 43: 207, 2005; Hosag., Meliolales of India 2: 331, 2008; Hosag. \& Agarwal, Taxonomic studies of Meliolales. Identification Manual, p. 232, 2008. (Fig. 117)

Materials examined: HClO 49809, TBGT 3961, 15.ix.2008, on leaves of Cyclea peltata Cooke (Menispermaceae), Nagarhole, coll. Robin et al.

Colonies epiphyllous, dense, velvety, up to $2 \mathrm{~mm}$ in diameter, confluent. Hyphae substraight, flexuous to crooked, branching alternate to irregular at acute to wide angles, loosely to closely reticulate, cells 16-22x4-7 $\mu \mathrm{m}$. Appressoria alternate, antrorse, 16-26 $\mu \mathrm{m}$ long; stalk
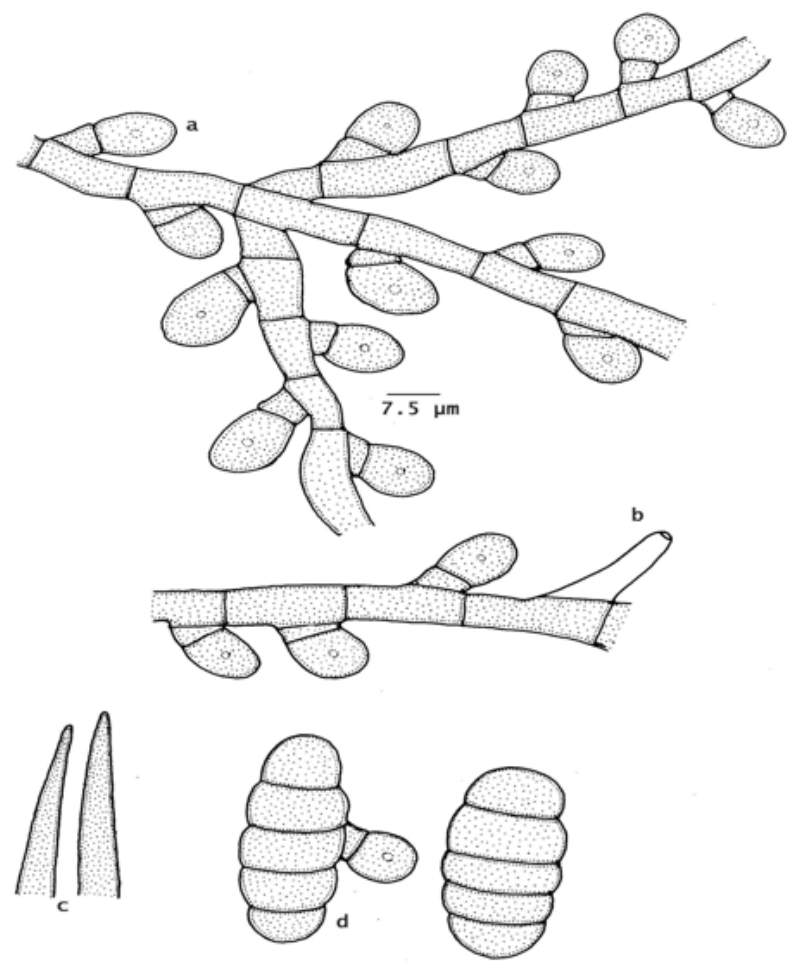

Figure 116. Meliola sterculiacearum

a - Appressorium; b - Phialide; c - Apical portion of mycelial setae; d - Ascospores cells cylindrical to cuneate, 4-10 $\mu \mathrm{m}$ long; head cells ovate, oblong, clavate, often attenuated at the apex, entire, 11-17x9-11 $\mu \mathrm{m}$. Phialides borne on a separate mycelial branch, alternate to opposite, ampulliform, 13-24x6-9 $\mu \mathrm{m}$. Mycelial setae mostly grouped around perithecia, simple, straight, flexuous to curved, up to $2 \%$ uncinate, obtuse at the tip, up to $312 \mu \mathrm{m}$ long. Perithecia scattered, globose, up to $171 \mu \mathrm{m}$ in diameter; ascospores oblong, cylindrical, 4-septate, constricted at the septa, 31-36x11-15 $\mu \mathrm{m}$.

The present species has flexuous to uncinate mycelial setae which distinguishes it from Meliola cissampelicola Hansf. \& Thirum. and $M$. cycleae Hosag. known on the members of the family Menispermaceae from the Western Ghats of Peninsular India (Hansford, 1961; Hosagoudar, 1996).

Meliola symplocicola Yamam., Trans., Nat. Hist. Soc. Taiwan 31: 57, 1941; Hansf., Sydowia Beih. 2: 519, 1961; Hosag. \& Goos, Mycotaxon 37: 249, 1990; Hosag., Meliolales of India, p. 318, 1996. (Fig. 118).

Materials examined: HClO 49811,TBGT 3963, 15.ii.2009, on leaves of Symplocos cochinchinensis (Lour.) Moore ssp. laurina (Retz.) Nooteboom (Symplocaceae), Periya, coll. Gireesh et al.; HCIO 48088, TBGT 2871, 6.xii.2006, Symplocos sp., Kunkichira, Periya, coll. M. Harish, V. Gireesh Kumar \& Anilkumar.

Colonies hypophyllous, subdense, velvety, up to

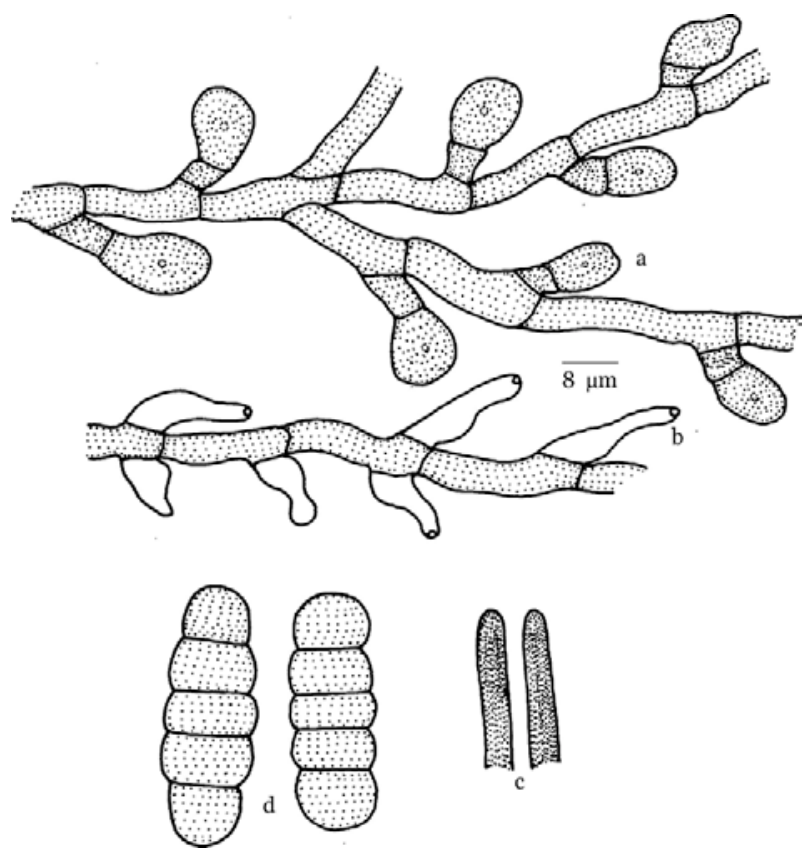

Figure. 117. Meliola subramanyaensis

a - Appressorium; b - Phialide; c - Apical portion of mycelial setae; d - Ascospores 
$8 \mathrm{~mm}$ in diameter, confluent. Hyphae substraight to flexuous, branching mostly opposite at wide angles, loosely reticulate, cells $18-34$ × 6-8 $\mu \mathrm{m}$. Appressoria alternate to unilateral, straight to variously curved, antrorse, spreading, 22-26 $\mu \mathrm{m}$ long; stalk cells cylindrical to cuneate, 6-10 $\mu \mathrm{m}$ long; head cells globose, angulose, truncate, variously curved, entire, 12-18 x 8-12 $\mu \mathrm{m}$. Phialides mixed with appressoria, alternate to opposite, ampulliform, 20-30 x 8-10 $\mu \mathrm{m}$. Mycelial setae grouped around perithecia, straight, simple, acute, very few 2-3 dentate, up to $360 \mu \mathrm{m}$ long. Perithecia scattered, up to $200 \mu \mathrm{m}$ in diam.; ascospores 4-septate, obovoidal to cylindrical, constricted at the septa, 48-59 x 16-20 $\mu \mathrm{m}$.

This is the only species known on this host plant from India

Meliola syzygiigena Hosag. \& Kamar., Zoos Print J. 18: 1061, 2002; Hosag., Meliolales of India 2: 334, 2008. (Fig. 119)

Materials examined: $\mathrm{HClO}$ 44386, TBGT 594, 6.ii.2002, on leaves of Syzygium sp. (Myrtaceae), Wayanad, coll. M. Kamarudeen.

Colonies hypophyllous, dense, velvety, up to $5 \mathrm{~mm}$ in diameter, confluent. Hyphae straight to substraight, branching alternate, opposite to irregular at acute angles, loosely to closely reticulate, cells $25-28 \times 6-7 \mu \mathrm{m}$. Appressoria alternate, less than 1\% opposite, antrorse, subantrorse, retrorse, straight, curved to uncinate, 16$23 \mu \mathrm{m}$ long; stalk cells cylindrical to cuneate, $3-8 \mu \mathrm{m}$ long; head cells ovate, oblong, cylindrical, straight to curved, entire, broadly rounded to truncate at the apex, 12-16x6-8 $\mu \mathrm{m}$. Phialides few, mixed with appressoria, alternate to opposite, ampulliform, 19-24x6-8 $\mu \mathrm{m}$. Mycelial setae numerous, scattered, simple, straight, acute at the tip, up to $294 \mu \mathrm{m}$ long. Perithecia loosely grouped, verrucose, up to $144 \mu \mathrm{m}$ in diameter, wall cells projected; ascospores oblong to subellipsoidal, 4-septate, constricted at the septa, 43-48×15-18 $\mu \mathrm{m}$.

Based on the Beeli formula and the morphology of the head cells of the appressoria, the present species, Meliola syzygigena is similar to an endemic species, Meliola ranganathi Hansf. but differs from it in having hypophyllous velvet colonies, distantly placed and variously curved appressoria (Hansford, 1961; Hosagoudar, 1996).

Meliola tamarindi Sydow \& Sydow, Ann. Mycol. 10: 79, 1912; Hansf., Sydowia Beih. 2: 250, 1961; Hosag \& Goos, Mycotaxon 37: 249, 1990; Hosag., Dayal \& Goos, Mycotaxon 46: 208, 1988; Hosag., Kaveriappa, Raghu \& Goos, Mycotaxon 51: 116, 1994; Hosag., Meliolales of India, p. 321, 1996. (Fig. 120).

Materials examined: M.C HClO 51032, TBGT 4949, 11.x.2008, on leaves of Tamarindus indica L. (Caesalpiniaceae), $16^{\text {th }}$ mile, Padinharathara, coll. M.C. Riju.

Colonies amphigenous, mostly epiphyllous, dense, velvety, up to $2 \mathrm{~mm}$ in diameter, confluent. Hyphae undulate to tortuous, branching opposite at wide angles, loosely reticulate, cells 16-28x6-10 $\mu \mathrm{m}$. Appressoria alternate to $5 \%$ opposite, antrorse, spreading, straight to curved, 19-29 $\mu \mathrm{m}$ long; stalk cells cylindrical to cuneate, 4-12 $\mu \mathrm{m}$ long; head cells ovate, angular, entire to sublobate, straight to curved, 13-20x10-16 $\mu \mathrm{m}$. Phialides mixed with appressoria, alternate to opposite, scattered, 15-28x6-10 $\mu \mathrm{m}$. Mycelial setae scattered to grouped around perithecia, simple, obtuse at the tip, up

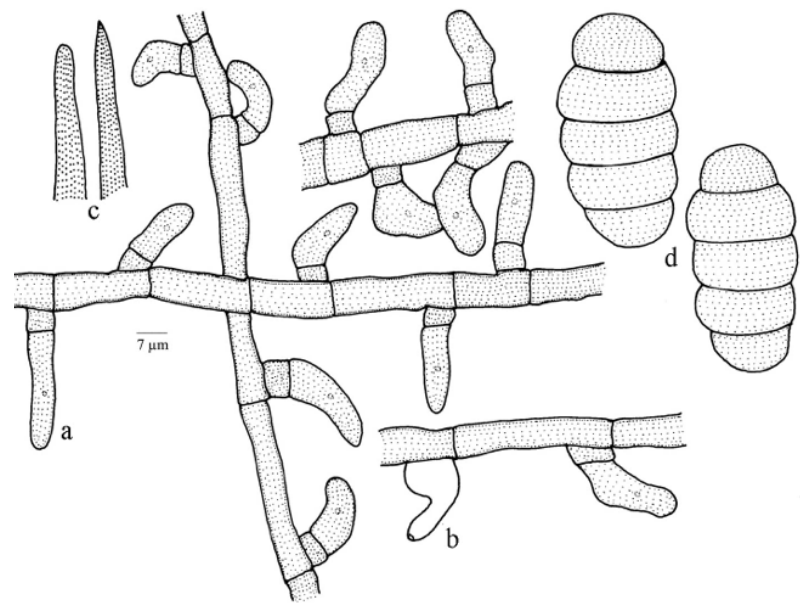

Figure 119. Meliola syzygiigena

a - Appressorium; b - Phialide; c - Apical portion of mycelial setae; d - Ascospores
Figure 118. Meliola symplocicola

a - Appressorium; b - Phialide; c - Apical portion of mycelial setae; d - Ascospores 
to $463 \mu \mathrm{m}$ long. Perithecia scattered, verrucose, up to $155 \mu \mathrm{m}$ in diameter; ascospores obovoidal, 4-septate, constricted at the septa, 45-50x17-20 $\mu \mathrm{m}$.

This is the only species known on this host plant.

Meliola tecleae Hansf. var. toddaliae-asiaticae Hansf., Proc. Linn. Soc. London 153: 11, 1941; Hansf., Sydowia Beih. 2: 392, 1962; Hosag., Meliolales of India, p. 323, 1996. (Fig. 121)

Materials examined: $\mathrm{HClO}$ 42963, TBGT 249, 11.viii.1998, on leaves of Toddalia asiatica (L.) Lam. (Rutaceae), Tirunelly, coll. C.K. Biju; HCIO 50016, TBGT 4168, 14.ii.2009, coll. Girish Kumar et al. TBGT 5715, 30.ix.2007, Padinharathara, coll. M.C. Riju.

Colonies epiphyllous, dense, scattered, up to $3 \mathrm{~mm}$ in diameter, rarely confluent. Hyphae straight, branching mostly opposite at wide angles, loosely to closely reticulate, cells $28-32 \times 6-8 \mu \mathrm{m}$. Appressoria alternate, straight to curved, antrorse to subantrorse, 19-29 $\mu \mathrm{m}$ long; stalk cells cylindrical to cuneate, 3-9 $\mu \mathrm{m}$ long; head cells oblong to cylindrical, often clavate, entire, 16-19x8-11 $\mu \mathrm{m}$. Phialides mixed with appressoria, alternate to opposite, ampulliform, 16-21x6-8 $\mu \mathrm{m}$. Mycelial setae scattered to grouped around perithecia, simple, straight, acute at the tip, up to $588 \mu \mathrm{m}$ long. Perithecia scattered to loosely grouped, up to $250 \mu \mathrm{m}$ in diameter; ascospores oblong to cylindrical, 4-septate, strongly constricted at the septa, 48-50×18-20 $\mu \mathrm{m}$.

This species is recorded from different parts of southern Western Ghats

Meliola tenella Pat., Mycol. 10: 140, 1888; Hansf., Sydowia Beih. 2: 381, 1961; Hosag., Meliolales of India, p. 324, 1996. (Fig. 122 \& Image 10).
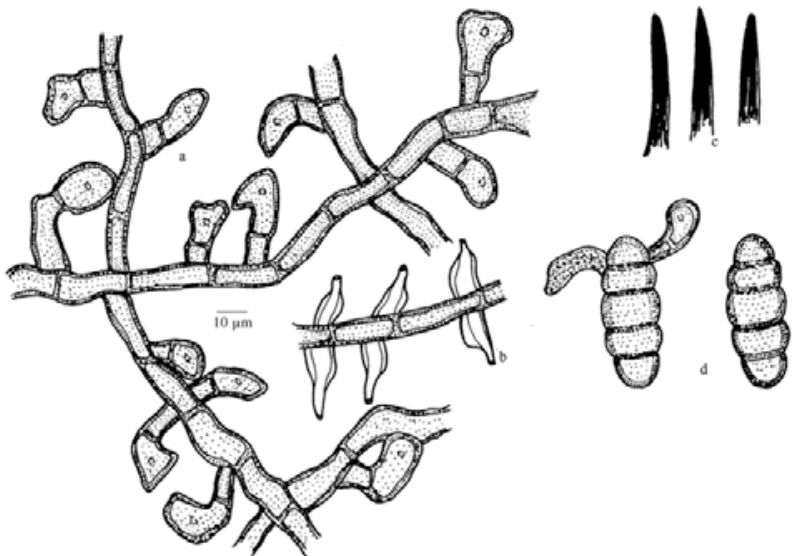

Figure 120. Meliola tamarindi

a - Appressorium; b - Phialide; c - Apical portion of mycelial setae; d - Ascospores
Materials examined: TBGT 3930, 18.ii.2009, on leaves of Murraya paniculata (L.) Jack. (M. exotica L.) (Rutaceae), Muthanga, coll. Jacob Thomas et al.; HClO 49393, TBGT 3638, 14.ii.2009, Atlantia sp., Tirunely, coll. P.J. Robin et al.; HClO 49972, TBGT 4124, 14.iii.2007, Murraya sp., Puthuserrykadavu, coll. M.C. Riju.

Colonies amphigenous, dense, velvety, up to $4 \mathrm{~mm}$ in diameter, confluent. Hyphae straight to substraight, branching opposite at wide angles, loosely to closely reticulate to form mycelial mat, cells $14-34 \times 7-10 \mu \mathrm{m}$. Appressoria alternate, antrorse to spreading, straight to curved, $16-26 \mu \mathrm{m}$ long; stalk cells cylindrical to cuneate, 4-7 $\mu \mathrm{m}$ long; head cells cylindrical, elongated, straight to curved, entire, $12-14 \times 8-12 \mu \mathrm{m}$. Phialides mixed with appressoria, opposite to alternate, 1624x7-10 $\mu \mathrm{m}$. Mycelial setae numerous, scattered, straight, dichotomously branched, $240 \mu \mathrm{m}$ long up to first branching, first ray up to $60 \mu \mathrm{m}$ long, second ray up to $40 \mu \mathrm{m}$ long and third ray up to $10 \mu \mathrm{m}$ long, acute to obtuse at the tip, branches reflexed. Perithecia scattered, verrucose, up to $220 \mu \mathrm{m}$ in diameter; ascospores

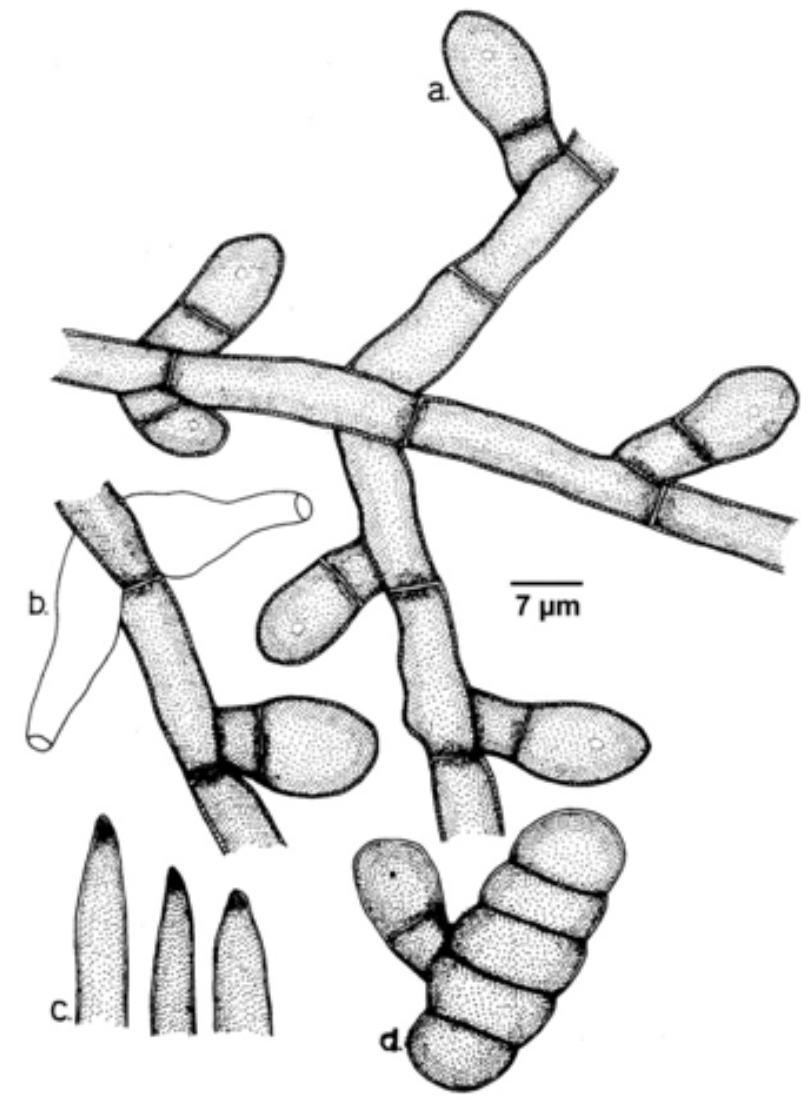

Figure 121. Meliola tecleae var. toddaliae-asiaticae a - Appressorium; b - Phialide; c - Apical portion of mycelial setae; d - Ascospores 


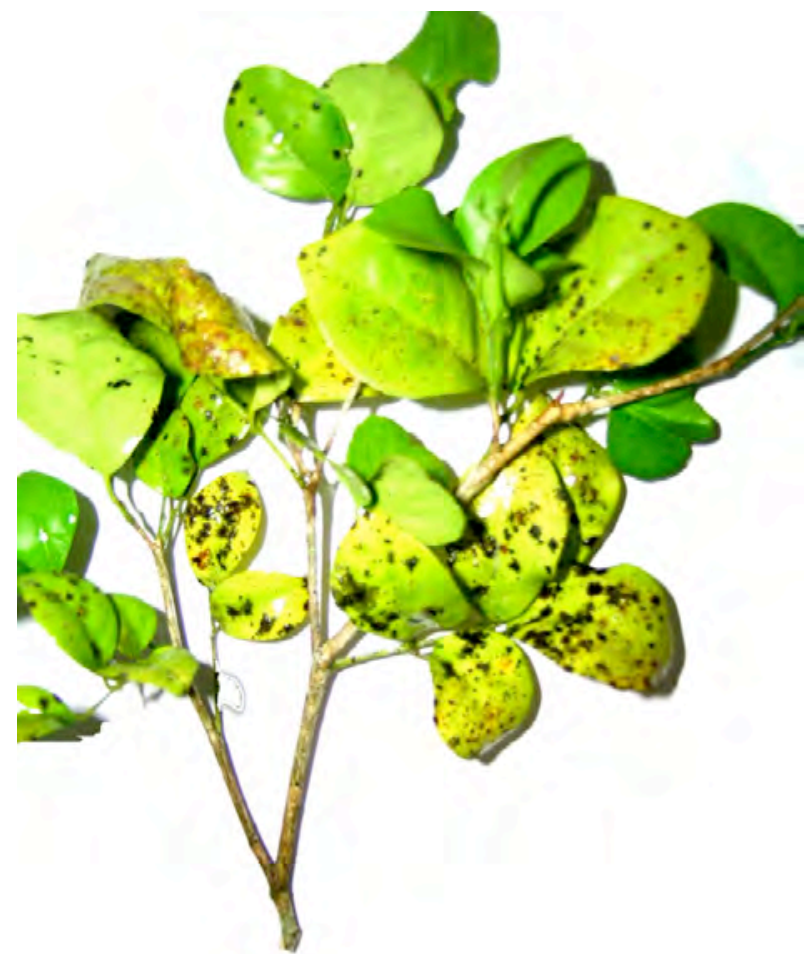

Image.21. Meliola tenella - Infected leaves, petiole and soft stem

subellipsoidal to cylindrical, 4-septate, constricted at the septa, 40-50x16-24 $\mu \mathrm{m}$.

Common in Western Ghats region of Kerala.

Meliola themedicola Hosag., C.K. Biju \& Abraham, Nova Hedwigia 80: 498, 2005; Hosag., Meliolales of India 2: 341, 2008. (Fig. 123)

Materials examined: $\mathrm{HClO}$ 43640, TBGT 315, 17.ii.2000, on leaves of Themeda triandra Forssk. (Poaceae), Chembra hills, coll. C.K. Biju.

Colonies mostly epiphyllous, dense, crustose, up to $2 \mathrm{~mm}$ diameter, rarely confluent. Hyphae substraight to crooked, branching irregular at acute angles, loosely to very closely reticulate and form solid mycelial mat, cells 20-26x6-8 $\mu \mathrm{m}$. Appressoria alternate, more scattered, antrorse to recurved, 19-56 $\mu \mathrm{m}$ long; stalk cells cylindrical, often flexuous, wall rugose, mostly unicellular, often 1-2-septate, 8-39 $\mu \mathrm{m}$ long; head cells ovate to globose, entire, angular, sublobate to irregularly and deeply lobate, 11-20x11-16 $\mu \mathrm{m}$. Phialides mixed with appressoria, alternate to opposite, ampulliform, 14-19x8-10 $\mu \mathrm{m}$. Mycelial setae numerous, scattered to grouped around perithecia, simple, straight, acute to broadly obtuse at the tip, up to $350 \mu \mathrm{m}$ long. Perithecia loosely grouped, verrucose, up to $175 \mu \mathrm{m}$ diameter; ascospores oblong to mostly cylindrical, 4-septate, constricted at the septa, 48-52×14-20 $\mu \mathrm{m}$.
Meliola themedae Stev. \& Rold. ex Hansf. and $M$. themedae Stev. \& Rold. ex Hansf. var. indica Hosag. are known on this host genus. $M$. themedicola differs from both in having aseptate to septate and long stalk cells of the appressoria. It also differs from $M$. panici Earle var. major Hansf. (having the same Beeli formula 3111. 5222) in having septate basal cell, entire to deeply lobate head cells of appressoria and phialides mixed with appressoria.

Meliola unonicola Hosag. \& Abraham, Kavaka 24: 16, 1996; Hosag., Meliolales of India, 2: 348, 2008; Hosag. \& Agarwal, Taxonomic studies of Meliolales. Identification Manual, p. 301, 2008. (Fig. 124).

Materials examined: $\mathrm{HClO}$ 43638, TBGT 317; HClO 47450, TBGT 2488, 16.iv.1999, on leaves of Meiogyne pannosa (Dalz.) Sinclair (Unona pannosa Dalz.) (Annonaceae), Banasuranmala, coll. C.K. Biju.

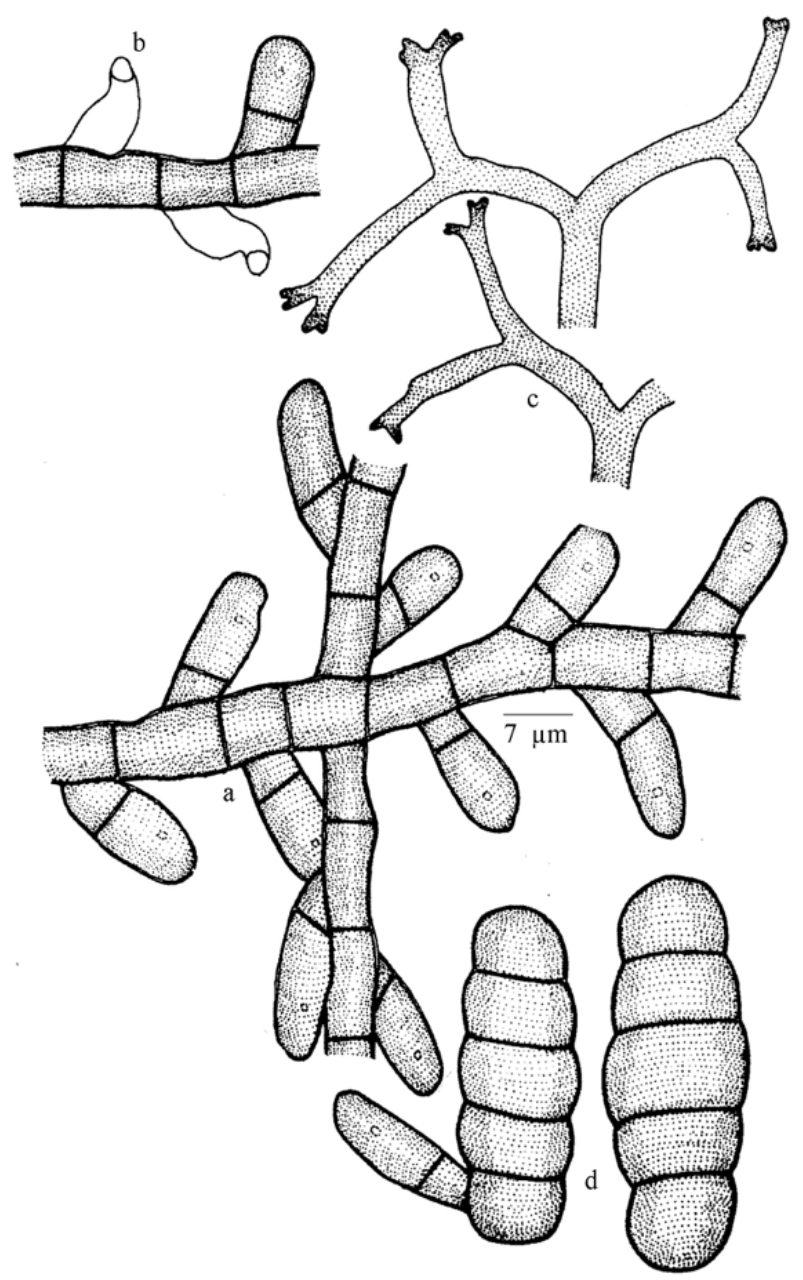

Figure 122. Meliola tenella

a - Appressorium; b - Phialide; c - Apical portion of mycelial setae; d - Ascospores 
Colonies amphigenous, dense, velvety, up to $3 \mathrm{~mm}$ in diameter, confluent. Hyphae straight, branching mostly opposite at acute angles, very closely reticulate and form solid mycelial mat, cells $15-19 \times 7-10 \mu \mathrm{m}$. Appressoria opposite, rarely alternate and unilateral, closely antrorse to antrorse, 20-25 $\mu \mathrm{m}$ long; stalk cells cylindrical to cuneate, 4-6 $\mu \mathrm{m}$ long; head cells ovate, cylindrical, broadly rounded to attenuated at the apex, entire 11-16x8-11 $\mu \mathrm{m}$. Phialides mixed with appressoria, alternate to opposite, ampulliform, 13-24x6-9 $\mu \mathrm{m}$. Mycelial setae numerous, densely scattered, simple, uncinate, sickle-shaped, septate, obtuse at the tip, up to $384 \mu \mathrm{m}$ long. Perithecia scattered, up to $242 \mu \mathrm{m}$ in diameter; ascospores cylindrical, 4-septate, constricted at the septa, 43-47x16-19 $\mu \mathrm{m}$.

This present taxon can be compared with Meliola uvariicola Hansf. but differs from it in having amphigenous, dense and velvety colonies, closely antrorse appressoria and uncinate mycelial setae (Hansford 1961).

Meliola vatsavayae Hosag . \& M.C. Riju, Indian J. Sci. and Technol. 2: 6, 2009. (Fig. 125)

Materials examined: $\mathrm{HClO}$ 48299, TBGT 3018,

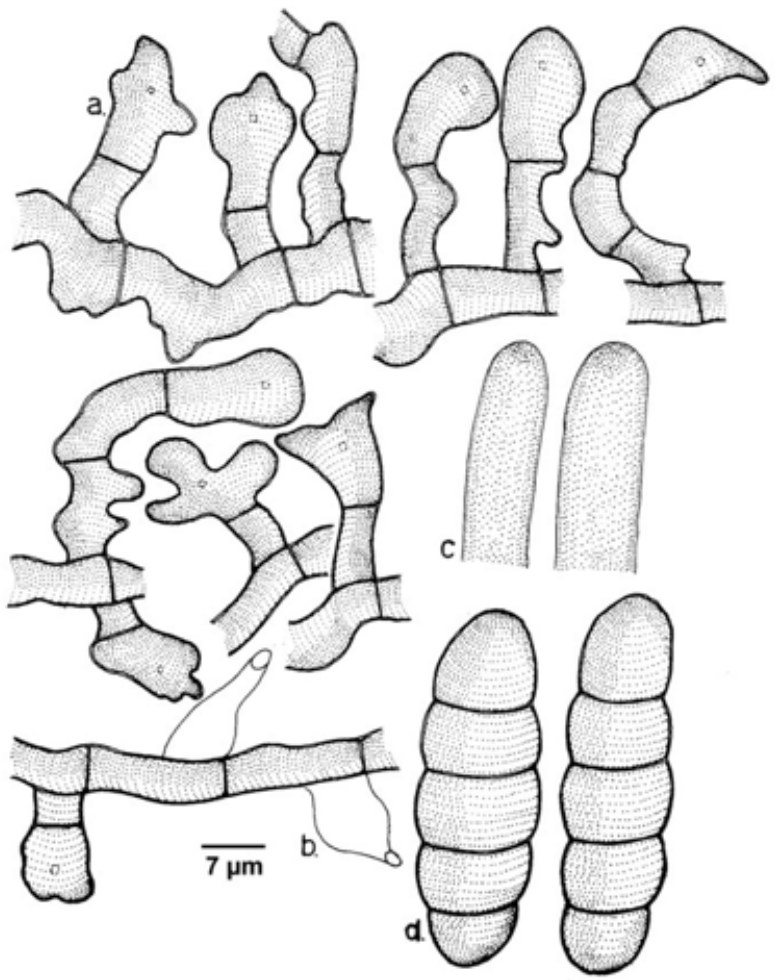

Figure 123. Meliola themedicola

a - Appressorium; b - Phialide; c - Apical portion of mycelial setae; d - Ascospores 22.iii.2008, on leaves of Zanthoxylum rhetsa (Roxb) DC. (Rutaceae), $16^{\text {th }}$ mile, Padinharathara, coll. M.C. Riju.

Colonies amphigenous, dense, velvety, scattered to confluent, up to $4 \mathrm{~mm}$ in diameter. Hyphae straight, branching opposite at acute to wide angles, closely reticulate, cells $13-18 \times 6-11 \mu \mathrm{m}$. Appressoria alternate, rarely unilateral, often crowded, antrorse, straight, 24-40 $\mu \mathrm{m}$ long; stalk cells cylindrical to cuneate, 8-13 $\mu \mathrm{m}$ long; head cells ovate, angular, sinuately lobate to deeply lobate, $15-27 \times 9-18 \mu \mathrm{m}$. Phialides mixed with appressoria, mostly opposite, rarely alternate to unilateral, ampulliform, 22-31x4-9 $\mu \mathrm{m}$. Mycelial setae straight to slightly curved, scattered to grouped around perithecia, obtuse at the tip, up to $270 \mu \mathrm{m}$ long. Perithecia scattered, up to $110 \mu \mathrm{m}$ in diameter; ascospores cylindrical to slightly ellipsoidal, 4- septate, constricted at the septa, 37-44x15-20 $\mu \mathrm{m}$.

Based on the digital formula 3113.4221, this species can be compared with $M$. toddaliicola Hansf. and $M$. toddaliicola Hanf. indica Hansf. \& Thirum. known on the host genus Toddalia from Uganda and India, respectively. However, the present new species differs from both in

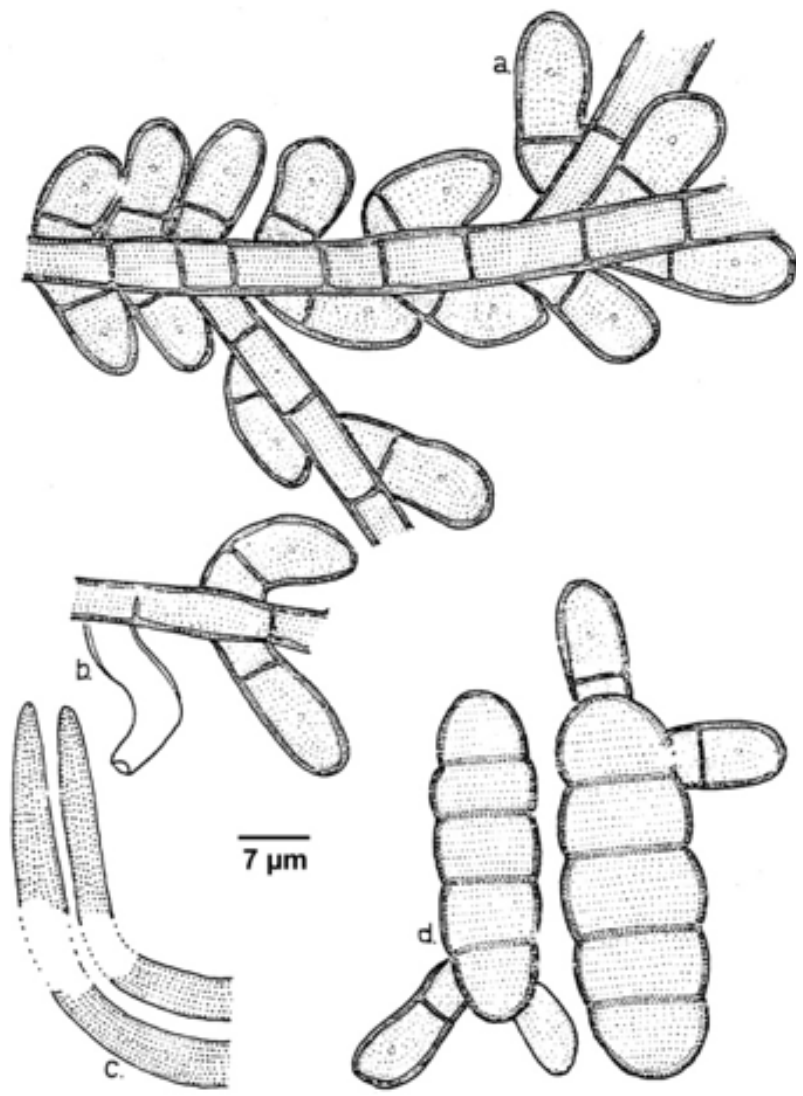

Figure 124. Meliola unonicola

a - Appressorium; b - Phialide; c - Apical portion of mycelial setae; d - Ascospores 
having angular, sinuately to deeply lobate head cells of the appressoria (Hansford 1961; Hosagoudar 1996, 2008; Hosagoudar et al. 1997).

Meliola wendlandiae Hosag. in Hosag. \& Goos, Mycotaxon 37: 251, 1990; Hosag., Meliolales of India, p. 340, 1996 (Fig. 126).

Materials examined: $\mathrm{HClO}$ 43693, TBGT 346; 319, HCIO 43635, TBGT 319, 18.xi.1998, on leaves of Wendlandia thyrsoidea (Roemer \& Schults) Steude (Rubiaceae), Chembra hills, coll. C.K. Biju; HClO 44390, TBGT 714, 6.xi.2001, Brahmagiri, coll. S. Shiburaj; HCIO 49905, TBGT 4057, 11.xi.2007, Wenlandia sp., Banasuramalai, coll. A. Chandraprabha; HCIO 50917, TBGT 4834, 23.xii.2008, coll. M.C. Riju.

Colonies amphigenous, mostly hypophyllous, subdense, subvelvety, up to $4 \mathrm{~mm}$ in diameter, confluent. Hyphae sinuous to crooked, branching opposite to irregular at acute angles, loosely to closely reticulate, cells $18-32 \times 6-10 \mu \mathrm{m}$. Appressoria alternate, spreading, antrorse, 20-30 $\mu \mathrm{m}$ long; stalk cells cuneate to cylindrical, 6-12 $\mu \mathrm{m}$ long; head cells ovate, narrow

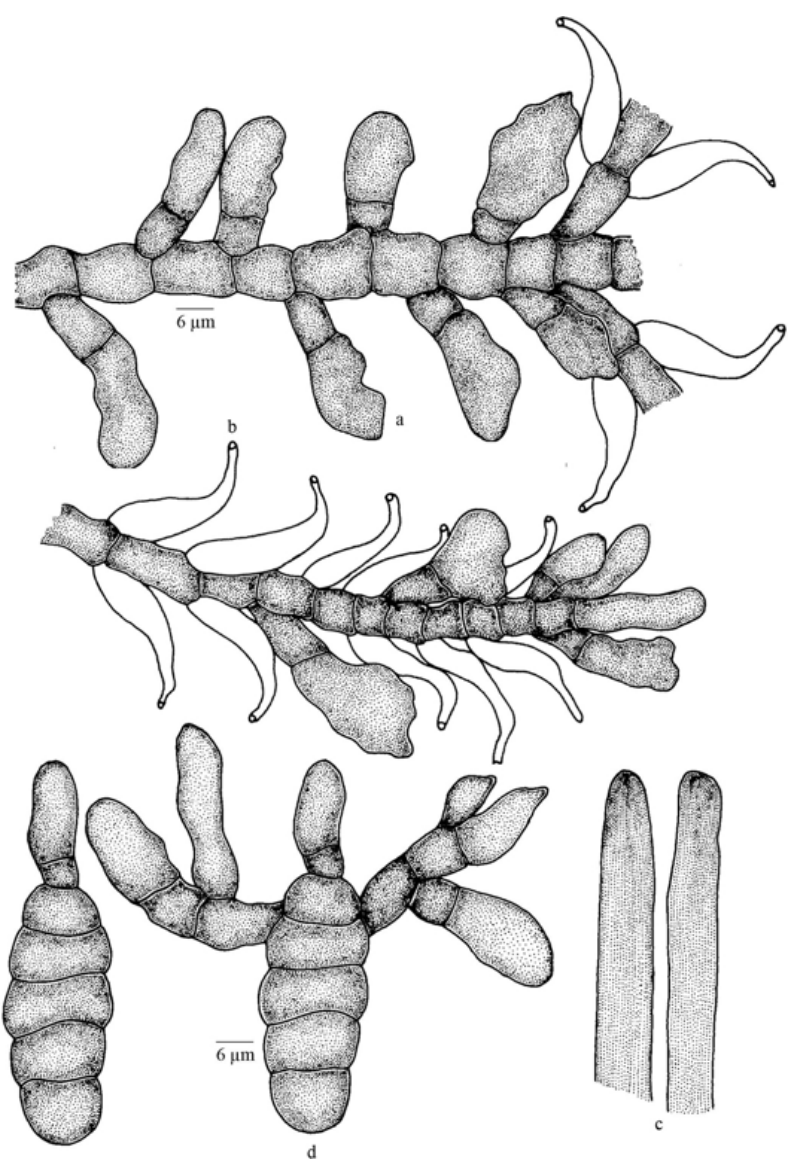

Figure 125. Meliola vatsavayae

a - Appressorium; b - Phialide; c - Apical portion of mycelial setae; d - Ascospores towards apex, slightly angular, entire, 15-18x12-14 $\mu \mathrm{m}$. Phialides borne on a separate mycelial branch, alternate to opposite, ampulliform, 14-20x8-10 $\mu \mathrm{m}$. Mycelial setae few, grouped around perithecia, simple, straight, acute to subacute at apex, up to $344 \mu \mathrm{m}$ long. Perithecia scattered, up to $168 \mu \mathrm{m}$ in diameter; ascospores obovoidal, 4-septate, constricted at the septa, 36$46 \times 12-18 \mu \mathrm{m}$.

This is the only species known on this host genus from India.

Meliola zanthoxyli Hansf., Proc. Linn. Soc. London 158: 37, 1946; Hansf., Sydowia Beih. 2: 386, 1961; Hosag., Meliolales of India, p. 341, 1996. (Fig. 127)

Materials examined: $\mathrm{HClO}$ 43634, TBGT 326, 2.vi.2000, on leaves of Zanthoxylum tetraspermum Wight \& Arn. (Rutaceae), Mannavan shola, coll. C.K. Biju; TBGT 6215, 6.ix.2009, Zanthoxylum sp., Wayanad, coll. M.C. Riju \& A. Sabeena.

Colonies epiphyllous, dense, up to $2 \mathrm{~mm}$ in diameter, rarely confluent. Hyphae straight to slightly flexuous, branching opposite to alternate at acute angles, closely reticulate and form solid mycelial mat, cells 19-27x8-10 $\mu \mathrm{m}$. Appressoria alternate, antrorse, 30-37 $\mu \mathrm{m}$ long; stalk cells cylindrical to cuneate, 11-18 $\mu \mathrm{m}$ long; head cells globose, ovate, stellately sublobate to lobate, 19-21x19-26 $\mu \mathrm{m}$. Phialides mixed with appressoria, alternate to opposite, ampulliform, 17-27x8-11 $\mu \mathrm{m}$. Mycelial setae densely scattered all over the colonies, simple, sickle-shaped, curved to very closely arcuate, acute to obtuse at the tip, up to $335 \mu \mathrm{m}$ long. Perithecia

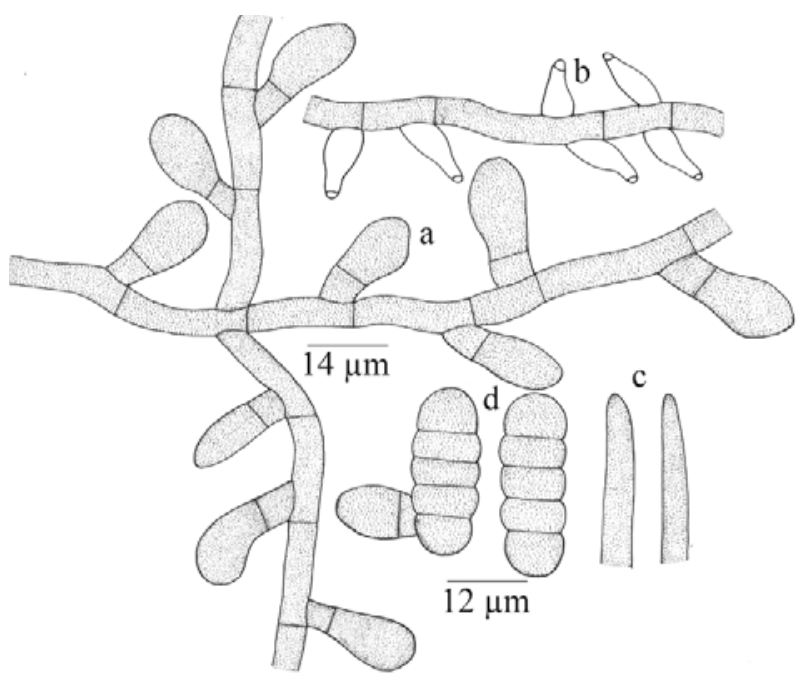

Figure 126. Meliola wendlandiae

a - Appressorium; b - Phialide; c - Apical portion of mycelial setae; d - Ascospores 
loosely to closely scattered, up to $250 \mu \mathrm{m}$ in diameter; ascospores oblong, 4-septate, constricted at the septa, 50-53×17-23 $\mu \mathrm{m}$.

This species occurs throughout the Western Ghats of Peninsular India and was also associated with Asterina zanthoxyli Yamam.

Meliola ziziphi Hansf. \& Thirum., Farlowia 3: 299, 1948; Hansf., Sydowia Beih. 2: 368, 1961; Thite \& Kulkarni, J. Shivaji Univ. 6: 163, 1972; Hosag. \& Goos, Mycotaxon 37: 251, 1990; Hosag., Crypt. Bot. 2/3: 187, 1991; Meliolales of India, p. 342, 1996. (Fig. 128).

Materials examined: HClO 50715, TBGT 4632, 6.xi.2009, on leaves of Ziziphus sp. (Rhamnaceae), Chennalode, coll. A. Sabeena \& M.C. Riju; TBGT 6196, 26.iii.2009, Kandeykayal, coll. M.C. Riju.

Colonies amphigenous, mostly epiphyllous, thin, up to $5 \mathrm{~mm}$ in diameter, confluent. Hyphae straight to substraight, branching alternate to opposite at acute angles, loosely reticulate, cells $20-38 \times 6-8 \mu \mathrm{m}$. Appressoria alternate to opposite, straight, spreading, antrorse, 10-14 $\mu \mathrm{m}$ long; stalk cells cylindrical to cuneate, 2-6 $\mu \mathrm{m}$ long; head cells globose, entire, 8-10 $\mu \mathrm{m}$. Phialides mixed with appressoria, alternate to opposite, ampulliform, 16-18x6-8 $\mu \mathrm{m}$. Mycelial setae scattered and grouped around perithecia, straight, simple, acute to variously dentate at the tip, up to $342 \mu \mathrm{m}$ long. Perithecia scattered, up to $116 \mu \mathrm{m}$ in diameter; ascospores ellipsoidal, 4-septate, constricted at the septa, $30-32 \times 10-12 \mu \mathrm{m}$.

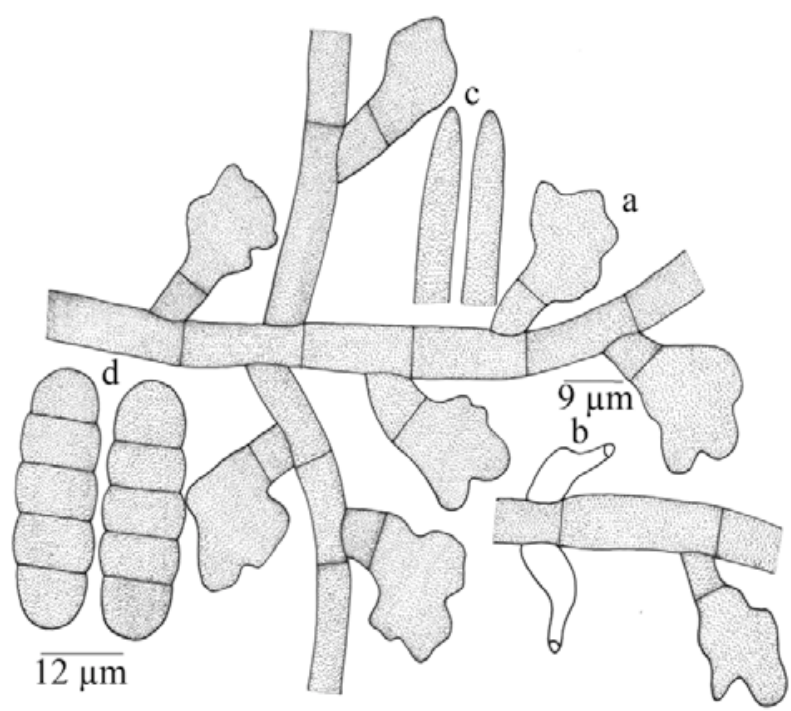

Figure 127. Meliola zanthoxyli

a - Appressorium; b - Phialide; c - Apical portion of mycelial setae; d - Ascospores
This is the only species known on this host genus

\section{Materials to be identified}

\section{Meliola sp.}

Materials examined: $\mathrm{HClO}$ 45097, TBGT 1152, 21.iv.2003, on Litsea deccanensis, Periya, Wyanad, coll. G. Rajkumar \& P.A. Jose; HClO 45270, TBGT 1308, 18.iv.1999, on Allophyllus concanicus, Chembra, coll. C.K. Biju; HClO 48179, TBGT 2915, 10.xi.2007, Allophyllus sp., $16^{\text {th }}$ mile, Padinharathara.

\section{MELIOLINACEAE}

This family constitutes a single genus, Meliolina, comprising 36 species (Hughes, 1993). However, the present study represents a single species.

Meliolina pulcherrima (H. Sydow \& P. Sydow) H. Sydow \& P. Sydow, Ann.Mycol. 12: 553, 1914 (Image 11).

Material examined: HCIO 44895, TBGT 1124, 21.iv.2003, on leaves of Syzygium cumini L. (Myrtaceae), Periya, coll. G. Rajkumar \& P.A. Jose; HCIO 49996, TBGT 4148, 17.ix.2008, Syzigium sp., Periya, coll. P.J. Robin.

Colonies hypophyllous, black, thick, wooly, velvety,

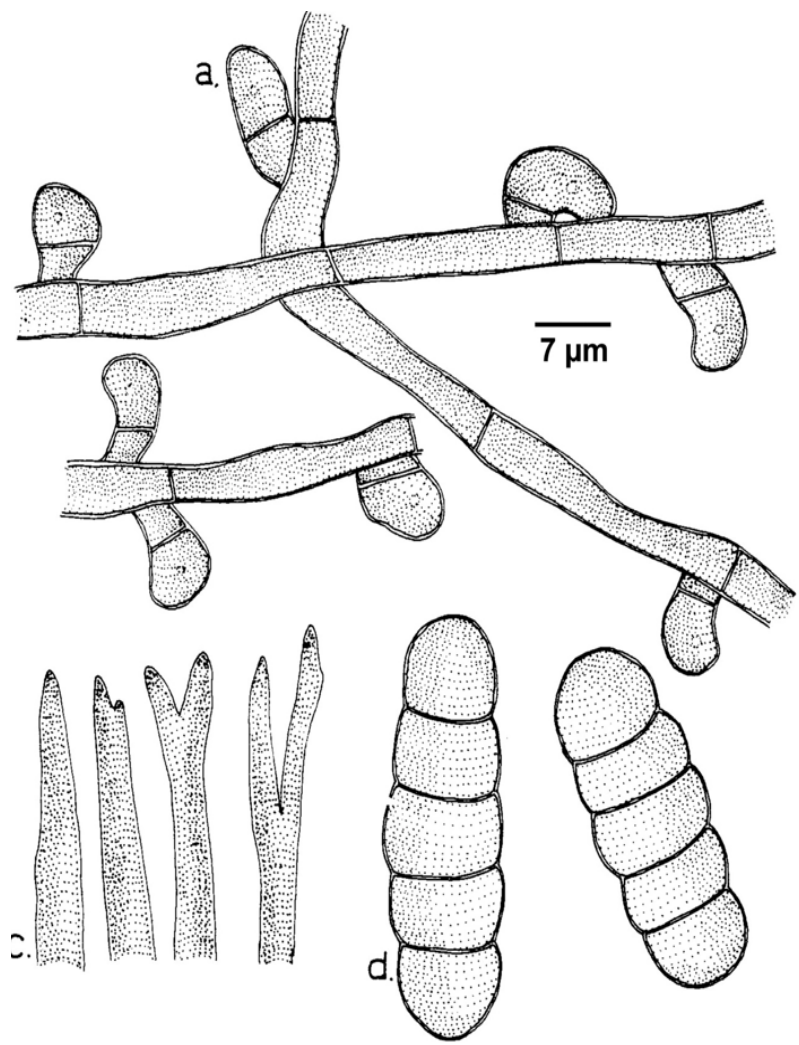

Figure 128. Meliola ziziphi

a - Appressorium; b - Phialide; c - Apical portion of mycelial setae; d - Ascospores 
3-5 $\mathrm{mm}$ in diameter, a pinkish or discoloration occurs on the opposite surface of the leaves, and some times it is also evident on the upper surface. Superficial hyphae form a cushion of closly interwoven, irregularly branched, brown to dark brown hyphae, septate, cells 32-43 $\mu \mathrm{m}$ long and 7-10 $\mu \mathrm{m}$ wide. Phialophores arising as branches of the compact superficial hyphae, densely crowded, up to $128 \mu \mathrm{m}$ long, flexuous, simple, or 1 or 2 dichotomously or irregularly branched and clearly differeniated into stalk and branches, 5-7 $\mu \mathrm{m}$ wide, brown towards the base, narrowing slightly to $3 \mu \mathrm{m}$ wide and brown to pale brown towards the ends of the branches which bear a single phialide. Philides straight to curved, funnel shaped, 30-37x3-6 $\mu \mathrm{m}$. Phialoconidia scanty and minute. Perthecia black. Perthecial phialophores absent. Paraphysis persistant, more or less cylindrical, septate, often in pairs on a short basal cell, 3-5 $\mu \mathrm{m}$ wide towards the base, tapering to 2-3 $\mu \mathrm{m}$ at the rounded apex. Asci obovoid, and eight spored, upto $45 \mu \mathrm{m}$ long; ascospores ellipsoidal, brown, 3-septate, scarsely constricted at the septa, 20-36x7-11 $\mu \mathrm{m}$. Polar caps hyaline.

\section{Order Asterinales}

Leaf parasites. Mycelium ectophytic, with or without appressoria, nutrient mycelium and leaf permeating stroma present. Ascomata ectophytic, dimidiate, orbicular, elliptic, elongated, $\mathrm{X}$ or $\mathrm{Y}$ shaped, with radiating cells, astomatous, orbicular thyriothecia dehisce stellately at the center, elliptic, elongated, $X$ or Y-shaped thyriothecia dehisce vertically with a central suture; asci globose, spherical, oval or rarely cylindrical, octosporous, bitunicate; ascospores two to many septate, conglobate, hyaline, brown at maturity.

Type Family: Asterinaceae.

\section{Key to the families of the order Asterinales}

1. Thyriothecia orbicular, dehisce stellately at the center. Asterinaceae

1. Thyriothecia oval to elongated, $X$ or $Y$ shaped, dehisce longitudinally at the center.

Lembosiaceae

\section{The family Asterinaceae}

Asterinaceae Hansf., Mycol. Pap. 15: 189, 1946; Arx \& Muller, Stud. Mycol. 9: 40, 1975; Hosag., Abraham \& C.K. Biju, J. Mycopathol. Res. 39: 62, 2001; Hosag., Mycosphere 2(5): 625, 2012.

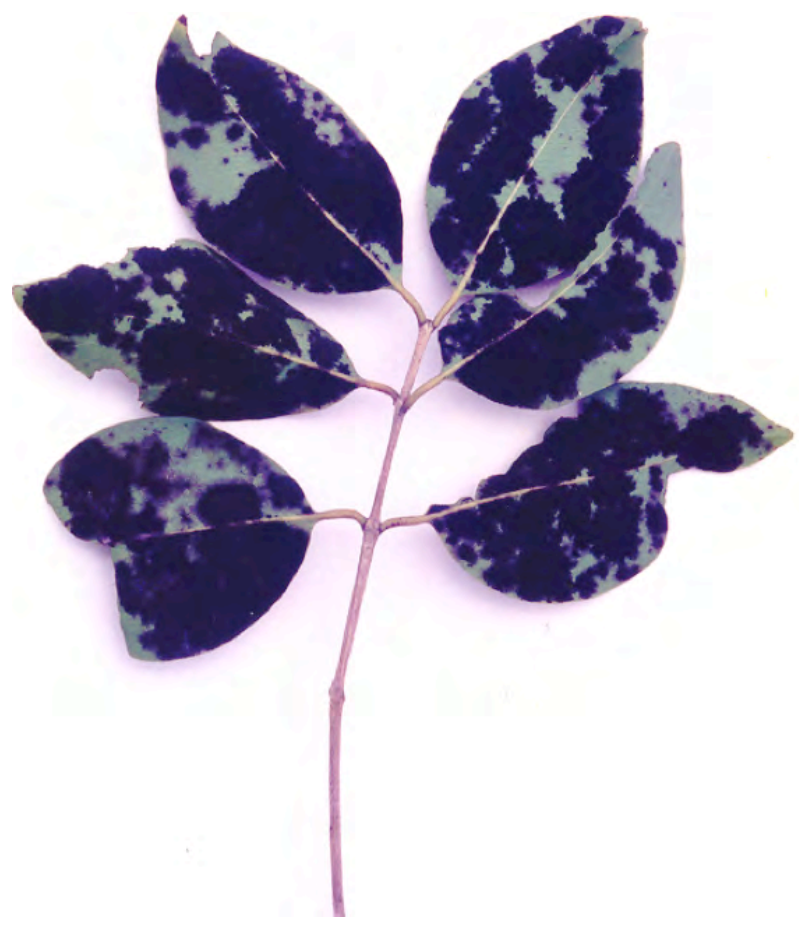

Image 11. Meliolina pulcherrima-Infected leaves

Leaf parasites. Mycelium ectophytic, with or without appressoria, nutrient mycelium and leaf permeating stroma present. Ascomata ectophytic, dimidiate, orbicular with radiating cells, astomatous, dehisce stellately at the center; asci globose, spherical, octosporous, bitunicate; ascospores two to many septate, conglobate, hyaline to brown.

Type Genus: Asterina Lev.

\section{KEY TO THE GENERA}

1. Appressoria present... 2

1. Appressoria absent.. Prillieuxina

2. Appressoria in clusters. Ishwaramyces

2. Appressoria not so. .4

3. Ascospores two septate and one cell taper.......

3. Ascospores not so

Meliolaster

4. Appressoria intercalary. Asterolibertia

4. Appressoria lateral. Asterina

Asterina Lev., Ann. Sci. Nat. Bot. Ser., 3(3):57, 1845; Hansf., Mycol. Pap. 15: 189, 1946b; Arx \& Muller, Stud. 
Mycol. 9: 42, 1975; Hosag., Abraham \& C.K. Biju, J. Mycopathol. Res. 39: 62, 2001; Hosag., Chandraprabha \& Agarwal, Asterinales of Kerala, p. 32, 2011; Hosag., Mycosphere 2(5): 632, 2012.

Dimerosporium Fuckel, Symb. Mycol. p. 86, 1870.

Asterella (Sacc.) Speg. ex Sacc., Syll. Fung. 9: 393, 1891 non P. de Beauvois 1805.

Myxasterina Hohnel, Sber. Akad. Wiss. Wien 118: 870, 1909.

Englerulaster Hohnel, Sber. Akad. Wiss. Wien 119: 454, 1910.

Parasterina Theiss., Sydow \& Sydow, Ann. Mycol. 15: 246, 1917.

Calothyriolum Speg., Boln Acad. nac. Cien. Cordoba 23: 498, 1919.

Opeasterina Speg., Boln Acad. nac. Cien. Cordoba 23: 498, 1919.

Englera F. Stev. in Stev. \& Ryan, Illinois. Biol. Monogr. 17: 45, 1939.

Leaf parasites. Mycelium ectophytic, appressoria lateral, setae absent. Thyriothecia orbicular with radiating cells, astomatous, dehisce stellately at the center; asci globose, octosporous, bitunicate; ascospores conglobate, uniseptate, brown.

Type sp.: A. melastomatis Lév.

Anamorphs: Asterostomella

Speg., Clasterosporium Schwein, Mahanteshamyces Hosag.

\section{KEY TO THE SPECIES}

(Based on host families)

\section{Acanthaceae}

\section{Asterina}

1. Appressoria entire.

1. Appressoria lobed

Asterina betonicae

Alangiaceae

Asterina tertia

\section{Asterina}

Single species. Asterina perpusilla

\section{Aristolochiaceae}

\section{Asterina}

Single species.

Asterina thotteae

\section{Asclepiacaceae}

\section{Asterina}

1. On Wattakakka Asterina travancorensis

1. On Gymnema Asterina gymnemae

\section{Caprifoliaceae}

Asterina

Single species

Asterina viburnicola

\section{Asterina}

Single species. Asterina microtropidicola

Chloranthaceae

\section{Asterina}

Single species. Asterina sarcandrae

Dipterocarpaceae

Asterolibertia

On Vateria

Asterolibertia vateriae

\section{Elaeocarpaceae}

\section{Asterina}

1. Appressoria ovate, oblong, ascospores less than $30 \mu \mathrm{m}$ long................Asterina elaeocarpi var. ovalis 1. Appressoria ovate, conoid, rounded at the apex, ascospores more than $30 \mu \mathrm{m}$ long.

Asterina gamsii

\section{Erythropalaceae \\ Asterina}

Single species. Asterina erythropalicola

\section{Euphorbiaceae \\ Asterina}

On Aporusa. Asterina aporusae

On Glochidion Asterina lobulifera Sydow var. indica

\section{Meliolaster}

Single species..... Meliolaster aporusae

Flacourtiaceae

Single species.

Ishwaramyces

Single species. Ishwaramyces flacourtiae

\section{Gentianaceae}

\section{Asterina}

Single species. Asterina enicostematis

\section{Lauraceae}

Asterina

1. On Cryptocarya.............Asterina cryptocariicola 1. On Litsea. Asterina litseae-ligustrinae

\section{Loranthaceae}

\section{Asterina}

Single species. Asterina deightonii

\section{Prillieuxina}

Single species. Prillieuxina anamirtae

\section{Magnoliaceae}

\section{Asterina}

1. Ascospores $22-25 \times 10-13 \mu \mathrm{m}$

\section{Asterina micheliifolia}

1. Ascospores $25-33 \times 15-18 \mu \mathrm{m}$ 
Asterina micheliigena

\section{Malvaceae}

\section{Asterina}

Single species Asterina hibisci

\section{Melastomataceae}

\section{Asterina}

Single species Asterina memecylonis

\section{Meliaceae}

\section{Asterina}

Asterina cipadessae

$1 . \quad$ On Trichilia

\section{Myrtaceae}

\section{Asterina}

1. Appressoria unicellular...

Asterina claviflori

1. Appressoria bicellular..........Asterina jambolana Oleaceae

\section{Asterina}

1.

On Ligustrum.

Asterina ligustricola

1. On Jasminum sp. 2

2. Appressoria opposite and alternate.

2.

Asterina erysiphoides

\section{Passifloraceae}

\section{Asterina}

Single species. Asterina adeniicola

Piperaceae

\section{Asterina}

1. On Lepianthes .................Asterina lepianthis

1. On Piper

\section{Ranunculaceae}

\section{Asterina}

Single species Asterina naraveliae

\section{Rubiaceae}

\section{Prillieuxina}

Single species Prillieuxina ixorigena

\section{Rutaceae}

\section{Asterino}

1. On Acronychia Asterina acronychiae

1. On other hosts Asterina piperina

2. Appressoria alternate and about 10-12\% opposite, on clausena... Asterina clausenicola

2. Appressoria not so ...3

3. Appressoria alternate to unilateral.

Asterina toddaliae

3. Appressoria not so. 4

4. Ascospores conglobate, $25-28 \times 14-18 \mu \mathrm{m}$............ ..................................................Asterina glycosmidis 4. Ascospores oblong, conglobate 14-19x7-10 $\mu \mathrm{m}$ Asterina glycosmidigena

\section{Sabiaceae}

Asterina

Single species Asterina sabiacearum

Santalaceae

\section{Asterina}

Single species Asterina congesta

Symplocaceae

\section{Asterina}

Single species Asterina indica

Tiliaceae

\section{Asterina}

Single species. Asterina triumfetticola

\section{Ulmaceae}

\section{Asterina}

Single species Asterina dallasica

Verbenaceae

\section{Asterina}

Single species. Asterina pusilla

\section{Description to species}

Asterina acronychiae Hosag. \& Goos, Mycotaxon 59: 150, 1996; Hosag., H. Biju \& Appaiah, J. Mycopathol. Res. 44: 5, 2006; Hosag., Chandra. \& Agarwal, Asterinales of Kerala, p. 32, 2011; Hosag., Mycosphere 2(5): 632, 2012. (Fig. 129)

Materials examined: $\mathrm{HClO}$ 45148, TBGT 1203, 19.xi.1999, on leaves of Acronychia pedunculata (L.) Miq. (Rutaceae), Banasuranmala, coll. C.K. Biju; $\mathrm{HClO} 48324$, TBGT 2972, 10.xi.2007, Acronychia sp. Padinharathara, coll. M.C. Riju; HClO 45202, TBGT 1238, 16.iv.1999, Acronychia laurifolia Blume, Banasuran mala, coll. C.K. Biju.

Colonies epiphyllous, dense, crustose, up to $3 \mathrm{~mm}$ in diameter, confluent. Hyphae straight to substraight, branching opposite at acute angles, loosely reticulate, cells $13-21 \times 3-7 \mu \mathrm{m}$. Appressoria mostly opposite, rarely solitary, unicellular, ovate, oblong, entire, angular to slightly lobate, 6-9x5-8 $\mu \mathrm{m}$. Thyriothecia scattered, orbicular, up to $132 \mu \mathrm{m}$ in diameter; margin fringed, stellately dehisced at the centre; asci numerous, globose, octosporous, 35-42 $\mu \mathrm{m}$ in diameter; ascospores brown, conglobate, uniseptate, deeply constricted at the septum, 20-24x9-12 $\mu \mathrm{m}$, wall minutely echinulate.

Asterina adeniicola Hosag. \& Kamar., Zoos print J. 21: 2303, 2006; Hosag., Chandraprabha \& Agarwal, Asterinales of Kerala, p.35, 2011; Hosag., Mycosphere 2(5): 633, 2012 (Fig. 130)

Materials examined: $\mathrm{HClO} 44792$ (holotype), 
TBGT 1029 (isotype), 17.xii.2002, on leaves of Adenia hondala (Gaertn.) Wilde (Passifloraceae), Periya, coll. M. Kamarudeen.

Colonies epiphyllous, dense, crustose, up to $1 \mathrm{~mm}$ in diameter, confluent. Hyphae strongly flexuous to rarely crooked, branching alternate to irregular at acute to wide angles,loosely to closely reticulate, cells 1115x4-7 $\mu \mathrm{m}$. Appressoria alternate, about 3\% opposite, unicellular, globose, ovate, sessile to slightly stipitate, mostly 2-3-lobate, often angular to rarely entire, 6-9x6-8 $\mu \mathrm{m}$. Thyriothecia loosely scattered to connate at the centre of the colony, orbicular, stellately dehisced at the centre, up to $75 \mu \mathrm{m}$ in diameter, margin crenate; asci few, globose, octosporous, up to $30 \mu \mathrm{m}$ in diameter; ascospores oblong, conglobate, uniseptate, slightly constricted at the septum, lower cell slightly larger, 1416x6-8 $\mu \mathrm{m}$, wall smooth.

The released ascospores readily germinated and formed colonies. Asterina adeniae Hansf. is known on Adenia lobata from Uganda (Hansford, 1945). However, Asterina adeniicola differs from it in having dense and crustose colonies, $3 \%$ opposite and smaller appressoria, smaller thyriothecia and shorter ascospores.

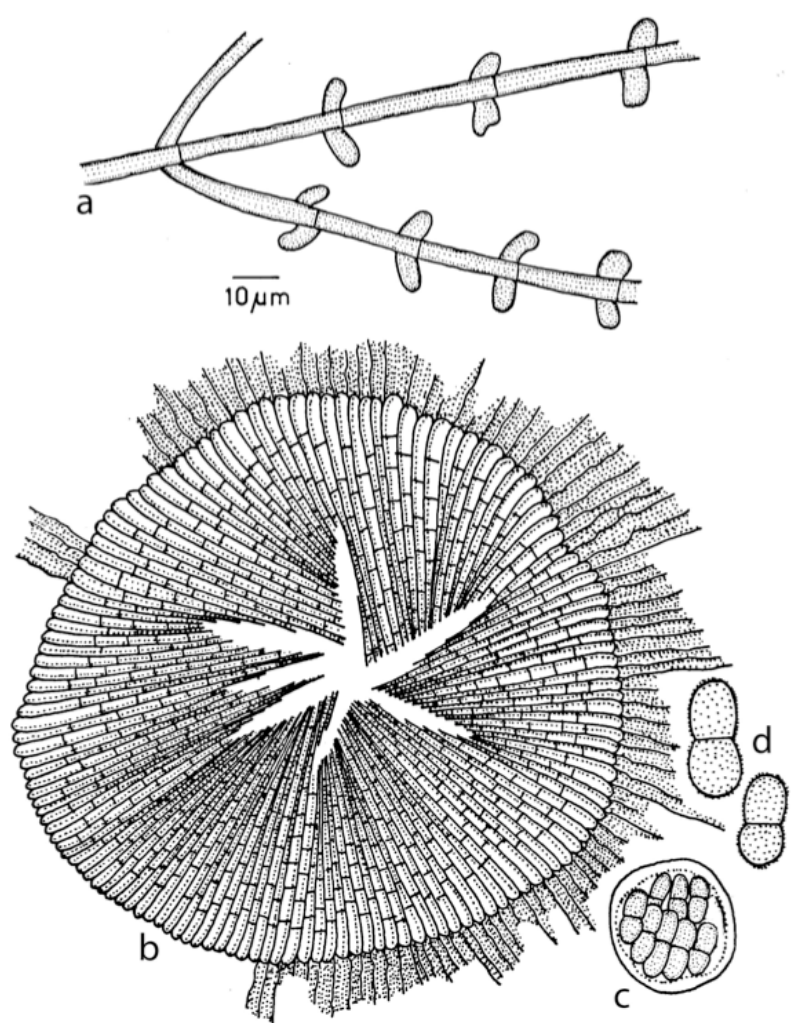

Figure 129. Asterina acronychiae

a - Appressorium; b - Thyriothecium; c - Ascus; d - Ascospores
Asterina aporusae Hansf., Reinwardtia 3: 129, 1954; Hosag. \& Agarwal, Indian Phytopath. 56: 98, 2003; Hosag. \& Appaiah, J. Mycopathol. Res. 43:168, 2005; Hosag., Chandraprabha \& Agarwal, Asterinales of Kerala, p. 37, 2011; Hosag., Mycosphere 2(5): 636, 2012 (Fig. 131).

Materials examined: $\mathrm{HClO}$ 49219, TBGT 3458, 15.ii.2009, on leaves of Aporusa lindleyana (Wight) Baill. (Euphorbiaceae), Begur, coll. Jacob Thomas et al.; HCIO 49633, TBGT 3875, 17.ix.2008, Periya, coll. M.Harish \& P.J. Robin; HClO 50377, TBGT 4294, 4.xi.2009, Padinharathara, coll. A. Sabeena \& M. C. Riju.

Colonies amphigenous, minute, thin, up to $2 \mathrm{~mm}$ in diameter, confluent. Hyphae straight, flexuous to crooked, branching alternate, opposite to irregular at acute angles, loosely to closely reticulate, cells 10-12×3-5 $\mu \mathrm{m}$. Appressoria opposite, subopposite, unilateral to rarely alternate, cylindrical, ovate, oblong, entire, rounded at the apex, 8-10x3-5 $\mu \mathrm{m}$. Thyriothecia scattered to grouped, orbicular, up to $160 \mu \mathrm{m}$ in diameter, crenate to slightly fimbriate at the margin, fringed hyphae flexuous and devoid of appressoria, thyriothecia initially longitudinally dehisced but later and frequently stellately dehisced at the centre; asci globose to ovate, octosporous, up to $30 \mu \mathrm{m}$ in diameter; ascospores brown, oblong, conglobate, 1-septate, constricted at the

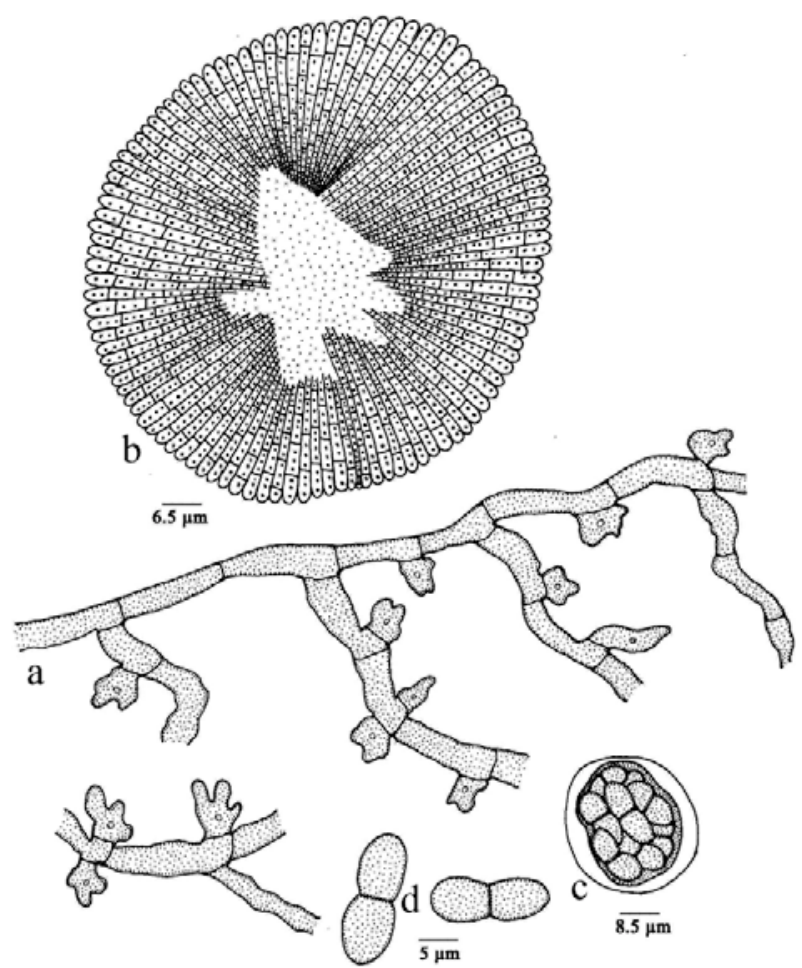

Figure 130. Asterina adeniicola

a - Appressorium; b - Thyriothecium; c - Ascus; $d$ - Ascospores 
septum, 11-13x4-5 $\mu \mathrm{m}$, wall smooth.

This species is often associated with Meliolaster aporusae Hosag. et al. but can be distinguished based on the morphology of appressoria and ascospores.

Asterina arkemibeyi Hosag., Sabeena \& S.P. Mathew, Journal of Threatened Taxa 5(2): 3670, 2013 (Fig. 132).

Materials examined: TBGT 6648,6.iii.2008, on leaves of Flacourtia montana Graham (Flacourtiaceae), Palcherry, coll. P.J. Robin et al.

Colonies hypophyllous, thin to subdense, up to $2 \mathrm{~mm}$ in diameter, confluent. Hyphae flexuous, branching opposite to alternate at acute to wide angles, loosely reticulate, cells $16-27 \times 3-4 \mu \mathrm{m}$. Appressoria unicellular, mostly alternate, often sub-opposite to opposite, narrowly ovate, elongated, tubular, entire to sublobate, straight to variously curved, $6-13 \times 3-5 \mu \mathrm{m}$. Thyriothecia scattered to connate, orbicular, up to $130 \mu \mathrm{m}$ in diameter, margin crenate to fimbriate, stellately dehisced at the centre; asci, octosporous, globose, up to $30 \mu \mathrm{m}$ in diameter; ascospores, conglobate, 1-septate, constricted at the septum, 17-20x7-10 $\mu \mathrm{m}$, wall smooth.

Hofmann \& Piepenbring (2008) showed the connection between Mahanteshamyces (Hosag.) and Asterina Lév. The former genus is an anamorph of the latter. The present collection reveals both anamorph and teleomorph in the same colonies, which supports and confirms the observations of Hofmann \& Piepenbring (2008). The teleomorph belongs to the genus Asterina and differs from the all known Asterina species on the members of the family Flacourtiaceae in having ovate, elongated, tubular, entire to sublobate and straight to variously curved appressoria (Hosagoudar \& Abraham 2000; Hosagoudar 2012).

Asterina betonicae Hosag. \& Goos, Mycotaxon 59: 153, 1996; Hosag., Chandraprabha \& Agarwal, Asterinales of Kerala, p.46, 2011; Hosag., Mycosphere 2(5): 644, 2012 (Fig. 133).

Materials examined: $\mathrm{HClO}$ 48237, TBGT 2975, 1.xi.2007, on leaves of Justicia betonica L. (Acanthaceae), Pakshipathalam, coll. A. Chandraprabha.

Colonies epiphyllous, thin to subdense, up to $2 \mathrm{~mm}$ in diameter, rarely confluent. Hyphae straight to substraight, branching opposite to irregular at acute to wide angles, loosely reticulate, cells $12-25 \times 5-7 \mu \mathrm{m}$. Appressoria alternate, about $30 \%$ opposite, unicellular, ovate, mammiform, seated on broad base, sessile, entire, 6-10x4-6 $\mu \mathrm{m}$. Thyriothecia loosely scattered, orbicular, up to $220 \mu \mathrm{m}$ in diameter, margin crenate to

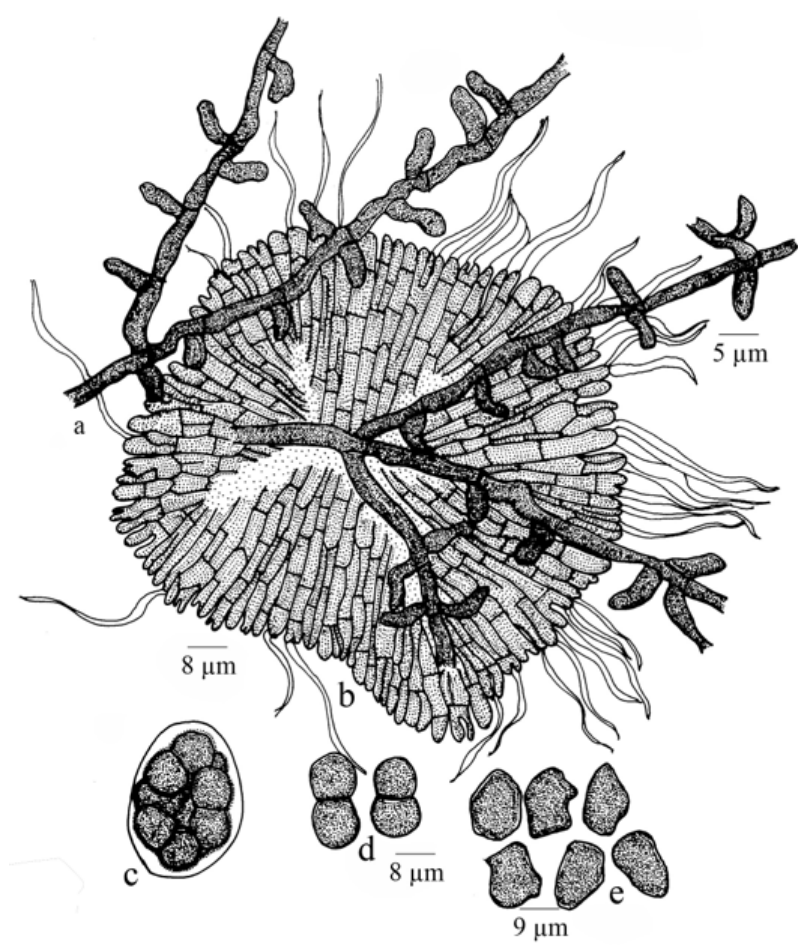

Figure-132. Asterina arkemibeyi

a - Appressorium; b - Thyriothecium; c - Ascus; d - Ascospores; e Pycnothyriospores

Figure 131. Asterina aporusae 
fimbriate, fringed hyphae flexuous, dehisced stellately at the centre; asci many, octosporous, globose, 31-35 $\mu \mathrm{m}$ in diameter; ascospores brown, conglobate, 1-septate, 15-19x9-10 $\mu \mathrm{m}$, wall smooth.

Alternate, opposite and entire head cells of the appressoria distinguishes this species from the other Asterina species reported on the members of the family Acanthaceae.

Asterina cipadessae Yates, Philippine J. Sci. 12: 371, 1917; Hosag., Balakr. \& Goos, Mycotaxon 60: 172, 1996; Hosag. \& Abraham, J. Econ. Taxon. Bot. 4: 574, 2000; Hosag., Zoos' Print J. 18: 1283, 2003; 21: 2326, 2006; Hosag., H. Biju \& Appaiah, J. Mycopathol. Res. 44: 6, 2006; Hosag., Chandraprabha \& Agarwal, Asterinales of Kerala, p.51, 2011; Hosag., Mycosphere 2(5): 654, 2012.

Parasterina cipadessae (Yates) Mendoza, Philippine J. Sci. 49: 446, 1932 (Fig. 134).

Materials examined: $\mathrm{HClO}$ 49207, TBGT 3446; $\mathrm{HClO}$ 49208, TBGT 3447, 15.ii.2009, on leaves of Cipadessa baccifera (Roth.) Miq. (Meliaceae), Begur, coll. Jacob Thomas et al.; HClO 49221, TBGT 3460, 14.ii.2009, Thirunelly, coll. Jacob Thomas et al HCIO 50356, TBGT 4273, 6.xi.2009, Padinharathara, coll. A. Sabeena \& M.C. Riju; TBGT 5724, 23.iii.2008, Padinharathara, coll. M.C. Riju.

Colonies epiphyllous, dense, up to $2 \mathrm{~mm}$ in diameter, confluent. Hyphae straight, flexuous to crooked, branching mostly opposite at acute angles loosely to closely reticulate, cells $12-34 \times 4-6 \mu \mathrm{m}$. Appressoria alternate and opposite, sessile, entire to mostly lobate, 9-13 $\times 7-10 \mu \mathrm{m}$. Thyriothecia scattered to grouped, often connate, orbicular, up to $202 \mu \mathrm{m}$ in diameter, dehisce stellately at the center, margin crenate, rarely slightly fimbriate; asci many, ovate to globose, eight spored, 30-44×30-35 $\mu \mathrm{m}$; ascospores conglobate, deep brown, 1-septate, slightly constricted at the septum, 24-28x12$15 \mu \mathrm{m}$, upper cell ovate and lower cell globose, wall smooth. Pycnothyria many, similar to the thyriothecia, smaller; pycnothyriospores brown, ovoid to pyriform, 12-16x4-7 $\mu \mathrm{m}$.

This is the only species known on this host and is common in the Southern Western Ghats.

Asterina clausenicola Doidge, Trans. Royal Soc. South Africa 8: 263, 1920; Hosag., Indian J. Forestry 18: 274, 1995; Hosag., Chandraprabha \& Agarwal, Asterinales of Kerala, p. 52, 2011; Hosag., Mycosphere 2(5): 656, 2012 (Fig. 135).

Materials examined: $\mathrm{HClO} 44550$, TBGT 836, 8.i.2001, on leaves of Melicope lunu-ankenda (Gaertn.) T. Hartley
(Euodia lunu-ankenda (Gaertn.) Merr. (Rutaceae), Periya, coll. M. Kamarudeen.

Colonies epiphyllous, dense to subdense, crustose, up to $3 \mathrm{~mm}$ in diameter, rarely confluent. Hyphae substraight to flexuous, branching mostly opposite at acute angles, loosely reticulate, cells $18-31 \times 3-5$ $\mu \mathrm{m}$. Appressoria alternate and about $12 \%$ opposite, straight to curved, oblong to globose, unicellular, entire and bluntly conoid towards the apex, uni-to multilobate, 6-13x4-8 $\mu \mathrm{m}$. Thyriothecia scattered, rarely 2-3 connate, roughly circular in outline, up to $125 \mu \mathrm{m}$ in diameter, margin crenate to fimbriate, fringed hyphae flexuous, stellately dehisced at the center; asci globose, rarely ovate or oblong, hexasporous, 30-38 $\mu \mathrm{m}$ in diameter; ascospores brown, conglobate, oblong, 1-septate, strongly constricted at the septum, rounded at both ends, 18-22x10-12.5 $\mu \mathrm{m}$, wall smooth.

This species was recorded on Clausena anisata from South Africa (Doidge, 1942).

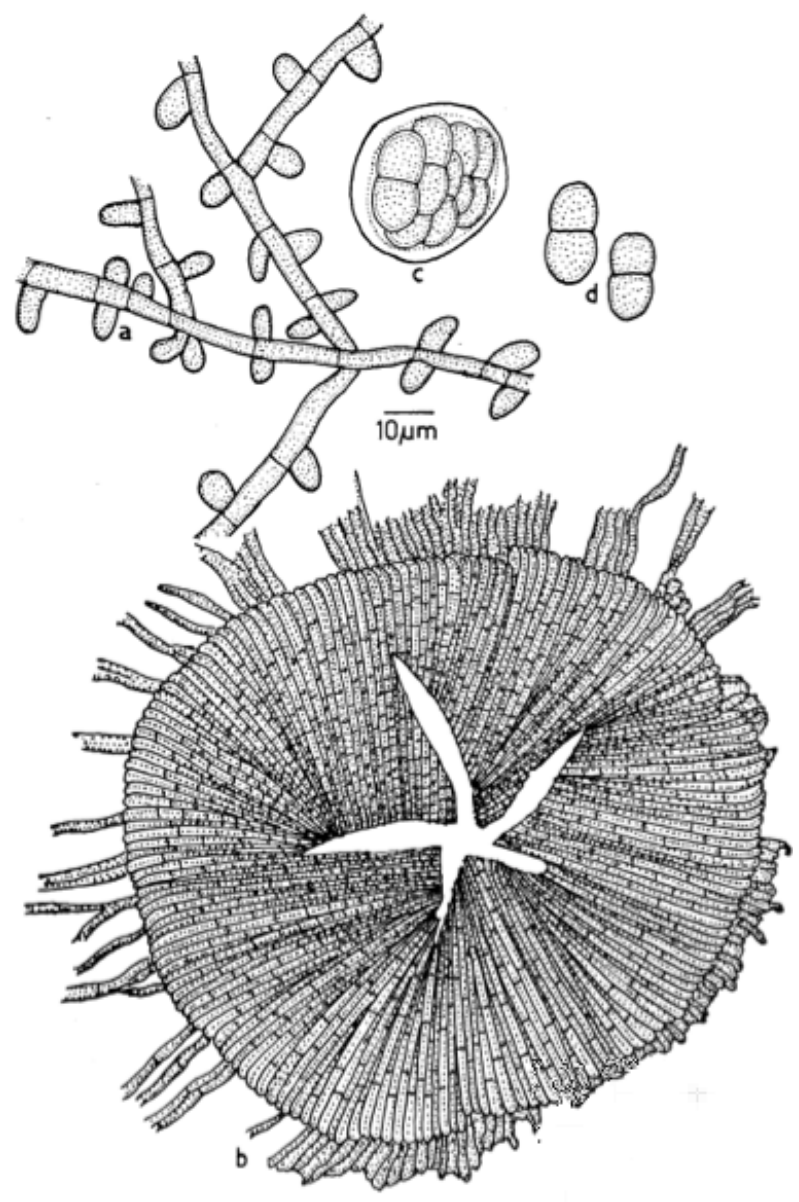

Figure 133. Asterina betonicae

a - Appressorium; b - Thyriothecium; c - Ascus; d - Ascospores 
Asterina claviflori Kar \& Maity, Trans. Brit. Mycol. Soc. 54: 441, 1970; Hosag., Chandraprabha \& Agarwal, Asterinales of Kerala, p.54, 2011; Hosag., Mycosphere 2(5): 657, 2012 (Fig. 136).

Materials examined: $\mathrm{HClO}$ 50725, TBGT 4642, 8.xii.2009, on leaves of Syzygium cumini (L.) Skeels (Myrtaceae), Chunkathara, coll. Sam P. Mathew; HCIO 50747, TBGT 4664, 5.xi.2009; HCIO 51066, TBGT 4983, 6.xii.2006, HCIO 49759, TBGT 3911, Syzygium sp., Gurukulam Botanical Garden, Periya, coll. M.C. Riju \& A. Sabeena et al.; TBGT 3934, 13.ii.2009, Thirunelly, coll. Jacob Thomas et al.; HCIO 49808, TBGT 3960, 15.ix.2008, Periya, coll. Robin et al.; HCIO 49971, TBGT 4123, 14.iii.2007, Puthuserrykadavu, coll. M.C. Riju; HCIO 50030, TBGT 4182, 6.ix.2006, Periya, coll. Gireesh et al.

Colonies epiphyllous, dense, up to $2 \mathrm{~mm}$ in diameter, confluent. Hyphae flexuous, branching alternate to irregular at acute to wide angles, loosely reticulate, cells 25-32x4-8 $\mu \mathrm{m}$. Appressoria alternate to unilateral, unicellular, ovate, oblong, cylindrical, antrorse to retrorse, straight to curved, entire, 9-18x6-8 $\mu \mathrm{m}$. Thyriothecia scattered, rarely connate, orbicular, up to $250 \mu \mathrm{m}$ in diameter, margin fimbriate, fringed hyphae

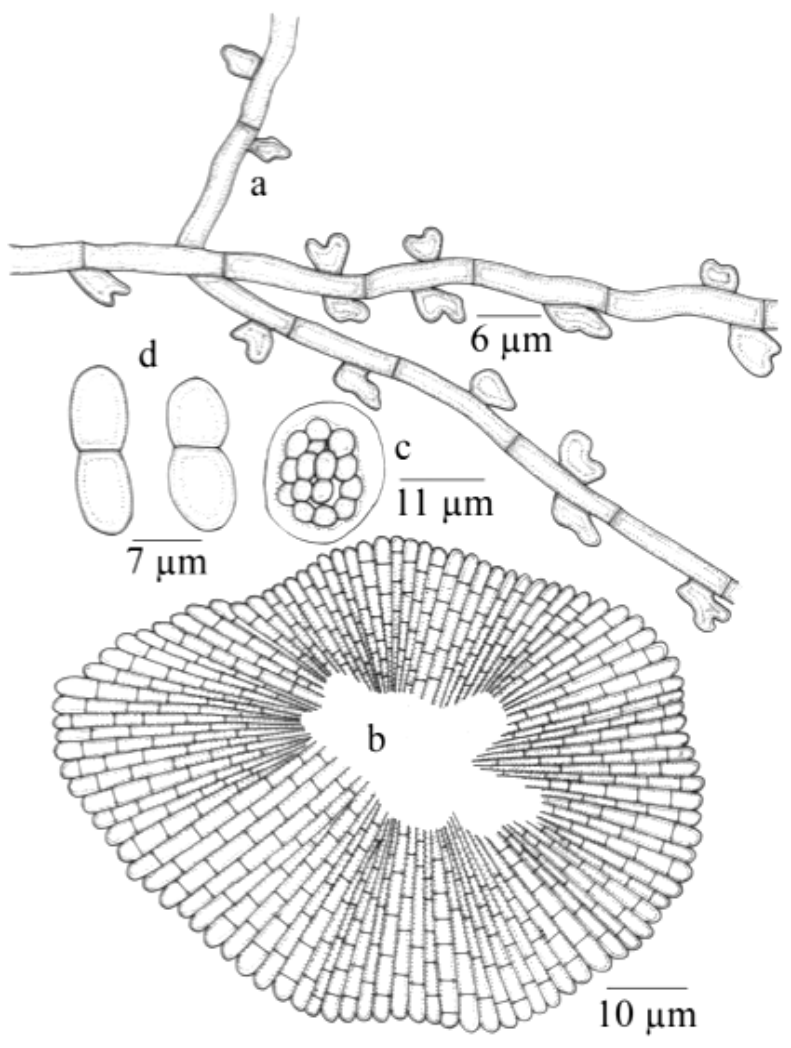

Figure 134. Asterina cipadessae

a-Appressorium; b - Thyriothecium; c - Ascus; d - Ascospores flexuous, stellately dehisced at the centre; asci few to many, ovate to globose, octosporous, 30-45 $\mu \mathrm{m}$ in diameter; ascospores oblong, brown, conglobate, uniseptate, constricted at the septum, 14-18x11-13 $\mu \mathrm{m}$, wall smooth to slightly verrucose.

About 30 species of the genus Asterina are known on the members of the family Myrtaceae. The unicellular appressoria matches with the assigned species. However, revision of this on Myrtaceae is needed.

Asterina congesta Cooke, Grevillea 8: 95, 1879; Hansf. \& Thirum., Farlowia 3: 305, 1948; Hosag., Balakr. \& Goos, Mycotaxon 59: 172, 1996; Hosag. Krishnan \& Abraham, New Botanist 24: 28, 1997; Hosag.,

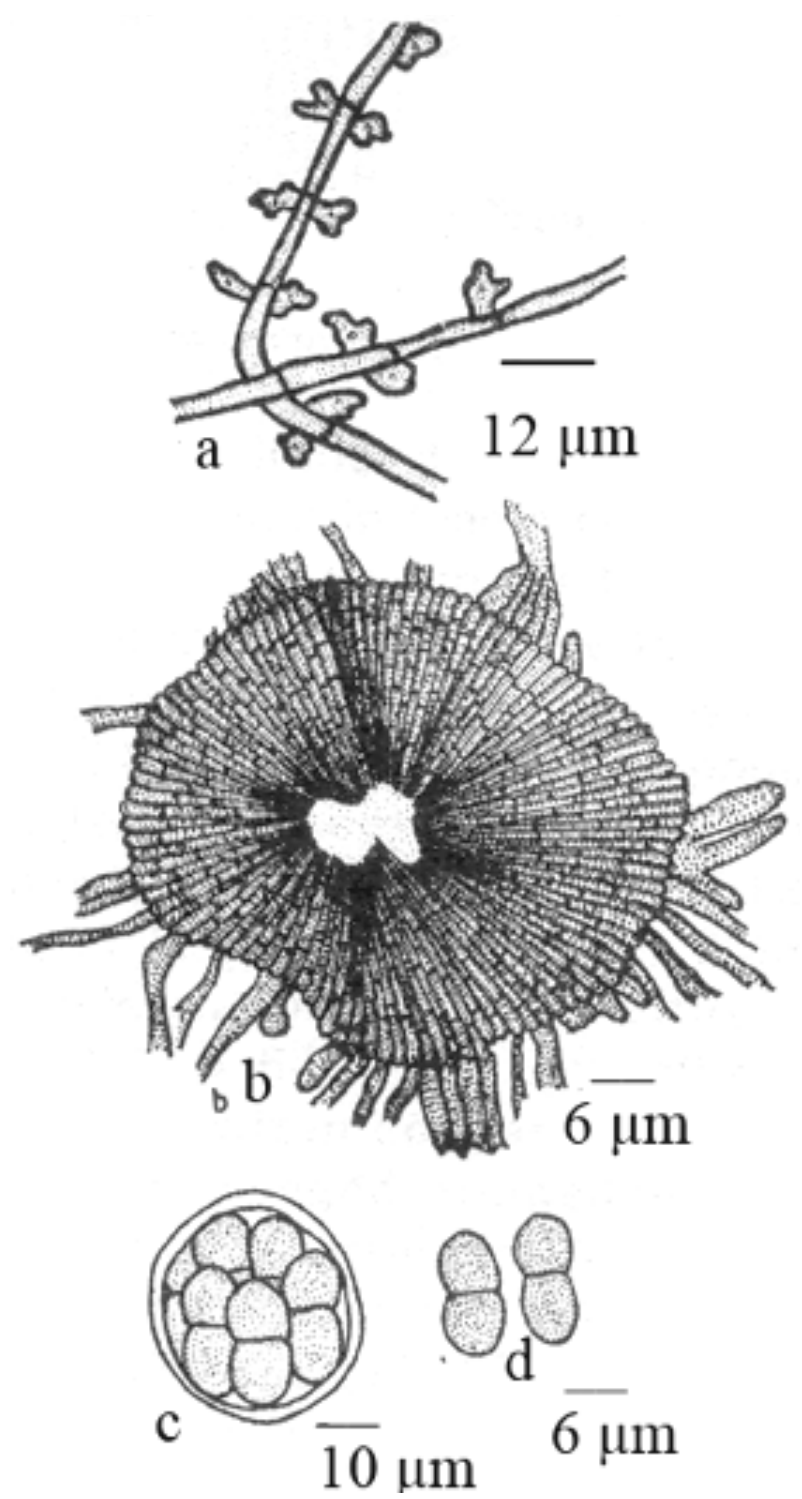

Figure 135. Asterina clausenicola

a - Appressorium; b - Thyriothecium; c - Ascus; $d$ - Ascospores 
Chandraprabha \& Agarwal, Asterinales of Kerala, p.57, 2011; Hosag., Mycosphere 2(5): 661, 2012 (Fig. 137).

Materials examined: $\mathrm{HClO}$ 49805, TBGT 3957, 15.ix.2008. on leaves of Santalum sp. (Santalaceae), Thirunelly, coll. Robin et al.; HCIO 50013, TBGT 4165, 20.ix.2008, Pulpally, coll. Gireesh et al.; HClO 48302, TBGT 3023, 30.x.2007, Thirunelly, coll. A. Chandraprabha.

Colonies initially epiphyllous, later on both surfaces of the leaves, caulicolous, often on tender stems, form a coating of black mat and are confluent. Hyphae straight to crooked, cells $10-15 \times 4-6 \mu \mathrm{m}$. Appressoria alternate to unilateral, unicellular, ovate to cylindrical, straight to curved, entire to sinuately lobate, 5-10x4$5 \mu \mathrm{m}$. Thyriothecia scattered, loosely aggregated, often coalesced, up to $130 \mu \mathrm{m}$ in diameter; asci many, aparaphysate, globose, octosporous, bitunicate,

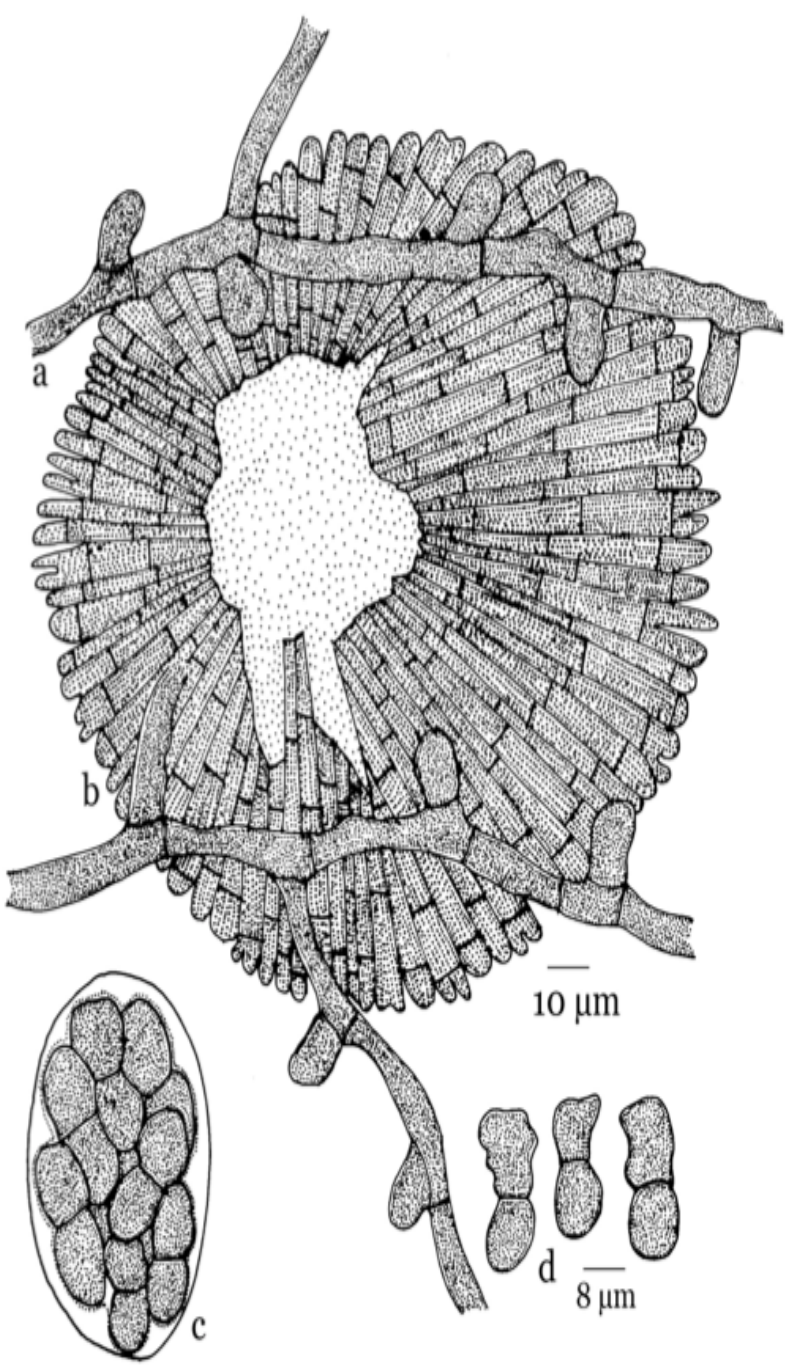

Figure 136. Asterina claviflori

a - Appressorium; b - Thyriothecium; c - Ascus; d - Ascospores
35-45×28-40 $\mu \mathrm{m}$; ascospores oblong, conglobate, uniseptate, slightly constricted at the septum, 1326x9-11 $\mu \mathrm{m}$, wall smooth. Pycnothyria scattered to connate, orbicular, up to $100 \mu \mathrm{m}$ in diameter, crenate to fimbriate at the margin, stellately dehisced at the centre; Pycnothyriospores pyriform to obpyriform, cinnamon brown, 17-20x8-10 $\mu \mathrm{m}$, wall smooth, often with a single hyaline band at the middle.

This fungus is very common throughout the Western Ghats of Peninsular India. Hansford \& Thirumalachar (1948) reported this species from Karnataka. Further, this is the first species of the genus Asterina known from India (Cooke, 1884).

Asterina cryptocariicola Hosag., C.K. Biju \& Abraham, Indian Phytopath. 54: 137, 2001; J. Mycopathol. Res. 40:195, 2002; Hosag., Chandraprabha \& Agarwal, Asterinales of Kerala, p.59, 2011; Hosag., Mycosphere 2(5): 663, 2012(Fig. 138).

Materials examined: $\mathrm{HClO}$ 49224, TBGT 3463, 16.ii.2009, on leaves of Litsea floribunda (Blume) Gamble (Lauraceae), Periya, coll. Jacob Thomas et al.

Colonies amphigenous, dense, up to $4 \mathrm{~mm}$ in diameter. Hyphae substraight to flexuous, branching mostly opposite at wide angles, loosely reticulate, cells 19-26x3-4 $\mu \mathrm{m}$. Appressoria scattered, alternate, unicellular, globose to ovoid, entire, 4-7x4-6 $\mu \mathrm{m}$. Thyriothecia scattered, orbicular, up to $100 \mu \mathrm{m}$ in diameter, stellately dehisced at the center, margin crenate; asci not seen; ascospores oblong, conglobate, brown, uniseptate, constricted at the septum, 12-16x6$8 \mu \mathrm{m}$. Wall smooth.

Asterina cryptocaryae Cooke is known on this host genus. After examining the holotype, Stevens \& Ryan (1939) transferred it to the genus Prillieuxina because of the lack of appressoria. Asterina woodiana Doidge is known on this host genus from South Africa. The present species differs from it in having only unicellular appressoria, smaller thyriothecia and ascospores.

Asterina dallasica Petrak, Sydowia 8:14, 1954; Hosag., Riju \& Uma Maheswari, Indian J. Sci. \& Techn. 1:1, 2008; Hosag., Chandraprabha \& Agarwal, Asterinales of Kerala, p. 60, 2011; Hosag., Mycosphere 2(5): 665, 2012 (Image 12).

Material examined: $\mathrm{HClO}$ 48324, TBGT 3045, 9.xi.2007, on leaves of Trema orientalis (L.) Blume (Ulmaceae), Mananthavady, M.C. Riju.

Colonies epiphyllous, scattered, up to $3 \mathrm{~mm}$ in diameter. Hyphae straight, flexuous to crooked, branching irregular at acute to wide angles, loosely 


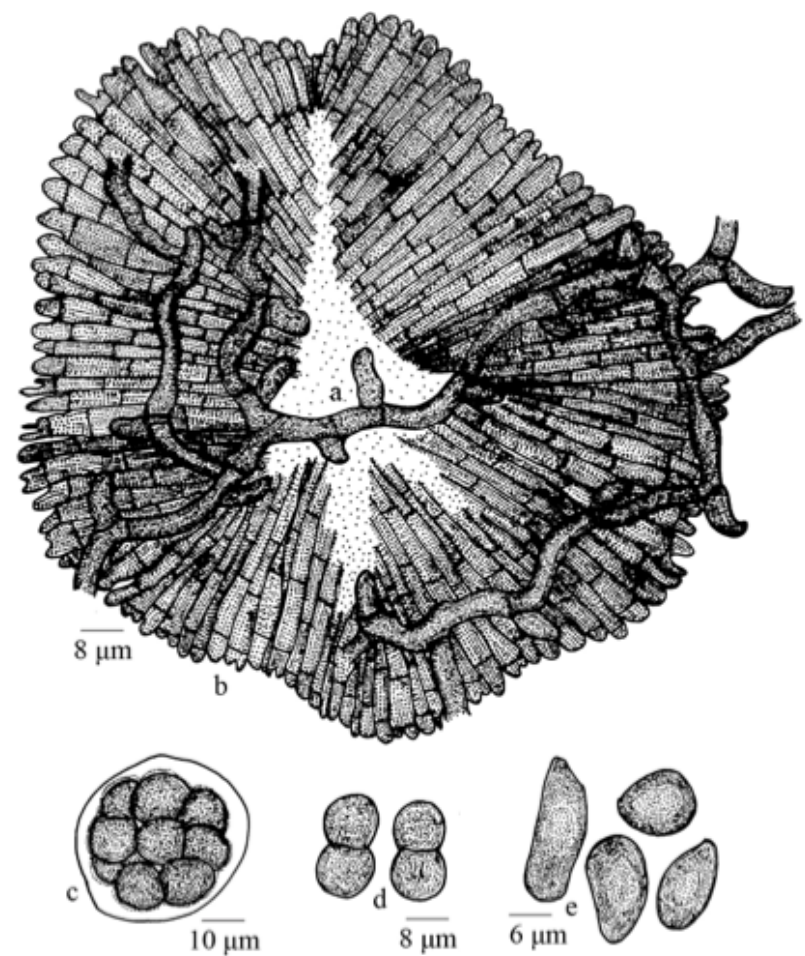

Figure 137. Asterina congesta

a - Appressorium; b - Thyriothecium; c - Ascus; d - Ascospores; e. Pycnothyriospores

reticulate, cells $11-26 \times 6-11 \mu \mathrm{m}$. Appressoria scattered, unicellular, alternate, unilateral, about $2 \%$ opposite, antrorse to subantrorse, globose, mammiform, mostly entire, rarely angular to crenately lobate, 6-11x6-11 $\mu \mathrm{m}$. Thyriothecia closely scattered, orbicular, up to $115 \mu \mathrm{m}$ in diameter, stellately dehisced at the centre, margin fimbriate; asci globose, octosporous, up to $26 \mu \mathrm{m}$ in diameter; ascospores brown, conglobate, uniseptate, constricted at the septum, 17-22x6-11 $\mu \mathrm{m}$, wall smooth.

Asterina celtidicola Henn., A. dallasica Petrak and A. sponiae Racib. are known on Celtis, Trema and Sponia species, respectively. A. dallasica matches well with that of assigned species. This species was known on Trema species from Borneo Islands (Petrak 1954; Hosagoudar \& Abraham 2000) and it reveals an affinity between the fungal flora of Wyanad and Borneo Islands.

Asterina deightonii Sydow, Ann. Mycol. 36: 172, 1938; Hosag., C.K. Biju, Abraham \& Agarwal, Indian Phytopath. 55: 497, 2002; Hosag., Zoos' Print J. 21: 2326, 2006; Hosag., Chandraprabha \& Agarwal, Asterinales of Kerala, p. 62, 2011; Hosag., Mycosphere 2(5): 665, 2012 (Fig. 139).

Materials examined: $\mathrm{HClO}$ 49244, TBGT 3483, 12.ii.2009, on leaves of Loranthus sp. (Loranthaceae),
Thirunelly, coll. Gireesh Kumar et al.

Colonies amphigenous, mostly epiphyllous, thin to subdense, up to $2 \mathrm{~mm}$ in diameter, rarely confluent. Hyphae substraight to flexuous, branching irregular at acute angles, loosely reticulate, cells $17-21 \times 4-5 \mu \mathrm{m}$. Appressoria unicellular, many, alternate, about $1 \%$ opposite, globose to ovate, entire, rarely slightly angular, 6-10x5-7 $\mu \mathrm{m}$. Thyriothecia scattered, often loosely grouped, orbicular, up to $145 \mu \mathrm{m}$ in diameter, margin crenate to fimbriate, fringed hyphae flexuous, stellately dehisced at the centre; asci few to many, globose, octosporous, up to $40 \mu \mathrm{m}$ in diameter; ascospores brown, oblong, conglobate, uniseptate, constricted at the septum, 21-23x11-13 $\mu \mathrm{m}$; wall glabrous to minutely echinulate. Pycnothyria similar to thyriothecia, smaller; pycnothyriospores few, globose to pyriform, brown, 16$18 \times 12-18 \mu \mathrm{m}$, wall smooth.

This species was known on Loranthus leonensis from Sierra Leone, collected by F. C. Deighton no. 1378 (Sydow 1938). Hughes (1952) proposed Asterina aburiensis and stated that the same fungus is also represented in two of Mr. F. C. Deighton's collections from Sierra Leone.

Asterina elaeocarpi Sydow var. ovalis Kar \& Maity, Indian Phytopath. 39: 218, 1986; Hosag., Balakr. \& Goos, Mycotaxon 60: 175, 1996; Hosag., J. Appl. \& Nat. Sci. 1(1): 29, 2009; Hosag., Chandraprabha \& Agarwal, Asterinales of Kerala, p. 68, 2011; Hosag., Mycosphere 2(5): 674, 2012 (Fig. 140).

Materials examined: HCIO 44297, TBGT 622,

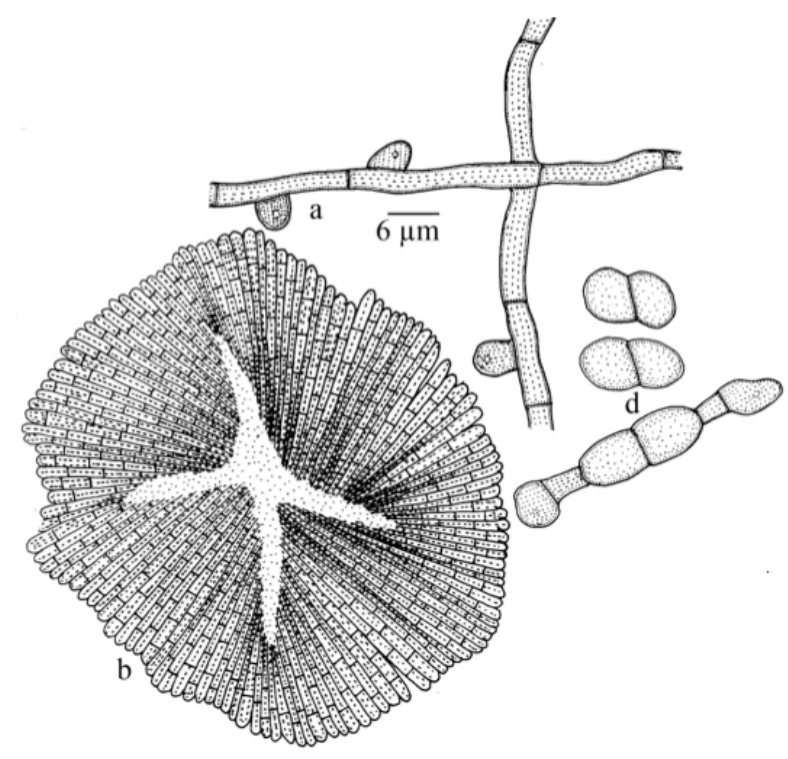

Figure 138. Asterina cryptocariicola

a - Appressorium; b - Thyriothecium; c - Ascus; d - Ascospores 
6.ii.2002, on leaves of Elaeocarpus tuberculatus Roxb. (Elaeocarpaceae), Periya, coll. M. Kamarudeen; HCIO 44638, TBGT 920, 20.v.2002, Thirunelly, coll. S. Shiburaj; HClO 44787, TBGT 1024, 27.xii.2002, Periya, coll. M. Kamarudeen \& P.A. Jose; HCIO 48035, TBGT 2818, 6.xii.2006, Mylattumala, coll. M. Harish et al.; $\mathrm{HClO}$ 49245, TBGT 3484, 16.ix.2008, Periya, coll. Harish et al.; HCIO 49815, TBGT 3967, 16.ii.2009, Periya, coll. Gireesh et al.

Colonies epiphyllous, thin to subdense, up to $2 \mathrm{~mm}$ in diameter, confluent and cover the entire upper surface of the leaves. Hyphae straight to substraight, branching alternate to opposite at acute to wide angles, loosely reticulate, cells $8-13 \times 3-4 \mu \mathrm{m}$. Appressoria alternate, opposite to subopposite, ovate to oblong, elongated, unicellular, entire, 4-24x4-5 $\mu \mathrm{m}$. Thyriothecia scattered to connate, orbicular, up to $160 \mu \mathrm{m}$ in diameter, stellately dehisced at the centre, crenate to fimbriate at the margin, fringed hyphae flexuous; asci few to many, globose to ovate, octosporous, 35-45 $\mu \mathrm{m}$ in diameter; ascospores oblong, conglobate, deep brown, uniseptate, constricted at the septum, 22-24x9-13 $\mu \mathrm{m}$, wall coarsely echinulate.

This species is very specific and infects this host plant throughout Western Ghats region.

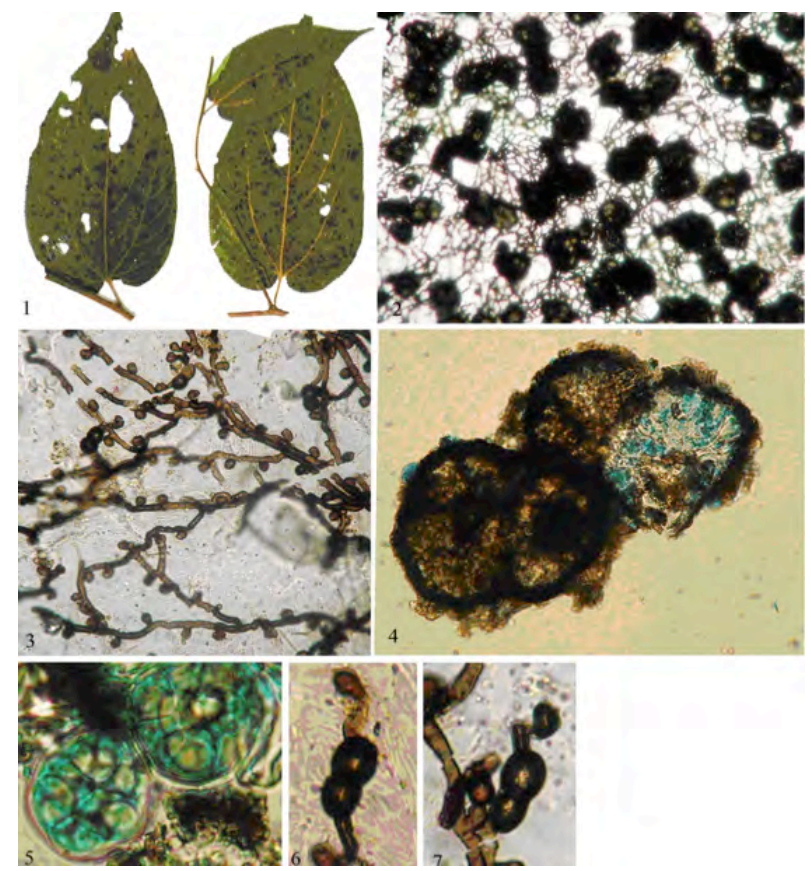

Image 12. Asterina dallasica

1 - Infected leaves; 2 - Mycelial colony with thyriothecia; 3 Appressoriate mycelium; 4 - Asci in exposed thyriothecia; 5 - Globose asci; 6-7 - Germinating ascospores
Asterina enicostematis Hosag. \& Chandraprabha., Indian J. Sci. \& Techn. 2(6):15, 2009 (enicostematis); Hosag., Chandraprabha \& Agarwal, Asterinales of Kerala, p. 70, 2011; Hosag., Mycosphere 2(5): 677, 2012 (Image.13).

Materials examined: HCIO 48242 (holotype), TBGT 2980 (isotype), 30.x.2007, on the leaves of Enicostema axillare (Lam.) A. Raynal. (Gentianaceae), upper peak of Pakshipathalam, coll. A. Chandraprabha.

Colonies amphigenous, dense, up to $3 \mathrm{~mm}$ in diameter. Hyphae crooked, branching opposite at acute to wide angles, loosely to closely reticulate, cells $18-33 \times 4-7 \mu \mathrm{m}$. Appressoria unicellular, alternate, ovate, mammiform, sessile, 7-13x4-9 $\mu \mathrm{m}$. Thyriothecia scattered, orbicular, up to $132 \mu \mathrm{m}$ in diameter, dehisce stellately at the center, margin crenate to fimbriate; asci globose, octosporous, up to $40 \mu \mathrm{m}$ in diameter; ascospores conglobate, uniseptate, constricted at the septum, 11-20×7-9 $\mu \mathrm{m}$, wall smooth. Pycnothyria similar to thyriothecia, orbicular, up to $110 \mu \mathrm{m}$ in diameter, margin crenate to fimbriate; pycnothyriospores ovate, pyriform, brown, 9-18x4-13 $\mu \mathrm{m}$, wall smooth.

Lembosia microtheca Theiss. is known on Goeppertia sp. of the family Gentianaceae (Stevens \& Ryan 1939) and is the first report of genus Asterina on the members of the family Gentianaceae (Hosagoudar \& Abraham 2000).

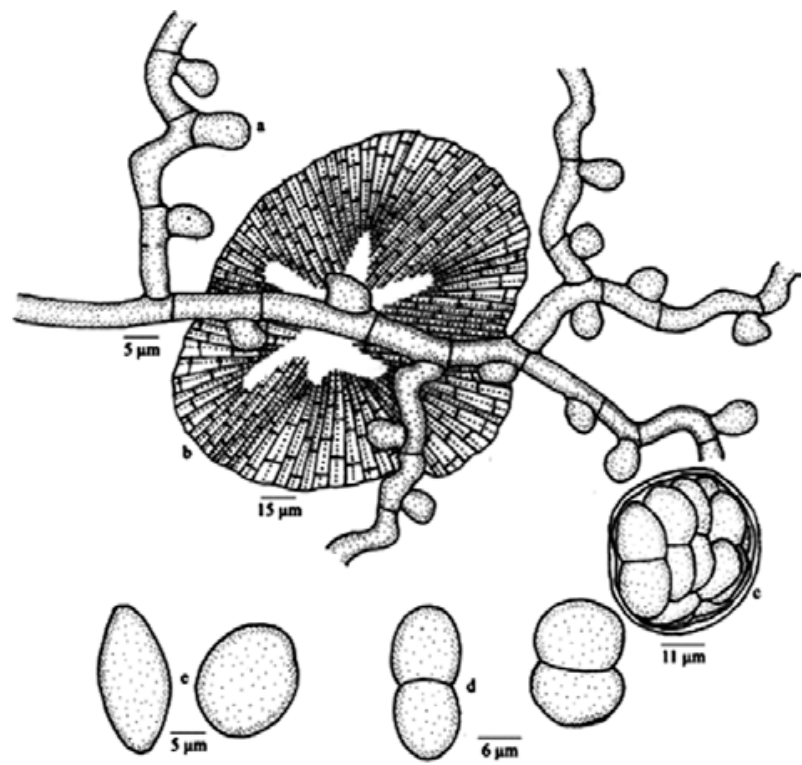

Figure 139. Asterina deightonii

a - Appressorium; b - Thyriothecium; c - Ascus; d. Ascospores, e Pycnothyriospores 


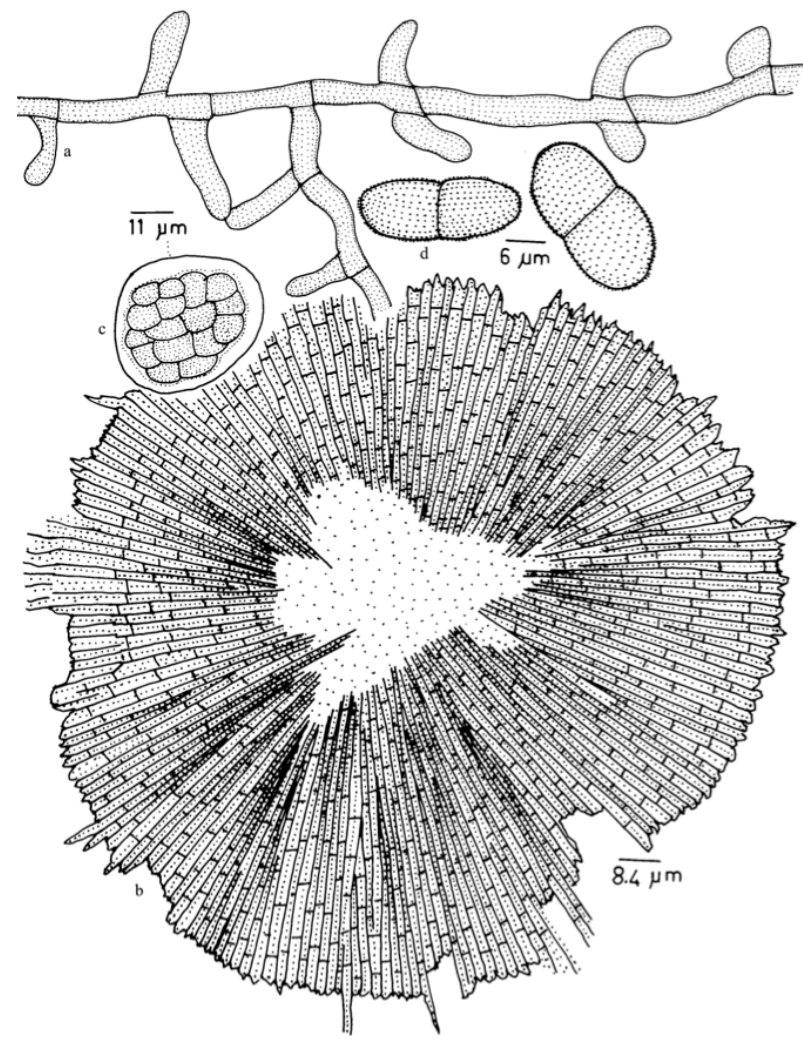

Figure 140. Asterina elaeocarpi var. ovalis a - Appressorium; b - Thyriothecium; c - Ascus; d - Ascospores
Sam P. Mathew; HCIO 50711, TBGT 4628, 6.xi.2009, Jasminum sambac (L) Aiton, Padinharathara, coll. A. Sabeena \& M.C. Riju; HClO 50841, TBGT 4758, 5.xi.2009, Jasminum malabaricum Wight, Gurukulam Botanical Garden, coll. M.C. Riju \& A. Sabeena; HCIO 50846, TBGT 4763, 6.ix.2009, Jasminum cordifolium Wallich ex G.Don, Padinharathara, M.C. Riju \& A. Sabeena; HClO 50848, TBGT 4765, 6.xi.2009, Chennalode, coll. A. Sabeena \& M.C. Riju; HClO 48055, TBGT 2838, 6.xii.2006, Jasminum sp., Kunkichira, Periya, coll. M. Harish et al.; $\mathrm{HClO} 49442$, TBGT 3687, 20.ix.2008, Mananthavady, coll. P.J. Robin et al.; HClO 49627, TBGT 3869, Pulpally, coll. M. Harish \& P.J. Robin; HClO 49637, TBGT 3879, 17.ix.2008, Periya, coll. M.Harish \& P.J. Robin; HClO 43831, TBGT 373, 19.xi.2000, Banasuranmala, coll. C.K. Biju.

Colonies epiphyllous, dense, up to $2 \mathrm{~mm}$ in diameter, rarely confluent. Hyphae flexuous to crooked, branching mostly opposite at acute angles, loosely to closely reticulate, cells $18-25 \times 2-5 \mu \mathrm{m}$. Appressoria opposite and alternate, antrorse to reflexed, straight to variously curved, 15-20 $\mu \mathrm{m}$ long; stalk cells cylindrical to cuneate, 4-13 $\mu \mathrm{m}$ long; head cells straight to curved, entire to lobate, $6-11 \times 7-10 \mu \mathrm{m}$. Thyriothecia numerous, scattered, often confluent, initially closed, stellately dehisced at center at maturity, margin crenate to

Asterina erysiphoides Kalch. \& Cooke, Grevillea 9: 32, 1880 emend. Doidge, Trans. Roy. Soc. South Africa 8: 256, 1920; Hansf. \& Thirum., Farlowia 3: 306, 1948; Hosag., Balakr. \& Goos, Mycotaxon 59: 175, 1996; Hosag., H. Biju \& Appaiah, J. Mycopathol. Res. 44: 7, 2006; Hosag., Chandraprabha \& Agarwal, Asterinales of Kerala, p. 72, 2011; Hosag., Mycosphere 2(5): 677, 2012 (Fig. 141).

Materials examined: $\mathrm{HClO}$ 45111, TBGT 1166, 16.iv.1999, on leaves of Jasminum cordifolium Wallich ex G. Don (Oleaceae), Banasuranmala, coll. C.K. Biju; HCIO, 45082, TBGT 1137, 15.v.1999, Jasminum sp., Thirunelli, coll. C.K. Biju; HCIO 48055, TBGT 2838, 6.xii.2006, Periya, Kunkichira, coll. M. Harish et al.; HCIO 49439, TBGT 3684, 15.ii.2009, Jasminum sp., Begoor, Harish et al.; TBGT 3701, 10.ix.2008, Thirunelly, coll. P.J. Robin et al.; HCIO 49462, TBGT 3704, 20.ix.2008, Pulpally, coll. P.J. Robin et al.; HCIO 49771, TBGT 3923, 14.ii.2009, Thirunelly, coll. Jacob Thomas et al.; HCIO 49773, TBGT 3925, 12.ii.2009, coll. Jacob Thomas et al.; HCIO 49775, TBGT 3927, TBGT 3936, 15.ii.2009, Jacob Thomas et al.; HClO 49969, TBGT 4121, 13.iii.2007, Puthuserrykadavu, coll. M.C. Riju; HCIO 50392, TBGT 4309, 8.xii.2009, on Jasminum malabaricum Wight, MS Swaminathan Foundation, coll.

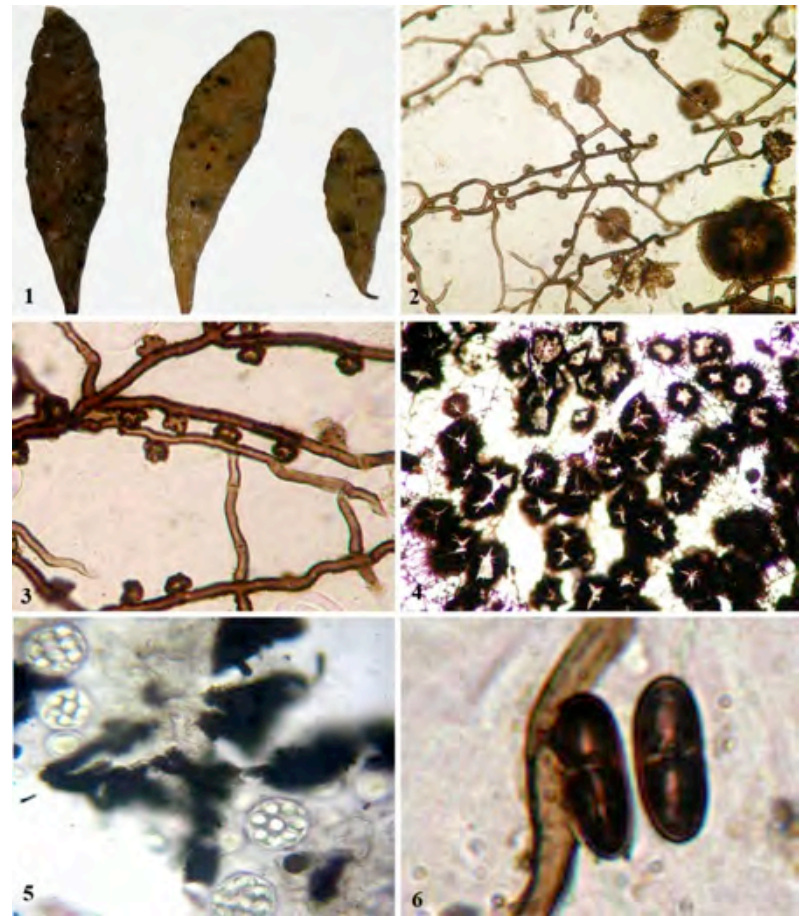

Image 13. Asterina enicostematis

1 - Infected leaves; $\mathbf{2}$ - Colony with thyriothecia; $\mathbf{3}$ - Appressoriate mycelium; 4 - Stellately dehisced thyriothecia; 5 - Asci; 6 - Ascospores 
fimbriate; asci numerous, ovoid to globose, octosporous, 30-33×27-30 $\mu \mathrm{m}$; ascospores initially hyaline, brown at maturity, conglobate, oblong, rounded at both ends, 1-septate, constricted at septum, 18-22x9-13 $\mu \mathrm{m}$.

In most of the collections, the colonies were associated with the colonies of Meliola gemellipoda Doidge and Meliola jasminii Hansf. \& Stev.

This species is common in the southern Western Ghats.

Asterina erythropalicola Hosag. \& Goos, Mycotaxon 59: 156, 1996; Hosag., Chandraprabha \& Agarwal, Asterinales of Kerala, p. 73, 2011; Hosag., Mycosphere 2(5): 679, 2012 (Fig. 142).

Materials examined: $\mathrm{HClO}$ 48037, TBGT 2820, 6.xii.2006, on leaves of Erythropalum populifolium (Arn.) Masters (Erythropalaceae) Periya, Kunkichira, coll. M. Harish et al.

Colonies epiphyllous, dense, crustose, up to $2 \mathrm{~mm}$ in diameter, confluent. Hyphae straight to substraight, branching mostly opposite at acute to wide angles, loosely reticulate, cells $21-28 \times 6-8 \mu \mathrm{m}$. Appressoria

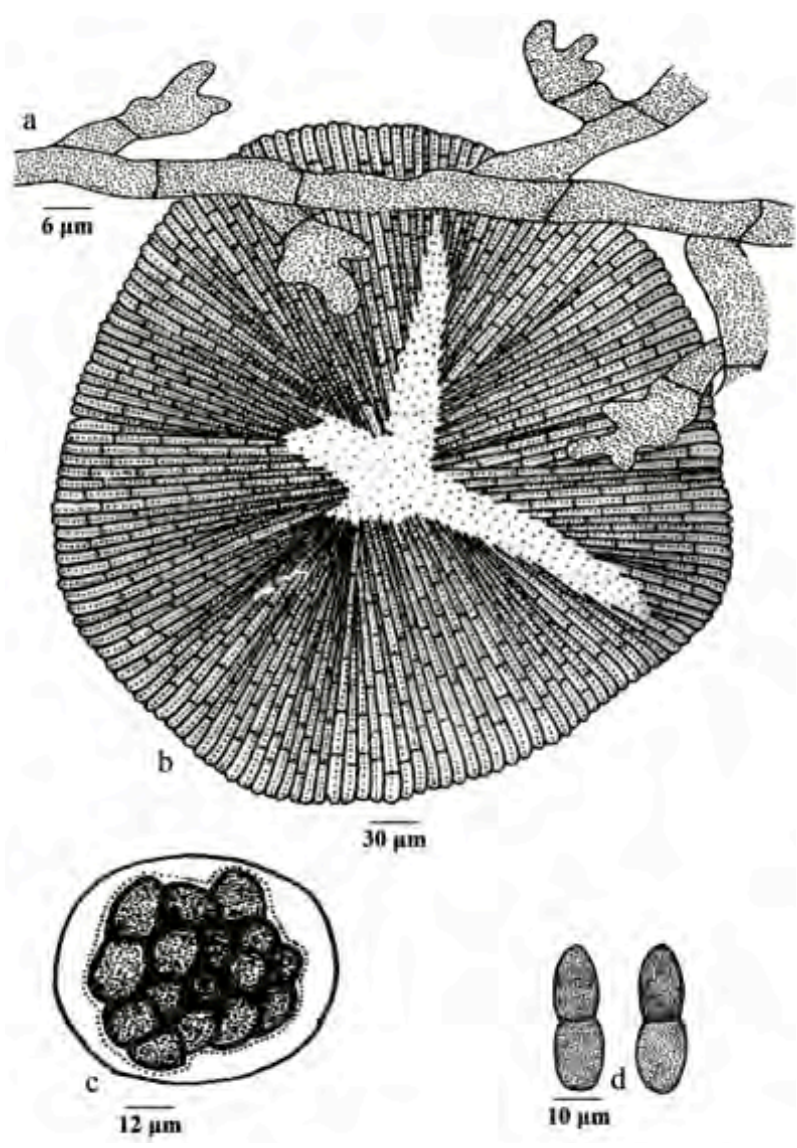

Figure 141. Asterina erysiphoides

a- Appressorium; b - Thyriothecium; c - Ascus; d - Ascospores alternate, unilateral, about 30\% opposite, subantrorse to perpendicular to the hyphae, mostly straight, 2-celled, 12-22 $\mu \mathrm{m}$ long; stalk cells cylindrical, 3-10 $\mu \mathrm{m}$ long; head cells ovate, globose, entire, rarely truncate, 9-13x6-8 $\mu \mathrm{m}$. Thyriothecia closely scattered, orbicular, up to $217 \mu \mathrm{m}$ in diameter, margin fringed, rarely crenate, fringed hyphae flexuous, with appressoria, thyriothecia dehisce stellately at the center and widely opened at maturity; asci many, globose, octosporous, 40-46 $\mu \mathrm{m}$ in diameter; ascospores conglobate, 1-septate, constricted at the septum, both cells unequal, 24-28x12-16 $\mu \mathrm{m}$, wall smooth. Pycnothyria attached or mixed with thyriothecia, slightly smaller; pycnothyriospores oval to pyriform, 18-20x12-14 $\mu \mathrm{m}$.

This species differs from Asterina erythropali Hansf. in having epiphyllous colonies and appressoria with entire head cells (Hansford 1954).

Asterina gamsii Hosag. \& C.K. Biju in Hosag., Indian Phytopath. 58: 195, 2005; Hosag., J. Appl. \& Nat. Sci. 1(1): 27, 2009; Hosag., Chandraprabha \& Agarwal, Asterinales of Kerala, p. 77, 2011; Hosag., Mycosphere 2(5): 683, 2012 (Fig. 143).

Materials examined: $\mathrm{HClO}$ 45166, TBGT 1221, 19.xi.2000, on leaves of Elaeocarpus variabilis Zmarzty (Elaeocarpus tectorius (Lour.) Poir.) (Elaeocarpaceae), Banasuran mala, coll. C.K. Biju.

Colonies epiphyllous, dense, velvety, up to $3 \mathrm{~mm}$ in diameter and cover an entire upper portion of the leaves. Hyphae straight to substraight, branching irregular at acute angles, loosely to closely reticulate, cells 16-23x4$7 \mu \mathrm{m}$. Appressoria alternate, unilateral and about $20 \%$ opposite to subopposite, mostly straight, subantrorse to rarely retrorse, ovate to cylindrical, entire, rounded at the apex, 8-13x6-8 $\mu \mathrm{m}$. Thyriothecia closely scattered, orbicular, up to $300 \mu \mathrm{m}$ in diameter, stellately dehisced at the centre, crenate to fimbriate at the margin, fringed hyphae flexuous; asci few to many, globose, octosporous, up to $38 \mu \mathrm{m}$ in diameter; ascospores oblong, brown, uniseptate, constricted at the septum, 32-36x11-18 $\mu \mathrm{m}$, wall smooth. Pycnothyria similar to thyriothecia, smaller; pycnothyriospores pyriform, apiculate, brown, 22-26x16-18 $\mu \mathrm{m}$.

There are five species, namely Asterina borneensis Hansf., A. elaeocarpi Sydow, A. elaeocarpi Sydow var. ovalis Kar \& Ghosh, A. elaeocarpicola Hansf. and A. elaeocarpi kobenmochi Yamam., known on the members of the family Elaeocarpaceae (Hosagoudar \& Abraham 2000). Asterina gamsii differs from $A$. elaeocarpicola and $A$. borneensis in having octosporous asci and straight appressoria (Hansford 1954). It differs 
from $A$. elaeocarpi in having opposite appressoria and larger ascospores. It also differs from $A$. elaeocarpi var. ovalis in having ovate appressoria in contrast to longer and cylindrical ones (Kar \& Ghosh, 1986; Hosagoudar, 2009). In A. elaeocarpi-kobanmochi appressoria are predominantly opposite and oblong and ascospores are smaller (Yamamoto 1957).

Asterina glycosmidigena Hosag. \& JacobThomas, J. Appl. Nat. Sci. 2: 102, 2010; Hosag., Mycosphere 2(5): 686, 2012 (Fig. 144).

Colonies epiphyllous, thin, up to $2 \mathrm{~mm}$ in diameter, confluent. Hyphae pale brown, straight to slightly crooked, branching irregular at acute to wide angles, loosely reticulate and form a loose mycelial net, cells 12 19x2-5 $\mu \mathrm{m}$ Appressoria sessile, mostly alternate, about $2 \%$ opposite, unicellular, ovate, subglobose, irregularly sublobate, entire, 4-10x4-7 $\mu \mathrm{m}$. Thyriothecia scattered, orbicular, often connate, up to $110 \mu \mathrm{m}$ in diameter,

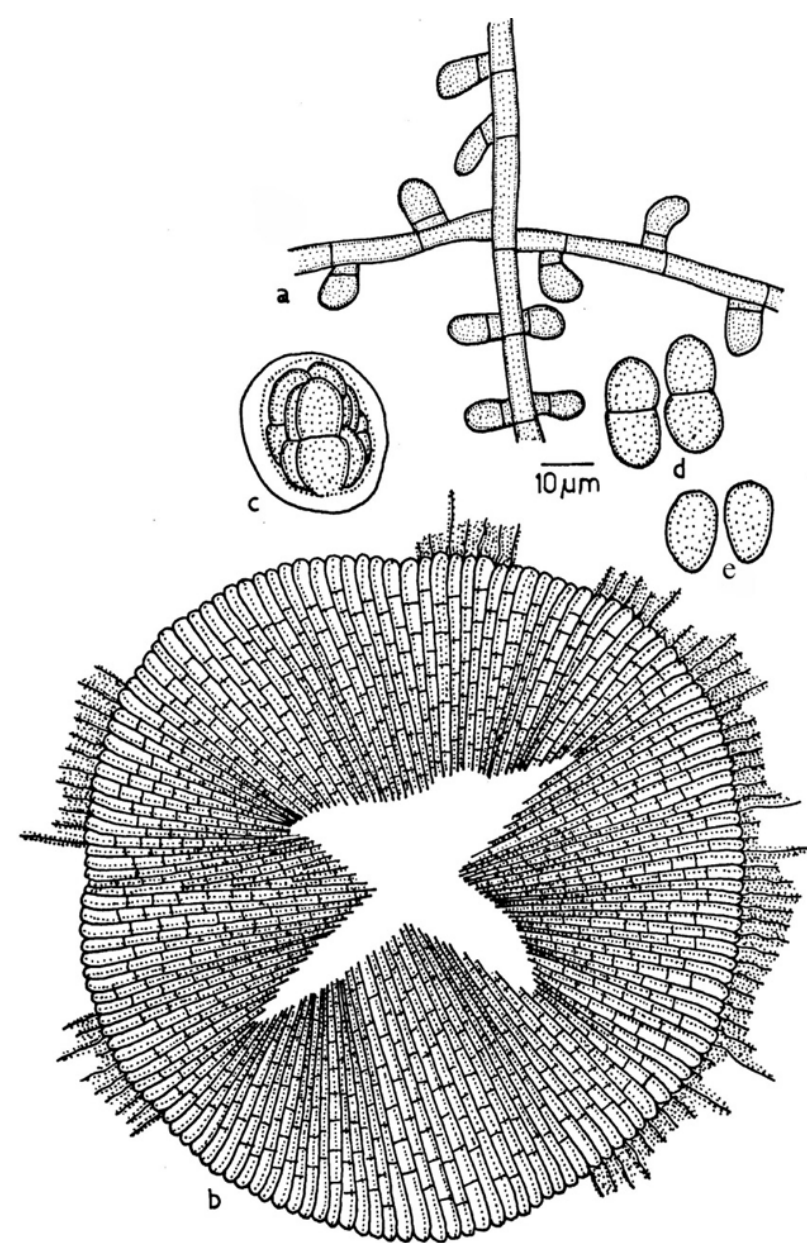

Figure 142. Asterina erythropalicola

a - Appressorium; b - Thyriothecium; c - Ascus; d - Ascospores stellately dehisced at the centre, margin crenate; asci globose, octosporous, 50-60 $\mu \mathrm{m}$ in diameter; ascospores oblong, conglobate, brown, uniseptate, strongly constricted at the septum, 14-19x7-10 $\mu \mathrm{m}$, wall smooth.

Materials examined: TBGT 3669, HClO 49424, 14.ii.2009, on leaves of Glycosmis pentaphylla (Retz.) DC. (Rutaceae), coll. Jacob Thomas et al.

The present species differs from Asterina glycosimidis Hosag. \& Rajkumar and A.banguiensis Yates known on the host genus in having hemispherical, broad based, irregularly sublobate to lobate appressoria (Yates 1918a,b; Hosagoudar 2005).

These colonies were mixed with the colonies of Meliola sp.

Asterina glycosmidis Hosag. \& Rajkumar in Hosag., Indian Phytopath. 58: 194, 2005; Hosag., Chandraprabha \& Agarwal, Asterinales of Kerala, p. 80, 2011; Hosag., Mycosphere 2(5): 687, 2012 (Fig. 145).

Materials examined: HCIO 45174 (holotype), TBGT

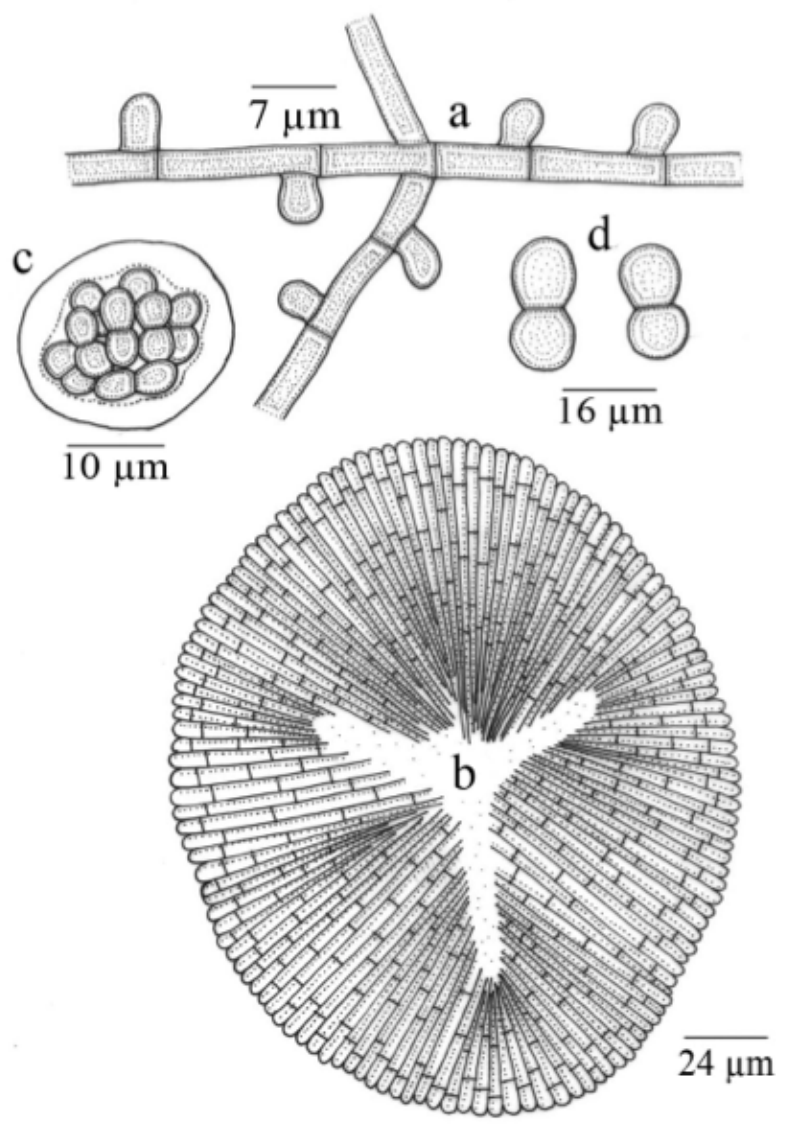

Figure 143. Asterina gamsii

a - Appressorium; b - Thyriothecium; c - Ascus; d - Ascospores 
1335 (isotype), 6.iii.2001, on leaves of Glycosmis sp. (Rutaceae), Wayanad, coll. G. Rajkumar.

Colonies mostly epiphyllous, subdense to dense, thinly velvety, up to $2 \mathrm{~mm}$ in diameter, confluent. Hyphae straight, substraight to flexuous, branching opposite to irregular at acute to wide angles, loosely to closely reticulate, cells $20-26 \times 4-6 \mu \mathrm{m}$. Appressoria unicellular, alternate, unilateral, about $40 \%$ opposite, ovate, conoid, oblong, often cylindrical, entire to rarely angular to sublobate, 6-13x4-6 $\mu \mathrm{m}$. Thyriothecia scattered to closely grouped, orbicular, up to $150 \mu \mathrm{m}$ in diameter,margin crenate to fimbriate, fringed hyphae small, stellately dehisced at the centre; asci few, globose, octosporous, up to $30 \mu \mathrm{m}$ in diameter; ascospores conglobate, brown, uniseptate, deeply constricted at the septum, 25-28x14-18 $\mu \mathrm{m}$, wall smooth.

Asterina banguiensis Yates is known on this host genus from Philippines (Yates, 1918a,b; Hosagoudar \& Abraham, 2000). Asterina glycosmidis differs from it in having opposite, alternate and unilateral appressoria,

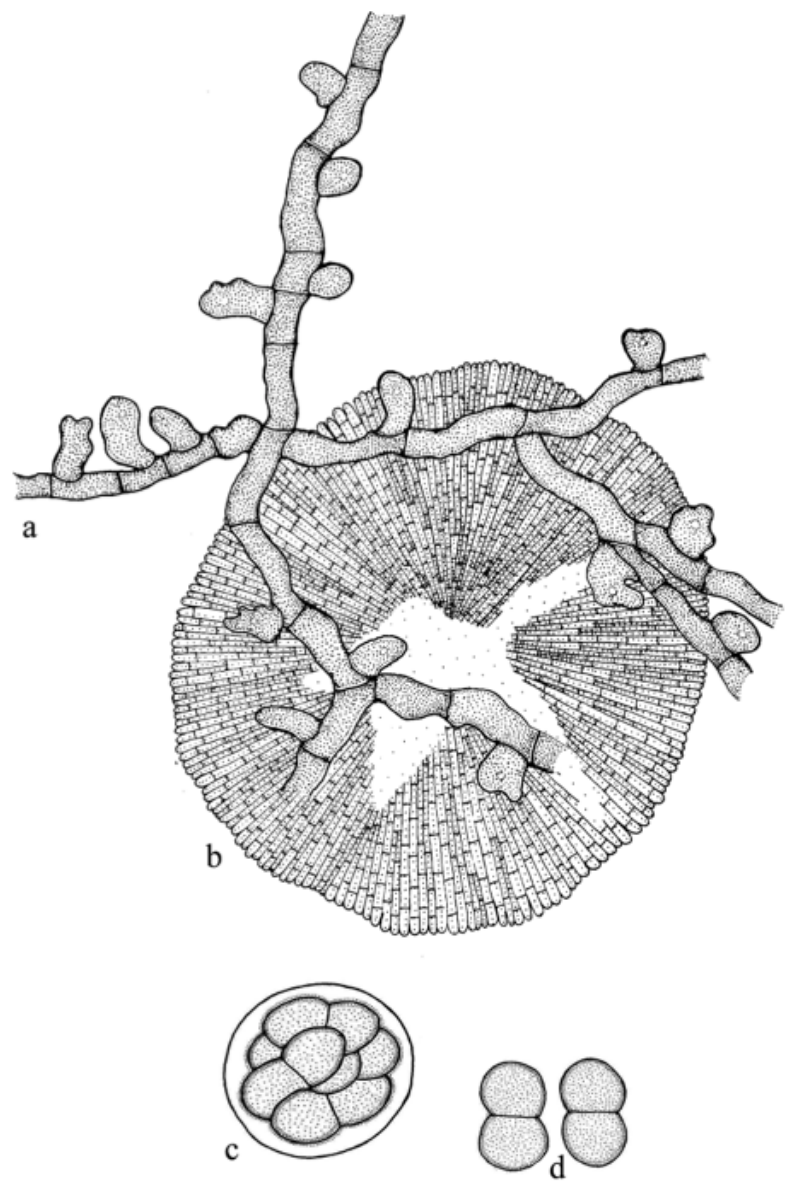

Figure 144. Asterina glycosmidigena a - Appressorium; b - Thyriothecium; c - Ascus; d - Ascospores differ in the shape of the appressoria, and possessing larger ascospores.

Asterina gymnemae Hosag. \& Jacob-Thomas, J. Appl. Nat. Sci. 2: 102, 2010; Hosag., Mycosphere 2(5): 690, 2012 (Fig. 146).

Materials examined: TBGT 3667a (holotype), HCIO 49422a (isotype), 14.ii.2009, on leaves of Gymnema sylvestre R.Br. (Asclepiadaceae), Thirunelly, February 14, 2009, coll. Jacob Thomas et al.; HCIO 49803, TBGT 3955, 8.iii.2008, on leaves of Asclepiadaceae member, Periya, coll. P.J. Robin et al.

Colonies epiphyllous, subdense, up to $1 \mathrm{~mm}$ in diameter, confluent. Hyphae substraight to undulate, branching opposite to irregular at acute to wide angles, loosely to closely reticulate, cells $19-34 \times 2-5$ $\mu \mathrm{m}$. Appressoria alternate, two celled, straight to curved, antrorse, 12-14 $\mu \mathrm{m}$ long; stalk cells cylindrical to cuneate, straight to crooked, 2-5 $\mu \mathrm{m}$ long; head cells ovate, globose, oblong, angular, sublobate to variously lobate, 4-7x4-10 $\mu \mathrm{m}$. Thyriothecia scattered,

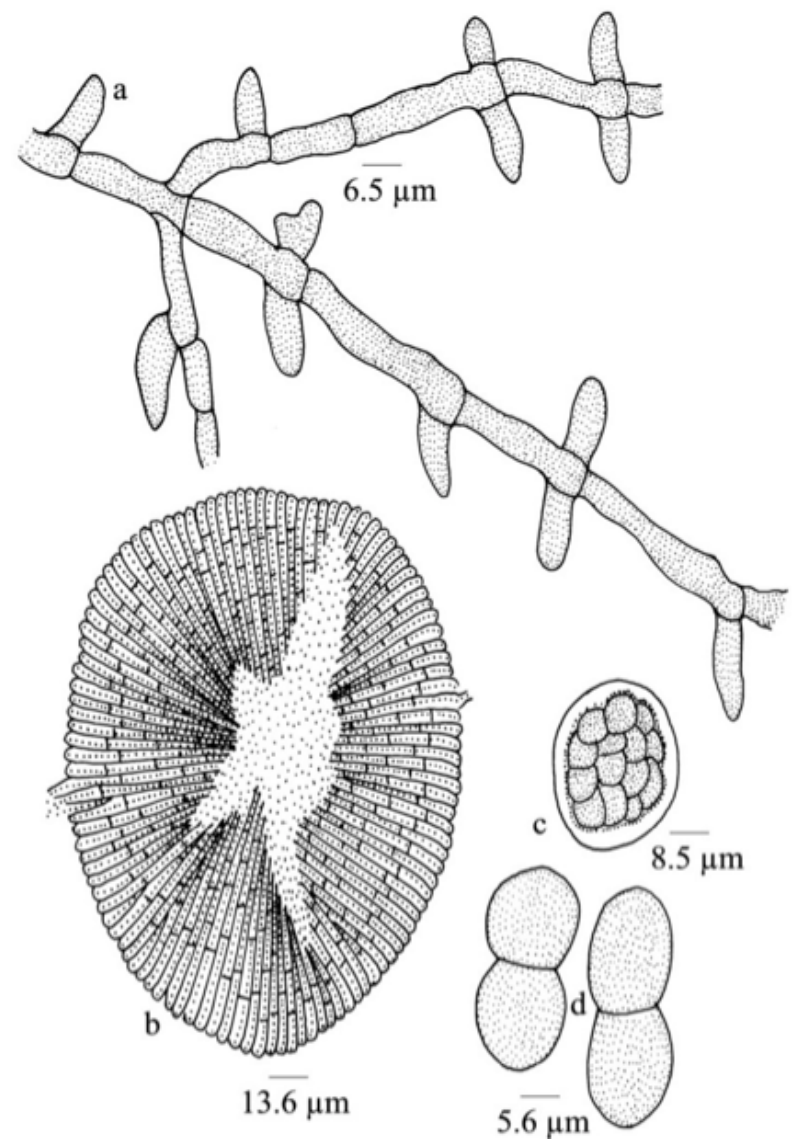

Figure 145. Asterina glycosmidis

a - Appressorium; b - Thyriothecium; c - Ascus; d - Ascospores 
orbicular, up to $150 \mu \mathrm{m}$ in diameter, stellately dehisced at the centre, margin crenate; asci few to many, globose, octosporous, 40-60 $\mu \mathrm{m}$ in diameter; ascospores conglobate, uniseptate, hyaline, constricted at the septum, 16-19x7-10 $\mu \mathrm{m}$, wall smooth.

There are six species of the genus Asterina known on the members of the family Asclepiadaceae, namely, Asterina asclepiadis Hosag. \& Goos (1996), A.coccina Sydow (1930), A. cynanchiHosag. \& Shiburaj(Hosagoudar 2002), A. leonensis Sydow (1938) and A. paraffinis Speg. (Theissen 1913). Based on the character of angular to sublobate head cells and evenly placed appressoria, the present species is closer to $A$. cynanchi, $A$. leonensis and A. paraffinis. However, the present species differs from A. paraffinis in having narrow ascospores and from $A$. cynanchi in having longer ascospores. It also differs from A. leonensis in having only alternate appressoria.

Asterina hibisci (Doidge) Hosag. in Hosag., C.K. Biju \& Abraham, J. Econ. Taxon. Bot. 28: 175, 2004; Hosag., Zoos' Print J. 21: 2327, 2006; Hosag., Chandraprabha \& Agarwal, Asterinales of Kerala, p. 88, 201; Hosag., Mycosphere 2(5): 693, 2012.

Asterina diplocarpa Cooke var. hibisci Doidge, Botahalia 4: 331, 1942 (Fig. 147).

Material examined: HCIO 45150, TBGT 1205, 2.vi.1999, on leaves of Symplocos rosea Bedd. (Symplocaceae), Banasuranmala, coll. C.K. Biju; HCIO 50924, TBGT 4841, 23.xii.2008, Symplocos sp., coll. M.C. Riju.

Colonies mostly epiphyllous, thin to subdense, up to $5 \mathrm{~mm}$ in diameter, confluent and thinly cover an entire upper surface of the leaves. Hyphae substraight to undulate, branching alternate to opposite at acute angles, loosely reticulate, $20-32 \times 2-4 \mu \mathrm{m}$. Appressoria unicellular, alternate, scattered, straight to rarely curved, ovate, globose, entire to sublobate, 9-12×4-9 $\mu \mathrm{m}$. Thyriothecia scattered, orbicular, up to $110 \mu \mathrm{m}$ in diameter, stellately dehisced at the center, margin crenate; asci few to many, mostly globose, octosporous, 25-35 $\mu \mathrm{m}$ in diameter; ascospores brown, conglobate, uniseptate, constricted at the septum, 20-23x9-12 $\mu \mathrm{m}$. wall verrucose. Pycnothyria few to many, similar but smaller than thyriothecia; pycnothyriospores unicellular, globose to pyriform, brown, 16-18x13-15, wall smooth.

Materials examined: TBGT 4496, 4498, 25.xi.2008, on leaves of Hibiscus rosa-sinensis L. (Malvaceae), 16th mile, Padinharathara, coll. M.C. Riju; TBGT 4644, 4.xi.2009, Padinharathara, coll. A. Sabeena \& M.C. Riju.

Doidge (1942) distinguished and placed this fungus by giving the status of variety. However, loosely

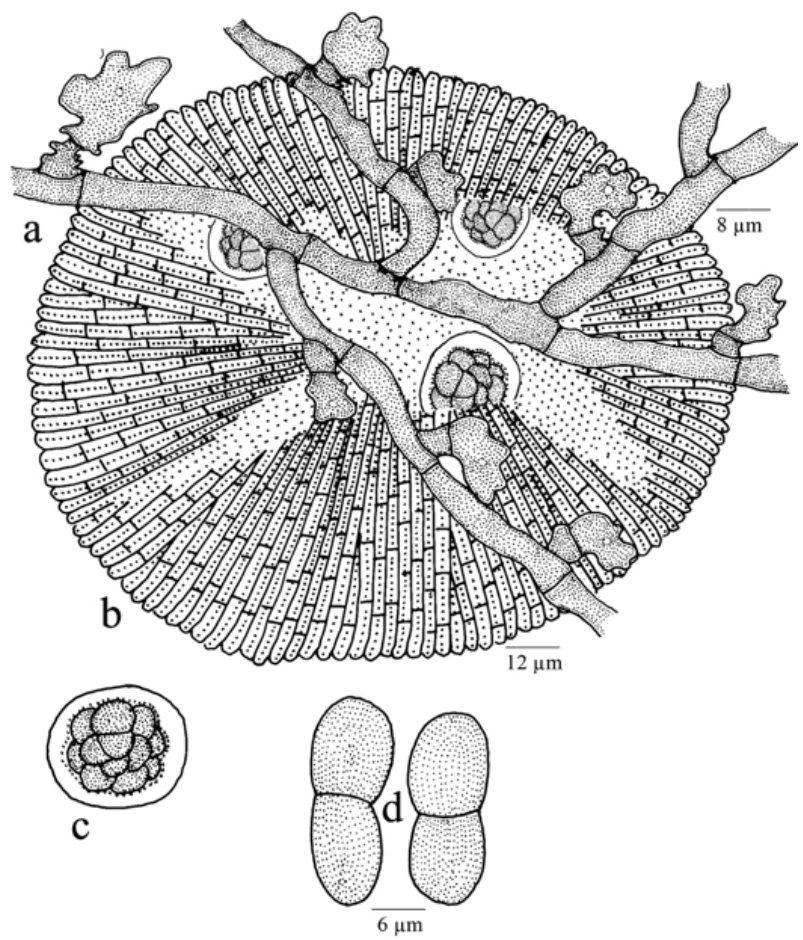

Figure 146. Asterina gymnemae

a - Appressorium; b - Thyriothecium; c - Ascus; d - Ascospores

reticulate mycelia, morphologically different and less number of appressoria and distinctly larger ascospores justifies its species status.

Asterina indica Sydow in Sydow, Sydow \& Butler, Ann. Mycol. 9: 390, 1911; Patil \& Thite, J. Shivaji Univ. 17: 152, 1977; Hosag., Zoos' Print J. 18: 1285, 2003; 21 : 2327, 2006; Hosag., H. Biju \& Appaiah, J. Mycopathol. Res. 44: 8, 2006; Hosag., Jacob Thomas \& Robin, Indian J. Sci. Techn. 2: 2, 2009; Hosag., Chandraprabha \& Agarwal, Asterinales of Kerala, p. 94, 2011; Hosag., Mycosphere 2(5): 693, 2012 (Fig. 148).

Colonies epiphyllous, thin, up to $2 \mathrm{~mm}$ in diameter. Hyphae straight to substraight, branching opposite to alternate at acute to wide angles, loosely reticulate, cells 31-38x8-12 $\mu \mathrm{m}$. Appressoria 95\% alternate and $5 \%$ opposite, unicellular, slightly antrorse, 14-22x7-10 $\mu \mathrm{m}$. Thyriothecia scattered, orbicular, up to $72 \mu \mathrm{m}$ in diameter, stellately dehisced at the centre; ascospores dark brown, 1-septate, constricted at the septum, 3843x14-19 $\mu \mathrm{m}$.

Asterina grammocarpa Sydow is known on the host genus Symplocos. Asterina indica differs from it in having unicellular appressoria. 
Asterina jambolana Kar \& Maity, Trans. Brit. Mycol. Soc. 54: 438, 1970; Hosag., Balakr. \& Goos, Mycotaxon 59: 180, 1996; Hosag. \& Abraham, J. Econ. Taxon. Bot. 4 576, 2000; Hosag., C.K. Biju \& Abraham, J. Econ. Taxon. Bot. 25: 306, 2001; J. Mycopathol. Res. 40:195, 2002; Hosag., Zoos' Print J. 18:1283, 2003; 21: 2327, 2006; Hosag., Chandraprabha \& Agarwal, Asterinales of Kerala, p. 96, 2011; Hosag., Mycosphere 2(5): 701, 2012 (Image 14, Fig. 149).

Materials examined: HClO 42958, TBGT 239, 13.vii.1998, on leaves of Syzygium sp. (Myrtaceae), Tirunelly, coll. C.K.Biju.

Colonies amphigenous, mostly epiphyllous, dense, crustose to velvety, up to $2 \mathrm{~mm}$ in diameter, confluent. Hyphae substraight to flexuous, branching irregular at acute angles, loosely to closely reticulate, cells 2532x4-7 $\mu \mathrm{m}$. Appressoria scattered, alternate, unilateral, mostly closely antrorse and appressed to the hyphae, often, curved, subantrorse to spreading, 16-20 $\mu \mathrm{m}$ long; stalk cells cylindrical to cuneate, 6-7 $\mu \mathrm{m}$ long; head cells ovate to globose, straight to slightly curved, entire, 9-13x8-10 $\mu \mathrm{m}$. Thyriothecia scattered to connate and often fused, orbicular, up to $300 \mu \mathrm{m}$ indiameter, stellately dehisced at the centre, margin crenate to fimbriate, fringed hyphae short; asci globose, octosporous, up to $50 \mu \mathrm{m}$ in diameter; ascospores oblong, conglobate, brown, uniseptate, slightly constricted at the septum, 32-34x13-16 $\mu \mathrm{m}$.

Kar \& Maity (1970) described this species from West Bengal. This is one of the most common species throughout the SouthernWestern Ghats.

Asterina lepianthis (Hosag., Balakr. \& Goos) Hosag. in Hosag.,C.K. Biju, Abraham \& Agarwal, Indian Phytopath. 55: 498, 2002 (lepianthedis); Hosag., Chandraprabha \& Agarwal, Asterinales of Kerala, p. 103, 2011; Hosag., Mycosphere 2(5): 708, 2012.

Anamorph: Asterostomella lepianthedis Hosag., Balakr. \& Goos, Mycotaxon 58: 492, 1996 (Fig. 150).

Materials examined: $\mathrm{HClO}$ 43714, TBGT 364, 8.xii.2000, on leaves of Lepianthes umbellata (L.) Rafin. [Hackeria subpeltata (Willd.) Kunth] (Piperaceae), coll. M. Kamarudeen.

Colonies amphigenous, mostly epiphyllous, thin to dense, up to $1 \mathrm{~mm}$ in diameter, confluent. Hyphae straight, flexuous to crooked, branching irregular at acute angles, loosely reticulate, cells $12-33 \times 3-5 \mu \mathrm{m}$. Appressoria scattered, alternate to unilateral, straight

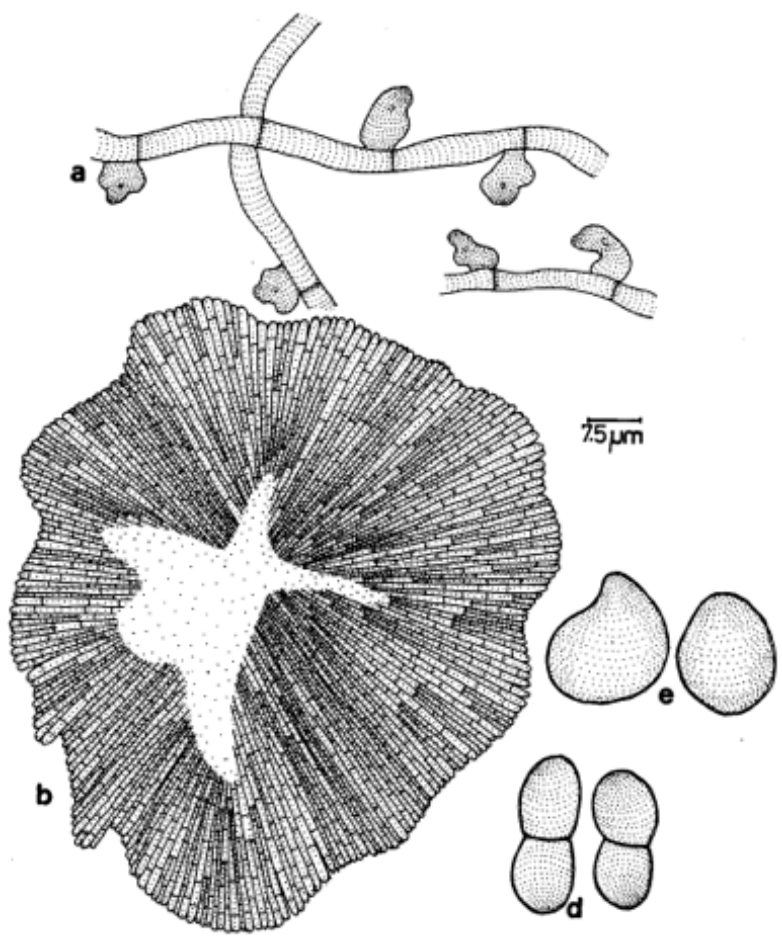

Figure 147. Asterina hibisci

a - Appressorium; b - Thyriothecium; c - Ascus; d - Ascospores

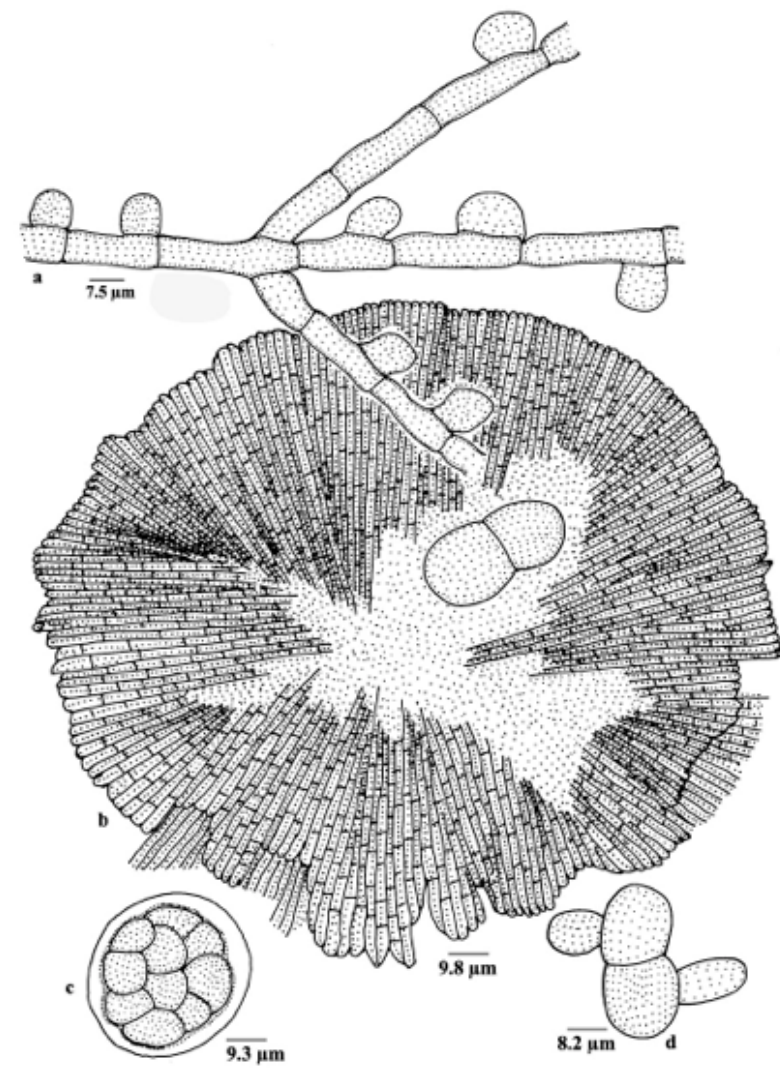

Figure 148. Asterina indica

a - Appressorium; b - Thyriothecium; c - Ascus; d - Ascospores 
to curved, two celled, 9-13 $\mu \mathrm{m}$ long; basal cells cuneate to cylindrical, 3-7 $\mu \mathrm{m}$ long, head cells ovate to globose, straight to slightly curved, entire, 9-13 x 8-10 $\mu \mathrm{m}$. Thyriothecia scattered to connate and often fused, orbicular, up to $300 \mu \mathrm{m}$ in diameter, stellately dehisced at the centre, margin crenate to fimbriate, fringed hyphae short; asci globose, octosporous, up to $50 \mu \mathrm{m}$ in diameter; ascospores oblong, conglobate, brown, uniseptate, slightly constricted at the septum, 32-34 x13-16 $\mu \mathrm{m}$. Pycnothyria scattered, orbicular, up to $60 \mu \mathrm{m}$ in diam., stellately dehisced at the centre, center, margin crenate; pycnothyriospores unicellular, globose to ellipsoidal, brown, 9-15x6-10 $\mu \mathrm{m}$.

Asterina ligustricola Hosag. \& Kamar. in Hosag., J. Econ. Taxon. Bot. 28: 187, 2004; Hosag., Chandraprabha \& Agarwal, Asterinales of Kerala, p. 106, 2011; Hosag., Mycosphere 2(5): 709, 2012.

Asterostomella ligustri Hosag., Balakr. \& Goos, Mycotaxon 58: 493, 1996 (Fig. 151).

Materials examined: $\mathrm{HClO}$ 44129, TBGT 528, 24.v.2001, on leaves of Ligustrum travencoricum Gamble (Oleaceae), M. Kamarudeen; HCIO 44867, TBGT 1095, 7.iii.2001, on leaves of Ligustrum walkeri auct. non
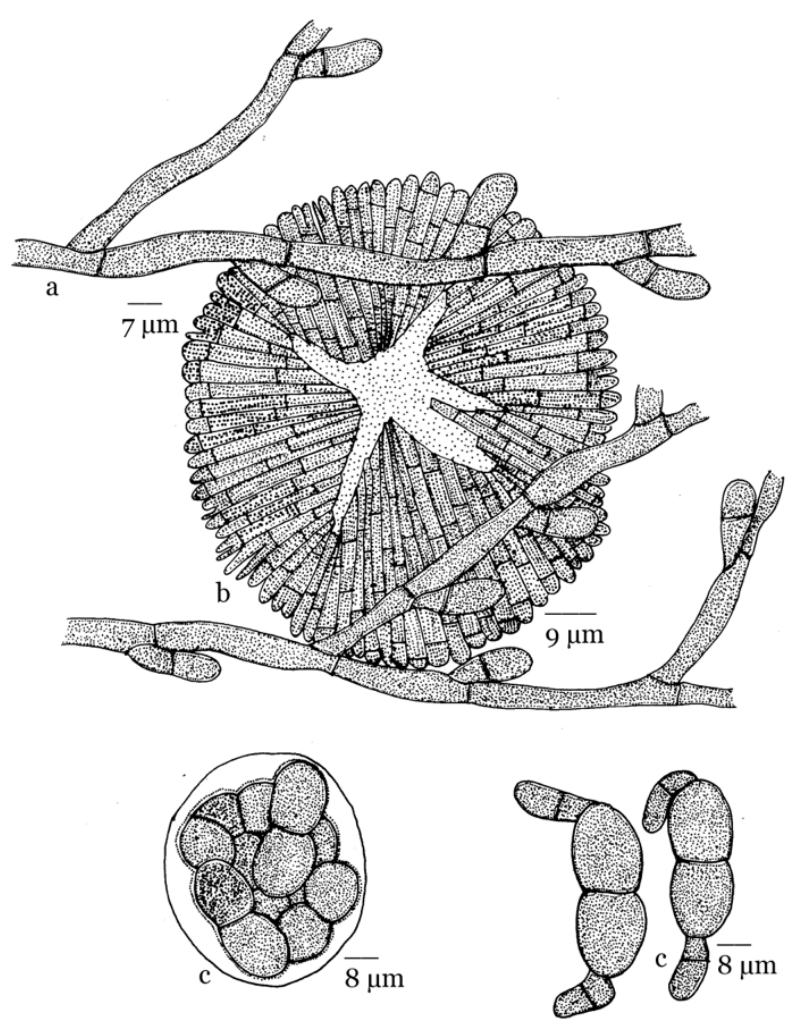

Figure 149. Asterina jambolana

a - Appressorium; b - Thyriothecium; c - Ascus; d - Ascospores
Decne, Periya, coll. G. Rajkumar \& P.A. Jose.

Colonies amphigenous, mostly epiphyllous, subdense to dense, up to $3 \mathrm{~mm}$ in diameter, confluent. Hyphae substraight to flexuous, branching irregular at acute angles, loosely reticulate, cells $11-15 \times 3-4 \mu \mathrm{m}$. Appressoria alternate to unilateral, scattered, unicellular, sessile to stipitate, irregularly and stellately sublobate to lobate, globose, 4-8x6-10 $\mu \mathrm{m}$. Pycnothyria numerous, scattered, orbicular, up to $50 \mu \mathrm{m}$ in diameter, margin fimbriate to crenate, stellately dehisced at the center; pycnothyriospores ellipsoidal, taper towards both ends, brown, 19-21x9-10 $\mu \mathrm{m}$. Thyriothecia scattered, orbicular, up to $130 \mu \mathrm{m}$ in diameter, margin crenate to fimbriate, fringed hyphae tortuous, thyriothecia stellately dehisced at the center; asci globose, octosporous, 30-35 $\mu \mathrm{m}$ in diameter; ascospores conglobate, brown, uniseptate, constricted at the septum, 16-19x9-10 $\mu \mathrm{m}$, wall minutely echinulate.

This species differs from Asterina ligustri P. Henn in having unicellular appressoria and is the teleomorph of Asterostomella ligustri Hosag. et al. (Katumoto 1975; Hosagoudar et al. 1996).
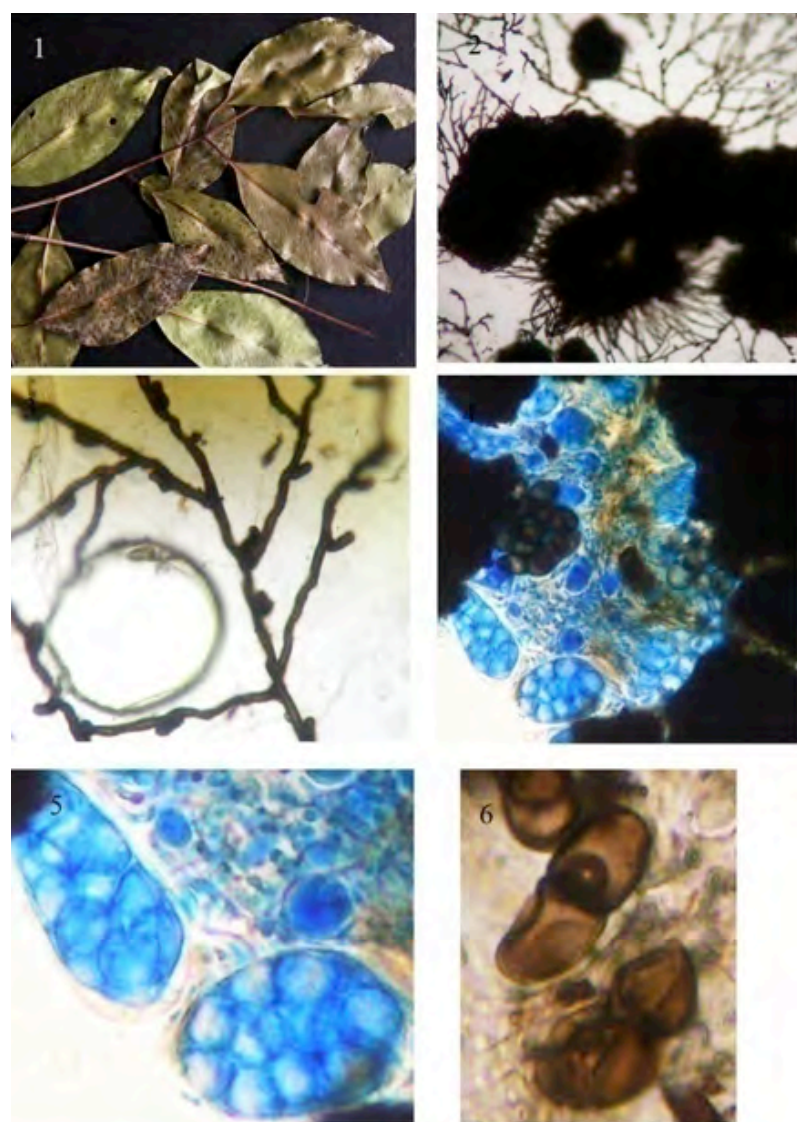

Image 14. Asterina jambolana

1 - Infected leaves; 2 - Thyriothecia; 3 - Appressoriate mycelium; 4 Asci in the Ascomata; 5 - Asci; 6 - Ascospores 
It was parasitised by Zygosporium sp.

Asterina litseae-ligustrinae Hosag., Balakr. \& Goos, Mycotaxon 59: 180, 1996; Hosag., Mycosphere 2(5): 711, 2012 (Fig. 152).

Materials examined: $\mathrm{HClO}$ 49871, TBGT 4023, 18.ix.2008, on leaves of Litsea sp. (Lauraceae), Thirunelly, coll. Harish et al.

Colonies hypophyllous, dense, crustose, up to $5 \mathrm{~mm}$ in diameter, rarely confluent. Hyphae straight to substraight and in few places crooked, branching opposite to irregular at acute to wide angles, loosely reticulate, cells $15-22 \times 3-5 \mu \mathrm{m}$. Appressoria alternate, about $15 \%$ opposite, straight to curved, unicellular, conoid, entire to variously sublobate, 9-13x6-10 $\mu \mathrm{m}$. Thyriothecia scattered to loosely grouped, round to ovate, up to $110 \mu \mathrm{m}$ in diameter, stellately fissured at the center, inner content deep yellow, margin crenate to fimbriate, fringed hyphae long and tortuous; asci many, globose, eight spored, 24-26 $\mu \mathrm{m}$ in diameter; ascospores conglobate, 1-septate, constricted at the septum, 18-19x6-10 $\mu \mathrm{m}$, upper cell slightly ovate, lower cell globose, wall echinulate.

This species is similar to Asterina litseae Yates in having yellow contents in the thyriothecia (Hansford, 1949) but differs from it in having hypophyllous colonies, substraight to crooked hyphae, $15 \%$ opposite, and entire to variously sublobate appressoria and echinulate ascospores.

Asterina lobulifera Sydow var. indica Hosag. \& Chandraprabha, Indian J. Sci. Techn. 2: 15, 2009; Hosag., Chandraprabha \& Agarwal, Asterinales of Kerala, p. 109, 2011; Hosag., Mycosphere 2(5): 711, 2013 (Fig. 153).

Materials examined: $\mathrm{HClO}$ 48236, TBGT 2974, 29.x.2007, on leaves of Glochidion sp. (Euphorbiaceae), Periya, coll. A. Chandraprabha.

Colonies amphigenous, dense, up to $2 \mathrm{~mm}$ in diameter. Hyphae flexuous to crooked, branching opposite to irregular at acute to wide angles, loosely to closely reticulate, cells $15-26 \times 4-7 \mu \mathrm{m}$. Appressoria 2-celled,

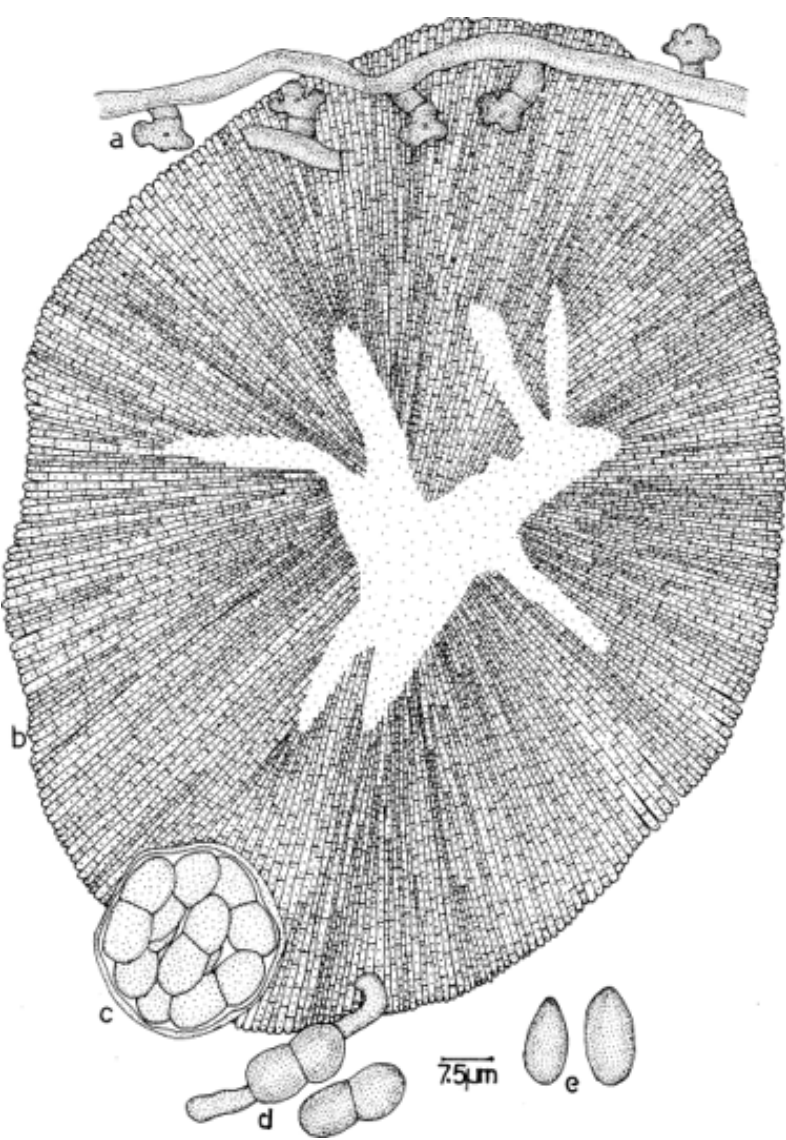

Figure 150. Asterina lepianthis

a - Appressorium; b - Thyriothecium; c - Ascus; d - Ascospores

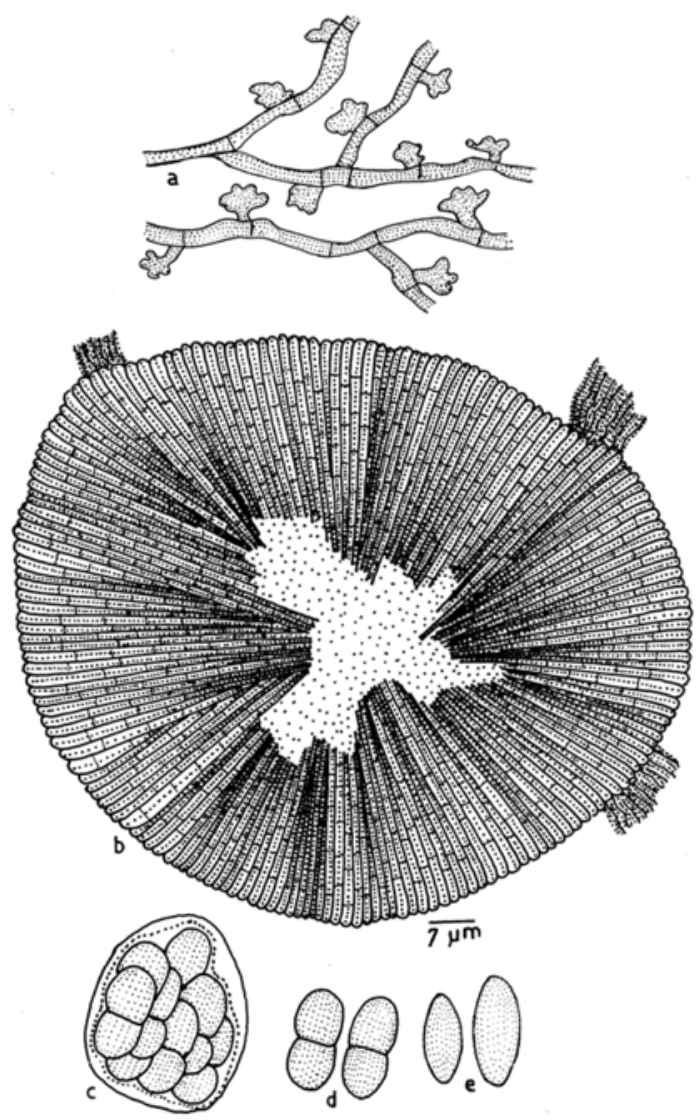

Figure 151. Asterina ligustricola a - Appressorium; b - Thyriothecium; c - Ascus; d - Ascospores; e Pycnothyriospores 
alternate to opposite (5-10\%), subantrorse, straight to curved, 11-15 $\mu \mathrm{m}$ long; stalk cells cylindrical to cuneate, 4-7 $\mu \mathrm{m}$ long; head cells ovate, globose, sublobate to lobate, 7-11x4-7 $\mu \mathrm{m}$. Thyriothecia scattered to grouped at the centre of the colonies, orbicular, up to $121 \mu \mathrm{m}$ in diameter, margin crenate to fimbriate, stellately dehisced at the center; ascospores oblong, conglobate, uniseptate, constricted at the septum, 1322x7-9 $\mu \mathrm{m}$, wall smooth. Pycnothyria smaller, similar to thyriothecia; pycnothyriospores ovate, pyriform, brown, 11-22x7-11 $\mu \mathrm{m}$, wall smooth.

This species was known from Philippines, Taiwan and Japan (Sydow \& Sydow 1914; Yamamoto 1956; Katumoto 1991).

Asterina melicopecola Hosag. \& Abraham, Indian Phytopath. 50: 216, 1997; Hosag., C.K. Biju \& Abraham, J. Econ. Taxon. Bot. 25: 305, 2001; Hosag., Zoos' Print J. 18:

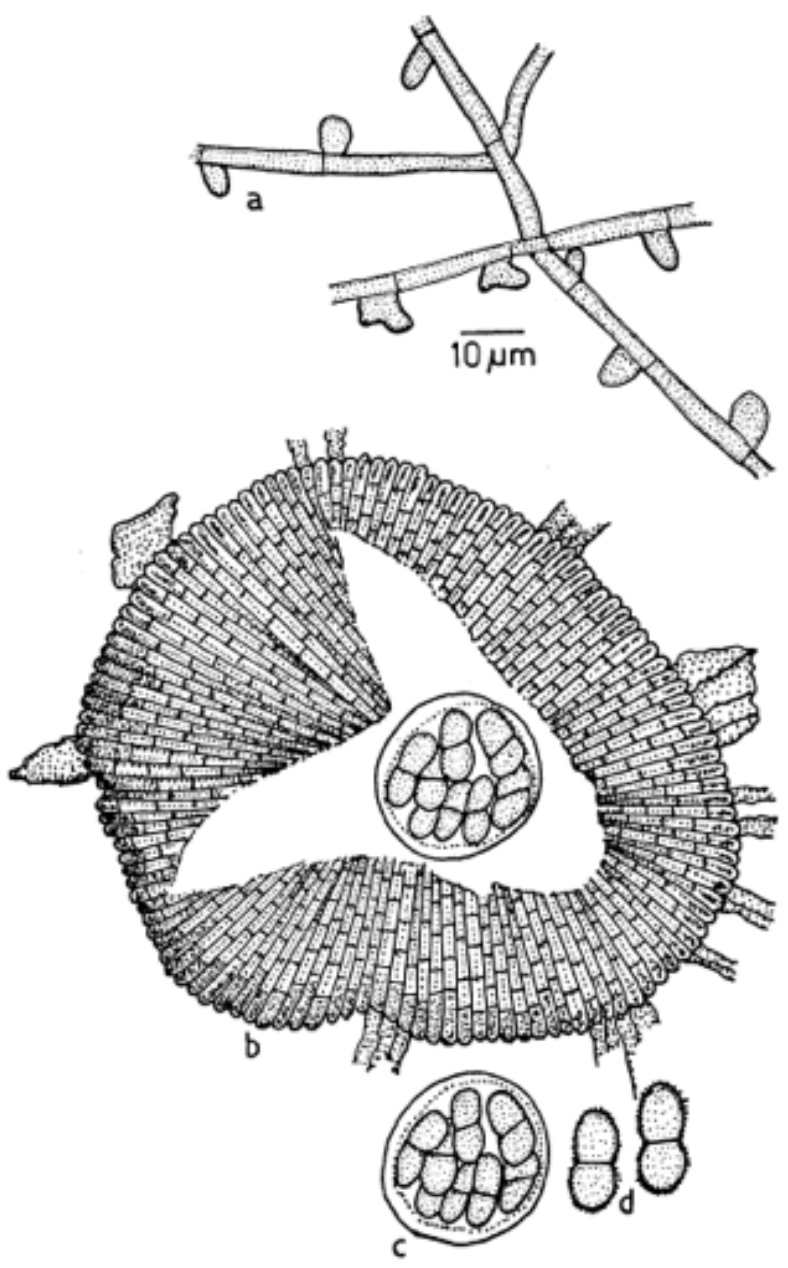

Figure-152. Asterina litseae-ligustrinae a - Appressorium; b - Thyriothecium; c - Ascus; d - Ascospores
1284, 2003; 21: 2328, 2006; Hosag., H. Biju \& Appaiah, J. Mycopathol. Res. 44: 9, 2006; Hosag., Chandraprabha \& Agarwal, Asterinales of Kerala, p. 115, 2011; Hosag., Mycosphere 2(5): 718, 2012 (Fig. 154).

Materials examined: HCIO 44301, TBGT 588, 10.i.2002, on leaves of Euodia luna-ankenda (Gaertner) Merr. (Rutaceae), Periya, coll. M. Kamarudeen; 16.iv.1999, HCIO 45147, TBGT 1202, Banasuran mala, coll. C.K. Biju; HCIO 45149, TBGT 1204, 19.xi.1999, coll. C.K. Biju; HClO 49223, TBGT 3462, Periya, coll. Jacob Thomas et al.

Colonies amphigenous, mostly epiphyllous, dense, up to $1 \mathrm{~mm}$ in diameter, confluent. Hyphae straight, branching opposite at acute angles, loosely reticulate, cells $19-24 \times 3.5-5 \mu \mathrm{m}$. Appressoria opposite, about $20 \%$ alternate, unicellular, ovate, globose, clavate, pyriform, irregularly sublobate to lobate, 9-12.5x6-7.5 $\mu \mathrm{m}$. Thyriothecia orbicular, loosely grouped in the center of the colony, scattered to connate, up to $150 \mu \mathrm{m}$ in diameter, stellately dehisced at the center, splitting up to margin, crenate to fimbriate at the margin, fringed hyphae small, profusely branched; asci globose, rounded, octosporous, up to $42 \mu \mathrm{m}$ in diameter; ascospores conglobate, brown, 1-septate, deeply constricted at the septum, upper cell globose, lower cell slightly ovate, 31-34×12-13.5 $\mu \mathrm{m}$.

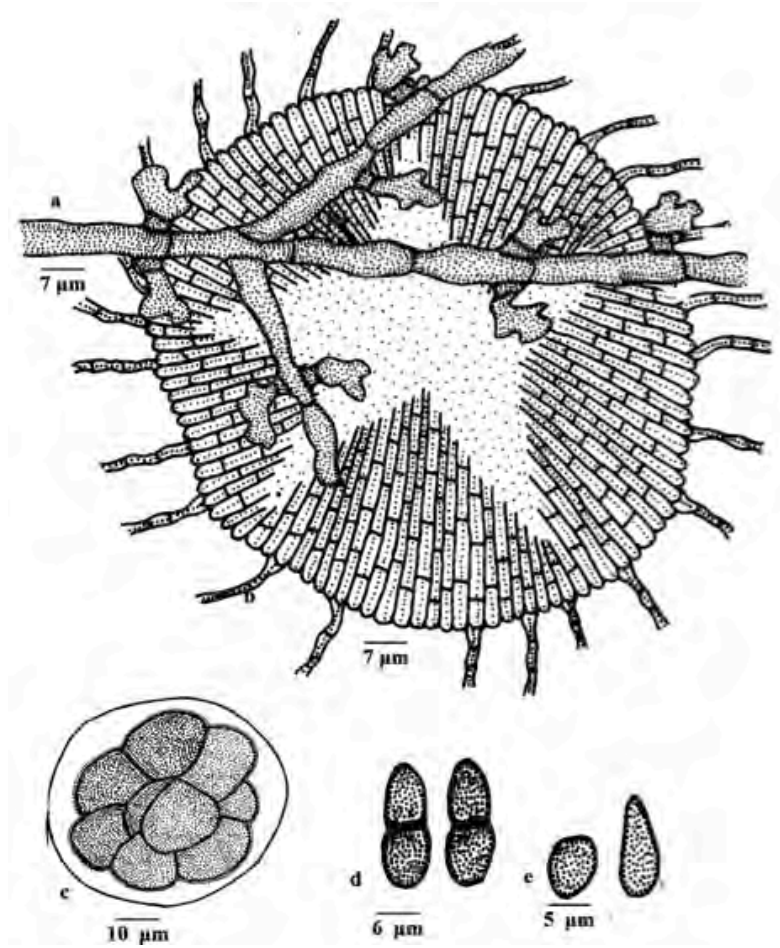

Figure 153. Asterina lobulifera var. indica

a - Appressorium; b - Thyriothecium; c - Ascus; d - Ascospores 
Asterina memecylonis Ryan, Mem. Dept. Agric. India 15: 105, 1921; Hosag., Zoos' Print J. 19: 1386, 2004; Hosag., H. Biju \& Appaiah, J. Mycopathol. Res. 43:204, 2005; Hosag., Zoos' Print J. 21: 2328, 2006; Hosag. Chandraprabha \& Agarwal, Asterinales of Kerala, p. 116, 2011; Hosag., Mycosphere 2(5): 720, 2012 (Fig. 155).

Materials examined: $\mathrm{HClO}$ 49629, TBGT 3871, 20.ix.2008, on leaves of Memecylon sp. (Melastomataceae), Pulpally, coll. M. Harish \& P.J. Robin; HCIO 45684, TBGT 1431,15.xi.2008, Memecylon sp., coll. V.B. Hosagoudar; TBGT 5726, 4.viii.2008; $\mathrm{HClO} 44585$, TBGT 872, 24.iv.2002, M. sylvaticum Thwaites, coll. H. Biju.

Colonies amphigenous, subdense to dense, up to $2 \mathrm{~mm}$ in diameter, confluent. Hyphae straight, branching alternate, opposite to irregular at acute angles, loosely to closely reticulate, cells 28-32x4-7 $\mu \mathrm{m}$. Appressoria scattered, alternate, unicellular, broad based, mammiform, globose, entire, angular, crenately lobate to slightly lobate, 11-13×11-15 $\mu \mathrm{m}$. Thyriothecia scattered, orbicular, up to $441 \mu \mathrm{m}$ in diameter; crenate at margin, irregularly dehisce at the centre; asci few, globose to ovate, octosporous, 56-62 $\mu \mathrm{m}$ in diameter; ascospores brown, conglobate, uniseptate, constricted at the septum, taper at both ends, 38-42×14-16 $\mu \mathrm{m}$.

Asterina micheliifolia Hosag. \& Riju, J. Threatened Taxa 3: 1942, 2011; Hosag., Mycosphere 2(5): 721, 2012. (Fig. 156).

Materials examined: $\mathrm{HClO}$ 49111, TBGT 3366; HClO 49112, TBGT 3367; HClO 49113, TBGT 3368; HClO 49114, TBGT 3369; HCIO 49115, TBGT 3370, 20.ix.2008, on leaves of Michelia chempaka L. (Magnoliaceae), Chennalode, Padinharathara, coll. M. C. Riju.

Colonies hypophyllous, thin, up to $2 \mathrm{~mm}$ in diameter, confluent. Hyphae flexuous to crooked, branching irregular at acute to wide angles, forming closely reticulated rings, cells $12-40 \times 3-5 \mu \mathrm{m}$. Appressoria scattered, unicellular, opposite, alternate, unilateral, antrorse to retrorse, globose to cylindrical, entire, 5-18x5-8 $\mu \mathrm{m}$. Pycnothyria scattered, orbicular, up to $58 \mu \mathrm{m}$ in diameter, stellately dehisced and widely opened at the centre; pycnothyriospores globose, clavate, 15-20 $\mu \mathrm{m}$ in diameter, wall smooth. Thyriothecia scattered, orbicular, up to $85 \mu \mathrm{m}$ in diameter, stellately dehisced and widely opened at the centre by exposing asci; asci globose to ovate, 37-45 $\mu \mathrm{m}$ in diameter; ascospores brown, uniseptate, constricted at the septum, 2225x10-13 $\mu \mathrm{m}$, wall smooth.

This species differs from Asterina micheliae Hansf. in having typically thyriothecium like fruiting bodies and differs from $A$. micheligena in having straight mycelium and larger ascospores.

Asterina micheliigena Hosag. \& Riju, J. Threatened Taxa 3: 1944, 2011; Hosag., Mycosphere 2(5): 722, 2012 (Fig. 157).

Materials examined: $\mathrm{HClO}$ 49111, TBGT 3366; HCIO 49112, TBGT 3367; HClO 49113, TBGT 3368; HClO 49114, TBGT 3369; HCIO 49115, TBGT 3370, 20.ix.2008, on leaves of Michelia chempaka L. (Magnoliaceae), Chennalode, Padinharathara, coll. M. C. Riju.

Colonies epiphyllous, dense, up to $3 \mathrm{~mm}$ in diameter, confluent and often trait along the major veins of the upper surface of the leaves. Hyphae substraight to flexuous, branching opposite, alternate to irregular at acute to wide angles, loosely to closely reticulate, cells 9-24x4-6 $\mu \mathrm{m}$. Appressoria scattered, unicellular, opposite, alternate, unilateral, globose, entire, mammiform, 4-7x4-9 $\mu \mathrm{m}$. Pycnothyria scattered, orbicular, up to $75 \mu \mathrm{m}$ in diameter, stellately dehisced and widely opened at the centre; pycnothyriospores globose to slightly ovate, $17-25 \mu \mathrm{m}$ in diameter, wall smooth. Thyriothecia scattered, orbicular, up to $188 \mu \mathrm{m}$ in diameter, stellately dehisced and widely opened at

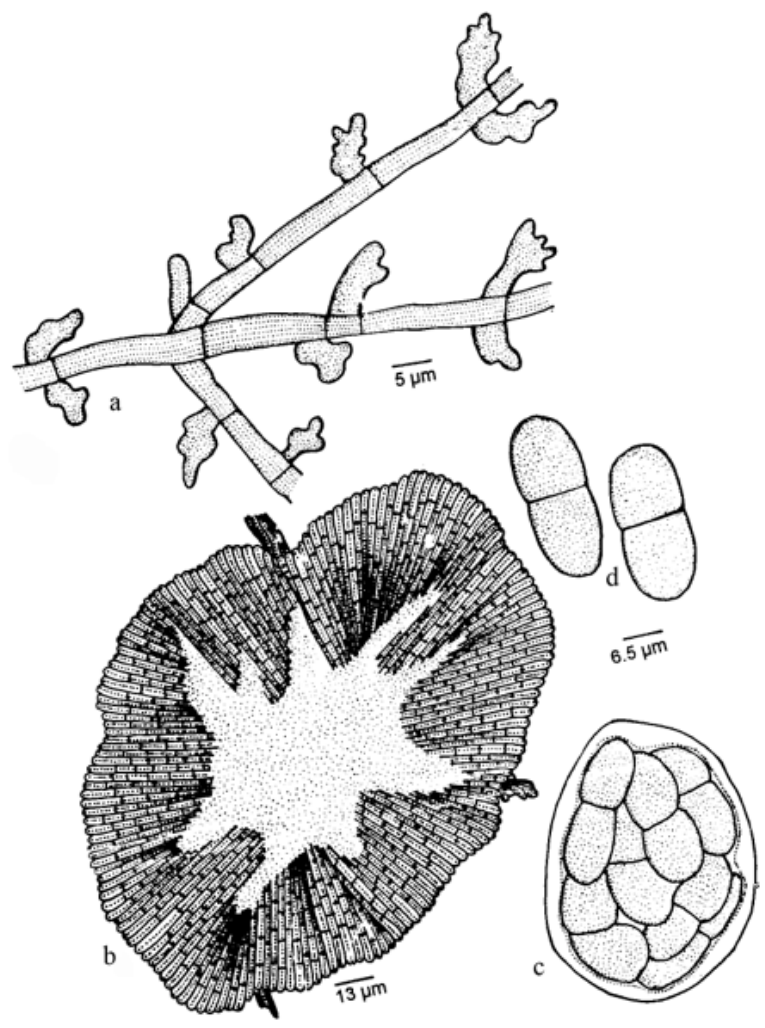

Figure 154. Asterina melicopecola

a - Appressorium; b - Thyriothecium; c - Ascus; d - Ascospores 


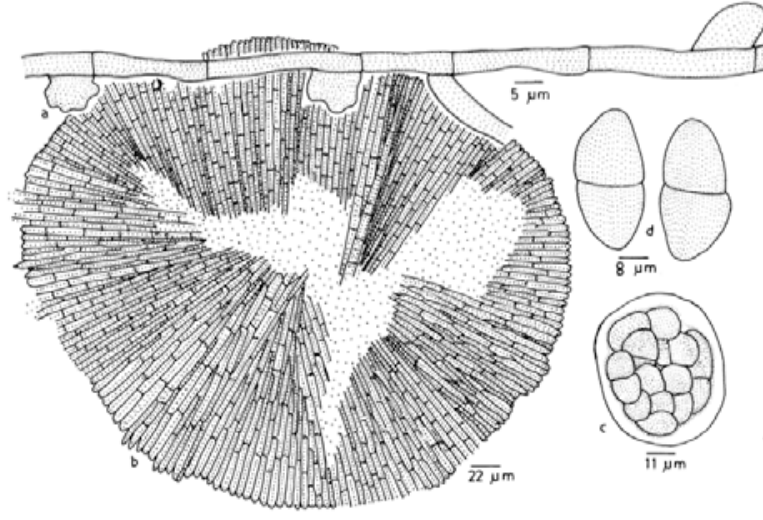

Figure 155. Asterina memecylonis

a - Appressorium; b - Thyriothecium; c - Ascus; d - Ascospores

the centre by exposing asci; asci globose to ovate, up to $63 \mu \mathrm{m}$ in diameter; ascospores brown, uniseptate, constricted at the septum, 25-33×15-18 $\mu \mathrm{m}$, wall smooth.

Asterina microtropidicola Hosag. \& C.K. Biju in Hosag., C.K. Biju, Abraham \& Agarwal, Indian Phytopath. 55: 499, 2002; Hosag., Zoos' Print J. 21: 2328, 2006; Hosag., Chandraprabha \& Agarwal, Asterinales of Kerala, p. 118, 2011; Hosag., Mycosphere 2(5): 722, 2012 (Fig. 158).

Materials examined: $\mathrm{HClO}$ 43712, TBGT 370, 12.viii.1999, on leaves of Microtropis latifolia Wight \& Lawson (Celastraceae), Thirunelly shola forest, coll. C.K. Biju.

Colonies amphigenous, dense, velvety, up to $5 \mathrm{~mm}$ in diameter, rarely confluent. Hyphae straight, rarely substraight to slightly flexuous, branching irregular at acute angles, loosely to closely reticulate, cells 12-20x3$5 \mu \mathrm{m}$. Appressoria unicellular, alternate, about 30\% opposite, straight to slightly curved, conoid, attenuated and broadly rounded at the apex, entire, 11-20x6$8 \mu \mathrm{m}$. Thyriothecia closely scattered, often connate, orbicular, up to $125 \mu \mathrm{m}$ in diameter, mostly crenate at the margin, stellately dehisced and widely opened at the centre; asci many, octosporous, globose, up to $40 \mu \mathrm{m}$ in diameter; ascospores oblong, conglobate, uniseptate, deeply constricted at the septum, 30-34×14-16 $\mu \mathrm{m}$, wall smooth.

Asterina microtropidis Hosag. et al. is known on Microtropis ovalifolia from the Western Ghats of peninsular India (Hosagoudar et al. 1996). However, Asterina microtropidicola differs from it in having alternate and opposite, conoid and straight appressoria.
Asterina naraveliae Hosag., C.K. Biju \& Agarwal, Indian Phytopath. 55: 499, 2002; Hosag., Chandraprabha \& Agarwal, Asterinales of Kerala, p. 126, 2011; Hosag., Mycosphere 2(5): 730, 2012 (Fig. 159).

Materials examined: HClO 43711, TBGT 369, 19.xi.2009, on leaves of Naravelia zeylanica (L.) DC. (Ranunculaceae), Banasuranmala, coll. C.K. Biju; HCIO 49968, TBGT 4120, 14.iii.2007, Puthuserry Kadavu, coll. M.C. Riju; HClO 50006, TBGT 4158, 27.xii.2007, coll. M.C. Riju; HClO 50740, TBGT 4657; HClO 51128, TBGT 5008, 5.xi.2009, Gurukulam Botanical Garden, Periya, coll. M.C. Riju \& A. Sabeena; HCIO 51175, TBGT 5055, 6.xi.2009, Thariode, coll. A. Sabeena \& M.C. Riju.

Colonies amphigenous, thin to subdense, up to $2 \mathrm{~mm}$ in diameter, rarely confluent. Hyphae flexuous to crooked, branching irregular at acute angles, loosely reticulate, cells $16-20 \times 3-4 \mu \mathrm{m}$. Appressoria two celled, very much scattered, antrorse, 9-15 $\mu \mathrm{m}$ long; stalk cells cylindrical to cuneate, $1.5-5 \mu \mathrm{m}$ long; head cells ovate, globose, mostly bilobate, rarely 3-4-times lobate, 8-10x6-10 $\mu \mathrm{m}$. Thyriothecia scattered, orbicular, up to $65 \mu \mathrm{m}$ in diameter, stellately dehisced at the centre, crenate at the margin; asci few to many, globose, octosporous, up to $28 \mu \mathrm{m}$ in diameter; ascospores oblong, brownish, conglobate, 1-septate, upper cell

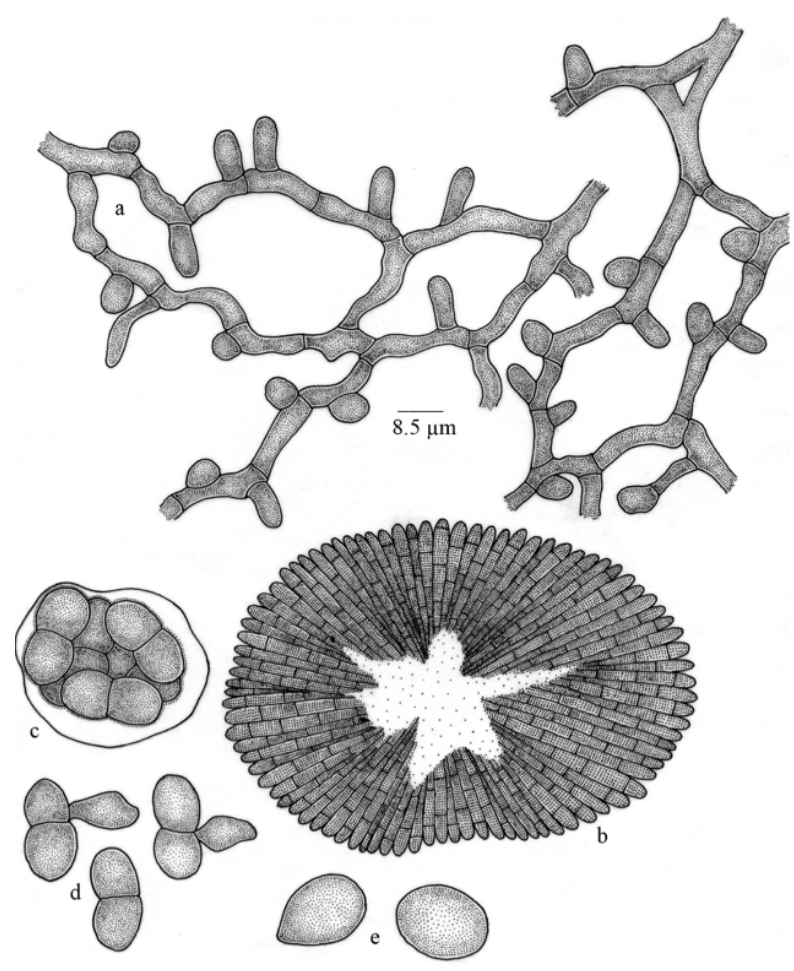

Figure 156. Asterina micheliifolia

a.Appressorium, b. Thyriothecium, c. Ascus, d. Ascospores 


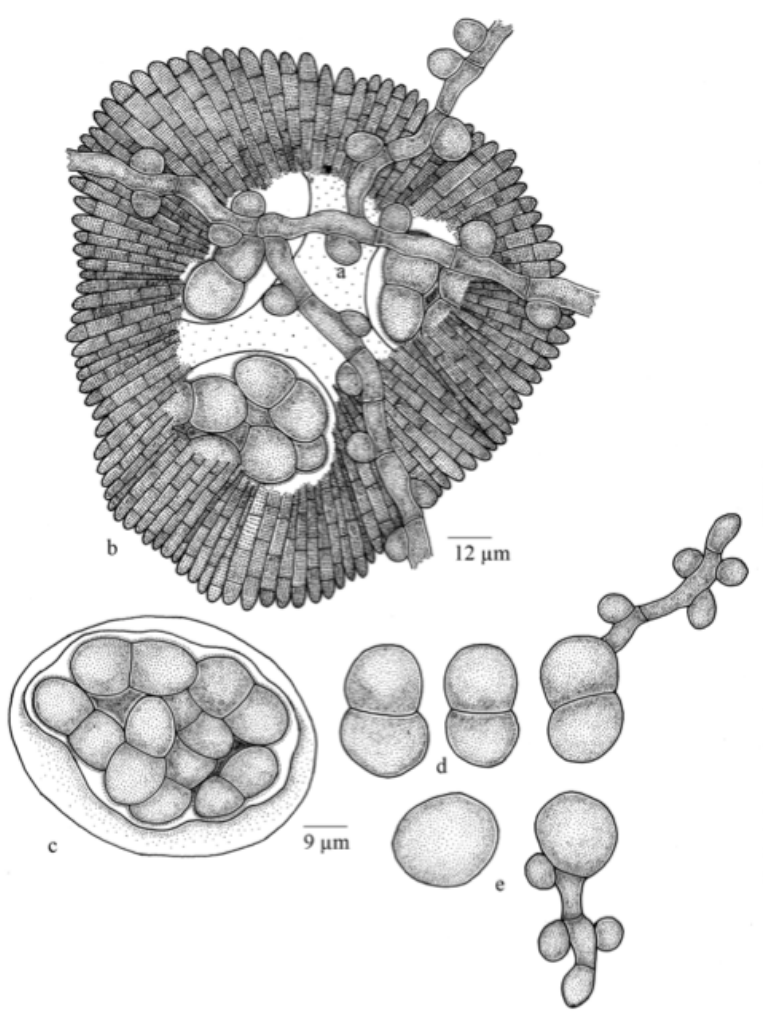

Figure 157. Asterina micheliigena

a.Appressorium, b. Thyriothecium, c. Ascus, d. Ascospores, e. Pycnothyriospores

slightly larger, 14-16x6-8 $\mu \mathrm{m}$, wall smooth. Pycnothyria not seen; pycnothyriospores ovate, pyriform, sometimes pale hyaline band present at the middle, 14-16×7-9 $\mu \mathrm{m}$.

Asterina clematidis Hansf. is known on Clematis glycinoides from Australia (Hansford, 1954). Asterina naraveliae differs from it in having sparsely arranged, alternate appressoria having deeply lobate head cells.

Asterina perpusilla Sydow, Ann. Mycol. 14: 366, 1916; Hosag., Mycosphere 2(5): 730, 2012.

Anamorph: Asterostomella alangii Hosag. \& Mohanan, Indian J. Forestry 19: 371, 1996 (Fig. 160).

Materials examined: $\mathrm{HClO}$ 50382, TBGT 4299, 4.xi.2009, on leaves of Alangium salvifolium (L.f.) Wans (Alangiaceae), Padinharathara, Alangium sp., A. Sabeena \& M.C. Riju; TBGT 5573, 22.v.2008, Alangium sundanum (Miq.) Bloemb., Padinharathara, coll. M.C. Riju.

Colonies epiphyllous, thin, up to $2 \mathrm{~mm}$ in diameter, confluent. Hyphae substraight, branching opposite, alternate to irregular, at acute to wide angles, loosely to closely reticulate, cells $11-24 \times 2-3 \mu \mathrm{m}$. Appressoria sessile, unilateral, alternate, angular, broad based, 4-10x4-10 $\mu \mathrm{m}$. Thyriothecia scattered to grouped, orbicular, stellately dehisced at the centre, up to

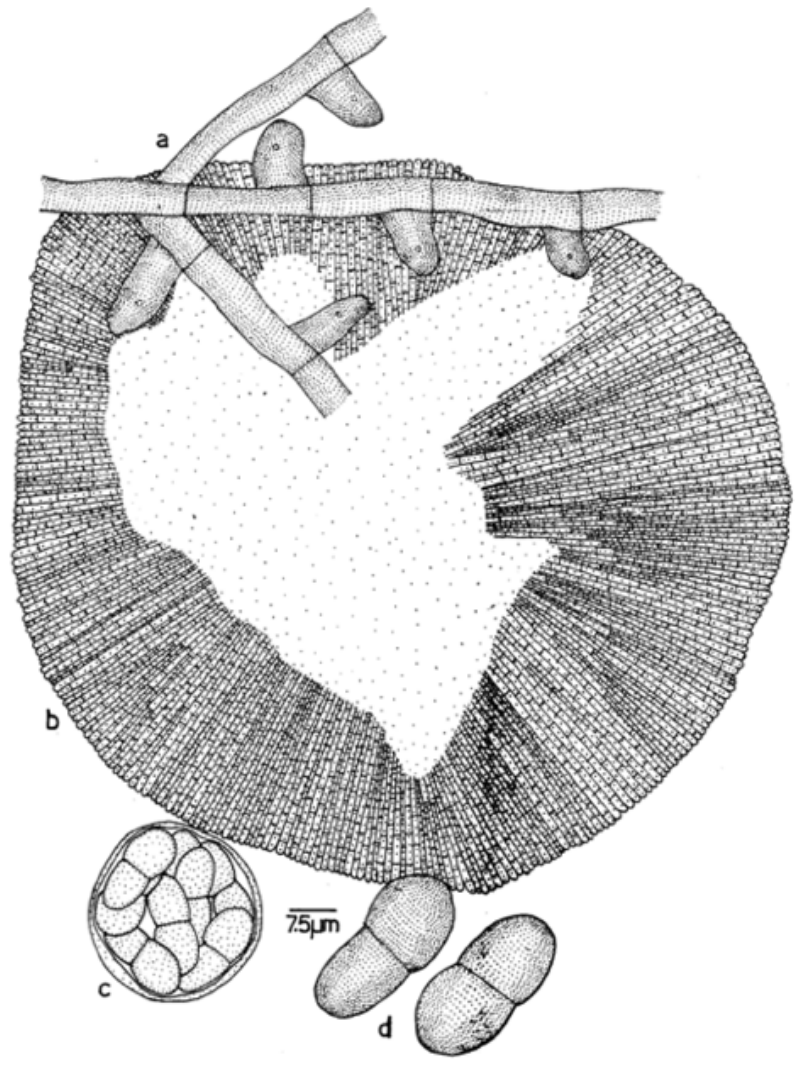

Figure 158. Asterina microtropidicola

a - Appressorium; b - Thyriothecium; c - Ascus; d - Ascospores

$160 \mu \mathrm{m}$ in diameter; ascospores conglobate, uniseptate, constricted at the septum, 19-26x9-11 $\mu \mathrm{m}$. Pycnothyria scattered, rarely connate, orbicular, up to $78 \mu \mathrm{m}$ in diameter, margin crenate, rarely fringed, stellately dehisced at the center; pycnothyriospores numerous, cinnamon brown, pyriform, 21-25×12-16 $\mu \mathrm{m}$.

Asterina piperina Sydow, Ann. Mycol. 15: 243, 1917; M. S. Patil \& Pawar, Indian Phytopath. 42: 251, 1989; Hosag., Mycosphere 2(5): 740, 2012.

Asterina piperis Yates, Philippine J. Sci. 13: 374, 1918 (Fig. 161).

Materials examined: $\mathrm{HClO}$ 49636, TBGT 3878, 17.ix.2008, on leaves of Piper sp. (Piperaceae), Periya, coll. M. Harish \& P.J. Robin

Colonies amphigenous, thin to dense, up to $1 \mathrm{~mm}$ in diameter, rarely confluent. Hyphae crooked, branching irregular at acute to wide angles, loosely to closely reticulate, cells 19-24 $\mu \mathrm{m}$. Appressoria scattered, alternate to unilateral, very closely antrorse, antrorse, subantrorse to retrorse, straight to curved, 12-20 $\mu \mathrm{m}$ long; stalk cells cylindrical to cuneate, 3-7 $\mu \mathrm{m}$ long; head cells ovate, globose, oblong, straight to curved, entire, 


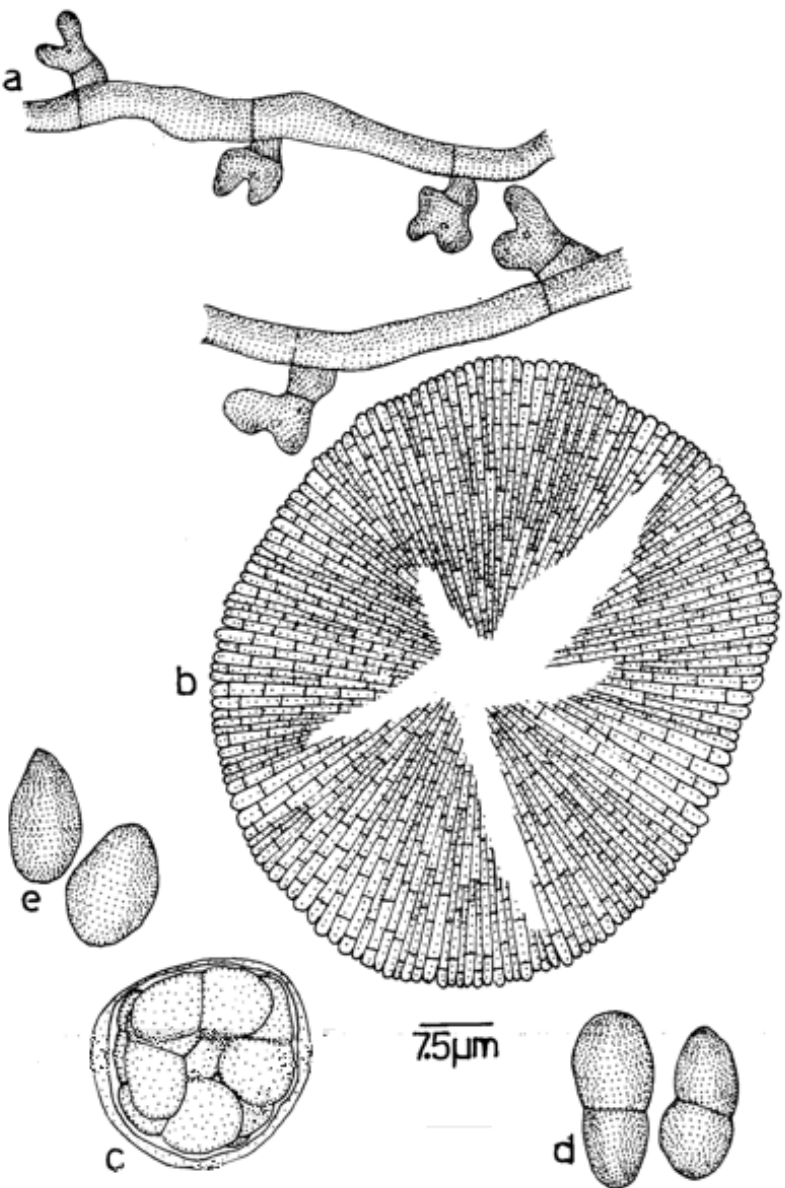

Figure 159. Asterina naraveliae

a - Appressorium; b - Thyriothecium; c - Ascus; d - Ascospores

angular, crenately lobate to deeply lobate, 9-13x9-11 $\mu \mathrm{m}$. Thyriothecia scattered to rarely connate, orbicular, up to $120 \mu \mathrm{m}$ in diameter, stellately dehisced at the centre, margin crenate to slightly fimbriate, fringed hyphae very small; asci globose, octosporous, up to $28 \mu \mathrm{m}$ in diameter; ascospores conglobate, brown, uniseptate, constricted at the septum, 14-21x6-11 $\mu \mathrm{m}$, wall smooth.

Asterina pongalaparensis Hosag., C.K. Biju \& Abraham, Indian Phytopath. 54: 138, 2001; Hosag., Chandraprabha \& Agarwal, Asterinales of Kerala, p. 136, 2011; Hosag., Mycosphere 2(5): 744, 2012 (Fig. 162).

Materials examined: TBGT 5549, 5.xi.2009, on leaves of Jasminum sambac (L.) Aiton, (Oleaceae), Wayanad, coll. M.C. Riju.

Colonies amphigenous, subdense to dense, up to $4 \mathrm{~mm}$ in diameter, rarely confluent. Hyphae undulate to crooked, branching alternate to unilateral at acute angles, loosely to closely reticulate, cells $17-23 \times 4-6$ $\mu \mathrm{m}$. Appressoria alternate, unilateral, two celled, straight to variously curved, smooth to variously bulged, entire to lobate, 5-10 $\mathrm{mm}$ long; head cells clavate, ovate, cylindrical, hamate, straight to curved, 3-7 times sublobate to lobate, 7-13x11-13 $\mu \mathrm{m}$. Thyriothecia scattered, orbicular, up to $150 \mu \mathrm{m}$ in diameter, stellately dehisced at the center, margin fringed, fringed hyphae flexuous, exappressoriate; asci globose, octosporous, 22-33 $\mu \mathrm{m}$ in diameter; ascospores oblong, cylindrical, brown, uniseptate, strongly constricted at the septum, 20-25x10-13 $\mu \mathrm{m}$, wall echinulate.

There are six taxa of the genus Asterina known on the members of the family Oleaceae (Yates 1918a; Doidge 1942; Hansford 1945, 1948; Yamamoto 1956; Hosagoudar \& Goos 1996). Asterina spissa Sydow known on this host genus is a doubutful species since it does not have appressoria (Sydow et al. 1911).

Asterina pusilla Sydow \& Sydow, Philippine J. Sci. 8: 488, 1913; Hosag. \& Sabeena, Zoos' Print J. 22: 2786, 2007; Hosag., Chandraprabha \& Agarwal, Asterinales of Kerala, p. 137, 2011; Hosag., Mycosphere 2(5): 746, 2012 (Fig. 163).

Materials examined:TBGT 5718, 30.ix.2007, on leaves of Premna serratifolia L. (Verbenaceae), Padinharathara, coll. M.C. Riju.

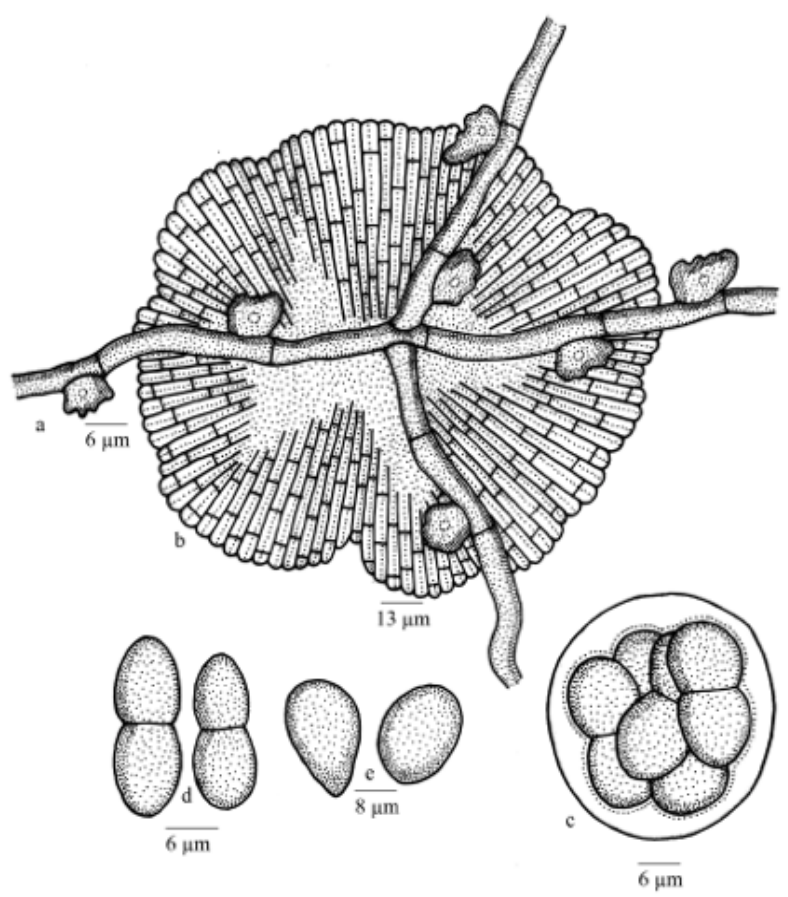

Figure 160. Asterina perpusilla

a - Appressorium; b - Thyriothecium; c - Ascus; d - Ascospores; e - Pycnothyriospores 

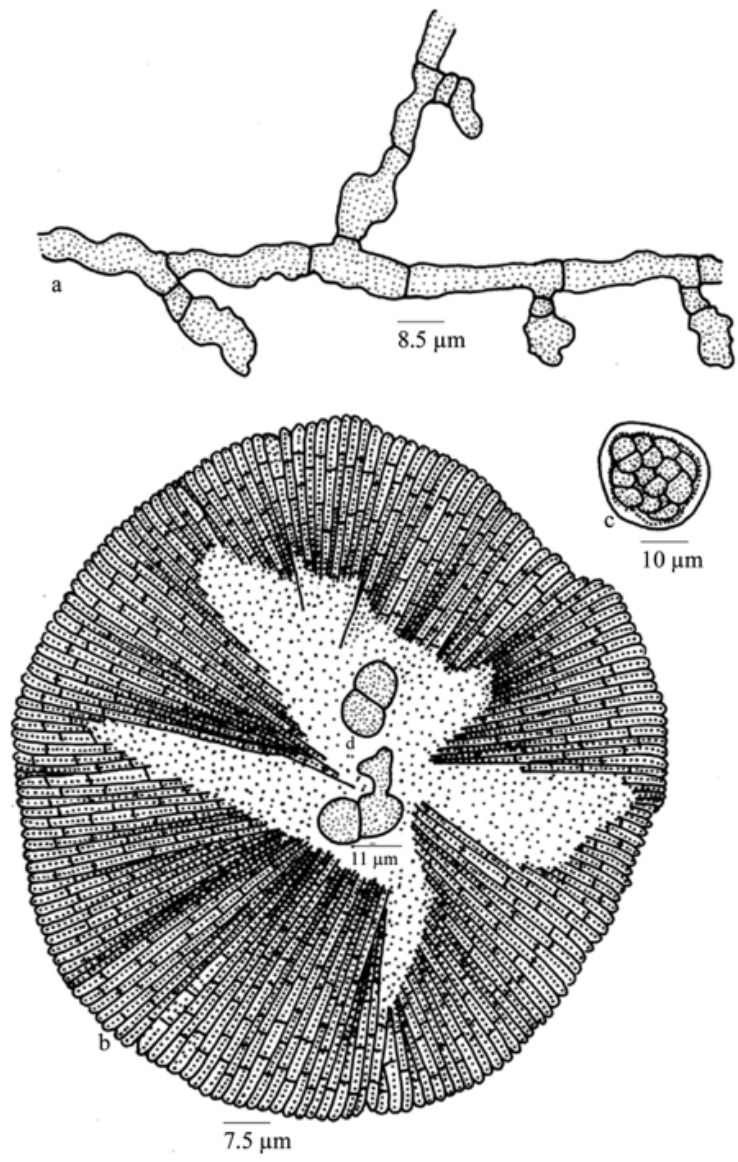

Figure 161. Asterina piperina

a - Appressorium; b - Thyriothecium; c - Ascus; d - Ascospores

Colonies epiphyllous, thin, dense, crustose, up to $2 \mathrm{~mm}$ in diameter, confluent. Hyphae straight to undulate, branching alternate, opposite to irregular at acute to wide angles, loosely reticulate, cells $20-48 \times 3-$ $5 \mu \mathrm{m}$. Appressoria alternate, scattered, unicellular, antrorse, subantrorse to retrorse, sublobate to lobate, mostly broad based, 8-11x6-11 $\mu \mathrm{m}$. Thyriothecia closely scattered, orbicular, up to $136 \mu \mathrm{m}$ in diameter, stellately dehisced at the centre, margin fimbriate, fringed hyphae long, crooked; asci globose, up to $34 \mu \mathrm{m}$ in diameter; ascospores brown, conglobate, uniseptate, constricted at the septum, $16-22 \times 6-10 \mu \mathrm{m}$, wall smooth. Pycnothyria numerous; pycnothyriospores brown, ovate, globose, pyriform, 10-15x10-14 $\mu \mathrm{m}$.

This species was known on Premna nauseosa from Philippines (Sydow \& Sydow 1913; Hosagoudar \& Abraham 2000). Perhaps, this is the first collection after its type collection.

Asterina sabiacearum Hosag. \& Goos, Mycotaxon 52: 469, 1994; Hosag. \& Abraham, J. Econ. Taxon. Bot.

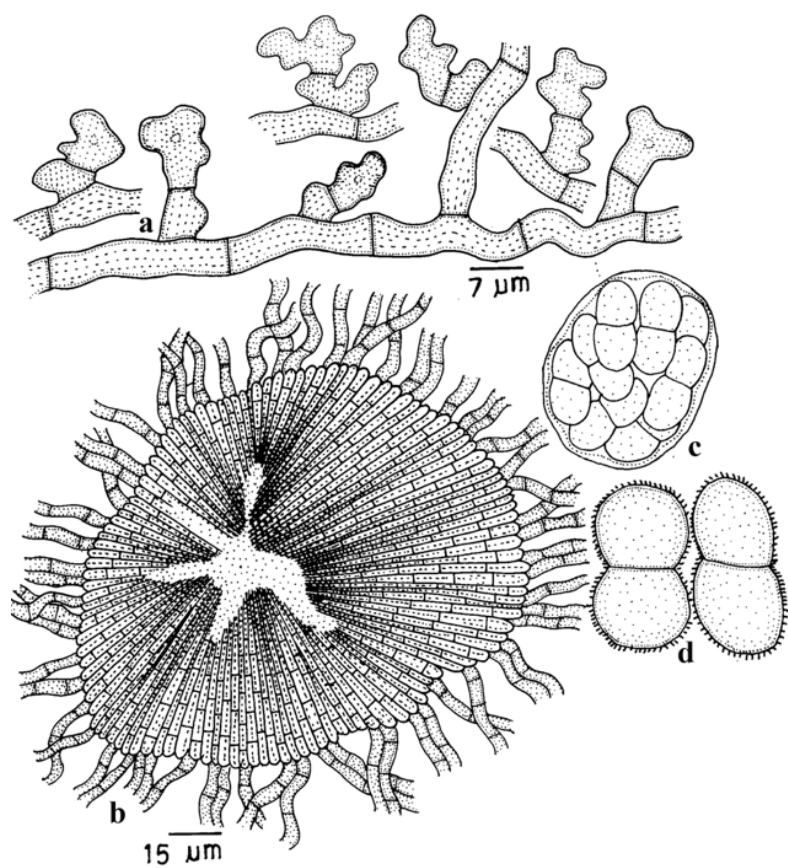

Figure 162. Asterina pongalaparensis

a - Appressorium; b - Thyriothecium; c - Ascus; d - Ascospores

4: 582, 2000; Hosag., Zoos' Print J. 18: 1284, 2003; 21: 2328, 2006; Singh, Duke, Bhandari \& Jain, J. Econ. Taxon. Bot. 30: 184, 2008; Hosag., Chandraprabha \& Agarwal, Asterinales of Kerala, p. 140, 2011; Hosag., Mycosphere 2(5): 748, 2012 (Fig. 164).

Materials examined: $\mathrm{HClO}$ 49070, TBGT 3325, 17.ix.2008, on leaves of Meliosma simplicifolia (Roxb.) Walp. ssp. pungens (Wall ex Wight \& Arn.) Beus (Sabiaceae), Periya, coll. M. Harish \& P.J. Robin; $\mathrm{HClO}$ 43804, TBGT 371, 19.xi.1999, Banasuran mala, coll. C.K. Biju; HClO 44882, TBGT 1110, 26.xii.2002, Periya, coll. M. Kamarudeen \& P.A. Jose

Colonies epiphyllous, subdense, minute, up to 1 $\mathrm{mm}$ in diameter. Hyphae flexuous to slightly crooked, branching alternate to irregular at acute angles, loosely reticulate, cells 30-37×3-5 $\mu \mathrm{m}$. Appressoria alternate, scattered, mostly unicellular, rarely two celled, mammiform, entire to sublobate, 13-22x5-7 $\mu \mathrm{m}$. Thyriothecia grouped at the center of the colony, stellately dehisced and widely opened, margin crenate, up to $60 \mu \mathrm{m}$ in diameter; ascospores conglobate, brown, 1-septate, deeply constricted at the septum, upper cell larger, lower cell smaller, 18-22×12-14 $\mu \mathrm{m}$, wall smooth.

This species can be compared with Asterina meliosmaticola Petrak \& Cif., reported on Meliosma sp. from which it differs in having unicellular to bicellular appressoria, and smaller thyriothecia, asci and 

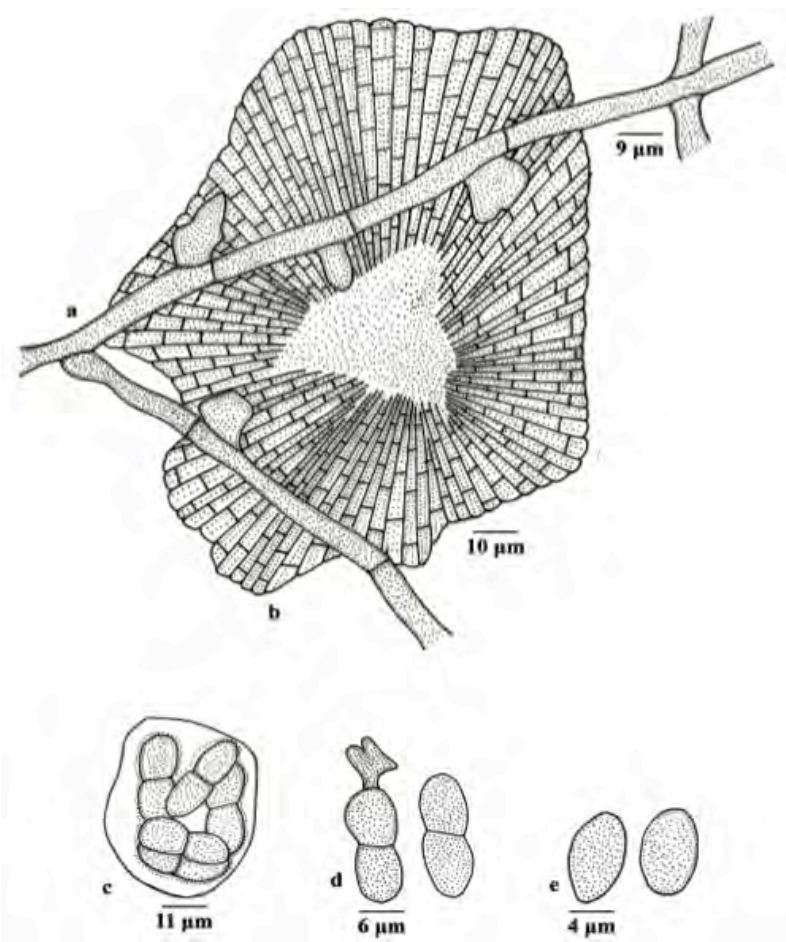

Figure 163. Asterina pusilla

a - Appressorium; b - Thyriothecium; c - Ascus; d - Ascospores; e Pycnothyriospores

ascospores (Petrak \& Cifferi 1932).

Asterina sarcandrae Hosag. \& Kamar. in Hosag., Zoos' Print J. 21: 2305, 2006; Hosag., Chandraprabha \& Agarwal, Asterinales of Kerala, p. 143, 2011; Hosag., Mycosphere 2(5): 751, 2012 (Fig. 165).

Materials examined: $\mathrm{HClO}$ 44794, TBGT 1031, 26.xii.2002, on leaves of Sarcandra chloranthoides Gard. (Chloranthaceae), Periya, coll. M. Kamarudeen.

Colonies hypophyllous, very thin, up to $5 \mathrm{~mm}$ in diameter. Hyphae flexuous, branching irregular at acute to wide angles, form a circularly angular and irregular net, cells 16-21x4-7 $\mu \mathrm{m}$. Appressoria scattered, alternate to irregular, two celled, antrorse, retrorse, spreading, straight to curved, 12-32 $\mu \mathrm{m}$ long; stalk cells cylindrical to cuneate, 3-7 $\mu \mathrm{m}$ long; head cells ovate, oblong, mostly curved, hamate, twisted, rarely straight, entire, angular to rarely sublobate, $10-26 \times 6-10 \mu \mathrm{m}$. Thyriothecia scattered, orbicular, stellately dehisced at the centre, up to $104 \mu \mathrm{m}$ in diameter, margin crenate; asci few, globose, octosporous, up to $30 \mu \mathrm{m}$ in diameter; ascospores conglobate, uniseptate, strongly constricted at the septa, 20-22x7-9 $\mu \mathrm{m}$, wall echinulate.

Asterina chloranthi Sydow is known on Chloranthus officinalis from Philippines (Sydow \& Petrak 1931;
Hosagoudar \& Abraham 2000). However, Asterina sarcandrae differs from it in having very thin hypophyllous colonies, net forming mycelia and longer appressoria.

Asterina tertia Racib. in Theiss., Die Gattung Asterina 7:103, 1913; Sacc., Sylloge Fungorum 24: 443, 1926; Hosag. \& Abraham, J. Econ. Taxon. Bot. 4: 558, 2000; Hosag., H. Biju \& Appaiah, J. Mycopathol. Res. 43: 204, 2005; 44:12, 2006; Hosag., Zoos' Print J. 21: 2329, 2006; Hosag., Chandraprabha \& Agarwal, Asterinales of Kerala, p. 147, 2011 ; Hosag., Mycosphere 2(5): 755, 2012 (Fig. 166).

Materials examined: $\mathrm{HClO}$ 50726, TBGT 4643, 6.xii.2009, on leaves of Adhatoda vasica Nees (Acanthaceae), Padinharathara, coll. A. Sabeena \& M.C. Riju; TBGT 4296, 6.xi.2009, Asystasia violacea Dalz. ex C.B. Clarke (Acanthaceae), Padinharathara, coll. A. Sabeena \& M.C. Riju; HClO 50614, TBGT 4531; HClO 50616, TBGT 4533; HClO 50618,TBGT 4535; HClO 50620, TBGT 4537; HClO 50622, TBGT 4539, 6.xi.2009, Lepidagathis sp. (Acanthaceae), 16 $6^{\text {th }}$ mile, Padinharathara, coll. A. Sabeena \& M.C. Riju.

Colonies amphigenous, up to $3 \mathrm{~mm}$ in diameter, confluent. Hyphal cells up to $4 \mu \mathrm{m}$ broad. Appressoria sparse, continuous, 3-4 lobate, 5-8x8-13 $\mu \mathrm{m}$. Thyriothecia 120-160 $\mu \mathrm{m}$ in diameter; margin fimbriate,

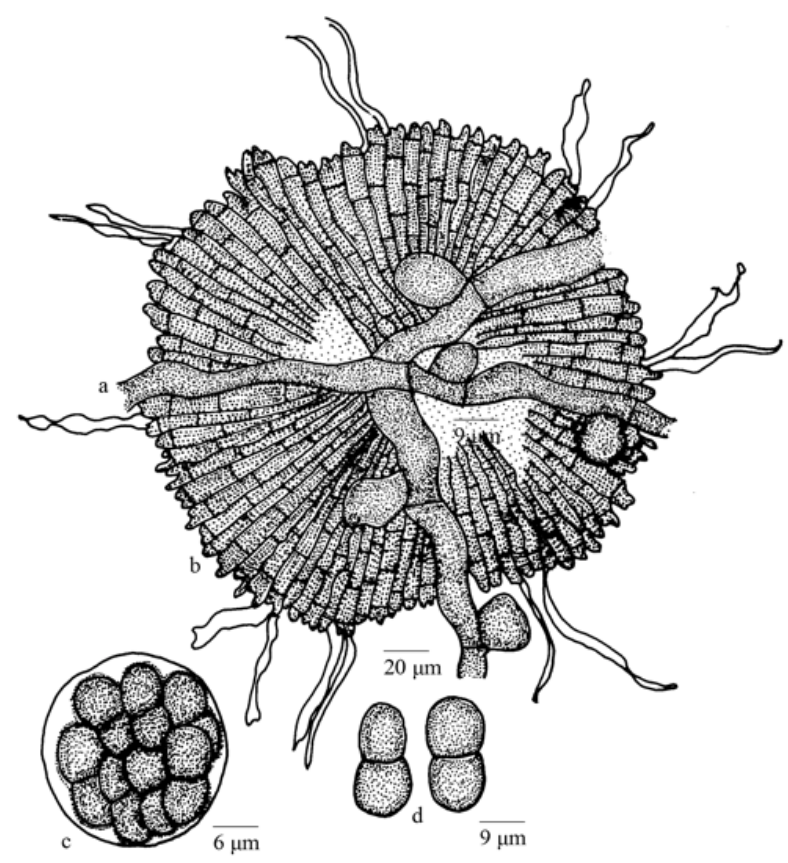

Figure 164. Asterina sabiacearum

a - Appressoriate mycelium; b - Thyriothecium; c - Ascus; d - Ascospores 
stellately dehisced in the centre; asci octosporous, 40 48x20-23 $\mathrm{mm}$; ascospores brown, 1-septate, constricted at the septum, $16-20 \times 8-10 \mu \mathrm{m}$. Pycnothyria 55-80 $\mu \mathrm{m}$; pycnothyriospores unicellular, ovate, brown, 17-20x12-15 $\mu \mathrm{m}$. Thyriothecia 120-160 $\mu \mathrm{m}$ in diam.; margin fimbriate, stellately dehisced in the centre; asci

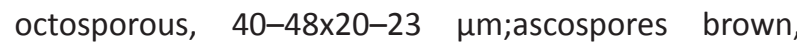
1-septate, constricted, 16-20x8-10 $\mu \mathrm{m}$. Pycnothyria 55-80 $\mu \mathrm{m}$; pycnothyriospores unicellular, ovate, brown, 17-20x12-15 $\mu \mathrm{m}$.

Asterina thotteae Hosag. \& Hanlin, New Botanist 22: 188, 1995; Hosag., H. Biju \& Appaiah, J.Mycopathol. Res. 44:12, 2006; Hosag., Chandraprabha \& Agarwal, Asterinales of Kerala, p. 152, 2011; Hosag., Mycosphere 2(5): 759, 2012 (Fig. 167).

Materials examined: $\mathrm{HClO}$ 48238, TBGT 2976, 29.x.2007, on leaves of Thottea siliquosa (Lam.) Ding Hou. (Aristolochiaceae), Periya, coll. A. Chandraprabha; HCIO 43811, TBGT 374, 14.iv.1999, T. sivarajanii Santhosh, Shanavas \& Binu (Aristolochiaceae), Chembra hills, coll. C.K.Biju; HCIO 44800, TBGT 1037, 27.xii.2002, Periya, coll. M. Kamarudeen \& P.A. Jose.

Colonies epiphyllous, thin to subdense, spreading, up to $3 \mathrm{~mm}$ in diameter, confluent. Hyphae substraight to rarely crooked, branching alternate to opposite at acute to wide angles, loosely reticulate, cells $31-38 \times 3-4$ $\mu \mathrm{m}$. Appressoria alternate and about 3\% opposite, straight to curved, antrorse to recurved, two celled, 9-19 $\mu \mathrm{m}$ long; stalk cells cylindrical to cuneate, 3-7 $\mu \mathrm{m}$ long; head cells ovoid, globose, entire to sublobate, angular, straight to curved, 6-13×6-10 $\mu \mathrm{m}$. Thyriothecia scattered, rarely $1-2$ connate, circular, up to $155 \mu \mathrm{m}$ in

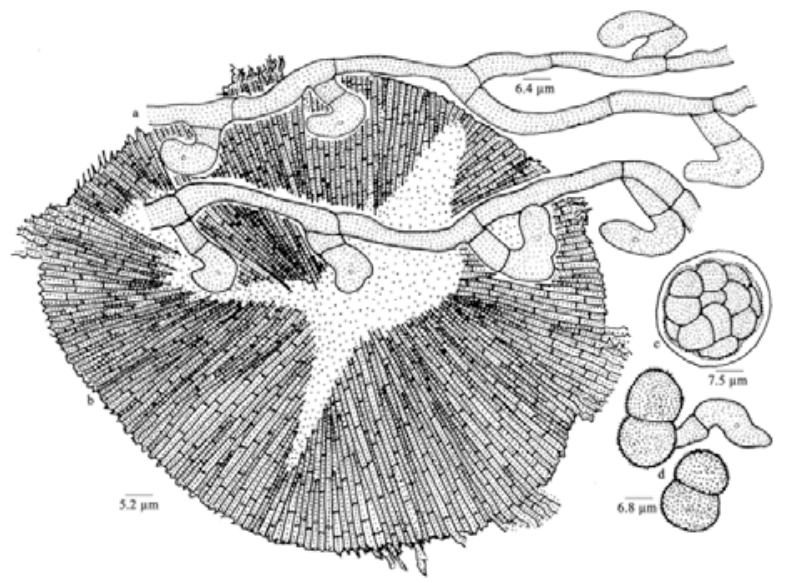

Figure 165. Asterina sarcandrae

a - Appressorium; b - Thyriothecium; c - Ascus; d - Ascospores diameter, margin fimbriate, fringed hyphae flexuous to crooked, pale yellow, center carbonaceous black and stellately dehisced at the center; asci many, initially globose, slightly clavate at maturity, octosporous, 3038x27-31 $\mu \mathrm{m}$; ascospores conglobate, oblong, deep brown, rounded at both ends, 1-septate, constricted at the septum, 18-20x9-10 $\mu \mathrm{m}$, wall verrucose.

This is the only species of the genus Asterina on the members of the family Aristolochiaceae (Steven \& Ryan 1939; Diodge 1942).

Asterina toddaliae Kar \& Ghosh, Indian Phytopath. 39: 210, 1986; Hosag. \& Goos, Mycotaxon 52: 470, 1994; Hosag., Chandraprabha \& Agarwal, Asterinales of Kerala, p. 155, 2011; Hosag., Mycosphere 2(5): 762, 2012 (Fig. 168).

Material examined: TBGT 6647, 19.ix.2008, on leaves of Toddalia sp. (Rutaceae), Pulpally, coll. M. Harish et al.

Colonies epiphyllous, thin to subdense, up to $4 \mathrm{~mm}$ in diameter, rarely confluent. Hyphae straight to flexuous, branching irregular at acute to wide angles, loosely to closely reticulate, cells $19-32 \times 4-6 \mu \mathrm{m}$. Appressoria alternate to unilateral, unicellular, antrorse, retrorse,

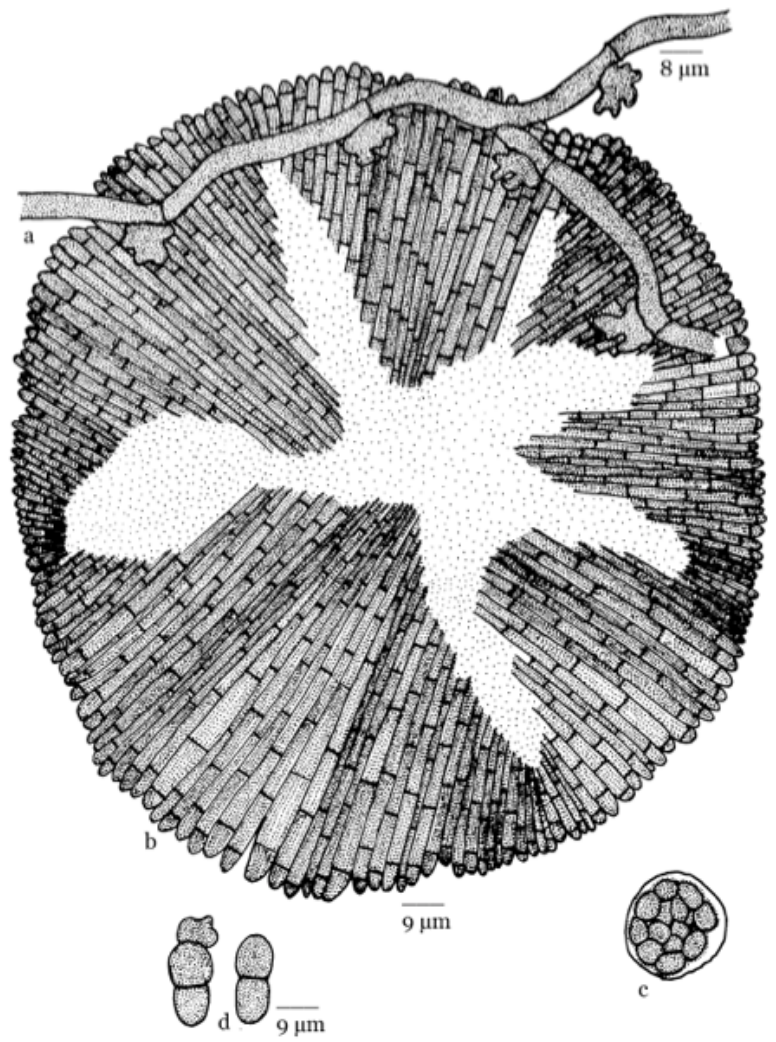

Figure 166. Asterina tertia

a - Appressorium, b - Thyriothecium, c - Ascus, d - Ascospores 
straight, flexuous to curved, ovate, oblong, cylindrical, broadly rounded at the tip, 11-18x4-6 $\mu \mathrm{m}$. Thyriothecia scattered, orbicular, up to $195 \mu \mathrm{m}$ in diameter, stellately dehisced at the centre, margin fimbriate, fringed hyphae small, crooked; asci globose, 8- spored, up to $40 \mu \mathrm{m}$ in diam.; ascospores oblong, brown, uniseptate, constricted at the septum, 27-30x10-12 $\mu \mathrm{m}$, margin tubercled.

Kar \& Ghosh (1986) reported this species from Rangpo forest, Darjeeling, West Bengal

Asterina travancorensis Sydow \& Sydow, Ann. Mycol. 13: 38, 1915; Hosag. \& Goos, Mycotaxon 69: 160, 1996; Hosag., Mycosphere 2(5): 764, 2012 (Fig. 169).

Materials examined: $\mathrm{HClO}$ 49846,TBGT 3998, 12.ii.2009, on leaves of Wattakaka volubilis (L. f.) Stapf. (Marsdenia volubilis (L.f.) Cooke) (Asclepiacaceae), Periya, coll. Jacob Thomas et al.

Colonies foliicolous, epiphyllous, often surrounded by yellow haloes, scattered, dense, crustose to velvety,

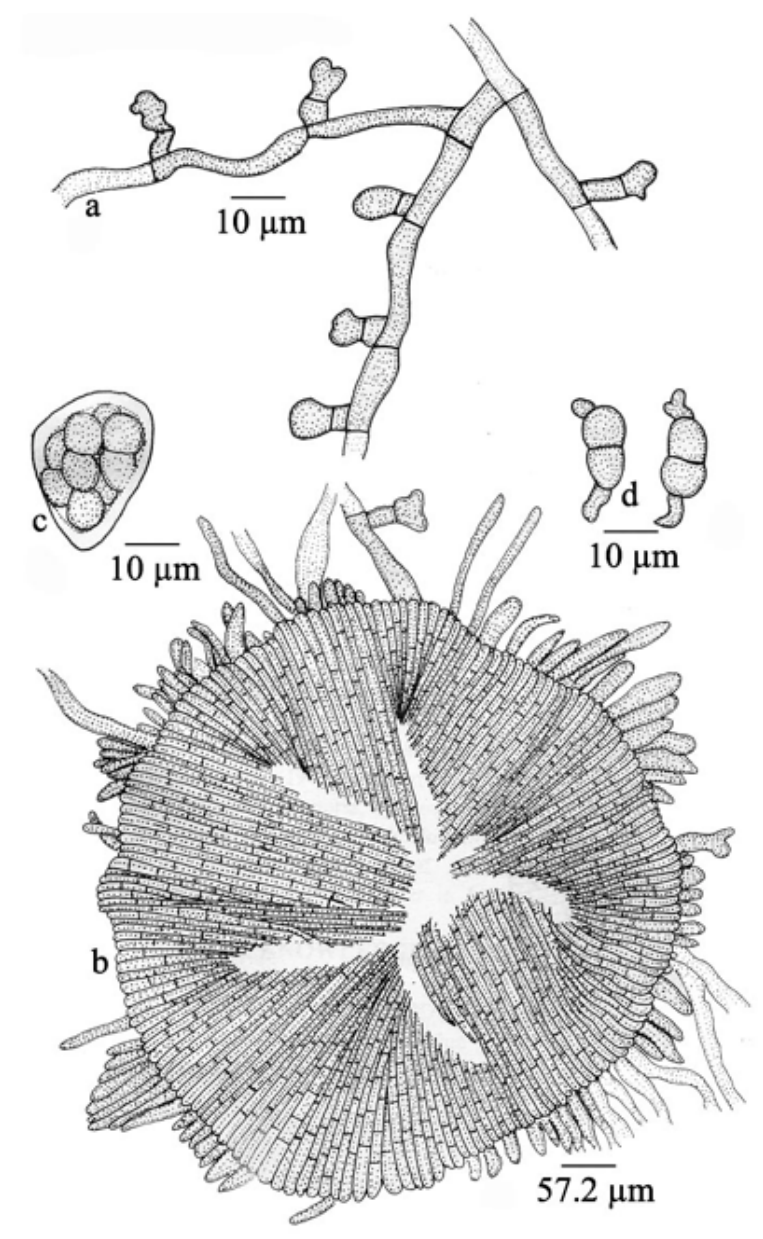

Figure 167. Asterina thotteae

a.Appressorium, b. Thyriothecium, c. Ascus, d. Ascospores up to $2 \mathrm{~mm}$ in diameter, rarely confluent. Hyphae straight to flexuous, branching opposite to irregular at acute angles, loosely reticulate, cells $18-25 \times 5-7 \mu \mathrm{m}$. Appressoria one to two celled, alternate, about $1 \%$ opposite, antrorse to spreading, straight to curved, 12-25 $\mu \mathrm{m}$ long; stalk cells cylindrical to cuneate, 3-19 $\mu \mathrm{m}$ long; head cells ovate, globose, entire to sublobate, 6-10x6-13 $\mu \mathrm{m}$. Thyriothecia scattered to connate up to 5 , round, up to $110 \mu \mathrm{m}$ in diameter, dehisce stellately at the centre, upper cells radiating, margin crenate; asci globose, octosporous, bitunicate, 27-31 $\mu \mathrm{m}$ in diameter; ascospores conglobate, one septate, upper cell slightly larger, 21-25x9-13 $\mu \mathrm{m}$, wall smooth.

Sydow \& Sydow (1915) described this species on Marsdenia sp., collected by E.J. Butler from Pulliyanur, Travancore of Kerala State on October 9, 1907.

This species is known only from the Southern Western Ghats.

Asterina trichiliae Doidge, Trans. Royal Soc. South Africa 8: 253, 1920; Hosag. \& Goos, Mycotaxon 60: 161,

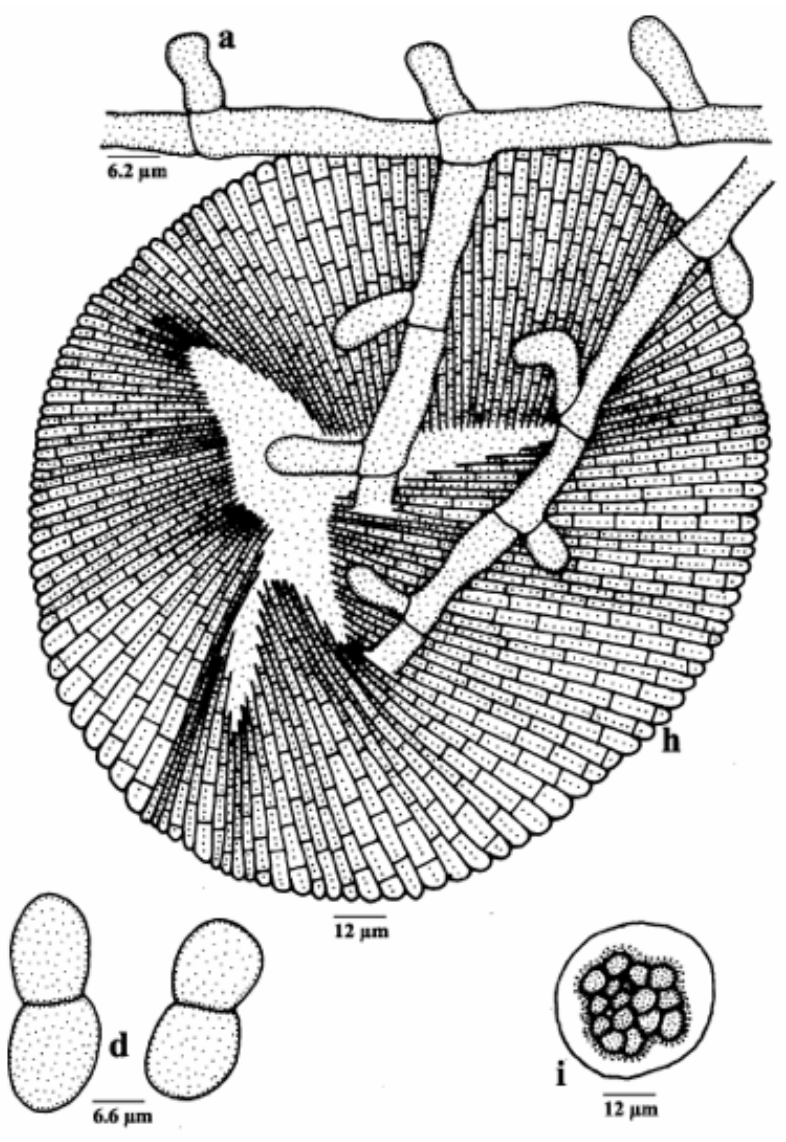

Fig. 168. Asterina toddaliae

a.Appressorium, b. Thyriothecium, c. Ascus, d. Ascospores 
1996; Hosag., Mycosphere 2(5): 764, 2012 (Fig. 170).

Materials examined: TBGT 5998, 6.ii.2006, on leaves of Trichilia connaroides (Wight \& Arn.) Bentv. (Meliaceae), Kunkidhira, coll. Harish et al.; $\mathrm{HClO} 49065$, TBGT 3320, 18.ix.2008, Trichilia sp., Thirunelly, coll. M. Harish et al.; HCIO 49635, TBGT 3877, 17.ix.2008, Periya, coll. M.Harish \& P.J. Robin.

Colonies epiphyllous, thin, up to $2 \mathrm{~mm}$ in diameter, confluent and covering the entire upper surface of the leaves. Hyphae straight, branching opposite to irregular at acute angles, loosely reticulate, cells $15-19 \times 3-7$ $\mu \mathrm{m}$. Appressoria opposite, subopposite, alternate and solitary, conoid, ovate, ampulliform, unicellular, entire, angular to rarely slightly lobate, $6-10 \times 6-8 \mu \mathrm{m}$. Thyriothecia loosely grouped, orbicular, up to $140 \mu \mathrm{m}$ in diameter, margin dentate to fringed, fringed hyphae tortuous, elongated and devoid of appressoria, such hyphae also emerge from the mycelia, thyriothecia dehiscing stellately at the center; asci many, globose, eight spored, 40-47 $\mu \mathrm{m}$ in diameter; ascospores conglobate, brown, 1- septate, deeply constricted at septum, both cells unequal, 27-31×15-19 $\mu \mathrm{m}$, wall smooth.

This species was first reported from South Africa (Doidge 1942).

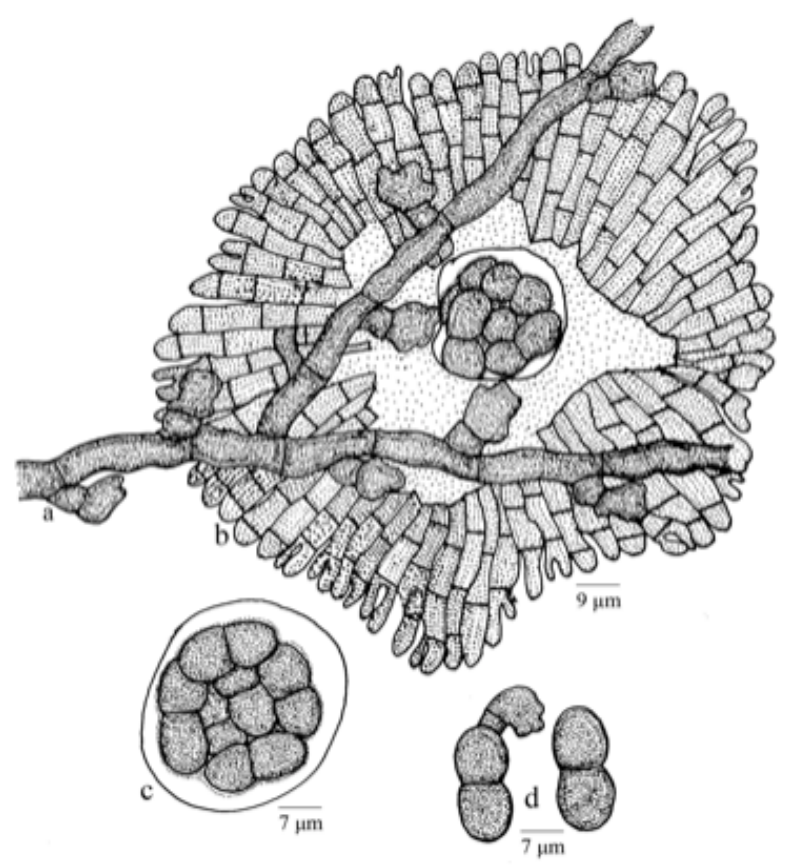

Figure 169. Asterina travancorensis

a.Appressorium, b. Thyriothecium, c. Ascus, d. Ascospores
Asterina triumfetticola Yamam., sci. Rep. Hyogo Univ. Agric., Agric. Biol. Ser. 3:29, 1957; Hosag. \& Abraham, J. Econ. Taxon. Bot. 4: 585, 2000; Hosag., Zoos' Print J. 17: 945, 2002; 21: 2329, 2006; Hosag., Chandraprabha \& Agarwal, Asterinales of Kerala, p. 158, 2011; Hosag., Mycosphere 2(5): 765, 2012 (Fig. 171).

Materials examined: $\mathrm{HClO} 50728, \mathrm{TBGT} 4645 ; \mathrm{HClO}$ 50730, TBGT 4647, 11.xi.2009, on leaves of Triumfetta sp. (Tiliaceae), Puthucherry Kadavu, coll. A. Sabeena \& M.C. Riju.

Colonies epiphyllous, subdense to dense, up to $2 \mathrm{~mm}$ in diameter, confluent. Hyphae strongly appressed to the host surface, substraight to crooked, branching irregular at acute to wide angles, loosely reticulate, cells $16-24 \times 3-4 \mu \mathrm{m}$. Appressoria alternate, unilateral, unicellular, stipitate to sessile, globose, clavate, angular to deeply lobate, 4-7 $\mu \mathrm{m}$ long, 7-9 $\mu \mathrm{m}$ broad. Thyriothecia scattered, orbicular, up to $70 \mu \mathrm{m}$ in diameter, stellately dehisced at the centre, margin crenate; asci globose, octosporous, bitunicate, 20-28 $\mu \mathrm{m}$ in diameter; ascospores pale-brown, conglobate, uniseptate, constricted at the septum, 14-16x6-8 $\mu \mathrm{m}$, wall smooth to slightly punctate. Pycnothyria numerous, orbicular, smaller than thyriothecia; pycnothyriospores pyriform, deep brown, 14-16x11-12 $\mu \mathrm{m}$.

This species was known on Triumfetta bartamia from Taiwan (Yamamoto 1956, 1957). This collection was associated with Irenopsis sp.

Asterina viburnicola Hosag., Mycosphere 2(5): 764, 2012.

Asterina viburni Hosag., Dhivaharan \& Nithytharani, J. Sci. Environ. \& Technov. 4: 47, 2010 (Fig. 172).

Materials examined: TBGT 6148, 6150, 6153, 7.i.2010, on leaves of Viburnum cylindricum Buch. Ham. ex D. Don (Caprifoliaceae), Periya, coll. M.C. Riju et al.

Colonies amphigenous, mostly epiphyllous, dense, scattered to confluent, 2-5 $\mathrm{mm}$ in diameter. Hyphae flexuous, branching opposite at acute angle, loosely reticulate, cells $15-25 \times 5-7 \mu \mathrm{m}$. Appressoria alternate, two celled, antrorse to retrorse, straight to curved, 17$20 \mu \mathrm{m}$ long; stalk cells cylindrical to cuneate, 7-10 $\mu \mathrm{m}$ long; head cells cylindrical, slightly angular to sublobate, 7-10x5-10 $\mu \mathrm{m}$. Thyriothecia grouped at the centre of the colony, orbicular, up to $95 \mu \mathrm{m}$ in diameter, dehisce stellately at the center, margin crenate; asci globose, eight spored, 32-35 $\mathrm{mm}$ in diameter; ascospores conglobate, 1-septate, slightly constricted at the septum, 17-20x7-10 $\mu \mathrm{m}$, wall smooth.

This is the only species of the genus Asterina known on the members of the family Caprifoliaceae 


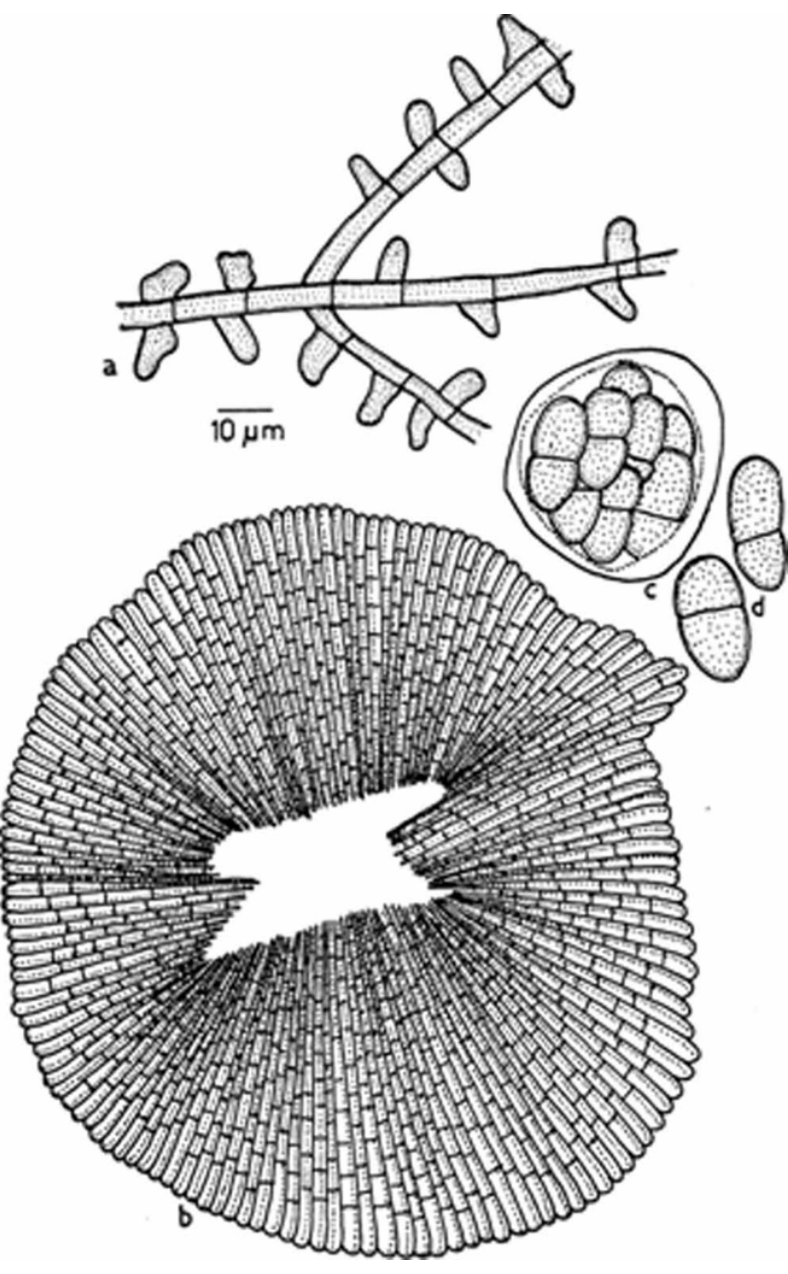

Figure 170. Asterina trichiliae

a.Appressorium, b. Thyriothecium, c. Ascus, d. Ascospores

(Hosagoudar \& Abraham 2000; Stevens \& Ryan 1939; Katumoto 1975; Yamamoto 1957).

\section{Materials to be identified}

\section{Asterina sp.}

Materials examined: $\mathrm{HClO} 44881$ TBGT 1109, 22.xii.2002, on leaves of Syzygium caryophyllatum (L.) Alston (Myrtaceae), Periya, coll. Kamarudeen \& P.A. Jose; HClO 45117, TBGT 1172, 7.iii.2001, Periya, coll. G. Rajkumar \& P.A. Jose; HCIO 45120, TBGT 1175, 8.i.2001, syzygium sp. Wayanad, coll. M. Kamarudeen; HCIO 45165, TBGT 1220, 8.i.2002, Chandanathode, coll. M. Kamarudeen \& P.A. Jose; HClO 45285 TBGT1323, 19.xi.1998 Banasuranmala, coll. C.K. Biju; HClO 45287, TBGT 1325, 14.ix.1999, Chembra, coll. C.K. Biju; HCIO 50049, TBGT 4201, 16.ii.2009, Periya, coll. Robin et al.; HCIO 45258,TBGT 1296, 12.vii.2002, on leaves of Litsea sp. (Lauraceae), Wayanad, coll. M. Kamarudeen; HCIO 47469, TBGT 2507, 15.iv.1999, on leaves of Canthium

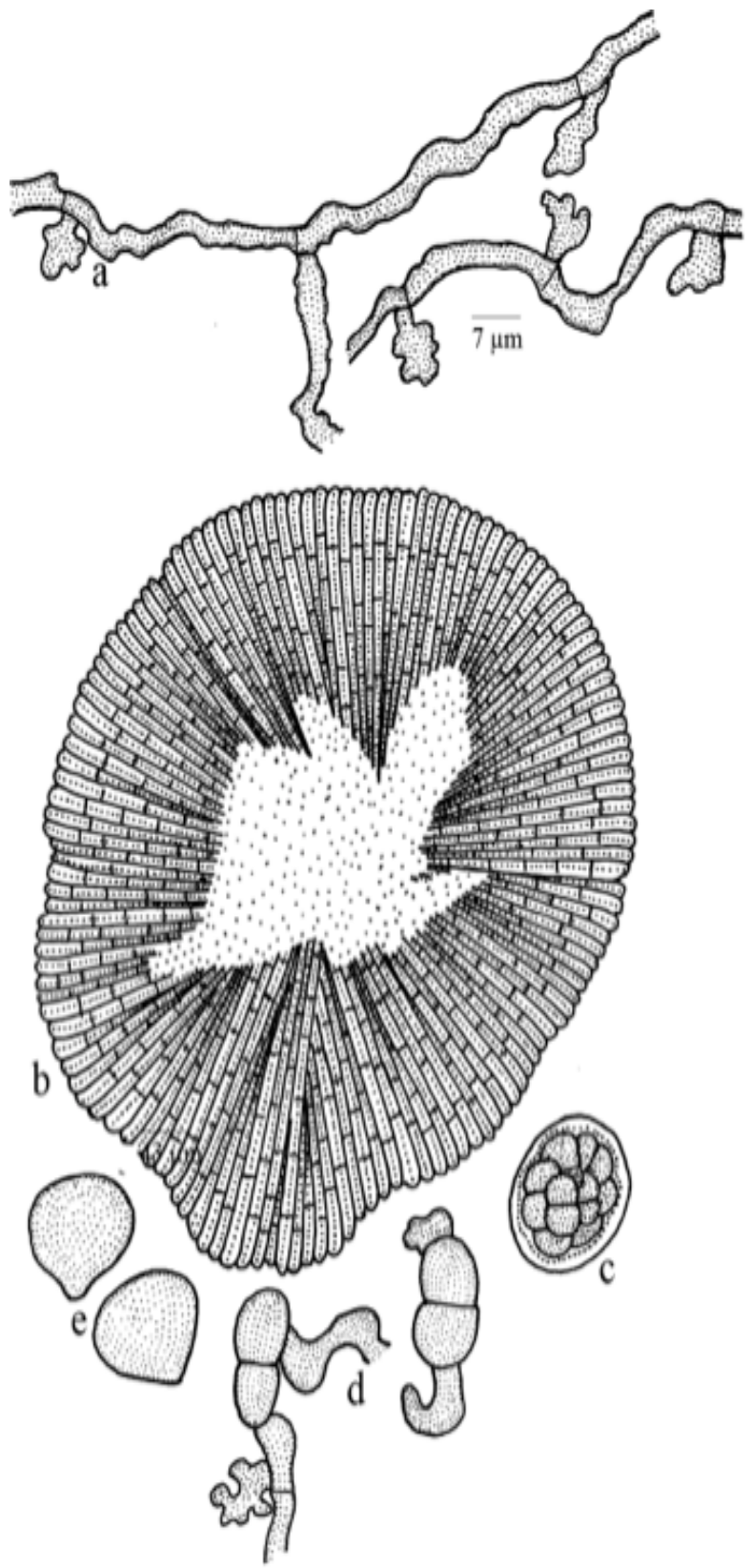

Figure-171. Asterina triumfetticola

a -Appressorium, b. Thyriothecium, c. Ascus, d. Ascospores

dicocerum (Rubiaceae), Thirunelly Shola, coll. C.K. Biju.

\section{The genus Asterolibertia}

Asterolibertia Arn., Les Asterinees, 1: 161, 1918; Hansf., Mycol. Pap. 15: 189, 1946; Muller \& Arx, Beitr. Krypt. Schw. 11:97, 1962; Arx \& Muller, Stud. Mycol. 9: 43, 1975; Bilgrami, Jamaluddin \& Rizwi, Fungi of India p. 54, 1991; Hosag., Abraham \& C.K. Biju, J. Mycopathol. Res. 39: 61, 2001; Singh, Duke, Bhandari \& Jain, J. Econ. 
Taxon. Bot. 30: 185, 2008; Hosag, Mycosphere 2(5): 772 , 2012. Steyaertia Bat. \& Maia, Univ. Recife, Inst. Mycol. Publ. 295:5, 1960.

Wardina Arn., Les Asterinees 1: 165, 1918.

Leaf parasites. Mycelium ectophytic, appressoria intercalary, setae absent. Thyriothecia orbicular with radiating cells, astomatous, dehisce stellately at the center; asci globose, octosporous, bitunicate; ascospores conglobate, uniseptate, brown.

Type sp. A. couepiae (Henn. ) Arn.

This genus represents here with a single species.

Asterolibertia vateriae Hosag., J. Mycopathol. Res. 44: 13, 2006; Hosag., Chandraprabha \& Agarwal, Asterinales of Kerala, p. 168, 2011; Hosag, Mycosphere 2(5): 774, 2012 (Fig. 173).

Material examined: $\mathrm{HClO}$ 49774, TBGT 3926, 13.ii.2009, on leaves of Vateria indica L. (Dipterocarpaceae), Thirunelly, coll. Jacob Thomas et al.

Colonies amphigenous, mostly epiphyllous, dense, crustose, cause water soaked lesions on the corresponding opposite surface of the leaves, up to $10 \mathrm{~mm}$ in diameter, confluent. Hyphae substraight

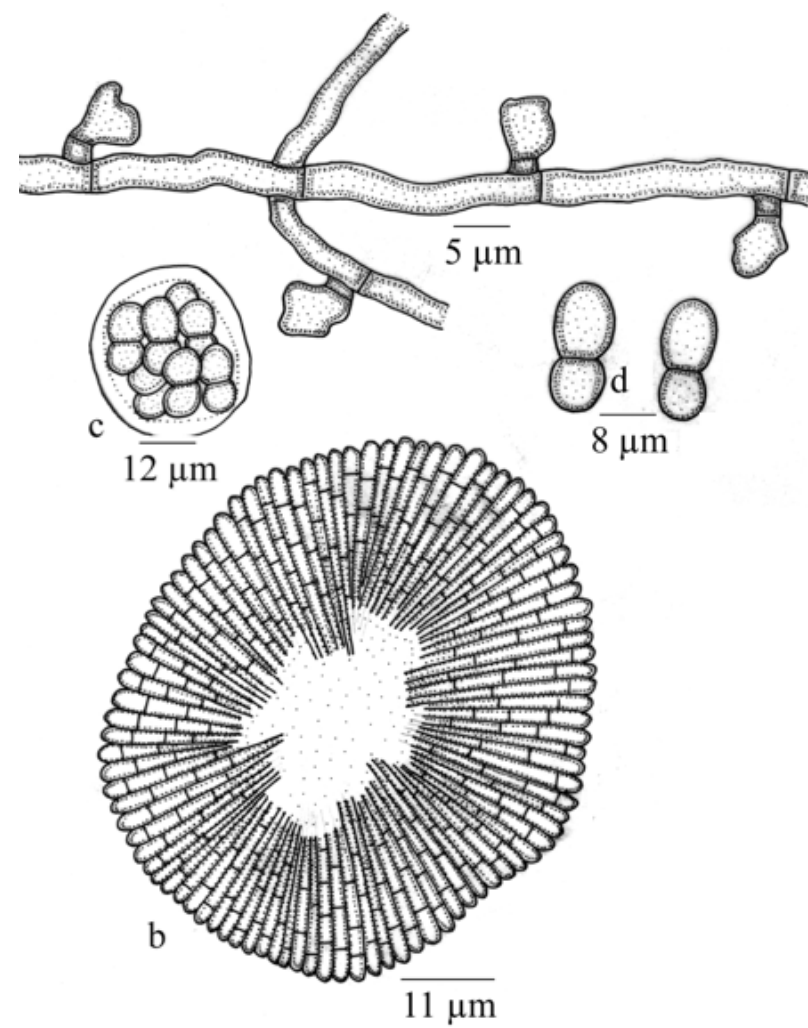

Figure-172. Asterina viburnicola

a - Appressorium; b - Thyriothecium; c - Ascus; d - Ascospores to crooked, branching opposite to irregular at acute to wide angles, loosely to closely reticulate, cells 12-21x11-13 $\mu \mathrm{m}$. Appressoria intercalary, ovate to oblong, located in the cell with a central marking, 1015x2-14 $\mu \mathrm{m}$. Thyriothecia scattered, initially orbicular, later ellipsoidal, 300-400×150-250 $\mu \mathrm{m}$, vertically to irregularly dehisced at the centre, often central portion dissolved, margin crenate to fimbriate, fringed hyphae flexuous, compact; asci globose, ovate, octosporous, up to $35 \mu \mathrm{m}$ in diameter; ascospores conglobate, brown, uniseptate, constricted at the septum, 36-39x21-23 $\mu \mathrm{m}$, wall smooth.

Asterolibertia anisopterae (Sydow) Hansf. and A. flabellariae (Sydow) Hansf. are known on Anisoptera thursifera and Flabelliferia paniculata from Philippines and Sierra Leone, respectively. A. vateriae differs from $A$. anisopterae in not forming polygonal meshes of hyphae, having smaller thyriothecia and in causing pathogenic effect on the host. It differs from A. fabelliferae in having distinctly larger ascospores (Hansford 1947, 1949). Ascospores are smaller than A. hydnocarpi Hosag. \& Abraham (Hosagoudar \& Abraham 1997a; Hansford 1947, 1949).

\section{The genus Ishwaramyces}

Ishwaramyces Hosag., J. Econ. Taxon. Bot. 28: 183, 2004; Hosag., Chandraprabha \& Agarwal, Asterinales of Kerala, p. 169, 2011; Hosag., Mycosphere 2(5): 779, 2012.

Leaf parasites. Mycelium ectophytic, appressoria appears in clusters, setae absent. Thyriothecia orbicular with radiating cells, astomatous, dehisce stellately at the center; asci globose, octosporous, bitunicate; ascospores conglobate, uniseptate, brown.

Type sp. I. flacourtiae Hosag., et al.

The genus Ishwaramyces differs from the genus Asterina in having axilliary clusters of appressoria (Muller \& Arx, 1962; Arx \& Muller, 1975).

Ishwaramyces flacourtiae Hosag., Kamar. \& Sabu in Hosag.,C.K. Biju \& Abraham, J. Econ. Taxon. Bot. 28: 183, 2004;Hosag., Chandraprabha \& Agarwal, Asterinales of Kerala, p. 169, 2011; Hosag., Mycosphere 2(5): 780, 2012. (Fig. 174).

Material examined: TBGT 6648, 6.iii.2008, on leaves of Flacourtia montana Graham (Flacourtiaceae), Palcherry, coll. P.J. Robin et al.

Colonies epiphyllous, subdense to dense, up to $2 \mathrm{~mm}$ in diameter, confluent and cover an entire upper surface of the leaves. Hyphae straight to substraight, 


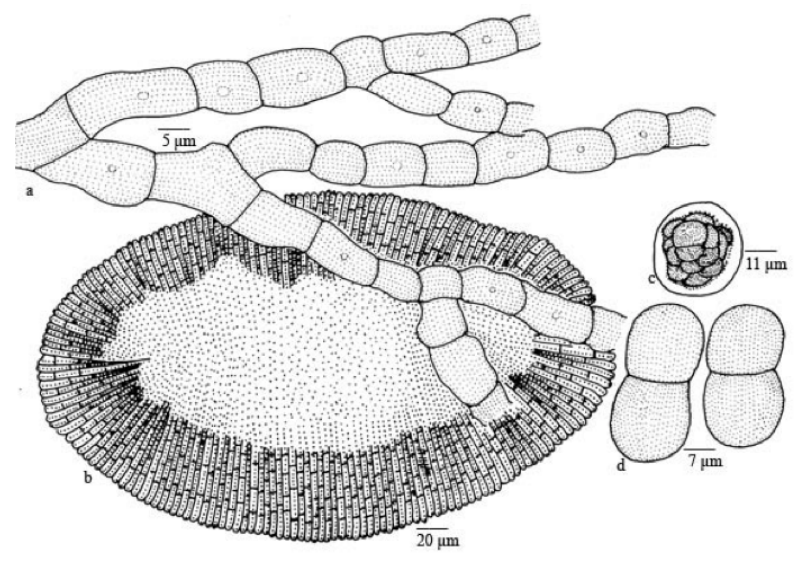

Figure 173. Asterolibertia vateriae

a - Mycelium with intercalary appressoria; b - Thyriothecium; c Ascus; d - Ascospores

branching opposite to closely reticulate, cells 1620x4-5 $\mu \mathrm{m}$. Appressoria opposite, 1-2 smaller at the axilliary, antrorse, two celled, 8-12 $\mu \mathrm{m}$ long; stalk cells cylindrical to cuneate, 3-4 $\mu \mathrm{m}$ long; head cells ovate, globose, entire, 4-8x7-9 $\mu \mathrm{m}$. Thyriothecia descrete to cuneate, orbicular, up to $345 \mu \mathrm{m}$ in diameter, stellately dehisced at the center, margin crenate to fimbriate; asci numerous, globose, octosporous, 45-56 $\mu \mathrm{m}$ in diameter; ascospores conglobate, initially hyaline, brown at maturity, uniseptate, deeply constricted at the septum, 30-37x19-21 $\mu \mathrm{m}$, wall smooth. Pycnothyria similar to thyriothecia, smaller; pycnothyriospores oblong to pyriform, brown, 26-30x17-19 $\mu \mathrm{m}$, wall smooth.

\section{The genus Meliolaster}

Meliolaster Hohnel, Ber. Deutsch. Bot. Ges. 35:701, 1918; Hosag., Chandraprabha \&Agarwal, Asterinales of Kerala, p. 171, 2011; Hosag, Mycosphere 2(5): 780, 2012.

Leaf parasites. Mycelium ectophytic, appressoria lateral. Thyriothecia orbicular with radiating cells, astomatous, dehisce stellately at the centre; asci globose to ovate, octosporous, bitunicate; ascospores brown, 2- septate, upper cell globose, the lower two cells narrowed and tapering at the base.

Type sp.: M. clavisporus (Pat.) Hohn.

Meliolaster aporusae Hosag., Harish \& Archana, Indian J. Sci. Techn. 2: 6, 2009; Hosag., Chandraprabha \& Agarwal, Asterinales of Kerala, p. 171, 2011; Hosag, Mycosphere 2(5): 781, 2012 (Image 15, Fig. 175).

Material examined: $\mathrm{HClO}$ 48296, TBGT 3015, 6.xii.2006, on leaves of Aporusa lindleyana (Wight) Baill. (Euphorbiaceae), Kunkichira, Periya, coll. M. Harish et al.
Colonies epiphyllous, thin, crustose, up to $4 \mathrm{~mm}$ in diameter, confluent. Hyphae straight, rarely slightly undulate, branching opposite to irregular at acute to wide angles, loosely reticulate, cells $12-22 \times 5-7 \mu \mathrm{m}$. Appressoria alternate, unilateral, unicellular, sessile, cylindrical, straight to curved, antrorse, subantrorse, entire, rounded at the apex, 9-11×4-7 $\mathrm{m}$. Thyriothecia uniformly scattered, orbicular, up to $250 \mu \mathrm{m}$ in diameter, margin crenate to fimbriate, fringed hyphae straight to slightly undulate and devoid of appressoria, thyriothecia stellately to irregularly dehisced at the centre; asci globose to ovate, octosporous, 54-61×49$55 \mu \mathrm{m}$; ascospores brown, oblong, 2-septate, upper cell globose, the lower two cells narrowed and tapering at base, constricted only at the upper septum, 41-45×12$14 \mu \mathrm{m}$, wall smooth. Pycnothyriospores brown, oblong, unicellular, 9-13×4-7 $\mu \mathrm{m}$.

\section{The genus Prillieuxina}

Prillieuxina Arn., Ann. Ecol. Nat. Agric.Montpellier 16:161, 1918; Hansf., Mycol. Pap. 15: 169, 1946; Muller \& Arx, Beitr. Krypt. Schw. 11:132, 1962; Luttrell in

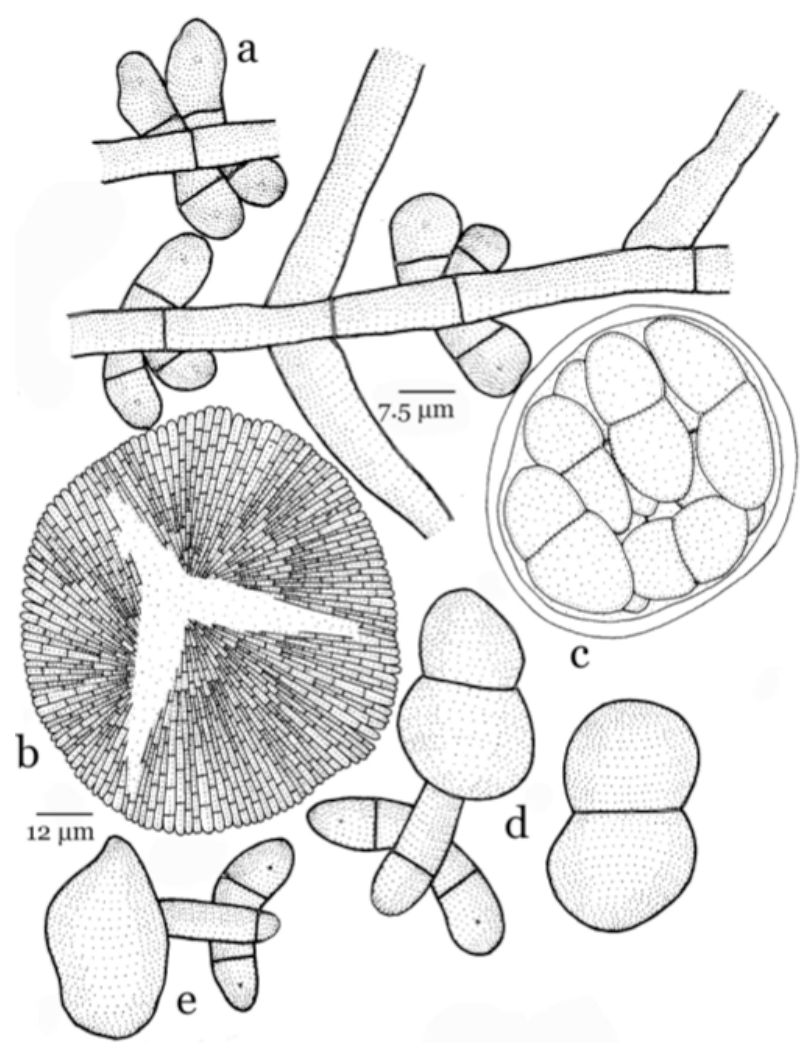

Figure 174. Ishwaramyces flacourtiae

a - Whorled appressoria; b - Thyriothecium; c - Ascus; d - Ascospores; e - Pycnothyriospore 
Ainsworth et al. (eds.). The Fungi. An advanced Treatise 4: 207, 1973; Arx \& Muller, Stud. Mycol. 9: 44, 1975; Bilgrami, Jamaluddin \& Rizwi, Fungi of India p. 407, 1991; Hosag., Abraham \& C.K. Biju, J.Mycopathol. Res. 39: 62, 2001; Singh, Duke, Bhandari \& Jain, J. Econ. Taxon. Bot. 30: 191, 2008; Hosag., Chandraprabha \& Agarwal, Asterinales of Kerala, p. 173, 2011; Hosag, Mycosphere 2(5), 782, 2012

Leaf parasites. Mycelium ectophytic, appressoria and setae absent. Thyriothecia orbicular with radiating cells, astomatous, dehisce stellately at the center; asci globose, octosporous, bitunicate; ascospores brown, conglobate, uniseptate.

Type sp. P. winteriana (Pazschke) Arn.

Prillieuxina ixorigena Hosag. \& Chandraprabha, Indian J. Sci. Technol. 2(6): 18, 2009; Hosag., Chandraprabha \& Agarwal,Asterinales of Kerala, p. 178, 2011; Hosag, Mycosphere 2(5), 787, 2012. (Fig. 176).

Material examined: TBGT 6190, 10.iii.2010, on leaves of Ixora coccinea L. (Rubiaceae), Wayanad, coll. M.C. Riju.

Colonies amphigenous, dense, up to $2 \mathrm{~mm}$ in diameter. Hyphae crooked, branching irregular at acute to wide angles, loosely to closely reticulate, cells $18-26 \mu \mathrm{m}$ long and up to $4 \mu \mathrm{m}$ broad. Appressoria absent. Thyriothecia scattered to grouped in the center of the colonies, orbicular, up to $100 \mu \mathrm{m}$ in diameter, stellately dehisced at the center, margin crenate; asci globose, octosporous, up to $30 \mu \mathrm{m}$ in diameter; ascospores oblong, conglobate, uniseptate, constricted at the septum, 20-26x7-11 $\mu \mathrm{m}$, wall smooth; pycnothyriospores ovate, pyriform, 1126x7-13 $\mu \mathrm{m}$, wall smooth.

Prillieuxina ixorae (Ryan) Ryan and Prillieuxina distinguenda (Sydow) Ryan are known on the members of the family Rubiaceae (Stevens \& Ryan, 1939). However, the present species differs from Prillieuxina ixorae in having larger ascospores (20-26×7-11 $\mu \mathrm{m})$ in contrast to $9 \times 2-7 \mu \mathrm{m}$. It also differs from Prillieuxina distinguenda in having smaller thyriothecia (up to $100 \mu \mathrm{m}$ in diameter) in contrast to $152-225 \times 100-170$ $\mu \mathrm{m}$ and larger ascospores $(20-6 \times 7-11 \mu \mathrm{m})$ in contrast to $12-14 \times 5-7 \mu \mathrm{m}$.

Prillieuxina loranthi (Syd. \& P. Syd.) Syd., Philippine J. Sci. 21(2): 141, 1922; Hosag., Sabeena \& Jacob Thomas, Plant Pathology \& Quarantine 1(1):7, 2011.

Asterinella loranthi Syd. \& P. Syd., Philippine J. Sci. C. 8: 490, 1913.

Asterostomula loranthi Theiss., Ann. Mycol. 14: 270, 1916 (Fig. 177)

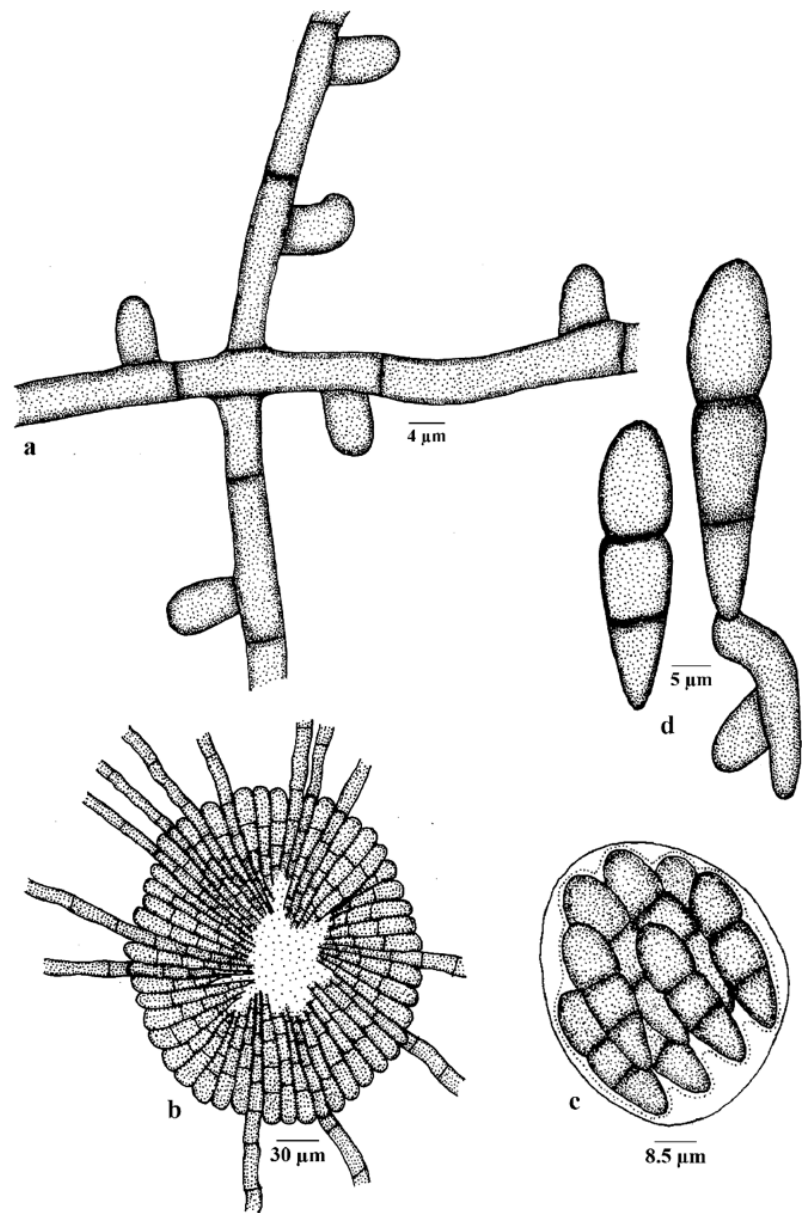

Figure 175.Meliolaster aporusae

a.Appressoriate mycelium, b. Thyriothecium, c. Ascus, d. Ascospores

Materials examined: TBGT 6243, 5.xi.2009, on leaves of Loranthus sp. (Loranthaceae), Gurukulam Botanic Garden, Periya, coll. A. Sabeena \& M.C. Riju.

Colonies amphigenous, subdense to dense, up to $4 \mathrm{~mm}$ in diameter, confluent. Hyphae flexuous to crooked, branching irregular at acute to wide angles, reticulate, cells $25-40 \times 3-5 \mu \mathrm{m}$. Appressoria lacking. Thyriothecia scattered to connate, orbicular, up to $120 \mu \mathrm{m}$ in diameter, stellately dehisced at the centre, margin crenate to fimbriate; asci globose, octosporous, up to $29 \mu \mathrm{m}$ in diameter; ascospores conglobate, uniseptate, constricted at the septum, 20-22×10-15 $\mu \mathrm{m}$. Pycnothyria many, orbicular, joined together marginally, up to $180 \mu \mathrm{m}$ in diameter, dehiscing stellately at the centre, margin crenate to fimbriate, fringed hyphae flexuous; pycnothyriospores unicellular, pyriform, ovate, 20-25x12-17 $\mu \mathrm{m}$, wall smooth.

This fungus mostly persists in its anamorph state but a few thyriothecia are mixed with pycnothyria. 

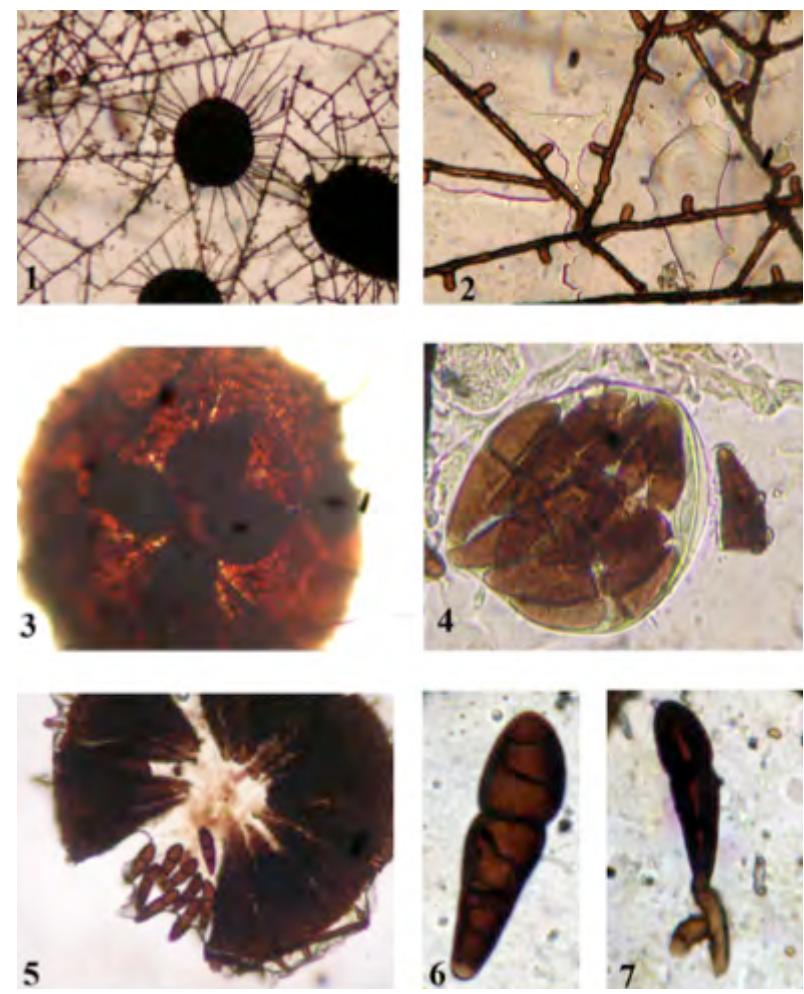

Image 15. Meliolaster aporusae

1 - Fungal colony with thyriothecia; 2 - Appressoriate mycelium; 3 - Thyriothecium with asci; 4 - Ascus; 5 - Dehisced thyriothecium; 6 - Ascospore; 7 - Germinating ascospore

\section{Prillieuxina sp.}

Materials examined: $\mathrm{HClO}$ 47438, TBGT 2476, 21.iv.2003, on leaves of Ixora coccinea L. (Rubiaceae), Periya, coll. G. Rajkumar \& P.A. Jose; HClO 47448, TBGT 2486, 14.ix.1999, on Lasianthus sp. (Rubiaceae), Chembra peak, coll. C.K. Biju; HCIO 47467, TBGT 2505, 12.viii.1998, Oxyceros rugulosus (Thwaites) (Rubiaceae), Tirunelly Shola, coll. C.K. Biju.

\section{Key to the Anamorphic Genera}

1. Appressoria absent. Asterostomula

1. Appressoria present ....2

2. Pycnothyriospores pyriform, ovate.

Asterostomella

2. Pycnothyriospores angular, truncate at the base Mahanteshamyces

\section{The genus Asterostomella}

Asterostomella Speg., Ann. Soc. Cien. Arg. 22: 198, 1886; Hosag., Chandraprabha \& Agarwal, Asterinales of Kerala, p. 224, 2011; Hosag, Mycosphere 2(5): 822,

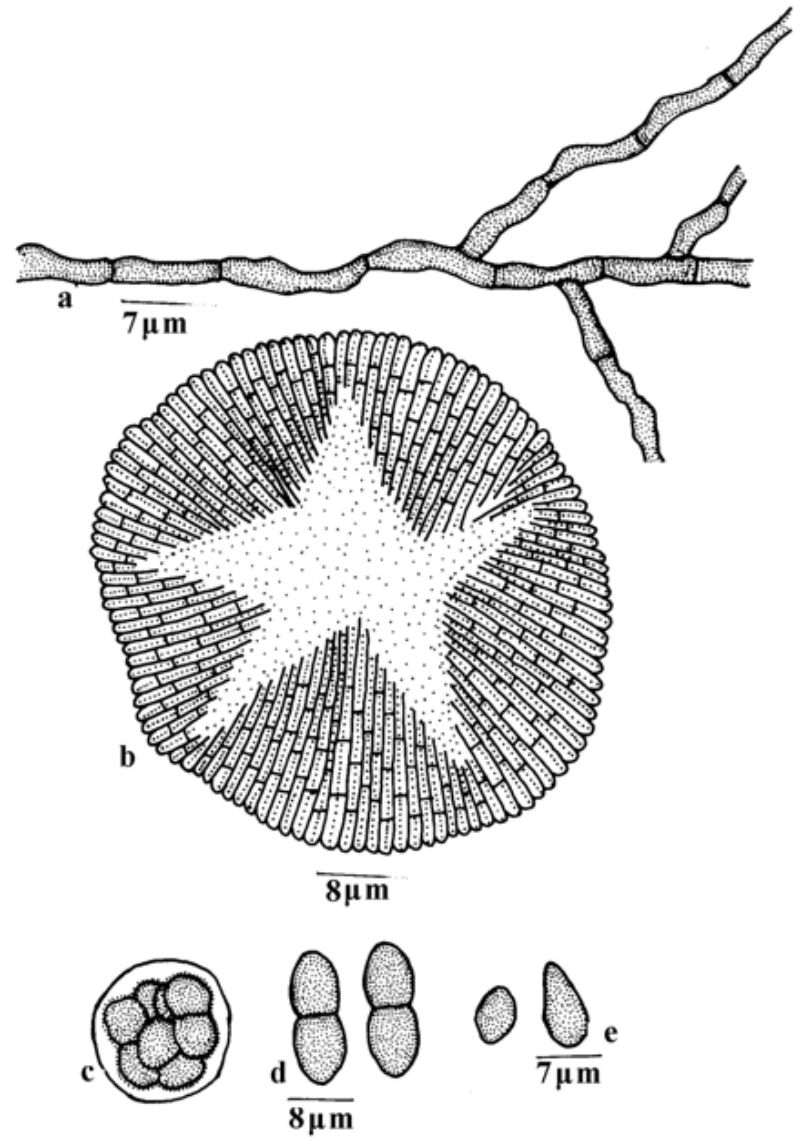

Figure 176. Prillieuxina ixorigena

a - Mycelium; b - Thyriothecium; c - Ascus; d - Ascospores;

e - Pycnothyriospores

2012.

Leaf parasites. Mycelium ectophytic, appressoria lateral, setae absent. Pycnothyria orbicular with radiating cells, astomatous, dehisce stellately at the center; pycnothyriospores ovate, pyriform, brown.

Type sp. A. paraguayensis Speg.

This genus represents here with a single species.

Asterostomella boehmeriae Hosag., Balakr. \& Goos, Mycotaxon 58: 491, 1996; Hosag., Zoos' Print J. 18: 1285, 2003; 21: 2412, 2006; Hosag., Chandraprabha \& Agarwal Asterinales of Kerala, p. 226, 2011; Hosag, Mycosphere 2(5): 823, 2012. (Fig.178).

Material examined: $\mathrm{HClO}$ 44791, TBGT 1028, 27.xii.2002, on leaves of Boehmeria sp. (Urticaceae), Chandanathode, coll. M. Kamarudeen \& P.A. Jose.

Colonies hypophyllous, black, velvety, later ashcoloured, mostly confluent, giving a dusty appearance, corresponding upper surface of the infected leaf portion turn brick red, severely infected leaves roll dorsally so 


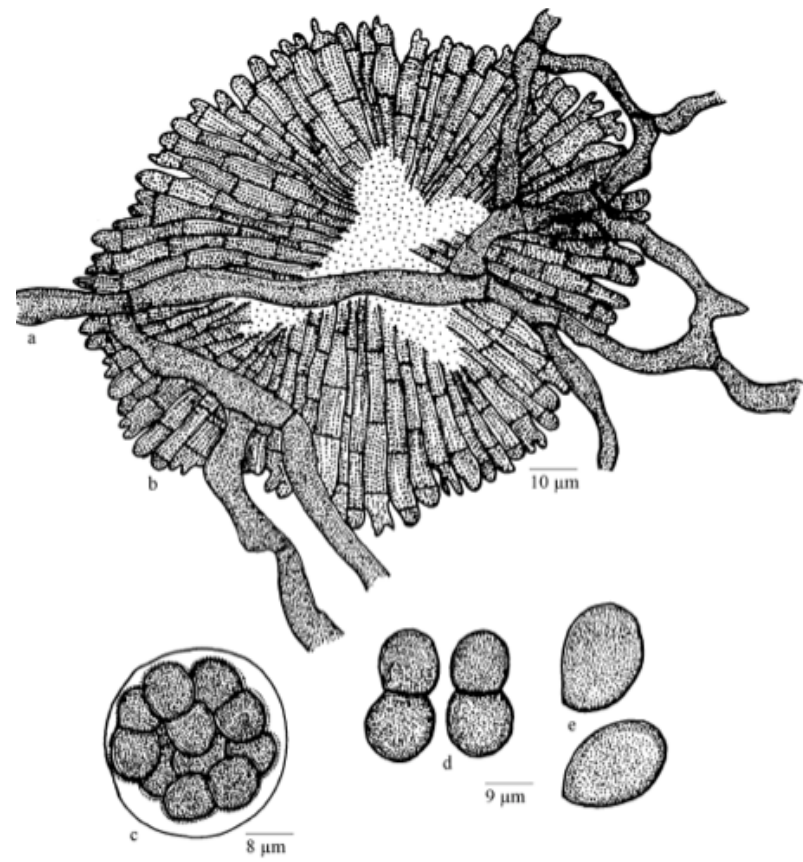

Figure 177. Prillieuxina loranthi

a - Mycelium; b - Thyriothecium; c - Ascus; d - Ascospores;

e - Pycnothyriospores

as to cover the infected parts by exposing the ventral surface. Hyphae pale yellow, strongly appressed to the host epidermis, straight to flexuous, branching opposite to irregular at acute angles, loosely reticulate, cells 12 $18.5 \times 5-6.5 \mu \mathrm{m}$. Appressoria one to two celled, sessile to stalked, alternate, 6-18.5 $\mu \mathrm{m}$ long; stalk cells (when two celled) cylindrical to cuneate, 6-6.5 $\mu \mathrm{m}$ long; head cells ovate, globose, entire to angular (in sessile), 9-12.5x6-8 $\mu \mathrm{m}$. Pycnothyria scattered to mostly grouped, orbicular, 90-155 $\mu \mathrm{m}$ in diameter, margin crenate, dehiscing stellately at the centre; pycnothyriospores brown, numerous, ellipsoidal, unicellular, tapered to broadly rounded at the apex, straight to slightly curved, a hyaline band often present in the middle, 18-31×12-15.5 $\mu \mathrm{m}$, wall smooth.

The infected leaves were rolled around.

\section{The genus Asterostomula}

Mycelium superficial, septate, lacking appressoria (Batista \& Ciferri 1959). Pycnothyria scutate, orbicular, with radiating cells on the upper surface, stellately dehiscing at the centre, with a crenate to fimbriate margin (Batista \& Ciferri 1959). Pycnothyriospores brown, unicellular, ovate, clavate, and pyriform to cylindrical.

Type sp. A. loranthi Theiss.
Asterostomula pavettae Hosag. \& A. Sabeena, Mycosphere 2(5): 837, 2012. (Fig. 179).

Material examined: TBGT 6203, 23.xii.2008, on leaves of Pavetta indica L. (Rubiaceae), Wayanad, coll. M.C. Riju.

Colonies amphigenous, thin, up to $2 \mathrm{~mm}$ in diameter, confluent. Hyphae flexuous to crooked, branching irregular at acute to wide angles, cells $20-37 \times 5-7 \mu \mathrm{m}$. Pycnothyria scattered to connate, orbicular, up to $140 \mu \mathrm{m}$ in diameter, stellately dehisced at the centre, margin mostly crenate; pycnothyriospores ovate to pyriform, 17-27x10-12 $\mu \mathrm{m}$.

This is the only species known on this host genus.

\section{The genus Mahanteshamyces}

Mahanteshamyces Hosag., J. Econ. Taxon. Bot. 28: 189, 2004; Hosag., Chandraprabha \& Agarwal, Asterinales of Kerala, p.241, 2011; Hosag., Mycosphere 2(5): 839, 2012.

Foliicolous, ectophytic, parasitic. Mycelium brown, superficial, appressoriate. Pycnothyria scutate, dimidiate, radiate, orbicular, stellately dehisced at the center; pycnothyriospores brown, angular, wall straight to sinuate.

Type sp. M. agrostistachydis Hosag. \& C.K. Biju.

The genus Mahanteshamyces differs from the genus Asterostomella in having roundedly projected and shallowly lobate, angular and thick walled pycnothyriospores (Batista and Cifferri, 1959; Sivanesan, 1981; Sutton, 1980). Hofmann \& Pipenbaring (2008) showed that this is an anamorph of the genus Asterina.

Mahanteshamyces agrostachydis Hosag. \& C.K. Biju in Hosag.,C.K. Biju \& Abraham, J. Econ. Taxon. Bot. 28: 189, 2004; Hosag., Chandraprabha \& Agarwal, Asterinales of Kerala, p. 241, 2011; Hosag, Mycosphere 2(5): 839, 2012 (Fig. 180).

Material examined: $\mathrm{HClO}$ 43993, TBGT 403, 14.iv.1999, on leaves of Agrostistachys indica Dalz. (Euphorbiaceae), towards the stream side of Chembra hills, coll. C.K. Biju.

Colonies hypophyllous, thin to subdense, spreading, up to $5 \mathrm{~mm}$ in diameter, confluent. Hyphae straight to substraight, branching alternate to opposite at acute angles, loosely to closely reticulate, cells $4-16 \times 1.5-$ $2.5 \mu \mathrm{m}$. Appressoria unicellular, alternate, about $20 \%$ opposite, ovate, globose, oblong, irregularly sublobate to lobate, 6-8x4-6.5 $\mu \mathrm{m}$. Pycnothyria scattered, orbicular, up to $80 \mu \mathrm{m}$ in diameter, margin crenate, stellately dehisced to widely opened at the center; 

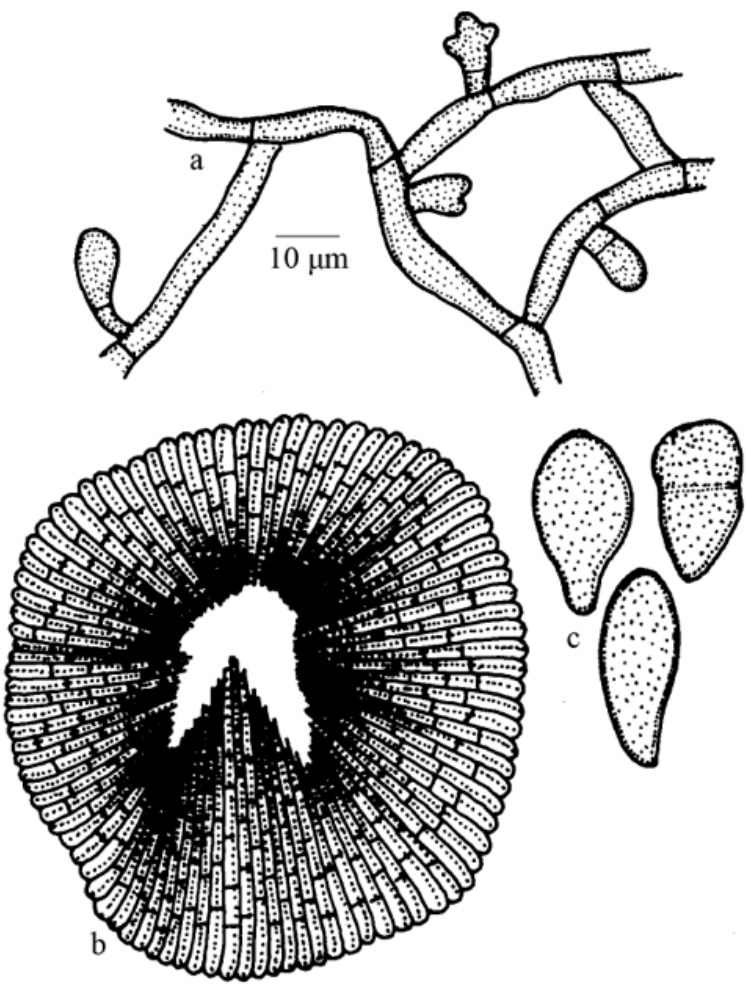

Figure 178. Asterostomella boehmeriae

a - Appressoriate mycelium; b - Pycnothyrium; c - Pycnothyriospores

pycnothyriospores brown, unicellular, truncate at the base, apex more or less flattened, 1-3 rounded projection or shallowly lobate, angular, 12-15x11-13 $\mu \mathrm{m}$, smooth, thick walled.

This is the anamorph of the genus Asterina.

\section{The family Lembosiaceae}

Lembosiaceae Höhn., Ann. Mycol. 16: 146, 1918. Lembosiaceae Hosag. in Abraham \& C.K. Biju, J. Mycopathol. Res. 39: 62, 2001.

Leaf parasites. Mycelium ectophytic, with or without appressoria, nutrient mycelium and leaf permeating stroma present. Ascomata ectophytic, dimidiate, oval, ellipsoidal, " $X$ " or " $Y$ " shaped, elongated with radiating cells, astomatous, dehisce longitudinally at the center; asci globose, spherical, octosporous, bitunicate; ascospores two to many septate, conglobate, hyaline to brown.

Type genus - Lembosia Lev.

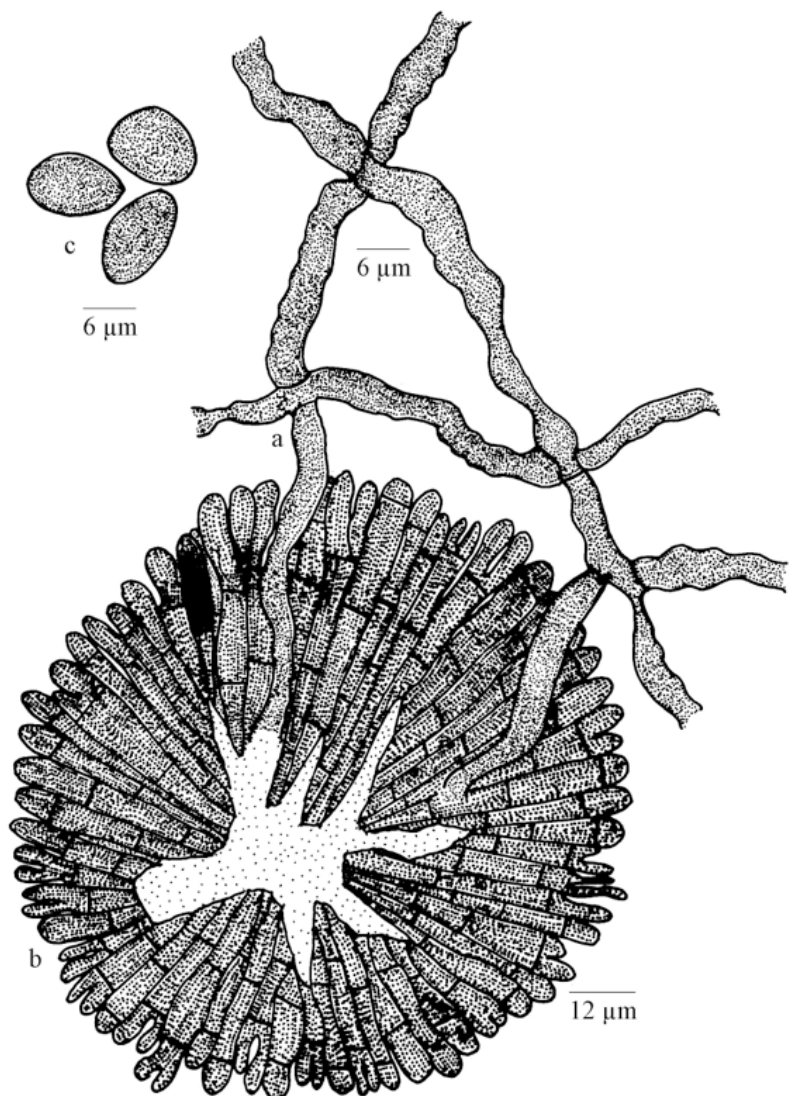

Figure 179. Asterostomula pavettae

a - Mycelium; b - Pycnothyrium; c - Pycnothyriospores

\section{Key to the genera of Lembosiaceae}

1. Appressoria present

Lembosia

1. Appressoria absent. Echidnodella

\section{Araceae}

Lembosia

Single species. L. malabarensis

\section{Myrtaceae}

Lembosia

Single species. hosagoudarii

Melastomataceae

Echidnodella

Single species E. memecyli

\section{The genus Echidnodella}

Echidnodella Theiss. \& Sydow, Ann. Mycol. 15: 422, 1917; Muller \& Arx, Beitr. Krypt. Schw. 11:118, 1962; Luttrell in Ainsworth et al. (eds.): The Fungi. An advanced 


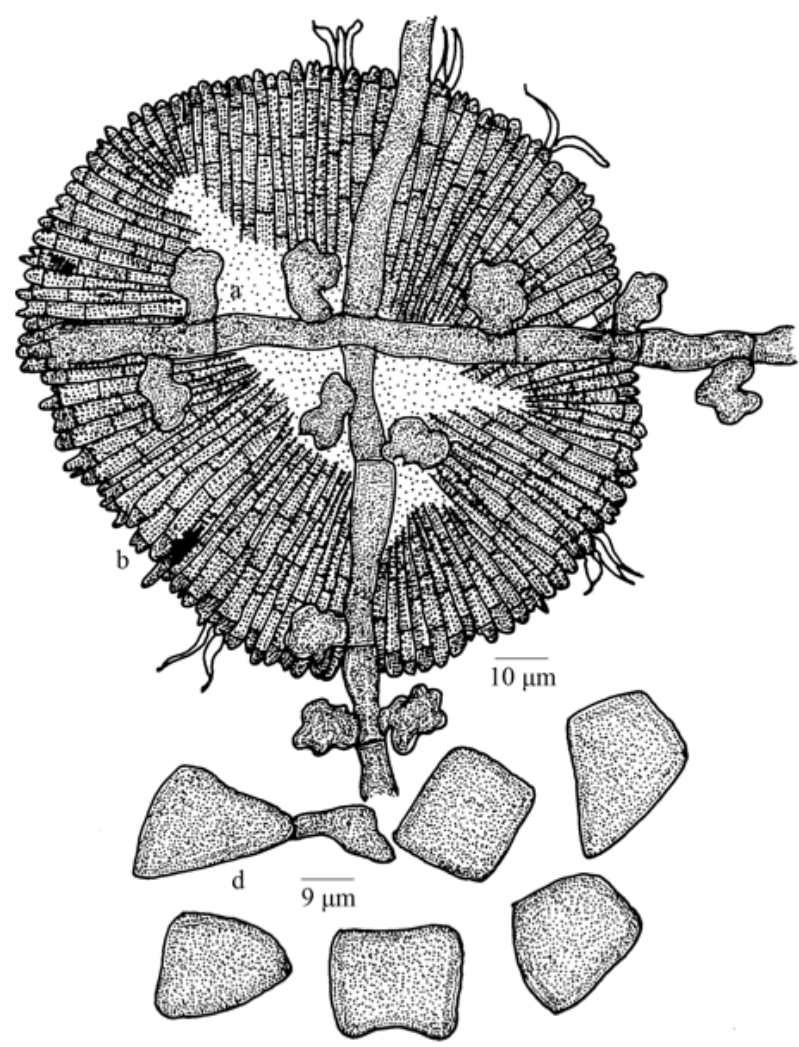

Figure 180. Mahanteshamyces agrostachydis

a - Appressoriate mycelium; b - Pycnothyrium; c - Pycnothyriospores

Treatise 4: 207, 1973; Arx \& Muller, Stud. Mycol. 9: 46, 1975; Bilgrami, Jamaluddin \& Rizwi, Fungi of India p. 185, 1991; Hosag., Abraham \& C.K. Biju, J. Mycopathol. Res. 39: 62, 2001; Singh, Duke, Bhandari \& Jain, J. Econ. Taxon. Bot. 30: 187, 2008; Hosag., Chandraprabha \& Agarwal, Asterinales of Kerala, p. 194, 2011; Hosag, Mycosphere 2(5): 799, 2012.

Leaf parasites. Mycelium ectophytic, appressoria absent, hypostroma absent. Thyriothecia oval, ellipsoidal, $\mathrm{X}$ or $\mathrm{Y}$ shaped, elongated with radiating cells, astomatous, dehisce longitudinally at the center; asci oval, octosporous, bitunicate; ascospores brown, conglobate, uniseptate.

Type sp: E. linearis (Sydow) Theiss. \& Sydow

Echidnodella memecyli Hosag. \& Abraham, J. Mycol. Res. 102: 185, 1998; Hosag., C.K. Biju \& Abraham, J. Econ. Taxon. Bot. 25: 306, 2001; Hosag., Zoos' Print J. 18: 1283, 2003; Hosag., Chandraprabha \& Agarwal, Asterinales of Kerala, p. 194, 2011; Hosag., Mycosphere 2(5): 801, 2012 (Fig. 181)

Material examined: TBGT 5988, 19.xi.2003, on leaves of Memecylon sp. (Melastomataceae), Banasuramala, coll. C.K. Biju.

Colonies hypophyllous, subdense, spreading, up to $5 \mathrm{~mm}$ diameter, widely confluent; Hyphae substraight, flexuous to crooked, branching opposite to irregular at acute to wide angles, loosely reticulate, cells 24-29x2.5$3.5 \mu \mathrm{m}$. Appressoria absent. Thyriothecia scattered, rarely connate, ovate, elongate, straight or curved to acutely sinuate or variously branched, 530-635x31-36 $\mu \mathrm{m}$, longitudinally split at the centre, mostly crenate at the margin and rarely fimbriate, fringed hyphae very small; asci ovate, clavate, globose, 8-spored, 33-36×19$24 \mu \mathrm{m}$; ascospores conglobate, 1-septate, constricted at the septum, lower cell slightly attenuated and upper rounded, 12-14.5x4-6 $\mu \mathrm{m}$, wall smooth.

Echidnodella memecyli Hosag. \& Abraham, Echidnodella miconiae Ryan and E. melastomatacearum Ryan have been reported on Miconia spp. from Puerto Rico (Stevens \& Ryan 1939). E. memecyli differs from both in having different shaped, larger thyriothecia and smaller ascospores.

\section{The genus Lembosia}

Lembosia Lev., Ann. Sci. Nat. Bot. Ser., 3, 3: 58, 1845; Hansf., Mycol. Pap. 15: 189, 1946; Muller \& Arx, Beitr. Krypt. Schw. 11: 111, 1962; Luttrell in Ainsworth et al. (eds.): The Fungi. An advanced Treatise 4: 207, 1973; Arx \& Muller, Stud. Mycol. 9: 43, 1975; Hosag., Chandraprabha \& Agarwal, Asterinales of Kerala, p. 204, 2011; Hosag, Asterinales of India. Mycosphere 2(5): 805, 2012.

Heraldoa Bat., Att. Est. Bot. Lab. Critr. Univ. Pavia 16:105, 1959.

Lembosidium Speg., Biol. Acad. Nac. Cien. Cordova. 26:342, 1923.

Lembosiellina Bat. \& Maia, Atas Inst. Mycol. Recife 1:329, 1960.

Morenoella Speg., Fungi Guar. 1: 258, 1883.

Leaf parasites. Mycelium ectophytic, appressoria lateral. Thyriothecia oval, ellipsoidal, $X$ or $Y$ shaped, elongated with radiating cells, astomatous, dehisce longitudinally at the center; asci oval, octosporous, bitunicate; ascospores conglobate, uniseptate, brown.

Type sp.: L. melastomatum Mont.

Lembosia hosagoudarii Sivanesan \& Shivas, Fungal Diversity 11: 163, 2002; Hosag., Chandraprabha \& Agarwal, Asterinales of Kerala, p. 205, 2011; Hosag., Mycosphere 2(5): 808, 2012.

Lembosia syzygiicola Hosag., Indian J. Forestry 18: 276, 1995 (Fig. 182). 
Material examined: $\mathrm{HClO}$ 49999, TBGT 4151, 20.ix.2008, on leaves of Syzygium sp. (Myrtaceae), Periya, coll. P.J. Robin et al.; HClO 49810,TBGT 3962, 15.ii.2009, coll. Gireesh et al.,

Colonies amphigenous, mostly epiphyllous, dense, crustose, up to $3 \mathrm{~mm}$ in diameter, rarely confluent. Hyphae straight to substraight, branching alternate to irregular at acute to wide angles, loosely reticulate, cells 31-38×3-5 $\mu \mathrm{m}$. Appressoria two celled, scattered, alternate, straight to curved, 9-18 $\mu \mathrm{m}$ long; stalk cells cylindrical to cuneate, 4-7 $\mu \mathrm{m}$ long; head cells ovate, globose, entire, 4-11×4-7 $\mu \mathrm{m}$. Thyriothecia scattered to grouped, rarely connate, initially circular, linear to elliptical at maturity, carbonaceous black, margin crenate to fimbriate, fringed hyphae flexuous, thyriothecia dehiscing by a longitudinal slit at the center, 640-930×214-286 $\mu \mathrm{m}$; asci globose initially, cylindrical to clavate at maturity, octosporous, $71-84 \times 37-46.5$ $\mu \mathrm{m}$; ascospores deep brown, conglobate, uniseptate, constricted at the septum, both cells mostly equal in size and shape, 21-28×9-12.5 $\mu \mathrm{m}$, wall smooth.

Many species of the genus Eugenia have been brought under the genus Syzygium. So far, three species, namely, Lembosia eugeniae Rehm, L. robinsonii Sydow and $L$. tenella Lev. are reported on the host species of

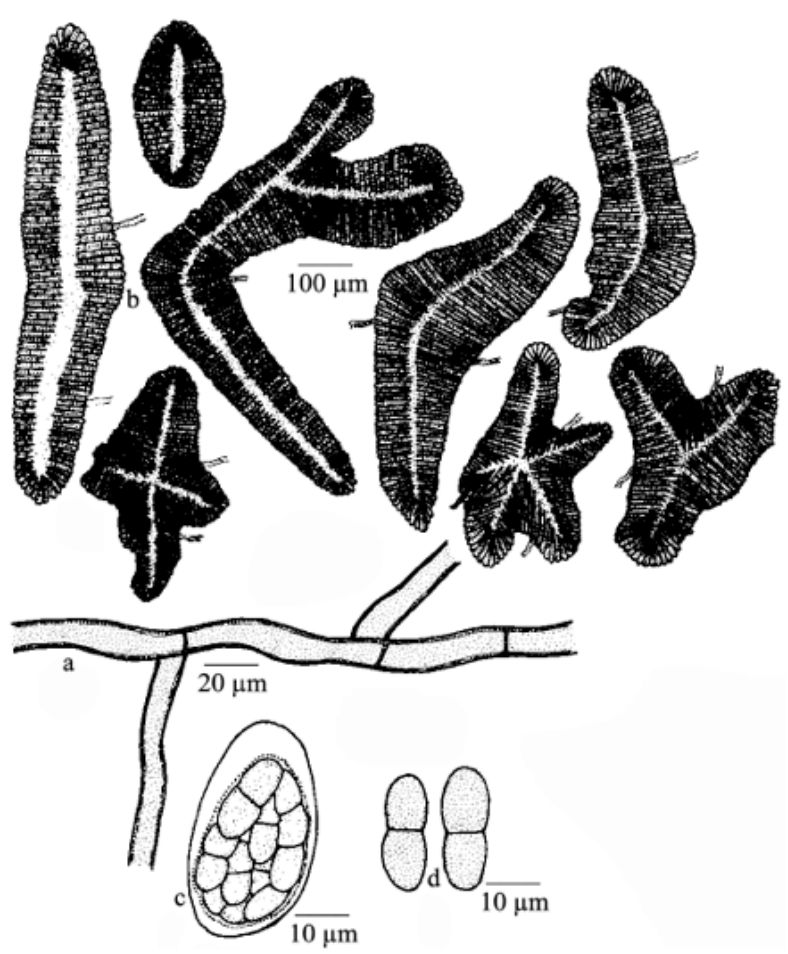

Figure 181. Echidnodella memecyli

a - Mycelium; b - Thyriothecia; c - Ascus; d - Ascospores the genus Eugenia. The present species differsfrom L. eugeniae Rehm in having larger thyriothecia, asci and ascospores; L. robinsonii Sydow in having smaller ascospores and from L. tenella Lev. in having larger asci and narrower ascospores (Stevens \& Ryan, 1939).

Lembosia malabarensis (Sydow \& Sydow) Hosag. \& Goos, Mycotaxon 52: 472, 1994; Song Bin \& Hosag., Guizhou Science 21: 94, 2003; Hosag., Chandraprabha \& Agarwal, Asterinales of Kerala, p. 213, 2011; Hosag., Mycosphere 2(5): 813, 2012.

Asterina malabreansis Sydow \& Sydow in Sydow, Sydow \& Butler, Ann. Mycol. 9: 391, 1911.

Asterinla malabarensis (Sydow \& Sydow) Theiss., Broteria 10: 106, 1912.

Prilliexina malabarensis (Sydow \& Sydow) Ryan in Stevens \& Ryan, Illinois Biol. Monographs 17: 80, 1939 (Image 16).

Material examined: TBGT 6209, 26.iii.2009, on leaves of Pothos scandens L. (Araceae), Kandeykayal, coll. M.C. Riju.

Colonies hypophyllous, on sheaths, up to $3 \mathrm{~mm}$ in diameter, confluent. Hyphae flexuous to crooked, branching irregular at acute to wide angles, loosely to closely reticulate, cells $15-23 \times 3-4 \mu \mathrm{m}$. Appressoria alternate, unilateral, opposite, unicellular, cylindrical, straight, curved, flexuous, zig-zag to uncinate, broadly rounded at the apex, 19-24×4-5 $\mu \mathrm{m}$. Thyriothecia initially orbicular, later elongated, straight to curved, 500-1000×290-400 $\mathrm{mm}$, dehisce longitudinally at the centre or sub centre, margin crenate to fimbriate, fringed hyphae compact, flexuous; asci few, globose to ovate, octosporous, $40-60 \times 25-40 \mu \mathrm{m}$; ascospores oblong, conglobate, brown, uniseptate, constricted at the septum, 26-30×16-18 $\mu \mathrm{m}$, wall smooth. Pycnothyria mixed with thyriothecia, similar to thyriothecia, smaller; pycnothyriospores oval, oblong, brown, 28-30×16-18 $\mu \mathrm{m}$.

This is the only species of the genus known on the members of the family Araceae. Malabar is the type locality of this fungus. Pycnothyriospores are reported for the first time for this species. This species was collected by E. J. Butler from Kanouth of Malabar region.

Elongated thyriothecia with a central longitudinal slit and the presence of appressoria are characteristic of the genus Lembosia.

\section{Schiffnerulaceae}

Black colonies formed on the leaf surface, mycelium brown, superficial, septate, appressoriate; appressoria unicellular, formed laterally. Thyriothecia orbicular, cells 


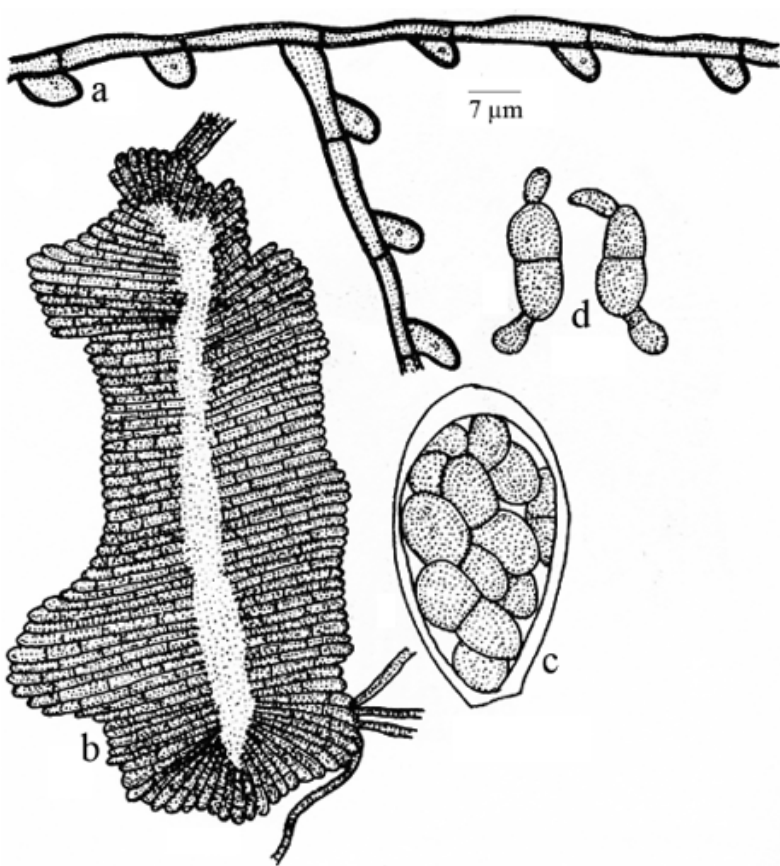

Figure 182. Lembosia hosagoudarii

a - Appressoriate mycelium; b - Thyriothecium; c - Ascus; d Ascospores

on the upper surface radiating, dissolve at the centre at maturity; asci globose, bitunicate, 8-spored; ascospores conglobate, brown, uniseptate, constricted at the septum.

Type genus: Schiffnerula Hohnel

(Synamorphs: Digitosarcinella, Mitteriella, Questieriella and Sarcinella).

Teleomorph and the latter two form genera (Questieriella and Sarcinella) are known in the present work.

\section{Key to the genera}

1.Teleomorph present. Schiffnerula

1.Known only with anamorphs.

2.Black, sarciniform conidia present..................Sarcinella 2.Subhyaline to brown, 3-septate, ellipsoidal or fusiform, straight to curved conidia present. Questieriella

Form genus Sarcinella is considered as advanced than Questieriella. If the fungus possesses both Questieriella and Sarcinella conidia, the fungus is placed under the form genus Sarcinella.
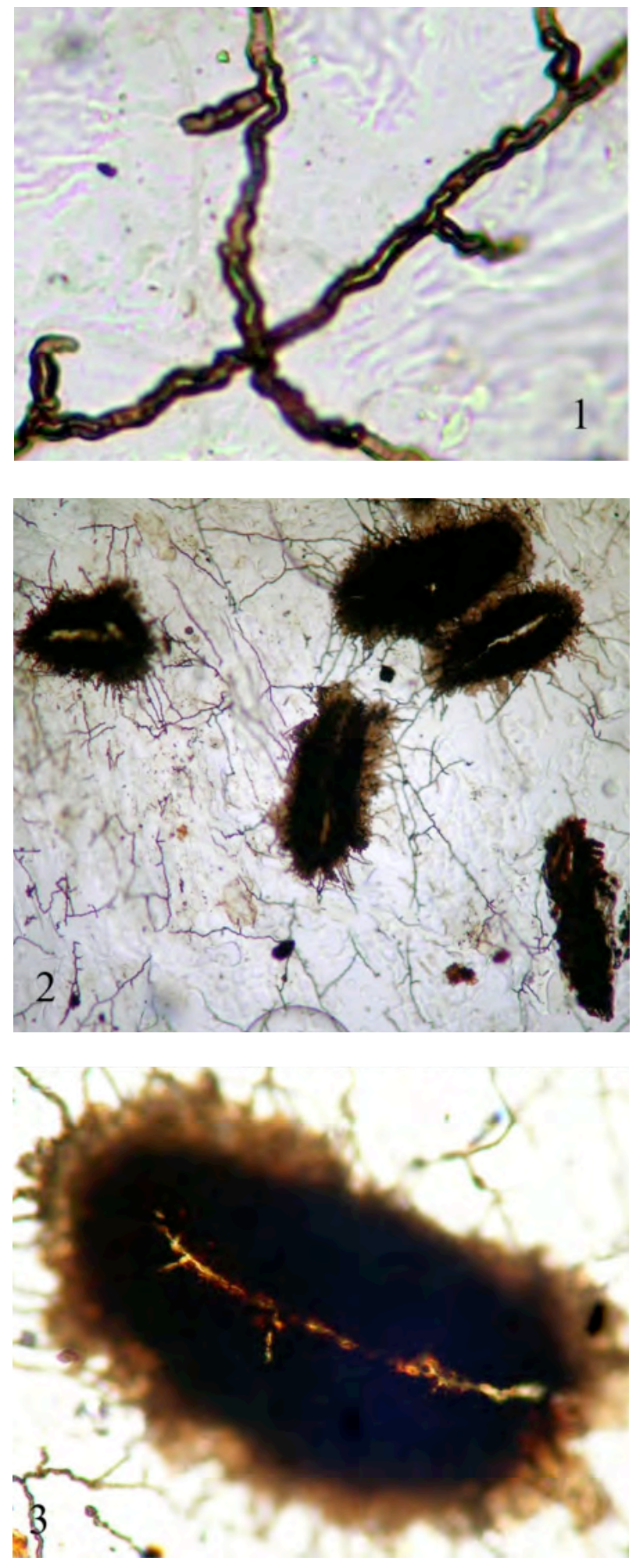

Image 16. Lembosia malabarensis

1 - Appressoriate mycelium; $\mathbf{2}$ - Thyriothecia in the colony; 3 - Thyriothecium 


\section{Key to the species}

\section{ASTERACEAE}

Schiffnerula

1. On Spilanthus.

S. spilanthi

1. On Vernonia S. vernoniae

\section{BUXACEAE}

Questieriella

Single species Q. sarcococcae

\section{CAESALPINIACEAE}

Schiffnerula

Single species S. tamarind

\section{CELASTRACEAE}

Schiffnerula

Single species S. celastri

\section{EUPHORBIACEAE}

Schiffnerula

1.On Bridelia

1.On Ricinus...

S. brideliae S. ricini

FABACEAE

Sarcinella

Single species S.dalbergiae

\section{ICACINACEAE}

\section{Sarcinella}

Single species

S. hughesii

\section{LYTHRACEA}

\section{Schiffnerulo}

Single species S. lagerstroemiae

\section{SAPINDACEAE}

\section{Sarcinella}

Single species

S. allophyli

\section{SOLANACEAE}

Schiffnerula

Single species

S. palodensis

\section{THEACEAE}

Schiffnerula

Single species S. camelliae

\section{VERBENACEAE} Schiffnerula
Single species

S. tectonae

\section{The genus Questieriella}

Questieriella Arn. ex Hughes, Can. J. Bot. 61: 1729, 1983; Hosag., Plant Pathology \& Quarantine 1(2): 136, 2011.

Colonies black, hyphae superficial, brown, branched, septate, appressoriate. Appressoria lateral, unicellular. Conidiophores micronematous, mononematous, lateral, 0-2-septate. Conidiogenous cells monoblastic to polyblastic, integrated, terminal, lateral or incorporated in the hyphae. Conidia blastic, terminal, solitary, narrowly ellipsoidal to obovoidal, curved, falcate, sigmoid, truncate at the base, 3-septate.

Type: Q. pulchra Hughes .

This genus represents here with a single species.

Questieriella sarcococcae Hosag., Manoj. \& H. Biju, Indian Phytopath. 58: 203, 2005; Hosag., Plant Pathology \& Quarantine 1(2):140, 2011 (Fig. 183).

Material examined: TBGT 6179, TBGT 6181, 4.i.2010, on leaves of Sarcococca sp. (Buxaceae), Periya, coll. M.C. Riju.

Colonies epiphyllous, thin, spreading, up to $3 \mathrm{~mm}$ in diameter, confluent. Hyphae straight to substraight, branching alternate to irregular at acute angles, loosely to closely reticulate, cells $16-23 \times 4-7 \mu \mathrm{m}$. Appressoria alternate, about 5\% opposite, oval, globose, entire, 8-12x8-10 $\mu \mathrm{m}$. Tip of the mycelium converted as conidiophores, pale yellow, micronematous, mononematous, 0-2-septate, simple, 5-15x5-6 $\mu \mathrm{m}$. Conidiogenous cells monoblastic, terminal, integrated, conidia blastic, solitary, fusiform, straight to slightly curved, pale yellow, 3-septate, slightly constricted at the septa, end cells attenuated to broadly rounded at the tip, 45-56x9-11 $\mu \mathrm{m}$.

This species appears to be restricted to high altitudinal areas.

Questieriella strychni Hosag., J. Econ. Taxon. Bot. 28: 196, 2004. Hosag., The genus Schiffnerula in India. Plant Pathology \& Quarantine 1(2), 140, 2011 (Fig. 184).

Material examined: TBGT 4044, 20.ix.2008, on leaves of Strychnos nux-vomica L. (Strychnaceae), Pulpalli, coll. M. Harish \& P.J. Robin.

Colonies amphigenous, dense, up to $5 \mathrm{~mm}$ in diameter, confluent. Hyphae substraight to flexuous, branching irregular at acute angles, loosely to closely reticulate, cells $17-21 \times 4-5 \mu \mathrm{m}$. Appressoria numerous to scarce, scattered, alternate to about $5 \%$ opposite, 
globose, entire, 8-10 $\mu \mathrm{m}$ in diameter. Questieriella type of conidia produced from the pore of hyphal cells, fusiform, pale brown, 3-septate, straight to curved, sigmoid, often constricted at the middle, end cells pale, conoid, smaller, 40-45×9-10 $\mu \mathrm{m}$.

This fungus was associated with the dark colonies of Meliola sp. However, when Meliola colonies matured, a whitish coating formed on the black colonies and it may be due to the production of enormous number of Questieriella conidia. The end cells of the conidia were much smaller and paler than the central two cells. Later, these two end cells wrinkle and disappear as the spore starts germinating.

This species differs from Schiffnerula spigeliae Hansf. known on Spigelia anthelmia from Sierra Leone in having larger falcate conidia (Hansford 1949, Sivanesan 1984).

\section{The genus Sarcinella}

Sarcinella Sacc., Michelia 2: 31, 1880; Hosag., Plant Pathology \& Quarantine 1(2):144, 2011.

Colonies black. Hyphae superficial, branched, septate, appressoriate. Appressoria lateral, unicellular. Conidiophores macronematous, semimacronematous, simple to branched. Conidiogenous cells monoblastic, integrated, terminal, intercalary, determinate. Conidia solitary, acrogenous or acropleurogenous, subspherical, sarciniform, dark brown to reddish brown, smooth, constricted at the septa.

Type - S. heterospora Sacc.

Sarcinella allophyli Hosag., J. Mycopathol. Res. 44: 20, 2006; Hosag. \& Riju, Indian J. Sci. \& Techn. 2(6): 7, 2009; Hosag., Plant Pathology \& Quarantine 1(2):144, 2011 (Fig. 185).

Material examined: $\mathrm{HClO}$ 48179, TBGT 2915, 9.xi.2007, on leaves of Allophylus sp. (Sapindaceae), 16th mile, Padinharathara, coll. M.C. Riju; HClO 49908, TBGT 4060, 11.xi.2007, coll. A. Chandraprabha.

Colonies amphigenous, mostly hypophyllous, dense, spreading, up to $3 \mathrm{~mm}$ in diameter. Hyphae straight to flexuous, pale brown, branching irregular at acute to wide angles, loosely reticulate, cells $17-24 \times 3-5$ $\mu \mathrm{m}$. Appressoria scattered, alternate, unilateral, rarely opposite, ovate to mostly globose, entire, 7-9x6-11 $\mu \mathrm{m}$. Conidiophores produced lateral to the hyphae, simple, branched, straight to flexuous, micronematous to semi-macronematous, 9-32x4-6 $\mu \mathrm{m}$. Conidiogenous cells terminal, intercalary, monoblastic, integrated, determinate, cylindrical. Sarciniform conidia solitary, dry, simple, subspherical to oval, 2-10-celled, brown to

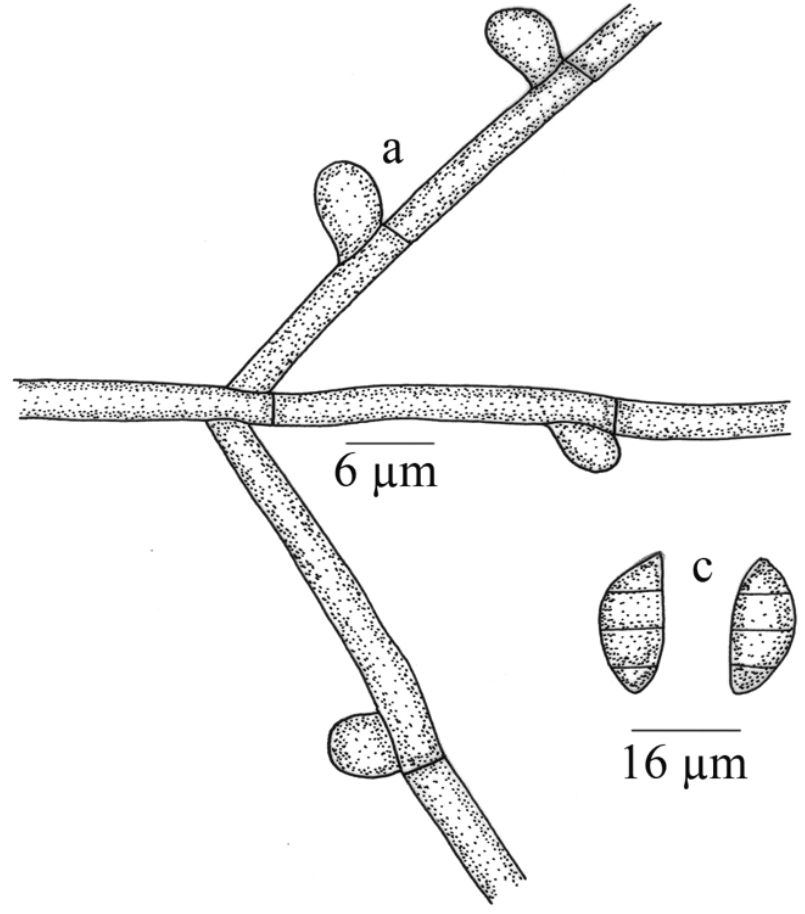

Figure 183.Questieriella sarcococcae

a - Appressorium; b - Three septate conidia

charcoal black, muriform, constricted at the septa, 24$32 \mu \mathrm{m}$ in diameter, wall smooth.

Schiffnerula allophyli Hansf. is known on Allophylus sp. from Uganda (Hansford, 1946, Hosagoudar 2003a,b) and the present fungus is only with the Sarcinella state.

Sarcinella dalbergiae Hosag. \& Agarwal, Indian Phytopath. 55: 501, 2002; Hosag., Plant Pathology \& Quarantine 1(2): 150, 2011 (Fig. 186).

Material examined: $\mathrm{HClO}$ 43806, TBGT 391, 19.iv.1999, on leaves of Dalbergia sp. (Fabaceae), Banasuran mala, coll. C.K. Biju.

Colonies epiphyllous, subdense, up to $2 \mathrm{~mm}$ in diameter, confluent. Hyphae flexuous to crooked, branching irregular at acute angles, loosely reticulate and form loose mycelial net, cells $12-21 \times 3-5 \mu \mathrm{m}$. Appressoria alternate, very few opposite, unicellular, globose, broad based, entire, 9-12 $\mu \mathrm{m}$ broad and 6-7 $\mu \mathrm{m}$ high. Conidiophores micronematous, mononematous simple, straight, cylindrical, 18-22x11-12 $\mu \mathrm{m}$. Conidiogenous cells integrated, terminal, monoblastic, determinate, cylindrical, conidia solitary, simple, acrogenous, spherical to subspherical, 4-12 celled, sarciniform, deeply constricted at the septa, charcoal black, 19-30 $\mu \mathrm{m}$ in diameter, wall smooth.

Sarcinella cassiae Butler is known on Cassia tora 


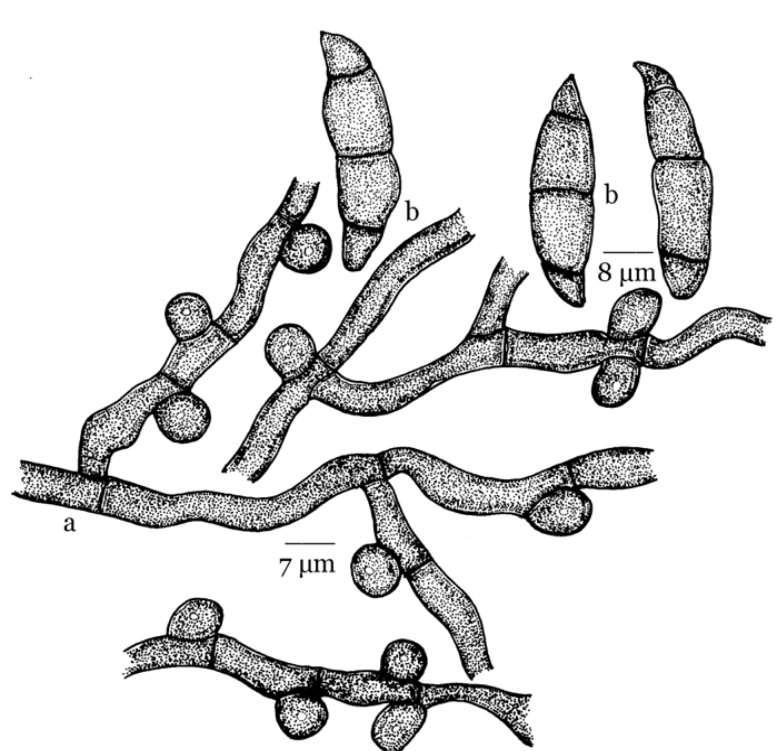

Figure 184. Questieriella strychni

a - Appressoriate mycelium; b - Conidia of Questieriella

(Ceasalpiniaceae). Loosely net forming hyphae and few opposite, globose and larger apressoria distinguishes the present anamorph from it.

Sarcinella hughesii Hosag. \& Venkanna, J. Econ. Taxon. Bot. 17: 457, 1993; Hosag., Plant Pathology \& Quarantine 1(2): 154, 2011 (Fig. 187).

Material examined: HCIO 51232, TBGT 5112, 23.xii.2008, on leaves of Nothopodytes sp. (Icacinaceae), Padinharathara, coll. M.C. Riju.

Colonies amphigenous, thin, scattered, up to $2 \mathrm{~mm}$ in diameter. Hyphae flexuous, branching opposite to unilateral at acute to wide angles, loosely reticulate, cells $17-30 \times 6-7 \mu \mathrm{m}$. Appressoria alternate to unilateral, globose, broad based, entire, 5-12x7-12 $\mu \mathrm{m}$. Questieriella conidia few, scattered, ellipsoidal, straight to sigmoid, 3-septate, slightly constricted at the septa, 37-45x9-11 $\mu \mathrm{m}$. Sarcinella conidiophores simple, micronematous, mononematous, unicellular to septate, 5-25x4-6 $\mu \mathrm{m}$; conidiogenous cells monoblastic, terminal. Conidia solitary, subspherical to oval, sarciniform, 2-5-celled, constricted at the septa, 1530x15-32 $\mu \mathrm{m}$.

Sarcinella tamarindi Hosag. \& Riju, Mycosphere 2(2): 157, 2011; Hosag., Plant Pathology \& Quarantine 1(2): 154, 2011 (Image.17; Fig. 188).

Material examined: HCIO 50595, TBGT 4512 (holotype); 10.x.2010, on leaves of Tamarindus indica

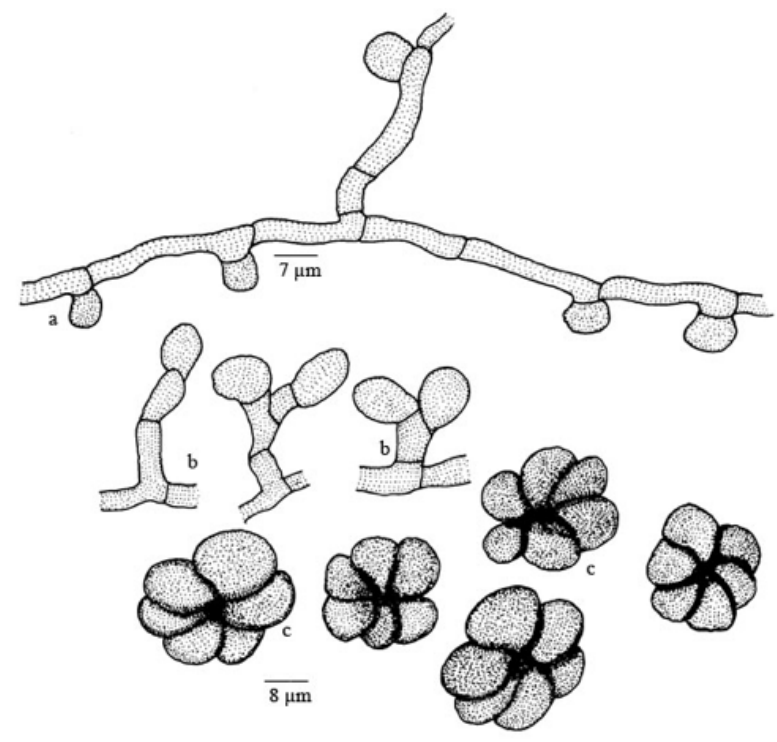

Figure 185.Sarcinella allophyli

a - Appressoriate mycelium; b - Conidiophores; c - Sarciniform conidia

L. (Caesalpiniaceae), 16th mile, Padinharathara, coll. M.C. Riju; HClO 51032, TBGT 4949 11.x.2011 coll. M.C. Riju; HCIO 51035, TBGT 4952, 8.x.2010, $16^{\text {th }}$ mile, Padinharathara, coll. M.C. Riju.

Colonies amphigenous, thin, scattered, up to $3 \mathrm{~mm}$ in diameter. Hyphae substraight, branching mostly opposite, alternate to irregular at acute to wide angles, loosely reticulate, cells $15-28 \times 2-5 \mu \mathrm{m}$. Appressoria alternate to unilateral, one celled, globose, broad based, entire, 7-8x5-8 $\mu \mathrm{m}$. Questieriella conidia few, monoblastic, polyblastic, terminal, cylindrical; conidia solitary, acrogenous, subspherical, oval, sarciniform, 2-7 celled, constricted at the septa, 25-38x18-32 $\mu \mathrm{m}$, wall smooth, brown in colour.

This fungus was associated with the colonies of Meliola tamarindi.

\section{The genus Schiffnerula}

Schiffnerula Hohnel, Sber, Akad. Wiss. Wien, math. Nat.kl., I, 118: 867, 1909; Arx \& Mueller, Stud. Mycol. 9: 48, 1975; Hughes, Can. J. Bot. 61: 1763, 1983; Hosag., Plant Pathology \& Quarantine 1(2):167, 2011.

Clypeolella Hohnel, Sber. Akad. Wiss. Wien., math.nat.kl. I, 119: 403, 1910.

Phaeoschiffnerula Theiss., Broteria 12: 21, 1917.

Questieria Arn., Les Asterinees 1: 186, 1918.

Diathrypton Sydow, Philippine J. Sci. 21: 137, 1922.

Coniosporiella Bat., Atas Inst. Univ. Recife 3: 113, 1966. 


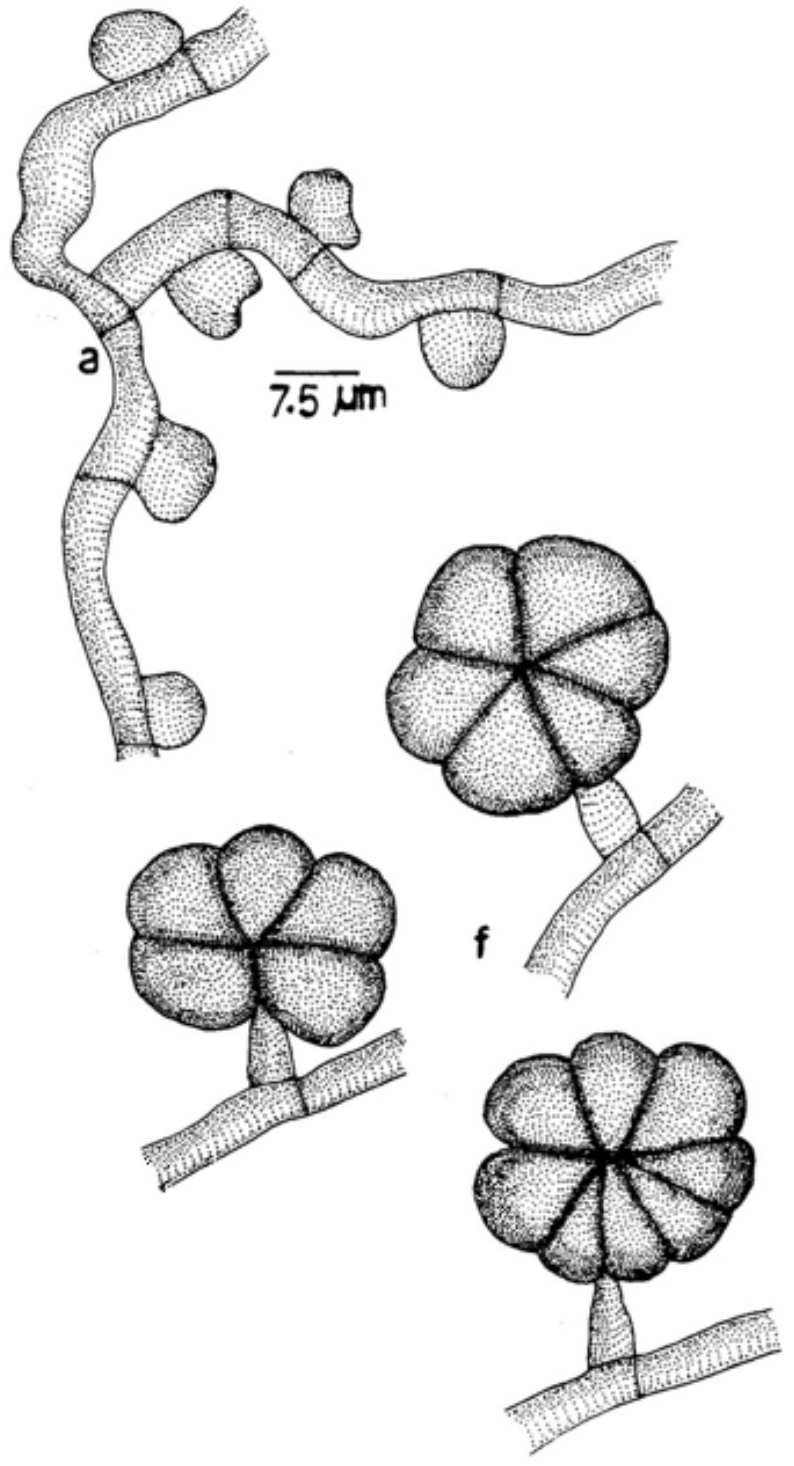

Figure 186.Sarcinella dalbergiae

a - Appressoriate mycelium; f - Sarciniform conidia

Hypahe superficial, colonies foliicolous, brown, appressoriate, appressoria unicellular. Ascomata arise from the short lateral branches, initially with radiating cells but the cells dissolve when the ascomata start resuming globose appearance. Asci few, bitunicate, broadly ellipsoid to globose, sessile, octosporous, exposed after deliqusing the ascomatal wall; ascospores brown, 1-septate, constricted at the septum.

Type - S. mirabilis Hohnel

Schiffnerula brideliae Hansf., Proc. Linn. Soc. London 153(1): 12, 1941; Hosag. \& Riju, Indian J. Sci. \& Techn. 2(6): 7, 2009; Hosag., Plant Pathology \& Quarantine 1(2): 172, 2011 (Fig. 189).
Material examined: HClO 48169, TBGT 2905; HClO 48172, TBGT 2908, 10.xi.2007, on leaves of Bridelia sp. (Euphorbiaceae), 16th mile, Padinharathara, coll. M. C. Riju.

Colonies amphigenous, thin, up to $2 \mathrm{~mm}$ in diameter, confluent. Hyphae substraight to flexuous, branching opposite, alternate to unilateral at acute to wide angles, loosely reticulate, cells $13-38 \times 4-7 \mu \mathrm{m}$. Appressoria alternate, unilateral, globose, mammiform, entire, 6-13x6-11 $\mu \mathrm{m}$. Conidia of Questieriella scattered in the colonies, curved, 3-septate, slightly constricted at the septa, taper towards both ends, 28-30x8-11 $\mu \mathrm{m}$. Conidiophores of Sarcinella produced lateral to the hyphae, single, straight to flexuous, macronematous, mononematous, $\quad 0-3$ septate, $4-7 \times 6-9 \quad \mu \mathrm{m}$; conidiogenous cells terminal, monoblastic, integrated, cylindrical; conidia blastic, terminal, mostly sessile, solitary, dry, ovate to globose, sarciniform, cruciately septate, 4-8 celled, constricted at the septa, 26-40 $\mu \mathrm{m}$ in diameter, wall smooth. Thyriothecia scattered, globose, ovate, peridial cells initially radiating, later central portion dissolved by exposing asci, up to 121

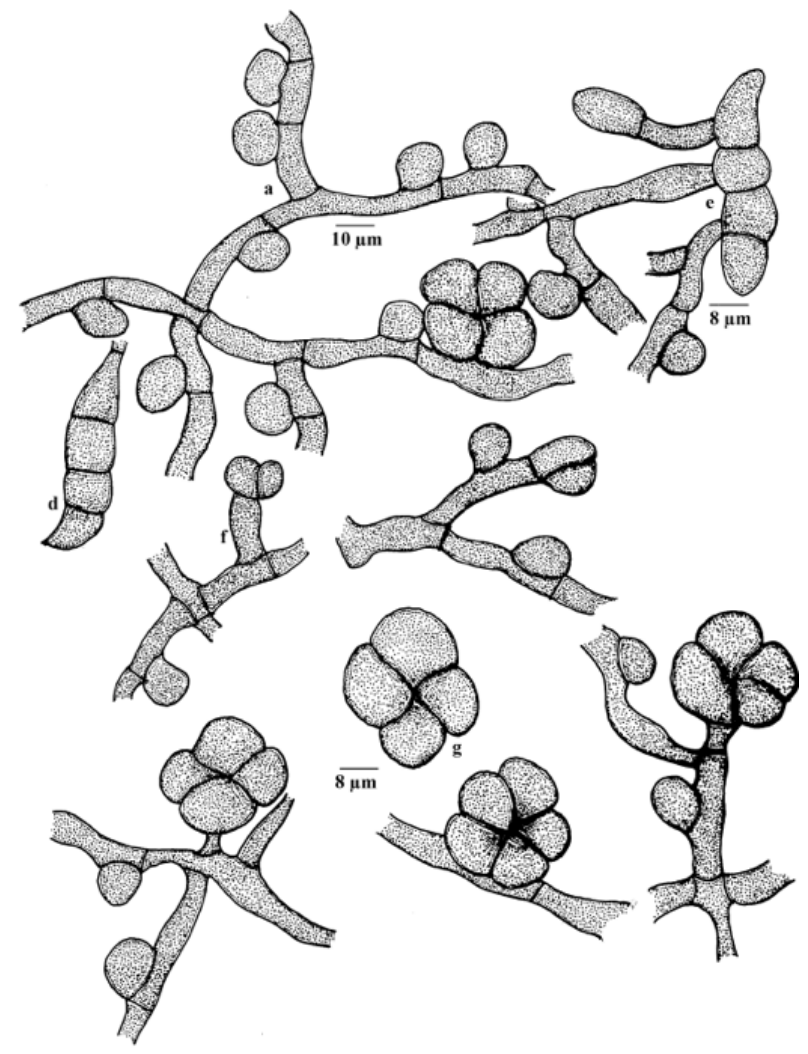

Figure 187. Sarcinella hughesii

a - Appressoriate mycelium; d - Conidia of Questieriella; g - Conidia of Sarcinella 


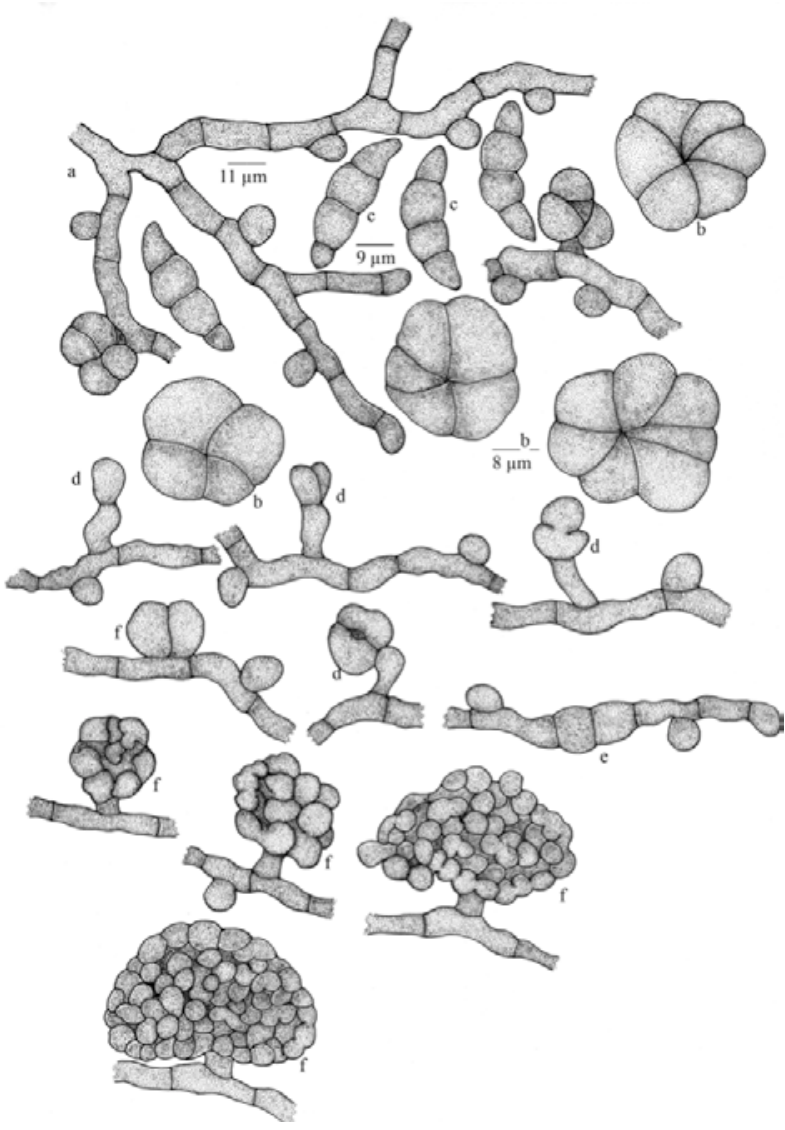

Figure 188. Sarcinella tamarindi

a - Appressoriate mycelium; b - Sarcinella conidia; c - Questieriella conidia; d - Development of Sarcinella conidia; e - Germinating Questieriella conidia; $f$ - Developing thyriothecium

$\mu \mathrm{m}$ in diameter; asci 3-4 per thyriothecia, globose, octosporous, bitunicate, 27-32 $\mu \mathrm{m}$ in diameter; ascospores oblong, conglobate, uniseptate, constricted at the septum, $8-13 \times 5-7 \mu \mathrm{m}$, remain hyaline for some time but turn brown at maturity, wall smooth.

This fungus was known on Bridelia macrantha from Uganda (Hansford 1941a, b).

Schiffnerula camelliae (Sydow, Sydow \& Butler) Hughes, Pleomorphic Fungi. The Diversity and its Taxonomic Implications, p. 133, 1987; Hosag., J. Mycopath. Res. 37: 27, 1999; Hosag., Plant Pathology \& Quarantine 1(2): 173, 2011.

Asterina camelliae Sydow, Sydow \& Butler, Ann. Mycol. 9: 389, 1911.

Clypeolella camelliae (Sydow, Sydow \& Butler) Hansf., Reinwardtia 3: 127, 1954 (Fig. 190).

Material examined: $\mathrm{HClO} 50820$, TBGT 4737; $\mathrm{HClO}$ 50822, TBGT 4739; HCIO 50824, TBGT 4741, 5.xi.2009, on leaves of Thea sinensis (L.) Kuntze (Theaceae), Periya,
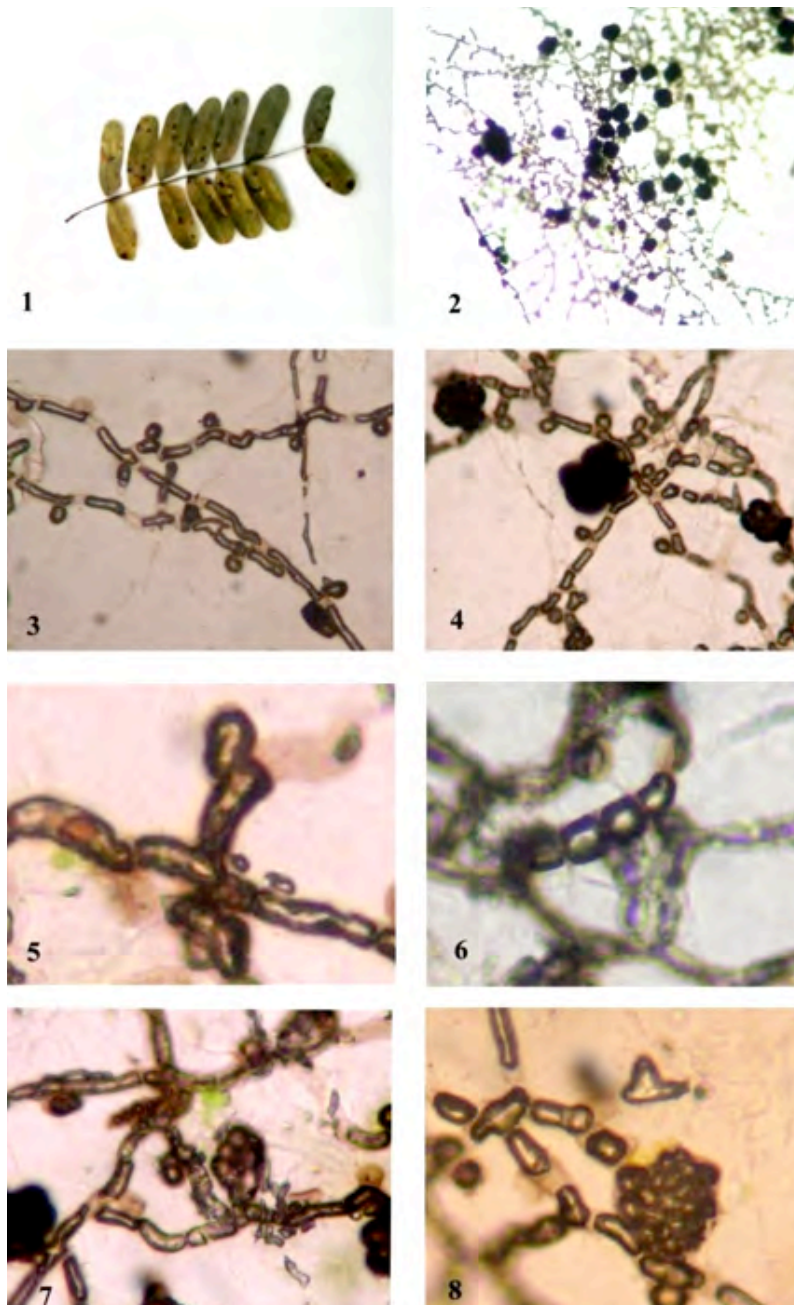

Image 17. a.Sarcinella tamarindi

1 - Infected leaves; 2 - Fungal colony; 3 - Appresoriate mycelium; 4 - Hyphae with sarciniform conidia; 5 - Conidiophore of Sarcinella; 6 Questieriella conidia; 7\&8 - Developing thyriothecium.

coll. M.C. Riju \& A. Sabeena.

Colonies epiphyllous, rarely amphigenous, caulicolous, dense, velvety, crustose, up to $5 \mathrm{~mm}$ in diameter, confluent. Hyphae straight to substraight, outer surface tubercled to crenulated, branching alternate, opposite to irregular at acute to wide angles, loosely to closely reticulate, cells $32-40 \times 7-9 \mu \mathrm{m}$. Appressoria scattered, alternate, unilateral, globose, oval, broad based, unicellular, entire, crenulated to rarely sublobate, $12-18 \times 14-16 \mu \mathrm{m}$. Questieriella type of conidia were few, fusiform, curved, 3-septate, central cells darker, distal cells paler, attenuated towards the tip and acute to obtusely rounded at the apices, 80-93x9-10 $\mu \mathrm{m}$. Thyriothecia scattered to connate, dimidiate, orbicular, up to $150 \mu \mathrm{m}$ in diameter, spreading marginally, dehisce stellately and dissolve at the centre; 

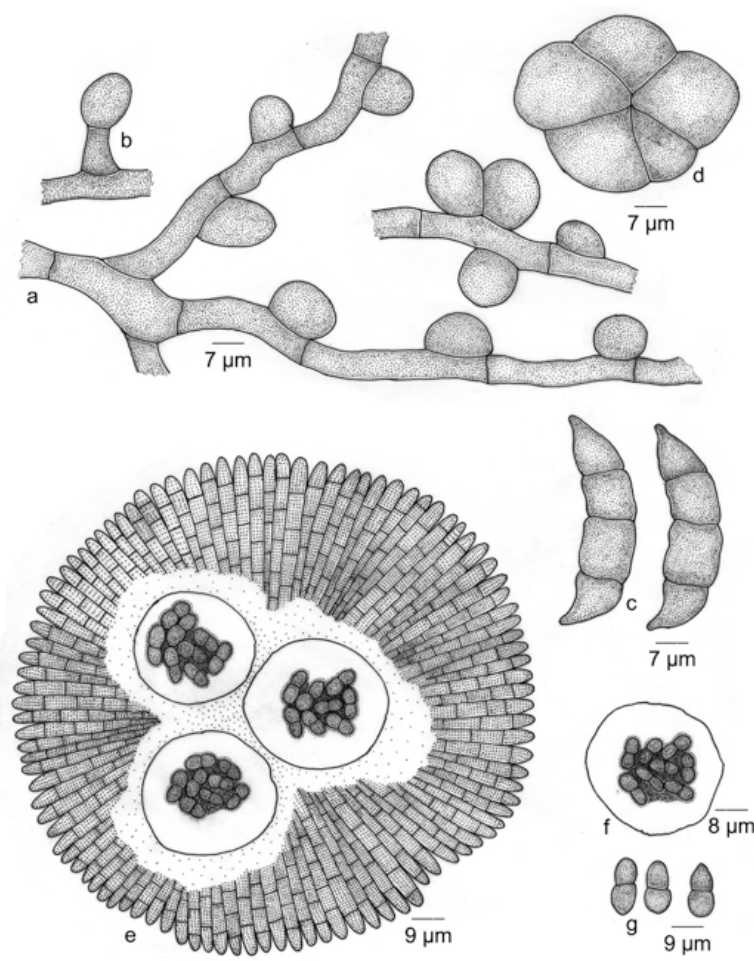

Figure 189. Schiffnerula brideliae

a - Appressoriate mycelium; b - Conidiophore; c - Conidia of Questieriella; d - Conidia of Sarcinella; e - Thyriohtecium; f - Ascus; g- Ascospores

asci many, cylindrical, octosporous, 100-120x30-35 $\mu \mathrm{m}$, sessile; ascospores biseriate, 1-septate, brownish, upper cell smaller and globose, lower cell oval and slightly attenuated, 30-37x15-17 $\mu \mathrm{m}$, wall smooth.

Schiffnerula celastri Hosag., Riju \& Sabeena, Indian J. Sci. Techn. 2(6): 8, 2009; Hosag., Plant Pathology \& Quarantine 1(2): 177, 2011.

Stigmella palawanensis Sydow, Philippine J. Sci. 9: 189, 1914; Sahni, Mycopath. Mycol. Appl. 23: 332, 1964.

Sarcinella palawanensis (Sydow \& Sydow) Sahni, Mycopath. Mycol. Appl. 29: 241, 1966.

Sarcinella paniculatae Verma, Tripathi \& R. K. Choudhary, Indian Phytopath. 52: 379, 1999.

Clypeolella inversa Hohn. sensu Thite \& Kulkarni, Indian Phytopath. 26: 76, 1973; (Image 18; Fig. 191).

Material examined: HClO 48181, TBGT 2917, 16.iii.2007, on leaves of Celastrus paniculatus Willd. (Celastraceae), Padinharathara, coll. M.C. Riju; HClO 48229, TBGT 2966, 30.ix.2007, Padinharathara, coll. M.C. Riju; HClO 48230, TBGT 2968, 23.i.2008, Padinharathara, coll. M.C. Riju; TBGT 4303, 8.xii.2009, on the way to Chungattara, Mepadi, coll. Sam P. Mathew; TBGT 4667,

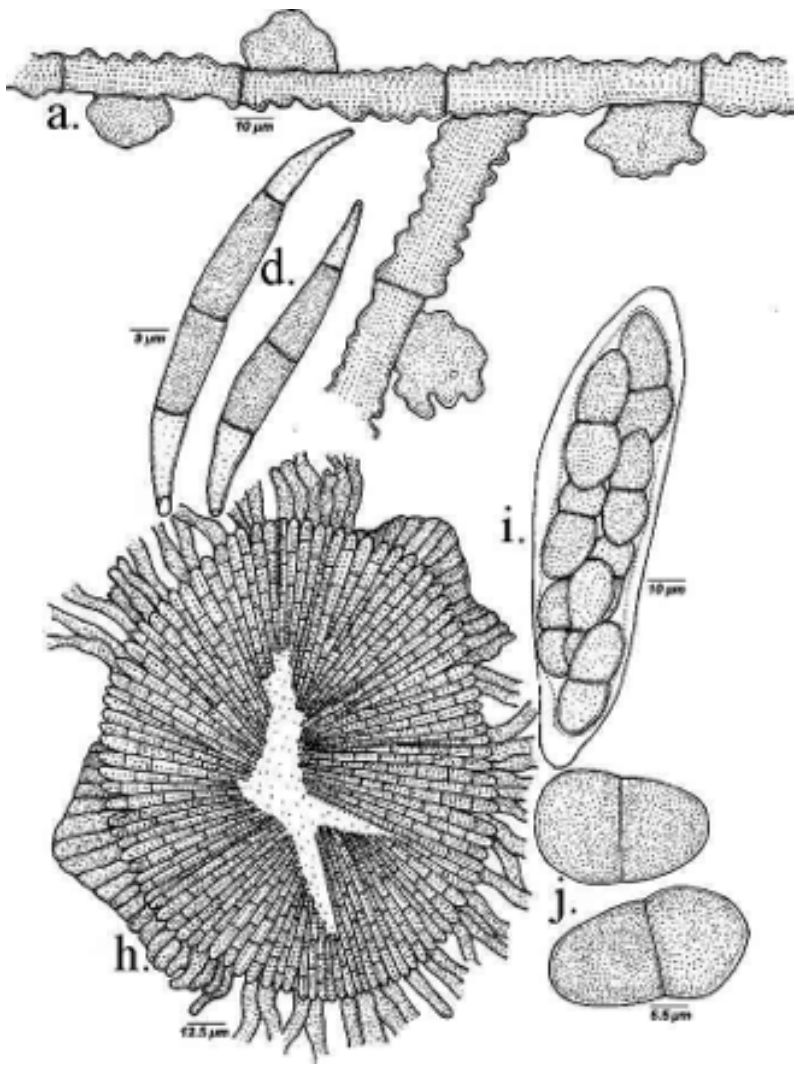

Figure 190.Schiffnerula camelliae a - Appressoriate mycelium; d - Conidia of Questieriella; h Thyriothecium; i - Ascus; j - Ascospores

6.xi.2009, Padinharathara, coll. A. Sabeena \& M.C. Riju; HCIO 48061, TBGT 2844, 16.iii.2007, coll. M.C. Riju; TBGT 5567, 30.ix.2007, coll. M.C. Riju.

Colonies amphigenous, up to $4 \mathrm{~mm}$ in diameter, confluent. Hyphae substraight to flexuous, branching opposite, alternate to unilateral at acute to wide angles, loosely reticulate, cells $13-35 \times 3-4 \mu \mathrm{m}$. Appressoria opposite, globose, mammiform, entire, 3-6x6-9 $\mu \mathrm{m}$. Conidia of Questieriella were scattered, not attached, curved, 3-septate, slightly constricted at the septa, taper towards both ends, 33-55x6-9 $\mu \mathrm{m}$. Sarcinella conidiophores produced lateral to the hyphae, single, straight to flexuous, macronematous, mononematous, 0-2 septate, 11-31x4-6 $\mu \mathrm{m}$. Conidiogenous cells terminal, monoblastic, integrated, cylindrical. Sarcinella conidia blastic, terminal, mostly sessile, solitary, dry, ovate to globose, sarciniform, sarcinately septate, 2-8 celled, constricted at the septa, 13-26 $\mu \mathrm{m}$ in diameter, wall smooth. Thyriothecia scattered, orbicular, ovate, initially radiating, later central portion dissolved by exposing asci, up to $174 \mu \mathrm{m}$ in diameter, marginal cells radiating; asci 5-8 per thyriothecia, globose, 
octosporous, bitunicate, $15-28 \mu \mathrm{m}$ in diameter; ascospores oblong, conglobate, uniseptate, constricted at the septum, 17-26x6-13 $\mu \mathrm{m}$, remain hyaline for some time but turn brown at maturity.

Schiffnerula lagerstroemiae Hosag. \& Riju, Bioscience Discovery 2 (2):272, 2010; Hosag., Plant Pathology \& Quarantine 1(2): 186, 2011.

Sarcinella lagerstroemiae Hosag. \& Mohanan, New Botanist 22: 31, 1995 (Fig. 192).

Material examined: $\mathrm{HClO}$ 48130, TBGT 2967, 10.x.2007, on leaves of Lagerstroemia microcarpa Wight (Lythraceae), 16th mile, Padinharathara, coll. M.C. Riju; $\mathrm{HClO}$ 48231, TBGT 2969; HClO 43813, TBGT 392; HClO 48233, TBGT 2971, 19.xi.1999 on Lagerstroemia sp., Banasuranmala, coll. C.K.Biju; HCIO 48235, TBGT 2973, 9.xi.2007, Mananthavady, coll. M.C. Riju.

Colonies epiphyllous, dense, confluent, up to $2 \mathrm{~mm}$ in diameter. Hyphae substraight to undulating, branching opposite to alternate at acute to wide angles, loosely to closely reticulate, cells $11-26 \times 4-7 \mu \mathrm{m}$. Appressoria alternate, unilateral, globose, mammiform, entire, 6-9x8-11 $\mu \mathrm{m}$. Conidia of Questieriella type were few, scattered, attached directly to the hyphae, curved, 3-septate, slightly constricted at the septa, taper towards both ends, 28-37x8-11 $\mu \mathrm{m}$. Sarcinella conidiophores produced lateral to the hyphae, single, straight, flexuous, macronematous, mononematous, 0-3 septate, 2031x4-6 $\mu \mathrm{m}$; conidiogenous cells terminal, monoblastic, integrated, cylindrical. Sarcinella conidia blastic, terminal, mostly sessile, solitary, dry, ovate to globose, sarciniform, 2-8 celled, constricted at the septa, 17-40 $\mu \mathrm{m}$ in diameter, wall smooth. Thyriothecia scattered, globose, orbicular, peridial cells initially radiating, later central portion dissolved by exposing the asci, up to $66 \mu \mathrm{m}$ in diameter, marginal cells radiating; asci 1-2 per thyriothecia, globose, 4-6- spored, bitunicate, 17-26 $\mu \mathrm{m}$ in diameter; ascospores cylindrical, oblong, uniseptate, constricted at the septum, 17-22x6-9 $\mu \mathrm{m}$, remain hyaline for some time but turn brown at maturity.

Schiffnerula palodensis Hosag. \& Riju, Bioscience Discovery 2(2): 272, 2011; Hosag., Plant Pathology \& Quarantine 1(2): 191, 2011 (Fig. 193 \& Image 19).

Material examined: $\mathrm{HClO} 51067, \mathrm{TBGT} 4984 ; \mathrm{HClO}$ 51069, TBGT 4986; HCIO 51071, TBGT 4988, 6.xi.2009, on leaves of Solanum sp. (Solanaceae), Padinharathara, coll. A. Sabeena \& M.C. Riju.

Colonies epiphyllous, thin, up to $2 \mathrm{~mm}$ in diameter, confluent. Hyphae substraight, branching alternate to irregular at acute to wide angles, loosely reticulate,

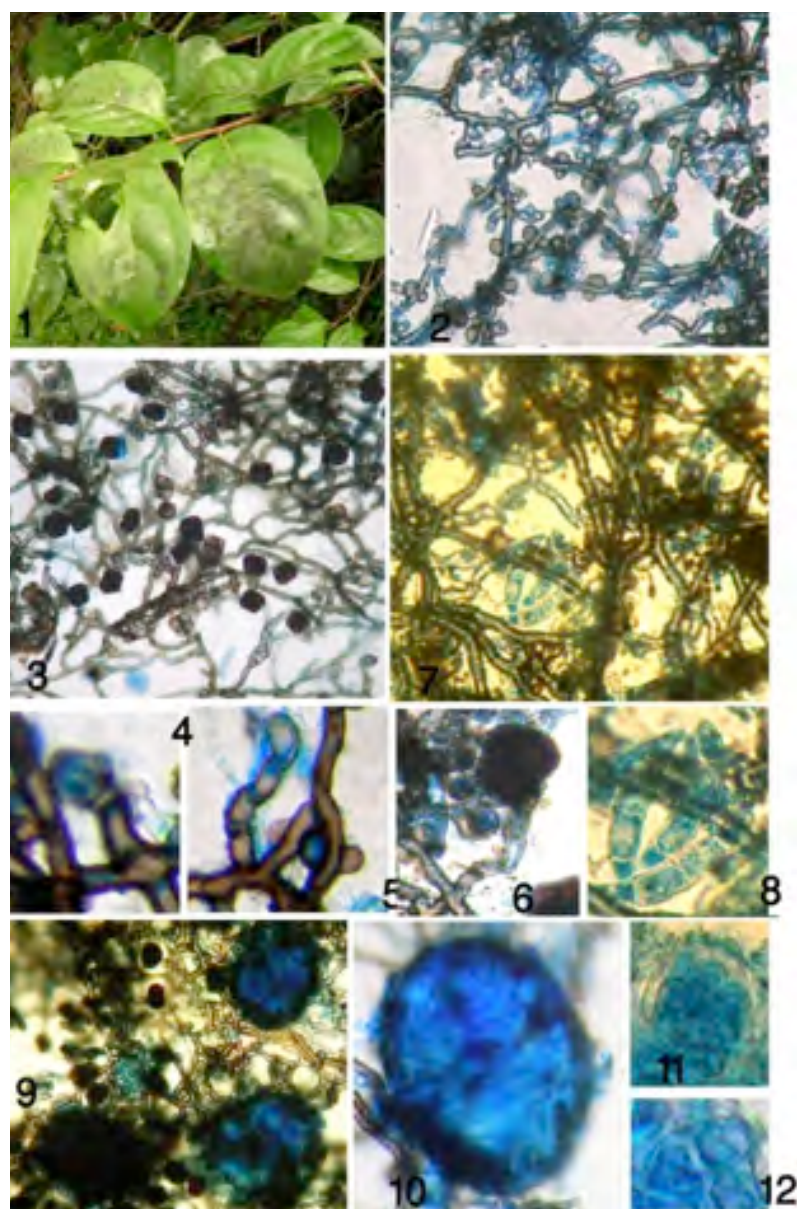

Image 18. a. Schiffnerula celastri

1 - Infected leaves; 2 - Appressoriate mycelium; 3 - Colony with sarciniform and Questieriella conidia; 4 - Conidiophores; 6 Sarciniform conidia; 7-8 - Conidia of Questieriella; 9 - Thyriothecia, 10 - Centrally dissolved thyriothecium; 11 - Ascus; 12 - Ascospore

cells $8-20 \times 4-6 \mu \mathrm{m}$. Appressoria alternate to unilateral, ovate, globose to mammiform, entire, 8-10x6-10 $\mu \mathrm{m}$. Conidia of Questieriella were scattered, not attached, curved, 3-septate, slightly constricted at the septa, taper towards both ends, 14-31x8-11 $\mu \mathrm{m}$. Sarcinella conidiophores produced lateral to the hyphae, single, straight to flexuous, micronematous, mononematous, 0-1 septate, 5-22×3-5 $\mathrm{mm}$; conidiogenous cells terminal, monoblastic, integrated, cylindrical. Sarcinella conidia blastic, terminal, mostly sessile, solitary, dry, ovate to globose, sarciniform, sarcinately septate, 3-7 celled, constricted at the septa, 19-33 $\mu \mathrm{m}$ in diameter, wall smooth. Thyriothecia scattered, orbicular, ovate, peridial cells initially radiating, later central portion dissolved by exposing the asci, up to $75 \mu \mathrm{m}$ in diameter, marginal cells radiating; asci 2-5 per thyriothecia, globose, octosporous, bitunicate, 12-24 $\mu \mathrm{m}$ in diameter; 


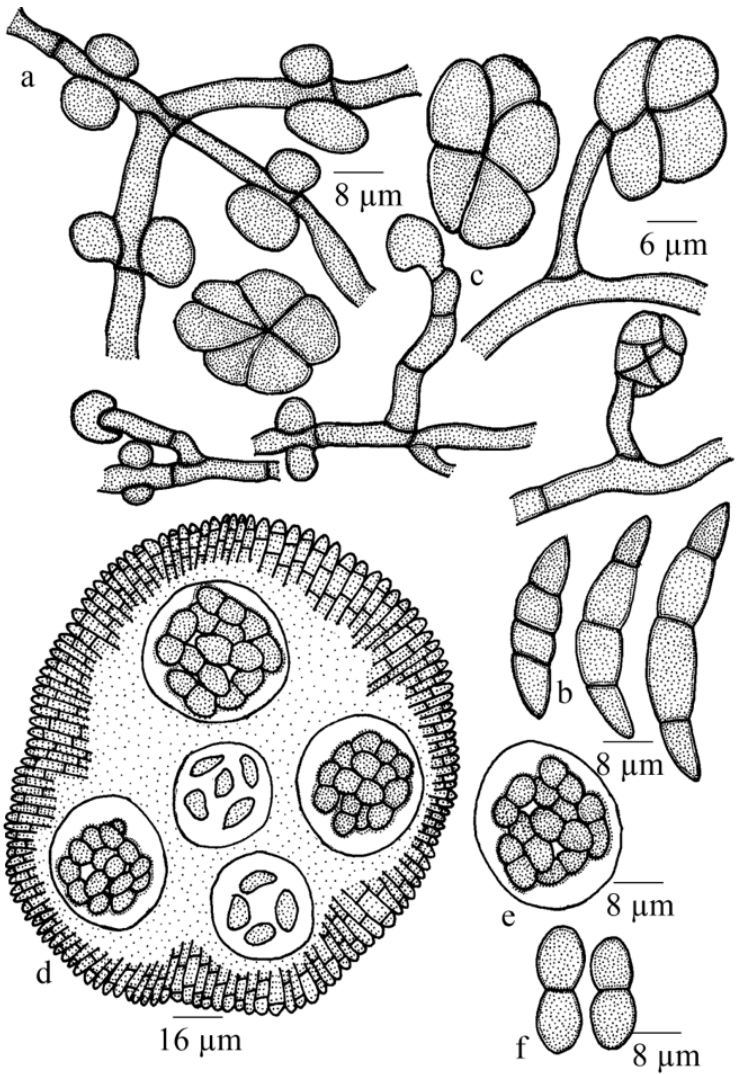

Figure 191. Schiffnerula celastri

a - Appressoriate mycelium; b - Conidia of Questieriella; c Conidiophore and conidia of Sarcinella; d. Thyriothecium; e - Ascus; f - Ascospores

ascospores oblong, conglobate, uniseptate, constricted at the septum, 20-23×10-12 $\mathrm{mm}$, brown at maturity, wall smooth.

Schiffnerula ricini Hansf., Proc. Linn. Soc. London 160: 117, 1947-48; Hosag., H. Biju \& Appaiah, J. Mycopathol. Res. 4: 23, 2006; Hosag. \& Riju, Indian J. Sci. \& Techn. 2(6): 7, 2009; Hosag., Plant Pathology \& Quarantine 1(2): 193, 2011 (Fig. 194).

Material examined: HClO 48180, TBGT 2916, 10.xi.2007, on leaves of Ricinus communis L. (Euphorbiaceae), Puthuserikadavu, Padinharathara, coll. M. C. Riju.

Colonies amphigenous, up to $3 \mathrm{~mm}$ in diameter, epiphyllous colonies subdense, confluent, hypophyllous colonies crustose, some times confluent. Hyphae substraight to flexuous, branching opposite, irregular at acute to wide angles, loosely reticulate, cells 8-33x2-5 $\mu \mathrm{m}$. Appressoria alternate, unilateral, globose, mammiform, entire, 6-9 x 6-10 $\mu \mathrm{m}$. Conidia of Questieriella were scattered, mostly not attached,

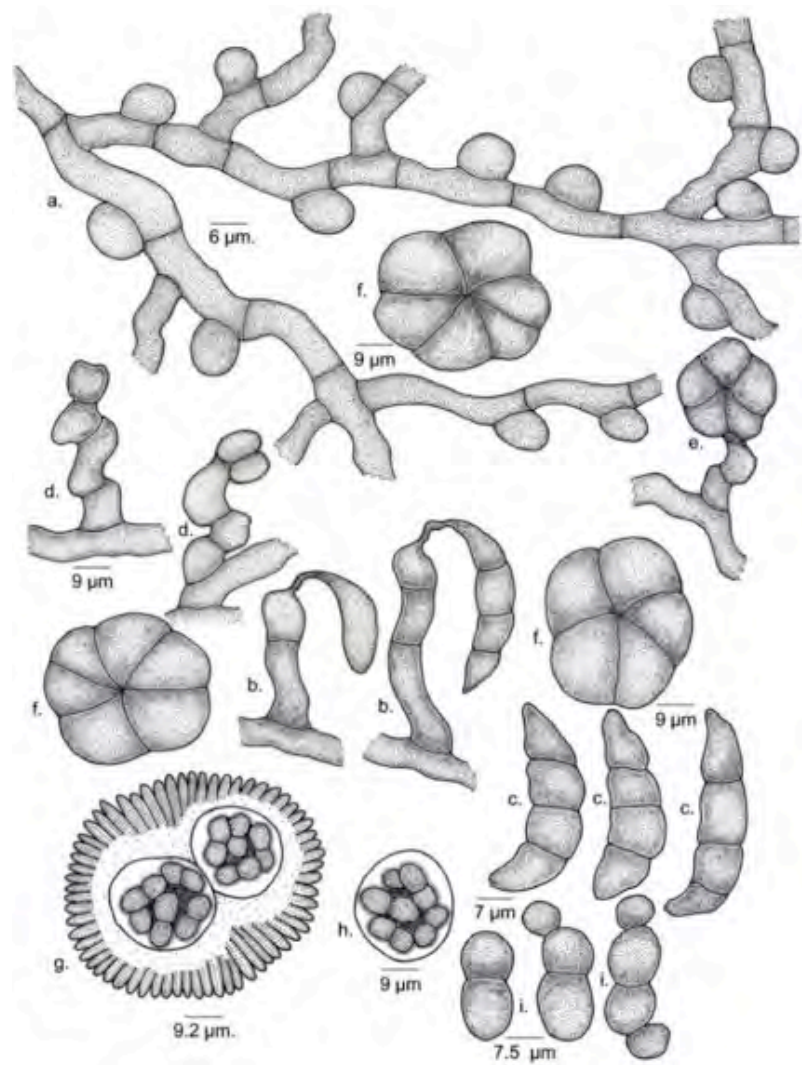

Figure 192.Schiffnerula lagerstroemiae

a - Appressoriate mycelium; b - Conidiophores of Questieriella; c Conidia of Questieriella; $\mathrm{d}$ - Conidiophores of Sarcinella, e. Sarcinella conidia on conidiophores; $f$ - Conidia of Sarcinella; $g$ - Thyriotheicum; h - Ascus; i - Ascospores

curved, 3-septate, slightly constricted at the septa, taper towards both ends, 26-31x8-11 $\mu \mathrm{m}$. Sarcinella conidiophores produced lateral to the hyphae, single, straight to flexuous, macronematous, mononematous, 0-2 septate, 9-12×2-5 $\mu \mathrm{m}$, conidiogenous cells terminal, monoblastic, integrated, cylindrical; conidia present mostly on the lower surface of the leaves, blastic, terminal, solitary, dry, ovate to globose, sarciniform, cruciately septate, 4-8 celled, constricted at the septa, 19-31 $\mu \mathrm{m}$ in diameter, brown and turn to dark at maturity, wall smooth. Thyriothecia mostly on the upper surface of the leaves, scattered, globose, orbicular to ovate, peridial cells initially radiating, later central portion dissolved by exposing asci, up to $110 \mu \mathrm{m}$ in diameter, marginal cells mostly persist and radiate; asci 4-8 per thyriothecia, globose, octosporous, bitunicate, 22-29 $\mu \mathrm{m}$ in diameter; ascospores oblong, conglobate, uniseptate, constricted at the septum, 19-22x8-11 $\mu \mathrm{m}$, remain hyaline for some time but turn brown at maturity. 


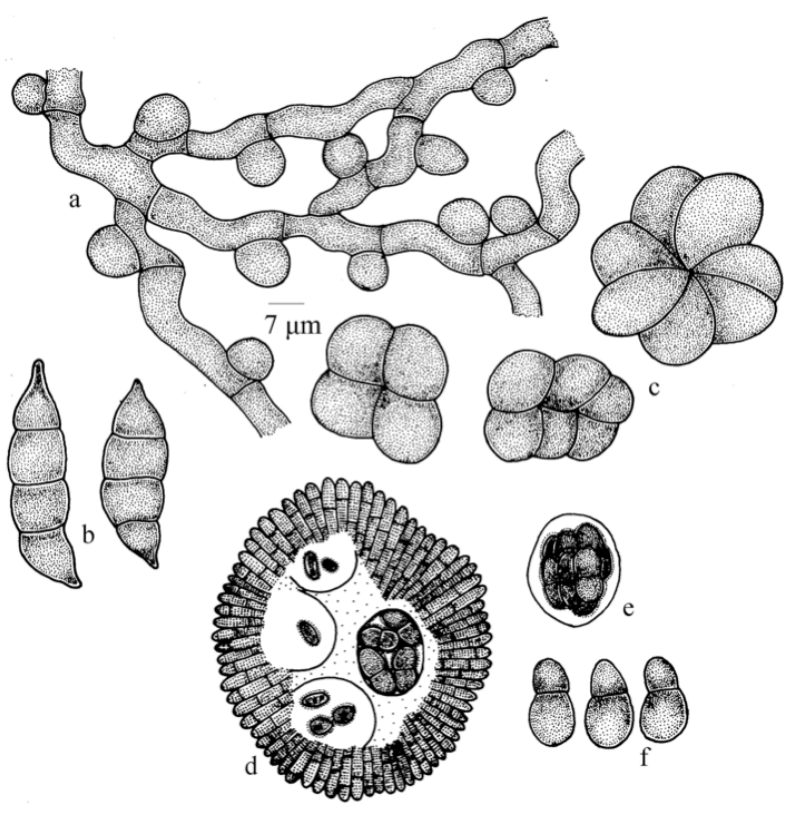

Figure 193.Schiffnerula palodensis

a - Appressoriate mycelium; b - Conidia of Questieriella; c - Conidia of Sarcinella; $\mathrm{d}$ - Thyriothecium; e - Ascus; $\mathrm{f}$ - Ascospores

Schiffnerula spilanthi Hosag., Sabeena \& Riju, Indian Phytopath. 63: 321, 2010; Hosag., Plant Pathology \& Quarantine 1(2): 193, 2011 (Image 20; Fig. 195 ).

Material examined: HCIO 49106, TBGT 3361, 23.xii.2008, on leaves of Spilanthes radicans Jaca. (Asteraceae), Padinharathara, coll. M.C. Riju; HCIO 49108, TBGT 3363; HCIO 49109, TBGT 3364, 9.i.2009, 16th mile, Padinharathara, coll. M.C. Riju.
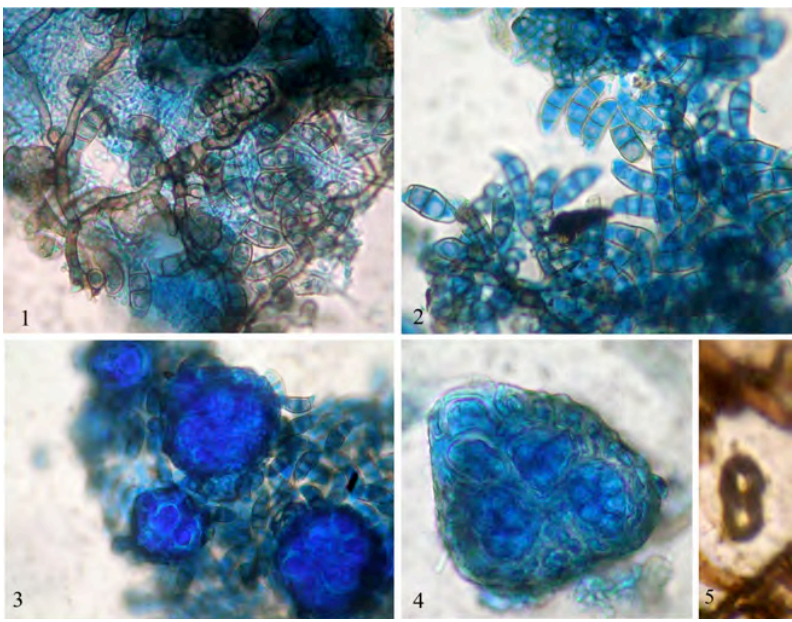

Image.19 Schiffnerula palodensis

1 - Colony with thyriothecia and Questieriella conidia; 2 Questieriella conidia; 3 - Thyriothecia; 4 - Arrangement of asci in the thyriothecium; 5 - Ascospore

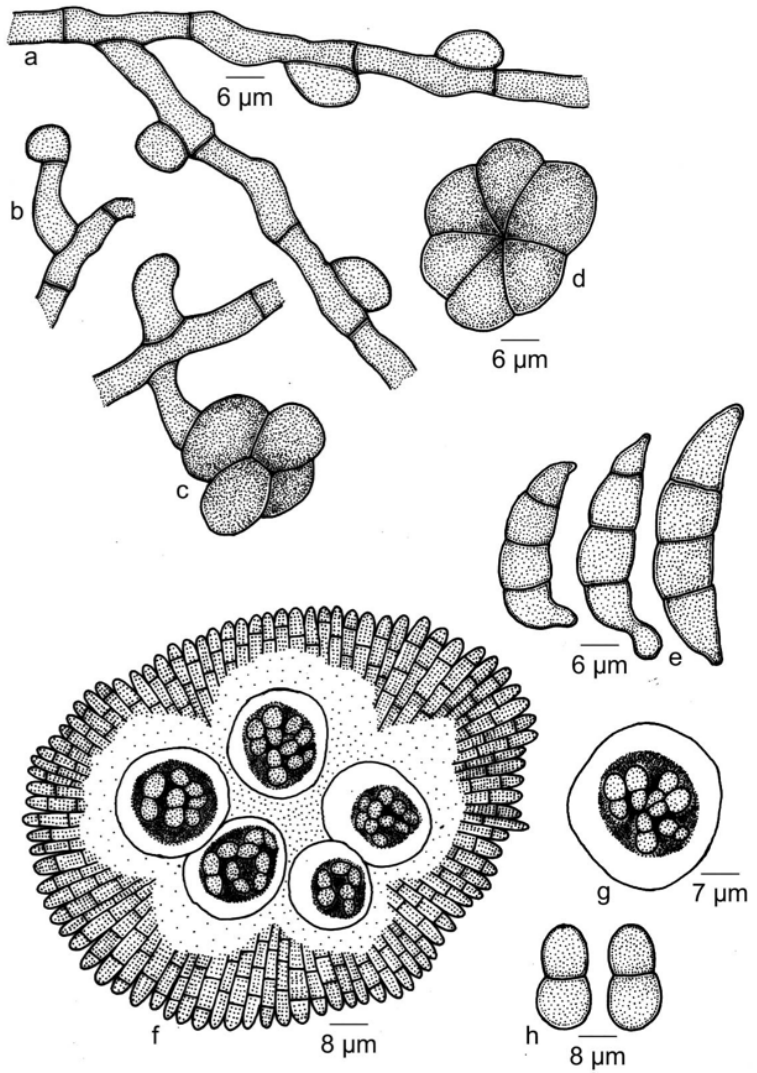

Figure 194. Schiffnerula ricini

a.Appressoriate mycelium, b.Conidiophore, c. Sarcinella conidia on conidiophore, d. Conidia of Sarcinella, e. Conidia of Questieridiella, f. Thyriothecium, g. Ascus, h. Ascospores

Colonies epiphyllous, thin, scattered to confluent, up to $3 \mathrm{~mm}$ in diameter. Hyphae substraight to flexuous, branching opposite, alternate to unilateral at acute to wide angles, loosely to closely reticulate, cells 10 38x5-8 $\mu \mathrm{m}$. Appressoria scattered, alternate, unilateral, rarely opposite, globose, ovate, unicellular, entire, 1015×10-14 $\mu \mathrm{m}$. Conidia of Questieriella were scattered, not attached, curved, 3-septate, slightly constricted at the septa, taper towards both ends, 37-43×10-15 $\mu \mathrm{m}$. Sarcinella state not found. Thyriothecia scattered, ovate, orbicular, peridial cells initially radiating, later the central portion dissolved by exposing asci, 25-63 $\mu \mathrm{m}$ in diameter, marginal cells radiating; asci 2-4 per thyriothecia, globose, octosporous, 25-35 $\mu \mathrm{m}$ in diameter; ascospores oblong, conglobate, uniseptate, constricted at the septum, 20-23x10-13 $\mu \mathrm{m}$, wall smooth.

Schiffnerula tectonae (Thite \& Patil) Hosag., Zoos Print J. 18: 1077, 2003; Hosag., Plant Pathology \& Quarantine 1(2): 196, 2011. 
Clypeolella tectonae Thite \& Patil, Geophytology 15: 84, 1985

Stat. Anamorph: Sarcinella tectonae Hosag. \& Manoj., Zoos' Print J. 19: 1389, 2004; Hosag., Plant Pathology \& Quarantine 1(2): 196, 2011 (Fig. 196).

Material examined: $\mathrm{HClO}$ 49978, TBGT 4130, 14.iii.2007, on leaves of Tectona grandis L. (Verbenaceae), Puthuserykadavu, coll. M.C. Riju; HClO 49982, TBGT 4134, HClO 50879, TBGT 4796, Padinharathara, 4.xi.2009, coll. A. Sabeena \& M.C. Riju.

Colonies amphigenous, mostly epiphyllous, dense, up to $1 \mathrm{~mm}$ in diameter, rarely confluent. Hyphae pale brown, slightly flexuous, branching alternate to irregular at acute angles, loosely to closely reticulate, cells 12 20x4-7 $\mu \mathrm{m}$. Appressoria brown, scattered, alternate, globose to slightly ovate, entire, 9-12 $\mu \mathrm{m}$ in diameter; conidiophores simple, micronematous, mononematous, pale, entire, 5-8 $\mu \mathrm{m}$ long; conidiogenous cells integrated, monoblastic, terminal; conidia solitary, dry, acrogenous, simple, globose, sarciniform, 4-12-celled, carbonaceous black, septa not visible, slightly constricted at the septa, 16-40 $\mu \mathrm{m}$ in diameter, wall smooth. Thyriothecia scattered, orbicular, cells radiating at the upper portion, up to $200 \mu \mathrm{m}$ in diameter, dissolved at the central portion by exposing asci; asci ovate to globose, eight spored, 30-50x12-22 $\mu \mathrm{m}$; ascospores oblong, conglobate, uniseptate, constricted at the septum, 10-20x9-11 $\mu \mathrm{m}$.

Colonies were hyperparasitized by Acremoniula sarcinellae.

Schiffnerula vernoniae Hosag., Sabeena \& Riju, Indian Phytopath. 63: 3231, 2010; Hosag., Plant Pathology \& Quarantine 1(2): 198, 2011.

Sacinella vernoniae (Dearn. \& Barth.) Hughes, Can. J. Bot. 61: 1748, 1983; Hosag., C.K. Biju \& Abraham, J. Econ. Taxon. Bot. 25: 281, 2001.

Piricauda vernoniae (Dearn. \& Barth.) Moore, Rhodora 61:106, 1959 (Fig. 197; Image 21).

Material examined: HCIO 49105, TBGT 3360, 23.xii.2008, on leaves of Vernonia anthelmintica (L.) Willd. (Asteraceae), Padinharathara, coll. M.C. Riju; HCIO 49107, TBGT 3362, 9.i.2009, 16 ${ }^{\text {th }}$ mile, Padinharathara, coll. M.C. Riju; Anamorphs: $\mathrm{HClO}$ 44789, TBGT 1026, 12.xii.2002, on leaves of $V$. conyzoides DC., Chandanathode, coll. M. Kamarudeen \& P.A. Jose; HCIO 44410 , TBGT 667, 7.xi.2001, on Vernonia sp., Brahmagiri, coll. S.Shiburaj.

Colonies epiphyllous, thin, up to $2 \mathrm{~mm}$ in diameter, confluent. Hyphae substraight to undulating, branching alternate, unilateral to opposite at acute to wide angles, loosely reticulate, cells $7-38 \times 5-7 \mu \mathrm{m}$. Appressoria
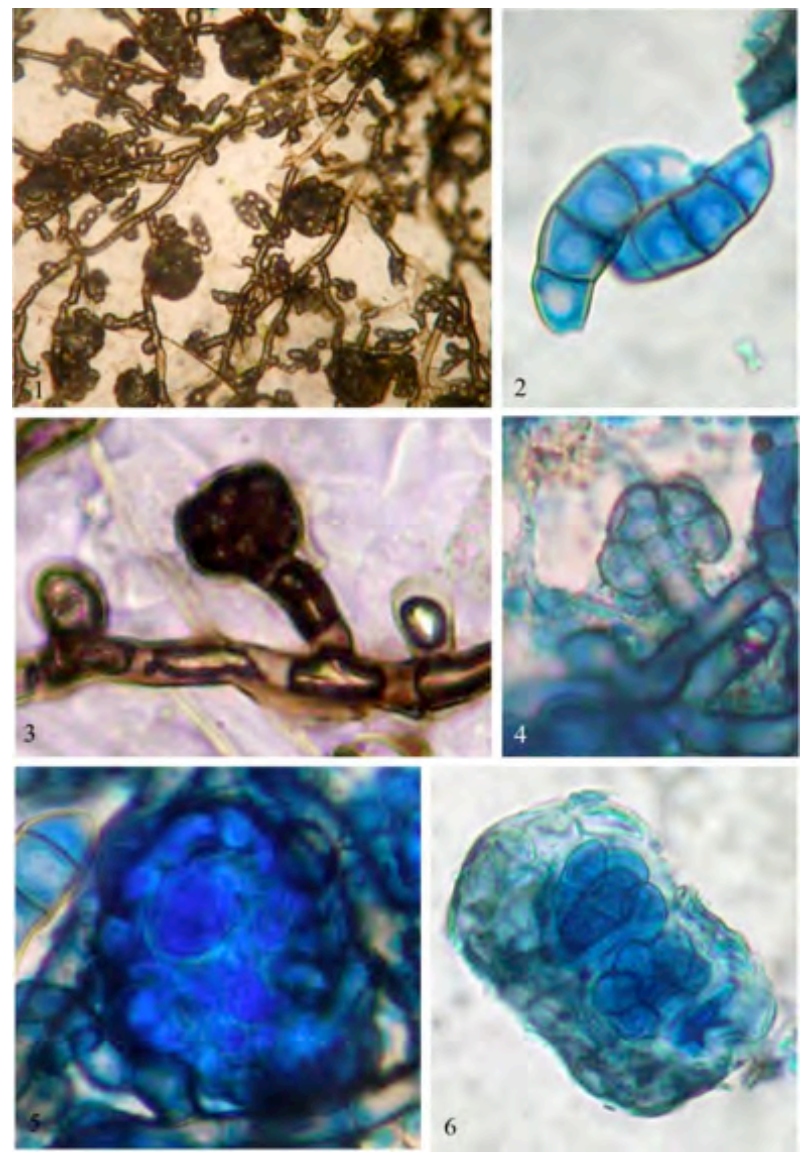

Image 20. Schiffnerula spilanth

1 - Colony with thyriothecia and Questieriella conidia; 2 - Questieriella conidia; 3-4 - Developmental stages of thyriothecia; 5 - Thyriothecia with asci; 6 - Asci with ascospores

scattered, alternate, unilateral, opposite to subopposite, globose, mammiform, entire, 7-13x7-12 $\mu \mathrm{m}$. Conidia of Questieriella scattered, 3-septate, straight, slightly constricted at the septa, taper towards both ends, 30$35 \times 10-13 \mu \mathrm{m}$. Sarcinella conidiophores produced lateral to the hyphae, single, straight, flexuous, micronematous, mononematous, $8-14 \times 5-7$, conidiogenous cells terminal, monoblastic, integrated, cylindrical. Sarcinella conidia blastic, terminal, mostly sessile, solitary, dry, ovate to globose, sarciniform, 2-7 celled, constricted at the septa, 30-38 $\mu \mathrm{m}$ in diameter, wall smooth. Thyriothecia scattered, ovate, orbicular, peridial cells initially radiating, later central portion dissolved by exposing the asci, up to $83 \mu \mathrm{m}$ in diameter, marginal cells radiating; asci 2-4 per thyriothecia, globose, octosporous, 20-23 $\mu \mathrm{m}$ in diameter; ascospores oblong, conglobate, uniseptate, constricted at the septum, 20$25 \times 10-13 \mu \mathrm{m}$, wall smooth. 


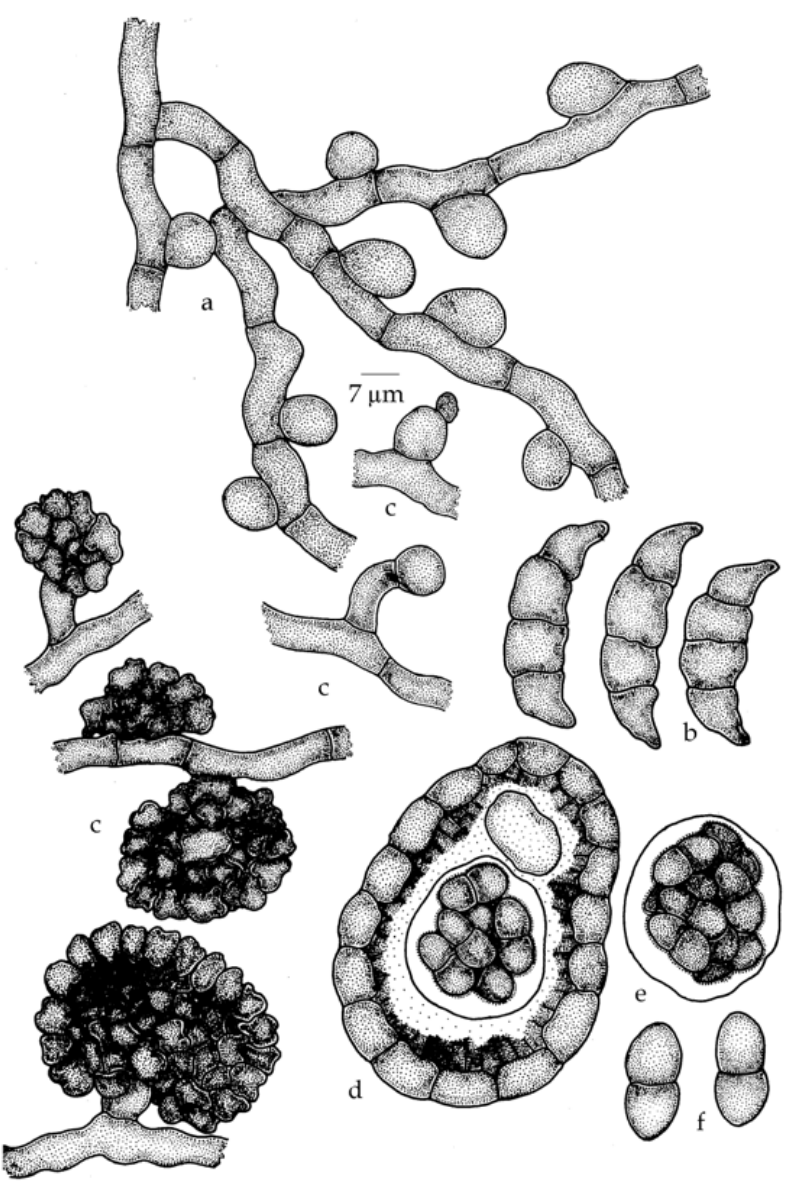

Figure 195. Schiffnerula spilanthi

a - Appressoriate mycelium; b - Conidia of Questieriella; c Thyriothecium initials; $d$ - Thyriothecium; e - Ascus; f - Ascospores

\section{Phyllachorales}

Stromata absent to well developed, immersed in plant tissue, clypeate; ascocarps perithecial, thin walled; interascal tissue simple, thin walled, wide paraphyses, may be deliquescent; asci cylindrical, thin walled, persistent, apical ring inconspicuous; scospores hyaline, one celled, rarely ornamented, parasitic on leaves and stems, some necrotrophic, a few saprophytic; anamorphs coelomycetous. This order represents here a single family.

\section{Phyllachoraceae}

Stromata well developed, immersed in plant tissue, clypeate, black, very rarely bright coloured, ascocaps perithecial, thin walled, ostiolate; paraphyses thin walled; asci cylindrical, thin walled, persistent, apical ring inconsicuous; ascospores hyaline, non septate to septate, rarely ornamented, parasitic on living leaves and young stems; anamorphs coelomycetous.
The members of this family produce "tar spot" disease symptoms. Perithecia completely buried in the host tissues, globose, membranous to leathery, dark, more or less aggregated with clypeus, formed by the filling of the epidermal layers of the host with dark, dense fungus tissue, through which the ostioles of the perithecia open (Hansford, 1946).

Type genus: Phyllachora Nitschke ex Fuckel

\section{The genus Phyllachora}

Phyllachora Nitschke ex Fuckel, Jb. Nassau. Ver Naturk. 23-24: 217, 1870.

Catacauma Theiss. \& Sydow, Ann. Mycol. 12: 280, 1914.

Clypeostigma Hohnel, Sitx. Ber. K. Akad. Wiss. Wien. Math. Nat. KI. 1. Abt. 128: 556, 1919.

Clypeotrabutia Seav. \& Chard., Scient. Surv. Porto Rico Virg. Isl. 8/1, Bot. 60, 1926.

Diplosporis Clem., Gen. Fung. 27, 1909.

Discomycopsella P. Henn., Hedwigia 41: 146, 1902.

Endodothella Theiss. \& Sydow, Ann. Mycol. 13: 582, 1915.

Endophyllachora Rehm, Philippine J. Sci. 7:197, 1913.

Endotrabutia Chard., J. Agric. Porto Rico 14:270, 1930.

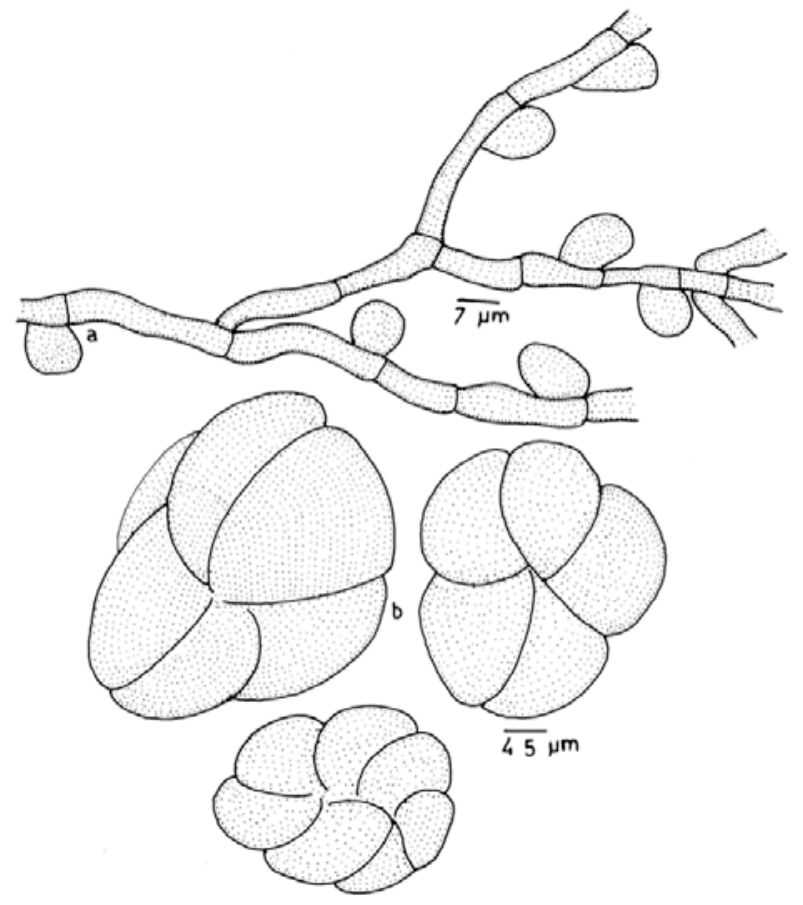

Figure 196 c.f. Schiffnerula tectonae

a - Appressoriate mycelium; b - Sarciniform conidia 


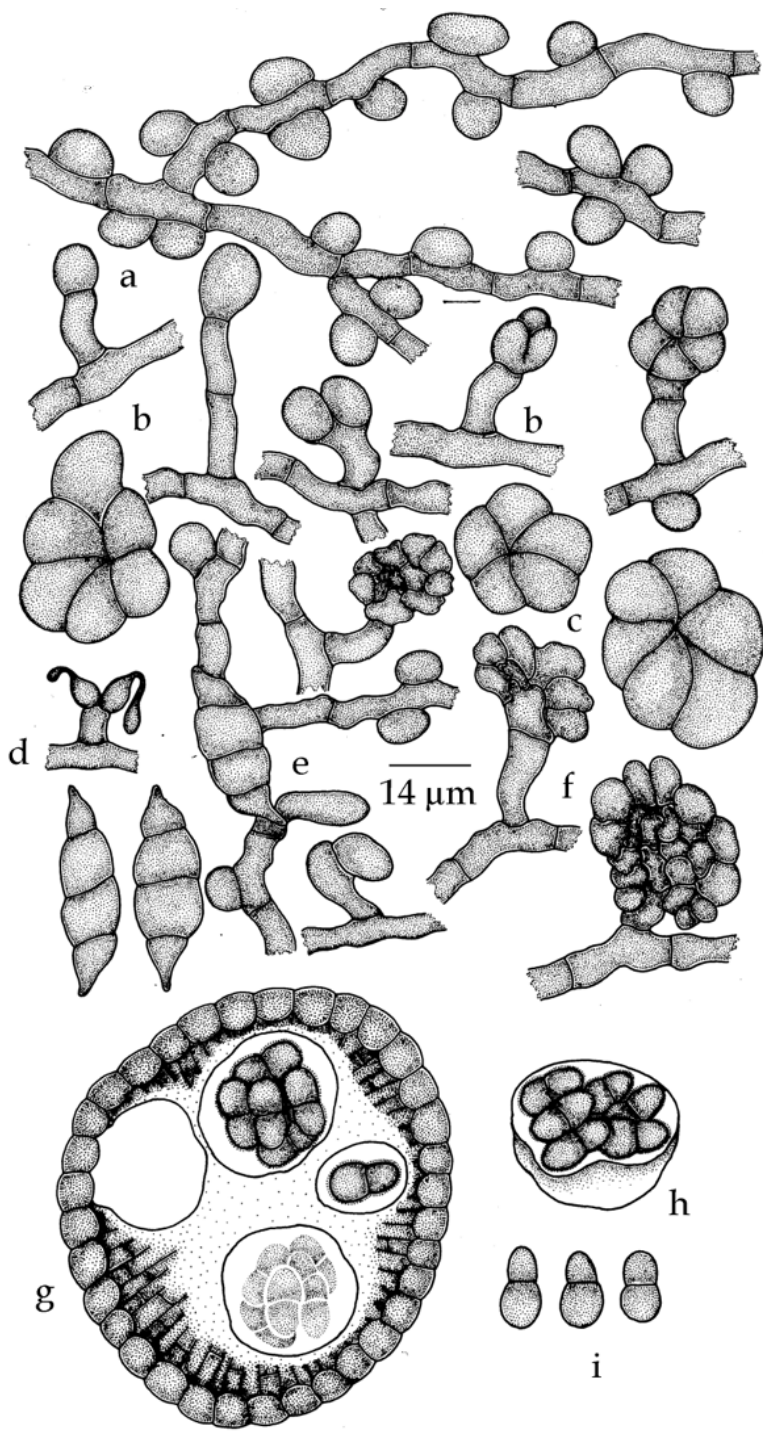

Figure 197 Schiffnerula vernoniae

a.Appressoriate mycelium, b. Conidiophores, c. Conidia of Sarcinella d. Conidiophore, e. Germinating conidia of Questieriella, $f$. Thyriothecium initials, g. Thyriothecium, h. Ascus, i. Ascospores

Geminispora Pat., Bull. Soc. Mycol. France 9: 151, 1893.

Halstedia Stev., Bot. Gaz. 69: 253, 1920.

Metachora Sydow \& Butler, Ann. Mycol. 9: 400, 1911.

Phaeotrabutia Garces, Caldasia (Columbia) 1: 77, 1941.

Phaeotrabutiella Theiss. \& Sydow, Ann. Mycol. 13: 360, 1915.

Phragmocarpella Theiss. \& Sydow, Ann. Mycol. 13: 602, 1915.

Plectastroma Theiss. \& Sydow, Ann. Mycol. 12: 269, 1914.

Plectosphaera Theiss., Ann. Mycol. 32: 413, 1934.

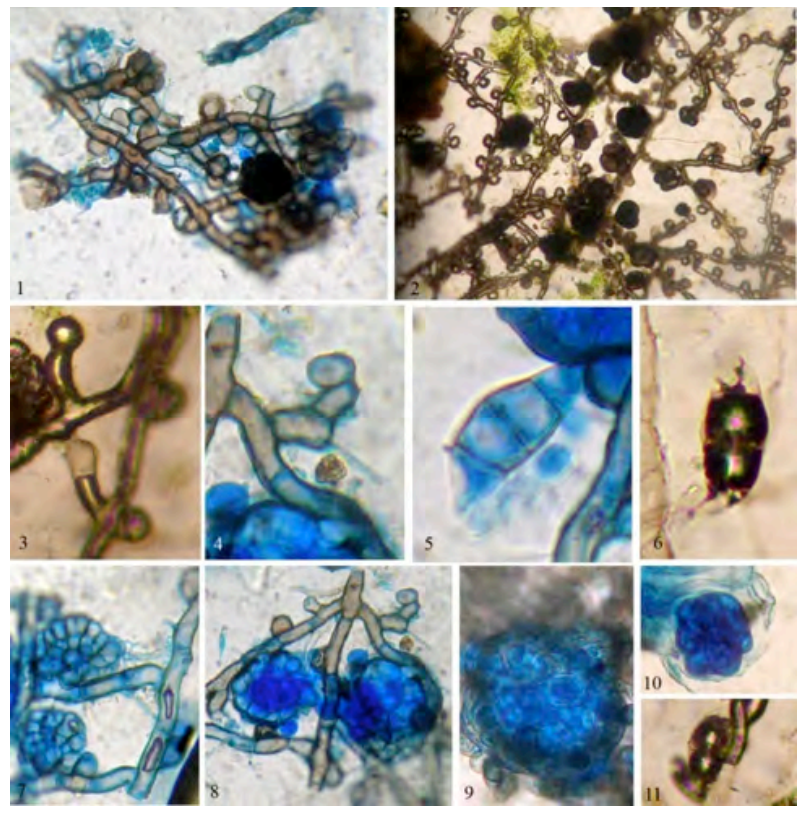

Image 21, Schiffnerula vernoniae

1. Appressoriate mycelium, 2. Mycelium with Sarcinella conidia, 3-4. Conidiophore of Sarcinella, 5-6. Questieriella conidia, 7-8, Developmental stages of thyriothecium, 9. Thyriothecium with asci, 10. Ascus, 11. Ascospore

Pseudomelasmia P. Henn., Hedwigia 41: 115, 1902. Sirentiloma P. Henn., Hedwigia, p. 319, 1895.

Tolediella Viegas, Bragntia 3: 128, 1943.

Trabutiella Theiss. \& Sydow, Ann. Mycol. 12: 180, 1912.

Infection produces "tar-spots". Clypei darkbrown to black, develop in the epidermal cells and sometimes beneath the perithecial; perithecial wall pseudoparenchymatous, perithecia ostiolate, ostioles extending through the clypeus. Asci unitunicate, peristant, clavate to cylindrical, possessing crown at the apex, slightly or distinctly stipitate. Ascospores hyaline, single celled, oval, ovoid to truncate, uniseriate to biseriate but may be irregular at maturity. Spermogonia frequently found (Parbery, 1967).

Type: P. graminis (Pers.: Fr.) Nke.

\section{Key to the species}

1. On the members of Asclepiadaceae.

Phyllachora gymnemae

1. On the members of other families.............................2

2. On Moraceae...........................................................

2. On the members of other families.............................4

3. Stroma epiphyllous, cause depression on the lower surface... Phyllachora catarvaria 
3. Not so Phyllachora infectoriae

4. On Glycosmis. Phyllachora glycosmidis

4. On Symplocos Phyllachora symploci

Phyllachora catarvaria (Berk.) Sacc., Syll. Fung. 2: 598, 1883; Theiss. \& Sydow, Ann. Mycol. 13: 469, 1915; Kamat, Seshadri \& Pande, A Monographic study of Indian species of Phyllachora, p. 20, 1978; Hosag., Indian Phytopathol. 38: 447, 1985; J. Econ. Taxon. Bot. 13: 121 1989.

Phyllachora topographica Sacc., Syll. Fung. 14: 669, 1899.

Phyllachora fici- hispidae Seshadri, Mycopath. Mycol. Appl. 34: 318, 1968.

Materials examined: $\mathrm{HClO}$ 49882, TBGT 4034, 7.ix.2008, on leaves of Ficus hispida L. (Moraceae), Periya, coll. Harish et al.

Infection hypophyllous, rarely amphigenous, black, 1-2 $\mathrm{mm}$ in diameter, rarely confluent. Stromata hypophyllous, black, raised, shiny, up to $1 \mathrm{~mm}$ in diameter, loculate. Perithecia 1-5 per stroma, immersed, oval to irregular, 216-506x54-146 $\mu \mathrm{m}$; asci many, cylindrical, octosporous, stipitate, $58-84 \times 8-10 \mu \mathrm{m}$; ascospores uniseriate to biseriate, hyaline, globose, 5-9 $\mu \mathrm{m}$ in diameter.

This infection starts soon after the emergence of the young leaves and makes the infected leaves to roll inwardly, making the infected leaves distinct from rest of the leaves and can be detected even from a distance. Often cause depression and pseudo blisters of the infected leaves.

Phyllachora glycosmidis Petch. in Saccardo, Syll Fung. 24: 603, 1926; Ramakrishnan, T. S. \& Ramakrishnan, K., Proc. Indian Acad. Sci. Sect. B, 32: 100, 1950; Ananthakrishnan, S., Mycopath. Mycol. appl., 11,1964

Materials examined: HClO 49399, TBGT 3644, 12.ii.2009, on leaves of Glycosmis pentaphylla (Retz.) DC. (Rutaceae), Thirunelly, coll. P.J.Robin et al.

Infection spots epiphyllous, gregarious in circular beaded spots, showing corresponding eruptions on the lower sides. Stromata black, minute, shining, scattered, uni- to biloculate. perithecia innate, ostiolate, flask- shaped, 151-345×138-290 $\mu \mathrm{m}$; asci cylindrical, pedicellate, octosporous, but often 6- spored, 92.8112.0x5-7 $\mu \mathrm{m}$; ascospores ellipsoid, monostichous, thin walled, 9.6-12.8x5.6-7.2 $\mu \mathrm{m}$.

Phyllachora gymnemae Hosag. \& Jacob Thomas, J. Appl. Nat. Sci. 2(1):104, 2010.
Materials examined: $\mathrm{HClO}$ 49423, TBGT 3668, 14.ii.2009, on leaves of Gymnema sp. (Asclepiadaceae), Thirunelly, coll. Harish et al.

Stromata epiphyllous, caulicolous, up to $5 \mathrm{~mm}$ in diam., shining, black, raised; perithecia 1-3 per stromata, oval, globose to craterviform, ostiolate, 105-220x130-180 $\mu \mathrm{m}$; asci numerous, cylindrical, paraphysate, unitunicate, up to $94 \mu \mathrm{m}$ long; ascospores uniseriate, oval, hyaline, elongated and slightly pointed at both ends, 9-14x4-7 $\mu \mathrm{m}$.

Phyllachora infectoriae Cooke, Grevillea 13: 63, 1885; Sacc., Syll. Fung. 9: 1013, 1891; Sydow \& Butler, Ann. Mycol. 9: 396, 1911; Kamat, Seshadri \& Pande, A Monogrphic Study of Indian species of Phyllachora, p. 46, 1978; Hosag., Indian Phytopath. 38: 449, 1985; J. Econ. Taxon. Bot. 13: 122, 1989.

Materials examined: $\mathrm{HClO}$ 49883, TBGT 4035, 19.ix.2008, on leaves of Ficus infectoria Roxb. (Moraceae), Baveli, coll. Robin et al.

Infection foliicolous, epiphyllous in big patches, black, corresponding lower surface depressed, rarely amphigenous, 5-10 $\mathrm{mm}$ in diameter. Stromata epiphyllous, black, shining, raised, clypeate, up to $10 \mathrm{~mm}$ in diameter, often coalesced, loculate. perithecia 1-10 per stroma, spherical to flask shaped, 210-520×214$276 \mu \mathrm{m}$; asci cylindrical, many, unitunicate, stipitate, octosporous, 89-112x14-16 $\mu \mathrm{m}$; ascospores hyaline, oval, uniseriate to irregular, $12-19 \times 7-9 \mu \mathrm{m}$, contents granular.

This species stands distinct in having largely spreading epiphyllous stromata and the corresponding opposite surface of the infected portion got depressed.

Phyllachora symploci Pat. in Sacc., Syll, Fung., II: 371, 1895; Ananthanarayanan, Mycopath. Mycol. Appl. 22: 6, 1964.

Phyllachora ectophytica Tilak, Sydowia 12: 186, 1958.

Materials examined: $\mathrm{HClO} 50840, \mathrm{TBGT} 4757 ; \mathrm{HClO}$ 50842, TBGT 4759, 5.xi.2009, on leaves of Symplocos sp. (Symplocaceae), Gurukulam Botanical Garden, coll. M.C. Riju \& A. Sabeena.

Infection spots prominent, epiphyllous, in beaded circular outline, scattered, 1-4 $\mathrm{mm}$ or even more in diam. Stromata epiphyllous, black, cushion shaped, highly developed, scattered. Perithecia typically bowlshaped, hemispherical, ostiolate, subcuticular, 637-728 $\mu \mathrm{m}$; asci cylindrical, pedicellate, octosporous, obtuse at the apex, in basal layers, paraphysate, 86-99x15-17 $\mu \mathrm{m}$; ascospores 8 , monostichous, oblong to ellipsoid, 21-22x8-10 $\mu \mathrm{m}$. 


\section{Phyllachora sp.}

Materials examined: $\mathrm{HClO}$ 47423, TBGT 2461, 19.xi.1999, on leaves of Ficus sp. (Moraceae), Banasuran Hills, coll. C.K. Biju; HCIO 47470, TBGT 2508, 15.xi.1999, Caryota urens L.(Arecaceae)., Chembra peak, coll. C.K. Biju; HClO 47524, TBGT 2546, 14.ix.1999, Flacourtia sp. (Flacourtiaceae), Chembra peak, coll. C.K.Biju.

\section{Other Ascomycetes}

1.Produce tar spots. ascomata innate. Rehmidothis 1.Produce superficial ascomata, cause leaf rolling Leptosphaerulina

\section{The genus Leptosphaerulina}

Leptosphaerulina McAlpine, Fungus diseases of stone fruit trees in Australia, p. 103, 1902.

Ascomata ostiolate, uniloculate, perithecoid, pseudothecium superficial but appressed on the host with hyphae, apex erumpent at maturity. Ascoma composed of pseudo parenchymatous cells, cells of outer layer are brown and thick walled, interior cells hyaline and thin walled. Centrum pseudoparenchymatous. Asci few, bitunicate, saccate, thick walled, eight spored. Ascospores brown, ellipsoidal, 3-4-horintally septate on the host but the central cells produce vertical septa in cultures, thin gelatinous sheath formed around the spores.

Type: L. crassiasca (Sechet) C.R. Jackson \& Bell

This genus respresents a single species.

Leptosphaerulina australis McAlp., Fung. Dis. 103, 1902; Barr, Preliminary studies on the Dothideales in the Temperate North America, p. 541, 1972.

Materials examined: $\mathrm{HClO}$ 47455, TBGT 2493, 13.vii.1998, on leaves of Crotalaria sp. (Fabaceae), Thirunelly, coll. C.K. Biju; HCIO 47457, TBGT 2495, 12.viii.1998, coll. C.K. Biju.

Infection epiphyllous. Ascomata superficial, firmly placed on the host epidermis, globose, 40-70 $\mu \mathrm{m}$ in diameter; asci few to many, clavate, octosporous, 50-90×30-45 $\mu \mathrm{m}$, persistent; ascospores hyaline, transversely septate on the host but deep brown with 1-3-septate vertical septa in the middle cells when grown in culture, $25-40 \times 10-15 \mu \mathrm{m}$.

This is one of the most common diseases on this host genus. Infected plants can be easily recognised by their unusually folded or rolled leaves. The upper surface of the infected leaves are being articulately and uniformly arranged with a dark perithecia and can be easily sensed by gently moving the fingers on the infected leaf surface.

\section{The genus Rehmidothis}

Rehmidothis Theiss. \& Sydow, Ann. Mycol. 12:192, 1914.

Stromata amphigenous, black, raised, shining. Perithecia in stroma, oval, ostiolate; asci clavate to cylindrical, unitunicate, flattened at the base, octosporous, persistent; ascospores uniseriate, biseriate to irregular at maturity, ovoid, hyaline, uniseptate at the basal part, slightly constricted at the septum and give the spore proper pinch-off appearance.

Type: R. osbeckiae (Berk. \& Broome) Theiss. \& Sydow This genus represents here with a single species

Rehmidothis osbeckiae (Berk. \& Broome) Theiss. \& Sydow, Ann. Mycol. 12: 192, 1914.

Trabutia osbeckiae Ramakr. \& Sundaram, Proc. Indian Acad. Sci. 40: 19, 1954.

Materials examined: $\mathrm{HClO}$ 47459, TBGT 2497, 19.xi.1999, on leaves and stems of Osbeckia sp. (Melastomataceae), Banasuranmala, coll. C.K. Biju.

Stromata amphiphyllous, caulicolous, mostly epiphyllous, black, raised, shining, scattered to often coalesced, up to $2 \mathrm{~mm}$ diameter. Perithecia 1-3 per stroma, oval, 150-220×100-160 $\mathrm{m}$, ostiolate; asci clavate to cylindrical, unitunicate, flattened at the base, octosporous, $25-52 \times 12-16 \mu \mathrm{m}$ at the basal portion and 14-22 $\mu \mathrm{m}$ broad at the apical portion, persistent; ascospores uniseriate, biseriate to irregular at maturity, ovoid, hyaline, uniseptate at the basal part, slightly constricted at the septum and give the spore proper pinch-off appearance, $12-18 \times 5-7 \mu \mathrm{m}$.

This is a very common fungus on this host genus and cause tar spot disease.

\section{Key to the Hyphomycetes}

1.Parasiticfungi. 4

1. Hyperparasites........................................................ 2

2.On Sarcinella..............................................Acremoniula

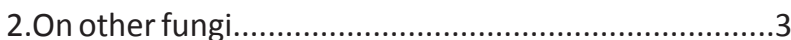

3. On Balladyna..............................................Acrodictys

3. On Meliolaceae members........................................6

4. Lateral ampulliform appressoria present.

.Ampullifera

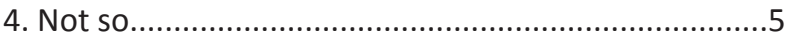

5. On Gmelina .............................................. Passalora

5. On Terminalia........................................Colemaniella

6. On Armatella ............................Spiropes armatellicola

6. On other fungi..........................................................

7. Conidiophore zig-zag at fertile portion. 
Spiropes guareicola

7. Conidiophore not so.

Spiropes capensis

Acremoniula sarcinellae (Pat. \& Har.) Arn. ex Deight., Mycol. Pap. 118: 3, 1969; Hosag., Biju, C.K. and Abraham, J. Econ.Taxon. Bot. 25: 283, 2001; Hosag., Zoos' Print J. 21: 2322, 2006.

Acremoniela sarcinellae Pat. \& Har., J. Bot. Paris 14: 245. 1900.

Acremoniula sarcinellae (Pat. \& Har.). Arnaud, Bull. Trimest. Soc. Mycol. France 69: 268. 1954.

Dicoccum pulchrum Thumen, Revu Mycol. 1: 11. 1879.

Domingoella pycnopeltarum Batista, Anais IV congr. Bot. Brasil: 77. 1953 (Fig. 198).

Materials examined: $\mathrm{HClO}$ 44789, TBGT 1026, 27.xii.2002, colonies of Sarcinella vernoniae (Dearn. \& Barth.) Hughes, Vernonia conyzoides DC. (Asteraceae), Chandanathode, coll. V.B. Hosagoudar et. al.

Hyphae hyaline, branched, septate, up to $3 \mu \mathrm{m}$ wide. Conidiophores arise one to many from the single hyphal cells, micronematous, mononematous, mostly straight, hyaline, aseptate, 3-9 $3-5 \mu \mathrm{m}$; conidiogenous cells monoblastic, integrated, terminal, determinate, cylindrical; conidia solitary, dry, unicellular, brown to deep black, globose, oval to pyriform, 10-14 $\mu \mathrm{m}$ in diameter, wall smooth, a portion of hyaline conidiophore often attached with the base.

Acrodictys balladynae (Hansf.) M.B. Ellis Dematiaceous Hyphomycetes, p. 129, 1971.

Acrospeira balladynae Hansf., Proc. Linn. Soc. London 157: 40, 1945.

Material examined: $\mathrm{HClO}$ 4515, TBGT 801, 5.ii.2002, on Balladyna sp. infected leaves of Pavetta sp. (Rubiaceae), Chandanathode forest, coll. M. Kamarudeen.

Colonies amphigenous, mostly hypophyllous, dense, crustose to velvety, up to $5 \mathrm{~mm}$ in diameter. Hyphae superficial, pale, branched, septate, 1.5-2.5 $\mu \mathrm{m}$ broad. Conidiophores macronematous, mononematous, simple, cinnamon brown, erect, straight, smooth, rarely septate, slightly tapering towards apex, 30-40 $\mu \mathrm{m}$ long; 3-5 $\mu \mathrm{m}$ broad at the base; $1.5-3 \mu \mathrm{m}$ broad at the tip. Conidia solitary, dry, terminal, obpyriform, clavate, broadly triangular, brown to black, upper stratum with 2-3-cells, second stratum with two cells and the lowest basal cell pale, 17-20 $\mu \mathrm{m}$ long; $13-15 \mu \mathrm{m}$ broad at the upper portion, 9-12 $\mu \mathrm{m}$ broad at the second cell layer and up to $3 \mu \mathrm{m}$ broad at the basal cell.
This species was known from Ghana, Sierra Leone and Uganda (Ellis 1971).

Ampullifera foliicola Deight., Mycol. Pap. 78: 36, 1960; Ellis, Dematiaceous Hyphomycetes, p. 96, 1971.

Material examined: $\mathrm{HClO}$ 43463, TBGT 286, 19.xi.1999, on leaves of Neolitsea scrobiculata (Meisner) Gamble (Lauraceae), Banasuran Hills, coll. C.K. Biju.

Colonies mixed with other parasites. Hyphae superficial, cinnamon brown, straight to substraight, branching alternate to irregular at acute to wide angles, loosely to rarely closely reticulate, septate, often constricted at the septa, cells cylindrical, 8-10x5-7 $\mu \mathrm{m}$. Appressoria (Hyphopodia) almost have similar colour to that of hyphal cells, often deep brown, initially globose, later ampulliform, neck pale and elongated, 6-10x4-7 $\mu \mathrm{m}$. Conidiophores few to many, arise laterally, later perpendicular to the hyphae, dark brown, straight to slightly curved, macronematous, mononematous, septate, often constricted at the septa, 16-40×3-5 $\mu \mathrm{m}$; conidiogenous cells integrated, terminal, monoblastic, percurrent; conidia produced in chains of 1-7 numbers, ovate, versiform, rarely globose, pale brown to cinnamon brown, 8-10x4-6 $\mu \mathrm{m}$.

This genus was associated with Meliola neolitseae Yamam. and Armatella sp. and was known on various plants from Brazil, Ghana, Malaya, Sahah, San Domingo, Sarawak and Sierra Leone.

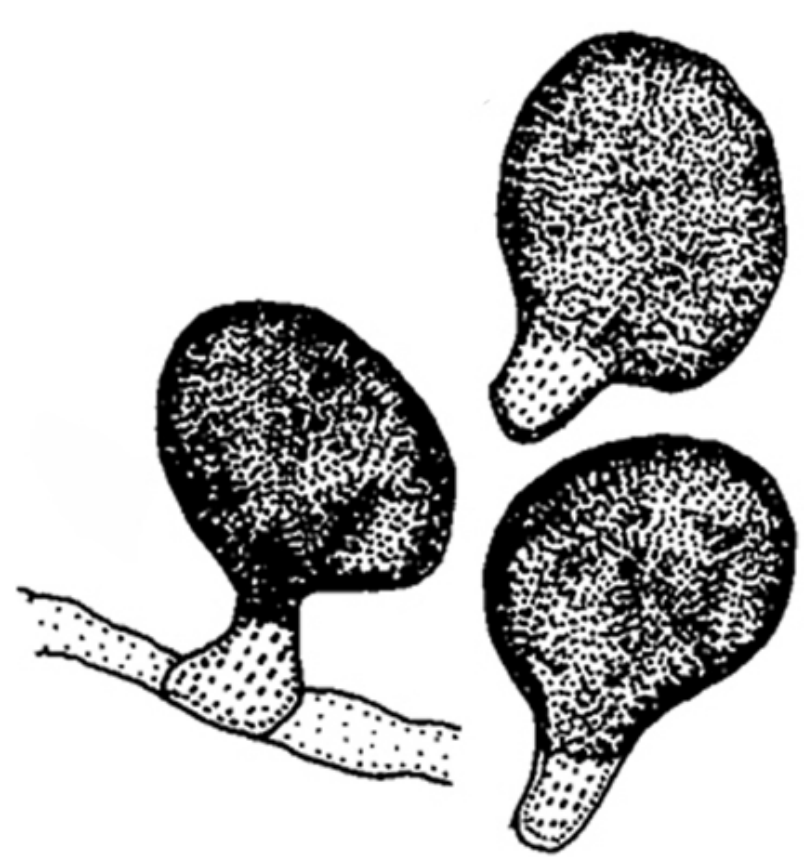

Figure 198. Acremoniula sarcinellae-Black conidia 
Colemaniella osoori Agnihothrudu, J. Coffee Res. 4: 3, 1974; Ellis, More Dematiaceous Hyphomycetes,366, 1976; Karandikar \& Patwardhan, Biovigyanam 11: 143, 1985 (Image 21).

Material examined: HCIO 49776, TBGT 3928, 12.ii.2009; TBGT 3931, 18.ii.2009, on leaves of Terminalia sp. (Combretaceae), Muthanga, coll. Jacob Thomas et al.

Colonies hypophyllous, black, velvety, up to $3 \mathrm{~mm}$ in diameter. Hyphae ectophytic, brownish black, septate, branched at acute to wide angles, loosely reticulate, cells $10-20 \times 3-5 \mu \mathrm{m}$. Appressoria few, scattered, lateral and intercalary, mostly globose, entire, 8-12x10-12 $\mu \mathrm{m}$. Conidiophores micronematous, 1-2-celled, mostly straight, 8-10X4-6 $\mu \mathrm{m}$. Conidiogenous cells integrated and terminal on short branches, enteroblastic, cyathiform, striated, 14-20x7-20 $\mu \mathrm{m}$. Conidia solitary, dry, straight to slightly curved, broadly ellipsoidal to obovoidal, dark brown to black, 3-5 horizontal septa with a vertical one, outer wall constricted at the septa, 24-50x16-25 $\mu \mathrm{m}$, protruded and bluntly pointed towards the tip, hyaline to pale brown, up to $10 \mu \mathrm{m}$ long.

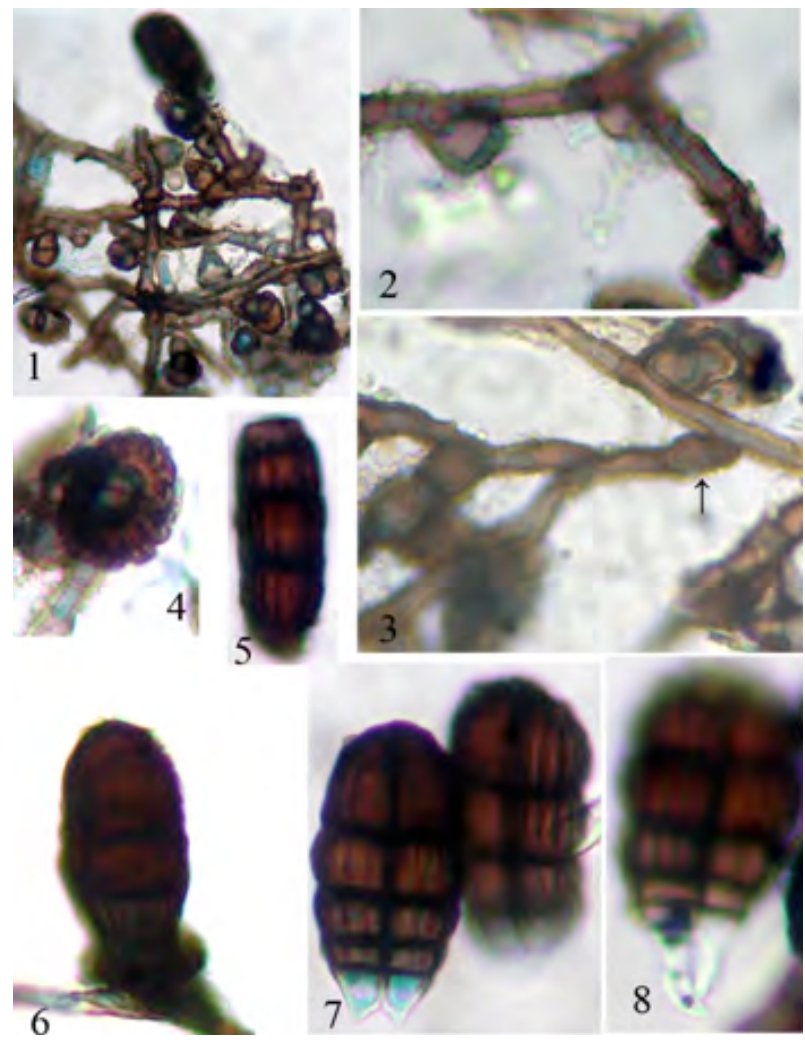

Image 21. Colemaniella osoori

1 - Fungal colony; 2 - Hyphae with lateral appressoria; 3 - Hyphae with intercalary appressorium; 4 - Coniogenous cell; 5 - Conidium; 6 - Conidium on conidiogenous cell; 7\&8 - Conidia with hyaline hinged base

\section{The genus Passalora}

Passalora Fries, Summa Veg. Scane. p. 500, 1849.

Colonies usually hypophyllous, effuse, olivaceous, velvety, sometimes causing leaf spots. Mycelium immersed. Stroma none. Setae and appressoria absent. Conidiophores macronematous, mononematous, caespitose, emerging through stomata, unbranched or occasionally branched, straight to flexuous, olivaceous brown, smooth. Conidiogenous cells polyblastic, sympodial, integrated, terminal, becoming intercalary, cicatrized; scars slightly but distinctly thickened, not or very slightly prominent. Conidia solitary, dry, acropleurogenous, obclavate, pale olivaceous brown, smooth, mostly 1-septate, the proximal cell swollen and long ellipsoidal, the distal cell narrow, sybcylindrical to very long ellipsoidal, rarely 2-3 septate.

Type: Passalora bacilligera (Mont. \& Fr.) Mont. \& Fr.

Passalora gmelinae-arboreae (A.K. Sarbhoy, Hosag. \& N. Ahmad) Braun \& Crous, Mycospherella and its anamorphs:1. Names published in Cercospora and Passalora: 454, 2003.

Mycovellosiella gmelinae-arboreae A.K. Sarbhoy, Hosag. \& N. Ahmad, J. Econ. Taxon Bot. 7 (3): 521, 1986 (Fig. 199).

Material examined: $\mathrm{HCIO} 51050$, TBGT 4967, 8.x.2010, on leaves of Gmelina arborea Roxb. (Verbenaceae), Vetarinary College Campus, Pookot, Vythiri, coll. M.C. Riju.

Colonies hypophyllous, greyish brown, velvety, 1-4 $\mathrm{mm}$ in diameter, often confluent. Mycelium superficial, olivaceous brown, septate, $6-8 \mu \mathrm{m}$ broad. Conidiophores macronematous, repeatedly branched, flexuous, intertwining, olivaceous brown, 72-88x4-6 $\mu \mathrm{m}$. Conidiogenous cells terminal, sympodial, scars conspicuous. Conidia solitary, rarely in chains, straight or curved, subhyaline to olivaceous brown, smooth, 1-8 septate, rarely up to 12 - septate, $72-88 \times 4-6 \mu \mathrm{m}$.

Spiropes armatellicola Hosag. \& D.K. Agarwal, J: Econ. Taxon. Bot. 26: 603, 2002 (Fig. 200).

Material examined: HCIO 43592, TBGT 287.2509, 16.iv.1999, on the colonies of Armatella sp., on Actinodaphne sp. (Lauraceae), Banasuran Hills, coll. C.K.Biju.

Colonies mostly epiphyllous, dense, up to $5 \mathrm{~mm}$ in diameter, confluent. Hyphae superficial, pale brown, branched, surrounded around appressoria and mycelium of the host, $1-2 \mu \mathrm{m}$ broad. Conidiophores solitary, simple, mononematous, erect, straight, brown, 

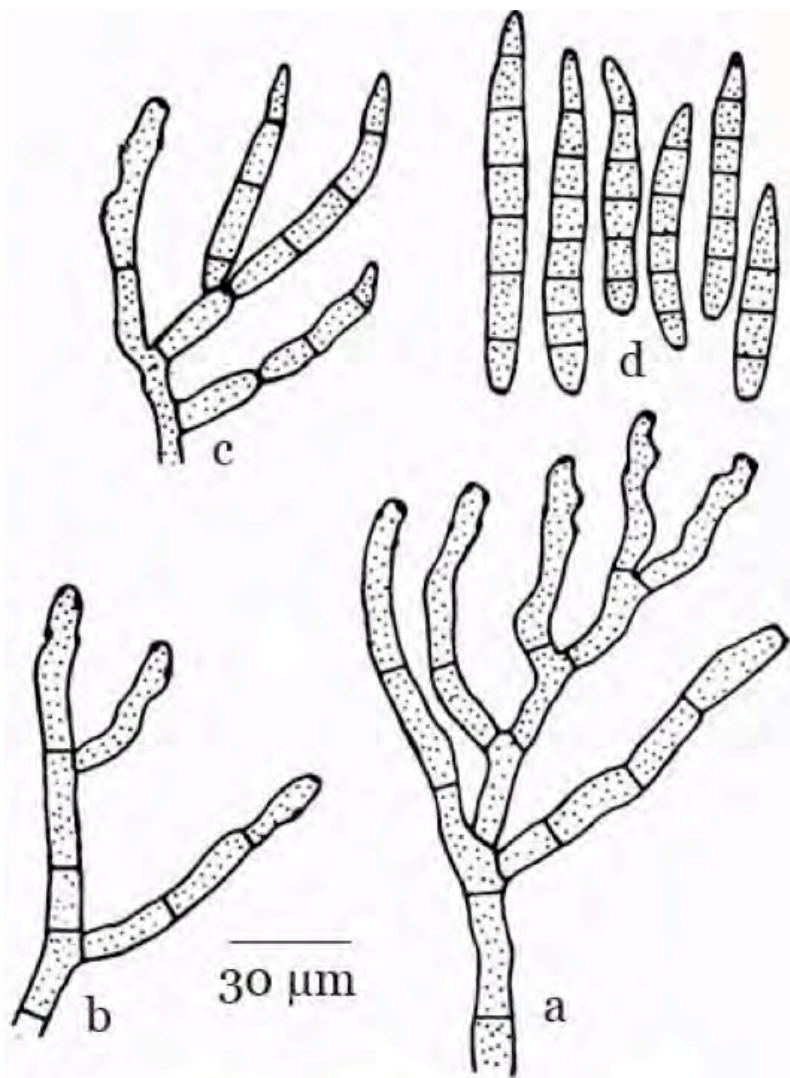

Figure 199. Passalora gmelinae-arboreae

a - Profusely branched conidiophores; b - Conidiophore with conidiogenous cells; c - Conidia attached to conidiogenous cells; $d$ - Conidia

straight to flexuous and paler towards apex, conidial scars scattered, 60-112x4-6.5 $\mu \mathrm{m}$. conidiogenous cells polyblastic, integrated, terminal and intercalary, conspicuous. Conidia straight to slightly curved, obclavate, rostrate at the apex, truncate at the base, pale brown, uniseptate, rostrate above the septum, ovate below the septum, slightly hinged at the base, 24-29 $\mu \mathrm{m}$ long, 6-8 $\mu \mathrm{m}$ broad at the broadest portion, up to $3 \mu \mathrm{m}$ broad at the base, beak 8-16 $\mu \mathrm{m}$ long and up to $1.5 \mu \mathrm{m}$ broad at the tip.

Spiropes capensis M.B. Ellis, Mycol. Pap. 114: 5, 1968; Dematiaceous Hyphomycetes p. 252, 1971 (Fig. 201).

Material examined: $\mathrm{HClO}$ 44412, TBGT 665, 20.x.2001, on Meliolaceae member, on leaves of Glycosmis pentaphylla (Retz.) DC. (Rutaceae), Wayanad, coll. M. Kamarudeen; HCIO 44642, TBGT 924, 20.v.2002, Mallotus sp. (Euphorbiaceae), Thirunelly, coll. S. Shiburaj; HCIO 44883, TBGT 1111, 26.xii.2002, on Meliolaceae member on Glycosmis pentaphylla (Retz.) DC., Periya,

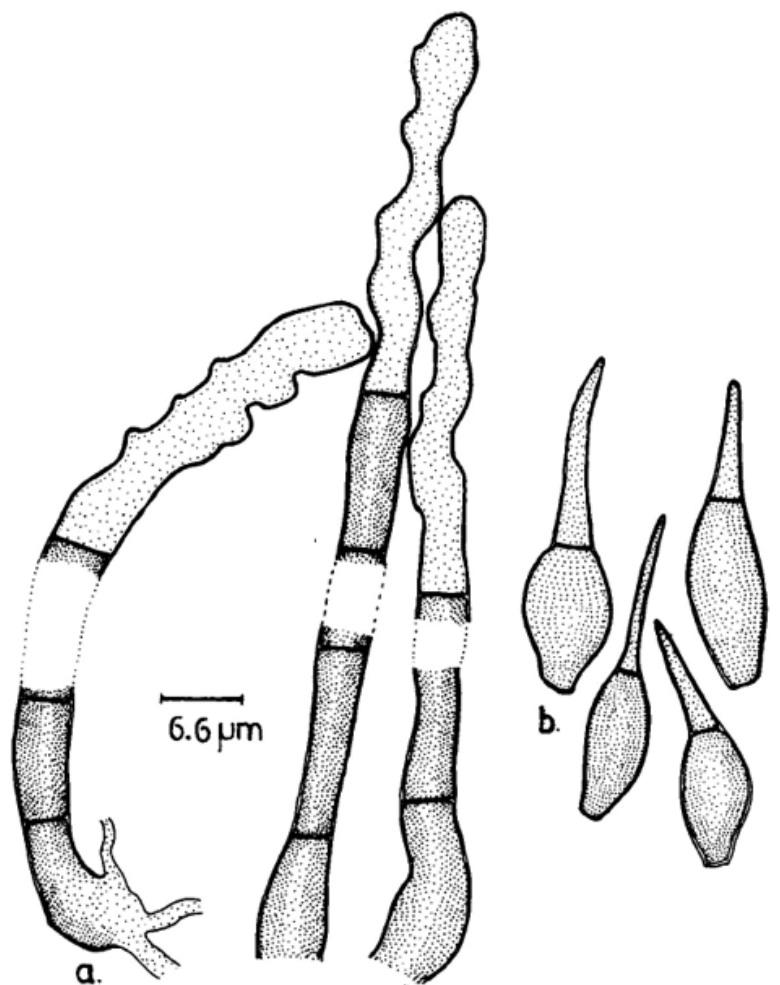

Figure 200.Spiropes armatellicola

a - Conidiophore; b - Conidia

coll. Kamarudeen \& P.A. Jose.

Colonies mostly hypophyllous, dense, velvety, up to $5 \mathrm{~mm}$ in diameter, confluent and cover most of the leaf area. Hyphae superficial, branched, pale to pale brown, smooth, cells 11-21X1.5-5 $\mu \mathrm{m}$. Appressoria and setae absent. Conidiophores macronematous, mononematous, solitary and also in groups but not synnematous, simple, brown, septate, paler towards the apex, 224-400X6-7 $\mu \mathrm{m}$; conidiogenous cells polyblastic, terminal and intercalary, sympodial, cylindrical, cicatrized, scars numerous and conspicuous; conidia solitary, dry, acropleurogenous, simple, broadly obclavate to ellipsoidal, straight to slightly curved-pale yellow to brown, 3-5 septate, mostly pseudoseptate, 41-53 $\mu \mathrm{m}$ long, 6-8 $\mu \mathrm{m}$ broad at the widest part, 1.5$4 \mu \mathrm{m}$ broad at the apical portion and $4-5 \mu \mathrm{m}$ wide at the basal portion, wall smooth.

This species was reported from several countries and is reported here for the first time from India (Bilgrami et al. 1991; Ellis, 1971).

Spiropes guareicola (Stev.) Cif., Sydowia 9: 303, 1955; Ellis, Dematiaceous Hyphomycetes p. 250, 1977. (Fig. 202).

Material examined: $\mathrm{HClO}$ 50843, TBGT 4760, 


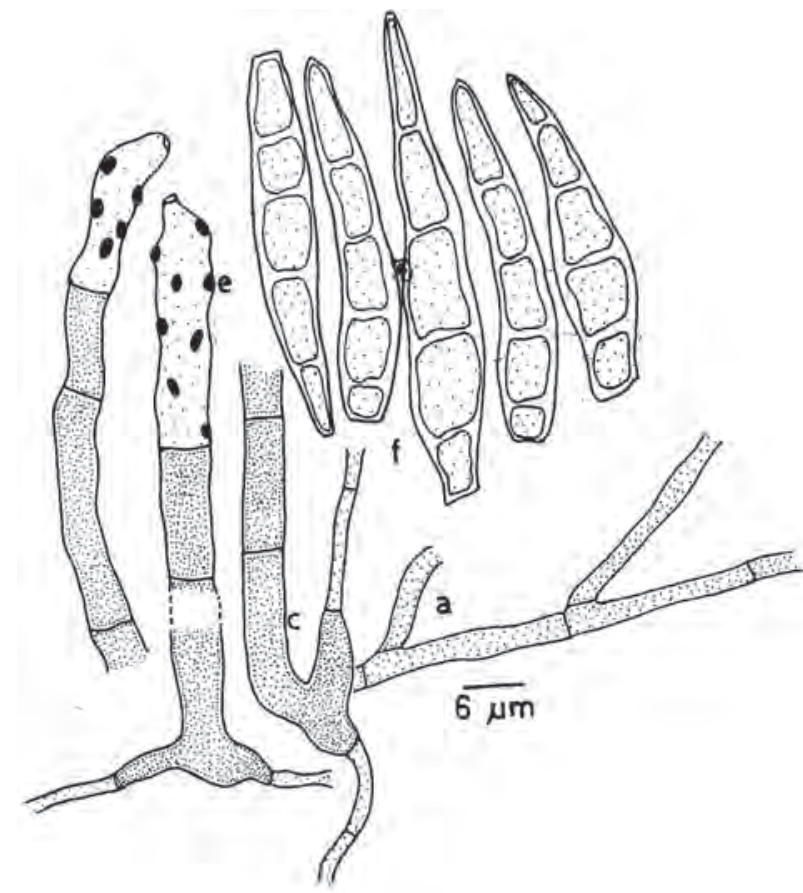

Figure 201. Spiropes capensis

a - Septate mycelium; c - Conidiophores; e - Conidiogenous cells; f Conidia

6.xi.2009, on leaves of Citrus sp. (Rutaceae), Padinharathara, coll. M.C. Riju \& A. Sabeena; HClO 49888, TBGT 4040, 18.ix.2008, Atalantia sp., (Rutaceae) Thirunelly, Gireesh et al.

Colonies black, velvety. Mycelium superficial, pale, olivaceous brown, branched, septate, appressed to the hyphae of the host fungus, 3-4 $\mu \mathrm{m}$ wide. Conidiophores arise singly or in loose groups from the hyphae, simple, straight to flexuous at the basal portion, zigzag in the upper fertile portion, septate, olivaceous brown, 250300x7-9 $\mu \mathrm{m}$, conidial scars numerous, distinct. Conidia solitary, fusiform, taper towards the apex, slightly narrower towards the truncate base, 3-pseudoseptate, not constricted, olivaceous brown, 37-55×10-13 $\mu \mathrm{m}$.

This species is common on most of the meliolaceous fungi.

\section{REFERENCES}

Biju, C.K., V.B. Hosagoudar \& T.K. Abraham (2005). Meliolaceae of Kerala, India - XV. Nova Hedwigia 80: 465-502.

Bilgrami, K.S., M. Jamaluddin \& M.A. Rizwi (1991). Fungi of India. List and References. Today and Tomorrow's Printers \& Publishers, New Delhi, 798pp.

Cooke, M.C. (1884). Some exotic fungi. Grevillea 12:85.

Doidge, E.M. (1942). A revision of the South African Microthyriaceae. Bothalia 4: 273-344.

Hansford, C.G. (1941a). Contribution towards the fungal flora of
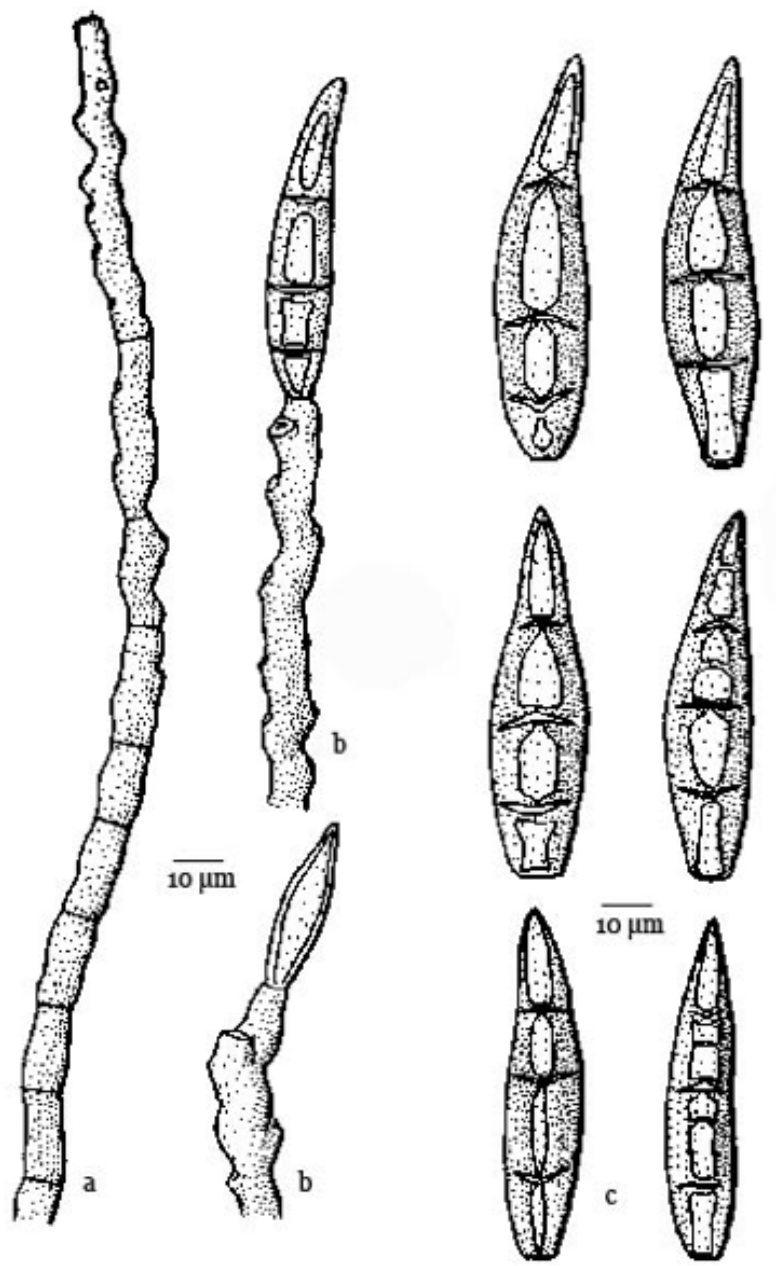

Figure 202. Spiropes guareicola

a - Conidiophore; b - Conidiogeneous cells; c - Conidia

Uganda II. Some Uganda Ascomycetes. proceedings of the Linnean Society of London 19: 14-52.

Hansford, C.G. (1941b). Contribution towards the fungal flora of Uganda III. Some Uganda Ascomycetes. proceedings of the Linnean Society of London 1: 4-52.

Hansford, C.G. (1945). Contribution towards the fungus flora of Uganda-VII. New records and revision. proceedings of the Linnean Society of London 157: 20-212.

Hansford, C.G. (1947). New or interesting tropical fungi-I. Proceedings of the Linnean Society of London 158: 28-50.

Hansford, C.G \& M.J. Thirumalachar (1948). Fungi of south India. Farlowia 3: 285-314.

Hansford, C.G. (1949) . Tropical fungi III. New species and revision. proceedings of the Linnean Society of London 160: 116-153.

Hansford, C.G. (1954a). Some Microthyriales and other fungi from Indonesia. Reinwardtia 3: 113-144.

Hansford, C.G. (1954b). Australian fungi-II. New records and revisions. proceedings of the Linnean Society of New South Wales 79: 3-4 \& 97-141.

Hansford, C.G. (1957). New or interesting tropical fungi - VI. Sydowia 10: 41-100.

Hansford, C.G. (1961). The Meliolineae. A Monograph. Sydowia Behefte 2: 1-806.

Hosagoudar, V.B. (1988). Uredinales of Kerala. Journal of Economic and Taxonomic Botany. 12: 265-272.

Hosagoudar, V.B., K.M. Kaveriappa, P.A. Raghu \& R.D. Goos (1994). 
Meliolaceae of southern India - XVI. Mycotaxon 51: 107-118.

Hosagoudar, V.B. (1996). Meliolales of India. Botanical Survey of India, Calcutta, 363pp.

Hosagoudar, V.B., N.P. Balakrishnan \& R.D. Goos (1996). Some Asterinella, Asterostomella and Echidnodella species from southern India. Mycotaxon 58: 489-498.

Hosagoudar, V.B., N.P. Balakrishnan \& R. D.Goos (1996b) . Some Asterina species from Southern India. Mycotaxon 59: 167-187.

Hosagoudar, V.B. \& R.D. Goos (1996). Some foliicolous fungi from Southern India. Mycotaxon 59: 149-166.

Hosagoudar, V.B. \& T.K. Abraham (1997a). A new species of Asterolibertia from Kerala, India. Journal of Mycopathological Research. 35: 55-56.

Hosagoudar, V.B., C.K. Biju \& T.K. Abraham (2002a). Diversity of foliicolous micro mycobionts in Munnar and Wyanad forest regions of Kerala. Journal of Mycopathological Research 40: 191-196.

Hosagoudar, V.B., A. Sabeena \& D.K. Agarwal (2009). Two new species and a new generic record of Asterinaceae on Mimusops elengi from Kerala. Indian Phytopathology 62: 229-232.

Hosagoudar, V.B. \& D.K. Agarwal (2008). Taxonomic studies of Meliolales. Identification Manual. International Book Distributors, Dehra Dun, 263pp.

Hosagoudar, V.B. (2005). Studies on foliicolous fungi-XIX. Indian Phytopathology 58: 194-204.

Hosagoudar, V.B. (2008). Meliolales of India. Vol. II. Botanical Survey of India, Calcutta, 390pp.

Hosagoudar, V.B. \& T.K. Abraham (2000). A list of Asterina Lev. species based on the literature. Journal of economic taxonomic Botany 24 557-587.

Hosagoudar, V.B., T.K. Abraham \& P. Pushpangadan (1997). The Meliolinae A suppliment. Tropical Botanic Garden and Research Institute, Palode, Kerala, 201pp.

Hosagoudar, V.B., C.K. Biju \& T.K. Abraham (2001c). Diversity in the foliicolous micro mycobionts in Peppara and Neyyar Wildlife Sanctuaries, Thiruvananthapuram, Kerala, India. Journal of economic taxonomic Botany 25: 297-307.

Hu, Y., Y. Ouyang, S. Bin \& G. Jiang (1996). Flora Fungorum Sinicorum. Vol. 4. Meliolales (1). Science Press Beijing, 270pp+plate IV.

Hu, Y., S. Bin, Y. Ouyang \& G. Jiang (1999). Flora Fungorum Sinicorum. Vol. 11. Meliolales (2). Science Press Beijing, 252pp.

Hughes, S.J. (1952). Fungi from the Gold Coast.Mycological Papers 48, 1-91.

Kamat, M.N., V.S. Seshadri \& A. Pande (1978). A Monographic study of Indian species of Phyllachora. University of Agricultural Sciences, Hebbal, Bangalore, 100pp.

Kapoor, J.N. (1967). Notes on Indian Meliolaceae. Indian Phytopath 20: 151-160.
Kar, A.K. \& S.N. Ghosh (1986). New Asterina species from West Bengal. Indian Phytopathology 39: 204-220.

Kar, A.K. \& M.K. Maity (1970). New Asterina species from West Bengal. Transactions of the British Mycological Society 54: 435-444.

Katumoto, K. (1975). The Hemisphaeriales in Japan. Bulletin Faculty of Agriculture, Yamaguti University 26: 45-122.

Katumoto, K. (1991). Three Ascomycetous fungi from the Ryukyu Islands, Japan.Transactions of the Mycological Society of Japan 32: 37-43.

Mibey, R.K. \& D.L. Hawksworth (1997). Meliolaceae and Asterinaceae of Shimba Hills, Kenya. Mycological Papers 174: 1-108.

Petrak, F. \& R. Cifferri 1932 . Fungi dominicani-II. Annales Mycologici 30: 149-353.

Petrak, F. (1954). Beitrage zur Pilzflora von Britisch Nord, Borneo. Sydowia 8: 12-26.

Sarbhoy, A.K., J.L. Varshney \& D.K. Agarwal (1996). Fungi of India. CBS Publishers and Distributors New Delhi.

Sharma, J.K., C. Mohanan \& M. Florence (1985). Kerala Forest Research Report 36: 248.

Sivanesan, A. (1984). The Bitunicate Ascomycetes. International Books \& Periodical Supply Service, New Delhi.

Stevens, F.L. \& M.H. Ryan (1939). The Microthyriaceae. Illinois Biol. Monograph. 17: 1-138.

Sydow, H. \& P. Sydow (1913). Enumeration of Philippines fungi with notes and description of new species. Philippines Journal of Science 8: $475-508$

Sydow, H. \& P. Sydow (1914). Fungi from northern Palawan. Philippines Journal of Science 9: 157-189.

Sydow, H. \& P. Sydow (1915). Novae fungorum species-XIII. Annales Mycologici 13: 35-43.

Sydow, H. (1930). Fungi venezuelani. Annales Mycologici 28: 29-224.

Sydow, H. \& F. Petrak (1931). Micromycetes Philippinensis II. Annales Mycologici 29: 145-279.

Sydow, H. (1938). Novae fungorum species-XXVI. Annales Mycologici 36: 156-197.

Theissen, F. (1913). Die Gattung Asterina. Bibliotheca Mycologica 10: 1-130.

Yamamoto, W. (1956). The Formosan species of Microthyriaceae - I. Science Reporter Hyogo University Agriculture Series, Agriculture Biology 2: 33-36.

Yamamoto, W. (1957) .The Formosan species of Microthyriaceae - II. Science Reporter Hyogo University Agriculture Series, Agriculture Biology 3: 23-31.

Yates, H.S. (1918a). Some recently collected Philippine fungi - I. Philippine Journal of Science 12: 61-80.

Yates, H.S. (1918b). Some recently collected Philippine fungi - II. Philippine Journalof Science13: 361-384. 
Table 1. Key to the Species

\begin{tabular}{|c|c|c|}
\hline & ACANTHACEAE & \\
\hline \multirow[t]{2}{*}{$\begin{array}{l}\text { Asteridiella } \\
3101.3220\end{array}$} & $\begin{array}{l}\text { Colonies epiphyllous, dense, hyphae substraight to flexuous; appressoria alternate, antrorse to } \\
\text { closely antrorse, head cells ovate to globose, entire, angular to stellately lobate; phialides mixed } \\
\text { with appressoria; perithecial wall cells conoid. }\end{array}$ & A. phaulopsidis \\
\hline & \multicolumn{2}{|l|}{ ANACARDIACEAE } \\
\hline $\begin{array}{l}\text { Meliola } \\
3111.5223\end{array}$ & $\begin{array}{l}\text { Colonies amphigenous, dense, velvety; hyphae straight; appressoria alternate, } 2 \% \text { unilateral, } \\
\text { straight to variously curved, head cells cylindrical, versiform, attenuated and rounded at the apex, } \\
\text { entire to subangular, straight to curved; phialides few, mixed with appressoria; mycelial setae fairly } \\
\text { numerous, scattered, simple, straight, acute, obtuse to dentate at the tip }\end{array}$ & M. mangiferae \\
\hline 3111.4223 & $\begin{array}{l}\text { Colonies amphigenous, mostly epiphyllous, subdense; hyphae of the epiphyllous colonies straight, } \\
\text { while the hyphae of the hypophyllous colonies crooked; appressoria alternate, subantrorse to } \\
\text { antrorse, head cells cylindrical, versiform, slightly angulose, entire; phialides mixed with appressoria; } \\
\text { mycelial setae scattered to grouped around perithecia, straight, simple, acute at the tip }\end{array}$ & M. nothopegiae \\
\hline \multirow[t]{2}{*}{3111.6333} & $\begin{array}{l}\text { Colonies hypophyllous, dense, velvety; hyphae strongly appressed to the host surface, crooked; } \\
\text { appressoria scattered, alternate to unilateral, antrorse to reflexed, variously curved, head cells ovate, } \\
\text { versiform, angulose, entire to lobate, straight to curved; phialides few, mixed with appressoria; } \\
\text { mycelial setae numerous, straight, flexuous, simple, acute to obtuse at the tip }\end{array}$ & M. holigarnae \\
\hline & \multicolumn{2}{|l|}{ ANNONACEAE } \\
\hline $\begin{array}{l}\text { Amazonia } \\
3101.4320\end{array}$ & $\begin{array}{l}\text { Colonies predominantly hypophyllous, subdense to dense; hyphae straight, appressoria alternate, } \\
\text { antrorse to closely antrorse, head cells ovate, oblong to cylindrical, phialides not seen. Perithecia } \\
\text { flattened-globose, radiating. }\end{array}$ & A. goniothalami \\
\hline \multirow[t]{2}{*}{$\begin{array}{l}\text { Meliola } \\
3123.4232\end{array}$} & $\begin{array}{l}\text { Colonies amphigenous, dense, velvety; hyphae straight; appressoria opposite, rarely alternate and } \\
\text { unilateral, closely antrorse to antrorse, head cells ovate, cylindrical, broadly rounded to attenuated } \\
\text { at the apex, entire; phialides mixed with appressoria; mycelial setae numerous, densely scattered, } \\
\text { simple, uncinate, sickle-shaped, septate, obtuse at the tip }\end{array}$ & M. unonicola \\
\hline & \multicolumn{2}{|l|}{ APOCYNANCEAE } \\
\hline $\begin{array}{l}\text { Meliola } \\
3111.3223\end{array}$ & $\begin{array}{l}\text { Colonies mostly epiphyllous, subdense; hyphae straight to flexuous; appressoria alternate, antrorse } \\
\text { to closely antrorse, head cells ovate, globose, slightly attenuated to truncate at the apex, mostly } \\
\text { entire, rarely sublobate; mycelial setae simple, straight, curved, acute to obtuse at the tip. }\end{array}$ & M. ichnocarpi-volubili \\
\hline \multirow[t]{2}{*}{$31 \frac{11 / 41.3221}{3}$} & $\begin{array}{l}\text { Colonies hypophyllous, scattered, dense, velvety; hyphae straight to substraight; appressoria } \\
\text { alternate, unilateral, straight, antrorse, head cells ovate, globose, mycelial setae numerous, simple, } \\
\text { straight, few slightly curved to uncinate, obtuse, bifid, trifid, often subdentate to furcate to branched } \\
\text { at the tip }\end{array}$ & M.kamettiae \\
\hline & \multicolumn{2}{|l|}{ ARALIACEAE } \\
\hline \multirow[t]{2}{*}{$\begin{array}{l}\text { Meliola } \\
31 \frac{1}{3} 1.3232\end{array}$} & $\begin{array}{l}\text { Colonies epiphyllous, crustose; hyphae straight to flexuous; appressoria alternate, unilateral, } \\
\text { antrorse to subantrorse, head cells globose, subglobose, entire; phialides mixed with appressoria; } \\
\text { mycelial setae simple, straight, obtuse, clavate, inflated, notched to bifid at the apex, ends broadly } \\
\text { rounded }\end{array}$ & M. abdulkalamii \\
\hline & \multicolumn{2}{|l|}{ ARISTOLOCHIACEAE } \\
\hline \multirow[t]{2}{*}{$\begin{array}{l}\text { Meliola } \\
3113.3222\end{array}$} & $\begin{array}{l}\text { Colonies epiphyllous, thin to dense; hyphae substraight to flexuous; appressoria alternate to about } \\
3 \% \text { opposite, antrorse to subantrorse, head cells ovate to globose, entire; phialides mixed with } \\
\text { appressoria; mycelial setae scattered, simple, straight, acute to obtuse at the tip }\end{array}$ & M. aristolochigena \\
\hline & \multicolumn{2}{|l|}{ ASCLEPIADACEAE } \\
\hline \multirow[t]{2}{*}{$\begin{array}{l}\text { Meliola } \\
3111.4222\end{array}$} & $\begin{array}{l}\text { Colonies epiphyllous, dense, scattered; hyphae straight to slightly flexuous; appressoria alternate } \\
\text { to unilateral, antrorse to subantrorse, head cells subglobose to cylindrical, entire, narrowed and } \\
\text { broadly rounded at the apex; phialides borne on a separate mycelial branch; mycelial setae straight } \\
\text { to slightly curved, simple, acute to obtuse at the tip }\end{array}$ & M. gymnemae \\
\hline & BIGNONIACEAE & \\
\hline $\begin{array}{l}\text { Meliola } \\
3111.3221\end{array}$ & $\begin{array}{l}\text { Colonies epiphyllous, thin to subdense, subvelvety; hyphae straight to substraight; appressoria } \\
\text { alternate, antrorse to subantrorse, straight to curved, head cells globose to subglobose, subangular, } \\
\text { entire; phialides mixed with appressoria; mycelial setae numerous, scattered, straight, simple, } \\
\text { subacute to obtuse at the tip }\end{array}$ & M. crescentiae \\
\hline
\end{tabular}




\begin{tabular}{|c|c|c|}
\hline & CAESALPINIACEAE & \\
\hline \multirow[t]{2}{*}{$\begin{array}{l}\text { Meliola } \\
3113.4232\end{array}$} & $\begin{array}{l}\text { Colonies amphigenous, mostly epiphyllous; hyphae undulate to tortuous; appressoria alternate to } \\
5 \% \text { opposite, antrorse, spreading, straight to curved; head cells ovate, angulose, entire to sublobate, } \\
\text { straight to curved; phialides mixed with appressoria; mycelial setae scattered to grouped around } \\
\text { perithecia, simple, obtuse at the tip }\end{array}$ & M. tamarindi \\
\hline & CELASTRACEAE & \\
\hline \multirow[t]{2}{*}{$\begin{array}{l}\text { Meliola } \\
3111.5322\end{array}$} & $\begin{array}{l}\text { Colonies hypophyllous, dense, velvety; hyphae straight, slightly undulate; appressoria alternate, } \\
\text { antrorse, subantrorse, spreading, retrorse, head cells ovate, clavate, lobate to stellately lobate; } \\
\text { phialides mixed with appressoria; mycelial setae numerous, scattered, simple, acute to obtuse at } \\
\text { the tip }\end{array}$ & M. celastrigena \\
\hline & COMBRETACEAE & \\
\hline \multirow[t]{2}{*}{$\begin{array}{l}\text { Asteridiella } \\
3101.4220\end{array}$} & $\begin{array}{l}\text { Colonies epiphyllous, subdense; hyphae substraight to undulate; appressoria alternate, straight, } \\
\text { antrorse, head cells globose, entire, angular; phialides borne on a separate mycelial branch; } \\
\text { perithecial cells mammiform. }\end{array}$ & A. combreti var. leonensis \\
\hline & CONVOLVULACEAE & \\
\hline $\begin{array}{l}\text { Meliola } \\
3113.4221\end{array}$ & $\begin{array}{l}\text { Colonies epiphyllous, dense, velvety; hyphae undulate to slightly crooked; appressoria opposite, } \\
20 \% \text { alternate, straight to curved, closely antrorse to spreading; head cells globose to subglobose, } \\
\text { ovate, entire; phialides mixed with appressoria; mycelial setae grouped around perithecia, straight, } \\
\text { simple, acute to obtuse at the tip }\end{array}$ & M. malacotricha \\
\hline 3112.3222 & $\begin{array}{l}\text { Colonies amphigenous, mostly epiphyllous, dense, velvety; hyphae straight to slightly crooked; } \\
\text { appressoria mostly opposite, about } 5 \% \text { unilateral, antrorse to spreading, straight to curved, head } \\
\text { cells ovate to subglobose, entire; phialides mixed with appressoria; mycelial setae fairly numerous, } \\
\text { scattered to grouped around perithecia, simple, straight, acute to obtuse at the tip }\end{array}$ & M. malacotricha var. major \\
\hline \multirow[t]{2}{*}{3141.4231} & $\begin{array}{l}\text { Colonies amphigenous, caulicolous, mostly epiphyllous, dense; hyphae undulate to tortuous; } \\
\text { appressoria alternate to unilateral, antrorse, spreading, straight to curved, head cells ovate, } \\
\text { versiform, angulose, rarely irregularly sublobate; phialides mixed with appressoria; mycelial setae } \\
\text { numerous, uniformly scattered, dichotomously branched, obtuse to acute at the tip }\end{array}$ & M. quadrispina \\
\hline & ELAEOCARPACEAE & \\
\hline \multirow[t]{2}{*}{$\begin{array}{l}\text { Asteridiella } \\
3101.4220\end{array}$} & $\begin{array}{l}\text { Colonies epiphyllous, subdense; hyphae substraight to undulate; appressoria alternate, straight } \\
\text { to curved, antrorse, head cells globose, ovate, truncate at the apex, entire; phialides borne on a } \\
\text { separate mycelial branch; perithecial cells conoid, curved, acute at the apex }\end{array}$ & A. elaeocarpi-tuberculati \\
\hline & ERYTHROPALACEAE & \\
\hline \multirow[t]{2}{*}{$\begin{array}{l}\text { Meliola } \\
3111.4222\end{array}$} & $\begin{array}{l}\text { Colonies amphigenous, caulicolous, dense, velvety; hyphae straight to slightly undulate; appressoria } \\
\text { alternate to unilateral, straight, antrorse, spreading, head cells ovate, globose, slightly curved, } \\
\text { entire; phialides few, mixed with appressoria; mycelial setae scattered, grouped around perithecia, } \\
\text { numerous, simple, straight, acute at the tip }\end{array}$ & M. erythropali \\
\hline & EUPHORBIACEAE & \\
\hline $\begin{array}{l}\text { Asteridiella } \\
3101.3220\end{array}$ & $\begin{array}{l}\text { Colonies hypophyllous; hyphae flexuous; appressoria alternate, antrorse to subantrorse, head cells } \\
\text { ovate to globose, entire, rarely angular; phialides mixed with appressoria }\end{array}$ & A. wyanadensis \\
\hline $\begin{array}{l}\text { Meliola } \\
3113.4221\end{array}$ & $\begin{array}{l}\text { Colonies amphigenous, caulicolous, mostly hypophyllous; hyphae straight to substraight; } \\
\text { appressoria opposite, solitary, about } 15 \% \text { alternate, head cells oblong to cylindrical, angular to } \\
\text { slightly sublobate, often entire; mycelial setae many, scattered, simple, straight, slightly curved and } \\
\text { often flexuous, acute at the tip }\end{array}$ & M. actephilae \\
\hline 3113.4222 & $\begin{array}{l}\text { Colonies amphigenous, mostly hypophyllous, crustose; hyphae straight to substraight; appressoria } \\
\text { alternate, about } 15 \% \text { opposite, antrorse to subantrorse, spreading, head cells ovate, clavate, } \\
\text { globose, entire to } 2-5 \text {-times lobate, often slightly angular; phialides mixed with appressoria; mycelial } \\
\text { setae few, simple, straight, obtuse at the tip }\end{array}$ & M. aporusae \\
\hline \multirow[t]{2}{*}{$31 \frac{1}{3} 1.5222$} & $\begin{array}{l}\text { Colonies epiphyllous, subdense; hyphae straight to substraight; appressoria densely arranged, } \\
\text { alternate, antrorse, subantrorse to closely antrorse, head cells ovate, globose, entire; phialides } \\
\text { mixed with appressoria; mycelial setae numerous, closely scattered, simple, straight, about } 10 \% \\
\text { uncinate, acute at the tip }\end{array}$ & M. phyllanthigena \\
\hline & FABACEAE & \\
\hline $\begin{array}{l}\text { Asteridiella } \\
3101.4320\end{array}$ & $\begin{array}{l}\text { Colonies hypophyllous, subdense; hyphae substraight to flexuous; appressoria alternate, straight } \\
\text { to curved, antrorse to subantrorse, head cells straight to variously curved, ovate, oblong, entire } \\
\text { to angular, sublobate to lobate; phialides mixed with appressoria; perithecial wall cells conoid, } \\
\text { mammiform }\end{array}$ & A. millettiicola \\
\hline $\begin{array}{l}\text { Meliola } \\
3111.3222\end{array}$ & $\begin{array}{l}\text { Colonies epiphyllous, thin, scattered; hyphae flexuous to crooked; appressoria alternate to } \\
\text { unilateral, up to } 1 \% \text { opposite, antrorse, subantrorse to retrorse, head cells globose, ovate, straight } \\
\text { to curved; phialides mixed with appressoria; mycelial setae scattered to grouped around perithecia, } \\
\text { simple, straight, acute at the tip }\end{array}$ & M. abri \\
\hline 3113.4223 & $\begin{array}{l}\text { Colonies epiphyllous, subdense, velvety; hyphae substraight to crooked, branching opposite to } \\
\text { irregular at wide angles, loosely to closely reticulate; appressoria alternate, opposite, antrorse, } \\
\text { mostly spreading, straight to curved; head cells globose, subglobose, mostly curved, entire to } \\
\text { slightly angular; phialides mixed with appressoria; mycelial setae grouped around perithecia, } \\
\text { simple, straight, acute to obtuse at the tip }\end{array}$ & M. buteae \\
\hline
\end{tabular}




\begin{tabular}{|c|c|c|}
\hline 3111.3222 & $\begin{array}{l}\text { Colonies foliicolous, epiphyllous, thin, scattered; hyphae flexuous to undulate; appressoria } \\
\text { alternate, unilateral, rarely opposite, straight to slightly curved, antrorse, subantrorse to retrorse, } \\
\text { head cells ovate, globose; phialides mixed with appressoria; mycelial setae scattered to grouped } \\
\text { around perithecia, simple, straight to slightly curved, acute to obtuse at the tip }\end{array}$ & M. canavaliae \\
\hline $31 \frac{1}{3} 3.3222$ & $\begin{array}{l}\text { Colonies epiphyllous, dense, crustose to velvety; hyphae substraight to flexuous; appressoria } \\
\text { alternate, about } 20 \% \text { opposite, antrorse, subantrorse to rarely recurved, head cells globose, entire, } \\
\text { rarely truncate at the apex; phialides mixed with appressoria; mycelial setae scattered to grouped } \\
\text { around perithecia, simple, straight, obtuse, dentate to cristate at the apex }\end{array}$ & M. flemingiicola \\
\hline 3113.3222 & $\begin{array}{l}\text { Colonies amphigenous, mostly epiphyllous, subdense to dense; hyphae straight to flexuous, } \\
\text { branching mostly opposite at acute to wide angles, loosely to closely reticulate; appressoria } \\
\text { alternate, opposite, subantrorse to spreading; head cells globose, rarely ovate, straight to slightly } \\
\text { curved, entire; phialides mixed with appressoria; mycelial setae scattered to grouped around } \\
\text { perithecia, simple, straight, acute at the tip }\end{array}$ & M. gliricidiicola \\
\hline $31 \frac{1}{3} 3.4222$ & $\begin{array}{l}\text { Colonies amphigenous, thin to crustose; hyphae straight to substraight; appressoria alternate and } \\
\text { opposite, straight to curved, antrorse to spreading, head cells ovate, globose to subglobose, entire; } \\
\text { phialides mixed with appressoria; mycelial setae fairly numerous, scattered, straight to curved but } \\
\text { not uncinate, acute, obtuse to minutely dentate at the tip }\end{array}$ & $\begin{array}{l}\text { M. millettiae-chryosophyllae } \\
\text { var. indica }\end{array}$ \\
\hline \multirow[t]{2}{*}{3113.3222} & $\begin{array}{l}\text { Colonies foliicolous, fructicolous, epiphyllous, thin, scattered; hyphae undulating; appressoria } \\
\text { alternate, unilateral, up to } 3 \% \text {, opposite, straight to slightly curved, subantrorse to retrorse, head } \\
\text { cells ovate, globose; Phialides mixed with appressoria; mycelial setae scattered, simple, straight to } \\
\text { slightly curved, acute to obtuse }\end{array}$ & M. psophocarpi \\
\hline & FLACOURTIACEAE & \\
\hline $\begin{array}{l}\text { Asteridiella } \\
3103.4220\end{array}$ & $\begin{array}{l}\text { Colonies amphigenous, dense, crustose; hyphae straight to substraight; appressoria alternate, about } \\
1 \% \text { opposite in loosely reticulated colonies while about } 5 \% \text { opposite in densely reticulated colonies, } \\
\text { antrorse; phialides mixed with appressoria; perithecial cells mammiform, straight to curved }\end{array}$ & A. scolopiae \\
\hline \multirow[t]{2}{*}{$\begin{array}{l}\text { Amazonia } \\
3101.4220\end{array}$} & $\begin{array}{l}\text { Colonies amphigenous, thin to subdense; Hyphae substraight to flexuous; appressoria alternate, } \\
\text { straight, rarely curved, antrorse, head cells ovate, entire; phialides mixed with appressoria }\end{array}$ & A. flacourtiae \\
\hline & HIPPOCRATACEAE & \\
\hline \multirow[t]{2}{*}{$\begin{array}{l}\text { Meliola } \\
3111.4221\end{array}$} & $\begin{array}{l}\text { Colonies amphigenous, mostly epiphyllous, dense, velvety; hyphae substraight to flexuous; } \\
\text { appressoria alternate, antrorse to subantrorse, straight to rarely curved, head cells ovate, globose, } \\
\text { angular, sublobate to irregularly lobate; phialides mixed with appressoria; mycelial setae numerous, } \\
\text { simple, mostly straight, often curved, acute at the tip }\end{array}$ & M. oligomera \\
\hline & ICACINACEAE & \\
\hline $\begin{array}{l}\text { Meliola } \\
3113.4222\end{array}$ & $\begin{array}{l}\text { Colonies amphigenous, caulicolous, mostly epiphyllous, velvety, cover almost all the part of upper } \\
\text { surface of the leaf; hyphae substraight to undulate; appressoria alternate, about } 1 \% \text { opposite, } \\
\text { straight to curved, spreading, mostly antrorse, head cells subglobose, ovate, angular to sublobate; } \\
\text { phialides borne on a separate mycelial branch; mycelial setae numerous, scattered to grouped } \\
\text { around perithecia, straight, simple, acute to obtuse at the tip }\end{array}$ & M. chandrasekharanii \\
\hline \multirow[t]{2}{*}{3113.4223} & $\begin{array}{l}\text { Colonies epiphyllous, subdense, subvelvety; hyphae flexuous, branching opposite to irregular } \\
\text { at acute to wide angles, loosely to closely reticulate; appressoria alternate and unilateral, rarely } \\
\text { opposite, straight to curved, antrorse to reflexed, spreading, head cells globose, ovate, curved, } \\
\text { entire; phialides mixed with appressoria; mycelial setae numerous, scattered, often grouped around } \\
\text { perithecia, straight, simple, acute. }\end{array}$ & M. dimidiatae \\
\hline & LAURACEAE & \\
\hline $\begin{array}{l}\text { Armatella } \\
11 \times 3.3240\end{array}$ & $\begin{array}{l}\text { Colonies amphigenous, thin to subdense; hyphae flexuous to crooked, branching irregular at acute } \\
\text { to wide angles; appressoria alternate, rarely opposite, straight to variously curved, antrorse to sub } \\
\text { antrorse; head cells ovate, oblong, straight to curved mostly entire, but rarely sinuate }\end{array}$ & A. apollonigena \\
\hline $11 \times 2.2232$ & $\begin{array}{l}\text { Colonies epiphyllous, thin to subdense, crustose; hyphae crenulated, straight to substraight; } \\
\text { appressoria alternate, antrorse to spreading, straight to curved, head cells ovate, broadly conoid, } \\
\text { rarely globose }\end{array}$ & A. cinnamomicola \\
\hline $11 \times 2.3222$ & $\begin{array}{l}\text { Colonies epiphyllous, thin, crustose; hyphae smooth walled, straight to substraight; appressoria } \\
\text { alternate, antrorse to spreading, head cells ovoid, conoid, slightly angular, entire, outer wall } \\
\text { crenulated }\end{array}$ & A. cryptocaryae \\
\hline $11 \times 2.3231$ & $\begin{array}{l}\text { Colonies hypophyllous, thin, crustaceous; hyphae smooth walled, substraight to undulate; } \\
\text { appressoria alternate, about } 5 \% \text { opposite, antrorse, straight to curved, head cells globose, } \\
\text { stellately sublobate }\end{array}$ & A. litseae \\
\hline $11 \times 2.3234$ & $\begin{array}{l}\text { Colonies hypophyllous, thin, scattered, diffused; hyphae smooth walled, flexuous to crooked; } \\
\text { appressoria alternate, variously curved, head cells ovate to globose, entire to stellately lobate }\end{array}$ & A. katumotoi \\
\hline $11 \times 3.432$ & $\begin{array}{l}\text { Colonies ColColonies hypophyllous thin, spreading; hyphae smooth walled, crooked, branching } \\
\text { alternate to irregular at acute angles, closely reticulate; head cells globose, narrowly ovate, angular, } \\
\text { entire }\end{array}$ & A. balakrishnanii \\
\hline
\end{tabular}




\begin{tabular}{|c|c|c|}
\hline $\begin{array}{l}\text { Meliola } \\
311 / 31.5333\end{array}$ & $\begin{array}{l}\text { Colonies hypophyllous, dense, velvety; hyphae flexuous; appressoria alternate, straight to variously } \\
\text { curved, antrorse to reflexed, head cells globose, ovate, angular, entire; phialides mixed with } \\
\text { appressoria; mycelial setae numerous, scattered, straight, simple, acute to variously dentate at the } \\
\text { tip }\end{array}$ & $\begin{array}{l}\text { M. beilschmiediae var. } \\
\text { cinnamomicola }\end{array}$ \\
\hline 3111.3223 & $\begin{array}{l}\text { Colonies epiphyllous, subdense; hyphae substraight; appressoria alternate, antrorse, head cells } \\
\text { ovate, versiform, entire; phialides mixed with appressoria; mycelial setae few, mostly grouped } \\
\text { around perithecia, simple, acute }\end{array}$ & M. litseae var. keralensis \\
\hline 3111.4223 & $\begin{array}{l}\text { Colonies epiphyllous, dense, velvety; hyphae straight to undulate; appressoria alternate, straight to } \\
\text { curved, antrorse, rarely spreading, head cells versiform, obovate, rarely truncate, entire; phialides } \\
\text { mixed with appressoria; mycelial setae few, straight, simple, acute at the tip }\end{array}$ & M. litseae var. rotundipoda \\
\hline 3111.5332 & $\begin{array}{l}\text { Colonies hypophyllous, dense, velvety; hyphae crooked and geniculate; appressoria alternate } \\
\text { to unilateral, straight to curved, antrorse, spreading, head cells ovate, globose, slightly angular, } \\
\text { truncate, entire; phialides mixed with appressoria, alternate to unilateral; mycelial setae numerous, } \\
\text { scattered to grouped around perithecia, straight, simple, acute at the tip }\end{array}$ & M. machili \\
\hline $31 \frac{1}{3} 1.5333$ & $\begin{array}{l}\text { Colonies hypophyllous, subdense, subvelvety; hyphae substraight to tortuous; appressoria alternate } \\
\text { to unilateral, straight to curved, antrorse, spreading, head cells clavate, versiform, angulose, entire } \\
\text { to slightly lobate; phialides mixed with appressoria; mycelial setae scattered, straight, simple, acute } \\
\text { to 2-3 dentate }\end{array}$ & M. neolitseae \\
\hline \multirow[t]{2}{*}{3111.4234} & $\begin{array}{l}\text { Colonies hypophyllous, thin, scattered, spreading; hyphae crooked; appressoria scattered, alternate, } \\
\text { antrorse, subantrorse to retrorse, straight to curved, head cells globose, entire; phialides mixed with } \\
\text { appressoria mycelial setae mostly grouped around perithecia, simple, straight to flexuous, acute at } \\
\text { the tip }\end{array}$ & M. pushpangadanii \\
\hline & LECYTHIDACEAE & \\
\hline \multirow[t]{2}{*}{$\begin{array}{l}\text { Meliola } \\
3113.4222\end{array}$} & $\begin{array}{l}\text { Colonies epiphyllous, dense; hyphae straight to substraight; appressoria opposite, about } 3 \% \\
\text { alternate, head cells ovate, rarely globose, entire; phialides mixed with appressoria; mycelial setae } \\
\text { scattered to grouped around the perithecia, simple, straight, acute at the tip }\end{array}$ & $\begin{array}{l}\text { M. careyae } \\
\text { var. indica }\end{array}$ \\
\hline & MAGNOLIACEAE & \\
\hline \multirow[t]{2}{*}{$\begin{array}{l}\text { Asteridiella } \\
3101.3230\end{array}$} & $\begin{array}{l}\text { Colonies epiphyllous, thin; appressoria alternate, antrorse, mostly straight, head cells ovate, oblong, } \\
\text { angular to sublobate; phialides mixed with appressoria; perithecial wall cells mammiform, obtuse } \\
\text { at the tip }\end{array}$ & A. micheliae \\
\hline & MALPHIGIACEAE & \\
\hline \multirow[t]{2}{*}{$\begin{array}{l}\text { Irenopsis } \\
3403.5320\end{array}$} & $\begin{array}{l}\text { Colonies amphigenous, subdense; hyphae straight to substraight; appressoria alternate, unilateral to } \\
3-4 \% \text { opposite, antrorse to subantrorse, head cells ovate, entire, mostly angular to rarely sublobate; } \\
\text { phialides mixed with appressoria; perithecial setae simple, straight, obtuse at the tip }\end{array}$ & I. hiptages var. indica \\
\hline & MALVACEAE & \\
\hline $\begin{array}{l}\text { Irenopsis } \\
3401.3220\end{array}$ & $\begin{array}{l}\text { Colonies epiphyllous, thin, subvelvety; hyphae substraight to undulate; appressoria alternate, } \\
\text { antrorse to spreading, straight to curved, head cells ovate, subglobose, entire, subangular to slightly } \\
\text { sublobate; phialides mixed with appressoria, perithecial setae few, 10-16 in number, simple, straight } \\
\text { to slightly flexuous, septate, smooth, obtuse to subacute at the tip }\end{array}$ & I. molleriana \\
\hline \multirow[t]{2}{*}{3403.3220} & $\begin{array}{l}\text { Colonies amphigenous, mostly epiphyllous, subdense to dense; hyphae straight to flexuous; } \\
\text { appressoria alternate, about } 5 \% \text { opposite, antrorse, subantrorse to rarely retrorse, head cells } \\
\text { ovate to globose, entire, angular to truncate at the apex, straight to curved; phialides mixed with } \\
\text { appressoria; perithecial setae } 0-12 \text { in numbers, simple, straight, acute at the apex, deep brown, } \\
\text { septa not visible }\end{array}$ & I. sidae var. indica \\
\hline & MELASTOMATACEAE & \\
\hline \multirow[t]{2}{*}{$\begin{array}{l}\text { Meliola } \\
3111.3223\end{array}$} & $\begin{array}{l}\text { Colonies hypophyllous, very thin; hyphae substraight to undulate; appressoria alternate, distantly } \\
\text { arranged, straight to curved, mostly antrorse, head cells ovate, pointed towards the apex with } \\
\text { broadly rounded ends, entire; phialides mixed with appressoria; mycelial setae grouped around } \\
\text { perithecia, straight, simple, acute }\end{array}$ & M. affinis var. indica \\
\hline & MELIACEAE & \\
\hline $\begin{array}{l}\text { Irenopsis } \\
3401.4220\end{array}$ & $\begin{array}{l}\text { Colonies epiphyllous, subdense, scattered; hyphae straight to flexuous, appressoria alternate, } \\
\text { unilateral, antrorse to subantrorse, head cells globose, angular, sublobate to deeply lobate phialides } \\
\text { mixed with appressoria, perithecial setae } 0-5 \text { in number, straight, simple, obtuse at the apex }\end{array}$ & Irenopsis trichiliae \\
\hline $\begin{array}{l}\text { Meliola } \\
3112.5333\end{array}$ & $\begin{array}{l}\text { Colonies epiphyllous, dense, velvety; hyphae substraight to slightly crooked; appressoria opposite, } \\
\text { crowded after intervals, rarely solitary, antrorse, subantrorse, recurved, head cells ovate, globose, } \\
\text { angular, truncate, straight to curved, entire; phialides mixed with appressoria; mycelial setae mostly } \\
\text { grouped around perithecia, simple, straight, acute to obtuse }\end{array}$ & M. aphanamixidis \\
\hline $31 \frac{1}{3} 3.3231$ & $\begin{array}{l}\text { Colonies epiphyllous, dense, velvety; hyphae substraight to crooked; appressoria alternate, } \\
\text { unilateral, opposite, antrorse, subantrorse to retrorse, head cells globose, subglobose, entire to } \\
\text { rarely truncate; phialides mixed with appressoria; mycelial setae scattered, simple, straight, acute, } \\
\text { 2-3-times dentate at the tip }\end{array}$ & M. dysoxyligena \\
\hline 3111.3222 & $\begin{array}{l}\text { Colonies epiphyllous, minute; hyphae straight, substraight to flexuous; appressoria alternate, } \\
\text { antrorse to subantrorse, head cells ovate, broadly rounded at the apex, straight to curved, entire; } \\
\text { phialides mixed with appressoria; mycelial setae few, grouped around perithecia, straight, flexuous, } \\
\text { acute to obtuse at the tip }\end{array}$ & M. nairii \\
\hline
\end{tabular}




\begin{tabular}{|c|c|c|}
\hline & MENISPERMACEAE & \\
\hline $\begin{array}{l}\text { Meliola } \\
3111.3222\end{array}$ & $\begin{array}{l}\text { Colonies amphigenous, mostly epiphyllous, subdense to dense; hyphae substraight to slightly } \\
\text { undulate; appressoria alternate to unilateral, straight, antrorse, head cells ovate, versiform, slightly } \\
\text { and bluntly pointed at the apex, entire; phialides borne on a separate mycelial branch, alternate to } \\
\text { opposite, conoid to ampulliform; mycelial setae scattered to grouped around the perithecia, simple, } \\
\text { acute at the tip }\end{array}$ & M. cycleae \\
\hline \multirow[t]{2}{*}{$31 \frac{1}{21.3221}$} & $\begin{array}{l}\text { Colonies epiphyllous, dense, velvety; hyphae substraight, flexuous to crooked; appressoria alternate, } \\
\text { antrorse, head cells ovate, oblong, clavate, often attenuated at the apex, entire; phialides borne } \\
\text { on a separate mycelial branch; mycelial setae mostly grouped around perithecia, simple, straight, } \\
\text { flexuous to curved, up to } 2 \% \text { uncinate, obtuse at the tip }\end{array}$ & M. subramanyaensis \\
\hline & MORACEAE & \\
\hline $\begin{array}{l}\text { Irenopsis } \\
3401.4220\end{array}$ & $\begin{array}{l}\text { Colonies amphigenous, mostly epiphyllous, subdense to dense; hyphae straight to undulate; } \\
\text { appressoria alternate, antrorse to subantrorse, spreading, head cells globose, subangulose to } \\
\text { irregularly sublobate; phialides mixed with appressoria and also born on a separate mycelial branch, } \\
\text { perithecial setae } 4-8 \text {, straight, spreading, dark-brown at base and pale brown towards the apex, } \\
\text { obtuse and mostly straight at the tip }\end{array}$ & I. benguetensis \\
\hline \multirow[t]{2}{*}{$\begin{array}{l}\text { Meliola } \\
3121.5322\end{array}$} & $\begin{array}{l}\text { Colonies epiphyllous, dense, velvety; hyphae straight to substraight; appressoria alternate, antrorse, } \\
\text { head cells ovate, angular to sublobate; phialides borne on separate mycelial branch, } 1 \% \text { mixed with } \\
\text { appressoria; mycelial setae densely scattered, simple, curved, obtuse at the tip }\end{array}$ & M. artocarpi \\
\hline & MYRSINACEAE & \\
\hline $\begin{array}{l}\text { Amazonia } \\
3101.4230\end{array}$ & $\begin{array}{l}\text { Colonies amphigenous, mostly hypophyllous, crustaceous; hyphae straight to undulating; } \\
\text { appressoria alternate to unilateral, very closely arranged, antrorse, straight to curved, head cells } \\
\text { globose, entire; phialides mixed with appressoria }\end{array}$ & A. peregrina \\
\hline $\begin{array}{l}\text { Meliola } \\
3111.3222\end{array}$ & $\begin{array}{l}\text { Colonies epiphyllous, dense, crustose; hyphae straight to substraight; appressoria alternate, closely } \\
\text { placed, straight to curved, mostly antrorse, rarely retrorse, head cells oblong, cylindrical, rarely } \\
\text { broadly ovate, entire, straight to slightly curved; mycelial setae scattered, simple, straight, acute } \\
\text { at the tip }\end{array}$ & M. ardisiicola \\
\hline 3113.5221 & $\begin{array}{l}\text { Colonies hypophyllous, subdense to dense; hyphae substraight; appressoria alternate, up to } 30 \% \\
\text { opposite to unilateral, antrorse to subantrorse, head cells ovate, globose, entire, phialides mixed } \\
\text { with appressoria; mycelial setae simple, straight, acute to obtuse at the tip }\end{array}$ & M. ardisiigena \\
\hline \multirow[t]{2}{*}{$31 \frac{1}{2} 3.3221$} & $\begin{array}{l}\text { Colonies mostly hypophyllous, dense, velvety; hyphae straight to flexuous; appressoria alternate, } \\
\text { about } 30 \% \text { opposite, antrorse to subantrorse, head cells predominantly globose, rarely ovate, } \\
\text { entire; phialides few, mixed with appressoria; mycelial setae densely scattered, simple, straight to } \\
\text { flexuous, acute, obtuse to acute at the tip }\end{array}$ & $\begin{array}{l}\text { M. groteana } \\
\text { var. maesae }\end{array}$ \\
\hline & MYRTACEAE & \\
\hline $\begin{array}{l}\text { Amazonia } \\
3101.4220\end{array}$ & $\begin{array}{l}\text { Colonies amphigenous, subdense, crustose to slightly velvety; hyphae substraight to slightly } \\
\text { undulate; appressoria alternate, straight, antrorse to spreading, head cells ovate to subglobose, } \\
\text { entire; phialides mixed with appressoria }\end{array}$ & A. syzygii \\
\hline $\begin{array}{l}\text { Meliola } \\
3121.4221\end{array}$ & $\begin{array}{l}\text { Colonies hypophyllous, dense, velvety; hyphae substraight to tortuous; appressoria alternate, } \\
\text { straight to variously curved, antrorse to spreading, head cells straight to curved, ovate, cylindrical, } \\
\text { entire to angular; phialides mixed with appressoria; mycelial setae fairly numerous, simple, broadly } \\
\text { uncinate to arcuate above, very few are straight, acute to obtuse at the tip }\end{array}$ & M. densa \\
\hline \multirow[t]{2}{*}{3111.4221} & $\begin{array}{l}\text { Colonies hypophyllous, dense, velvety; hyphae straight to substraight; appressoria alternate, less } \\
\text { than } 1 \% \text { opposite, antrorse, subantrorse, retrorse, straight, curved to uncinate, head cells ovate, } \\
\text { oblong, cylindrical, straight to curved, entire, broadly rounded to truncate at the apex; phialides } \\
\text { few, mixed with appressoria mycelial setae numerous, scattered, simple, straight, acute at the tip }\end{array}$ & M. syzygiigena \\
\hline & OLEACEAE & \\
\hline $\begin{array}{l}\text { Asteridiella } \\
3101.4220\end{array}$ & $\begin{array}{l}\text { Colonies epiphyllous, dense, crustose; hyphae substraight to undulate; appressoria alternate, } \\
\text { mostly antrorse, rarely recurved, head cells ovate, globose, deeply and irregularly lobate; phialides } \\
\text { mixed with appressoria, conoid to ampulliform, perithecial cells conoid to mammiform }\end{array}$ & A. americana \\
\hline $\begin{array}{l}\text { Meliola } \\
3112.4223\end{array}$ & $\begin{array}{l}\text { Colonies amphigenous, mostly epiphyllous, dense; hyphae straight to slightly undulate; appressoria } \\
\text { opposite (very few unilateral), straight to slightly curved, closely antrorse, head cells subglobose to } \\
\text { ovate, entire; phialides few, mixed with appressoria; mycelial setae fairly numerous, scattered to } \\
\text { mostly grouped around perithecia, straight, simple, acute to obtuse at the tip }\end{array}$ & M. gamellipoda \\
\hline 3111.3221 & $\begin{array}{l}\text { Colonies amphigenous, subdense to dense; hyphae substraight to flexuous; appressoria alternate, } \\
\text { straight to curved,antrorse to subantrorse, head cells oblong to cylindrical, broadly rounded to } \\
\text { rarely truncate at the apex, entire; phialides mixed with appressoria; mycelial setae scattered, } \\
\text { simple, straight, acute to slightly obtuse at the tip }\end{array}$ & M. glanduliferae \\
\hline 3111.3222 & $\begin{array}{l}\text { Colonies amphigenous, mostly epiphyllous, dense, velvety; hyphae straight to substraight; } \\
\text { appressoria alternate, straight, antrorse, head cells ovate, entire; phialides borne on a separate } \\
\text { mycelial branch; mycelial setae fairly numerous, scattered, straight, simple, acute to obtuse }\end{array}$ & M. jasmini \\
\hline 3111.2221 & $\begin{array}{l}\text { Colonies amphigenous, thin; hyphae straight to substraight; appressoria alternate, antrorse, rarely } \\
\text { 3-celled, straight, head cells ovate to clavate, entire to sublobate; phialides borne on a separate } \\
\text { mycelial branch; mycelial setae few, grown from the subiculum of perithecia, acute to obtuse at the } \\
\text { apex, simple, straight }\end{array}$ & $\begin{array}{l}\text { M. jasmini } \\
\text { var. microspora }\end{array}$ \\
\hline 3111.4222 & $\begin{array}{l}\text { Colonies epiphyllous, thin, scattered; hyphae crooked; appressoria alternate to unilateral, antrorse, } \\
\text { subantrorse to retrorse, head cells ovate, clavate, oblong to cylindrical, entire, angular and crenately } \\
\text { lobate to sublobate; phialides mixed with appressoria, mycelial setae numerous, simple, straight, } \\
\text { acute at the tip }\end{array}$ & M. jasminigena \\
\hline
\end{tabular}




\begin{tabular}{|c|c|c|}
\hline 3111.3231 & $\begin{array}{l}\text { Colonies amphigenous, subdense; hyphae flexuous; appressoria alternate, spreading, antrorse, } \\
\text { straight to curved, head cells globose, cylindrical, versiform, angulose, entire; phialides mixed with } \\
\text { appressoria; mycelial setae fairly numerous, scattered, simple, acute to obtuse at the tip }\end{array}$ & M. ligustri \\
\hline 3111.2221 & $\begin{array}{l}\text { Colonies amphigenous, moistly epiphyllous, thin; hyphae substraight to undulate; appressoria } \\
\text { alternate, straight to slightly curved, head cells ovate to obovate, attenuated and broadly rounded } \\
\text { towards apex, entire; phialides borne on a separate mycelial branches; mycelial setae few, grouped } \\
\text { around perithecia, simple, straight, flexuous to curved, acute at the apex }\end{array}$ & M. ligustricola \\
\hline 3111.3222 & $\begin{array}{l}\text { Colonies hypophyllous, thin; hyphae straight to slightly undulate; appressoria alternate, straight to } \\
\text { curved, antrorse to spreading, head cells ovate, globose, cylindrical, often curved, slightly truncate } \\
\text { at the apex, entire; phialides mixed with appressoria; mycelial setae grouped around perithecia, } \\
\text { straight, simple, acute at the tip }\end{array}$ & M. malabarensis \\
\hline 3111.4221 & $\begin{array}{l}\text { Colonies epiphyllous, dense; hyphae straight to flexuous; appressoria alternate, antrorse, reflexed } \\
\text { to spreading, mostly straight, head cells cylindrical, ovate, entire, angular to sublobate; phialides } \\
\text { mixed with appressoria; mycelial setae grouped around perithecia, straight, simple, acute to obtuse }\end{array}$ & M. mayapeae \\
\hline 3111.4322 & $\begin{array}{l}\text { Colonies epiphyllous, rarely hypophyllous, dense, crustose to velvety; hyphae substraight; } \\
\text { appressoria alternate, antrorse to recurved, head cells ovate, cylindrical, entire, rarely angular to } \\
\text { sublobate; phialides mixed with appressoria, mycelial setae grouped around perithecia, straight to } \\
\text { curved, simple, acute at the tip }\end{array}$ & M. mayapeicola var. indica \\
\hline $31 \frac{1}{2} 1.3222$ & $\begin{array}{l}\text { Colonies hypophyllous, dense, scattered; hyphae flexuous to crooked; appressoria alternate, } \\
\text { antrorse, retrorse, spreading, curved towards hyphae; head cells ovate, oblong, entire, rarely } \\
\text { angular to sublobate, straight, curved to uncinate; phialides mixed with appressoria; mycelial setae } \\
\text { numerous, scattered, simple, straight, flexuous, sigmoid, curved, uncinate, subobtuse to obtuse at } \\
\text { the tip }\end{array}$ & M. oleacearum \\
\hline \multirow[t]{2}{*}{ 3111. 3211} & $\begin{array}{l}\text { Colonies epiphyllous, thin to subdense; hyphae straight to substraigh; appressoria alternate } \\
\text { to unilateral, antrorse to subantrorse, head cells, ovate, clavate, entire; phialides mixed with } \\
\text { appressoria; mycelial setae scattered, simple, straight, acute to obtuse at the tip }\end{array}$ & M. oleicola \\
\hline & PERIPLOCACEAE & \\
\hline \multirow[t]{2}{*}{$\begin{array}{l}\text { Meliola } \\
3111.3223\end{array}$} & $\begin{array}{l}\text { Colonies epiphyllous, dense, confluent and cover the entire upper leaf surface; hyphae straight to } \\
\text { slightly flexuous; appressoria alternate, antrorse to subantrorse; head cells ovate, globose, entire; } \\
\text { phialides mixed with appressoria; mycelial setae fairly numerous, scattered, simple, straight, acute } \\
\text { at the tip }\end{array}$ & M. hemidesmicola \\
\hline & PIPERACEAE & \\
\hline $\begin{array}{l}\text { Meliola } \\
311 / 21.4221\end{array}$ & $\begin{array}{l}\text { Colonies amphigenous, predominantly epiphyllous, dense; hyphae straight to flexuous; appressoria } \\
\text { alternate, antrorse to subantrorse, head cells globose, minutely and irregularly lobate; phialides } \\
\text { borne on a separate mycelial branch; mycelial setae scattered to grouped around perithecia, simple, } \\
\text { straight to uncinate, acute to broadly rounded at the apex }\end{array}$ & M. lepianthedis \\
\hline 3111.4223 & $\begin{array}{l}\text { Colonies hypophyllous, thin, spreading; hyphae substraight to slightly crooked; appressoria alternate } \\
\text { to unilateral, straight to curved, antrorse to spreading, head cells truncate, angular to slightly lobate; } \\
\text { Phialides borne on a separate mycelial branch; mycelial setae simple, straight, acute at the tip }\end{array}$ & M. stenospora \\
\hline \multirow[t]{2}{*}{3111.4223} & $\begin{array}{l}\text { Colonies mostly epiphyllous, subdense, thinly velvety; hyphae substraight to slightly undulate; } \\
\text { appressoria alternate, about } 1 \% \text { opposite, spreading to antrorse, straight to curved, head cells } \\
\text { subglobose with crenate to lobulate margin; phialides borne on a separate mycelial branch; mycelial } \\
\text { setae mostly grouped around perithecia, straight, simple, acute }\end{array}$ & M. stenospora var. major \\
\hline & POACEAE & \\
\hline $\begin{array}{l}\text { Meliola } \\
3141.4221\end{array}$ & $\begin{array}{l}\text { Colonies epiphyllous, rarely amphigenous, subdense to dense, velvety; hyphae straight to tortuous, } \\
\text { straight hyphae run along the veins and tortuous hyphae cross the straight hyphae; appressoria } \\
\text { alternate, unilateral, antrorse, spreading, head cells ovate, globose, angular to sublobate; phialides } \\
\text { few, mixed with appressoria; mycelial setae straight, dichotomously branched at the tip }\end{array}$ & M. cymbopogonis \\
\hline 3111.3222 & $\begin{array}{l}\text { Colonies epiphyllous, dense; hyphae straight to substraight; appressoria alternate, straight to curved } \\
\text { antrorse to recurved, head cells ovate, globose, entire, angular to sublobate; phialides borne on a } \\
\text { separate mycelial branch; mycelial setae few, straight, simple, acute to obtuse }\end{array}$ & M. panici \\
\hline \multirow[t]{2}{*}{3111.5222} & $\begin{array}{l}\text { Colonies mostly epiphyllous, dense, crustose; hyphae substraight to crooked; appressoria alternate, } \\
\text { more scattered, antrorse to recurved, head cells ovate to globose, entire, angular, sublobate to } \\
\text { irregularly and deeply lobate; phialides mixed with appressoria; mycelial setae numerous, scattered } \\
\text { to grouped around perithecia, simple, straight, acute to broadly obtuse at the tip }\end{array}$ & M. themedicola \\
\hline & RHAMNACEAE & \\
\hline \multirow[t]{2}{*}{$\begin{array}{l}\text { Meliola } \\
31 \frac{1}{3} 3.3222\end{array}$} & $\begin{array}{l}\text { Colonies amphigenous, mostly epiphyllous, thin; hyphae straight to substraight; appressoria } \\
\text { alternate to opposite, straight, spreading, antrorse, head cells globose, entire; phialides mixed } \\
\text { with appressoria, alternate to opposite, ampulliform; mycelial setae scattered and grouped around } \\
\text { perithecia, straight, simple, acute to variously dentate at the tip }\end{array}$ & M. ziziphi \\
\hline & ROSACEAE & \\
\hline \multirow[t]{2}{*}{$\begin{array}{l}\text { Appendiculella } \\
2101.4230\end{array}$} & $\begin{array}{l}\text { Colonies amphigenous, mostly epiphyllous, dense, crustose; hyphae mostly straight; appressoria } \\
\text { alternate, antrorse to spreading, head cells globose, irregularly sublobate; phialides mixed with } \\
\text { appressoria; perithecial appendages many, cylindrical to conoid twisted, rounded at the apex }\end{array}$ & A. calostroma \\
\hline & RUBIACEAE & \\
\hline $\begin{array}{l}\text { Meliola } \\
31 \frac{1}{3} 1.3221\end{array}$ & $\begin{array}{l}\text { Colonies epiphyllous, thin; hyphae substraight to undulate; appressoria closely arranged, alternate, } \\
\text { unilateral, closely antrorse, head cells ovate, globose, entire, slightly angular; phialides mixed with } \\
\text { appressoria; mycelial setae scattered to grouped around perithecia, straight to curved, simple, } \\
\text { rounded to bifid at the tip, often show knobs in the middle }\end{array}$ & M. anceps \\
\hline
\end{tabular}




\begin{tabular}{|c|c|c|}
\hline 3111.4332 & $\begin{array}{l}\text { Colonies amphigenous, mostly epiphyllous, dense, velvety; hyphae straight to flexuous; appressoria } \\
\text { alternate, antrorse to closely antrorse, head cells ovate, oblong, entire, angular to slightly lobate, } \\
\text { attenuated and broadly rounded to truncate at the apex; phialides borne on a separate mycelial } \\
\text { branch; mycelial setae scattered, simple, straight to rarely curved, acute at the tip }\end{array}$ & M. canthiicola \\
\hline 3111.4222 & $\begin{array}{l}\text { Colonies hypophyllous, thin; hyphae substraight to flexuous; appressoria alternate, straight to } \\
\text { variously curved, head cells semilunar, versiform, ovate, angular, straight to mostly curved; phialides } \\
\text { mixed with appressoria; mycelial setae thinly scattered, simple, straight, acute }\end{array}$ & M. plectroniae \\
\hline \multirow[t]{2}{*}{3111.4222} & $\begin{array}{l}\text { Colonies amphigenous, mostly hypophyllous, subdense, subvelvety; hyphae sinuous to crooked; } \\
\text { appressoria alternate, spreading, antrorse; head cells ovate, narrow towards apex, slightly angular, } \\
\text { entire; phialides borne on a separate mycelial branch; mycelial setae few, grouped around perithecia, } \\
\text { simple, straight, acute to subacute at apex }\end{array}$ & M. wendlandiae \\
\hline & \multicolumn{2}{|l|}{ RUTACEAE } \\
\hline $\begin{array}{l}\text { Asteridiella } \\
3101.4210\end{array}$ & $\begin{array}{l}\text { Colonies amphigenous, crustose; hyphae substraight; appressoria alternate, antrorse to closely } \\
\text { antrorse, head cells straight to curved, ovate, cylindrical to globose, rarely entire, sublobate to } \\
\text { deeply and irregularly lobate; phialides mixed with appressoria, numerous in some colonies }\end{array}$ & A. glycosmidis \\
\hline $\begin{array}{l}\text { Meliola } \\
31 \frac{1}{3} 3.42 \times 3\end{array}$ & $\begin{array}{l}\text { Colonies amphigenous, mostly hypophyllous, crustaceous; hyphae straight to substraight to } \\
\text { crooked; appressoria alternate, about } 20 \% \text { opposite, straight to curved, subantrorse to spreading, } \\
\text { head cells ovate, conoid, rounded at the apex, entire; phialides mixed with appressoria, mycelial } \\
\text { setae scattered, straight, often curved, simple, acute to } 2-3 \text { dentate to cristate }\end{array}$ & M. atalantiae \\
\hline $31 \frac{1}{3} 3.4233$ & $\begin{array}{l}\text { Colonies amphigenous, mostly epiphyllous, dense; hyphae straight to undulate; appressoria } \\
\text { alternate to opposite, antrorse, curved; head cells ovate, clavate, cylindrical, often curved, entire; } \\
\text { phialides mixed with appressoria; mycelial setae scattered, straight, acute to dentate }\end{array}$ & M. butleri \\
\hline $31 \frac{1}{3} 3.3223$ & $\begin{array}{l}\text { Colonies amphigenous, mostly epiphyllous, dense, velvety, scattered, cover all the upper surface } \\
\text { of the leaves; hyphae straight to substraight; appressoria alternate and opposite, crowded, straight } \\
\text { to curved, antrorse to spreading, head cells ovate, globose to subglobose, entire, rounded at the } \\
\text { apex; phialides mixed with appressoria; mycelial setae numerous, scattered, straight, simple, acute } \\
\text { to dentate at the tip }\end{array}$ & M. cadigensis var. glycosmidis \\
\hline 3113.3223 & $\begin{array}{l}\text { Colonies amphigenous, dense; hyphae substraight to flexuous; appressoria alternate, } 5 \% \text { opposite, } \\
\text { antrorse to closely antrorse, head cells mostly ovate, entire; mycelial setae scattered to grouped } \\
\text { around perithecia, simple, predominantly straight, few curved, acute to obtuse at the tip }\end{array}$ & $\begin{array}{l}\text { M. cadigensis } \\
\text { var. toddaliae }\end{array}$ \\
\hline 3113.4223 & $\begin{array}{l}\text { Colonies epiphyllous, dense; hyphae straight to substraight; appressoria alternate, } 5 \% \text { opposite, } \\
\text { antrorse to subantrorse, head cells oblong, clavate, cylindrical, entire to rarely slightly angular; } \\
\text { phialides mixed with appressoria mycelial setae scattered, simple, straight, acute at the tip }\end{array}$ & M. cannonicola \\
\hline $31 \frac{1}{3} 3.4223$ & $\begin{array}{l}\text { Colonies amphigenous, caulicolous, mostly hypophyllous, dense, velvety; hyphae substraight to } \\
\text { undulate; appressoria alternate, opposite, antrorse, spreading, straight to curved; head cells ovate, } \\
\text { cylindrical, entire, straight to curved; phialides mixed with appressoria; mycelial setae scattered, } \\
\text { straight, simple, obtuse to variously dentate at the tip }\end{array}$ & M. citricola \\
\hline $31 \frac{1}{3} 3.4303$ & $\begin{array}{l}\text { Colonies amphigenous, mostly hypophyllous, crustose; hyphae straight, substraight to crooked; } \\
\text { appressoria alternate, about } 20 \% \text { opposite, straight to curved, subantrorse to spreading, head } \\
\text { cells ovate, conoid, rounded at the apex, entire; phialides mixed with appressoria; mycelial setae } \\
\text { scattered, straight, often curved, simple, acute, } 2-3 \text { dentate to cristate }\end{array}$ & Meliola cranei \\
\hline 3111.4223 & $\begin{array}{l}\text { Colonies epiphyllous, dense, scattered, hyphae straight; appressoria alternate, straight to curved, } \\
\text { antrorse to subantrorse, head cells oblong to cylindrical, often clavate, entire; phialides mixed with } \\
\text { appressoria; mycelial setae scattered to grouped around perithecia, simple, straight, acute at the tip }\end{array}$ & $\begin{array}{l}\text { M. tecleae var. toddaliae- } \\
\text { asiaticae }\end{array}$ \\
\hline 3141.5221 & $\begin{array}{l}\text { Colonies amphigenous, thin to subdense, velvety; hyphae straight to undulate; appressoria alternate, } \\
\text { subantrorse to spreading, straight to curved, head cells cylindrical to clavate, usually curved, entire; } \\
\text { phialides few, mixed with appressoria; mycelial setae scattered, straight, dichotomously branched }\end{array}$ & M. tenella \\
\hline 3111.4221 & $\begin{array}{l}\text { Colonies amphigenous, dense, velvety; hyphae straight; appressoria alternate, rarely unilateral, } \\
\text { often crowded, antrorse, straight, head cells ovate, angular, sinuately lobate to deeply lobate; } \\
\text { phialides mixed with appressoria; mycelial setae straight to slightly curved, scattered to grouped } \\
\text { around perithecia, obtuse at the tip }\end{array}$ & M. vatsavayae \\
\hline 3121.5332 & $\begin{array}{l}\text { Colonies epiphyllous, dense; hyphae straight to slightly flexuous; appressoria alternate, antrorse, } \\
\text { head cells globose, ovate, stellately sublobate to lobate; phialides mixed with appressoria; mycelial } \\
\text { setae densely scattered all over the colonies, simple, sickle-shaped, curved to very closely arcuate, } \\
\text { acute to obtuse at the tip }\end{array}$ & M. zanthoxyli \\
\hline & SAPINDACEAE & \\
\hline $\begin{array}{l}\text { Meliola } \\
31 \frac{1}{3} 3.3223\end{array}$ & $\begin{array}{l}\text { Colonies epiphyllous, scattered, dense; hyphae straight; appressoria opposite, crowded after an } \\
\text { interval, antrorse to subantrorse, recurved, head cells globose, cylindrical, entire; phialides mixed } \\
\text { with appressoria; mycelial setae grouped around perithecia, simple, straight, acute, obtuse to } \\
\text { dentate at the tip }\end{array}$ & M. allophyli-concanici \\
\hline 3113.4223 & $\begin{array}{l}\text { Colonies hypophyllous, subdense, crustose; hyphae straight, rarely crooked; appressoria opposite, } \\
\text { about } 5 \% \text { alternate, antrorse to subantrorse, mostly straight, rarely curved, head cells globose, } \\
\text { ovate, rounded to rarely truncate at the apex, entire; mycelial setae moderately numerous, to } \\
\text { grouped around perithecia, scattered simple, straight to curved, acute to obtuse at the tip }\end{array}$ & M. allophyli-serrulati \\
\hline $31 \frac{1}{3} 3.4223$ & $\begin{array}{l}\text { Colonies mostly epiphyllous, rarely amphigenous, dense, velvety; hyphae straight to undulate; } \\
\text { appressoria alternate, opposite, antrorse, straight to curved, head cells ovate, globose, entire; } \\
\text { phialides mixed with appressoria; mycelial setae numerous, scattered, simple, straight, acute, } \\
\text { obtuse to dentate at the tip }\end{array}$ & M. capensis var. allophylicola \\
\hline
\end{tabular}




\begin{tabular}{|c|c|c|}
\hline $31 \frac{1}{3} 2.3223$ & $\begin{array}{l}\text { Colonies amphigenous, mostly hypophyllous, dense, velvety; hyphae straight; appressoria regularly } \\
\text { opposite, subantrorse to antrorse, head cells conoid, bluntly pointed towards the apex, entire; } \\
\text { phialides mixed with appressoria; mycelial setae scattered to grouped around perithecia, simple, } \\
\text { acute, obtuse to variously dentate at the tip }\end{array}$ & M. capensis var. malayensis \\
\hline \multirow[t]{2}{*}{$31 \frac{1}{3} 2.3222$} & $\begin{array}{l}\text { Colonies mostly epiphyllous, rarely amphigenous, dense, velvety; hyphae straight; appressoria } \\
\text { opposite, head cells conoid, rounded at the apex, entire; phialides mixed with appressoria; mycelial } \\
\text { setae scattered, straight, acute to dentate at the tip }\end{array}$ & M. capensis var. schleicherae \\
\hline & SANTALACEAE & \\
\hline \multirow[t]{2}{*}{$\begin{array}{l}\text { Meliola } \\
3111.3221\end{array}$} & $\begin{array}{l}\text { Colonies amphigenous, dense, velvety; hyphae substraight to undulate; appressoria alternate, } \\
\text { subantrorse to antrorse, head cells ovate to subglobose, rarely subangular, entire; phialides mixed } \\
\text { with appressoria; mycelial setae numerous, scattered, straight to slightly curved, flexuous, simple, } \\
\text { acute to obtuse at the tip }\end{array}$ & M. scleropyri \\
\hline & SIMAROUBACEAE & \\
\hline $\begin{array}{l}\text { Meliola } \\
31 \frac{1}{3} 3.3221\end{array}$ & $\begin{array}{l}\text { Colonies epiphyllous, scattered, dense, velvety; hyphae straight, rarely substraight; appressoria } \\
\text { alternate, straight, antrorse, head cells ovate to cylindrical, entire; phialides mixed with appressoria; } \\
\text { mycelial setae numerous, straight to slightly curved but not uncinate, simple, acute to } 2-3 \text { times } \\
\text { dentate at the tip }\end{array}$ & M. ailanthi \\
\hline \multirow[t]{2}{*}{$31 \frac{1}{3} 1.4222$} & $\begin{array}{l}\text { Colonies hypophyllous, thin, hyphae crooked, appressoria alternate to unilateral, straight to curved, } \\
\text { antrorse, subantrorse to retrorse, head cells ovate, globose, truncate to slightly lobate, phialides } \\
\text { mixed with appressoria, mycelial setae scattered, simple, straight, acute, obtuse to } 2-5 \text { dentate at } \\
\text { the tip }\end{array}$ & M. ailanthicola \\
\hline & SMILACACEAE & \\
\hline \multirow[t]{2}{*}{$\begin{array}{l}\text { Meliola } \\
3111.4233\end{array}$} & $\begin{array}{l}\text { Colonies epiphyllous, dense, crustose; hyphae substraight to crooked; appressoria alternate, } \\
\text { straight to curved, antrorse to spreading, head cells ovoid to globose, straight to curved, often } \\
\text { bluntly pointed at the apex, entire, phialides mixed with appressoria; mycelial setae few, straight, } \\
\text { simple, acute to obtuse at the apex }\end{array}$ & M. gamblei \\
\hline & STERCULIACEAE & \\
\hline \multirow[t]{2}{*}{$\begin{array}{l}\text { Meliola } \\
3111.3222\end{array}$} & $\begin{array}{l}\text { Colonies amphigenous, dense, spreading; hyphae straight to substraight; appressoria alternate, } \\
\text { antrorse to closely antrorse, head cells ovate, globose, entire; phialides mixed with appressoria } \\
\text { mycelial setae thinly scattered, simple, straight, acute at the tip }\end{array}$ & M. sterculiacearum \\
\hline & STRYCHNACEAE & \\
\hline \multirow[t]{2}{*}{$\begin{array}{l}\text { Meliola } \\
31 \frac{1}{2} 1.3222\end{array}$} & $\begin{array}{l}\text { Colonies amphigenous, mostly hypophyllous, subdense; hyphae substraight, flexuous to crooked; } \\
\text { appressoria alternate, less than } 1 \% \text { opposite, antrorse, subantrorse to recurved, head cells ovate, } \\
\text { oblong, entire to angular, attenuated to truncate at the apex; phialides numerous, mixed with } \\
\text { appressoria; mycelial setae scattered to grouped around perithecia, simple, straight, curved to } \\
\text { uncinate, acute at the tip }\end{array}$ & M. cannonii \\
\hline & SYMPLOCACEAE & \\
\hline $\begin{array}{l}\text { Asteridiella } \\
3101.3230\end{array}$ & $\begin{array}{l}\text { Colonies amphigenous, subdense; hyphae straight to substraight; appressoria alternate to unilateral, } \\
\text { antrorse to subantrorse, head cells globose to ovate, entire; phialides mixed with appressoria; } \\
\text { perithecial wall cells conoid to mammiform }\end{array}$ & A. symploci-microphyllae \\
\hline \multirow[t]{2}{*}{$31 \frac{1}{3} 1.5222$} & $\begin{array}{l}\text { Colonies hypophyllous, subdense, velvety; hyphae substraight to flexuous; appressoria alternate } \\
\text { to unilateral, straight to variously curved, antrorse, spreading, head cells globose, angulose, } \\
\text { truncate, variously curved, entire; phialides mixed with appressoria; mycelial setae grouped around } \\
\text { perithecia, straight, simple, acute, very few } 2-3 \text { dentate }\end{array}$ & Meliola symplocicola \\
\hline & THEACEAE & \\
\hline $\begin{array}{l}\text { Amazonia } \\
3101.3220\end{array}$ & $\begin{array}{l}\text { Colonies mostly epiphyllous, subdense; hyphae straight to substraight; appressoria alternate, about } \\
1 \% \text { opposite, antrorse to subantrorse, head cells ovate, rarely oblong to globose, entire, rarely } \\
\text { angular to truncate at the apex, phialides mixed with appressoria }\end{array}$ & A. gordoniicola \\
\hline $\begin{array}{l}\text { Irenopsis } \\
3401.4230\end{array}$ & $\begin{array}{l}\text { Colonies amphigenous, mostly epiphyllous, subdense, scattered; hyphae undulate to tortuous; } \\
\text { appressoria alternate, mostly straight, antrorse, head cells globose, entire to sublobate; phialides } \\
\text { mixed with appressoria; perithecial setae } 6-8 \text {, straight, spreading, continuous, curved or uncinate } \\
\text { at the apex, apex obtuse }\end{array}$ & I. triumfettae \\
\hline \multirow[t]{2}{*}{3401.4220} & $\begin{array}{l}\text { Colonies amphigenous, dense; hyphae straight to flexuous; appressoria alternate, antrorse to } \\
\text { subantrorse, head cells globose to slightly ovate, entire; phialides numerous mixed with appressoria; } \\
\text { perithecial setae } 6-8 \text {, simple, straight to slightly curved, tortuous to beaded and granulose towards } \\
\text { the apex, obtuse at the apex }\end{array}$ & $\begin{array}{l}\text { I. triumfettae } \\
\text { var. indica }\end{array}$ \\
\hline & VACCINIACEAE & \\
\hline $\begin{array}{l}\text { Amazonia } \\
3101.3220\end{array}$ & $\begin{array}{l}\text { Colonies amphigenous, mostly epiphyllous; hyphae straight to substraight; appressoria alternate, } \\
\text { straight to slightly curved, antrorse to spreading, head cells oblong to globose, straight to } \\
\text { slightly curved, entire to sublobate; phialides mixed with appressoria but apparently on separate } \\
\text { mycelial branches; Perithecia hidden in the radiating mycelium, flattened-globose, fringed hyphae } \\
\text { appressoriate }\end{array}$ & A.vaccinii \\
\hline
\end{tabular}




\begin{tabular}{|l|l|l|}
\hline $\begin{array}{l}\text { Asteridiella } \\
3101.4320\end{array}$ & $\begin{array}{l}\text { Colonies epiphyllous, thin; hyphae substraight to undulate, branching alternate at wide angles; } \\
\text { appressoria alternate, straight to curved, antrorse, spreading, head cells ovate, clavate, entire to } \\
\text { sublobate; phialides borne on a separate mycelial branch, mostly opposite, rarely unilateral, often } \\
\text { two; phialides borne very closely to a single mycelial cell; perithecial wall cells obtusely conoid }\end{array}$ & A. formosensis \\
\hline 3101.3230 & $\begin{array}{l}\text { Colonies epiphyllous, subdense to dense; hyphae flexuous to crooked; appressoria alternate to } \\
\text { unilateral, straight to mostly curved, antrorse to spreading, head cells ovate, globose, entire to } \\
\text { angulose; phialides few, mixed with appressoria, perithecial cells conoid to mammiform }\end{array}$ & A. vivekananthanii \\
\hline $\begin{array}{l}\text { Meliola } \\
3111.3221\end{array}$ & $\begin{array}{l}\text { Colonies amphigenous, mostly epiphyllous, dense, scattered; hyphae flexuous, undulate to } \\
\text { tortuous; appressoria alternate to unilateral, straight to curved, antrorse to reflexed, head cells } \\
\text { ovate, globose, entire; phialides mixed with appressoria; mycelial setae grouped around perithecia, } \\
\text { simple, acute to obtuse at the tip }\end{array}$ & M. clerodendricola \\
\hline 3121.3221 & $\begin{array}{l}\text { Colonies epiphyllous, velvety; hyphae flexuous to crooked; appressoria alternate, unilateral, } \\
\text { antrorse to subantrorse, head cells globose, subglobose, entire to sublobate; phialides mixed with } \\
\text { appressoria; mycelial setae scattered, simple, straight, slightly curved to uncinate }\end{array}$ & M. premnigena \\
\hline
\end{tabular}

Table 2. Host family, host and fungus

\begin{tabular}{|c|c|c|}
\hline $\begin{array}{l}\text { Family of the host } \\
\text { plant }\end{array}$ & Host plant & Fungi \\
\hline \multirow{3}{*}{ Acanthaceae } & Justicia betonica & Asterina betonicae \\
\hline & Adhatoda vasica & Asterina tertia \\
\hline & Phallopsis micranthus & Asteridiella phaulopsidis \\
\hline Alangiaceae & $\begin{array}{l}\text { Alangium salvifolium } \\
\text { Alangium sundanum }\end{array}$ & Asterina perpusilla \\
\hline \multirow{3}{*}{ Anacardiaceae } & Holigarna ornottiana & Meliola holigarnae \\
\hline & Mangifera indica & Meliola mangiferae \\
\hline & Nothopegia sp. & Meliola nothopegiae \\
\hline \multirow[t]{2}{*}{ Annonaceae } & $\begin{array}{l}\text { Goniothalamus } \\
\text { wayanadensis }\end{array}$ & Amazonia goniothalami \\
\hline & Meiogyne pannosa & Meliola unonicola \\
\hline \multirow{2}{*}{ Apocynaceae } & Quirivelia frutescens & $\begin{array}{l}\text { Meliola ichnocarpi- } \\
\text { volubili }\end{array}$ \\
\hline & Kamettia caryophyllata & Meliola kamettiae \\
\hline Araceae & Pothos scandens & Lembosia malabarensis \\
\hline Araliaceae & Aralia sp. & Meliola abdulkalamii \\
\hline \multirow{2}{*}{ Aristolochiaceae } & Thottea siliquosa & Asterina thotteae \\
\hline & Aristolochia grandiflora & Meliola aristolochigena \\
\hline \multirow{4}{*}{ Asclepiadaceae } & Gymnema sylvestre & Asterina gymnemae \\
\hline & Wattakaka volubilis & Asterina travancorensis \\
\hline & Gymnema sylvestre & Meliola gymnemae \\
\hline & Gymnema sylvestre & Phyllachora gymnemae \\
\hline \multirow{3}{*}{ Asteraceae } & Vernonia conizoides & Acremoniula sarcinellae \\
\hline & Spilanthes radicans & Schiffnerula spilanthi \\
\hline & Vernonia anthelmintica & Schiffnerula vernoniae \\
\hline Bignoniaceae & Oroxylum sp & Meliola crescentiae \\
\hline Buxaceae & Sarcococca sp. & $\begin{array}{l}\text { Questieriella } \\
\text { sarcococcae }\end{array}$ \\
\hline Caprifoliaceae & Viburnum cylindricum & Asterina viburnicola \\
\hline \multirow{2}{*}{ Caesalpiniaceae } & Tamarindus indica & Meliola tamarindi \\
\hline & Tamarindus indica & Sarcinella tamarindi \\
\hline
\end{tabular}

\begin{tabular}{|c|c|c|}
\hline $\begin{array}{l}\text { Family of the host } \\
\text { plant }\end{array}$ & Host plant & Fungi \\
\hline \multirow{3}{*}{ Celasteraceae } & Microtropis latifolia & $\begin{array}{l}\text { Asterina } \\
\text { microtropidicola }\end{array}$ \\
\hline & Celasteraceae member & Meliola celastrigena \\
\hline & Celastrus paniculatus & Schiffnerula celastri \\
\hline Chloranthaceae & $\begin{array}{l}\text { Sarcandra } \\
\text { chloranthoides }\end{array}$ & Asterina sarcandrae \\
\hline \multirow{3}{*}{ Convolvulaceae } & Argyereia speciosa & Meliola malacotricha \\
\hline & Argyereia sp. & $\begin{array}{l}\text { Meliola malacotricha } \\
\text { var. major }\end{array}$ \\
\hline & Merremmia unbellata & Meliola quadrispina \\
\hline Combretaceae & Terminalia sp. & $\begin{array}{l}\text { Asteridiella combreti } \\
\text { var. leonensis }\end{array}$ \\
\hline Dipterocarpaceae & Vateria indica & Asterolibertia vateriae \\
\hline \multirow{3}{*}{ Elaeocarpaceae } & $\begin{array}{l}\text { Elaeocarpus } \\
\text { tuberculatus }\end{array}$ & $\begin{array}{l}\text { Asterina elaeocarpi var. } \\
\text { ovalis }\end{array}$ \\
\hline & $\begin{array}{l}\text { Elaeocarpus variabilis } \\
\text { Elaeocarpus tectorius }\end{array}$ & Asterina gamsii \\
\hline & $\begin{array}{l}\text { Elaeocarpus } \\
\text { tuberculatus }\end{array}$ & $\begin{array}{l}\text { Asteridiella elaeocarpi- } \\
\text { tuberculati }\end{array}$ \\
\hline \multirow{2}{*}{ Erythropalaceae } & $\begin{array}{l}\text { Erythropalum } \\
\text { populifolium }\end{array}$ & Asterina erythropalicola \\
\hline & $\begin{array}{l}\text { Erythropalum } \\
\text { populifolium }\end{array}$ & Meliola erythropali \\
\hline \multirow{10}{*}{ Euphorbiaceae } & Aporusa lindleyana & Asterina aporusae \\
\hline & Glochidion sp. & $\begin{array}{l}\text { Asterina lobulifera var. } \\
\text { indica }\end{array}$ \\
\hline & Mallotus sp. & $\begin{array}{l}\text { Asteridiella } \\
\text { wyanadensis }\end{array}$ \\
\hline & Agrostistachys indica & $\begin{array}{l}\text { Mahanteshamyces } \\
\text { agrostachydis }\end{array}$ \\
\hline & Actephila excelsa & Meliola actephilae \\
\hline & Aporusa sp. & Meliota aporusoe \\
\hline & Phyllanthus sp. & Meliola phyllanthigena \\
\hline & Aporusa lindleyana & Meliolaster aporusae \\
\hline & Bridelia sp. & Schiffnerula brideliae \\
\hline & Ricinus communis & Schiffnerula ricini \\
\hline \multirow{2}{*}{ Fabaceae } & Milletita sp. & Asteridiella millettiicola \\
\hline & Crotalaria sp. & $\begin{array}{l}\text { Leptosphaerulina } \\
\text { australis }\end{array}$ \\
\hline
\end{tabular}




\begin{tabular}{|c|c|c|}
\hline $\begin{array}{l}\text { Family of the host } \\
\text { plant }\end{array}$ & Host plant & Fungi \\
\hline & Abrus pulchellus & Meliola abri \\
\hline & Butea parviflora & Meliola buteae \\
\hline & Canavalia sp. & Meliola canavaliae \\
\hline & Flemingia $\mathrm{sp}$ & Meliola flemingiicola \\
\hline & Gliricidia sp. & Meliola gliricidiicola \\
\hline & Derris benthamii & $\begin{array}{l}\text { Meliola millettiae- } \\
\text { chrysophyllae var. } \\
\text { indica }\end{array}$ \\
\hline & $\begin{array}{l}\text { Psophocarpus } \\
\text { tetragonolobus }\end{array}$ & Meliola psophocarpi \\
\hline & Dalbergia sp. & Sarcinella dalbergiae \\
\hline \multirow{4}{*}{ Flacourtiaceae } & Flacourtia sp. & Amazonia flacourtiae \\
\hline & Flacourtia montana & Asterina arkemibeyi \\
\hline & Scolopia crenata & Asteridialla scolopiae \\
\hline & Flacourtia montana & $\begin{array}{l}\text { Ishwaramyces } \\
\text { flacourtiae }\end{array}$ \\
\hline Gentianaceae & Enicostema axillare & Asterina enicostematis \\
\hline Hippocrateaceae & Hippocratea sp. & Meliola oligomera \\
\hline \multirow{3}{*}{ Icacinaceae } & $\begin{array}{l}\text { Nothapodytes } \\
\text { nimmoniana }\end{array}$ & $\begin{array}{l}\text { Meliola } \\
\text { chandrasekharanii }\end{array}$ \\
\hline & $\begin{array}{l}\text { Nothopodytes } \\
\text { nimmoniana }\end{array}$ & Meliola dimidiatae \\
\hline & Nothopodytes sp. & Sarcinella hughesii \\
\hline \multirow{16}{*}{ Lauraceae } & Neolitsea scrobiculata & Ampullifera foliicola \\
\hline & Litsea sp & $\begin{array}{l}\text { Asterina litseae- } \\
\text { ligustrinae }\end{array}$ \\
\hline & Litsea floribunda & Asterina cryptocariicola \\
\hline & Apolonias sp. & Armatella apollonigena \\
\hline & $\begin{array}{l}\text { Cinnamomum } \\
\text { malabatrum }\end{array}$ & $\begin{array}{l}\text { Armatella } \\
\text { balakrishnanii }\end{array}$ \\
\hline & $\begin{array}{l}\text { Cinnamomum } \\
\text { malabatrum }\end{array}$ & $\begin{array}{l}\text { Armatella } \\
\text { cinnamomicola }\end{array}$ \\
\hline & Litsea coriacea & Armatella cryptocaryae \\
\hline & $\begin{array}{l}\text { Persea macrantha } \\
\text { (Machilus macrantha) }\end{array}$ & Armatella katumotoi \\
\hline & $\begin{array}{l}\text { Cinnamomum } \\
\text { malabathrum }\end{array}$ & Armatella litseae \\
\hline & $\begin{array}{l}\text { Cinnamomum } \\
\text { macrocarpum }\end{array}$ & $\begin{array}{l}\text { Meliola beilschmiediae } \\
\text { var. cinnamomicola }\end{array}$ \\
\hline & Litsea sp. & $\begin{array}{l}\text { Meliola I itsea var. } \\
\text { keralensis }\end{array}$ \\
\hline & Actinodaphnae sp. & $\begin{array}{l}\text { Meliola litseae var. } \\
\text { rotundipoda }\end{array}$ \\
\hline & Persea macrantha & Meliola machili \\
\hline & Neolitsea sp. & Meliola neolitseae \\
\hline & Persea sp. & Meliola pushpangadanit \\
\hline & Actinodaphne sp. & Spiropes armatellicola \\
\hline Lecythidaceae & Careya arborea & $\begin{array}{l}\text { Meliola careyae var. } \\
\text { indica }\end{array}$ \\
\hline \multirow{2}{*}{ Loranthaceae } & Loranthus sp. & Asterina deightonii \\
\hline & Loranthus sp. & Prillieuxina loranthi \\
\hline Lythraceae & $\begin{array}{l}\text { Lagerstroemia } \\
\text { microcarpa }\end{array}$ & $\begin{array}{l}\text { Schiffnerula } \\
\text { lagerstroemiae }\end{array}$ \\
\hline
\end{tabular}

\begin{tabular}{|c|c|c|}
\hline $\begin{array}{l}\text { Family of the host } \\
\text { plant }\end{array}$ & Host plant & Fungi \\
\hline \multirow{3}{*}{ Magnoliaceae } & Michelia chempaka & Asterina micheliifolia \\
\hline & Michelia chempaka & Asterina micheliigena \\
\hline & Michelia champaka & Asteridiella micheliae \\
\hline \multirow{3}{*}{ Malvaceae } & Hibiscus rosa-sinensis & Asterina hibisci \\
\hline & Hibiscus furcatus & Irenopsis molleriana \\
\hline & Sida sp. & $\begin{array}{l}\text { Irenopsis sidae var. } \\
\text { indica }\end{array}$ \\
\hline Malphigiaceae & Hiptage sp. & $\begin{array}{l}\text { Irenopsis hiptages var. } \\
\text { indica }\end{array}$ \\
\hline \multirow{5}{*}{ Melastomataceae } & Memecylon sp. & Asterina memecylonis \\
\hline & Memecylon sp. & $\begin{array}{l}\text { Meliola affinis var. } \\
\text { indica }\end{array}$ \\
\hline & Memecylon sp. & Echidnodella memecyli \\
\hline & Ficus infectoria & Phyllachora infectoriae \\
\hline & Osbeckia wightiana & Rehmidothis osbeckiae \\
\hline \multirow{6}{*}{ Meliaceae } & Cipadessa baccifera & Asterina cipadessae \\
\hline & Trichilia connaroides & Asterina trichiliae \\
\hline & Trichilia sp. & Irenopsis trichiliae \\
\hline & $\begin{array}{l}\text { Aphanamixis } \\
\text { polystachya }\end{array}$ & Meliola aphanamixidis \\
\hline & Dysoxylum sp. & Meliola dysoxyligena \\
\hline & $\begin{array}{l}\text { Aphanamixis } \\
\text { polystachya }\end{array}$ & Meliola nairii \\
\hline \multirow[b]{2}{*}{ Menispermaceae } & Cyclea peltata & Meliola cycleae \\
\hline & Cyclea peltata & $\begin{array}{l}\text { Meliola } \\
\text { subramanyaensis }\end{array}$ \\
\hline \multirow{4}{*}{ Moraceae } & Ficus exaspirata & Irenopsis benguetensis \\
\hline & $\begin{array}{l}\text { Artocarpus } \\
\text { heterophyllus }\end{array}$ & Meliola artocarpi \\
\hline & Ficus hispida & Phyllachora catarvaria \\
\hline & Ficus infectoria & Phyllachora infectoriae \\
\hline \multirow{4}{*}{ Myrsinaceae } & Maesa indica & Amazonia peregrina \\
\hline & Ardisia missionis & Meliola ardisiicola \\
\hline & Ardisia sp. & Meliola ardisiigena \\
\hline & Maesa indica & $\begin{array}{l}\text { Meliola groteana var. } \\
\text { maesae }\end{array}$ \\
\hline \multirow{7}{*}{ Myrtaceae } & Syzygium sp. & Amazonia syzygii \\
\hline & Syzygium sp. & Asterina jambolana \\
\hline & Syzygium cumini & Asterina claviflori \\
\hline & Syzygium sp. & Lembosia hosagoudari \\
\hline & Syzygium sp & Meliola densa \\
\hline & Syzygium sp. & Meliola syzygigena \\
\hline & Syzygium cumini & $\begin{array}{l}\text { Meliolina } \\
\text { pulcherrima }\end{array}$ \\
\hline
\end{tabular}




\begin{tabular}{|c|c|c|}
\hline $\begin{array}{l}\text { Family of the host } \\
\text { plant }\end{array}$ & Host plant & Fungi \\
\hline \multirow{17}{*}{ Oleaceae } & $\begin{array}{l}\text { Ligustrum } \\
\text { travencoricum }\end{array}$ & Asterina ligustricola \\
\hline & $\begin{array}{l}\text { Jasminum cordifolium } \\
\text { Jasminum malabaricum } \\
\text { Jasminum sambac }\end{array}$ & Asterina erysiphoides \\
\hline & Jasminum sambac & $\begin{array}{l}\text { Asterina } \\
\text { pongalaparensis }\end{array}$ \\
\hline & Linoceira malabarica & Asteridiella americana \\
\hline & Jasminum sp. & Meliola gemellipoda \\
\hline & Olea glandulifera & Meliola glanduliferae \\
\hline & $\begin{array}{l}\text { Jasminum-rottlerianum } \\
\text { Jasminum cordifolium }\end{array}$ & Meliola jasmini \\
\hline & Jasminum sp. & $\begin{array}{l}\text { Meliola jasmini var. } \\
\text { microspora }\end{array}$ \\
\hline & $\begin{array}{l}\text { Jasminum } \\
\text { bignoniaceum }\end{array}$ & Meliola jasminigena \\
\hline & $\begin{array}{l}\text { Ligustrum walkeri ssp. } \\
\text { walkeri }\end{array}$ & Meliola ligustri \\
\hline & Ligustrum perrottettii & Meliola ligustricola \\
\hline & Olea dioica & Meliola malabarensis \\
\hline & Ligustrum sp. & Meliola mayapeae \\
\hline & $\begin{array}{l}\text { Chionanthus mala- } \\
\text { elengi } \\
\text { Linociera malabarica }\end{array}$ & $\begin{array}{l}\text { Meliola mayapiicola } \\
\text { var. indica }\end{array}$ \\
\hline & Olea dioica & Meliola oleacearum \\
\hline & Ligustrum sp. & Meliola oleicola \\
\hline & Olea dioica & Zhaghounia oleae \\
\hline Passifloraceae & Adenia hondala & Asterina adeniicola \\
\hline Periplocaceae & Hemidesmus indicus & Meliola hemidesmicola \\
\hline \multirow{5}{*}{ Piperaceae } & Lepianthes umbellata & Asterina lepianthis \\
\hline & Piper sp. & Asterina piperina \\
\hline & Lepianthes umbellata & Meliola lepianthedis \\
\hline & Piper sp. & Meliola stenospora \\
\hline & Piper sp. & $\begin{array}{l}\text { Meliola stenospora var. } \\
\text { major }\end{array}$ \\
\hline \multirow{3}{*}{ Poaceae } & Cymbopogon sp. & Meliola cymbopogonis \\
\hline & Poaceae (Grass) & Meliola panici \\
\hline & Themeda triandra & Meliola themedicola \\
\hline Ranunculaceae & Naravelia zeylanica & Asterina naraveliae \\
\hline Rhamnaceae & Ziziphus sp. & Meliola ziziphi \\
\hline Rosaceae & Rubus ellipticus & $\begin{array}{l}\text { Appendiculella } \\
\text { calostroma }\end{array}$ \\
\hline \multirow{7}{*}{ Rubiaceae } & Pavetta sp. & Acrodictys balladynae \\
\hline & Pavetta indica & Asterostomula pavettae \\
\hline & Mussaenda philippica & Meliola anceps \\
\hline & Canthium rheedii & Meliola canthiicola \\
\hline & Canthium dicoccum & Meliola plectroniae \\
\hline & Wendlandia thyrsoidea & Meliola wendlandiae \\
\hline & Ixora coccinea & Prillieuxina ixorigena \\
\hline
\end{tabular}

\begin{tabular}{|c|c|c|}
\hline $\begin{array}{l}\text { Family of the host } \\
\text { plant }\end{array}$ & Host plant & Fungi \\
\hline \multirow{18}{*}{ Rutaceae } & $\begin{array}{l}\text { Melicope lunu-ankenda } \\
\text { Euodia lunu-ankenda }\end{array}$ & Asterina clausenicola \\
\hline & Euodia luna-ankenda & Asterina melicopecola \\
\hline & Glycosmis sp. & Asterina glycosmidis \\
\hline & Glycosmis pentaphylla & $\begin{array}{l}\text { Asterina } \\
\text { glycosmidigena }\end{array}$ \\
\hline & Toddalia sp. & Asterina toddaliae \\
\hline & $\begin{array}{l}\text { Glycosmis pentaphylla } \\
\text { (G. cochinchinensis) }\end{array}$ & Asteridiella glycosmidis \\
\hline & Acronychia pedunculata & Asterina acronychiae \\
\hline & Atlantia sp. & Meliola atalantiae \\
\hline & Citrus sp. & Meliola butleri \\
\hline & Glycosmis mauritiana & $\begin{array}{l}\text { Meliola cadigensis var. } \\
\text { glycosmidis }\end{array}$ \\
\hline & Toddalia sp. & $\begin{array}{l}\text { Meliola cadigensis } \\
\text { Yates var. toddaliae }\end{array}$ \\
\hline & Toddalia asiatica & Meliola cannonicola \\
\hline & Citrus sp. & Meliola citricola \\
\hline & Atalantia sp. & Meliola cranei \\
\hline & Toddalia asiatica & $\begin{array}{l}\text { Meliola tecleae Hansf. } \\
\text { var. toddaliae-asiaticae }\end{array}$ \\
\hline & Zanthoxylum rhetsa & Meliola vatsavayae \\
\hline & $\begin{array}{l}\text { Zanthoxylum } \\
\text { tetraspermum }\end{array}$ & Meliola zanthoxyli \\
\hline & Glycosmis pentaphylla & Phyllachora glycosmidis \\
\hline Sabiaceae & Meliosma simplicifolia & Asterina sabiacearum \\
\hline \multirow{5}{*}{ Sapindaceae } & Allophylus sp. & $\begin{array}{l}\text { Meliola allophyli- } \\
\text { concanici }\end{array}$ \\
\hline & Allophylus cobbe & $\begin{array}{l}\text { Meliola allophyli- } \\
\text { serrulati }\end{array}$ \\
\hline & Allophylus sp. & $\begin{array}{l}\text { Meliola capensis var. } \\
\text { allophylicola }\end{array}$ \\
\hline & Nephelium longan & $\begin{array}{l}\text { Meliola capensis var. } \\
\text { malayensis }\end{array}$ \\
\hline & Schleichera oleosa & $\begin{array}{l}\text { Meliola capensis var. } \\
\text { schleicherae }\end{array}$ \\
\hline Sapindaceae & Allophyllus sp. & Sarcinella allophyli \\
\hline \multirow{2}{*}{ Santalaceae } & Santalum sp. & Asterina congesta \\
\hline & $\begin{array}{l}\text { Scleropyrum } \\
\text { pentandrum }\end{array}$ & Meliola scleropyri \\
\hline \multirow{2}{*}{ Simaroubaceae } & Ailanthus malabarica & Meliola ailanthi \\
\hline & Ailanthus triphysa & Meliola ailanthicola \\
\hline Smilacaceae & Smilax sp. & Meliola gamblei \\
\hline Solanaceae & Solanum sp. & Schiffnerula palodensis \\
\hline Sterculiaceae & Sterculia sp. & Meliola sterculiacearum \\
\hline \multirow[t]{2}{*}{ Strychnaceae } & Strychnos nux-vomica & Meliola cannonii \\
\hline & Strychnos nux-vomica & Questieriella strychni \\
\hline \multirow{4}{*}{ Symplocaceae } & Symplocos rosea & Asterina indica \\
\hline & Symplocos macrophylla & $\begin{array}{l}\text { Asteridiella symploci- } \\
\text { microphyllae }\end{array}$ \\
\hline & $\begin{array}{l}\text { Symplocos } \\
\text { cochinchinensis }\end{array}$ & Meliola symplocicola \\
\hline & Symplocos sp. & Phyllachora symploci \\
\hline
\end{tabular}




\begin{tabular}{|l|l|l|}
\hline $\begin{array}{l}\text { Family of the host } \\
\text { plant }\end{array}$ & Host plant & Fungi \\
\hline Ulmaceae & Trema orientalis & Asterina dallasica \\
\hline \multirow{2}{*}{ Urticaceae } & Boehmeria sp. & $\begin{array}{l}\text { Asterostomella } \\
\text { boehmeriae }\end{array}$ \\
\hline Vacciniaceae & Vaccinium sp. & Amazonia vaccinii \\
\hline \multirow{5}{*}{ Verbenaceae } & Premna serratifolia & Asterina pusilla \\
\cline { 2 - 3 } & Clerodendrum viscosum & Asteridiella formosensis \\
\cline { 2 - 3 } & Callicarpa sp. & $\begin{array}{l}\text { Asteridiella } \\
\text { vivekananthanii }\end{array}$ \\
\cline { 2 - 3 } & Clerodendrum viscosum & Meliola clerodendricola \\
\cline { 2 - 3 } & Premna glaberrima & Meliola premnigena \\
\cline { 2 - 3 } & Tectona grandis & Schiffnerula tectonae \\
\hline
\end{tabular}

\begin{tabular}{|l|l|l|}
\hline $\begin{array}{l}\text { Family of the host } \\
\text { plant }\end{array}$ & Host plant & Fungi \\
\hline \multirow{3}{*}{ Theaceae } & Gordonia sp. & Amazonia gordoniicola \\
\cline { 2 - 3 } & Triumfetta sp. & Asterina triumfetticola \\
\cline { 2 - 3 } & Thea sinensis & Schiffnerula camelliae \\
\hline \multirow{3}{*}{ Tiliaceae } & Triumfetta rhomboidea & Irenopsis triumfettae \\
\cline { 2 - 3 } & Triumfetta sp. & $\begin{array}{l}\text { Irenopsis triumfettae } \\
\text { var. indica }\end{array}$ \\
\hline
\end{tabular}

